\title{
المستجدات الحديثة في السندات التنفيـذية (دراسة هقارنة)
}

\author{
shel \\ د ا طلعت يوسف خاطر \\ أستاذ قانون المرافعات المساعد \\ كليتا الحقوق- جامعتالمنصورة
}




\section{هقدمة}

للتنفيذ الجبري أهميّة بالغة في العياة القانونية بجناحيها العلمي والعملي(').

ولعل الجناح العملي في التتفيذ بثكل خاص هو الغاية النهائية لصاحب الحق، خاصة مع التطورات الاقتصادية المتزايدة التي يشهدها العالم، والتي أدت إلى تفشي ظاهرة التضخم النقدي وانخفاض قيمة النقود، وهذا الأمر دعا غالب المدينين إلى محاولة إطالة أمد التقاضي، ويساعدهم في ذلك الإجراءات التنفيذية المطولة التي تتسم بالتعقيد مما يلحق خسارة فادحة بالدائنين.

ويذهب الفقه الإجرائي(؟) إلى الاعوة إلى تحديث الاراسة الإجرائية وتطويرها بصفة عامة، وهذه الدعوة أكثر إلحاحاً في نطاق دراسة السندات التتفيذية في قانون المرافعات؛ ويرجع ذلك إلى أن قواعد التنفيذ الجبري أكثر مساسا بالواقع العلي، بالإضافة إلى أنها ألصق قواعد القانون تأثراً بالحياة والتطورات الاقتصادية الحديثة، وأقربها تأثيراً في مصالح الناس وأموالهم، مما يكسبها أهمية بالغة، ويضفي عليها طابعاً عملياً لا يمكن إنكاره. وهذا يقتضي الحاجة المستمرة إلى دراسة علمية تحث المشرع على الأخذ بما هو حديث في مجال السندات التنفيذية وإجراعات تتفيذها؛ حيث إن غاية علم القانون الإجرائي تطوير قو اعده وترشيدها وتسهيلها.

(1) د/ أحمد ماهر زغلول، آثار إلغاء الأحكام بعد تتفيذها، الطبعة الثانية، بدون دار نشر، ولا سنة

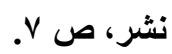

Salati. Droit et pratique des voies d'exécution, DALLOZ ACTION 2018/2019, n. 111.00 s.

(Y) د/ فتحي والي، مناهج البحث في قانون المرافعات، من الثرح على المتون إلى المدرسة الإيطالية

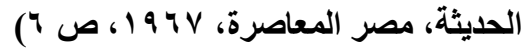




$$
\begin{aligned}
& \text { وسنشير في هذه المقدمة إلى الآتي: } \\
& \text { • أهمية موضوع البحث وتساؤلاته. }
\end{aligned}
$$

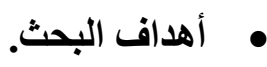

$$
\begin{aligned}
& \text { • منهجية البحث. } \\
& \text { خطة البحث. } \\
& \text { أولاً: أهمية موضوع البحث وتساؤلاته }
\end{aligned}
$$

يتوقف على التنفيذ الجبري تحقيق العدالة عن طريق ترجمة الحق المشار إليه في السند التنفيذي إلى واقع عملي ملموس، ومن ناحية أخرى فإن النظام القضائي يقوم على عدة أركان أساسية، يعد من أهمها نظام التنفيذ الجبري، والذي يجب أن تتسم إجر اعاته بالبساطه والحزم(')، ونظراً لمـا يتميز بـه التنفيذ الجبري من خطورة كبيرة بالنسبة للمنقَذ ضده لأنها تسلب أمواله، فقد حصر القـانون سبب التنفيذ في أعمـال قانونية معينة(؟)، ورأى أنها وحدها الجديرة بتأكيد الحق الموضوعي المراد تنفيذه، وأطلق عليها مصطلح السندات التنفيذية(")، ومن ثم لا يكفي أن يكون لثخص قِبَّل آخر حق موضوعي محقق الوجود ومعين المقدار() وحسال الأداع(')، حتى يكون بإمكانـه أن

(1) د/ فتحي والي، بحث نحو مشروع جديد للفصل في القضائيا المدنية والجديدة، الندوة المشتركة

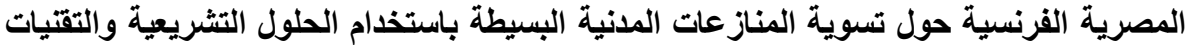

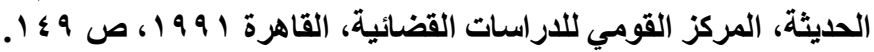

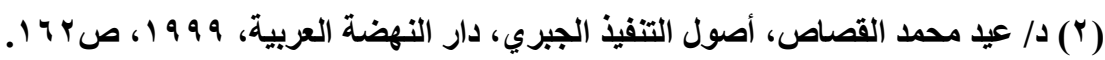

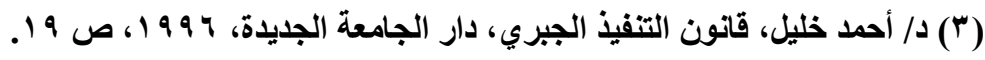
(4) Cass. Civ. 2e, 22 mars 2001, Bull. civ. II, no 61; Cass. Civ. 2e, 19 Nov. 2008, Bull. civ. II, no 253. 
يطالب بالتنفيذ الجبري لهذا الحق على المدين(†)، كما لا يكفي أن يكون هذا الحق ثابتاً في مستند؛ إنما لابد أن يكون ثابتاً بموجب أحد السندات التي أعطاهـا القـانون صـلاحية

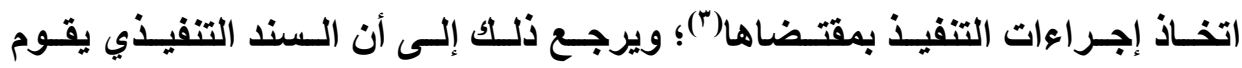

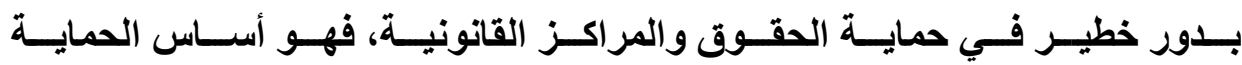
التنفيذية ومحورها(؛)، لأنه يعد الواقعة القانونية المنشئة للحق في التنفيذ الجبري (•)، فلا تنفيذ بـلا سند تنفيذي، وقد أكد المشرعان المصري والفرنسي هذه القاعدة في لوكي

(1) Cass. Civ. 2e, 12 oct. 2006, pourvoi no 04-18.238, D. 2006, somm. 339, obs. P. Julien

(2) Didier CHOLET, Exécution des jugements et des actes, D., septembre 2015, n. 32.

(3) R. PERROT et Ph. THÉRY, Procédures civiles d'exécution, 3e éd., 2013, Dalloz, no 118; LEBORGNE, Droit de l'exécution, 2e éd., 2014, Dalloz, nos 432 s; Civ. 2e, 22 oct. 2009, no 08-19.072, Bull. civ. II, no 254 ; Dr. et proc. 2010. 86, note Léon.

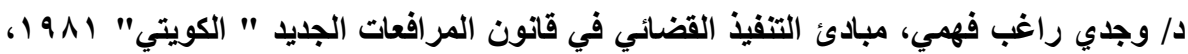

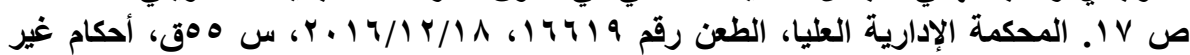
منشورة.

(4) Didier CHOLET Exécution des jugements et des actes, op. cit., n0 32.

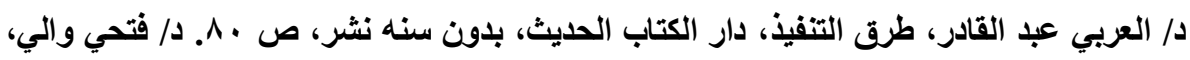

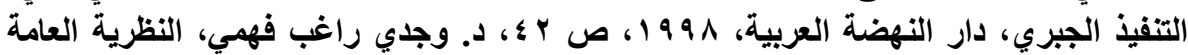

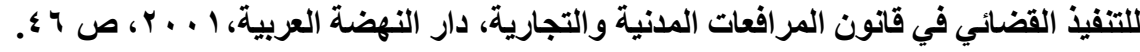

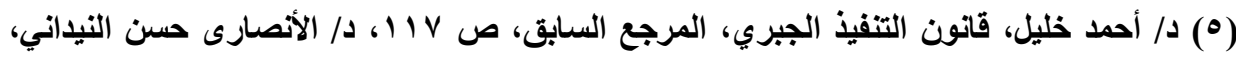

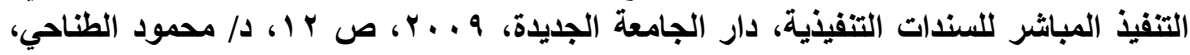

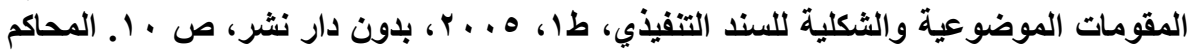

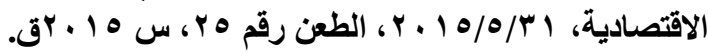

Didier CHOLET, Exécution des jugements et des actes, op. cit., n. 28.

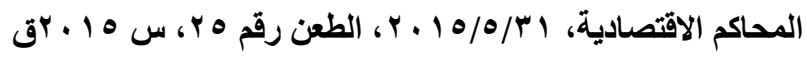




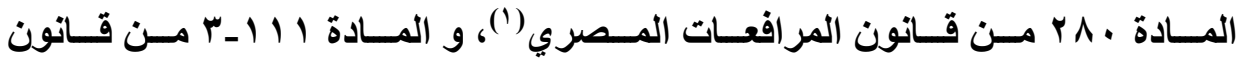
الإجراعات المدنية للتنفيذ(؟)

وفي إطـار أزمـة العدالة التي تمر بها عديـ من الدولتة، والتي نتجت بشكل

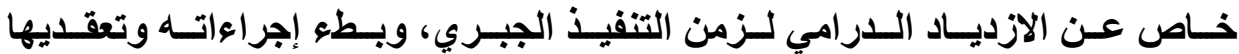
والإثكاليات التي تثار حول السندات التنفيذية، فإن بعض التثريعات الحديثة ـ من أجل معالجة كلّ المشاكل والعقبـات التي تواجـه بطع التقاضسي قد اتجهت إلى الأخذ في التوسع في أنواع السندات التنفيذية، لمواجهة الظروف الواقعية والتطورات الحديثة، وتسهيل حصول اللائن على حقـه("). ويعد هذا اتجاهـاً صـائباً، إذ إنـه يحقق مصلحة الـائن ومصصحة المدين والمصلحة العامـة كذلكت. ومسن هنـا وجب الاهتمـام بالسندات التنفيذية؛ عن طريق تسليط الأضواء على التطورات الحديثة بشأنها في مجال الفقهـ والقضاء والتشريعات المختلفة، وذلكك من أجل توخي الفائدة الأعمّ، وذلك في ضوء الاسـتناره بـالملائم مـن آراء العلـم ومواقـف الاجتهــاد، فـي أنـواع السندات التنفيذيـة المستحدثة في مختلف التشريعات.

ورغم التطورات الحديثة في مجـال السندات التنفيذية وإجراءاتها فأنها يلاحظ وجود تقصير في بعض الأقطار من قبل التشريع في اللحسق بركب التطور المتواتر لقانون المرافعات؛ فقد أفرزت بعض التطورات الحديثة في مجال السندات التففيذية، عن دور الإرادة الخاصـة في تكوين بعض السندات التنفيذيـة، وهذا اللدور لا يعترف بـه

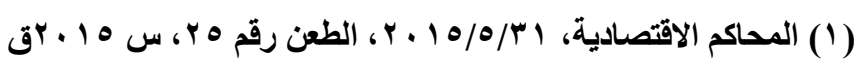

(2) Cass. Civ 1، 16 Jan 2007, Bull civ I، No. 19; Berlioz, limites et difficultés d'exécution de l'acte authentique, JCP, 2014, 1249.

(3) Cass. Com. 27 mars 2007, Bull. civ. IV, no 99 ; Cass. Civ. 2e, 17 oct. 2013Dr. et proc. 2013. 285, note Vinckel. 
المشرع المصري، فـلا يمكن لـلإِرادة الخاصـة لأطراف العهل القـانوني القيـام بتكوين سندات تنفيذية، على عكس بعض التشريعات الأخرى التي أجازت ذلك.

ورغم أن كتب التنفيذ ومؤلفاته جميعها قد تناولت السندات التنفيذيـة بالبحث والاراسة، فإن المكتبة القانونية العربية تخلو - على حد علمنـا ـ من أي مؤلَف خـاص يتنـاول السندات التنفيذيـة الحديثة وتطبيقاتها العمليـة، والخلافـات الفقهية التي ثنارت بشأنها. ونحساول في هذه الدراسـة الكشف عن أهم المستجدات الحديثة في أنـواع السندات التنفيذية وإجراء|تها، وتقييمها ومدى الأخذ بها في النظام المصري. والواقع أن هذه الدعوة العلمية طريقها محفوف بالمنـاهج المتنازعة حول مسألة المستجدات الحديثة، وهي مناهج لها مصادرها الفكرية المختلفة، ولها أيضا نتائجها؛ حيث تقتضي هذه الدراسـة الـربط بيلن مـواد القـانون بمجملـه وخاصـة القـانون التجـاري والقـانون المدني، إذ إن للتنفيذ جذوراً متفرقة لا مفرّ من تلمَّسـها، مـع رصد حركة الاجتهـاد في

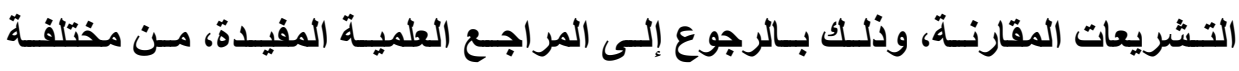
التشريعات القانونية، سواء عربية أو أجنبية، والتي يكون لها الفضل في توطيد أركان عملنا، وفي تذليل بعض الصعوبات. وتثير هذه الدراسة عديدا من التساؤلات الآتية؛ من نحو: ما منـاهج الدول في تحديد أنواع السندات التنفيذية؟ وما السندات التنفيذية المستجدات؟ ومـا الدوافع التي متي أدت إلى استحداث سندات تنفيذيـة غير تقليدية؛؟ ومـا الإجراءات القانونية الحديثة في تنفيذ السندات؟ ومـا موقف الفقه والقضاء المقارن من هذه المستجدات الحديثة في مجال السندات التنفيذية؛ وما موقف المشرع المصري من التطورات القانونيـة الحديثة في أنواع السندات التنفيذية وإجراعات تنفيذها؟ 


\section{ثانيًا: أهداف البحث}

تهدف دراسة موضوع المستجدات الحديثة في السندات التنفيذية إلى البحث

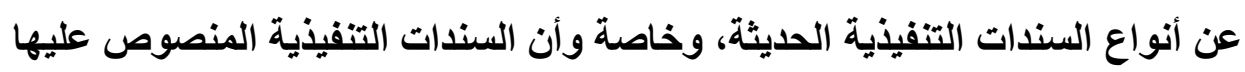

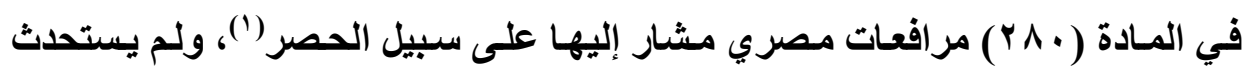

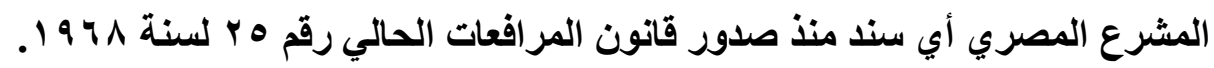

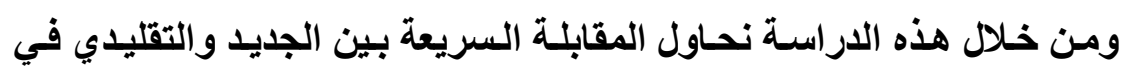

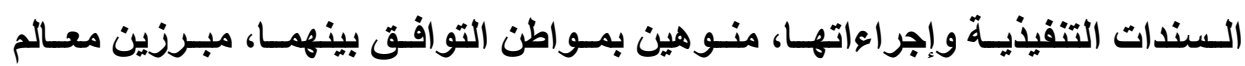

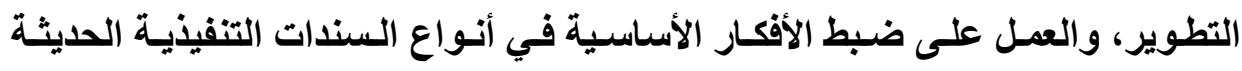
وإجراءات تتفيذها.

$$
\text { وتهذف هذه الدراسة إلى الآتي: }
$$

• بيان ماهية السندات التنفيذية وخصائصها. • عديد أنواع السندات التنفيذية طبقاً للاتجاه التقليدي. • • بيان التطورات الحديثة في أنواع السندات التنفيذية. • بيان عيوب السندات الحديثة ومميزاتها التي أخذ بها القانون المقارن. • بيان المستجدات الحديثة في تفعيل إجراءات تتفيذ السندات التنفيذية. • عديد موقف المشرع المصري من المستجدات الحيثة في السندات التنفيذية. • بيان المستحدث من الإجراءات في تفعيل تنفيذ السندات. • الوقوف على بعض الحلول العملية لبعض العقبات في تنفيذ السندات. 
إذا كان لكل موضوع نهج فإن المنهج الذي تستلزمه هذه الدارسة هو المنهج

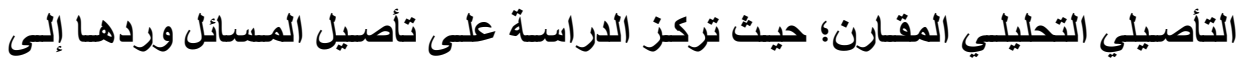
أصولها القانونية، ومحاولة صباغة قواعد تتتـاول دراسة الموضوع من خلال نظريـة

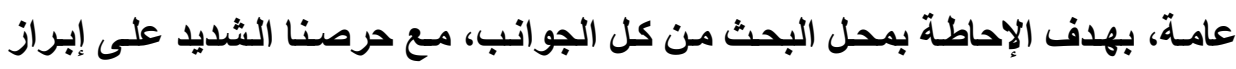
الجانب العملي في الموضوع وربطه بالنتائج والحلول التي توصلتا إليها من خلال البحث، وذلك لأن موضوع المستجدات الحديثة في السندات التنفيذية لـه شق عملي التهي وآخر نظري، ومن ثم فإنتا سنتبع المنهج الاستقرائي للنصوص القانونية في القانون المقارن، ثم نتنـاول تلك النصوص بالتحليل، وذلكك بدراسة أحكام السندات التنفيذيـة

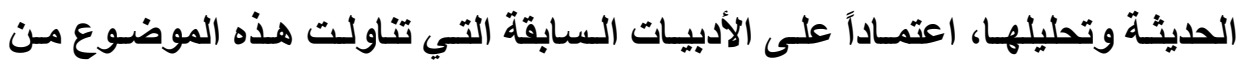

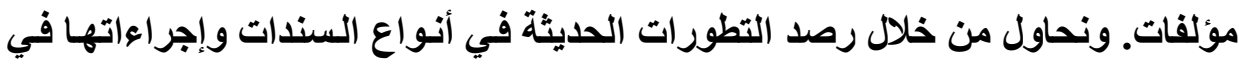

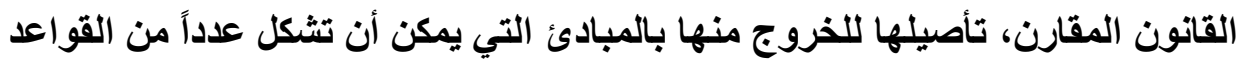
العامة القابلة للتطبيق على ما يثيره موضوع الاراسة من إثكاليات. ونحساول في هذه الاراسـة تسليط الضوء على التطور الكبير في القـانون

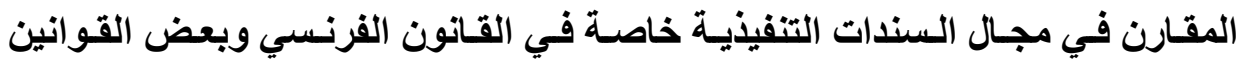
العربية والغربية، ونرجو أن يحذو المشرع المصري حذوهم؛ بحيث يتحرى التطورات

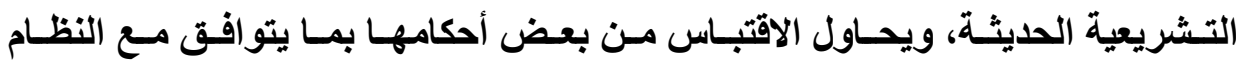

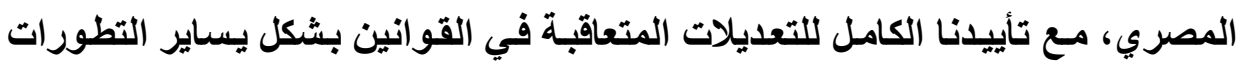

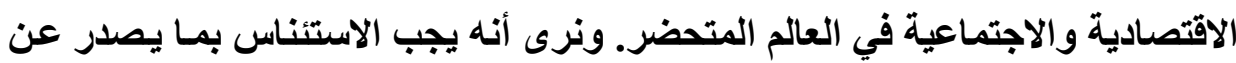

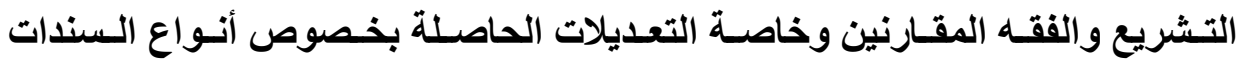

التفيذية وتسهيل إجراءات تنفيذيها. 
ولقد حاولنا الاختصار لاى شرح بعض الأفكار المقصودة مـا أمكن الاختصار، من أجل توخي الوضوح في إطلاق الأفكار والتركيز على النقاط المهـة في مجـال البحث.

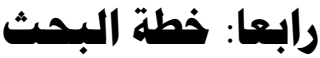

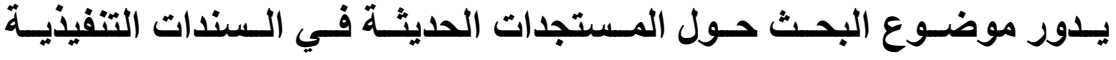
وإجراءات تنفيذها، بمـا يوفره ذلك من حماية للائنين و القضاء على بطء التقاضي والحصول على عدالة ناجزة، وما يقره من ضمانات للمنفذ ضده مخاطر التنفيذ، وكون هذا الموضوع يظلب عليه الطابع العملي أكثر من النظري، فقد رأيت أن نعالج موضوع

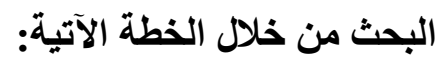

$$
\text { • المبحث التمهيدي: ماهية السندات التنقيذية. }
$$

$$
\text { • الفصل الأول: المستحدث في أنواع السندات التنفيذية. }
$$

• الفصل الثاني: التطورات الحديثة في تفعيل إجراءات تنفيذ السندات التفيذية. وقد اختتمنا هذه الارسـة بخاتمـة تتضمن أهم النتائج التي توصلنا إليها من خلال البحث، مع اقتراح بعض التوصيات. 


\section{المبحث التمههيدي \\ هاهية السندات التنفيدذية}

للسند التنفيـي دور مهـم في حمايـة الحقوق (')؛ وذلـك لمـا لهذه السندات التنفيذية من قوة تنفيذية(؟)، توجب تلخخل الدولة بسلطتها القضائية والتنفيذية في إجبار المدين على الوفاء، ولقد نظم المشرع السندات التنفيذيـة بهدف التوفيق بين مصلحة

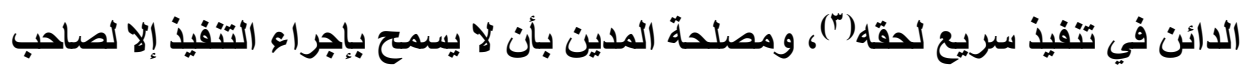

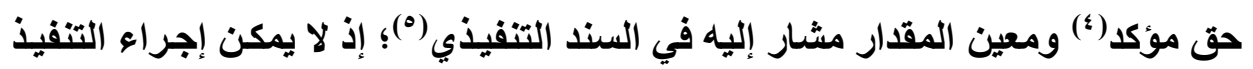
الجبري لاقتضاء الحقوق مالم يوجد سند تنفيذي(")

ولن نتنـاول في هذا المبحث بالتفصيل السندات التنفيذيـة من حيث أنواعها التقليدية وشروطها وأركانها، فمكان دراستها التفصيلية في المؤلفات العامة في التنفيذ

(1) Didier CHOLET Exécution des jugements et des actes, op. cit., n0 33. CA Toulouse, 23 oct. 2009, AJDA 2010. 448, note Bioy.

(2) HÉBRAUD, L'exécution des jugements civils, RID comp. 1957. 170, Didier CHOLET, Exécution des jugements et des actes, op. cit., n. 1. PUTMAN, La contrainte dans le droit de l'exécution, RRJ 1994. 341.

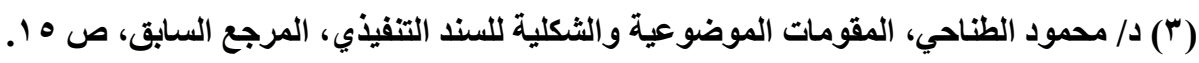

(4) R. PERROT et Ph. THÉRY, Procédures civiles d'exécution, op. cit., no 118; LEBORGNE, Droit de l'exécution, op. cit., nos 432 s. CA Lyon, 9 mai 2001, RG no 2000/00816, JCP N 2002. 1099, note Laporte.

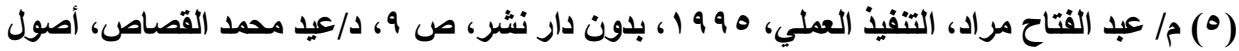

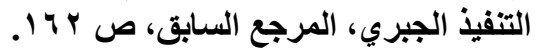


الجبـري، ولكنتـا سـنتعرض فـي المبحث التمهيدي لبيـان تعريـف السندات التنفيذيـة ومضمونها ووظيفتها.

وسنشير إلى تعريف السند التنفيذي ونشأته، وذلك في المطلب الأول، ثم نعالج

$$
\begin{aligned}
& \text { مضمون السند التنفيذية ووظيفته، وذلك في المطلب الثاني. } \\
& \text { المطلب الأول } \\
& \text { تعريف السند التنفيدي ونشأته }
\end{aligned}
$$

لا شك في أن وضع التعريفـات للمفـاهيم القانونيـة مسألة تغلب عليها الصبغة

الفقهية؛ لذا نجد التشريعات المختلفة لـم تضع تعريفاً للسند التنفيذي، وكل مـا نصت عليه هو أن السند التنفيذي مفترض ضروري للتنفيذ(')، ولا يغني عن السند التنفيذ أي

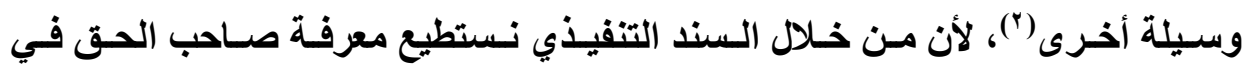

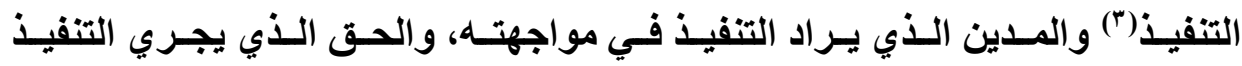

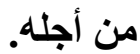

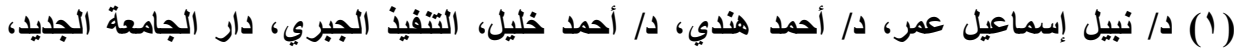

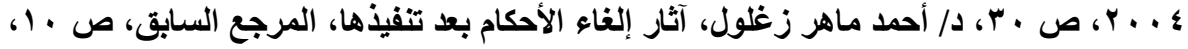

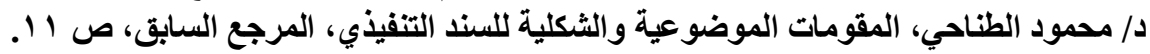

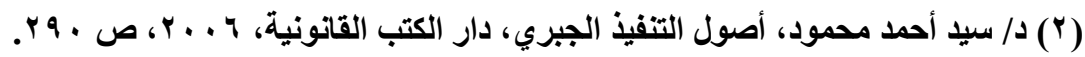

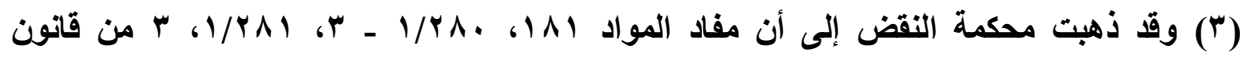

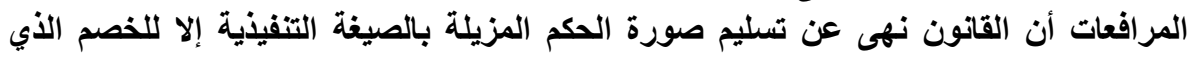

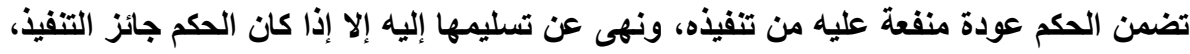

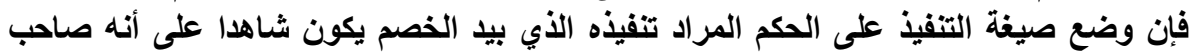

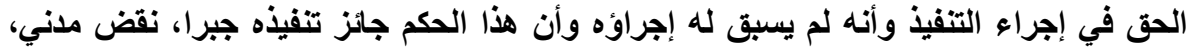

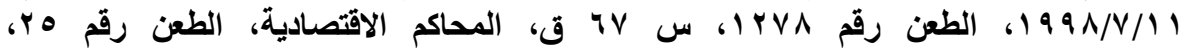

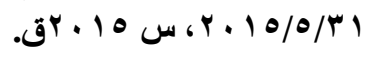


وسنعالج في هذا المطلب تعريف السند التنفيذي وخصائصه، وذلكك في الفرع الأول، ثم نشير إلى لمحه تاريخية عن نشأة السند التنفيذي، وذلك في الفرع الثاني،

$$
\text { وذلك على النحو الآتي: }
$$

\section{الفرع الأول \\ تعريف السند التنفيذي وخصائصه}

سنشير إلى تعريف السند التنفيذي، وخصائصه، وذلك في النقاط الآتية:

أولاً: تعريف السند التنفيذي:

عرف بعض الفقه السند التتفيذي بأنها محرر مكتوب، لـه مضمون معين بـه وبيانات معينة وشكل خاص، وعليه توقيع وأختام حددها القانون (')، كما عرفه البعض

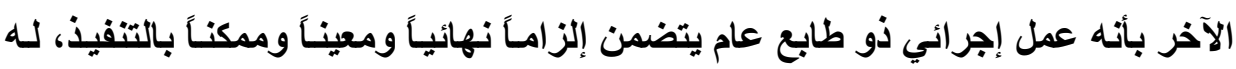
قوة التنفيذية الجبرية بشكلها التشريعي ممثلاً في الصيغة التنفيذيـة(؟). وقد عُرف بأنـه عبارة عن ورقة يعترف لها القانون بالقوة التنفيذية متى كاتت من بين الأوراق التي حددها القانون، ومشتملة على حق محقق الوجود ومعين المقدار وحال الأداء ومزيلة بالصيغة التنفيذية("). وقيل بأن السند التنفيذي عبارة عن وثيقة مكتوبـة بـالحق المراد تنفيذه، له شكل قانوني معين ويلزم تقديمة لجهة التنفيذ لإجرائهـ("). وعُرف بأنه عمل (1) د. نبيل إسماعيل عمر، الوسيط في التففيذ الجبري للأحكام، دار الجامعة الجديدة، ط.... ب،

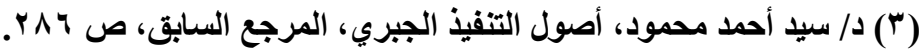

Didier CHOLET Exécution des jugements et des actes, op. cit., n0 32. (؛) د/ وجدي راغب فهمي، مبادئ التنفيذ القضائي في قانون المرافعات الجديد " الكويتي"، المرجع

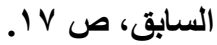


قانوني له شكل معين يتضمن تأكيداً لحق الدائن المراد اقتضائه جبراً، فهو ورقة معدة لإثبات حق الـائن، مهيأة لتكون أسـاس حقهـ في إجبار المدين على أداء هذا الحق الموضوعي(')، فالسند التنفيذي مستتد رسمي يتم في شكل خـاص، ويتضمن تأكيدا للحق الموضوعي()، ويقرر له المشرع تبعا لذلك قوة خاصة هي صلاحيته كأداة للتففيذ الجبري (آ).

ويلاحظ على التعريفـات الفقهية للسند التفيذي، أن منهـا مـا يعتد بالشكل الخارجي للسند التنفيذي كمستتد يسمح بذاته في إجراء التتفيذ، ومنها ما يعتد بمضمون

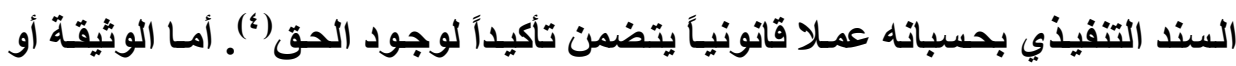
المستند فليست سوى الثكل الخارجي الأي يتم فيه إفراغ هذا العمل القانوني(ْ). وفي الواقع لا يمكن الاعتداد بالشكل الخارجي فقط مع إغفال مضمون السند التنفيذي، كمـا لا يجوز أيضاً الاعتداد بالمضمون وحده مـع إغفال الشكل الخـارجي (")؛ وذلك لأن السند التنفيذي عبارة عن محرر مكتوب له شكل معين، وشكله يعبر عن مضمونه(V)، وله قوة الهن (1) دا أسامة أحمد شوقي المليجي، الإجراءات المدنية للتنفيذ الجبري في قانون المرافعات المصري،

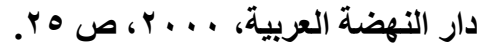

(Y) دا (Y) عاشور مبروك، الوسيط في التنفيذ وفقا لمجموعة المرافعات الحالية، دار النهضة العربية،

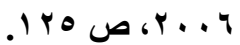

(r) د. عبد المنعم عبد العظيم جيرة، القواعد العامة في التنفيذ الجبري، مكتبة الوطنية، بدون سنة

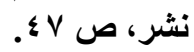

(؛) د/ عزمي عبد الفتاح عطية، قواعد التنفيذ الجبري في قانون المرافعات المصري، بدون دار

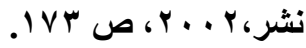

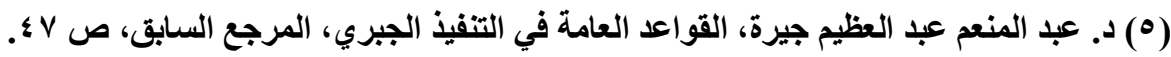

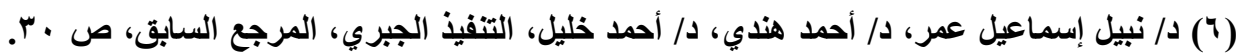

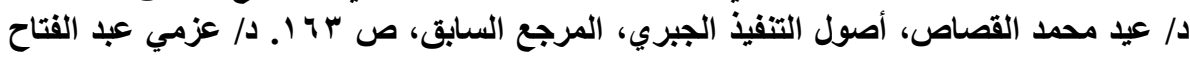

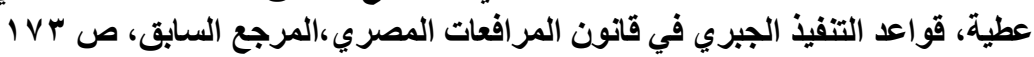

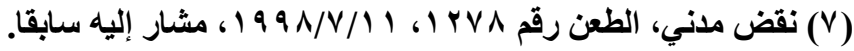


تنفيذية(')، وهذا نوع من الصلاحية أو القدرة التي يعترف بها القانون لمحرر مسا، تلك الصلاحية التي تكون لها القدرة على تحريك الجهاز القضائي لمساعدة صساحبه في تحقيـق مـضمونه باتخــاذ إجـراءات التنفيـذ الجبـري المنـصوص عليـهـ فـي قـانون المرافعات()، وإن استمر في اتخاذ هذه الإجراءات حتى يستوفى الدائن حقه(").

وقيل بأن السند التنفيذي ورقة رسمية، والواقع أن السندات التنفيذيـة طبقا للاتجـاه الحديث لـم يعد مقصورا على السندات الرسمية، حيث يجوز أن يكون ورقة تجارية أو ورقة عادية في بعض الأنظمـة القانونيـة، ولكن في النظام المصري لايزال السند التنفيذي ورقة رسمية.

وعرف البعض السند التنفيذي بأنه يصدر من سلطة مخوله قانونـا بإصداره،

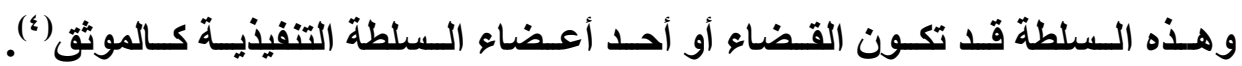
وينطوي السند التنفيذي على قوة ذاتية تعطي الحق في التنفيذ بصرف النظر عن وجود الحق الموضوعي(0). والواقع أنه طبقا للتطورات الحديثه قد يصدر السند التنفيذي عن الإرادة الذاتيـة لأطر اف السند، فـلا يشترط أن يتــخل موظف عـام في تكوين السند التنفيذي.

(1) PRÉVAULT, L'évolution de l'exécution forcée en droit français, Dr. et proc. 2001.72.

(2) HÉBRAUD, L'exécution des jugements civils, op. cit., p. 170, PUTMAN, La contrainte dans le droit de l'exécution, op. cit., p341.

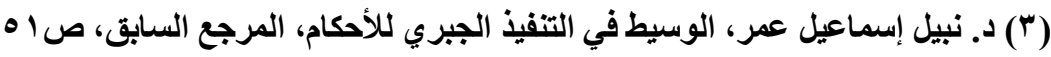

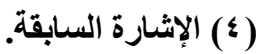

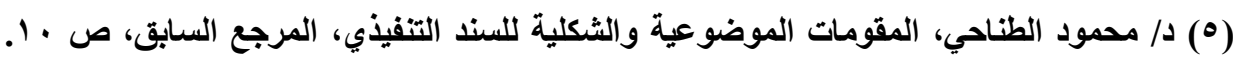

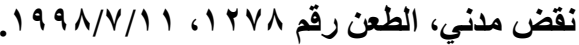


دا طلعت يوسف خاطر

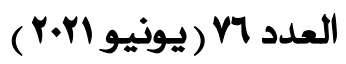

ونرى أن تعريف السند التنفيذي بأنها محرر قانوني لله شكل معين، يتضمن

تأكيدا لحق حال الأداء، ويتضمن قوة تنفيذية.

ثانياً: خصائص السند التنفيذي

السنـ التنفيـي محرر مكتـوب، ومنصوص عليـه في القـانون على سبيل

الحصر (')، ولـه شكل محدد طبقا للقـانون، ووجوده ضروري ولازم وكـاف للبدء في

التنفيذ، ولا يجوز لسلطة التفيذ تعديل مضمونه(؟).

ومن ثم يتميز السند التنفيذي بالخصائص الآتية:

1- السندات التنفيذية محرر مكتوب منصوص عليه على سبيل الحصر

لقد نص القانون المصري والقانون القرنسي في المادة ـ ـ مر مرافعات والمادة

111 T_ تنفيذي، على أن السندات التنفيذيـة منصوص عليها على سبيل الحصر (")،

ومن ثم لا يجوز القياس عليها أو الإضافة إليها باجتهاد الفقه أو القضاء أو بنـاء على اتفاق ذوي الثأن(؛)، ويبطل كل اتفاق من شأنه إضفاء الصفة التنفيذية على محرر لـم

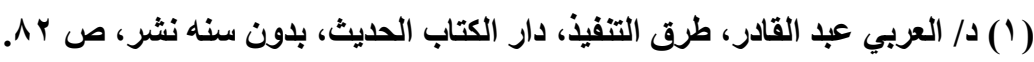

CA Nancy, 15 avr. 2013, RG no 11/02496.

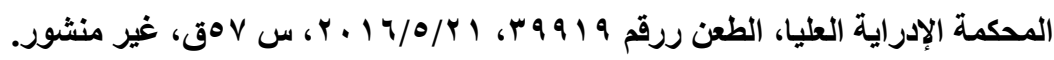

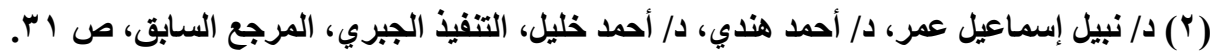

(3) L'article $L$. 113-3 du code des procédures civiles d'exécution énonce clairement que « seuls constituent des titres exécutoires...", CA Nancy, 15 avr. 2013, RG no 11/02496.

(؛) د/ نبيل إسماعيل عمر، د/ أحمد هندي، د/ أحمد خليل، التنفيذ الجبري، المرجع السابق، ص · ب.

Cass. Com. 2 mai 2001, Bull. civ. IV, no 82 ; RTD com. 2001. 773, obs. Vallens. 
يعده المشرع سندا تنفيذيا'(' وترجع الحكمة من حصر السندات التنفيذية إلى رعاية مصلحة الدائن والمدين(؟)، فلا يترك أنواع السندات التنفيذية لتقدير القائم على أمر التر التتفيذ أو حتى أطرافه، بل يـتم البدء في التنفيذ بمجرد تقديم السند المنصوص عليه قانونا، والذي يعد دليلا الكافيا على وجود الدق الموضوعي المطلوب اقتضاؤه(").ومن بـن ناحية أخرى يظلق الباب أمام المدين في إثارته للمنازعات حول نوع السند وشرعيته(؛). كما أن السندات التنفيذيـة محررات مكتوبـة، فلم يعترف المشرع المصري أو الفرنسي بالسند التفيذي الشفوي، حيث يجب أن يتضمن السند بيانـات نُصَّ عليها المشرع. وقد ذهب الفقهـ إلى وجـوب تـوافر معيـارين في السند التفيذي ()؛ معيـار موضوعي، وآخر شكلي، فالمعيار الموضوعي يتمثل في الحق الموضوعي الذي يجري

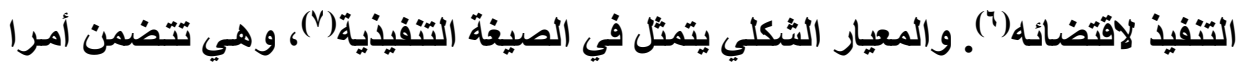

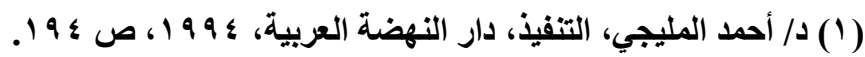

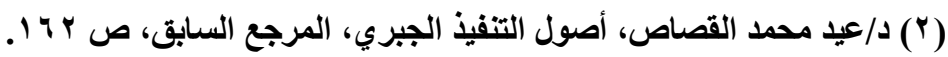

Cass. Civ. 2e, 18 oct. 2007, Bull. civ. II, no 234; Cass. Civ. 2e, 17 oct. 2013, Dr. et proc. 2013. 285, note Vinckel.

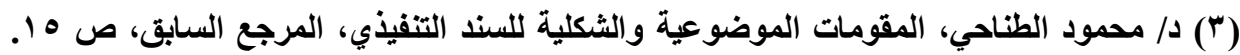

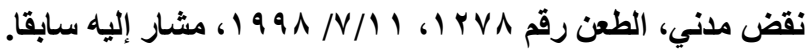

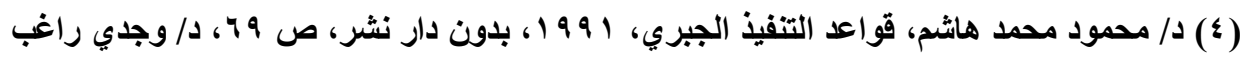

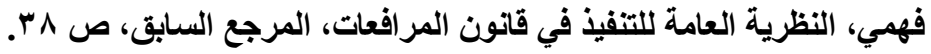

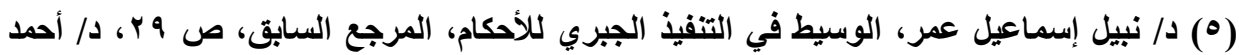

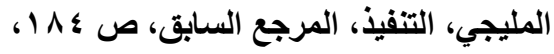

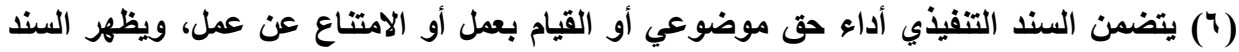

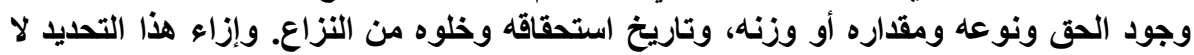

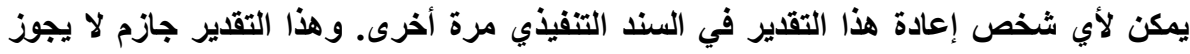
مراجعته أو تعديله إلا باتباع طرق المراجعة التي نص عليها القانون.

(7) Didier CHOLET, Exécution des jugements et des actes, op. cit., n. 29. 
لمعاون التنفيذ بإجراء التنفيذ وأمرا إلى رجال السلطة العامـة بمعاونتهم (')، فلابد من اجتماع المعيارين معا للوجود الفعلي للسند التنفيذي (†). r - السند التنفيذي مفترض للحق في التنفيذ الجبري

لا يمكن إجراء التنفيذ بغير سند تتفيذ(")، لأنه الوسيلة الوحيدة التي اعدّها القانون مؤكدة لوجود حق الدائن في التنفيذ الجبري (؛)، ومـا عدا الحسالات الاستثنائية

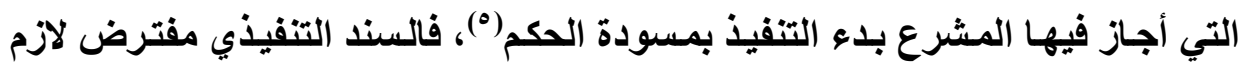
وضروري وكاف للتفيذ الجبري(")، ويؤدي إلى إبعاد أي تعسف في التنفيذ سواء من جانب الدائن أو المدين أو السلطة القائمة بالتنفيذ الجبري(v) وقد يرى البعض أن السند التنفيذي مفترض على وجود الحق الموضوعي قبل

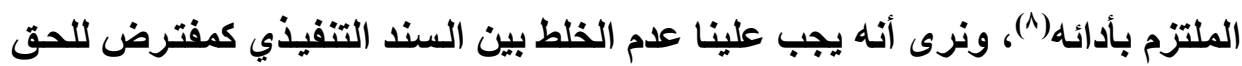
في التنفي، والسند التنفيذي كلاليل على الحق الموضوعي؛ فالسند التنفيذي دليل ليس

(1) دا وجدي راغب فهمي، النظرية العامة للتنفيذ القضائي في قانون المرافعات، المرجع السابق، ص .07

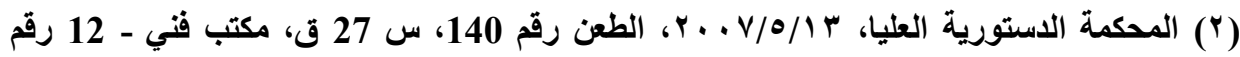

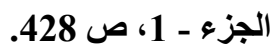

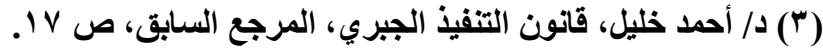

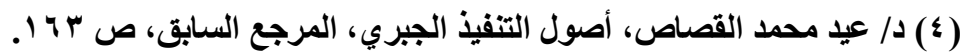

(5) art. 503, al. 2, C. pr. civ. Cass. Civ. 2e, 30 janv. 2014, D. avocats 2014. 114, obs. Royer.

(6) art. 495, al. 2. C. pr. civ., CA Paris, 5 nov. 1958, JCP 1958. II. 10893.

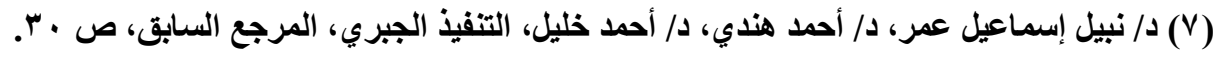

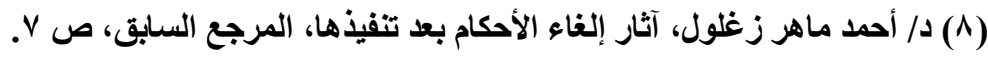


يقينيا كاملا على وجود الحق الموضوعي، ولكنه يقين نسبي (')، وهذا اليقين النسبي يؤدي إلى إمكانية البدء في التنفيذ()، وقد يُلفي هذا الحق في مرحله الطعن بالنقض، أو

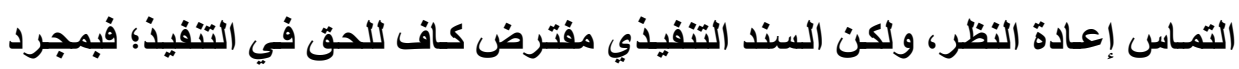
توافر السند التففيذي يكون للائن حق في بدء إجراعات التنفيذ دون أدنى مسئولية مـا لم يكن تنفيذا معجلا. إذن السند مفترض للحق في التنفيذ(")، ومصدر منشئ لحق التنفيذ

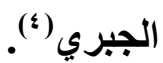

ونتيجة لذلك، إذا باشر إجراعات التنفيذ بدون سند تنفيذي تتوفر فيه مقتضيات

موضوعية وشكلية(ْ)، فيكون للمدين أن يستشكل في التنفيذ، وتكون جميع إجراءات التنفيذ باطلة"). وكما يجب أن يتوفر السند قبل البدء في التتفيذ، فلا يغتي عن السند أي وسيلة أخرى لإثبات الحق في التنفيذ مهما كاتت حاسمة مثل الإقرار أمام جهة التنفيذ.

(1) د/ فتحي والي، التنفيذ الجبري، المرجع السابق، ص • با، د/ أحمد المليجي، التنفيذ، المرجع

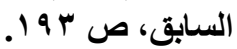

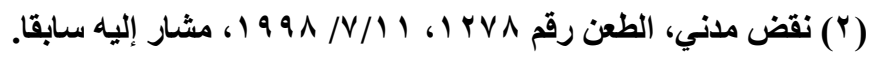

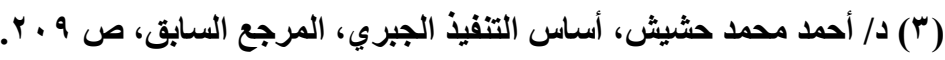

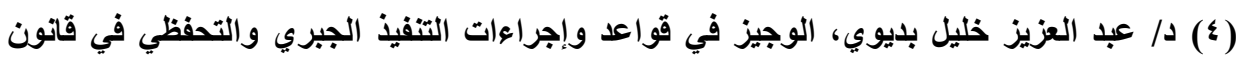

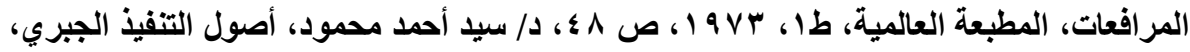

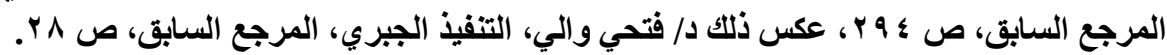

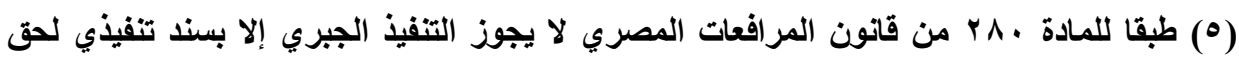

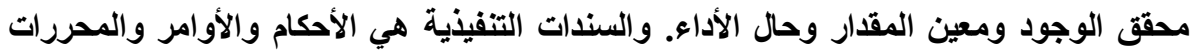

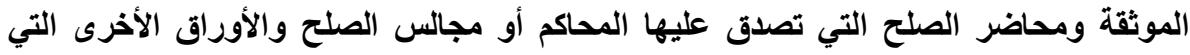

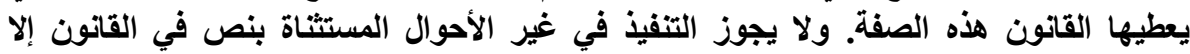
بموجب صوره من السند التنفيذي عليها صيغة التنفيذ.

Didier CHOLET Exécution des jugements et des actes, op. cit., n0 30.

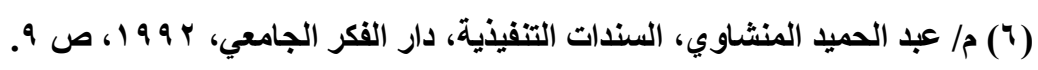

Didier CHOLET Exécution des jugements et des actes, op. cit., n0 32 


$$
\text { ب- السند التففيذي عمل إجرائي شكلي }
$$

هذه الطبيعة الإجرائية الشكلية للسند التنفيذي هي التي تميزه مـن الناحية القنيـة مـن الأعمـال القانونية التي ليس لها طبيعة إجرائية(')، وهـي التي تفسر من فن الناحية التشريعية إدراج قواعده ضمن قواعد قانون المرافعات(؟) وفي الواقع تتميز الإرادة الإجرائية في السند التنفيذي بطابعها العام(")، وهذه الطبيعة العامة هي التي تفسر خضوعه لنظام الإصدار الذي تتميز به الأعمال القانونية

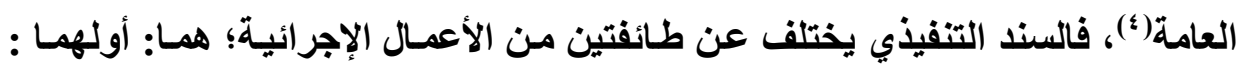
الأعمـال الإجرائية ذات الطـابع الخـاص، مثل صـحف الـدعاوي والإعلانـات ومقدمات التنفيذ وإجراءاتـه التنفيذ، والإقرار القضائي وغيرهـا من الأعمـال، والقاعدة أن هذه واله الأعمال تخرج عن فكرة السند التنفيذي. وثانيهــا: الأعمـال الإجرائية الأخرى كحكم التحكيم، فهذه الأعمال تخرج عن فكرة السند التنفيذي، فحم التحكيم لا يصلح أن يكون سندا تنفيذيا إلا بعد استصدار أمر بتنفيذه، وسلطة القاضسي الأمر بالتتفيذ تقتصر على

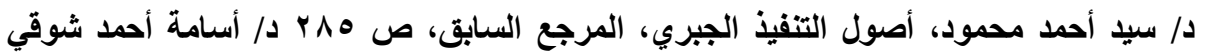

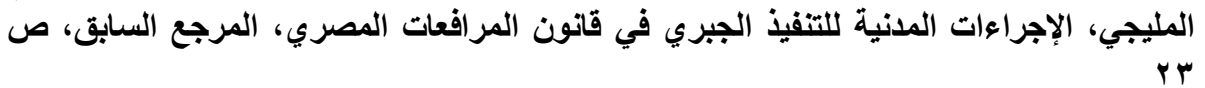
(1) دا وجدي راغب فهي، النظرية العامة للتنفيذ القضائي في قانون المرافعات، المرجع السابق، ص

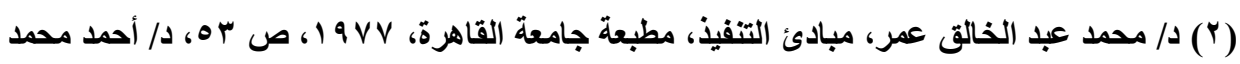

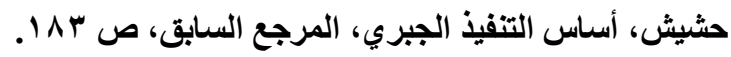

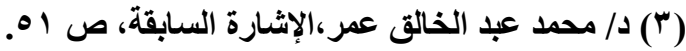

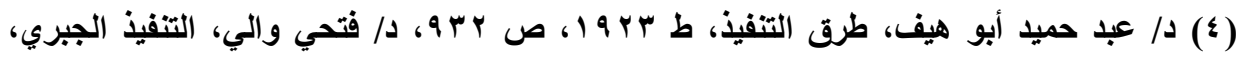
المرجع السابق، ص لو هو، د. نبيل إسماعيل عمر، الوسيط في التنفيذ الجبري للأحكام، المرجع

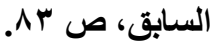


التحقق من خلو الحكم من بعض العيوب الثكلية، ويؤدي ذلك إلى رفع حكم التحكيم إلى مصاف الأعمال الإجرائية ذات الطابع العام، وهذا يجعل حكم التحكيم سندا تنفيذيا بشكله

\section{الفزرع الثانتي \\ لمة تاريخية عن نشأة السند التنفيدي}

تظهر أهمية الاراسة التاريخية لنظام من النظم القانونية، إذا ما سـلمنا بحقيقة أولية هي أن الجديل وليد القديم، وينبثق منـه، ويحمل آثـاره وانعكاسـاته، فمـا من نظـام قانوني حديث إلاو وعليه بصمات النظم السابقة عليه.

لقد كان التنفيذ في المجتمعات القديمة متروكا للائن بحيث يقتضي حقه بنفسه باسـتخدام القوة، فكـان يتسلط على نفس المدين ومالـه بالقدر الذي تسمسح بـه قوتـه الأتية، بحيث يمكنه أن يأخذ أكثر من حقه(')، قديما لم يكن السند التنفيذي متعارفا عليه بالثكل الحالي في القوانين الحديثة(؟).

ففكرة السندات التنفيذية حديثة في التشريع ولكنها وليدة تطورات تاريخية(")،

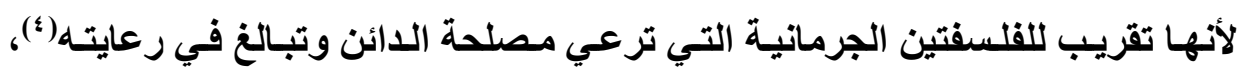

(1) د/ الأنصارى حسن النيداني، التنفيذ المباشر للسندات التنفيذية، المرجع السابق، ص 9.

(2) GUINOT, Aperçu historique de la formule exécutoire, Dr. et proc. 2010, supplément au no 11. 2; Civ. 2e, 11 oct. 1963, Bull. civ. II, no 616.

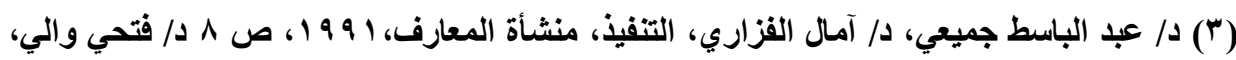

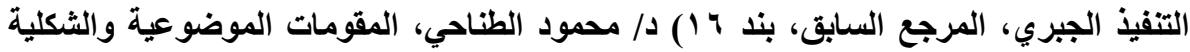

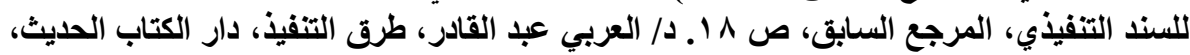

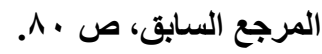

(؛) قد كان السند التنفيذي يأخذ الثكل العرفي عند القبائل الجرمانية، وقد تميزت الإجراءاءتات في النظام الجرماني بالشكلية الجامدة، وقد كانت تستخدم طرق للإثبات غير منطقية مثل الامتحان الإلهي 


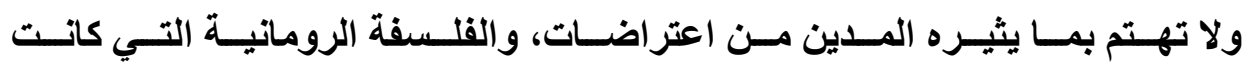

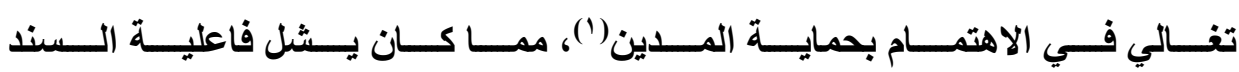

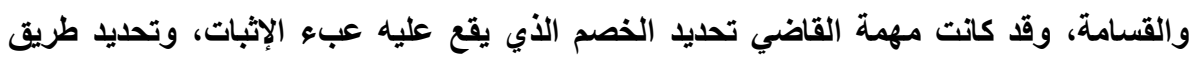

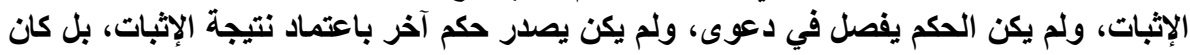

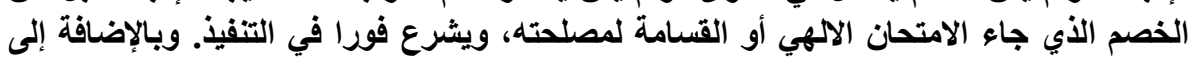

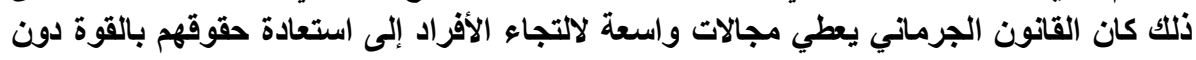

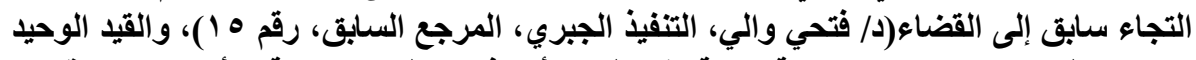

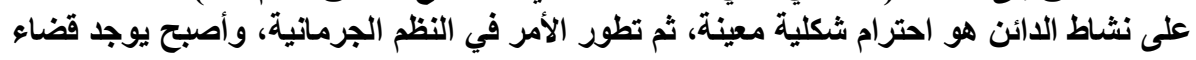

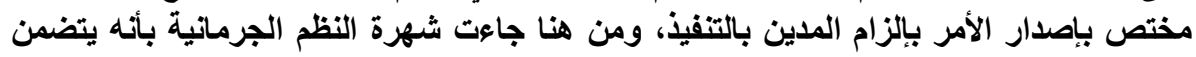

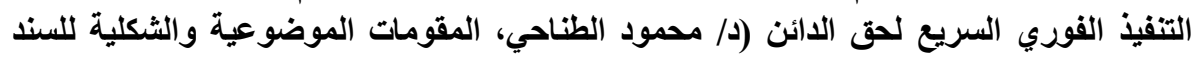

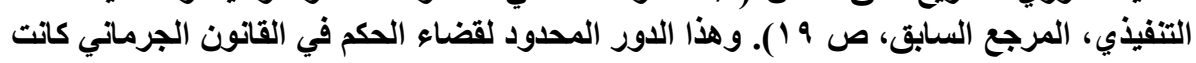

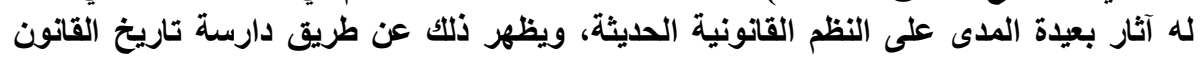

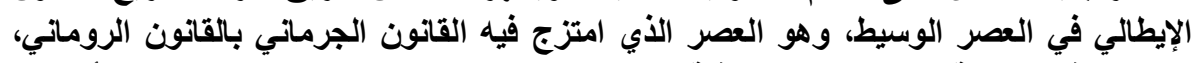

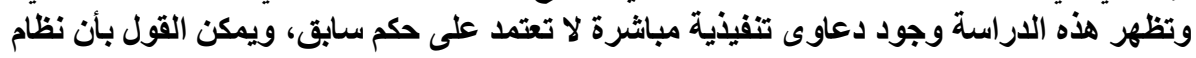

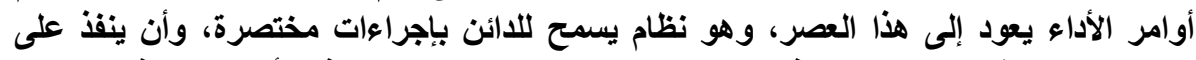

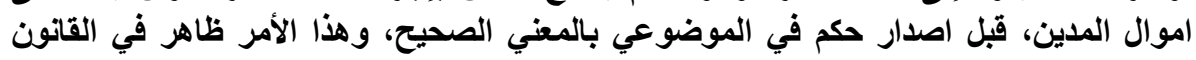

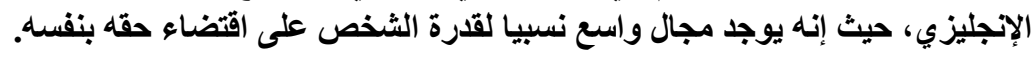

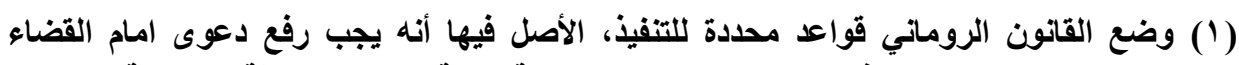

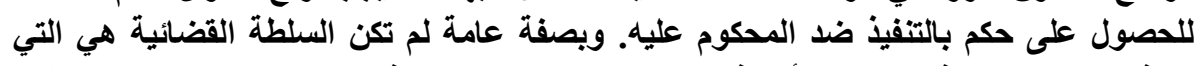

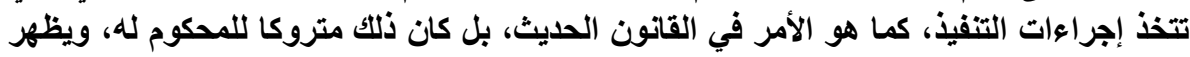

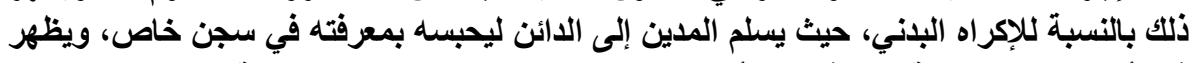

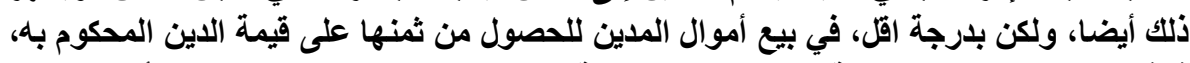

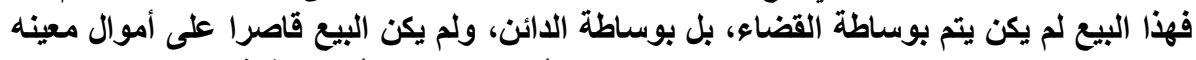

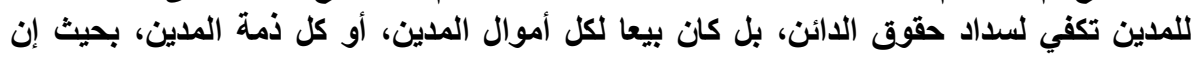

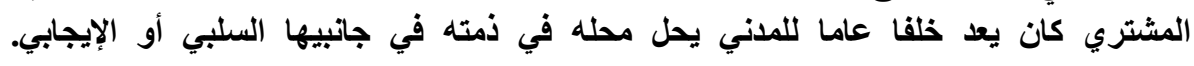
Besniers, Cours d'histoire des institution et des faits sociaux, les cours de droit 1955, p. 829.

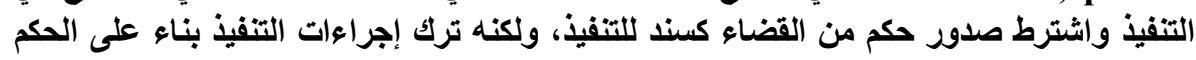

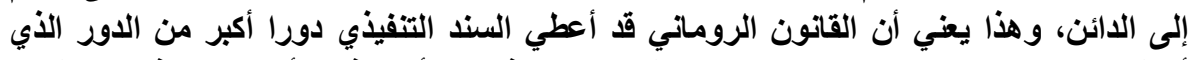

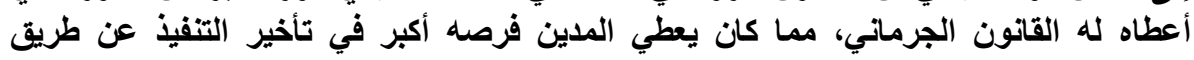

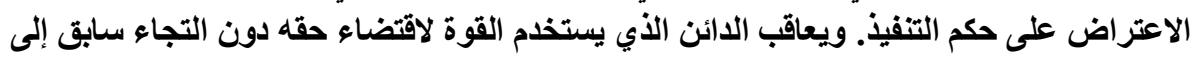
$=$ 


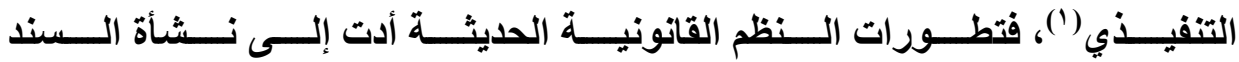

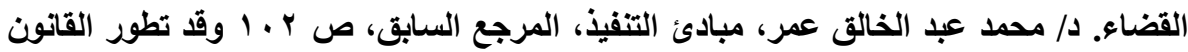

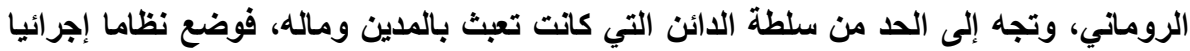

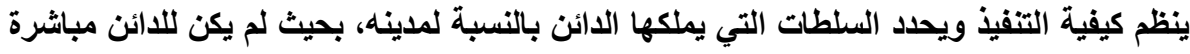

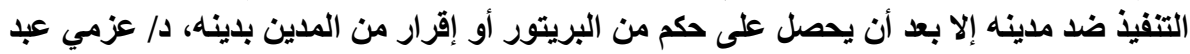

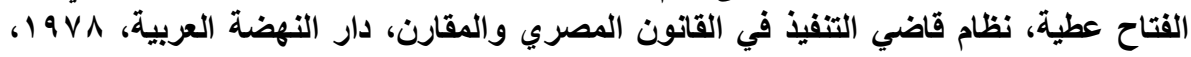

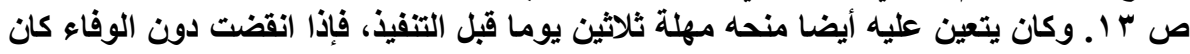

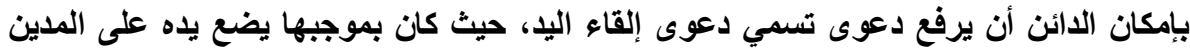

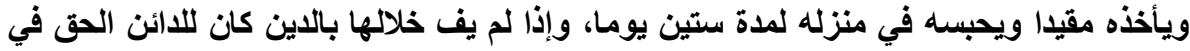

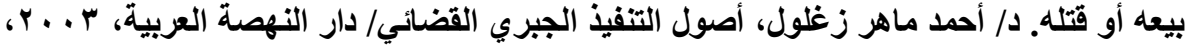

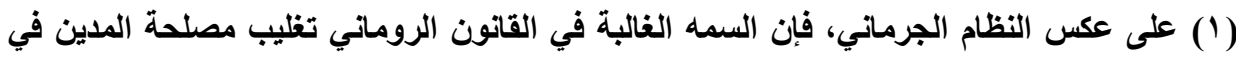

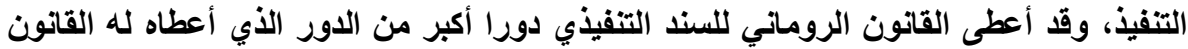

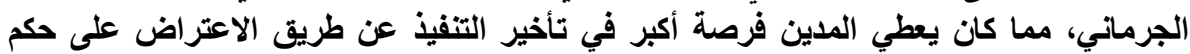
التنفيذ، (Besniers, Cours d'histoire des institution et des faits sociaux, les cours de droit 1955, p. 829)

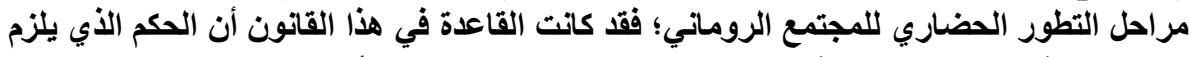

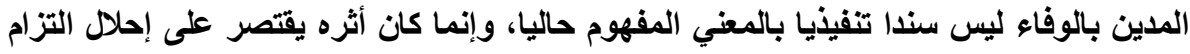

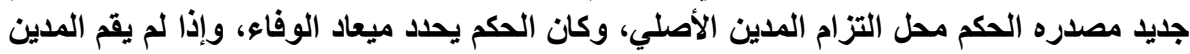

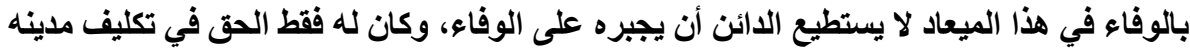

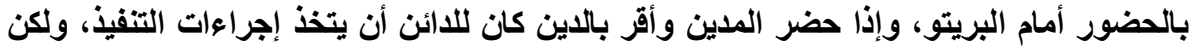

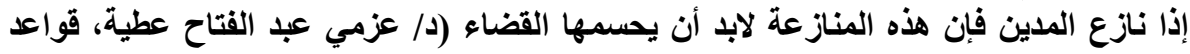

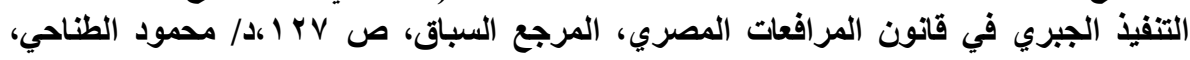

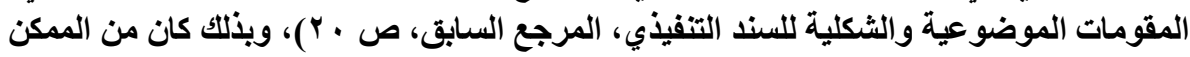

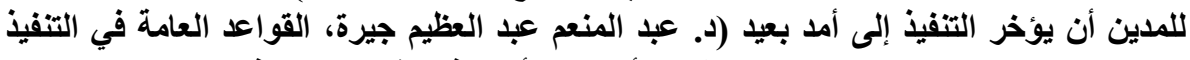

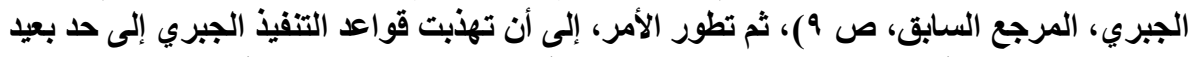

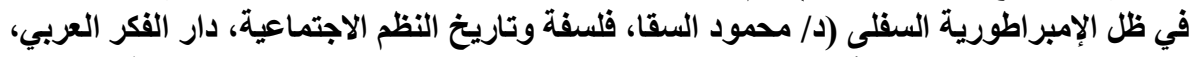
19VA

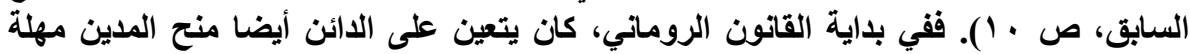

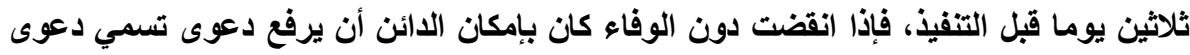
$=$ 
التنفيذي (')، وأصبح المبدأ يتمثل في وجد الحق في التنفيذ إذا كـان في يـ الدائن سند

فظهرت فكرة السند التنفيذي مـن أجل التوفيت بـين اعتبـارين متناقضين؛

الاعتبار الأول: هو مصلحة الأئن في تنفيذ سريع وفوري لحقه دون تعنت من المدين،

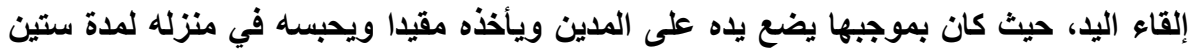

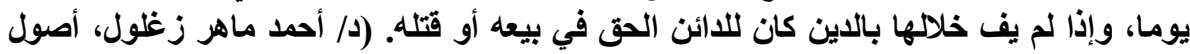

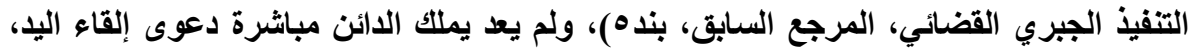

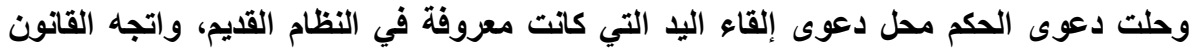

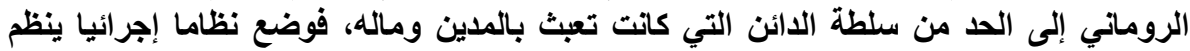

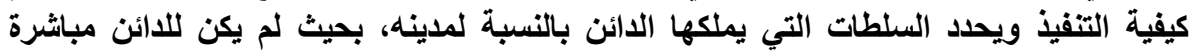

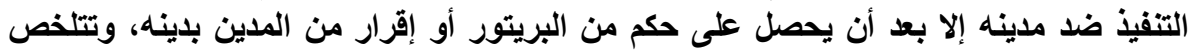

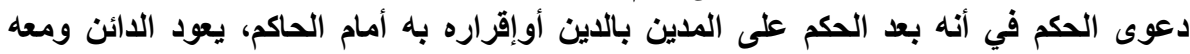

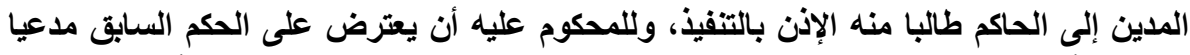

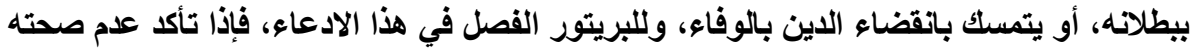

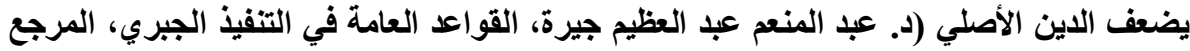

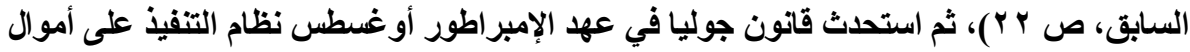

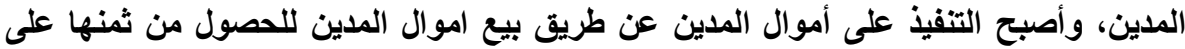

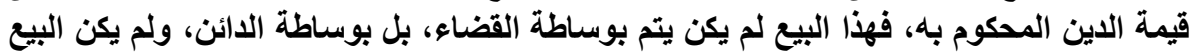

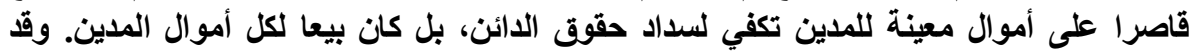

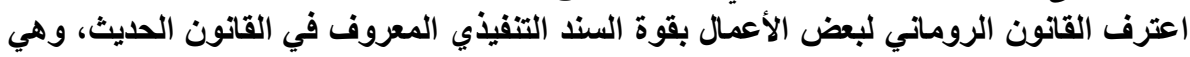

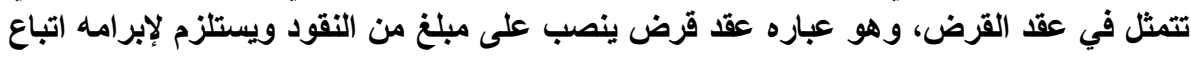

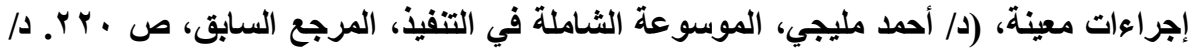

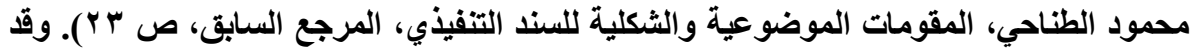

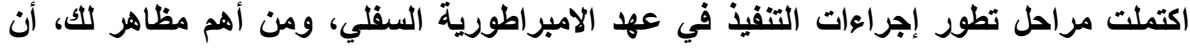

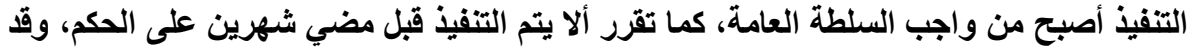

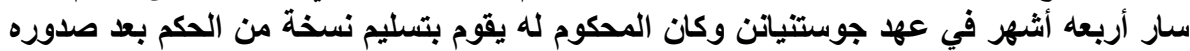

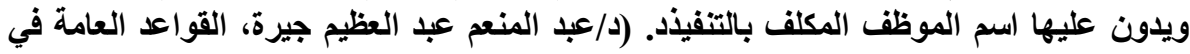

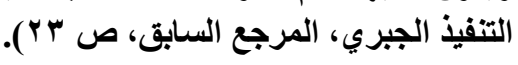

( ) د/عيد محمد القصاص، أصول التفيذ الجبري، المرجع السابق، ص • r. 
وهذه المصلحة تتطلب ألا يهتم الموظف القائم بالتنفيذ بـأي اعتراضـات يبديها المدين. والاعتبار الآخر، مصلحة المدين في منحه القدرة في المنازعة في التنفيذ إذا كان هنـاك

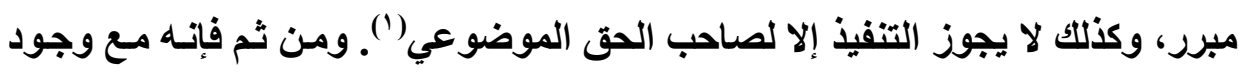
السند التنفيذي لا توجد أي وسيلة لتعسف الدائن أو المدين()، وذلك لأنه لن يدعي أحد مـع وجود السند تقديرا مخالفـا لمساورد بـه، وذلك لاعتبار العدالـة التي تقتضي عدم السماح بالتنفيذ إلا لصـاحب الحق الموضوعي، ولأن التنفيذ يؤدي إلى آثـار وخيمـة بالنسبة للمدين تصل إلى حد نزع مالهه، ولذلك يجب السماح لله بالمنازعة فيه إذا كان له له مبرر، وقد وقفت فكرة السند التفيذي بين هذين الاعتبارين المتناقضين بحيث لا يطفى أحدهما على الآخر كما يحدث في النظم القديمة'(") وبالنسبة لموقف الشريعة الإسـلامية مـن اشتراط السند التنفيذي للبدء في التنفيذ، نجد أن امتناع المدين عن الوفاء بالدين اختياريا يرتب في ذمته مسئولية دينية

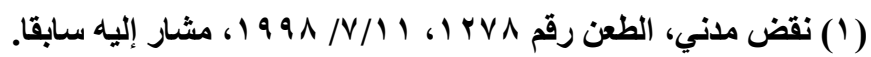

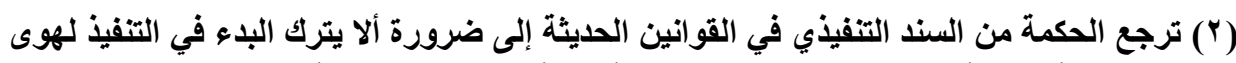

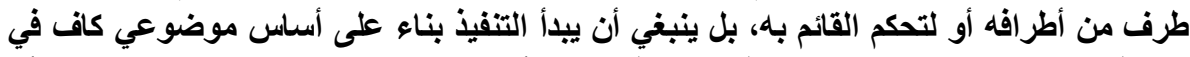

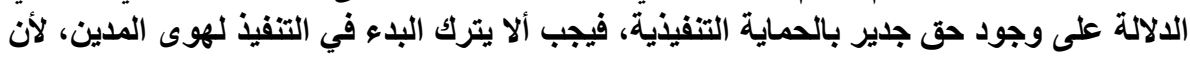

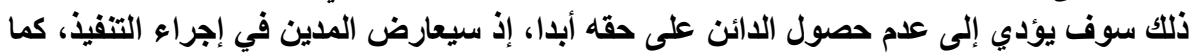

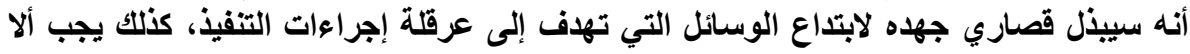

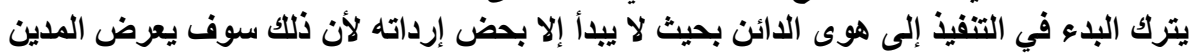

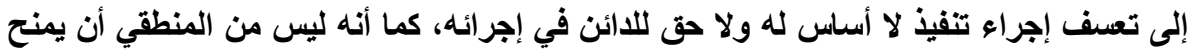

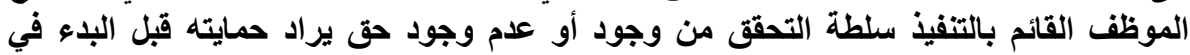

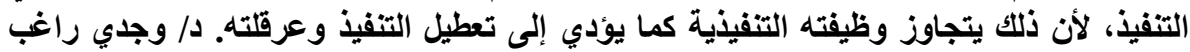

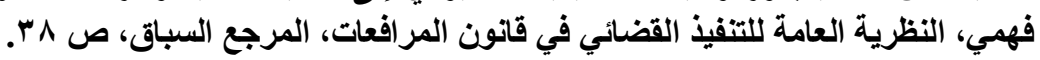

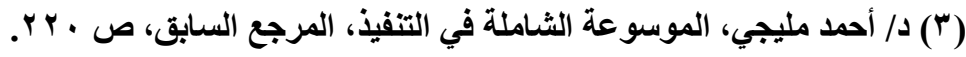


ودنيوية(')، فقد ورد الأمر بالوفاء صريحا وقاطعا في عديد من آيـات كتاب الله الحكيم؛ فقد جاء في سورة المائدة في قوله تعالي: " يا أيها الذين آمنـوا أوفوا بـالعقود"، ومـن المتفق عليه بين فقهاء المسلمين أنه إذا لم يتمثل المدين للوفاء فللدائن أن يطلب من بن القاضي إجباره على ذلك(). وقد اختلفت المـاهب الفقهيـة الإسـلامية في تحديــ مـدى حق الشخص في اقتضاء حقوقهه دون الالتجـاء إلى القضاء للحصول على سـند تنفيذي بين التضييق والتوسع("). والقاعدة في الشريعة الإسـلامية هى أن صساحب الحق لا ينتصف لنفسه،

(1) د/ عزمي عبد الفتاح عطية، نظام قاضي التنفيذ في القانون المصري والمقارن، المرجع السابق، ص IV

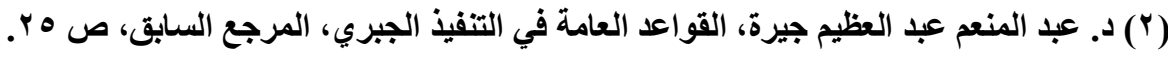

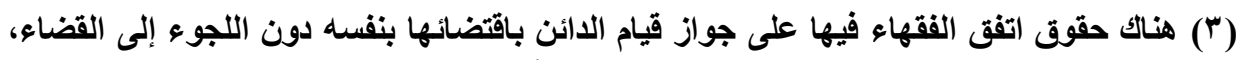

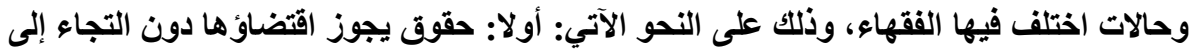

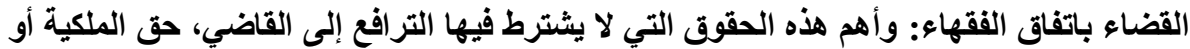

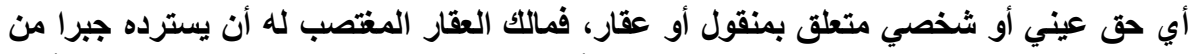

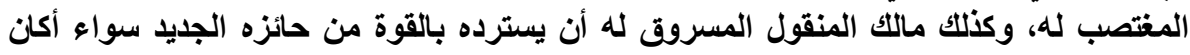

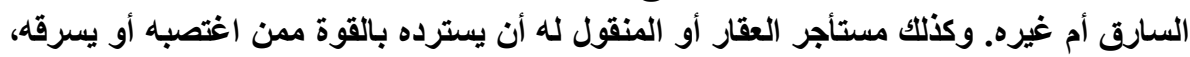

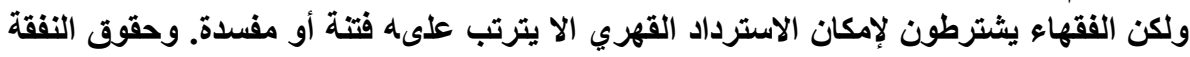

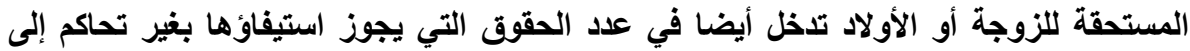

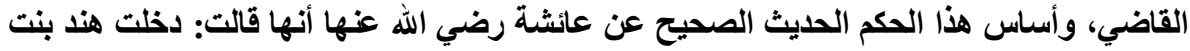

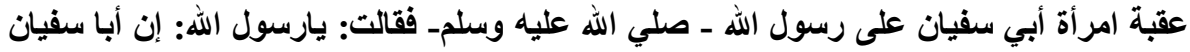

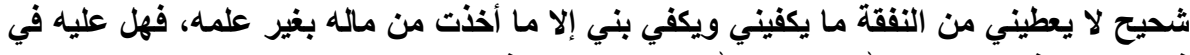

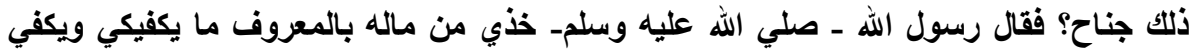

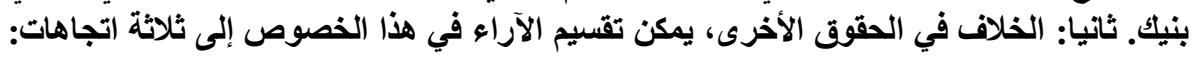

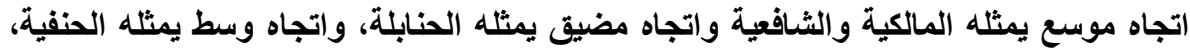

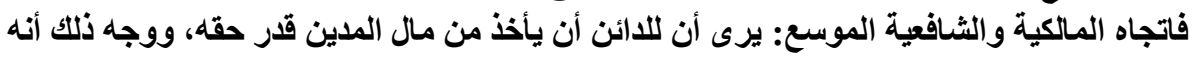

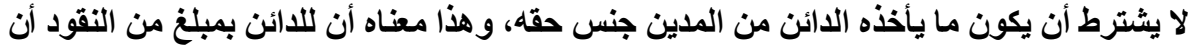

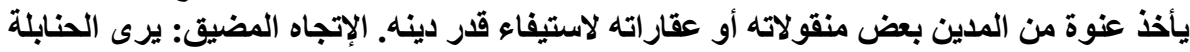

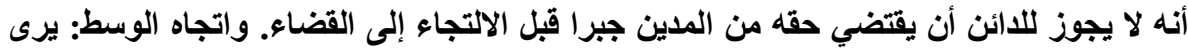
$=$ 


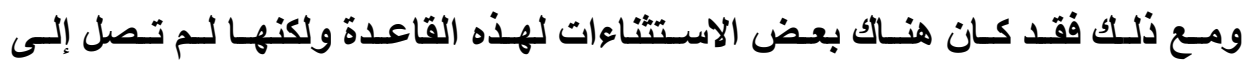

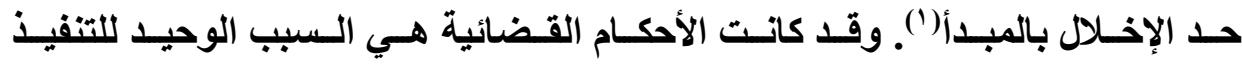
الجبري، ولـم تعرف الشريعة غيرهـا؛ إذ لـم تعرف المحررات الموثقــة أو غيرهـا مـن

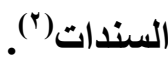

ونخلص من ذلك إلى تظور نظام السندات التنفيذية عمـا كاتت عليه في النظم

القديمة،، وأصبحت في العصر الحديث تتمثل في عدم التنفيذ بـون سند تنفيذي(").

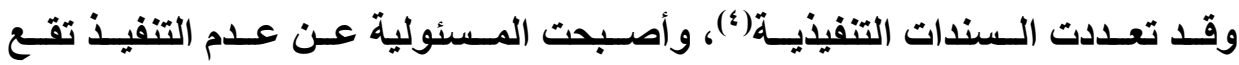
بقوة القانون بمجرد عدم القيام بالتنفيذ الاختياري(ْ).

الحنفية أنه يجوز للائن أن يأخذ جنس حقه دون ترافع إلى القضاءو، فاذا كان الدائن دنانير ووجد

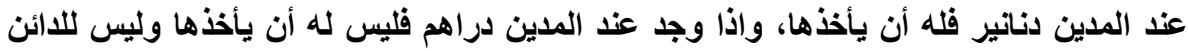

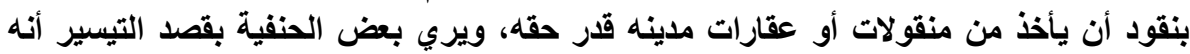

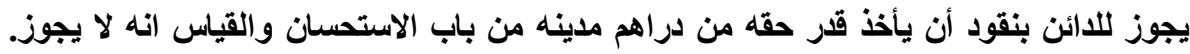

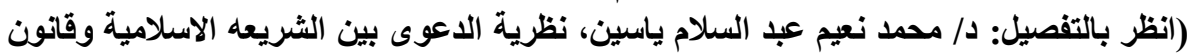

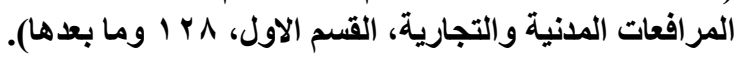

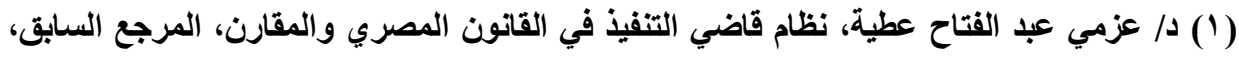

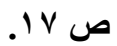

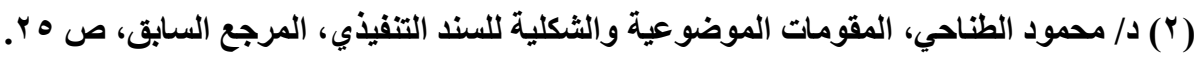

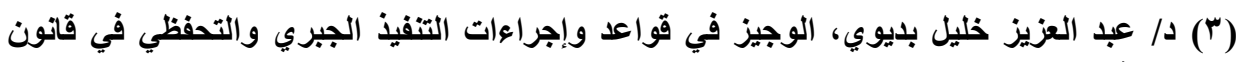

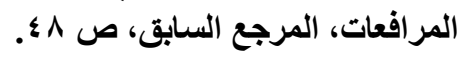

(؛) د/ عزمي عبد الفتاح عطية، نظام قاضي التنفيذ في القانون المصري والمقارن، المرجع السابق، ص r T

(5) R. PERROT et Ph. THÉRY, Procédures civiles d'exécution, op. cit., p. 139 


\section{الاطلب الثاني \\ هضمون السند التنفيذية ووظيفته}

إذا كان الحق في التنفيذ ينشأ من السند التنفيذ، فِان هذه الفكرة تحدها فكرة أخرى هي أن وجود هذا الحق منوط باستمرار الحق الموضوعي قائمال'، وإذا كان في

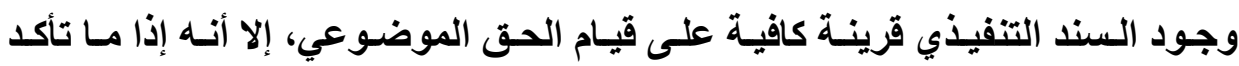
انقضاء الحق الموضوعي لأي سبب من الأسباب لـم يعد وجود السند التنفيذي كافياً بذاته للقول باستمرار الحق في التنفيذ قائما، فزوال الحق الموضوعي يؤدي إلى زوال القرينة التي يحملها السند التنفيذي وتسقط صـلاحيته للتنفيذ، لأن ذلك يتفق وحكمة المشرع من نظام السندات التنفيذية؛ والتي تثمثل في توفير الضمان الكافي للمدين في

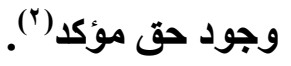

وسنشير في هذا المطلب إلى مضمون السند التنفيذي، وذلك في الفرع الأول، ثم نبين وظيفته، وذلك في الفرع الثاني، وذلك على النحو الآتي:

\section{الفرع الأول \\ هضمون السند التنفيذي}

لقد اختلف الرأي في الفقـه حول تحديد مضمون السند التنفيذي(")؛ فذهب البعض إلى أن مضمون السند التنفيذي يقوم على عنصر التأكيد للحق الموضوعي (')،

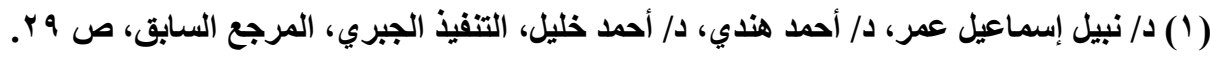

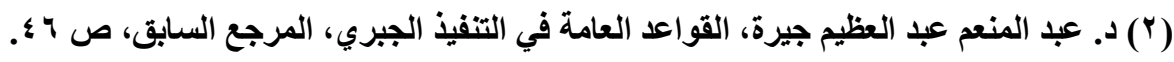

(3) R. PERROT et Ph. THÉRY, Procédures civiles d'exécution, op. cit., no 129, p. 139 
وهذا التأكيد القـانوني لـه وجود مستقل وقـائم بذاتـه بصرف النظر عن وجود الحق الموضوعي في الواقع، فالقانون أضفى على السند التنفيذي قوة ذاتية تحمي الحق الذي

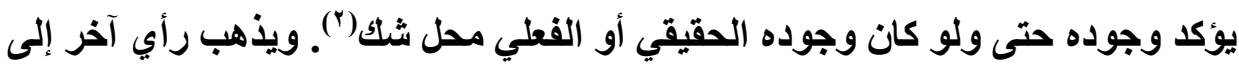
أن مضمون السند التنفيذي الذي يفسر قوتـه التففيذيـة، يتمثل في إعلان عن إرادة الثخص القائم به والمزود بسلطة في التتفيذ(")، وذهب هذا الرأي إلى نفي أن يكون الصفة التأكيديـة للحق تشكل جوهر أو مضمونه، فالسند التتفيذي وإن كـان يتضمن تأكيدا لوجود حق موضوعي، فهو ليس سوى مقدمة منطقية للسند التنفيذي وسبيا للإرادة المكونة له والمنشئة لقوته التنفيذية، ويذهب اتجاها ثالث إلى أن للسند التنفيذي مضمونـا مزدوجـا، فهو يتضمن تأكيدا لحق تتـوافر فيه الشروط التـي تجعله جديرا بالتنفيذ(")، حيث يتضمن السند تحديد أطرافه وموضوعه(') هويجب أن يصدر هذا التأكيد من جهة خولها القانون سلطة تكوين السند التنفيذي(؟).

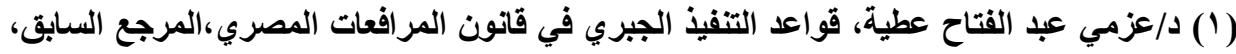

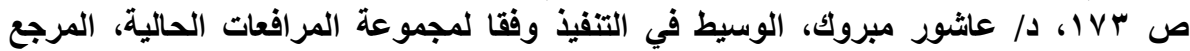

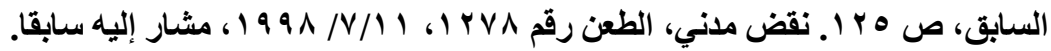

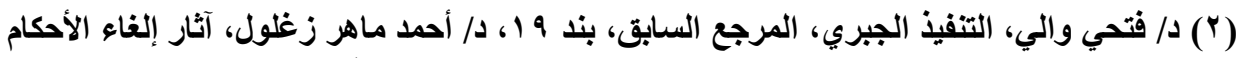

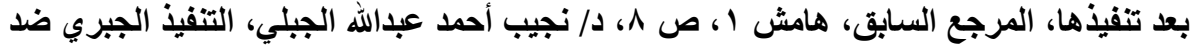

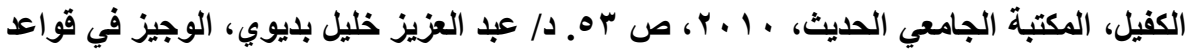

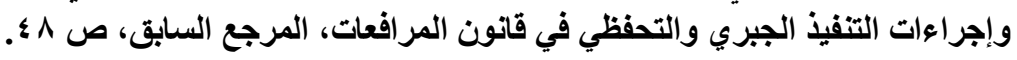

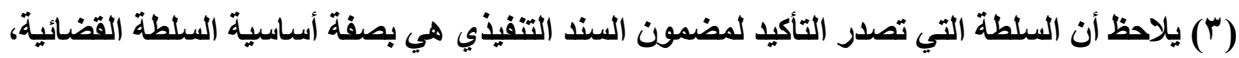

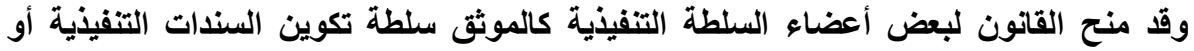

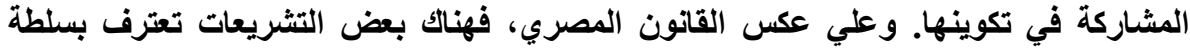

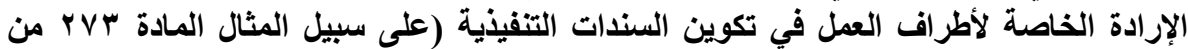

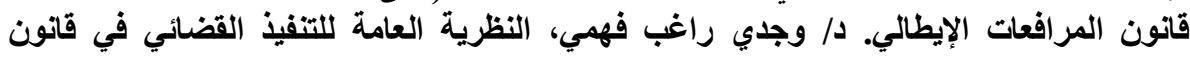

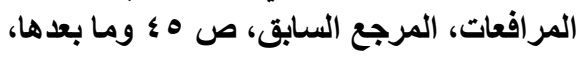

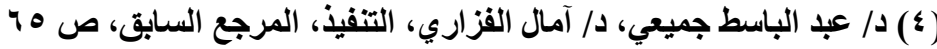


وفي حقيقة الأمر نرى أن مضمون السند التنفيذي يتكون من ركنين؛ أولهمـا: الركن الموضوعي وهو وجود تأكيد لإلزام(")، والركن الشكلي: وهو وجود شكل معين نص عليه القانون ويتمثل في الصيغة التنفيذية، ووجود سلطة تعبر عن إرادة، فهي لا تتلخل في تكوين السند التنفيذي، وذلك لأن مصدر هذه السلطة هو المشرع، فالمشرع هو مصدر أساسي لتكوين السند التنفيذي وليس السلطة التي أصدرته سواء سلطة قضائية أو أحد أعضاء السلطة التنفيذيـة أو غير ذلك؛ إذ يعد السند التنفيذي عمـلا قانونيا شكليا، فهو يتكون من ركنين؛ المضمون وهو العمل القانوني، والشكل وهو الصورة التنفيذية؛ ويحول هذا التحليل دون قبول الرأي الذي لايرى في السند التفيذي إلا شكله باعتباره مستتدا يذل على الحق على نحو كاف للتنفيذ(؛). وسنشير إلى الركن الموضوعي، والركن الشكلي في السند التنفيذي؛ وذلك في

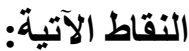

الأول: الركن الموضوعي

الركن الموضوعي للسند التنفيذي يتضمن تأكيدا لإلزام الموضوعي، ولا يقصد

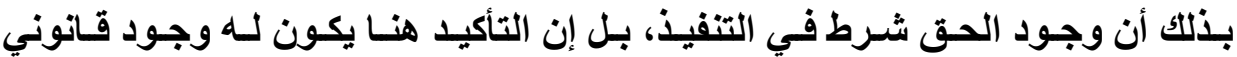
مستقل (0)، فكما أن الحكم يكون له حجية بصرف النظر عن وجود الحق الموضوعي،

(1) Cass. Civ. 2e, 15 janv. 2004, Bull. civ. II, no 9.

(ץ) د/أحمد ماهر زغلول، أصول التنفيذي، مكتبة وهبة، طץ، 9191 1)، بند ه.

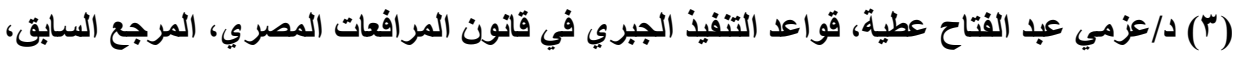
ص ص أl

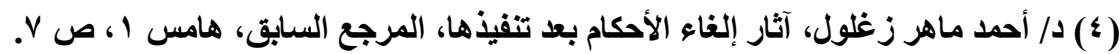

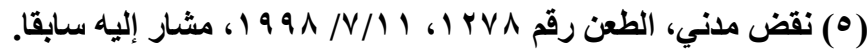


فكذلك يكون للسند التنفيذي قوة تأكيدية لوجود حق بصرف النظر عن هذا الوجود في الواقع، فالمشرع أخذ في اعتباره بالنسبة للتنفيذ ليس وجود الحق الموضوعي في

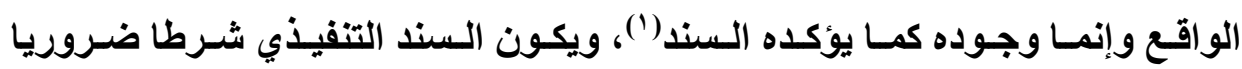
وكافيا للتنفيذ(؟)، فمحل السند التنفيذي هو حق إجرائي، وليس الحق الأصلي المعتدى عليه.

ويشترط في السند التنفيذي أن يتضمن إلزامـا بحق محقق الوجود(") ومعين

المقدار(؛) وحال الأداع، دون أهمية لسببه أو منشئه أو مقداره، فلو كان مبلغ الدين أقل أنل

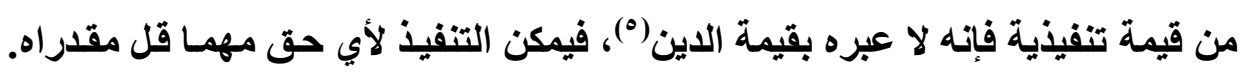
وبصرف النظر عن صفة الدين سواء أكان عاديا أم مضمونا برهن، فهذه الخصائص ليست شرطا في الحق في التنفيذ. وأهمية شروط الحق الموضوعي أن يكون المـين على علم بما عليه من ديون ليقوم بدفعها. ومقدار حق الدائن من أجله الكف عن البيع الجبري عندما يصل إلى نصاب حق الدائن. ويجب توافر هذه الشروط عند البدء في التنفيذ وإلا كان التنفيذ باطلاج(").

(1) د/ عبد العزيز خليل بليوي، الوجيز في قواعد وإجراءات التنفيذ الجبري والتحفظي في قانون

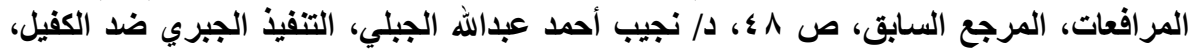

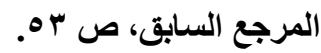

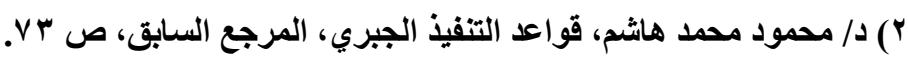

(3) Cass. Civ. 2e, 5 mars 2009, D. 2010. 1307, obs. A. Leborgne.

(4)Cass; Civ. 2e, 8 juill. 2004, Bull. civ. II, no 399.

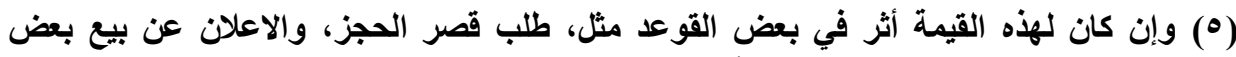

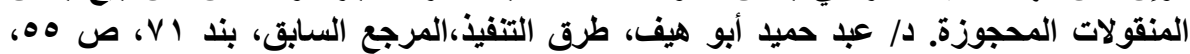

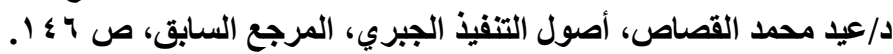

(7) د/ سيد أحمد محمود، أصول التنفيذ الجبري، المرجع السابق، ص 9 و ج. 


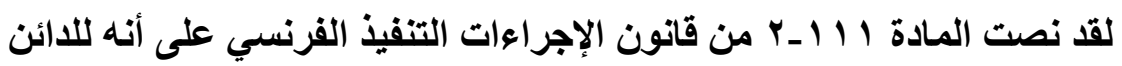
الأي يحوز سندا تنفيذيا يتضمن حقا مؤكدا(') وواجب الأداع(') يملك اتخـاذ إجراعات التنفيذ الجبري على مال المدين طبقا لإجراءات التفيذ المختلفة". ومن ثم يشترط طبقا لهذا النص أن يكون حق الدائن خاليا من النزاع وواجب الأداء(")، فيلاحظ أن المشرع هُع الفرنسي لم يشترط أن يكون حق الدائن معين المقدار كما نص المشرع المصري عليه في المادة • r r مرافعات، بل اكتفى بشرطين هما: خلوه من النزاع أي محقق الوجودد، وواجب الأداع(؛). وفي الواقع لا يمكن للائن أن يطلب من قاضي التنفيذ أن يحدد لـه مقدار دينه، فيجب أن يكون حق الدائن محدد المقدار، وهذا مـا جرى عليهه القضاء الفرنسي(ْ). وفي حالة الالتزام بعمل أو الامتناع عن عمل يكون خاضعا للتنفيذ الجبري أيضا(")، ولكن إذا تطلب التنفيذ التدخل الثخصي للمدين وامتتع عن التتفيذ فيتحول

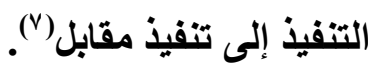

(1) Cass. Civ. 2e, 22 oct. 2009, Bull. civ. II, no 254 ; Dr. et proc. 2010. 86, note Léon.

(2) Cass. Civ. 2e, 21 janv. 1998, Bull. civ. II, no 24. Cass. Civ. 3e, 6 déc. 2006, Bull. civ. III, no 246.

(3) Didier CHOLET Exécution des jugements et des actes, op. cit., n0 31,

(4) Id.

(5) TGI Nantes, JEX, 18 févr. 2002, Dr. et proc. 2002. 303, note Putma; Cass. Civ. 2e, 22 mars 2001, Bull. civ. II, no 61 ; Cass. Civ. 2 e, 19 nov. 2008, Bull. civ. II, no 253; Cass. Civ. 2e, 7 janv. 2010, D. 2010. Pan. 1311, obs. Leborgne.

(6) Cass. Civ. 1re, 16 janv. 2007, Bull. civ. I, no 19.

(7) Didier CHOLET Exécution des jugements et des actes, op. cit., n0 32 
وإذا كان السند التنفيذي يتضمن حقا إجرائيا، فإنه يتميز من غيره من الأعمال

الإجرائية بمحله، حيث إن محل السند هو إلزام بالتنفيذ(')، ويتطلب قانون المرافعات

$$
\text { الشصري والفرنسي في الحق الشروط الآتية: }
$$

إن قابلية محل السند للتفيذ مرهونة بوصف معين وهو أن يكون حقا مؤكدا؛

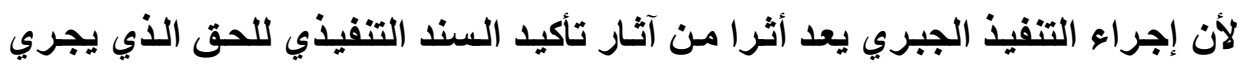

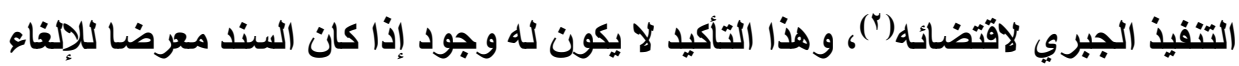
بقابلية للاعتراض عليه بطريق الطعن كالحكم القضائي أو بطريق التظلم كـالأوامر أو بطريق الدعوى كحم المحكمين، ومن ثم لا يكفي وجود الحق؛ إنما يلزم أن يكون إلزاما

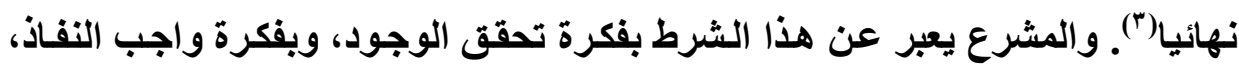
ولذلك يعد الحكم الابتدائي حكما غير واجب النفـاذ مـا لم يكن هذا الحكم مشمولا بنفاذ

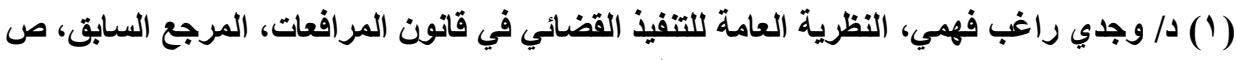

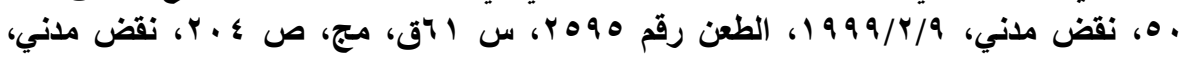
ا

BLÉRY, L'efficacité substantielle des jugements civils, 2000, LGDJ, n. 145 et 162. BAKER CHISS, Contribution à l'étude de l'exécution des jugements civils dans les rapports internes et internationaux de droit privé, thèse, Paris I, 2008, p. 409 s.

(ץ) د/ عبد العزيز خليل بديوي، الوجيز في قواعد وإجراءات التنفيذ الجبري والتحفظي في قانون

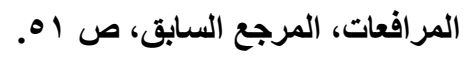

(3) BLÉRY, L'efficacité substantielle des jugements civils, op. cit., n. 145 et 162. BAKER CHISS, Contribution à l'étude de l'exécution des jugements civils dans les rapports internes et internationaux de droit privé, op. cit., p. $409 \mathrm{~s}$ 
معجل(')، ومن ثم فالحكم المعجل يرفع بصفة مؤقتة الحكم الإبتدائي بالتفيذ إلى مصاف الحكم النهائي، ومن ثم يكون هذا الحكم نهائيا حكما لا حقيقة(؟)، فإذا كانت الحجية غير مستقرة فلا يجوز من حيث الأصل التنفيذ.

وقد عبر البعض من الفقه عن هذه الصفة بخلو محل السند من النزاع(")، ويلاحظ أن هذه الصياغة ترتبط بفكرة الحق الموضوعي، فالسند التنفيذي لا يتضمن تأكيدا لوجود حق إلا حق التنفيذ الجبري، وهو حق إجرائس، لذا يرى الفقـه أن فكرة

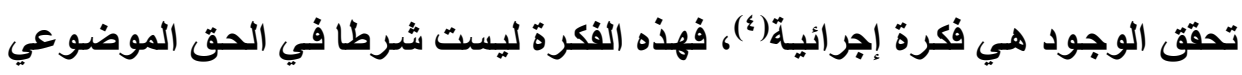
بقر ما هي شرط في السند التنفيذي (ْ). وقد ذهبت محكمة النقض إلى أنه يقصد بالأحكام القابلة للتنفيذ الجبري في معني المادة Y T Y مر افعات أحكام الإلزام التي تصدر في طلب موضوعي لأحد الخصوم،

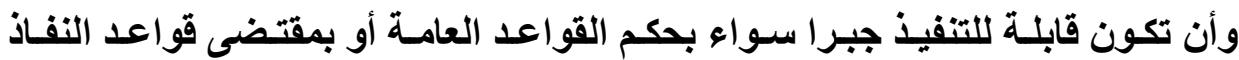
المعجل التي يتعين على المحكوم عليه وفقا لها القيام بعدل أو أعمـال لصالح المحكوم له، فإن نكل عن ذلك تلخلت الدولة في إضفاء الحماية القانونية عليه عن طريق التفيذ

(1) BLÉRY, id.

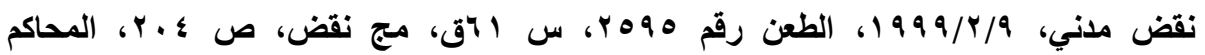

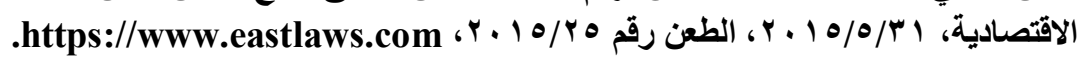

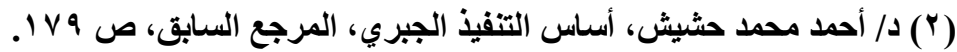

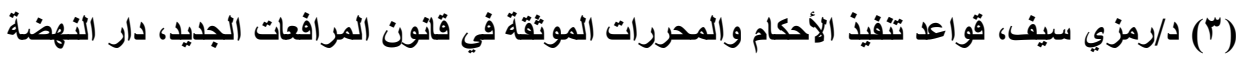

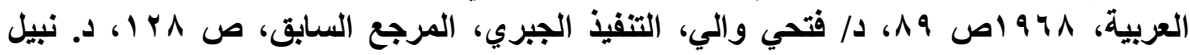

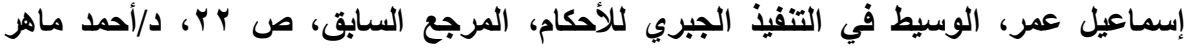

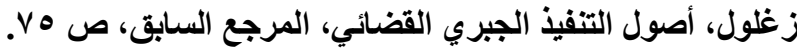

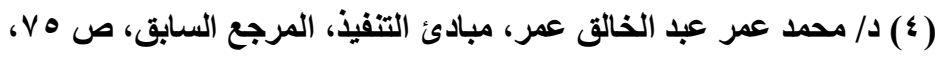

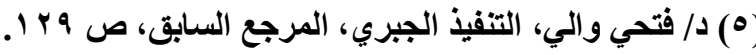


بوسائل القوة الجبرية، وكان المناط في تعرف ما للحكم الصادر من قوة الإلزام هو تفهم

مقتضاه وتقصى مراميه(')

وهنا يثار التساؤل عن الأنظمـة التي تأخذ بـالأوراق التجاريـة والأوراق العاديـة

كسندات تنفيذية، فهل يتحقق فيها شرط التأكيا أو خلوها من النزاع؟

في الواقع الأوراق التجارية والأوراق العادية قد تكون محل نزاع، سواء تعلق بموضوع الورقة أو تعلق بشكل الورقة، ومن ثم رفع دعوى بشأنها، فهذه السندات لا يتحقق فيها شـرط تأكيد الحق محل الورقـة التجاريـة أو العاديـة، ولهـذا ذهب بعض المشرعين إلى منح المدين حق الاعتراض على هذه الأوراق، ورتب على ذلكك وقف تنفيذ إلى أن يفصل القاضي الموضوعي في مدى صحة هذه الأوراق("). الثرط الثاني: أن يكون الحق معينا

يشترط أن يكون محل السند التنفيذي معينـا سـواء مـن الناحيـة الثخصية أو الموضوعية، ويعبر المشرع المصري عن هذا الشرط بفكرة تعيين المقدار("). وقد ذهب الفقه إلى تحميل هذه الفكرة طابعا شخصيا وموضوعيا، وهذا أمر بديهي، فلابد وأن يكون المدين والدائن معرفين في السند. كمـا يجب أن يكون محل السند محدد المقدار

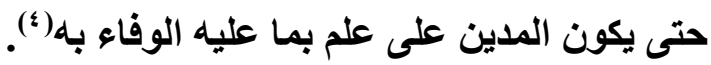

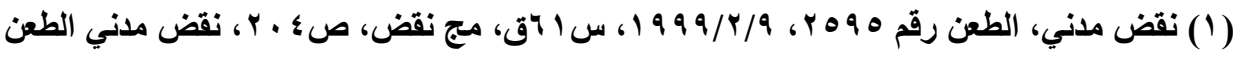

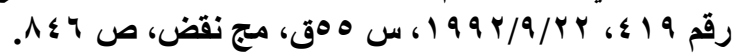

(ץ) المادة V تنفيذ أردني، المادة ه 10 من النظام السعودي للتنفيذ.

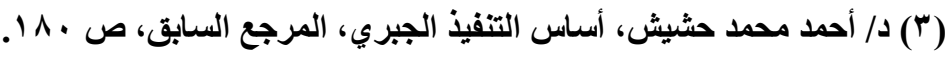

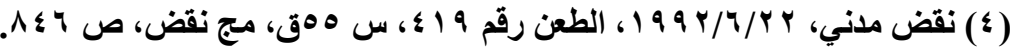

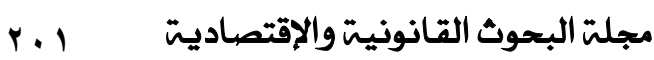


د/ طلعت يـوسف خاطر

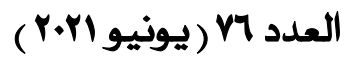

الثرط الثالث: أن يكون الحق ممكنا

يجب أن يكون محل السند حقا يمكن تنفيذه سـواء مـن الناحية الثخصية أو

الموضـوعية، ويعبر المسشرع عـن هـا الشرط بفكـرة حـول الأداء، وهـذه الـصياغة التثريعية معيبة بالقصور (')، وذلك لأن هذه الصياغة لا تنطبق إلا إذا كـان محل السند

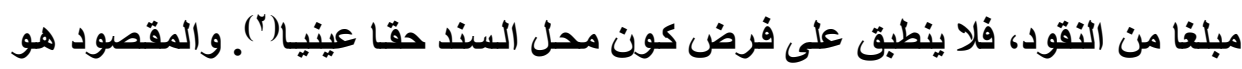
حلول التنفيذ بحلول الأجل التنفيذي أو بتحقق الشرط التنفيذي، إذا كـان محل السند التزامـا بتنفيذ مضاف إلى أجل أو معلق على شرط تنفيذي، والقاعدة أنه قبل حلول الأجل أو تحقق الشرط لا يكون التتفيذ الجبري ممكنا قانونا، ولذلك إذا حصل هذا التنفيذ فهو تنفيذ باطل، ولكن هذا التأويل لا يسد نقص الصياغة التشريعية. إذا يجب أن يكون التنفيذ الجبري ممكنا قانونا من الوجهة الشخصية للملتزم في السند التنفيذي (َ)، والتنفيذ الجبري لا يكون كذلك إلا إذا كـان محل السند التنفيذي، التزامـا بتنفيذ مـا يستوي فيها أن يتم من الملتزم في السند أو من غيره(؛)، فلو كان التفيذ غير ممكن، فإنه إما أن يتحول إلى التنفيذ بمقابل، أو ينقضي الحق الثن الثابت فيه، وذلك في حالة اعتماد التنفيذ على شخصية المنقَّ ضده.

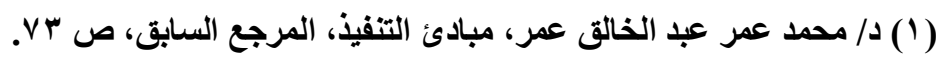

(2) Didier CHOLET Exécution des jugements et des actes, op. cit., n0 30.

(3) Cass. Civ. 2e, 19 mai 1998, Bull. civ. II, no 161 ; Com. 26 oct. 1999, RTD civ. 2000. 167, obs. Perrot.

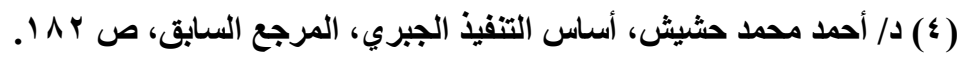

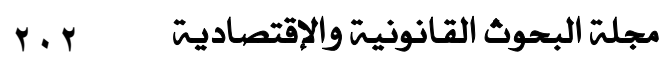


يقصد بـالركن الشكلي للسند صورة تحتوي على بيانـات معينة نص عليها

المشرع، فـالحكم مثثلا لا يكون سـندا تنفيذيا إلا إذا كـان يتضمن الصيغة التنفيذيـة'(')،

وبغير هذه الصور يستطيع عامـل التفيـذ أن يمتــع عن إجرائهـ(؟)، فـلا يكفي لإجراء

التنفيذ أن يكون بيد الدائن سند، بل يلزم أن يكون التنفيذ بموجب الصورة التنفيذية لهذا

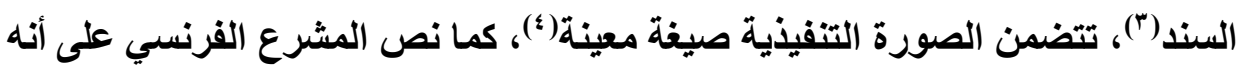

(1) Cass. Civ. 1re, 31 oct. 2012, D. 2012. Actu. 2671.

(2) Css. Civ. 2e, 1er juill. 1992, Bull. civ. II, no 194; Cass. Civ. 2 e, 28 juin 2006, Bull. civ. II, no 178.

(3) KRINGS, Force exécutoire et titre exécutoire en rapport avec les exécutions forcées de décisions et d'actes, in Mélanges Kerameus, 2009, Bruylant-Sakkoulas, p. 672.

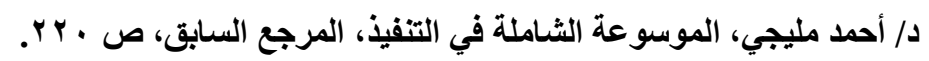

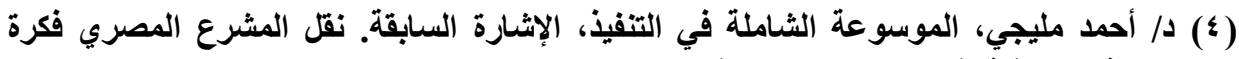

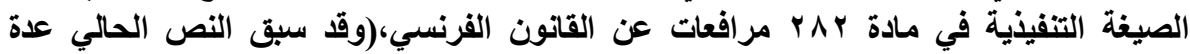

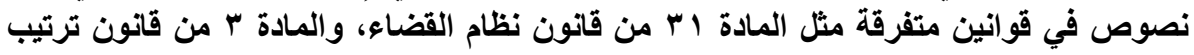

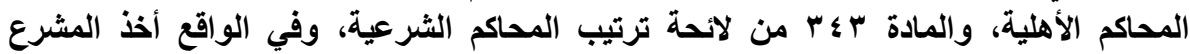

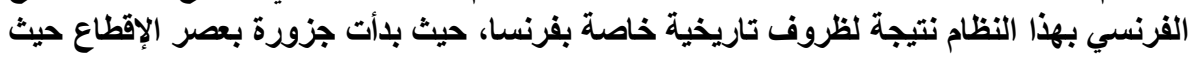

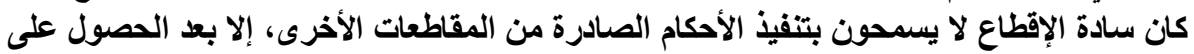

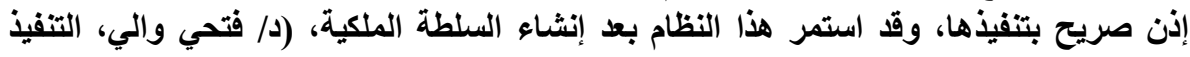

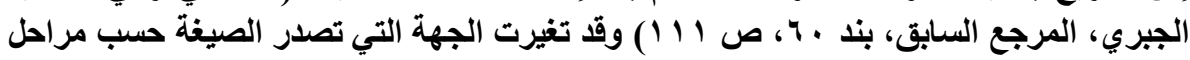

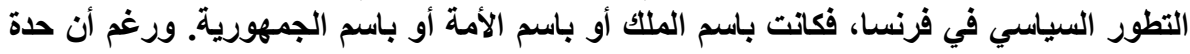

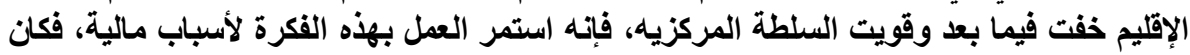

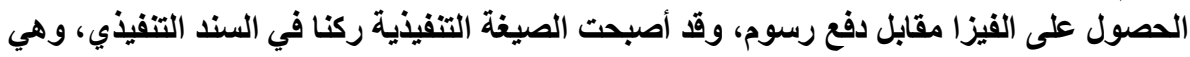

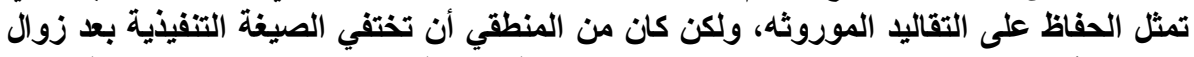

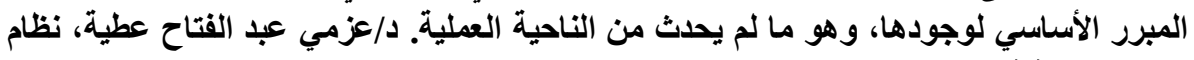

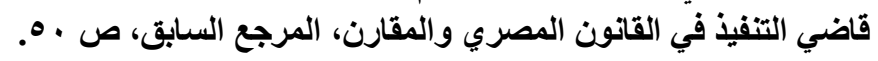

GUINOT, Aperçu historique de la formule exécutoire, op. cit., 11. 2. 


\section{لا يمكن تنفيذ السند إلا بمقتضى صورته التنفيذية(')}

ويقصد بالصورة التنفيذية هي صورة طبق أصل السند سواء أكان حكمـا أم

أمرا أو محضر صلح أم محررا موثقا أم غير ذلك، وتذيل هذه الصورة بألفـاظ معينة

باسم الصيغة التنفيذية(؟)، وهي تتضمن أمرا لمعاون التنفيذ بإجراء التفيذ، وأمرا إلى رجـال السلطة العامـة بمعـاونتهم (")، ويؤدي تخلف عنـصر الشكل إلى بطلان السند

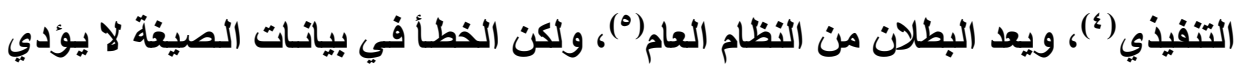

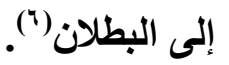

والصورة التتفيذيـة هـي الشكل الخـارجي للسند(V)، ولا يمكن أن تكون هي

جوهره ذاته، ولذلك لا يكفي وضع الصيغة التفيذية على أيـة ورقة حتى تنشأ لحاملها

(1) Selon l'article 502 du code de procédure civile, « nul jugement, nul acte ne peut être mis à exécution que sur présentation d'une expédition revêtue de la formule exécutoire, à moins que la loi n'en dispose autrement »; Cass. Civ. 2e, 11 oct. 1963, Bull. civ. II, no 616.

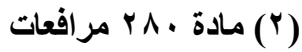

KRINGS, Force exécutoire et titre exécutoire en rapport avec les exécutions forcées de décisions et d'actes, op. cit, p. 672; Cass. Civ. 2e, 11 févr. 2010, Bull. civ. II, no 31.

(3)Civ. 2e, 28 juin 2006, Bull. civ. II, no 178; Cass. Civ. 2e, 1er juill. 1992, Bull. civ. II, no 194.

(4) Cass.Civ. 2e, 30 janv. 2014, D. avocats 2014. 114, obs. Royer; Cass. Com. 20 févr. 1996, RTD civ. 1996. 480, obs. Perrot.

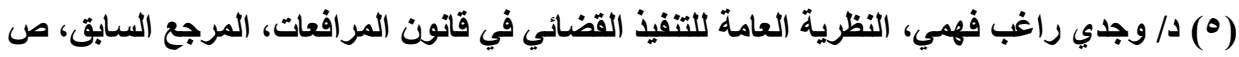

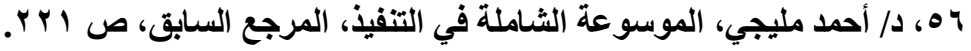

(6) Cass. Civ. 2e, 11 févr. 2010, Bull. civ. II, no 31.

(7) Cass. Civ. 2e, 30 janv. 2014, D. avocats 2014. 114, obs. Royer. 
الحق في التنفيذ مثل وضعها على حكم ابتدائي غير مشمول بالنفـاذ المعجل('). وإنمـا يجب للتلك أن توضـع الصيغة على ورقة متضمنة عمـلا من الأعمـال التي يعترف لها القانون بالقوة التنفيذية(؟)

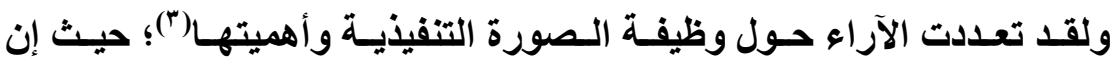

اشتراط الصورة التففيذيـة يسهل مهمة عامـل التنفيذ في التحقق من حق الطالب في التنفيذ، فالمعـاون يقوم بالتنفيذ دون أن تترك لـه مجـالا للتقدير حول وجـود السند التنفيذي، كما أن عبارات الصيغة التنفيذيـة تعد وسيلة ظاهرة لتسهيل تمييز الصورة التتفيذيـة مسن غيرهـا مـن الأوراق الرسـية المثبتـة لحقوق الأفراد كالصور البسيطة للأحكام القضائية(؛). ولكن هذا الرأي منتقد (0)؛ إذ من الممكن تمييز الصورة التتفيذية من غيرها من الصور بطرق أخرى غير الصيغة التنفيذيـة؛ كوضـع خـاتم خـاص على الصورة التنفيذية مكتوب عليه "صورة تنفيذية"، وهذا ما أخذت بـه بعض التشريعات كالقانون اللبناني، كما أن الصيغة التنفيذية لا تؤدي إلى اكتساب أحد حقوقا، لأن هذه

(1) د/ فتحي والي، التنفيذ الجبري، المرجع السابق، ص ؛ ع ب، د/ وجدي راغب فهمي، النظرية العامة

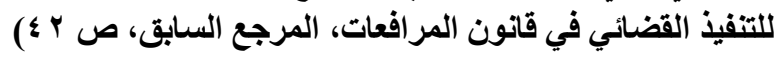

(2) Cass. Civ. 2e, 1er juill. 1992, Bull. civ. II, no 194; Cass. Civ. 2 e, 28 juin 2006, Bull. civ. II, no 178.

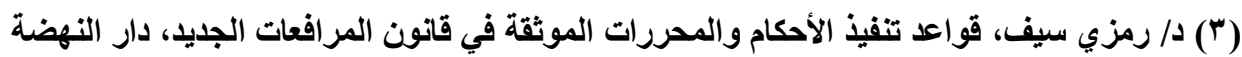

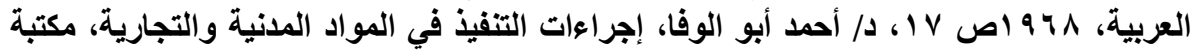

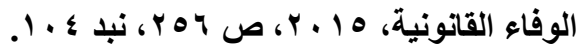

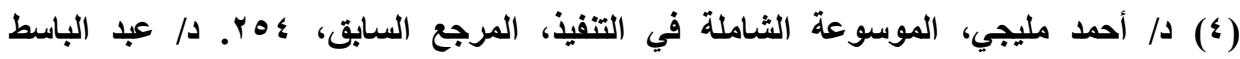

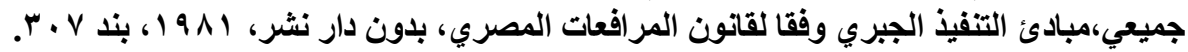

KRINGS, Force exécutoire et titre exécutoire en rapport avec les exécutions forcées de décisions et d'actes, op. cit., p. 672

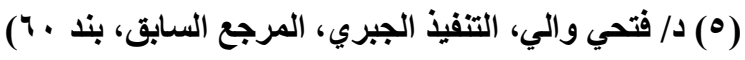


دا طلعت يوسف خاطر

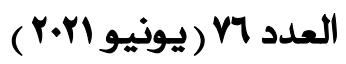

الصيغة لو وضعت خطأ على سند غير جائز تنفيذه، فإن إجراءات التنفيذ التي تتخذ في هذه الحالة تكون باطلة.

وذهب جاتب من الفقه إلى أن الصيغة التنفيذية تعد تاككيا لوجود السند التنفيذي

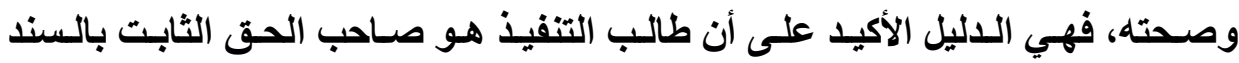
التفيذي(")، وأنه لم يستوف هذا الحق بتنفيذ سـابق("). ولكن هذا الرأي منتقد (")؛ لأن

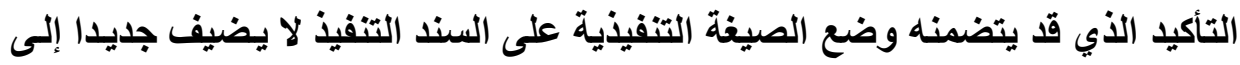
التاكيد الذي يتضمنه السند التنفيذي باعتباره سندا تنفيذيا في ذاتهه، كمـا أن وجود الصورة التنفيذيـة لا تغني بالضرورة أن المحكوم عليه لم يقم بالوفاء بالدين، فهذه المسألة تخضع للقو اعد العامة في الإثبات.

وذهب رأي آخر إلى أن أهميـة الصيغة التنفيذيـة تبدو في أنها تتضمن أمرا

صادرا إلى معاون التنفيذ والقضاة ورجال السلطة العامة بإجراء التنفيذ( (5)، لأن الحكم

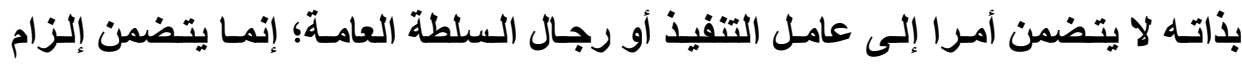

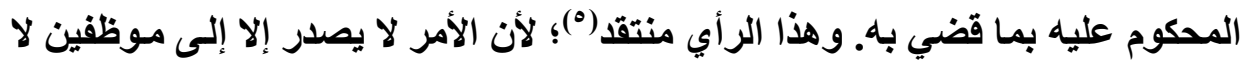

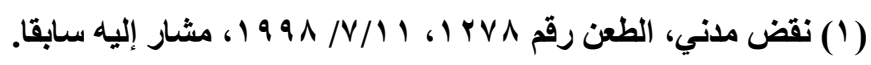

(2) Civ. 2e, 28 juin 2006, Bull. civ. II, no 178.

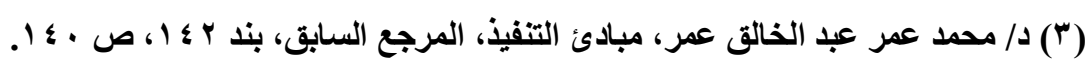

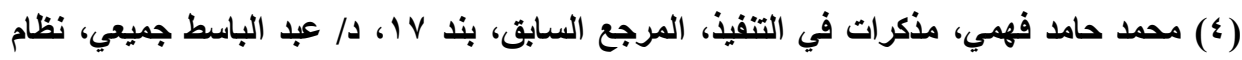

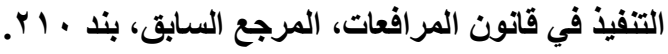

KRINGS, Force exécutoire et titre exécutoire en rapport avec les exécutions forcées de décisions et d'actes, op. cit., p. 672; CA Paris, 5 nov. 1958, JCP 1958. II. 10893.

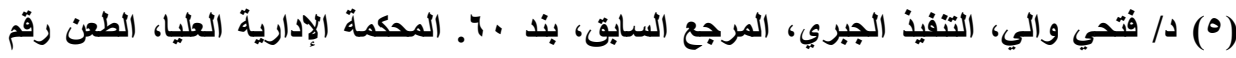

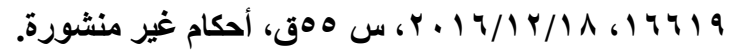

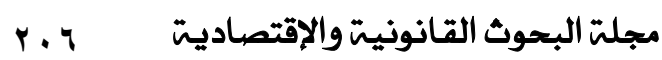


يحق لهم إصدار أوامر، فلو كان السند محررا موثقا، وصدرت الصيغة من الكاتب أو

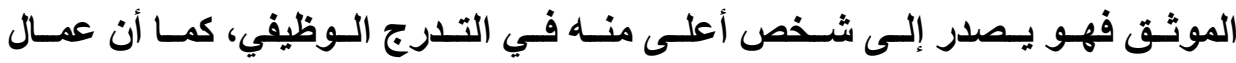

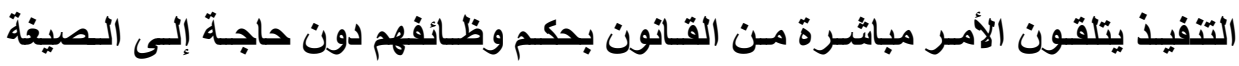
(التنفيذية) (1) (لتية

وذهب رأي آخر() إلى أن الصيغة التنفيذية تعد ركنا شكليا في السند التفيذي،

ووفقا لهذا الرأي فإن السند التنفيذي عمل قـانوني، أمسا الصورة التنفيذيـة فليست إلا شـكلا خارجيـا، لهـا العمـل، ولا يمكن تبنـي هـا الـرأي وذلـك لأن يخلط بـين الـركن والثرط، فالصيغة التنفيذية ليست إلا مجرد شرط شكلي في السند التنفيذي (")، ومن الممكن أن يوجد السند التنفيذي دون توافرها. والواقـع أن الـصيغة التنفيذيـة لا تـؤدي أي وظيفـة نافعـة ولا تـستجيب إلـى ضرورة قانونية أو منطقية (")، فهي مجرد شكل تـاريخي لا معنى لـه(')، كمـا أن وجود اله

(1) وتفصيلا لألك يلاحظ أن الصيغة التففيذية ليس المقصود منها توجيه الأمر إلى عمال التنفيذ

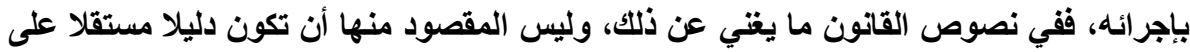

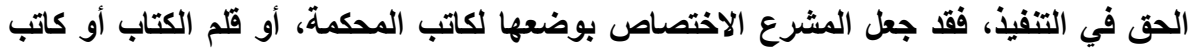

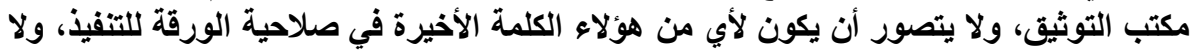

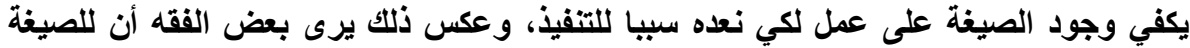

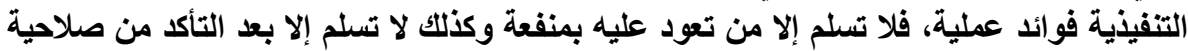

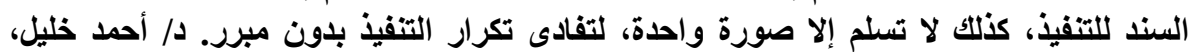

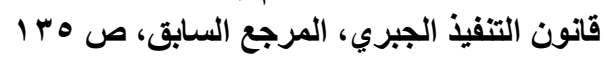

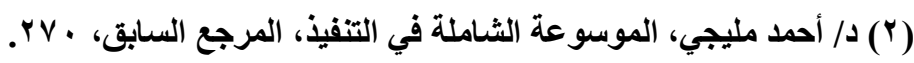

(3) Cass. Civ. 2e, 11 févr. 2010, Bull. civ. II, no 31.

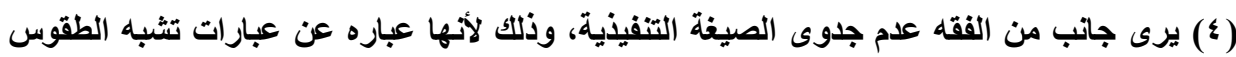

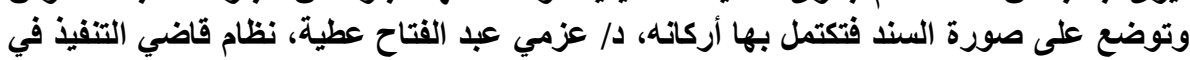

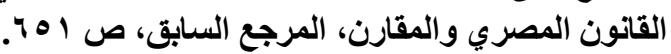

J. Maurice CAZAUX, la formale ecexution, thèse Paris, 1942, p. 5. $=$ 
الصيخة التنفيذية يتمضن المساس بالفصل بين السلطات في صورته التقليدية(؟). وهناك كثير من القوانين لا تأخذ بها كالقانون الإنجليزي(") والسوري والعراقي والسوداني(؛)؛

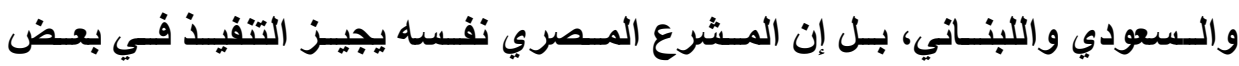

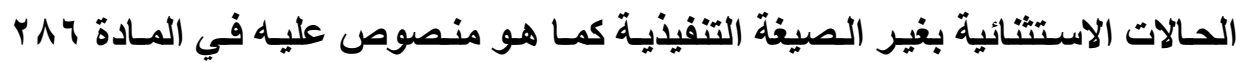

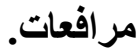

ويلاحظظ أن التشريعات التـي تأخــ بنظــام قاضــي التنفيـذ لا تأخــ بالـصيغة

التنفيذية(ْ)، وموقفها في هذا الشأن منطقي تمامسا مـادام التنفيذ لا يبدأ إلا بـأمر مـن قاضي التنفي، وهذا هو موقف القانون السوري(") والعراقي، والبحريني واللبنـاني في

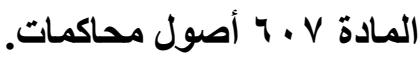

ولذلك يتعين إلغاء الصيغة التنفيذية(V) والأخذ بنظام الأمر بالتنفيذ المعروفة في التشريعات العربية والمعروف أيضا في القانون الإنجليزي والسوداني. ونقترح أن يسند

د/ عزمي عبد الفتاح عطية، نظام قاضي التنفيذ في القانون المصري والمقارن، المرجع السابق،

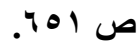

(1) GUINOT, Aperçu historique de la formule exécutoire, op. cit. no 11. 2

(2) Id.; Civ. 2e, 11 oct. 1963, Bull. civ. II, no 616.

(3) KRINGS, Force exécutoire et titre exécutoire en rapport avec les exécutions forcées de décisions et d'actes, op. cit., p. 672

(§) يشترط لتنفيذ السند في النظام العراقي أن يصدر قرار بالتنفيذ من رئيس إدارة التنفيذ المختصة،

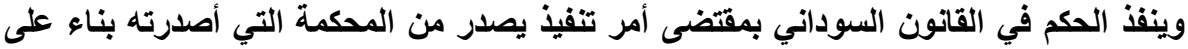

$$
\text { طلب المحكوم لله. }
$$

(5)KRINGS, Force exécutoire et titre exécutoire en rapport avec les exécutions forcées de décisions et d'actes, op. cit., p. 672

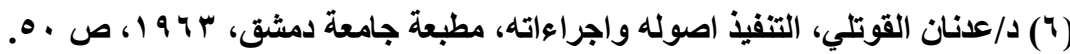

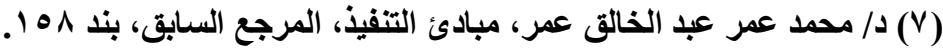

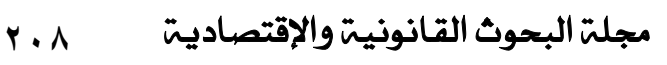


الأمر بالتنفيذ إلى رئيس إدارة التنفيذ، وهذا يتفق مع سطلتها في الإشراف على التنفيذ،

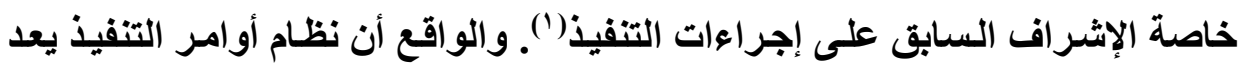

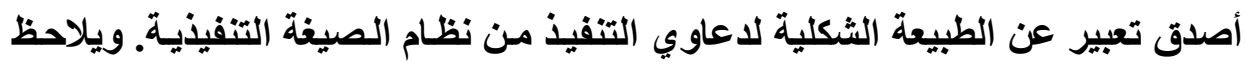
على نظام أوامر التنفيذ أنه أكثر تثددا في الرقابة من نظام الصيغة التنفيذية؛ ذلكك أن الن التهائ

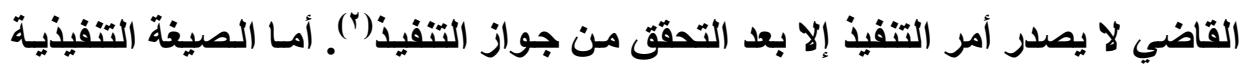

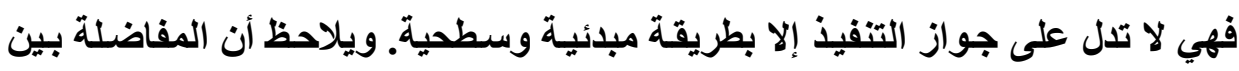
نظام أوامر التتفيذ ونظام الصيغة التنفيذية ليست مفاضلة بين مجموعتين مختلفتين من الأثنكال الإجرائية بقر ما هي اختيار بين التنفيذ على أساس تأكيد موضوعي وحقيقي

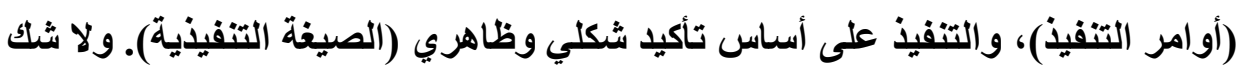

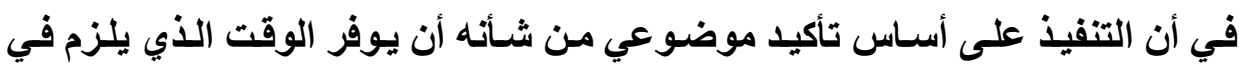

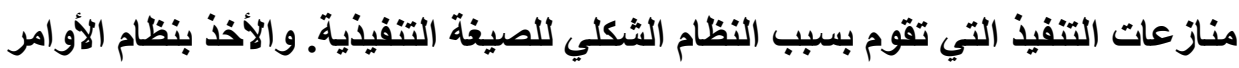
لم يعد للمفهوم الثكلي لسندات التنفيذ محل وجود، ويصبح شروط السند التنفيذي كلها

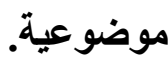

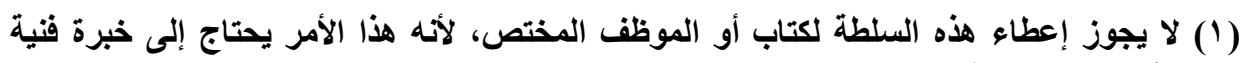

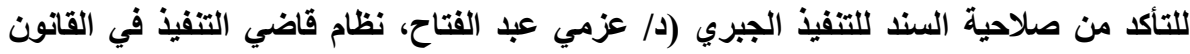

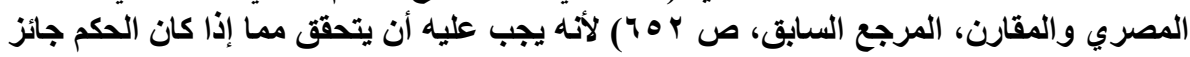

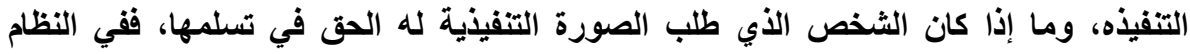

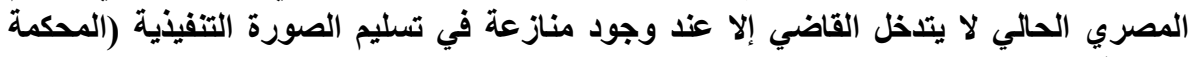

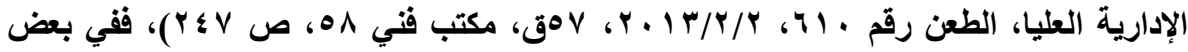

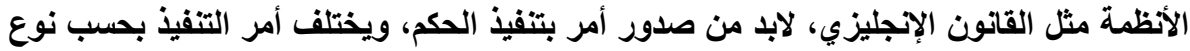

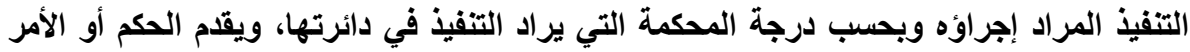

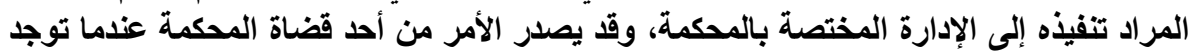

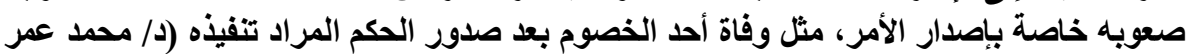

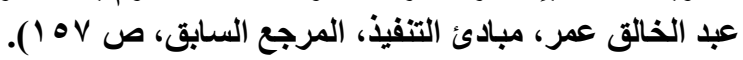

(2) TGI Rennes, 14 juin 1994, Rev. huiss. 1995. 1265. 
ونلخص من ذلك إلى أن الوظيفة الأساسية للصيغة التنفيذيـة كونها علامـة

مادية على جواز التنفيذ، ويمكن الاستغناء عنها بإجراء آخر كوضع ختم على الصورة

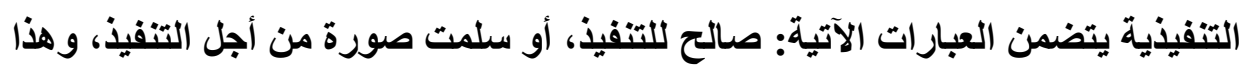
ما جرى عليه؛ القانون اللبناني في المادة V • ج أصول محاكمات. الثرع الثاني

\section{الوظيفة القانونية للسند التنفيذي}

يعد السند التنفيذي الأساس القانوني للقيام بالتنفيذ الجبري('). ولقد اختلفت

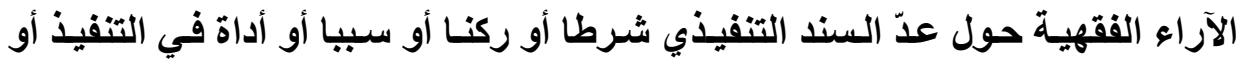

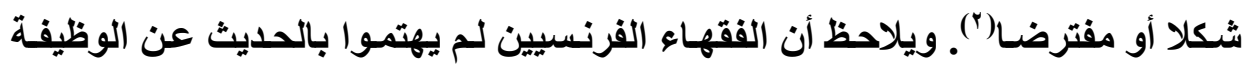

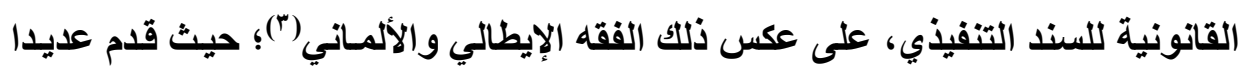

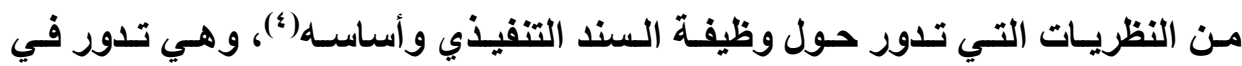
اتجاهين؛ الأول: يذهب إلى أن السند التنفيذي له وظيفة تأكيدية للحق الموضوعي، وإن كان تأكيدا مستقلا تمامـا عن وجود هذا الحق أو عدمه. والآخر: يذهب إلى أن السند

(1) Cass. Civ. 2e, 30 janv. 2014, D. avocats 2014. 114, obs. Royer.

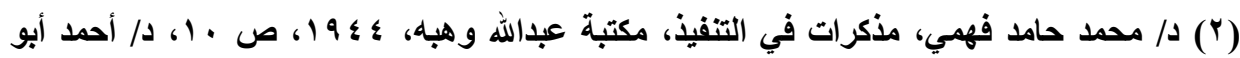

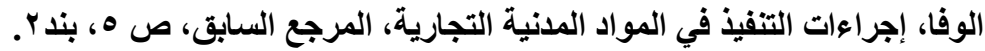

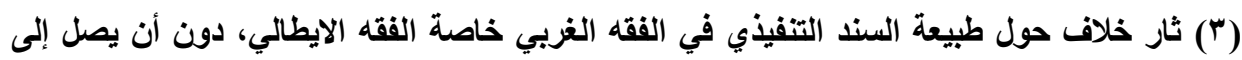

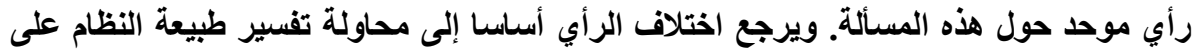

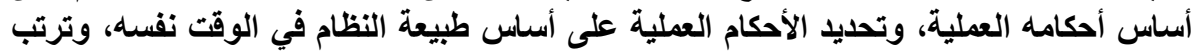

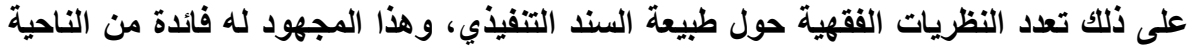

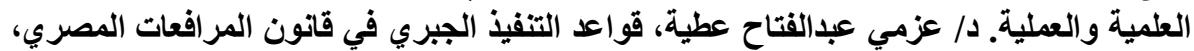

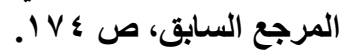
( ) راجع هذه النظريات بالتفصيل في د/ محمد عمر عبد الخالق عمر، مبادئ التنفيذ، المرجع السابق،

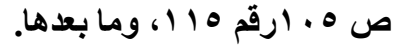


التتفيذي هو مجرد مستتد كـاف في حد ذاته لإجراء التنفيذ(')، فبمجرد تقديمـه لعامل التتفيذ، متى استوفى شروطه، عليه أن يقوم بالتنفيذ استنادا له دون التحقق من وجود

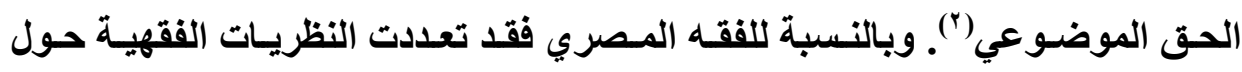
الوظيفة القانونية للسند التنفيذي ().

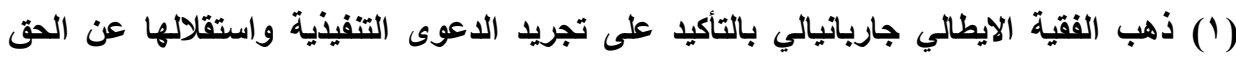

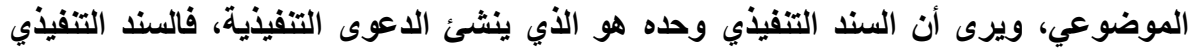

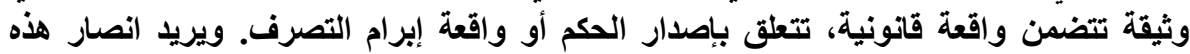

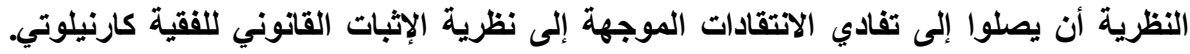

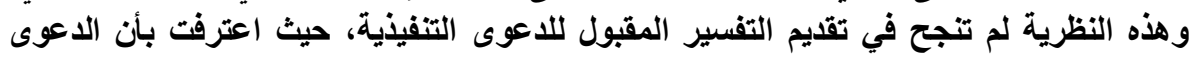

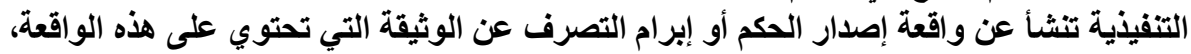

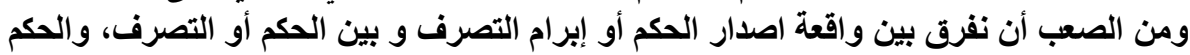

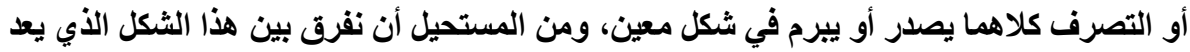

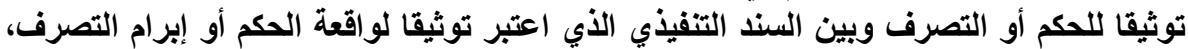

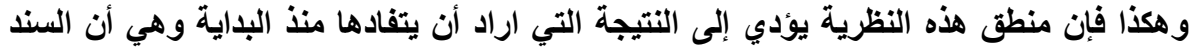

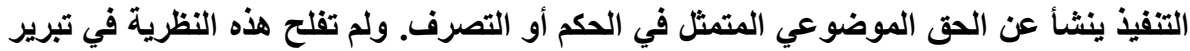

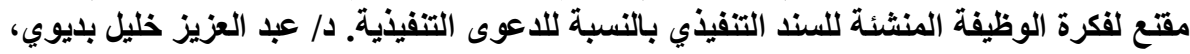

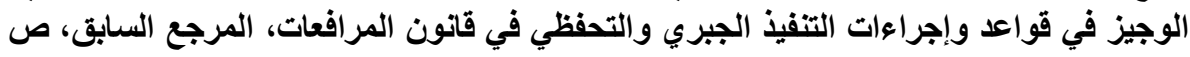

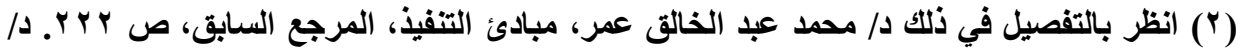

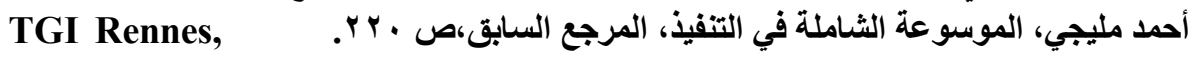

14 juin 1994, Rev. huiss. 1995.1265.

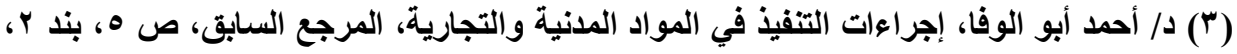

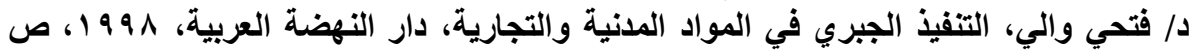

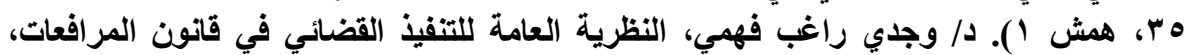

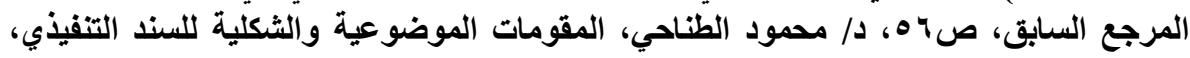

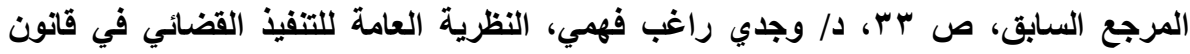

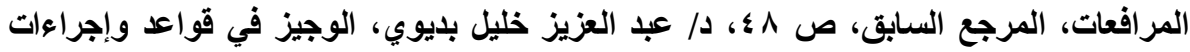

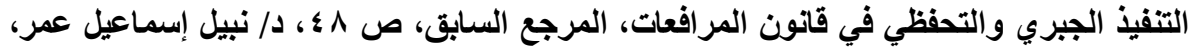

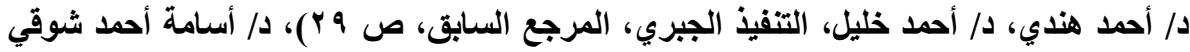

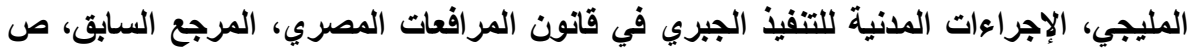
$=$ 
ويثار التساؤل: هل السند التنفيذي هو السبب الوحيد للحق في التفيذ؟ في الواقع اختلفت كلمة الفقه في هذه المسألة؛ حيث ذهب الرأي الأول(') إلى أن السند هو أداة التنفيذ وليس سبيه، ويرى أن سبب التتفيذ ليس هو السند؛ وإنمـا الواقعة المنشئة للحق الموضوعي الأي يجري التنفيذ اقتضاء لله سواء تمثلت هذه الواقعة في عقد أو تصرف بإرادة منفردة أو فعل نافع أو فعل ضار أو نص القانون، أما السند التنفيذي فلا يعدو أن يكون مجرد أداة شكلية خارجيـة للتفيذ، فسبب اللجوء إلى التنفيذ امتــاع المدين عن الوفاء بالحق الموضوعي، ومن ثم فالسند إذا ما أصبح قابلا للتنفيذ الجبري بذاته يكون أداة اقتضاء الحق الثابت به، فضلا عن كونه دليله(؟). والواقع لا يمكن التسليم بهذا الرأي لأن الحق في التنفيذ مستقل عن الحق الموضوعي؛ من حيث سبيه، وموضوعه. والقول بأن السند التنفيذي عمل مؤكد أو عمل تأكيدي لا معني له، فهذا التأكيد ربمـا كان في ذهن المشرع عندما قرر أن يرفع عملا أو تصرفا معينا إلى مرتبة السندات التففيذية، ولكنهـه لا قيمـة لـه في تحديد طبيعة السـندات التنفيذيـة فـي القـانون، ولـيس فـي طبيعـة الأحكـام أو قـرارات القـضـاء أو المحررات الموثقة أو الكمبيالات أو سندات الديون أن تكون مؤكدة أو متضمنة لعنصر

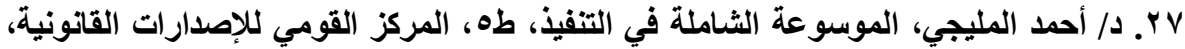

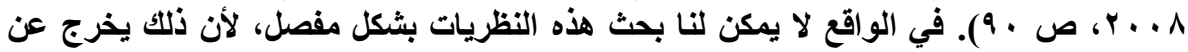

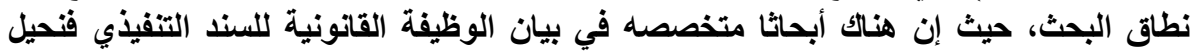

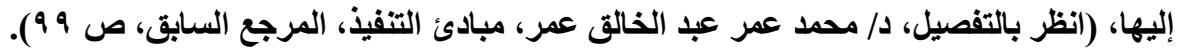

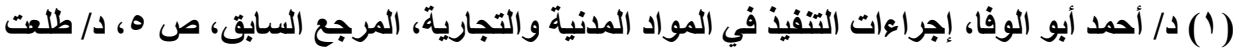

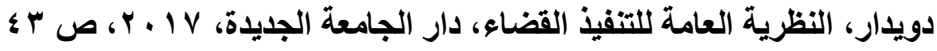

(2) R. PERROT et Ph. THÉRY, Procédures civiles d'exécution, op. cit., no 118; LEBORGNE, Droit de l'exécution, op. cit., nos 432 s. Cass. Civ. 2e, 22 oct. 2009, Bull. civ. II, no 254 ; Dr. et proc. 2010. 86, note Léon. 
التأكيد، وإنما هي أعمال أو تصرفات تنظم بطريقة معينـة مراكز الأشـخاص وعلاقاتهم ومصالحهم، وصلاحيتها للتنفيذ مستمدة من القانون، وليس من احتوائهـا على عنصر التأكيد، فضلا عن أن هذه الأعمال تتنج آثار متنوعة أخرى غير الأثر التنفيذي، بحيث يمكن القول بأن الصلاحية للتنفيذ تعد مجرد عارض من عوارض حياتها، وليست من صفاتها الجوهرية اللازمة. ويذهب رأي ثان إلى أنه يوجد معنيان لسبب التنفيذ(')؛ موضوعي: ويتمثل في الحق الموضوعي الذي يجري التنفيذ لاقتضائه. وشكلي: يتمثل في السند التنفيذي الذي هـو بمثابـة أداة تنفيـذ، والـذي يتبلـور فيـه الحـق الموضـوعي، فسبب السند معنى

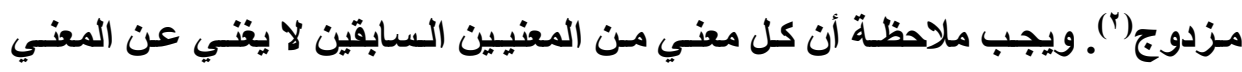
الآخر، بل لابد من اجتماع المعنيين معا، أي لابد من وجود الحق الموضوعي ووجود السند التنفيذي الذي يتبلور فيه هذا الحق حتى يتوقر سبب التنفيذ، فلا الحق يغني عن السند، ولا السند يغتي عن الحق. ومن ثم فبإذا كـان الدائن لايـه حق موضوعي ولكنـه غير ثابت في سند مستوفي للثكل الأي يزوده بالقوة التنفيذية فإنه لن يستطيع التنفيذ؛

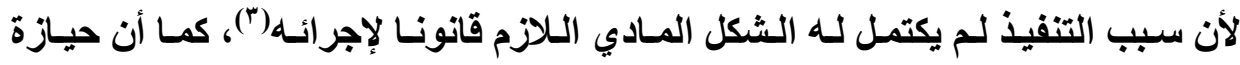
الأئن لسند تنفيذي مستوف شكله القانوني، ولكنه استوفى حقـه، فبان استخدامه لهذا

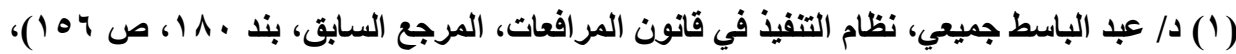

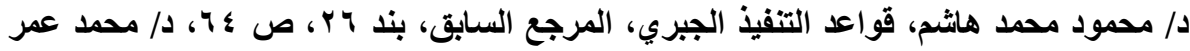

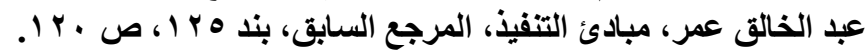

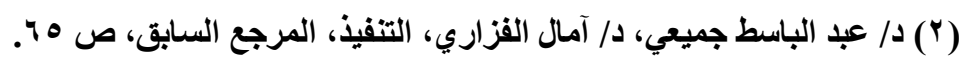

(3) Cass. Civ. 2e, 22 oct. 2009, Bull. civ. II, no 254 ; Dr. et proc. 2010. 86, note Léon. 
السند بعد الوفاء يؤدي إلى بطلان تنفيذه، فيجب اجتمـاع الحق والسند معـا حتى يكون

هنائ سبب للتنفيذ (')

ويذهب الرأي الثالث الأي نؤيده إلى أن السند التفيذي ليس مجرد أداة شكلية

خارجية لإجراء التنفيذ، وإنما هو في حقيقته السبب النظامي في التنفيذ(؟)، وهو أساس الحق في إلزام المدين بتنفيذ ما التزم به، أي قيامه بالوفاء، فلا تتفيذ بلا سند، ولا يمكن

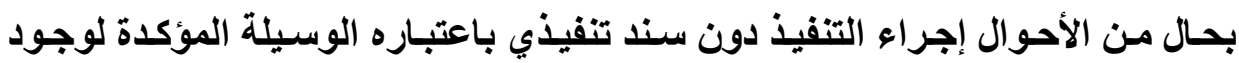
الحق("). ووجود السند قرينة على كون وجود الحق، ومن يدعي العكس فعليه يقع عبء الإثبات. و إذا كان لكل حق مصدر يستند إليه، فالحق في التنفيذ يجد مصدره أو

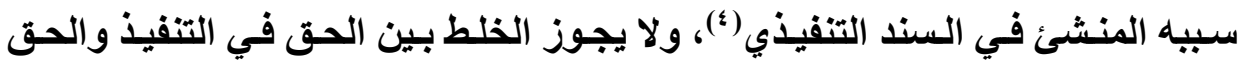
الموضوعي؛ فلا يجوز القول بأن سبب التنفيذ هو الحق الموضوعي الذي يجري التنفيذ لاقتضائه(')، كما لا يجوز القول بأن سبب الحق في التفيذ هو بعينه سبب أصل الحق، ولا يجوز القول أيضا بأن السند التنفيذي هو أداة التنفيذ وليس سببه أي هو الشكل

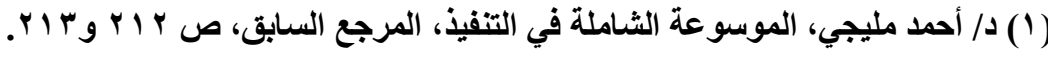

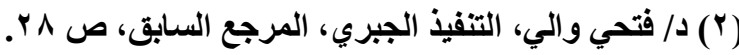

Didier CHOLET, Exécution des jugements et des actes, op. cit., n. 11.

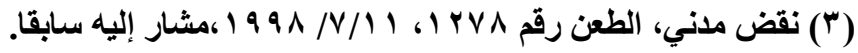

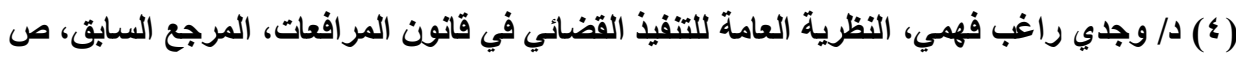

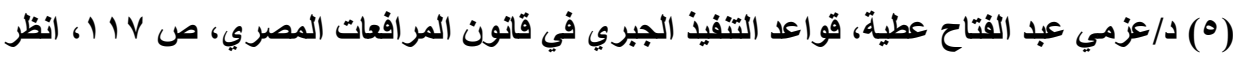

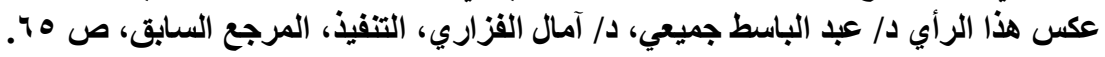


المطلوب لإجراء التنفيذ(')، كمـا أن التعبير عن السند التنفيذي بأنـهـ رمـز لا يجهوز

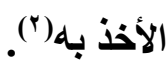

ويرى البعض من الفقه المصري(") أنه يمكن الوصول إلى الوظيفة الصحيحة

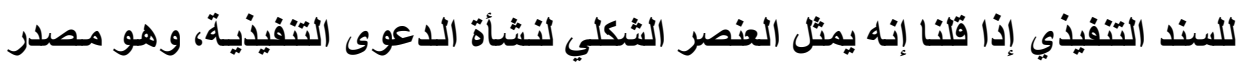

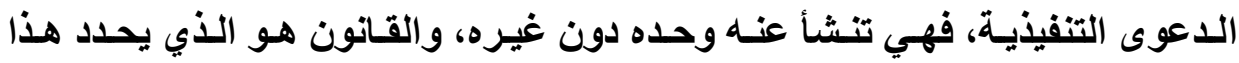

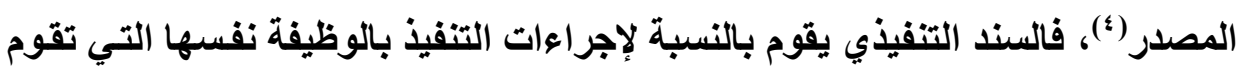

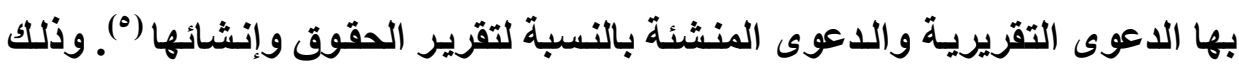
لأن السند التنفيذي مصدر للاعوى التنفيذية، ومن الخطأ وصف السند التنفيذي بأنه شرط ضروري للتنفيذ، لأن العند مصدر الدعوى التنفيذية.

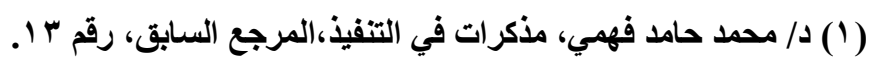

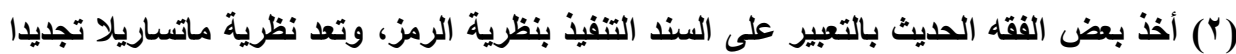

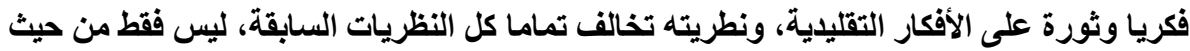

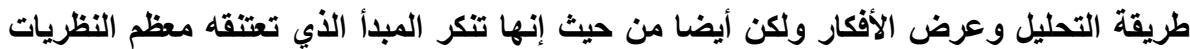

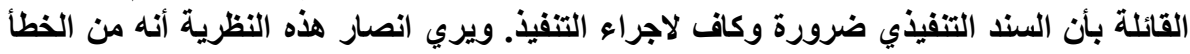

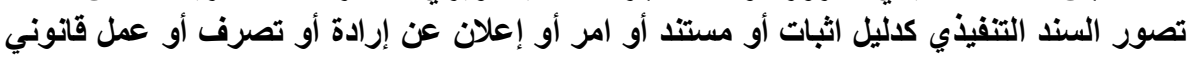

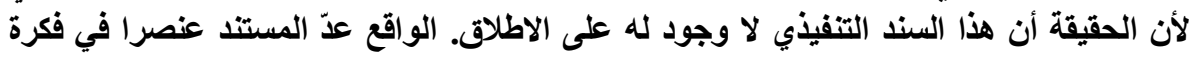

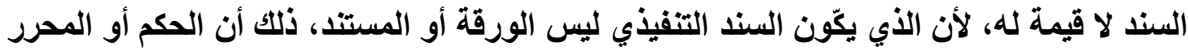

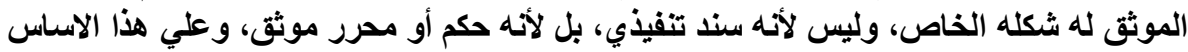

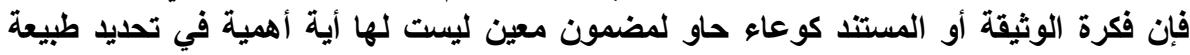

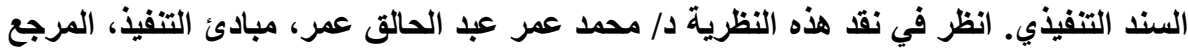


ونرى أن الرأي الذي يكيف السند التتفيذي على أنه السبب المنشئ للحق في التنفيذ هو الأولى بالتأييد، وذلك لأن للسند التنفيذي قوة ذاتية، فالتنفيذ يياشر إذا وجد

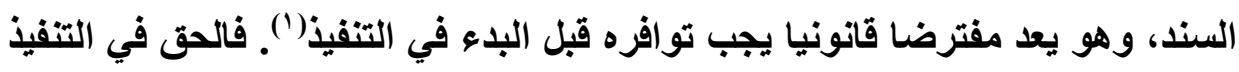
هو سلطة إجرائية تخول صاحبها تحريك الجهاز القضائي للقيام بالتفيذ، ولا يجوز التتفيذ الجبري إلا بسند تنفيذي(")، متضمنا شروطا معينة، موضوعية وشكلية(")،

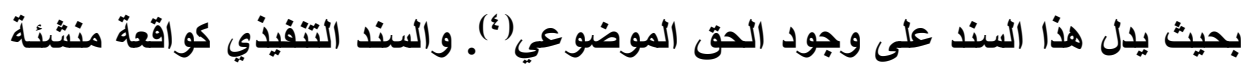

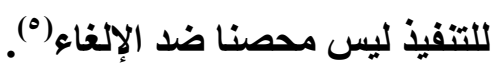

سنشير إلى الوظيفة التنفيذية للسند، والوظيفة التاكيدية للسند، وعدم اعتباره

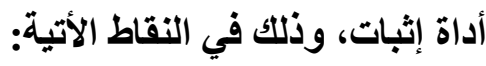

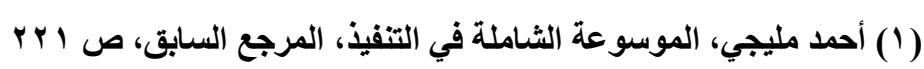

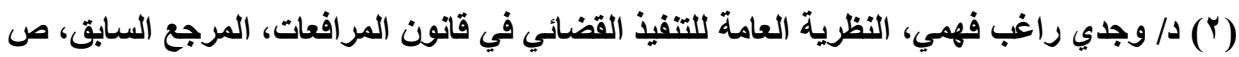

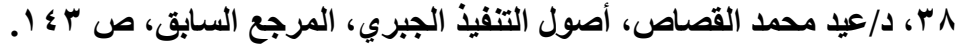

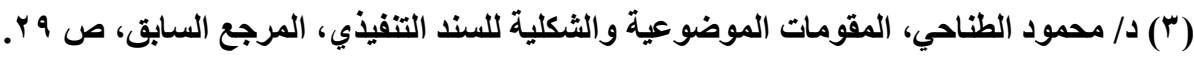

Didier CHOLET Exécution des jugements et des actes, op. cit., n0 30

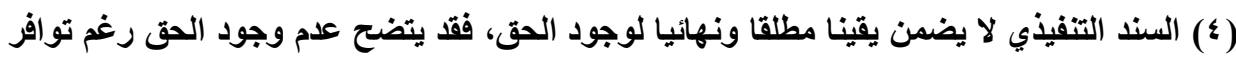

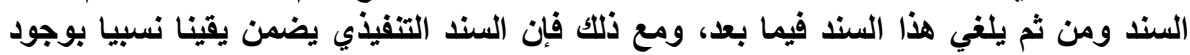

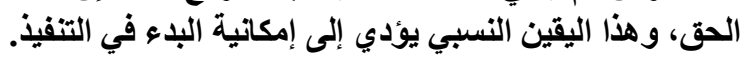

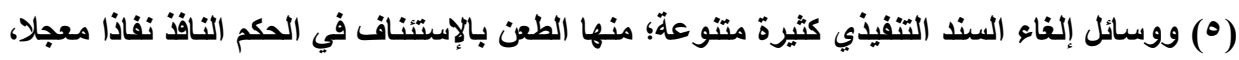

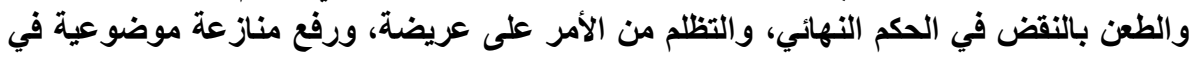

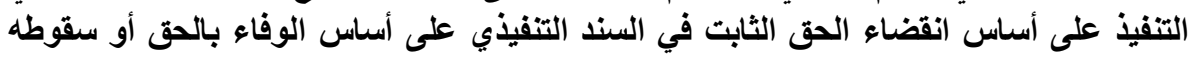

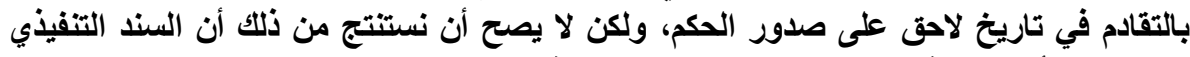

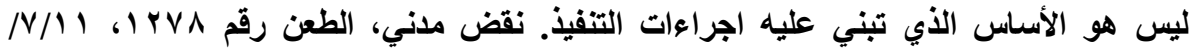


أولاً: الوظيفة التنفيذية للسند التنفيذي

لقد منح المشرع للسند التفيذي قوة تنفيذية، وهي نوع من الصلاحية أو القدرة التي يعترف بها القانون لمحرر مـا، والتي تكمن في تحريك الجهاز القضائي لمساعدة صساحبها في تحقيق مضمونها باتخاذ إجراءات التنفيذ الجبري المنصوص فئست عليها في قانون المرافعات، وأن يستمر في اتخاذ هذه الإجراءات حتى تمـام التنفيذ ('). وقد منحت الأنظمة القانونية المختلفة للسند التنفيذي القوة التنفيذية التي تسمح بإعادة التطابق بين المراكز القانونية للأثخاص؛ تلك المراكز التي يكون تطابقها قد حدث لده اختلاف نتيجة تعدد وجهات نظر الأفراد(")، وتم حسم هذا الاختلاف بالسند التنفيذي،

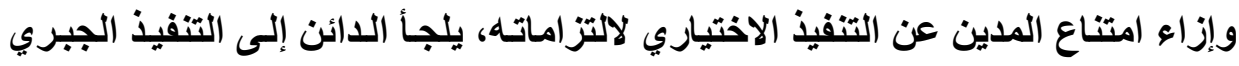

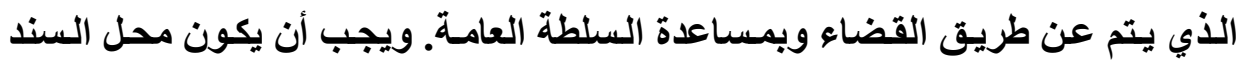
التنفيذي إلزامـا حتى تتحقق القوة التنفيذية، ويعبر الفقه عن ذلك بفكرة الصلاحية للتنفيذ الجبري"(") ويعبر المشرع عن ذلك بفكرة جائز التنفيذ. ويثار التساؤل: من أين تأتي القوة التنفيذية للسند؟ هل مصدرها القانون أم

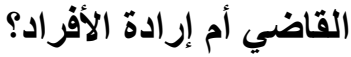
في الواقع لا يجوز لإرادة الأفراد أن تمنح مـا تشاء من المحررات هذه القوة،

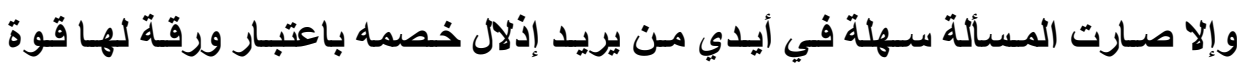
تنفيذية، وكذلك يخشى من جور القضاء لو سمحنا لهه بإسباغ هذه القوة على مـا يريد (1) د. نبيل إسماعيل عمر، الوسيط في التتفيذ الجبري للأحكام، المرجع السابق، ص 1 (ه.

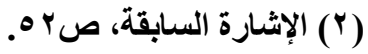

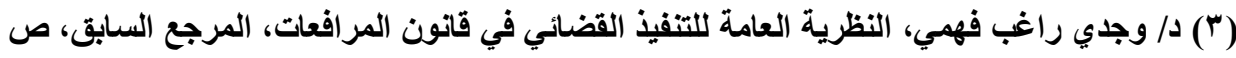

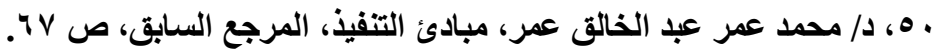


من محررات. والواقع أن القوة التنفيذية للسندات التنفيذية تجد مصدرها المباشر في

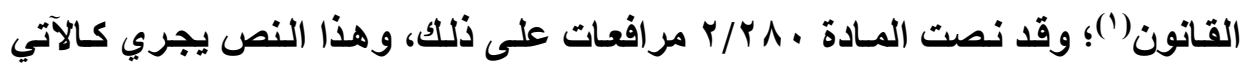
و"السندات التففيذية هي....: وهذا التعداد لأنواع السندات التنفيذيـة وارد في القانون على سبيل الحصر، فلا يجوز لإرادة الأطراف الإضـافة إليه(؟)، حتى عبارة " الأوراق الأخرى" الواردة في النص قيدها القانون بقوله: التي يعطيها القانون هذه الصفة" أي صـفة السند التنفيــي، فهذه الـصفة يجب أن تـصدر مسن المسشرع ولـيس مسن إرادة الأفراد("). وقد ذهب القضاء المصري إلى أن المقصود بالسندات التنفيذيـة: الأحكام

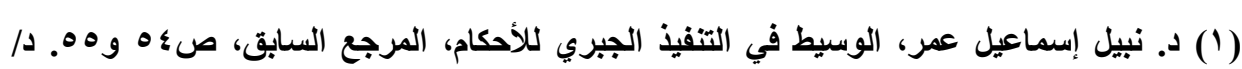

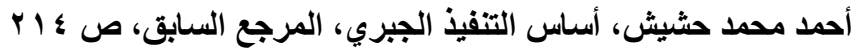

(2) Cass. Com. 2 mai 2001, Bull. civ. IV, no 82 ; RTD com. 2001. 773, obs. Vallens.

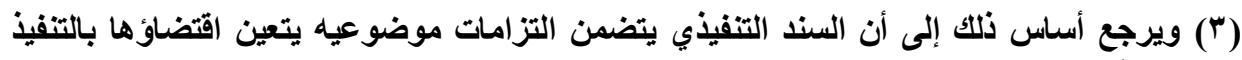

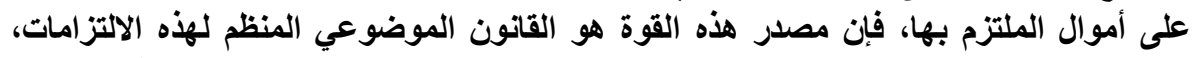

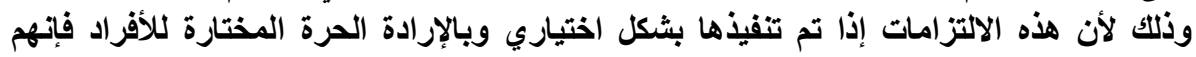

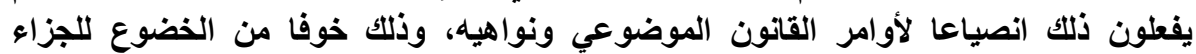

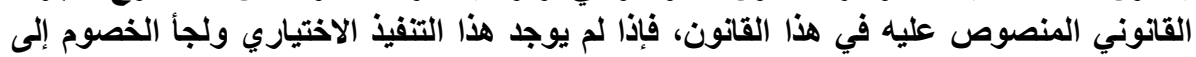

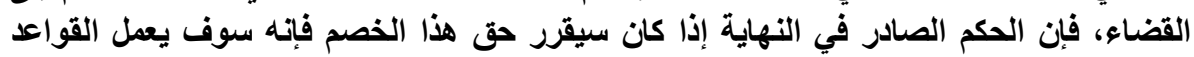

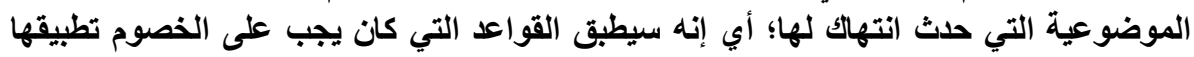

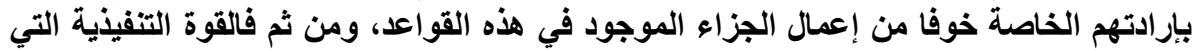

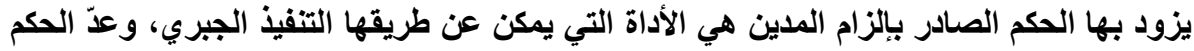

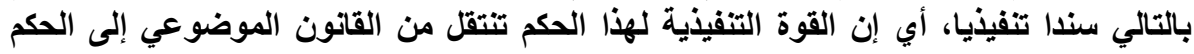

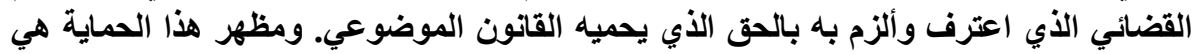

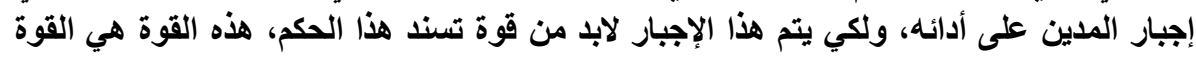

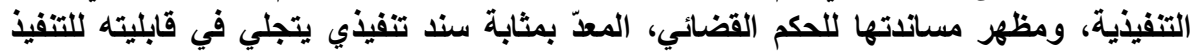

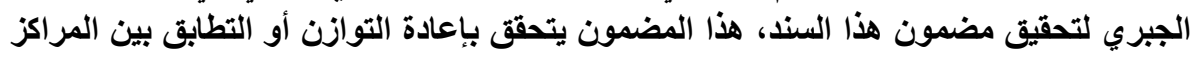

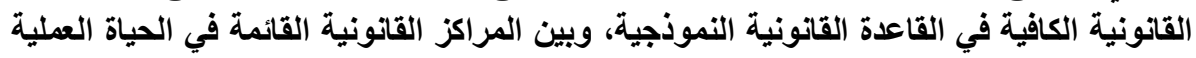

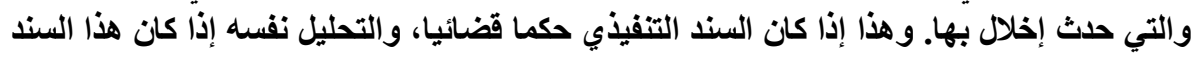

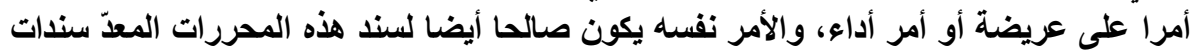
تنفيذية، أما محاضر الصلح التي يتفق عليها الخصوم ويصدق عليها القاضي فيصدق عليها أيضا لئنا $=$ 
والأوامر والمحررات الموثقة ومحاضر الصلح المصدق عليها، وكذلك الأوراق الأخرى التي يعطيها القـانون الصيفة التنفيذيـة(')، كمـا ذهب القضاء المـصري إلى أن أورد المشرع بقانون المر افعات المدنية والتجارية بياناً حصرياً للسندات التفيذية... مشترطاً ضرورة تذييل هذه السندات بالصيغة التنفيذية(؟)، وهذا ما نص عليه القانون الفرنسي في المادة س ا 1 ــ من قانون الإجراعات المدنية للتنفيذ(").

ويلاحظ أن جميع السندات التنفيذية متساوية في القوة التنفيذية، ومن ثم يمكن تزاحم تنفيذ السندات المختلفة، فيجوز تعدد الحجوز بناء على سندات مختلفة على مـال واحد للمدين، والتساوي في التوزيع(")، حيث إن القاعدة أن الحجز لا يمنع الحجز آخر على المال المحجوز نفسه، فأسبقية الحجز لا تحول أيـة أولويـة عند توزيع الحصيلة،

التحليل. الواقع أن هذا الشرح صالح للإعمال على جميع السندات التنفيذية التي تتضمن قضاءعً

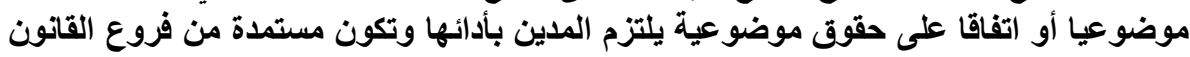

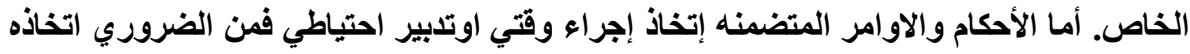

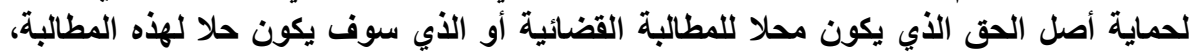

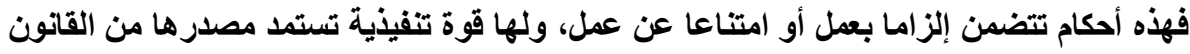

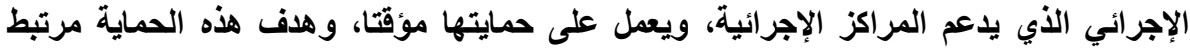

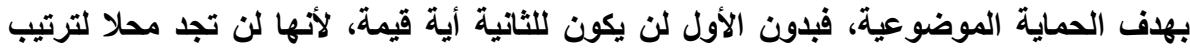

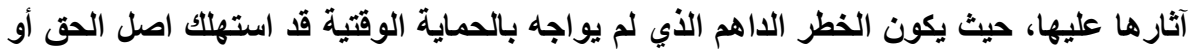
قضي عليه

(1) (1)

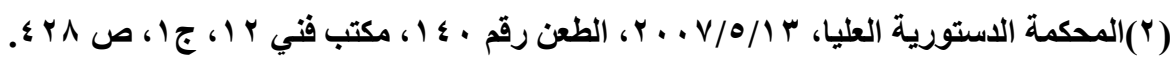

(3) Stéphane PIÉDELIÈVRE, Frédéric GUERCHOUN, Saisies et mesures conservatoires, Répertoire de procédure civileOctobre 2018, n0 65. RG no 17/01516; Marie-Pierre MOURRE-SCHREIBER, Huissier de justice, Répertoire de procédure civile Janvier 2017. 
فالسند التفيذي القضائي ليس أقوى من السند التنفيذي غير القضائي كمرر الموثق، كما أن السندات التنفيذية لا تتميز بعضها من البعض الآخر إلا إذا كانت لها ضمانة تنفيذيـة إضـافية، وهذه الضمانة قـ يكـون مـصدرها القـانون أو الاتفـاق أو القضاء، كالإيداع والتخصيص، والحقوق العينية التبعية، والأولوية الإجرائية عند التوزيع. وقد يكون مصدرها العقد كالرهن الرسمي (م اس ـ ( مدني)، أو مصدرها أمر قضائي كحق

$$
\text { الاختصاص (م 01 • 1 مدني). }
$$

نلخص مما سبق إلى أن وظيفة السند التنفيذي ذات طبيعة إجرائية، وقد صـاغ

الفقه الإجرائي الطبيعة الإجرائية لمحل السند التنفيذي لأن للقوة التنفيذية طبيعة جزائية إجرائية(')؛ فقد منح المشرع السند التنفيذي قوة ذاتية، ليعطي بذاته الحق في البدء في

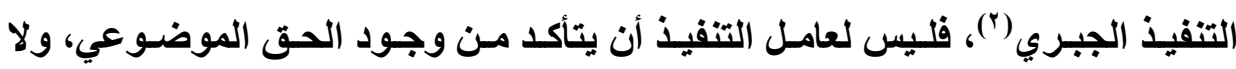
مناقشة مضمونه أو إعادة تقديره أو تعديله، بل عليه تنفيذه بالحالة التي هو عليها(")، فالقاعدة أن السند التنفيذي طريـق مفترض وكـاف للتنفيذ الجبـري، فيجـوز التنفيذ الجبري بصرف النظر عن وجود الحق الموضوعي. ثانياً: الوظيفة التأكيدية للسند التنفيذي

ذهب البعض إلى أنـه لـيس للسند التنفيـذي قوة تأكيديـة في نطساق التنفيذ الجبري(؛)؛ وذلك لأنه قوتـه التاكيديـة أو الثبوتيـة ليست محل عدّ إلا في نطاق الإثبات (1) د/ محمد عمر عبد الخالق عمر، مبادئ التنفيذ، المرجع السابق، ص بـه، ه، د/ أحمد محمد حشيش،

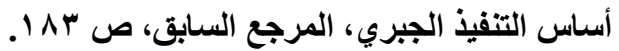

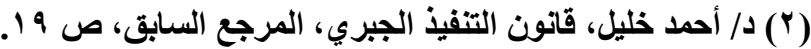

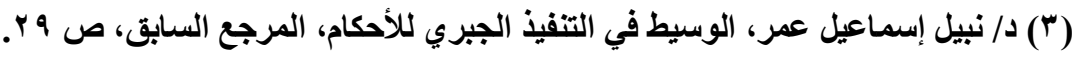

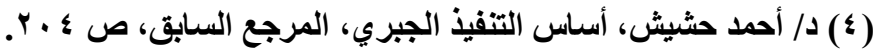

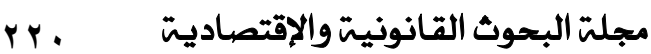


القضائي، أي الإثبات الذي يتجه إلى إقناع قاضي النزاع بحقيقة واقعة، ولكن هذه القوة لا تثبت للسند باعتباره سندا تنفيذيا، بل تثبت له باعتباره مجرد صورة رسمية، فليس الهـ للسند أي وظيفة في ضمان التأكيا الكامل لوجود الحق الموضوعي؛ حيث إن الأعمـال والتصرفات يعدها القانون سندات تنفيذية موجوده ولها طبيعتها الخاصة بغض النظر عن قدرتها على إنشاء السندات التنفيذية، فـالحكم موجود ولـه طبيعته القضائية بغض النظر عن كونه سندا تتفيذيا'(') والمحرر الموثق موجود وله طبيعته التعاقديـة، والذي ، يحول العمل القضائي أو العل التعاقدي أو التصرف إلى سند تنفيذي ليس احتواؤه على عنصر التأكيد أو إفراغه في مستتل يحتوي على هذا العنصر ولكن إرادة القانون في عدّ الحكم أو المحرر الموثق واقعة قانونية بالمعنى الواسع ينتج عنها أثر قانوني يكن في

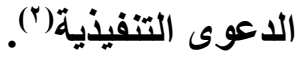

والرأي الراجح في الفقه أن للسند التتفيذي قوة تأكيدية(")؛ وذلك لأن وظيفة

السند التنفيذي تأكيا وجود الحق الموضوعي المراد اقتضاؤها جبرا(")، ولذلك يتطلب القـانون مجموعة مـن الشروط يجب توافرهـا في الحق الثابت في السند(ْ)؛ وهو أن

(1) Civ. 2e, 22 mars 2001, D. 2001. IR 1219, Cass. Civ. 2e, 28 juin 2006, D. 2007. Pan. 1388, obs. Julien.

(ץ) عكس ذلك انظر، د/ أحمد خليل، قانون التفيذ الجبري، المرجع السابق، ص · r. Civ. 2e, 3 nov. 2014, no 13-25.193, Bull. civ. II, no 231.

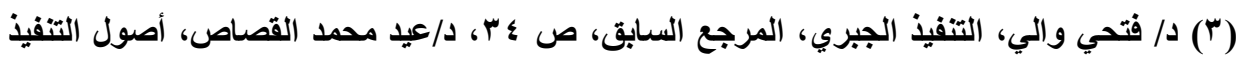

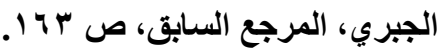

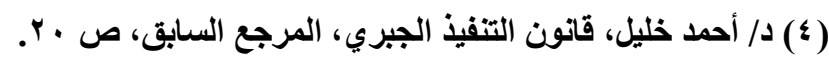

(5) R. PERROT et Ph. THÉRY, Procédures civiles d'exécution, op. cit., no 118. - LEBORGNE, Droit de l'exécution, op. cit., nos 432 s; CA Lyon, 9 mai 2001, RG no 2000/00816, JCP N 2002. 1099, note Laporte; Cass. 
دا طلعت يوسف خاطر

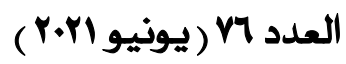

يكون محقق الوجود، وحال الأداء، ومعين المقار (') ويهدف من ذلك إلى تاكيد وجود

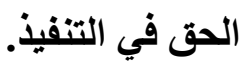

حيث ذهبت محكمة النقض إلى أن الأصل أن التنفيذ الجبري يكون بمقتضى

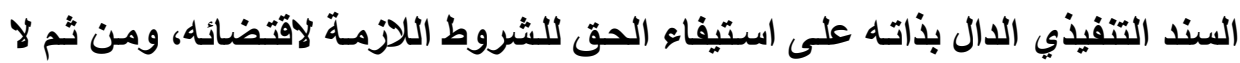
يجوز الاعتماد على دليل خارجي آخر لا يصلح بذاته سبيا للتنفيذ(ب). ونرى أن السند التنفيذي لا يتضمن يقينـا مطلقًاً(")ولكن يقينا نسبيا(")، فقد يتبين بعد البدء في التنفيذ عدم وجود الحق ويلغي السند التنفيذي ذاته، فالسند يضمن

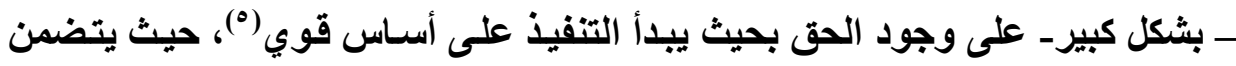
السند الشروط التي تجطله جديرا بالتنفيذ الجبري(")، ويصدر هذا التأكيد عن جهة

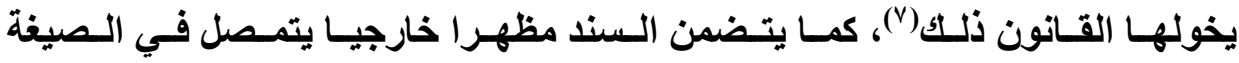

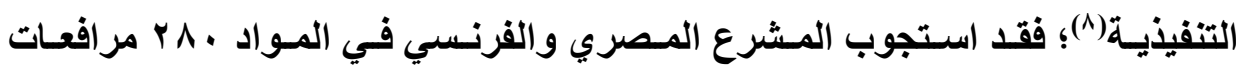

Civ. 2e, 22 oct. 2009, Bull. civ. II, no 254 ; Dr. et proc. 2010. 86, note Léon.

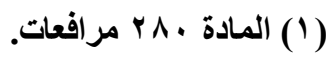

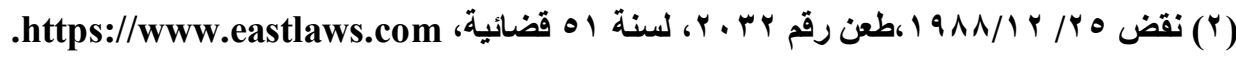
(3) Gerard Couchez et Daniel lebeau, voies dexecution, 19 éd. 2012, no 14.P11

( ) دا وجدي راغب فهمي، النظرية العامة للتفيذ القضائي في قانون المرافعات، المرجع السابق، ص

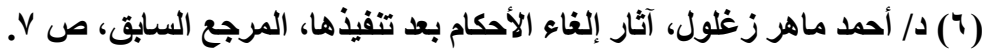

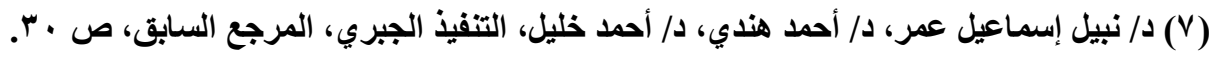

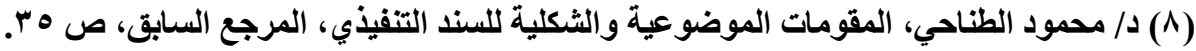

مجلت البحوث القانونيت والإقتصاديت 
مصري و اهه إجراءات فرنسي و r I Y مدني فرنسي، أن يكون محل السند التنفيذي حقا محقق الوجود، ومعين المقدار، وحال الأداء(').

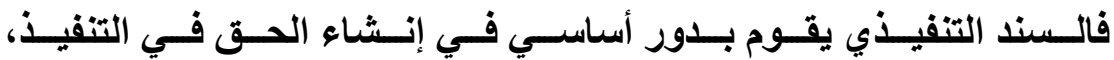
والحالات الاستثنائية التي يتم فيها التفيذ بدون سند(؟)، لا يصح أن يفهم منها عدم ضرورية السند التنفيذي؛ ذلك أن حسات التنفيذ بغير سـند تنفيذي تـخل في نطاق

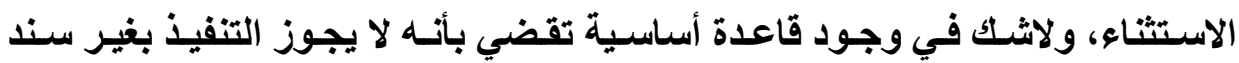
تتفيذي("). ويرجع ذلك إلى أن عنصر التأكيد للحق يهذف إلى تحقيق مصلحة المدين في السند، ولـذلك اشـترط أن يكون حق الـدائن محقت الوجـود، ومعين المقدار، وحسال

(1) د/ أحمد ماهر زغلول، آثار إلغاء الأحكام بعد تنفيذها، المرجع السابق، ص V، د/ محمود الطناحي،

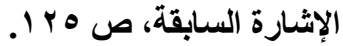

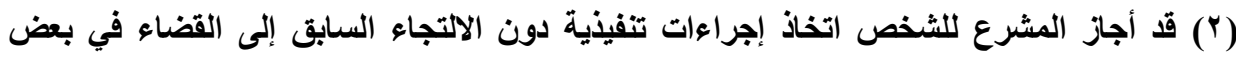

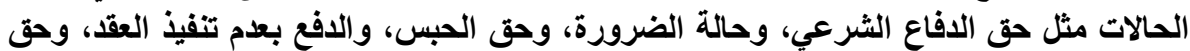

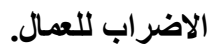

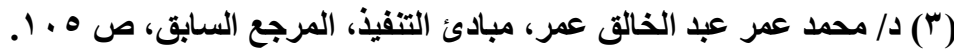

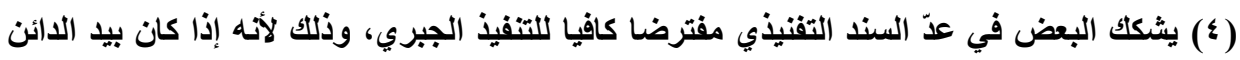

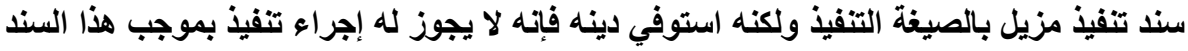

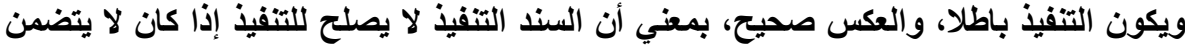

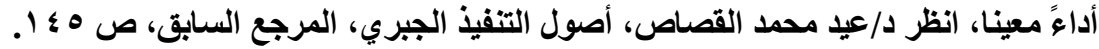




\section{ثالثاً: السند التفيذي لا يقوم بوظيفة إثبات الحق الموضوعي}

السند التنفيذي ليس دليلا لإثبات الحق الموضوعي(')؛ وذلك لأن الدليل إنمـا

يقدم للقاضي لاقتناعه بوجود واقعة معينة، ويكون للقاضسي سلطة تقدير هذا الدليل، وهذا ما لا يحدث بالنسبة للسند التنفيذي الذي يقدم لعامل التنفيذ؛ ليس لاقتناعه بوجود الحق بل للقيام بالتنفيذ الجبري، فهو ملزم بذلك، وإلا تعرض للمسئولية عن عدم القيام

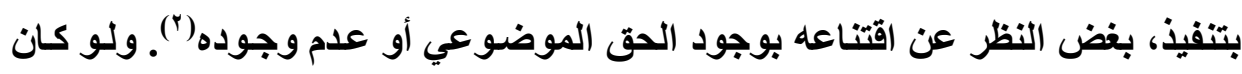
السند دليلا الحق الموضوعي لكسان الحق في التنفيذ ناشسئا عنهاه، وليس عن السند التنفيذي، وهو ما يتعارض مع استقلال الحق في التنفيذ الجبري كحق إجرائي مستقل عن الحق الموضوعي نفسه، فالحق في التنفيذ الجبري ينشأ عن السند التنفيذي، وليس اليس عن الحق الموضوعي الوارد فيه(").

(1) فكرة السند التنفيذي مستقلة عن فكرة دليل الإثبات القضائي، بالرغم من أنه يطلق على دليل

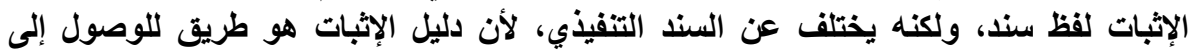

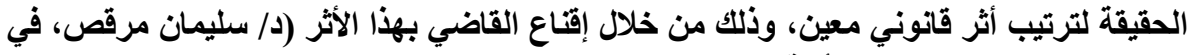

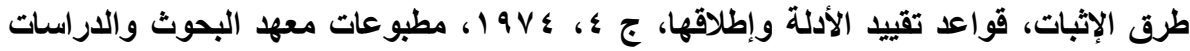

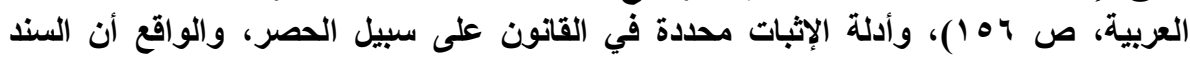

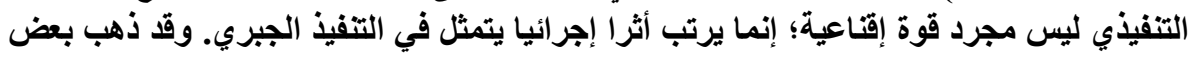

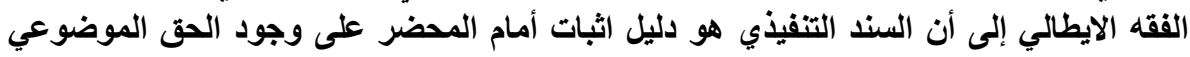

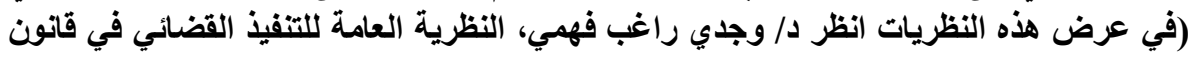

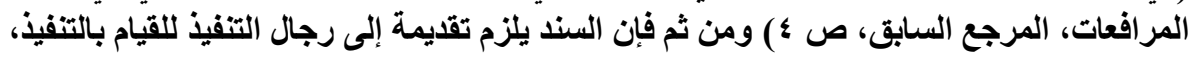

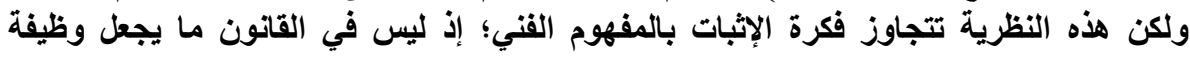

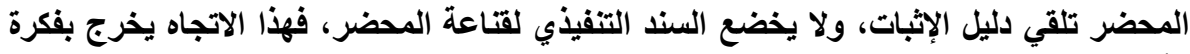
الأثبات عن معناها الفني.

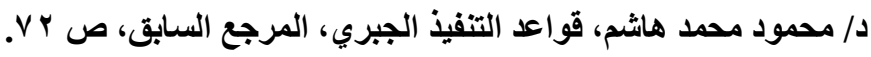

$$
\begin{aligned}
& \text { (r) د/ فتحي والي، التنفيذ الجبري، المرجع السابق، ص هـ هـ. }
\end{aligned}
$$


إن فكرة السند التنفيذي لا تعد دليل إثبات بالكتابـة الرسمية(')، ولو أن كل

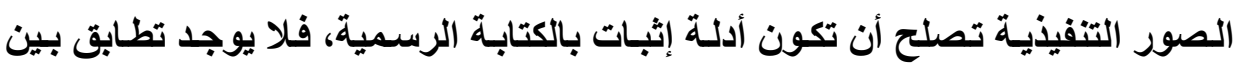
الفكرتين؛ فليست كل أدلة الإثبات بالكتابة الرسمية صورا تتفيذية، بل توجد أدلنة كتابية أخرى متعددة لا تعد صورا تنفيذية بمعناها الفني في القانون، وليس للصورة التنفيذية التئية

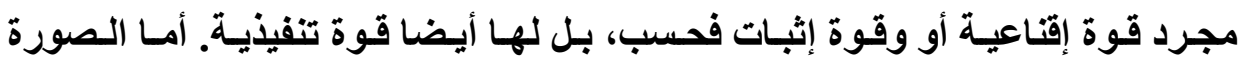

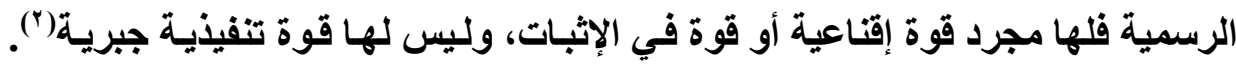

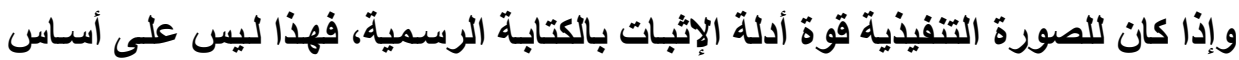

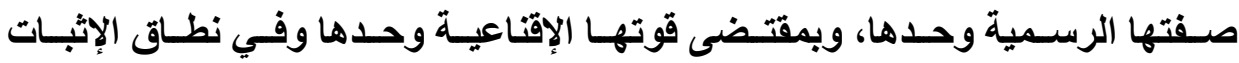

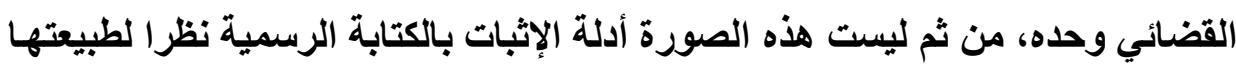
التنفيذية.

ونخلص من ذلك إلى أن المشرع يهاف من وجود السند التنفيذي إلى أن يكون

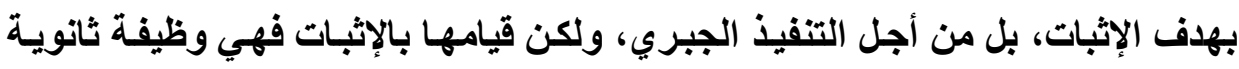

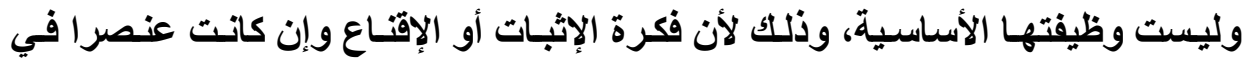
فكرة دليل الإثبات القضائية، فإنها ليست عنصرا في فكرة السند التنفيذي أو شرطا

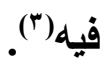

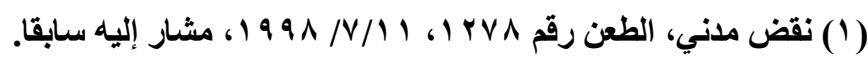

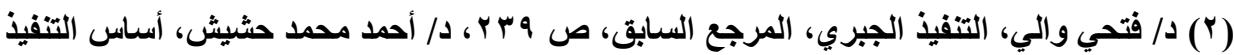

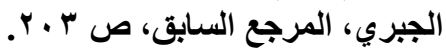

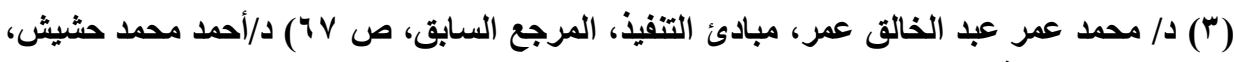

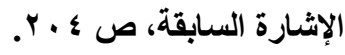




\section{خلاصة المبحث التمهيدي}

نلخص مما تقدم إلى أن فكرة السند التنفيذي عبارة عن عمل قانوني يستلزم

المشرع لتحقيقه شروطا معينهـه من شـأنها تأكيد وجـود الحق في التففيذ، فالأصل أن يكون محل التنفيذ حقا مؤكدا ومعيناً وممكناً كي يمنحه قانون المرافعـات قوتهه التنفيذيـة الجبريـة. وفكرة السند التنفيذي وليدة التطورات التاريخيةة(') فقد نتجبت فكرة السند التنفيذي مـن تفاعل الأنظمـة الجرمانيـة والقـانون الرومـاني، وأصبح السند التففيذي مفترضاً قانونياً للتنفيذ الجبري، فيجب أن يتوفر السند التنفيذي عند البدء في التنفيذ وإلا كان التفيذ باطلا، ولا يؤدي إلى صحة الإجراءات وجود السند بعد ذلك. ولقد اشترط القانون في السند التنفيذي شرطين حتى يمكن التنفيذ بـه، وهمـا: الأول: أن يكون من بين السندات التنفيذية التي نص عليها المشرع على سبيل الحصر، والشرط الآخر: أن يكون السند مشتملاً على الصيغة التنفيذية، فلا يجوز التنفيذ كقاعدة إلا بمقتضي صورة تنفيذية من السند التنفيذي. ويهذف المشرع من وراء السند التففيذي إلى تحقيق القوة التففيذية، والقوة التأكيدية، وعدم عدّه أداة إثبات لأي حق.

(1) GUINOT, Aperçu historique de la formule exécutoire, op. cit., no 11. 2. 


\section{الفصل الأول \\ المستحدث في أنواع السندات التنفيذية الاولية}

هقدهة:

إن فكرة السند التنفيذي حكر على قانون المرافعات(')، فهي فكرة إجرائية ذات

وظيفة تنفيذية(؟) ويلاحظ أن السياسـات التشريعية تختلف في إنشاء السندات التنفيذية

$$
\text { ما بين التضييق والتوسع على النحو الآتي: }
$$

الاتجاه الأول: النظم المضيقة في تحديد السندات التنفيذية:

هـذه الاتجـاه يقلـل مـن نطــاق الـسندات التنفيذيـة ويحـصر ها فـي الأحكــام

والأوامر(")، وهذا هو الاتجـاه الأنجلوسكسوني، مثنل القـانون الإنجليزي، والسوداني،

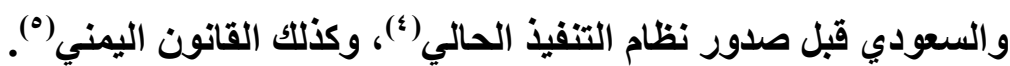

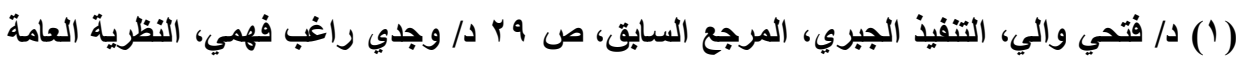

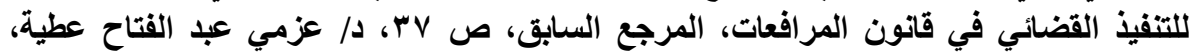

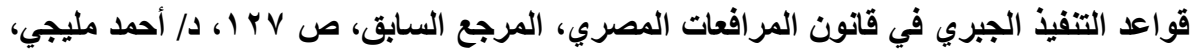

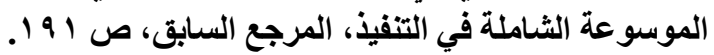

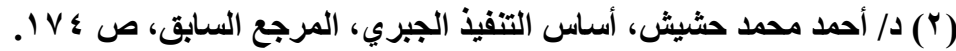

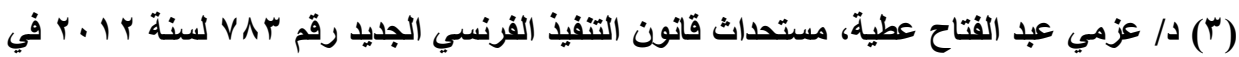

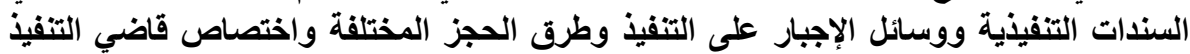

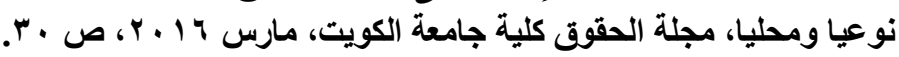

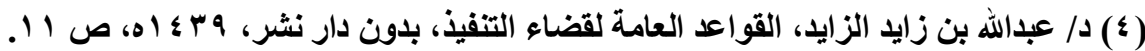

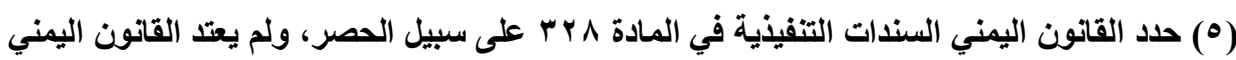

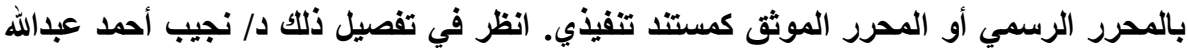

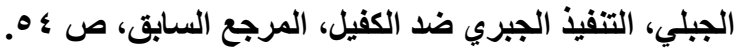




\section{الاتجاه الثاني: النظم المتوسعة في تحديد السندات التنفيذية('):}

هذا الاتجـاه يوسـع من نطـاق السندات التنفيذيةة(؟)، فتشمل السندات الأحكـام

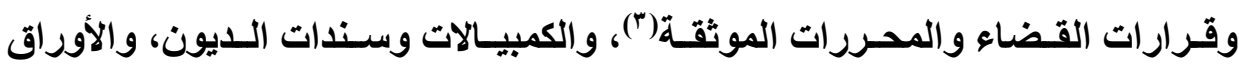

العادية، وذلك من نحو القانون الايطلي، والليبي، والعراقي، والسعودي(؛) والأردني،

واللبناني (0).

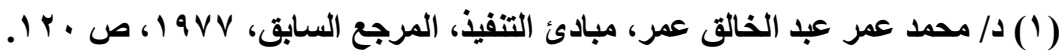

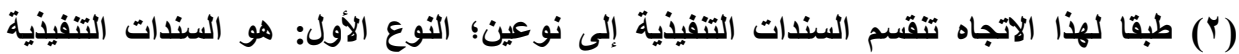

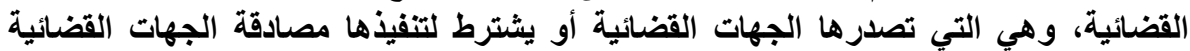

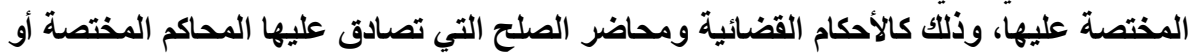

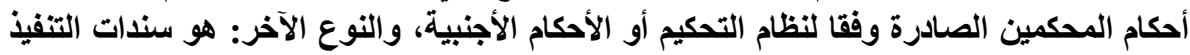

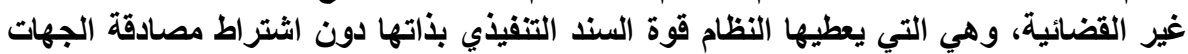

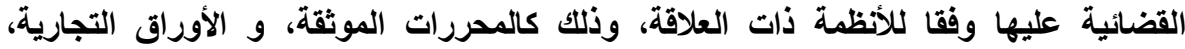

$$
\text { والأوراق الرسمية، والأوراق العادية. }
$$

(3) Cass. Civ. 2e, 1er févr. 2018, D. 2018. Actu. 299.

(؛) طبقا للنظام السعودي كاتت السندات التنفيذية في نظام التنفيذ السابق محصورة في الأحكام

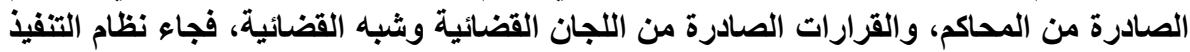

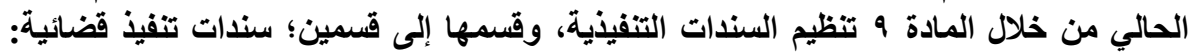

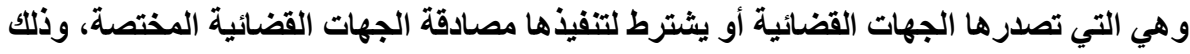

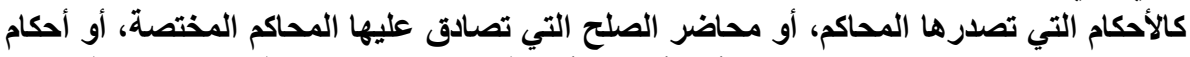

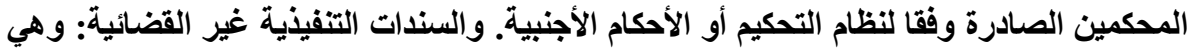

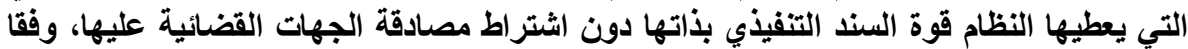

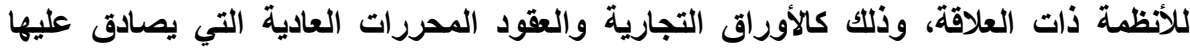

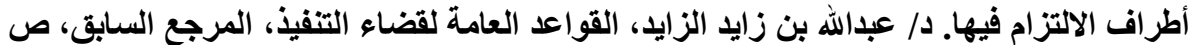

(0) كبريال سرياني وغالب غانم، قوانين التنفيذ في لبنان، الجزء الأول، دار المنشورات الحقوقية،

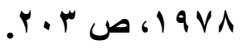




$$
\begin{aligned}
& \text { الاتجاه الثالث: النظم المتوسطة في تحديد السندات التنفيذية: } \\
& \text { وهــذه الـنظم التــي تـضيف مــع الأحكــام والأوامسر القـضائية، المحـررات } \\
& \text { الموثقة ومحاضر الصلح التي تصدق عليها المحاكم، والأوراق الأخرى التي يعطيها }
\end{aligned}
$$

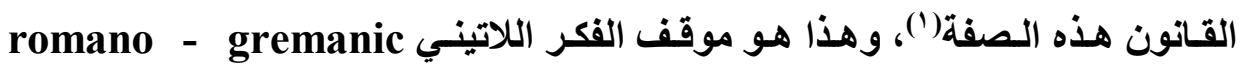

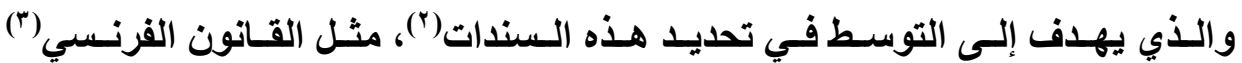

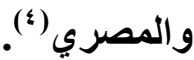

(1) CEDH 18 avr. 2002, D. 2002. Somm. 2572, obs. Fricero. CEDH, gr. ch., 15 oct. 2009, JCP 2010. Doctr. 70, no 6, obs. Sudre, CEDH 10 mai 2012, Roumanie, Procédures 2012, comm. 247, note Fricero, FRICERO, Procédures civiles d'exécution, 4e éd., 2014, Gualino, p 40.

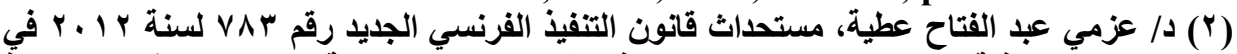

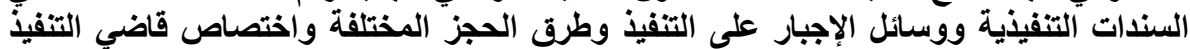

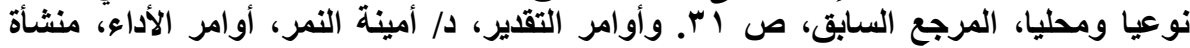

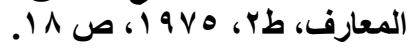

(3)Article L111-3 dispose que:Seuls constituent des titres exécutoires : $1^{\circ}$ Les décisions des juridictions de l'ordre judiciaire ou de l'ordre administratif lorsqu'elles ont force exécutoire, ainsi que les accords auxquels ces juridictions ont conféré force exécutoire ; $2^{\circ}$ Les actes et les jugements étrangers ainsi que les sentences arbitrales déclarés exécutoires par une décision non susceptible d'un recours suspensif d'exécution, sans préjudice des dispositions du droit de l'Union européenne applicables ; $3^{\circ}$ Les extraits de procès-verbaux de conciliation signés par le juge et les parties ; $4^{\circ}$ Les actes notariés revêtus de la formule exécutoire ; $4^{\circ}$ bis Les accords par lesquels les époux consentent mutuellement à leur divorce par acte sous signature privée contresignée par avocats, déposés au rang des minutes d'un notaire selon les modalités prévues à l'article $229-1$ du code civil ; $5^{\circ} \mathrm{Le}$ titre délivré par l'huissier de justice en cas de non-paiement d'un chèque ou en cas d'accord entre le créancier et le débiteur dans les conditions prévues à l'article $L .125-1 ; 6^{\circ}$ Les titres délivrés par les personnes morales de droit public qualifiés comme tels par la loi, ou les décisions auxquelles la loi attache les effets d'un jugement.

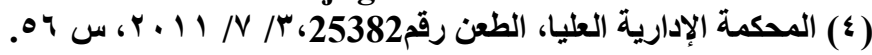


ولن نتناول في هذا الفصل بالتفصيل جميع السندات التنفيذية والثروط اللازم

تو افرها في كل منها، فمكان دراستها التفصيلية في المؤلفات العامة في التنفيذ الجبري،

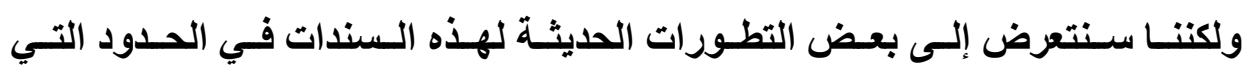
قد يبدو فيها حاجة المشرع المصري إلى النظر في هذه التطورات الحديثة في القانون

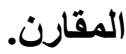

وسنعالج في هذا الفصل الأوراق التجارية كسندات تنفيذية، وذلك في المبحث

الأول، ثم نعالج الأوراق العادية والأوراق الرسمية كسندات تنفيذية، وذلك في المبحث الثاني، وذلك على النحو الآتي: 


\section{المبحث الأول \\ الأوراق التجارية كسندات تنفيذية}

السندات التنفيذية هي المصدر الوحيد للحق في إجراء التنفيذ الجبري(") ولقد

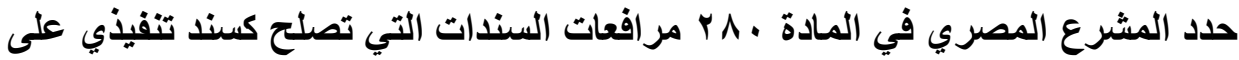

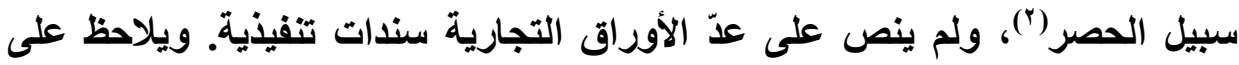

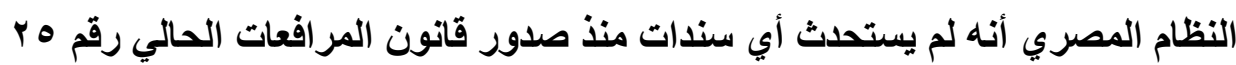

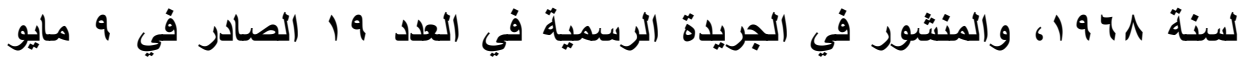
.1971

وعلى عكس المشرع المصري فقد اتجهت بعض الأنظمة العربية والأجنبية إلى

النص على عدّ الأوراق التجارية سندات تنفيذية، ومن الأنظمة التي أخذت بذلك النظام

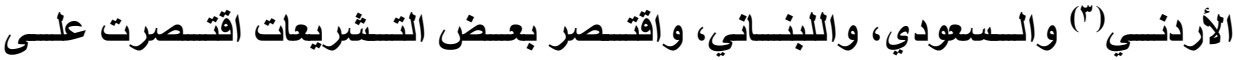

(1) د/ أحمد خليل، قانون التنفيذ الجبري، المرجع السابق، ص 9 الـ د داعيد محمد القصاص، أصول Marie-Pierre

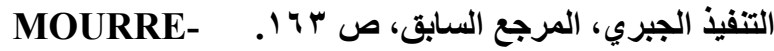

SCHREIBER, Huissier de justice, op. cit., N0 422.

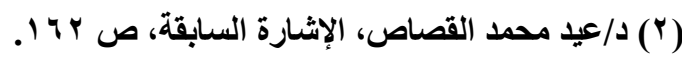

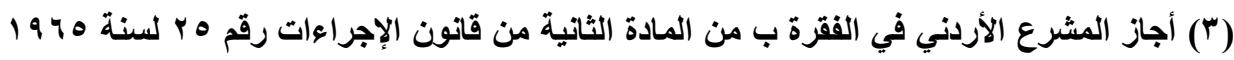

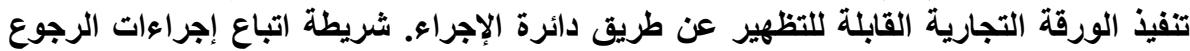

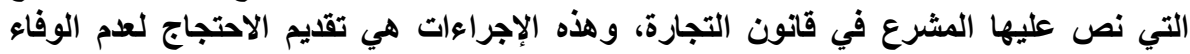

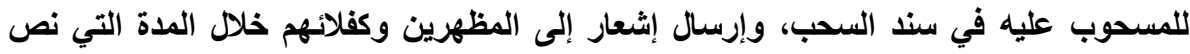

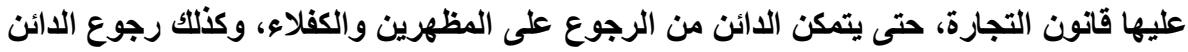

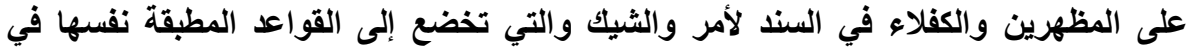

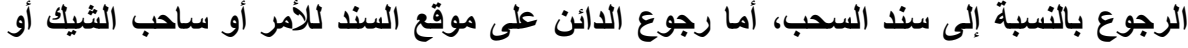

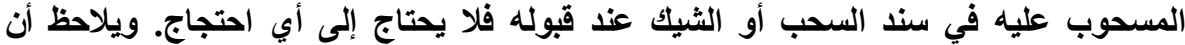
$=$ 
الشيك كسند تنفيذي مثل النظام الفرنسي (')

ويلاحظ أن هذه الأنظمة استشعرت أهمية الأوراق التجارية، فمنحتها صفة

السندات التنفيذية، وذلك من أجل تسهيل تنفيذها، لكون الأوراق التجارية عماد النظام

التجاري، كما أن ذلك نتيجة لتطور الحياة الاقتصادية المتسارعة، والتي أوجبت

ضرورة رعاية مصلحة صاحب الحق في تنفيذ الأوراق التجارية.

وسنشير في هذا المبحث إلى ماهية الأوراق التجارية، وذلك في المطلب الأول،

ثم نعالج إجراءات تنفيذ الأوراق التجارية في الأنظمة التي تأخذ بها كسند تنفيذي، وذلك

$$
\text { في المطلب الثاني. }
$$

\section{المطلب الأول

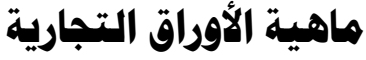

ورد اصــطلاح الأوراق التجاريـة فــي قـانون التجــارة المـصري والأردنــي

والسعودي، ولـم يتــاول المشرع المصري التعريـف، مكتفيـا بيـان أنـواع معينـة مـن

المشرع الأردني قد أوجب للرجوع على المظهرين والكفلاء في الأوراق التجارية أمام دائرة

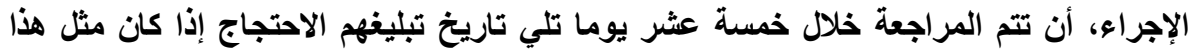

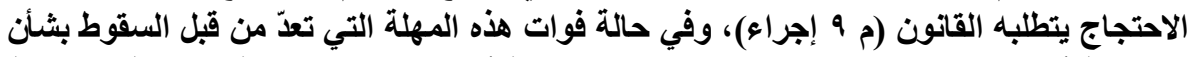

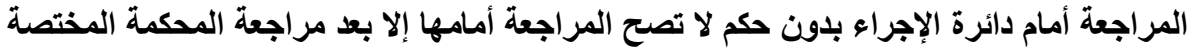

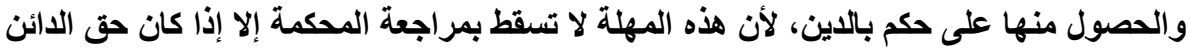

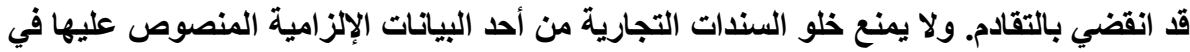

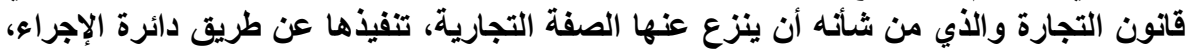

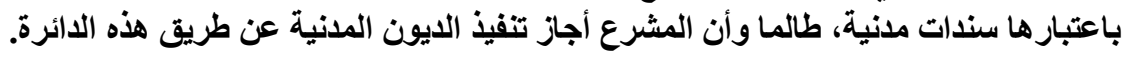

(1) Marie-Pierre MOURRE-SCHREIBER, Huissier de justice, op. cit., n. 422. 
الأوراق الشائع استعمالها في العمل؛ وهي الكمبيالة والسند لأمر والشيك، وغيرها من الأوراق التجاريـة الأخرى، وهذا الأمـر أدى إلى اختـلاف الرأي حـول تعريـف الورقة التجارية(')، وقا حاول الفقه وضع تعريف لها يُستمد من خصائصها التي تميزها من وهن غيرها من الأوراق والحوالات المتداولة في قانون المعاملات(؟). سنشير في هذا المطلب إلـى تعريـف الأوراق التجاريـة ودورهـا الاقتصادي، وذلك في الفرع الأول، ثم نبين أنواع الأوراق التجاريـة، وذلك في الفرع الثاني، وذلك

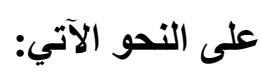

\section{الفرع الأول}

\section{تعريف الأوراق التجارية ودورها الاقتصادي}

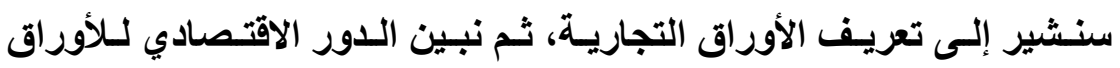

التجارية، وذلك في النقاط الآتية:

أولا: تعريف الأوراق التجارية

إذا كاتت اغلبية التشريعات الحديثة قد تركت التعريفات للفقه؛ وذللك لمسا يسببه

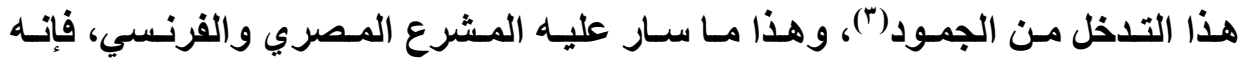

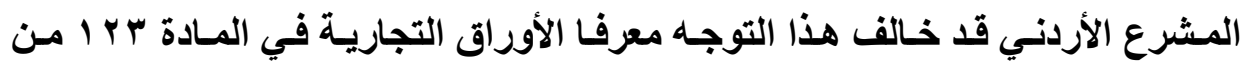

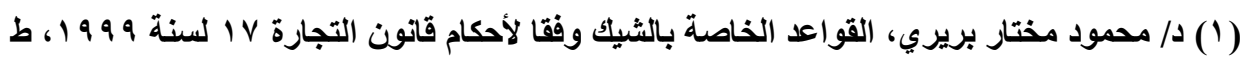

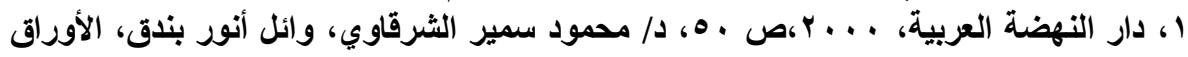

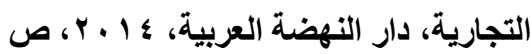

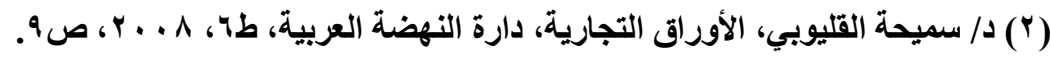

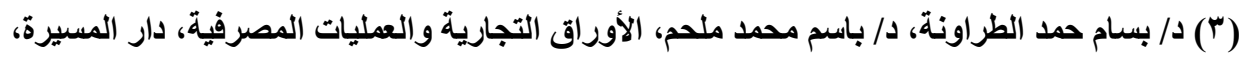

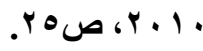


قانون التجارة الأردني رقم ج ا لسنة צ 9 ا 1، بقولله : " إسناد قابلة للتداول بمقتضى أحكام هذا القـانون..."، ثم تـلاه المشرع العراقي فعرفها في المـادة وب من القانون

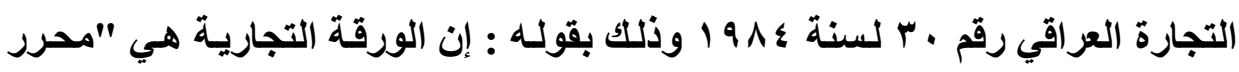
شكلي بصيغة معينة يتعهد شخص أو بأمر شخص آخر فيه بأداء مبلغ محدد من النقود وفي زمان ومكان معينين، ويكون قابلا للتداول بـالتظهير أو بالمناولةتة. ويطلق بعض

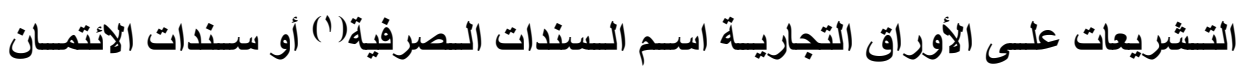
الصرفية، وأطلقوا على الالتزام الناثسئ عنها اسم التزام الصرف المسحوب، ويقصد بعقد الصرف مبادلة نقود بنقود (`)

وقد عرف بعض الفقه الإنجليزي الأوراق التجاريـة بأنها حق معنوي يمكن تداولها بالتسليم أو بالتظهير بحيث تنتقل ملكيتها بالكاملة، وخالية من أي عيب قد يكون عالقـا بـالحق الذي تمثلـه إلى المحال إليـه بشرط أن يكون الأخير حسن النيـة، ودفع قيمتها بالكامل (َ). وعرفها الفقه المصري بأنها "صك يحرر وفقا لشروط قانونية معينة يقبل التداول بالطرق التجارية ويقوم مقام التقود في المعاملات"(")، فالسمة الأساسية

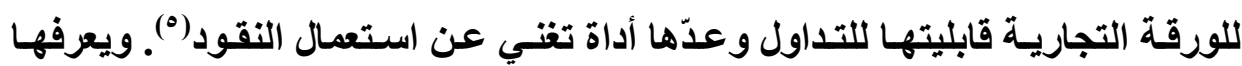
جانب من الفقه(') بأنها محرر قابل للتـاول بـالطرق التجاريـة ويمثل موضعاه مبلغـا من

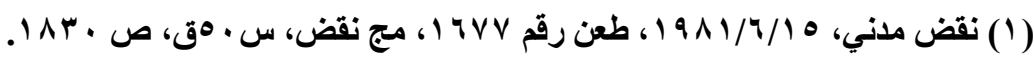

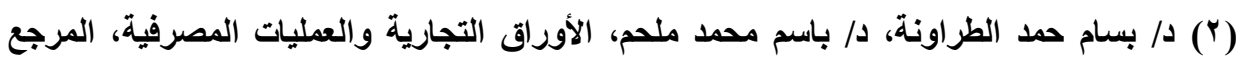

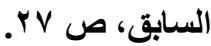

(3) Richardson, A guide to negotiable intstruments, $4^{\text {th }}$ ed. London, 1970, p. 150.

( ( ) د/ محمود سمير الثرقاوي، وائل أنور بندق، الأوراق التجارية، المرجع السابق، ص 9 أ.

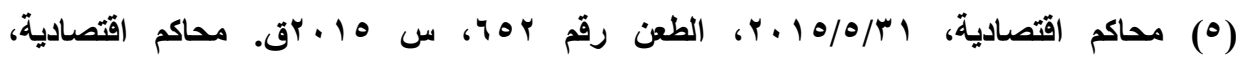

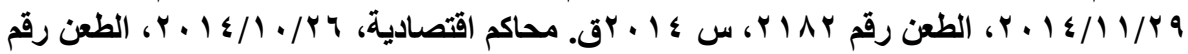

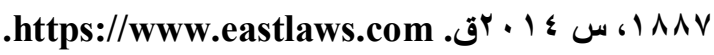


من الفقه(') بأنها محرر قابل للتداول بالطرق التجارية ويمثل موضعه مبلفا من النقود يستحق الوفاء بمجرد الاطلاع أو في ميعاد معين أو قابل للتعيين ويستقر العرف على اعدّه أداة للوفاء تقوم مقام النقود(؟) وقد عرفها البعض بأنها صكوك تمثنل حقا نقديا لـــالح حاملهــا، واجـب الــدفع بمجـرد الاطــلاع أو فـي ميعـاد أو قابـل للتعيسين، وقابـــه للتــداول بـالطرق التجاريـة على أن يـستقر العـرف على قبولهـا خلفـا للـدفع

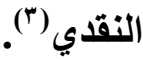
وقد عرفها بعض الفقه الأردني بأنها " صكوك مكتوبـة وفقا لأوضـاع قانونيـة محددة، وتتضمن التزاما بدفع مبلِغ من النقود في وقت معين أو قابـل للتعيين وتنتقل الحقوق الثابتة فيها بطريق التظهير أو المناولة، ويقبلها العرف التجاري كأداة لتسوية الايون بسبب سهولة تحويلها إلى نقود"(")

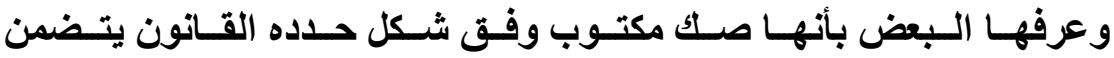

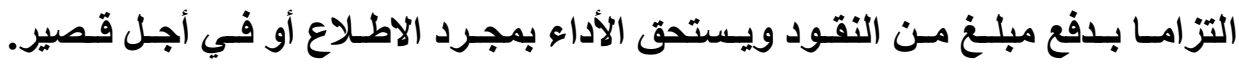

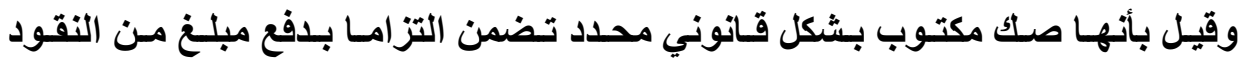
في وقت معين أو قابـل للتعيـين، ويمكن نقل الحق الثابـ فيهـا بطريـق التظهير أو المناولة)(ب).

$$
\begin{aligned}
& \text { (1) د. محسن شفيق، الوسيط في قانون التجاري المصري، } 999 \text { 19 1، ص } 109
\end{aligned}
$$

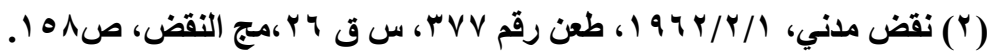

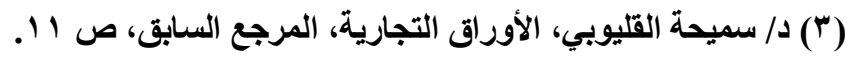
(؛) د/ بسام حمد الطراونة، د/ باسم محمد ملحم، الأوراق التجارية والعمليات المصرفية، المرجع

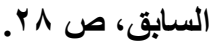

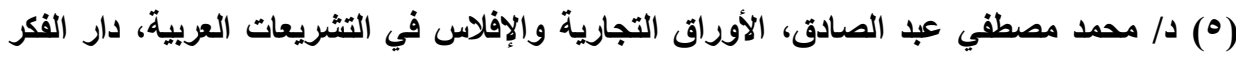

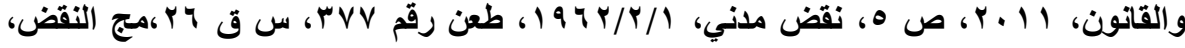




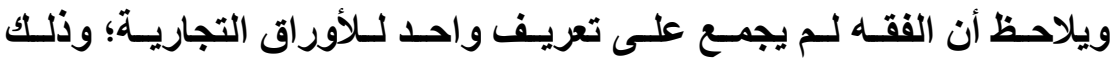

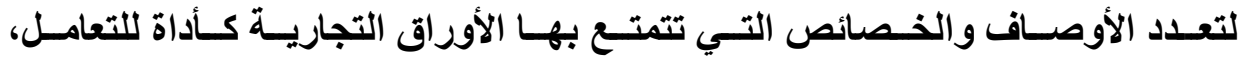

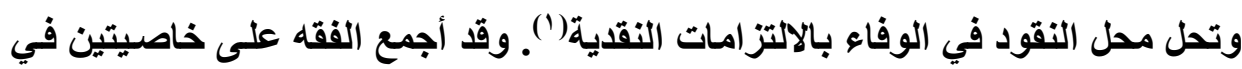

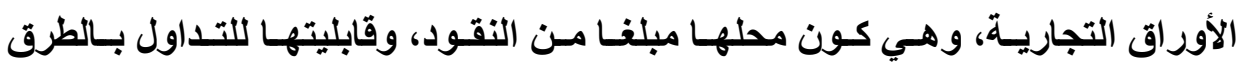

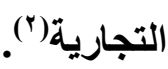

ويلاحظ على هذه التعريفـات أن الأوراق التجاريـة يجب أن تتضمن الشروط

1 - يشترط أن يكون محل الورقة التجارية مبلفا من النقود:

لاعتبار الورقة تجارية يجب أن تتضمن مبلغا من النقود(")، ومن ثم فالصكوك

التي يمثل موضعها بضاعة مـا، كسند الشحن البحري لا يعدّ ضمن الأوراق التجاريـة، وكذلك الشأن بالنسبة للسندات التي تصدرها المخـازن العامـة والتي تمثنل البضاعة المودعة لايها، وإن كانت هذه الصكوك قابلة للتداول بالطرق التجارية؛ ويرجع ذلك إلى الدور الذي تقوم بـه الأوراق التجاريـة في الحيـاة العملية، فهي تقوم بدور النقود في

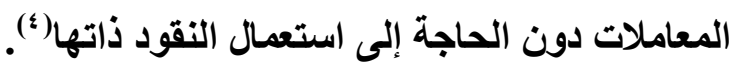

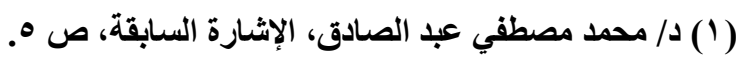

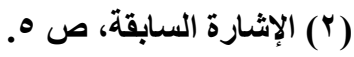

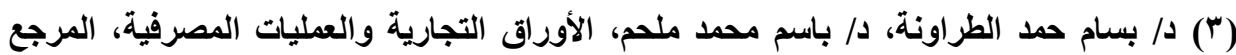

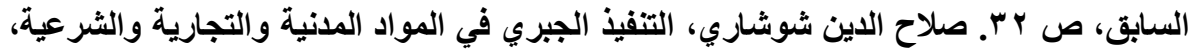

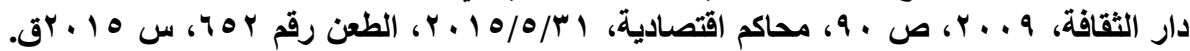

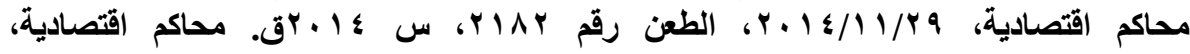

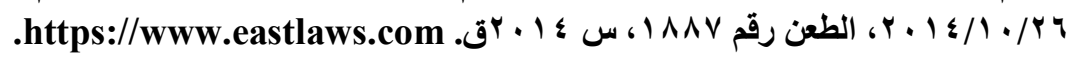

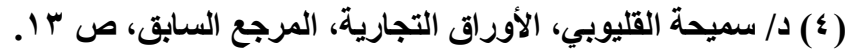


ويثترط أن يكون المبلغ من النقود موضوع الحق الثابت بالورقة غير معلق على شرط، ويجب أن يكون معين المقدار بكل دقة ومستحق الأداء للاى الاطلاع أو في

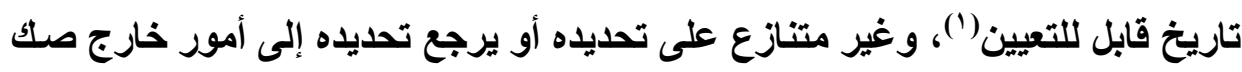

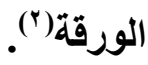

r- ق قابلية الورقة للتداول بالطرق التجارية: يقصد بها قابلية الورقة للتدوال من شخص إلى آخر بالطرق التجارية السريعة

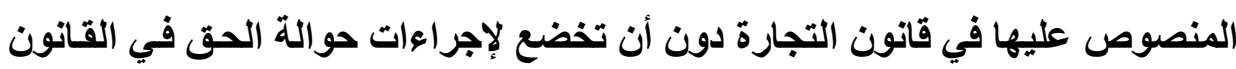

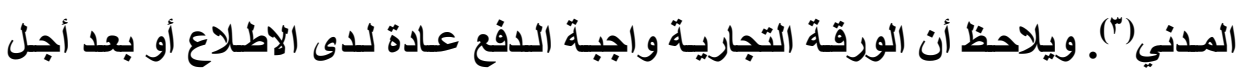
قصير.

ولقد أوجد العرف التجاري الأوراق التجاريـة ودعمها بأن منحها الثقة في التعامل (4) ولذا يرى الفقه وجوب قبول العرف للورقة بوصفها تجاريـة وتؤدي وظيفة

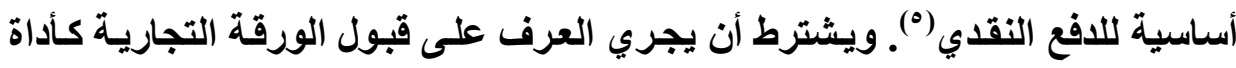

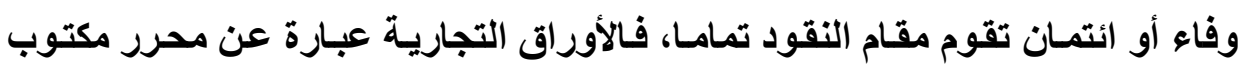

(1) صلاح الدين شوشاري، التفيذ الجبري في المواد المدنية والتجارية و الثرعية،، المرجع السابق،

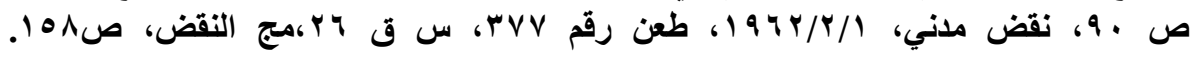
.https://www.eastlaws.com

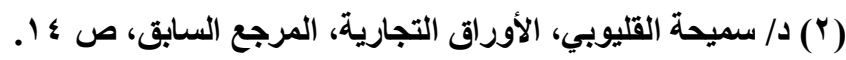

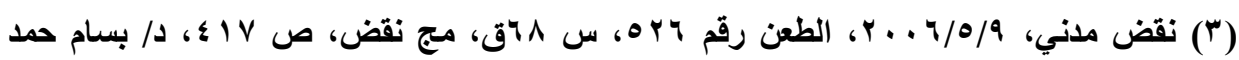

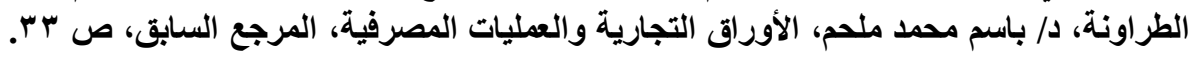
صلاح الدين شوشاري، التنفيذ الجبري في المواد الددنية والتجارية والثرعية، المرجع السابق، صلئ 
وفقا لأوضـاع شكلية يحددها القـانون، أمسا إذا لم يوجد محرر مكتوب فلا تكون هنـاك ورقة تجاريـة، ولكن تبقي علاقة المديونيـة الأصلية التي تتخذ الورقة التجاريـة أداة

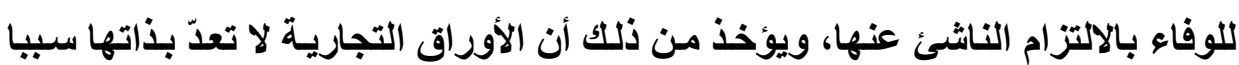
لإنشاء الالتزام ولكنها وسيلة لإثباته وأداة للوفاء بهـ('). ثانياً: الدور الاقتصادي للأوراق التجارية: إن الأي دفع المشرع الاجرائي في كثير من الدول إلى النص على عدّ الأوراق التجارية سندات تنفيذية، الدور الكبير لها في الواقع العملي سواء في النشاط التجاري أو المدني. ويلاحظ أن اصطلاح الأوراق التجارية يؤدي إلى الاعتقاد بأن استخدامها في

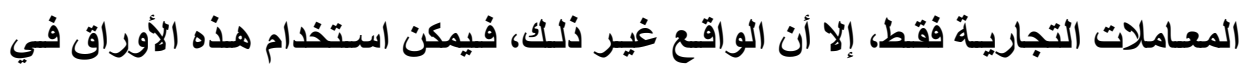
المعاملات المدنية، فالشيك يعدّ أكثر انتشارا في المعاملات المدنية.

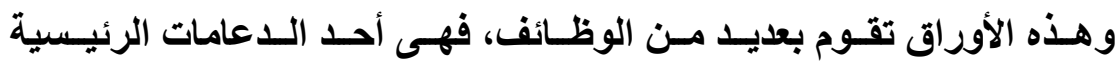
لحركة التجـارة والتداول()، وتعد وسيلة تنفيذ عقد الصرف، وأداة وفـاء رئيسية في المعاملات كما لو كاتت نقودا، وأداة ائتمان في الحـالات التي تتضمن فيهـا أجلا للوفـاء

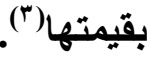

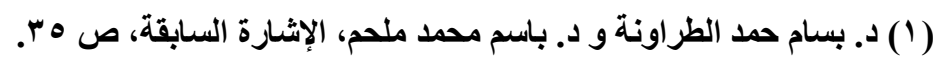

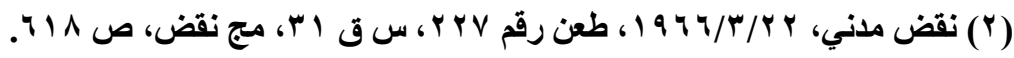

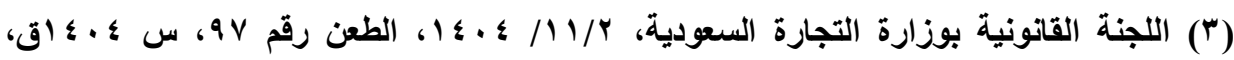
https://www.eastlaws.com 
ا - الأوراق التجارية أداة لتنفيذ عقد الصرف:

لقد ظهرت الورقة التجارية في بداية نشأتها كوسيلة لتفيذ عقد الصرف، وهي عبارة عن مبادلة نقود وطنية بنقود دولة أخرى(')، ويعد عقد الصرف المسحوب هو

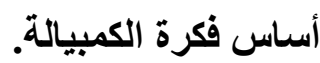

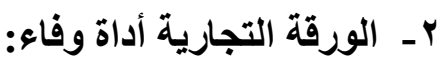

من أهم الوظائف الإقتصادية للأوراق التجارية كونها أداة للوفاء بالديون()، ويجتمع الثيك والسند لأمر مع الكمبيالة في القيام بهذه الوظيفة("). ولذلك فـإن التعقيد في إجراءات تنفيذ هذه الأوراق يخـالف الحكمة مـن وجودهـا، وهي تسهيل إجراءات تتفيذها وتبسيطها، ولهذا فقد عقلت بعذ التشريعات هذه الحكمة، ونصت منذزمن على إجراعات تنفيذ مبسطة للأوراق التجارية وذلك باعتبار هـا سندا تنفيذيا دون حاجة إلى لى اللجوء إلى القضاء.

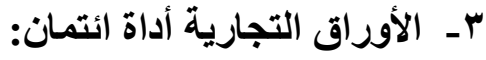
من المستقر عليه فقها أن الأوراق التجارية من أهم الأوراق في عالم التجـاره، وهي واجبة الدفع في أجل قصير، ويرجع ذلك إلى أن المعاملات التجاريـة تقوم بشكل أساسي على عنصري السرعة الائتمـان، ممـا يتــافى مـع إصدار أوراق تجاريـة لآجـال

(1) د/ بسام حمد الطراونة، د/ باسم محمد ملحم، الأوراق التجارية والعمليات المصرفية، المرجع السابق، ص • بـ الطام

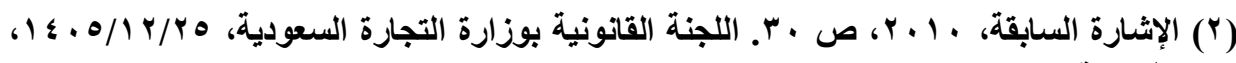

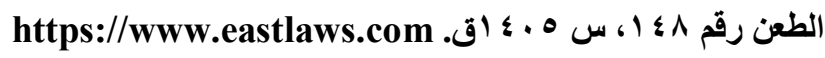

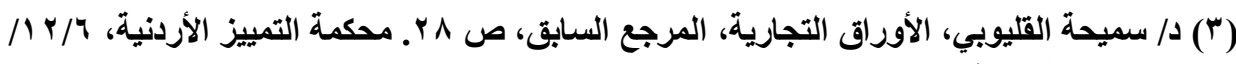

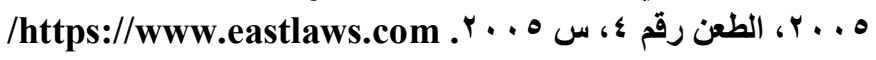


طويلة، كمـا أن العرف التجاري لا يقبل الآجـال الطويلـة(1)، فمن أهم وظـائف الأوراق

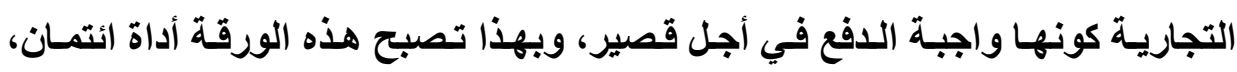

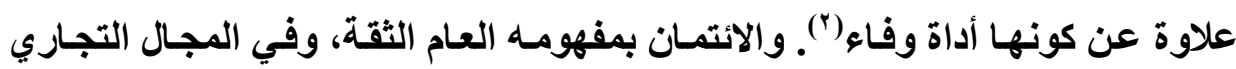

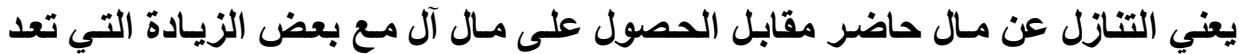
مقابل الأجل، وتعد الأوراق التجارية أفضل أداة للقيام بهذه الوظيفة("). ويمثل الأجل في المعاملات التجاريـة أهميـة كبيرة، لأن التجـارة تقوم على السرعة والاتتمـان في المعاملات، وتعد الأوراق التجاريـة المتضمنة أجلا للوفـاء مـن

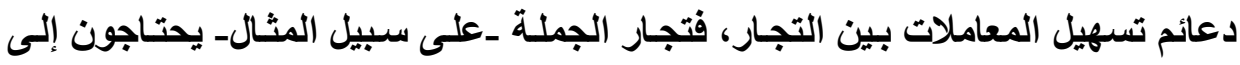

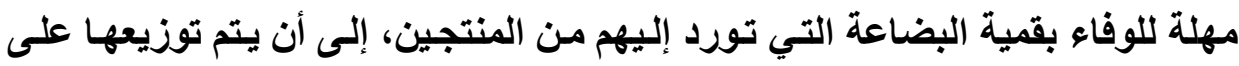

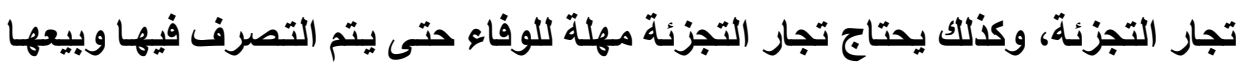

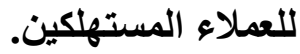
ويلاحظ أن وظيفة الإنتمان تؤديها كل من الكمبيالة والسند لأمر دون الشيك

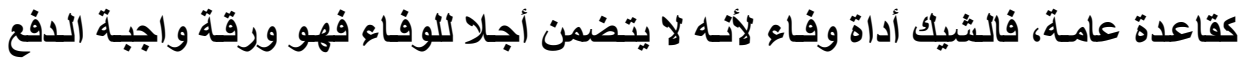

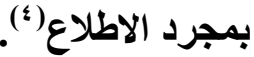
في واقع الأمر، بدون تنظيم المشرع لإجراءات ميسره للتنفيذ الجبري، ومنحها قوة السندات التنفيذية، فلن تؤدي هذه الأوراق وظائفها الاقتصادية، حيث إن استشعار (1) د/ بسام حد الطراونة، د/ باسم محمد ملحم، الأوراق التجارية والعمليت المصرفية، المرجع

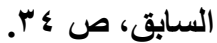

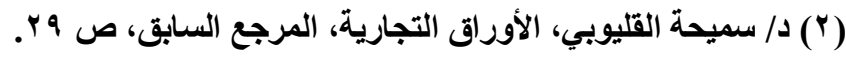

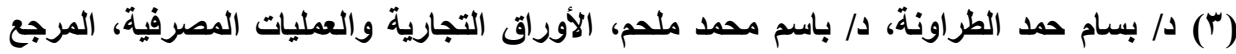

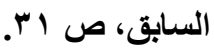

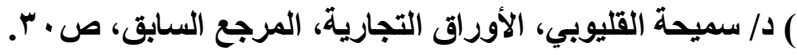


المتعاملين بالأوراق التجارية صعوبة التنفيذ يفقدها أهم وظائفها؛ وهي كونها أداة وفاء

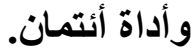

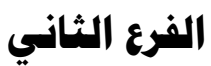 أنواع الأوراق التجارية}

لقد أكد قانون التجـارة المصري رقم V V لسنة 999 مـا جرى عليه الفقهـ والقضاء من عدّ الأوراق التجارية المسماة الكمبيالة والسند لأمر والشيك، وارده على سبيل المثال وليس الحصر؛ حيث جاعت عبارات المادة rVA صريحه في عدّ الصكوك التجارية على سبيل المثال وذلك بقولها: "... وغيرها من الأوراق التجارية الأخرى أيا كانت صسيفة ذوي الشأن فيها أو طبيعـة الأعمسال التي أنشئت مـن أجلهـا". ومـن ثم فالأوراق التجاريـة هي الكمبيالـة والسند لأمر والشيك، وغيرهـا مـن الأوراق التجاريـة الأخرى التي نص عليها القانون، أيا كانت صفة ذوي الثأن فيها أو طبيعة الأعمال التي أنشئت من أجلها(') ولم تشر المسادة rVA تجاري مصري، إلى السند لحاملـه على خلاف ما كان عليه أمر التشريع القديم، وسبب ذلك أن اتفاقية جنيف لم يرد بها تنظيم

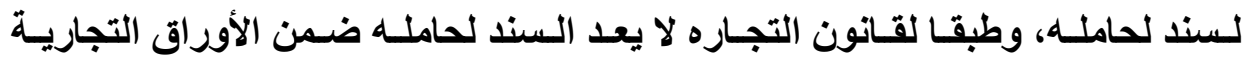

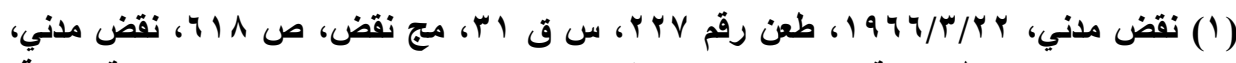
ه

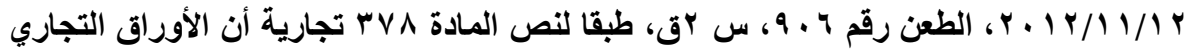

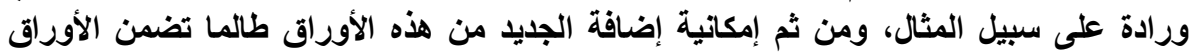

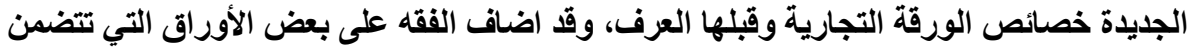

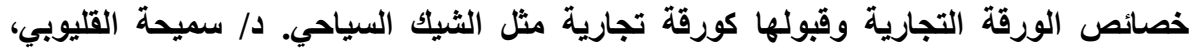

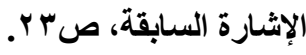


الخاضعه لحكم الباب الرابع منه رغم توافر خصائص الورقة التجاريـة بشأنه، وهذا مـا يسير عليه القانون القرنسي (').

وفي النظام السعودي نجد أن الأوراق التجارية هي الكمبيالة والسند لأمر(؟) والثيك(")، وجاء النص عليها على سبيل الحصر، ويحم الأوراق التجارية من حيث شروطها الثكلية وطرق تداولها نظام الأوراق التجارية الصادر بالمرسوم الملكي رقم

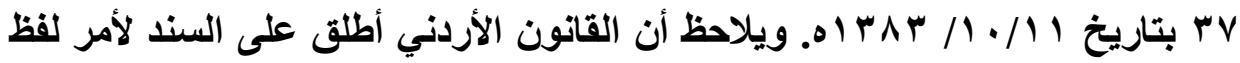
الكمبيالة(؛)، وذلك على عكس القانون المصري. ويعد السند لأمر (الكمبيالة) الورقة

(1) د/ سميحة القليوبي، الإثارة السابقة، ص † ـ د/ محمد حسن الجبر، القانون التجاري السعودي،

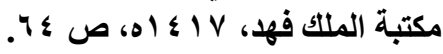

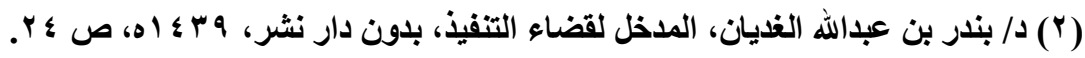

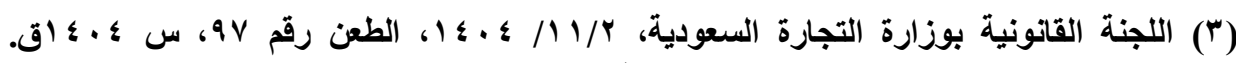


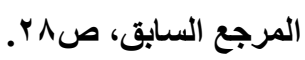

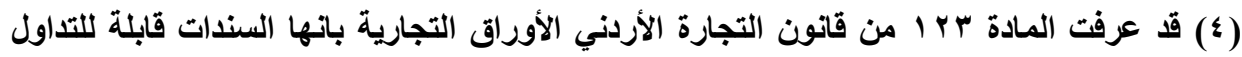

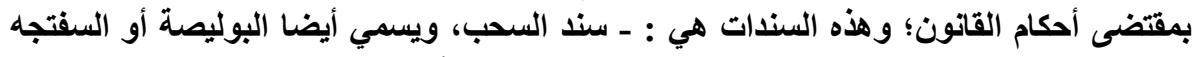

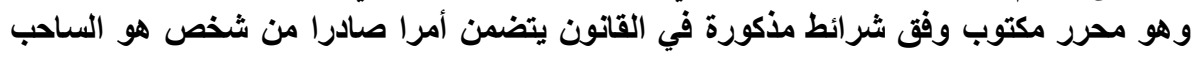

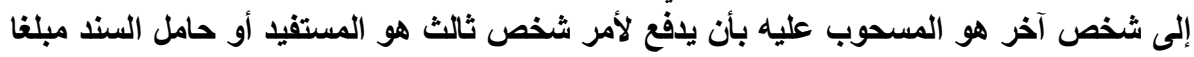
معينا بمجرد الاطلاع أو في ميعاد معين أو قابل للتعيين.

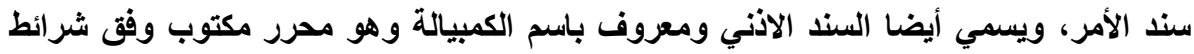

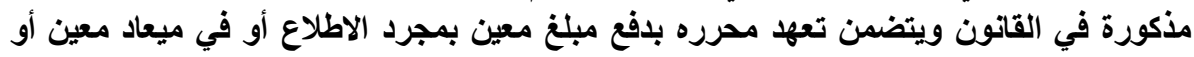
قابل للتعيين لأمر شخص فئون آخر هو المستفيد أو حامل السند.

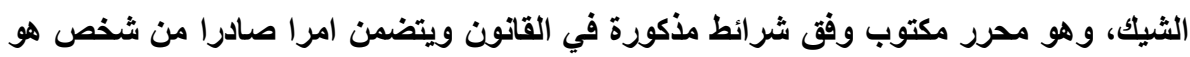

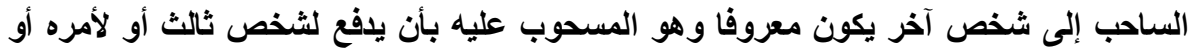

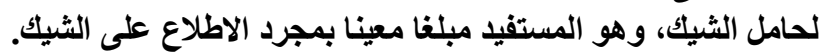

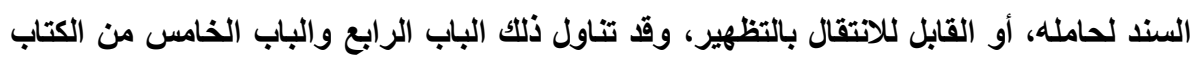

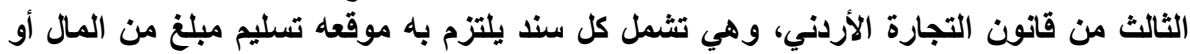
كمية من المثليات في محل وفي وقت معين ويجوز انتقال بطريقة التظهير إذا كان منثأ على وجه $=$ 
الأكثر استخداما بعد الثيك في النظام الأردني(')

ولن نخوض في شرح المبادئ العامة للأوراق التجارية، لأنها من موضوعات

القانون التجاري، وسنكتفي بنبذة بسيطة عن أنواع الأوراق التجارية والمتمثلة في الكمبيالة والسند لأمر والثيك باعتبارها من السندات التنفيذية في بعض الأنظمة

القانونية المقارنة.

وسنشير إلى الأوراق التجارية على النحو الآتي:

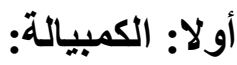

هي صك محرر وفقا لأوضاع شكلية معينة متضمنا بيانات معينه نص عليها

القانون تتضمن كلمة كمبيالة مكتوبا بمتن الصك وباللفة التي كتب بها؟"، تفيد أمرا

غير معلق على شرط بالوفاء بمبلغ معين من النقود موجه إلى المسحوب عليه لصالح

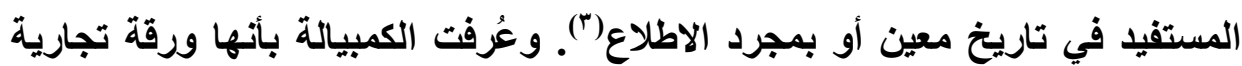

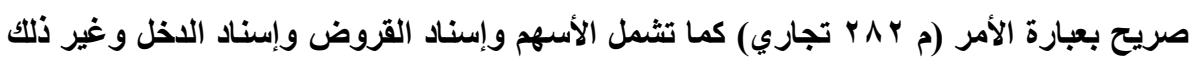

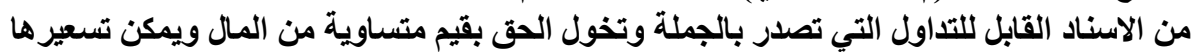

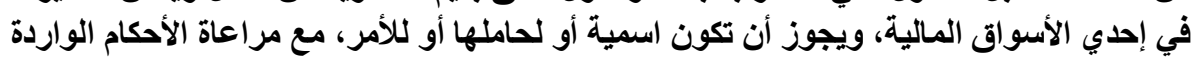

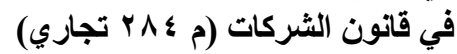
(1) د/ بسام حمد الطراونة، دا باسم محمد ملحم، الأوراق التجارية والعمليات المصرفية، المرجع

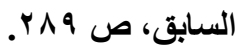

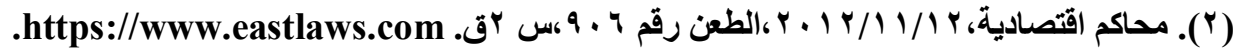

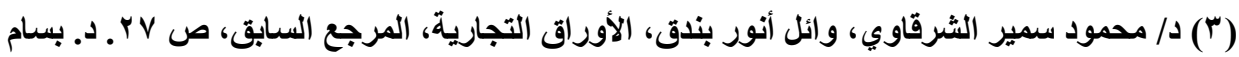

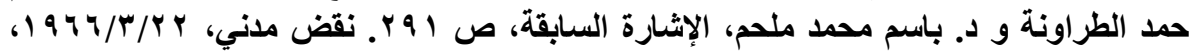

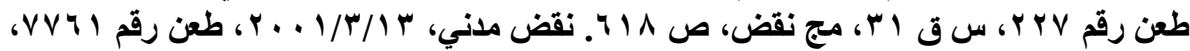

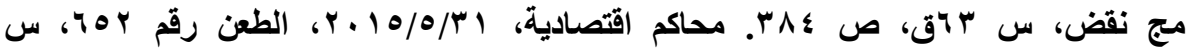
10 إن. 
تتضمن أمرا من شخص يسمى الساحب إلى شخص آخر يسمي المسحوب عليه بأن يدفع مبلغا معينا من النقود بمجرد الاطلاع أو في تاريخ معين أو قابل للتعيين لإذن أو أو الت

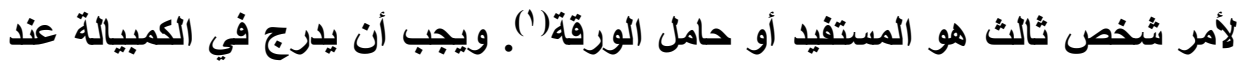

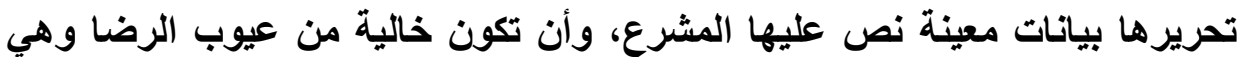
الظلط والإكراه و التلاليس والاستغلال (†).

وتفترض الكمبيالة وجود ثُلاثة أثخاص(")؛ هم : الساحب والمسحوب عليه والمستفيا. ويجب أن تتضمن الكمبيالة بيانات إلزامية وهي : كلمة كمبيالة في متن الصك، وأمر غير معلق على شرط بوفاء مبلغ معين من النقود، واسم من يلزمها الوفاء، وميعاد الاستحقاق ومكان الوفاء واسم من يجب الوفاء لهاء لهاء وتاريخ إصدار

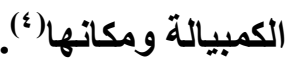

وإذا صدرت الكمبيالة ناقصة من أحد البيانات الإلزامية؛ كأن تصدر خالية من

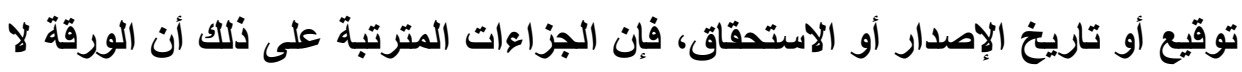

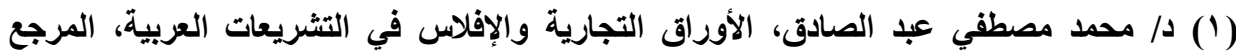

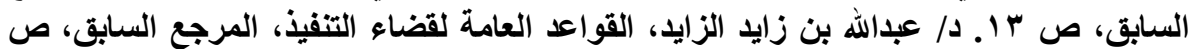
9 ז. نقض مدني، .https://www.eastlaws.com

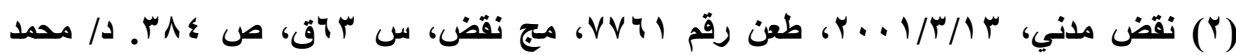

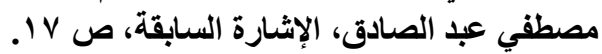

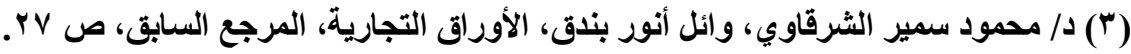

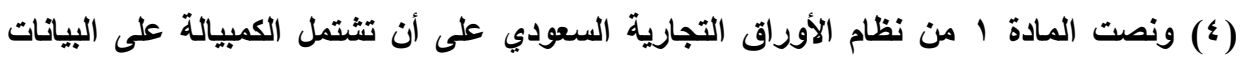

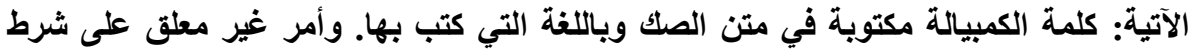

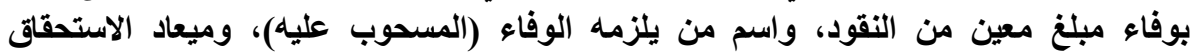

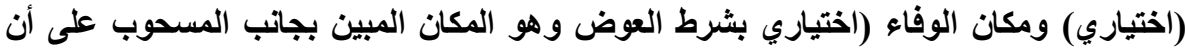

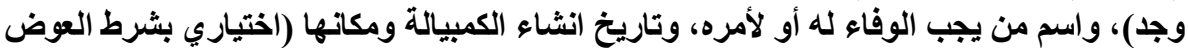
وهو الككان المبين بجاتب اسم الساحب أن وجد مع مراعاة أنه غير مشترط أصلا)، وتوقيع من الكارئ

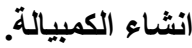


تعد كمبيالة، وتبطل الكمبيالة(')، وهذا البطلان من النظام العام، ومع ذلك يمكن أن تتحول الكمبيالة إلى صك من طبيعة أخرى إذا ما توافرت شروطه، فقد تصبح الكمبيالة تصرفا قانونيا عاديا يخضع لأحكام العامة في القانون المدني أو التجاري طبقا لطبيعة التصرف(؟). ويتم تنفيذ الالتزام وفقا لهذه الحالة طبقا للقواعد العامة في القانون المدني، ويتم تداول الالتزام طبقا لأحكام القانون المدني، وهذا يعد تطبيقا لمبأ تحول التصرفات القانونية المنصوص عليها في القانون المدني (م ع ؛ ا مدني). وتعد الكمبيالة من أهم الأوراق التجارية في نظر المشرع لظهورها تاريخيا قبل غيرها، لذلك نظم المشرع المصري والأردني والسعودي أحكامها بالتفصيل، وأحال إليها عند معالجة الأحكام الأوراق التجارية الأخرى ("). ثانيا: السند للأمر (السند الإذني): يعرف السند للأمر بصك محرر وفقا لشكل معين، ويتضمن بياتات نص عليها

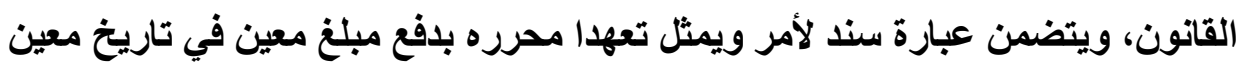

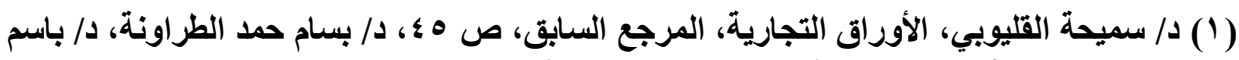

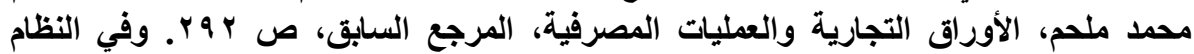

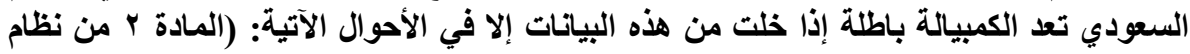

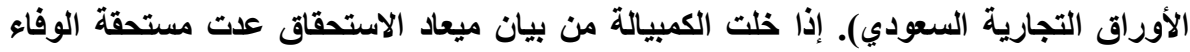

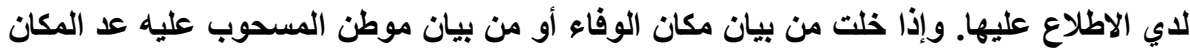

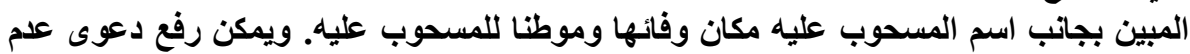

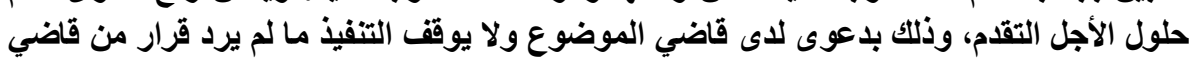

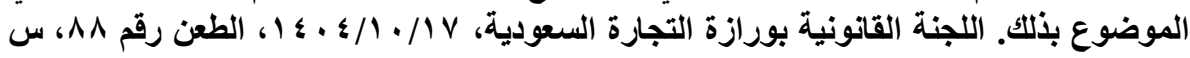

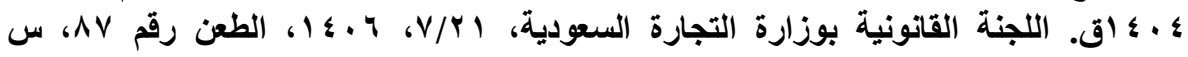

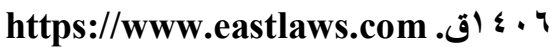

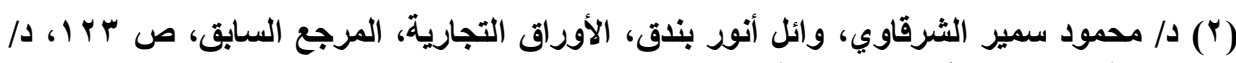

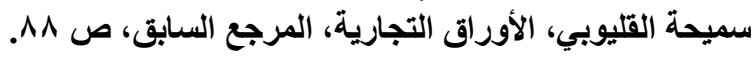

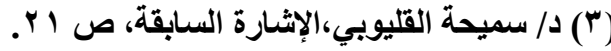


أو قابل للتعيين أو بمجرد الاطلاع لأمر المستفيد، وأن يكون هذا الأمر غير معلق على

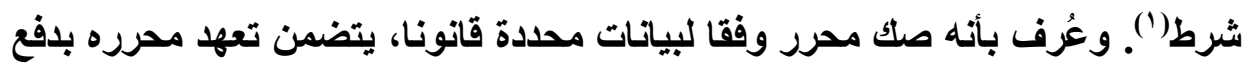

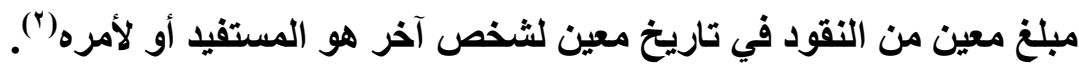
ويلاحظ أن السند لأمر يعرف باسم الكمبيالة في النظام الأردني، وهو محرر

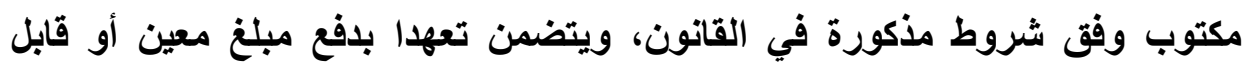

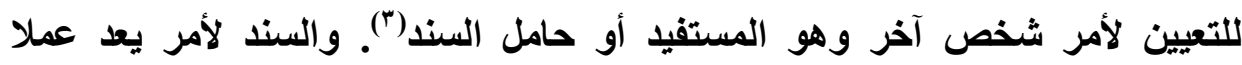

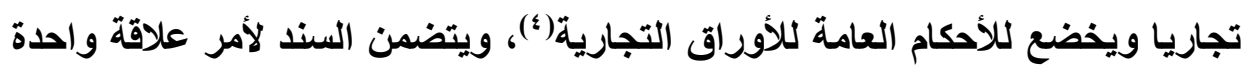

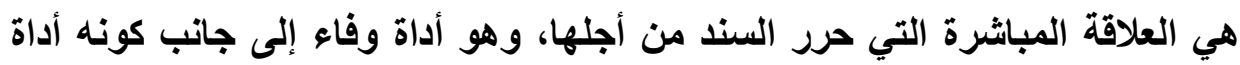

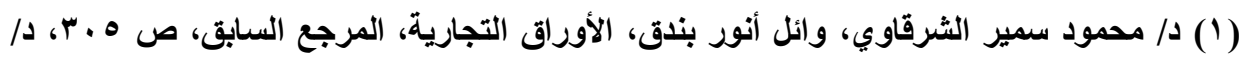

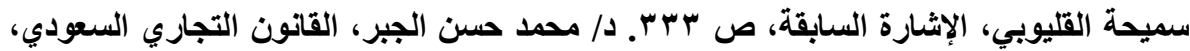

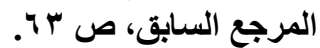

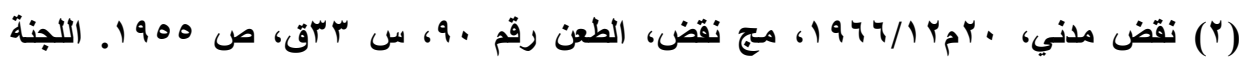

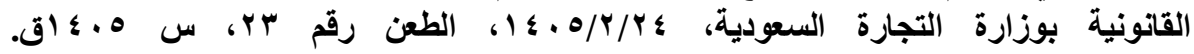


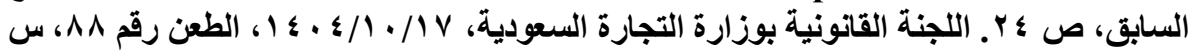

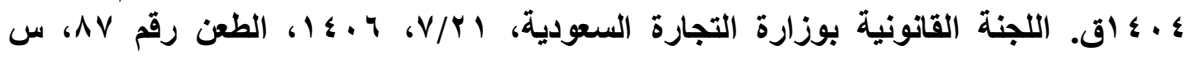

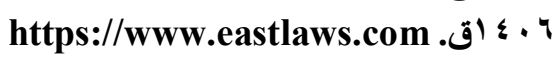

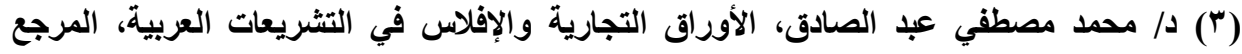

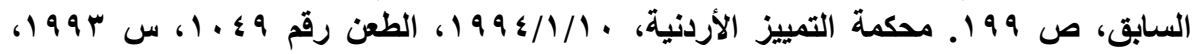

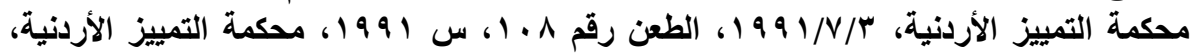

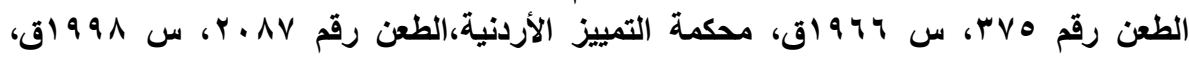
.https://www.eastlaws.com

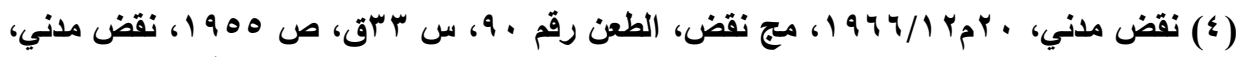

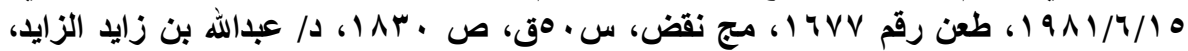

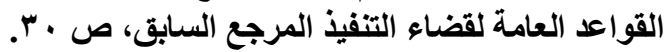

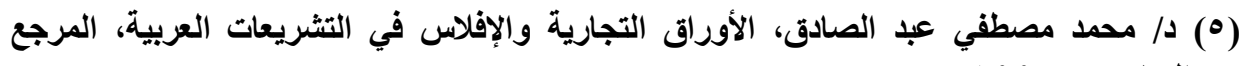

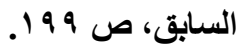


ويشترط لإنشاء السند لأمر الثروط الموضوعية ذاتها الواجب توافرها في

إنشاء الكمبيالة، ويترتب على مخالفة هذه الشروط فقدان السند لصفته ولا يخضع لأحكام قانون التجارة('). ويلاحظ أن السند يختلف عن الكمبيالة من حيث عدد الأشخاص، إذ تفترض الكمبيالة عند تحريرها وجود ثلاثة أشخاص هم الساحب والمسحوب عليه والمستفيد، في حين يتضمن السند لأمر شخصين فقط هما محرر السند و المستقيد("). ويجب أن يتضمن السند لأمر شروطه الموضوعية من الرضا، وأن يكون المحل مبلغا من النقود وأن يكون السبب مشروعا. ويفترض وجود السبب عند عدم

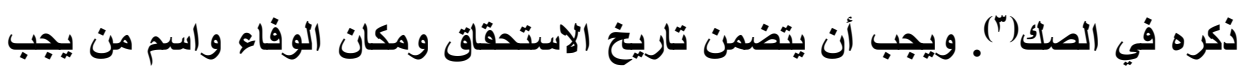
الوفاء له وتاريخ إنشاء السند ومكانه والتوقيع عليه(؛). ولا يشترط لصفة السند لأمر

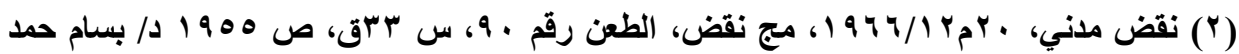

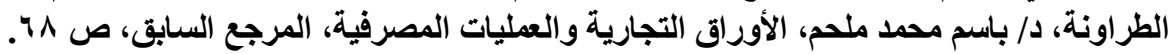

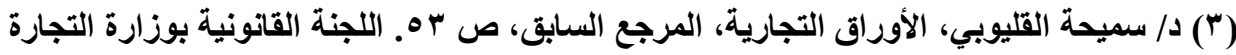

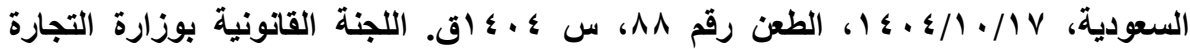

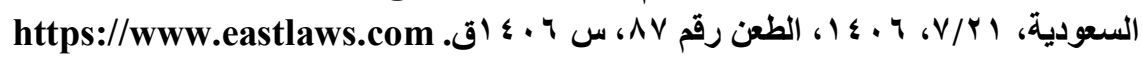

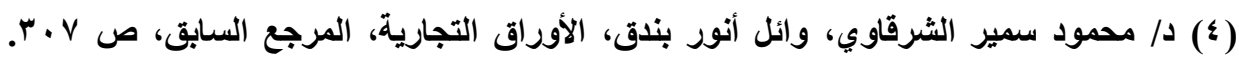

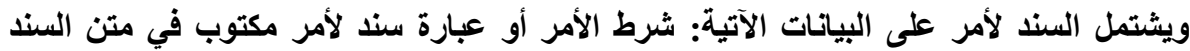

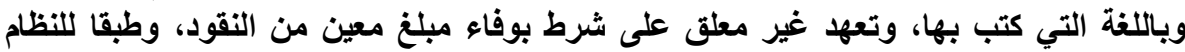

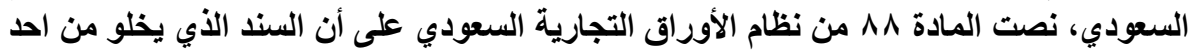

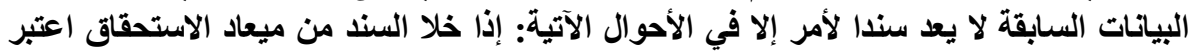

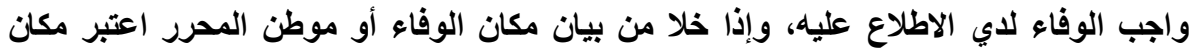

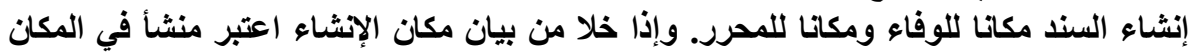

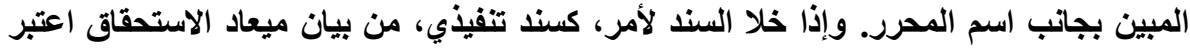

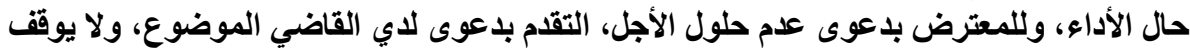

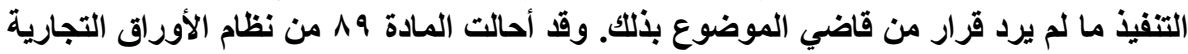
$=$ 
أن يكون محرر تاجر، كما لا يشترط أن يكون خاصا بعملية تجارية، شأنه في ذلك شأن

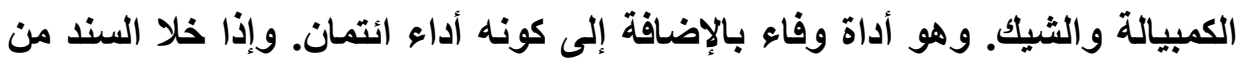

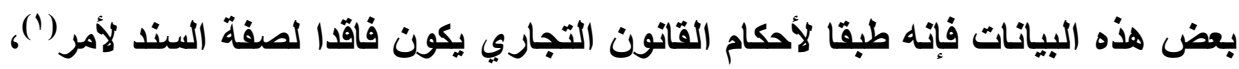

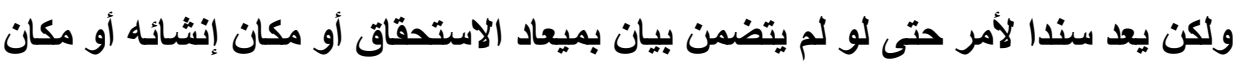

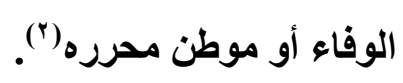

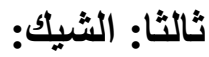

أصل كلمة الثيك مستمدة من اللغة الإنجليزية، ومعناها راجع إلى فحص، أي

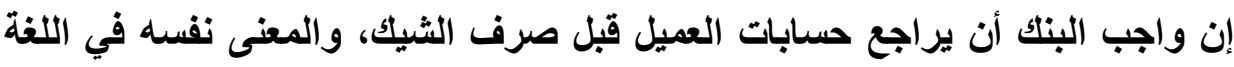

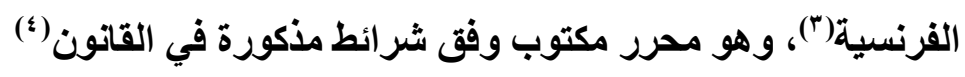

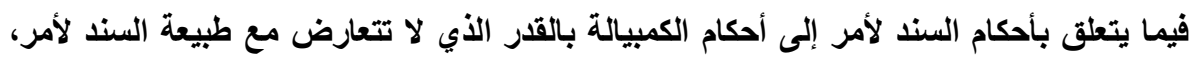

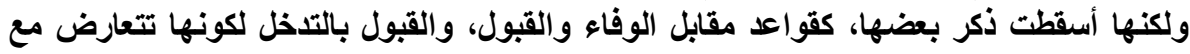

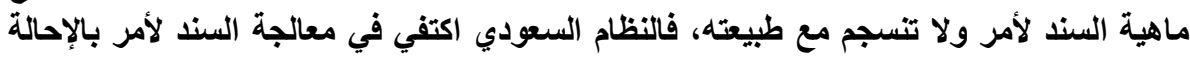

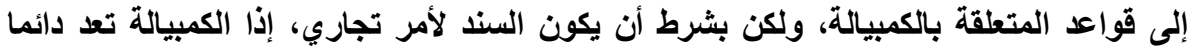

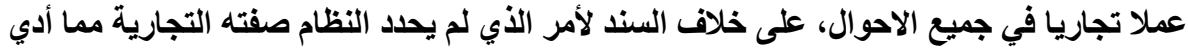

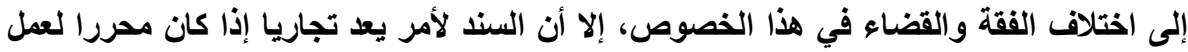

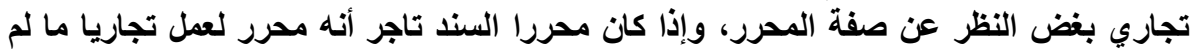

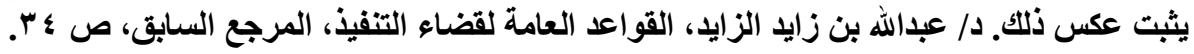

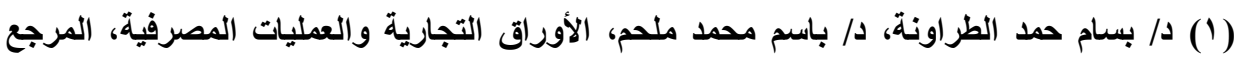

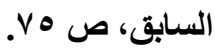

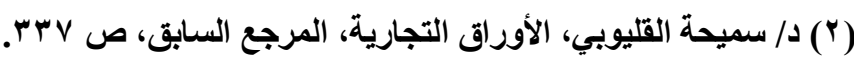

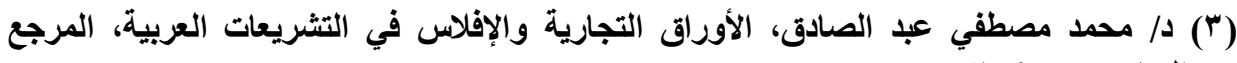

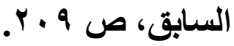

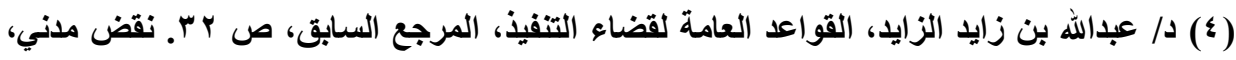

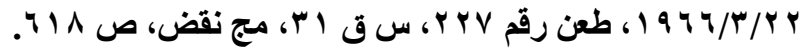


ونظرا لأهمية الثيك في فرنسا ومصر والدولة العربية ـ وذلك لاتتثار تداوله

في الحياة الاقتصادية بنوعيها التجارية والمدنية على السواء(')ـ فقد نظمه المشرع المصري بالقانون رقم IV لسنة 1999 تنظيما شاملا في الفصل الثالث من الباب الرابع، حيث تضمن القانون التجاري المصري لأول مرة تنظيما شاملا لأحكام الشيك في

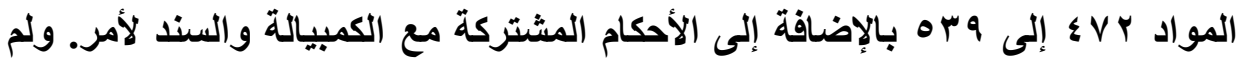
يضع المشرع المصري أو الفرنسي تعريفا للشيك، وإن كان قد حدد البيانات التي يجب إنى لهب أن يتضمنها الصك ليعد شيكا(). ويلاحظ أن كلمة شيك وردت لأول مره في قانون

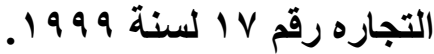

ويمكن تعريف الشيك بأنه صك محرر وفقا لأوضـاع معينة يتضمن أمرا غير معلق على شرط من الساحب إلى المسحوب عليه بوفاء مبلـغ مـن النقود إلى المستفيد بمجرد الاطلاع("). وعُرف بأنـه صك يكتب وفقـا لبيانـات محدده نص عليها القـانون يتضمن كلمة شيك، وأمر غير معلق على شرط بوفاء مبلغ معين من النقود موجها إلى المسحوب عليه وهو دائما بند لصالح المستفيد بمجرد الاطلاع عليه(؛). ويفترق الثيك عن الأوراق التجاريـة الأخرى بأن القانون يقر عقوبـة جنائية على الساحب الذي يصدر شيكا بـدون رصيّ. والشيك أداة وفـاء فقط، على عكس

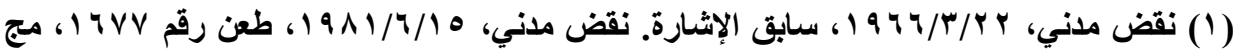

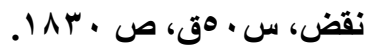

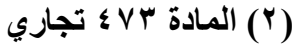

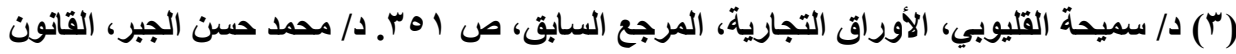

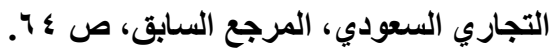

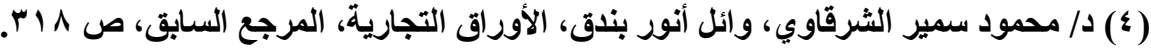


الكمبيالة والسند فهي أداة وفاء وائتمان('). ويجب أن يكون المسحوب عليه في الشيك مصرفا(ن)

والشيك مثل الكمبيالـة على خـلاف السند لأمـر يتضمن ثلاثنة أشـخاص هـم

الساحب والمسحوب عليه الذي أصبح دائمسا مصرفا. ويجب أن يكون الشيك مكتوبـا ومتضمنا عدة بيانات تجعله كافيا بذاته لإيضاح الحق الثابت بـه ويؤدي وظيفته كـأداة

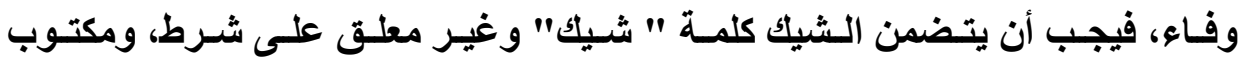
الحروف والأرقام، واسم البنك المسحوب عليه، ومكان الوفاء وتـاريخ إصدار الشيك ومكانه واسم وتوقيع من أصدر الشيك. والثيك يكون مستحق الوفاء بمجر الاطلاع ولو تضمن تاريخا آخر بصلبه، وذلك باستثناء الشيكات المسطرة، والشيكات الحكومية فلا تكون مستحقة الوفاء إلا في تاريخ المبين فيها"َ). وإذا تقدم حامل الثيك إلى المسحوب عليه وامتنع عن الوفاء وكان هذا التقدم خلال المدة المقررة لتقديم الثيك عليه أن يقوم بعمل احتجاج عدم الدفع أو ما يقوم مقامه.

(1) دابل محد مصطفي عبد الصادق، الأوراق التجارية والإفلاس في التشريعات العربية، المرجع

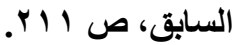

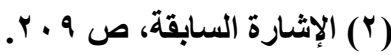

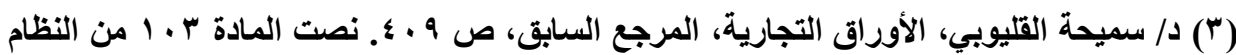

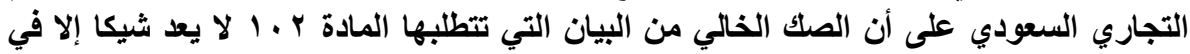

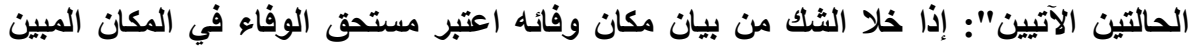

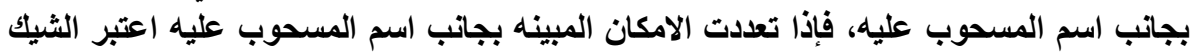

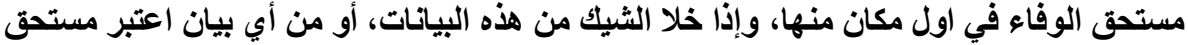

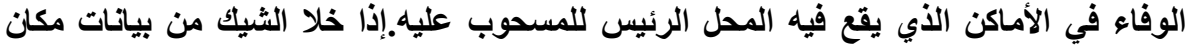

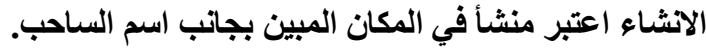


ويعد الثيك تصرفا قانونيا لابد أن تتوافر فيه الثروط الموضوعية الواجب تو افرها في أي تصرف قانوني آخر (1)، وهي الرضا والأهلية و المحل و السبب، بالإضافة

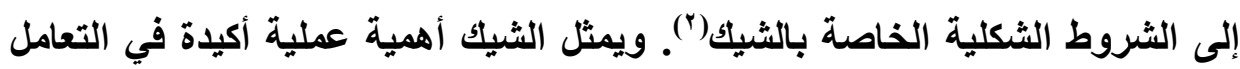

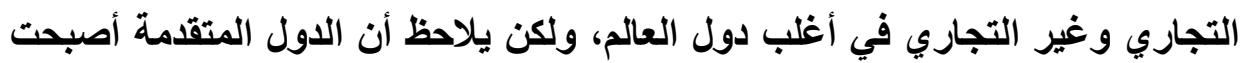
أقل استخذاما للشيك لاعتمادها على وسائل حديثة أخرى للافع خلافه، وذلك نتيجة لانتشار الوفاء بمقتضى كروت الوفاء المنتشرة في الاول المتقدمة("). وتوجد أنواع من الثيكات، وهي الثيك السياحي، والثيك المسطر أو المتتمد

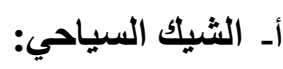

هو الذي يستخدمه صاحبه عند السفر لتفادي مخاطر حمل النقود، وظهر هذا

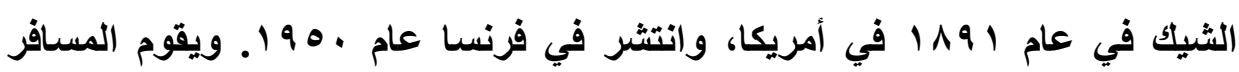

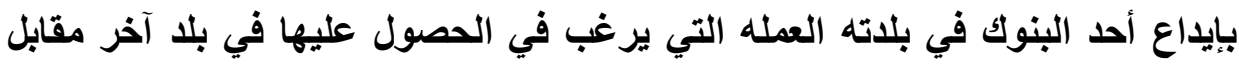
عدد من الثيكات مسحوب على جميع فروع هذا البنك في الخارج أو بنوك يتعامل معها. ب - الثيك المسطر أو الثيك المعتمد:

نظم قانون التجارة المصري أحكام الشيك المسطر لأول مرة في المادة 10 هام

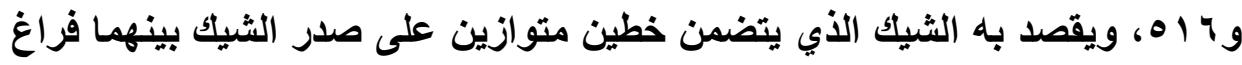
دون اشتراط اتجاه معين لهذين السطرين، ويقصد من هذين الخطين تنبيه المسحوب عليه إلى ضرورة صرف قيمة الثيك عن طريق أحل البنوك، ومقتضي ذلك أنه لا يجوز

(1) Didier CHOLET Exécution des jugements et des actes, op. cit., n0 30 (ץ) د/ بسام حمد الطراونة، د/ باسم محمد ملحم، الأوراق التجارية والعمليات المصرفية، المرجع

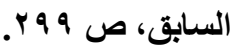

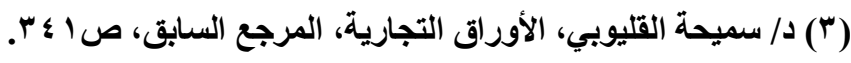


الوفاء بمقتضي إلى حامله إذا كان فردا عاديا، بل يجب عليه تظهير الثيك إلى أحد البنوك أو توكيل البنك الذي يقوم بدور المسحوب عليه(').

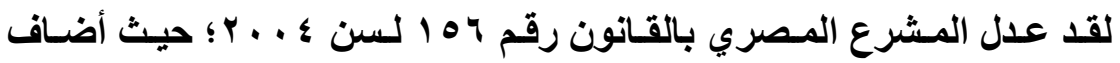

فقرة ثاتية للمادة ب ـ 0 واستثناء الثيكات المسطرة المنصوص عليها في المـادة ه 1 هـ إلسى جـواز الـشيكات الحكوميـة حيـث تكـون واجبـة الوفـاء في تــاريخ المبـين بهـا

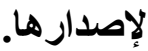

\section{الإطلب الثاني \\ إجراءات تنفيذ الأوراق التجارية}

استشعر بعض مشرعي اللدول العربيـة والغربيـة بأنهـ في بعض الحسالات قـ يضار حامل الأوراق التجارية من اللجوء إلى القضاء للحصول على حكم قضائي لتنفيذ

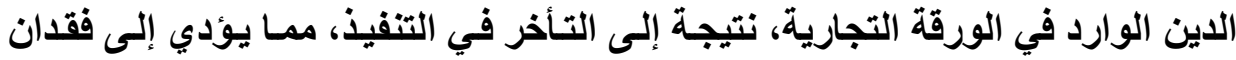

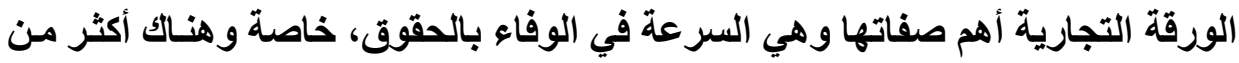

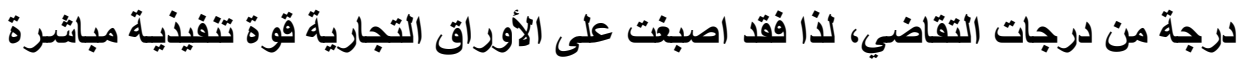

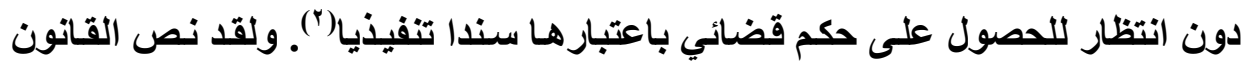

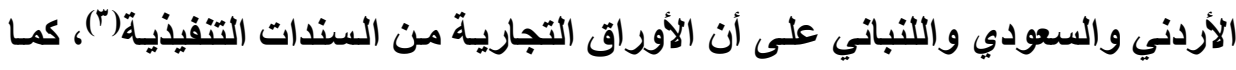
نص القانون الفرنسي على أن الشيك من السندات التنفيذية، ومن ثم فلا نكون بحاجـ الأنه

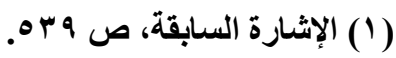

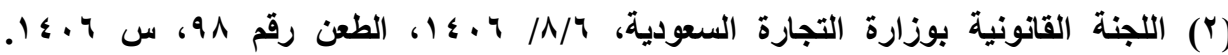
https://www.eastlaws.com

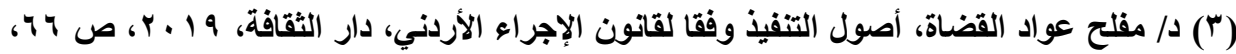

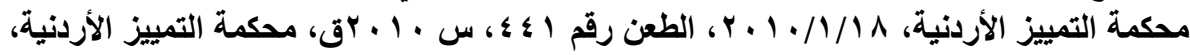

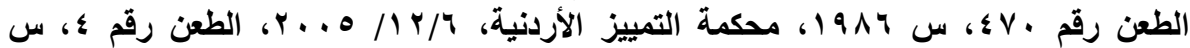


إلى اللجوء إلى القضاء للحصول على حكم بثأن الاين الوارد في الأوراق التجاريـة أو الثيك في النظام الفرنسي.

سنثير إلى إجراءات تنفيذ الأوراق التجارية في بعض الأنظمة العربية، وذلك

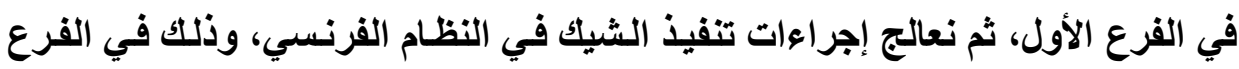
الثاني، ثم نبحث، موقف المشرع المصري من عدّ الأرواق التجارية سندا تنفيذيا، وذلك التكان في الفرع الثالث، وذلك على النحو الآتي:

\section{الفرع الأول \\ إجراءات تنفيذ الأوراق التجارية في بعض الأنظمة العربية}

لقد تتضمن قانون الصرف عدة ضمانات للوفاء بقيمة الأوراق التجارية خاصة

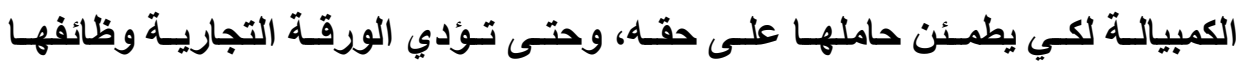

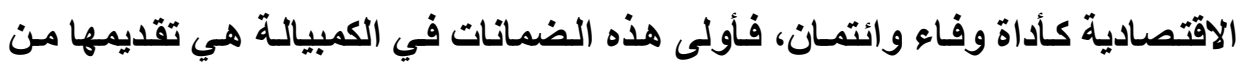

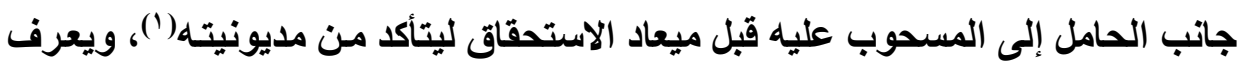

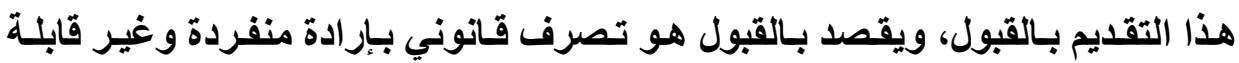

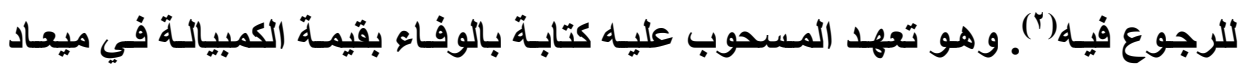

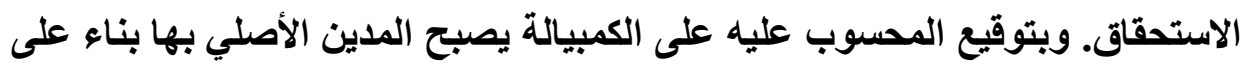

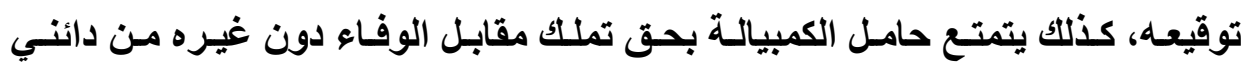

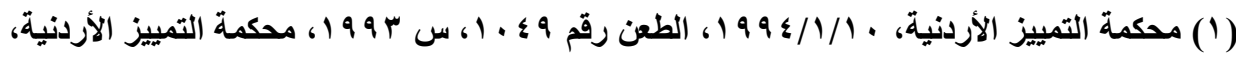

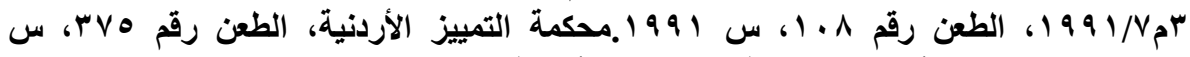

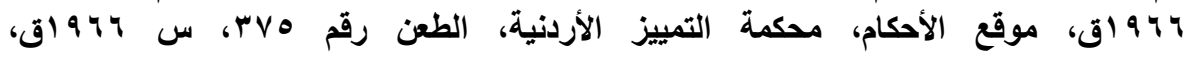
.https://www.eastlaws.com

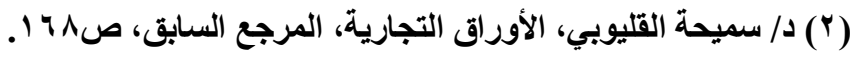


الساحب(')، يعد جميع الموقعين على الكمبيالة ملتزمين بالوفاء بقيمتها على سبيل

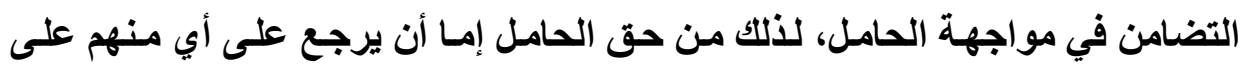

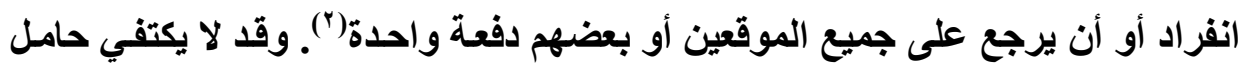

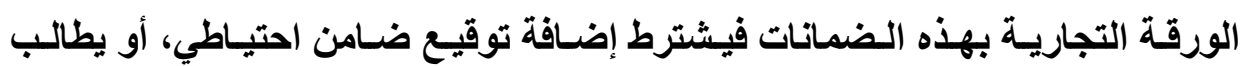
بتأمين عيني كالرهن، وهذه تسمى الضمانات الاتفاقية)("). وبالنسبة لضمانات حامل السند الإذني، فإنه يقدمه للمسحوب عليه في ميعاد

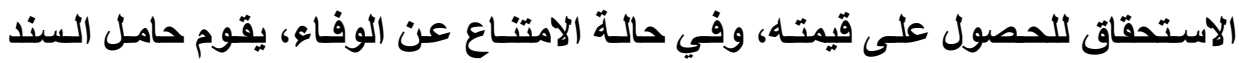

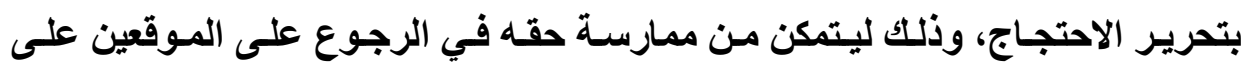

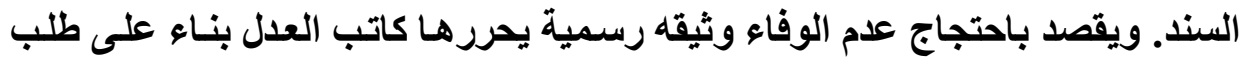

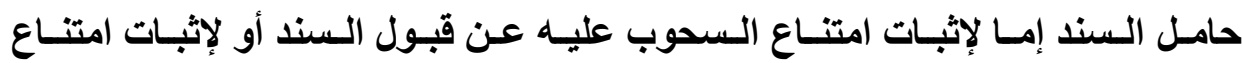
المسحوب عليه عن الوفاء بقيمة السند (4). ولم يكتف بعض المشرعين بالضمانات التي نص عليها القـانون التجاري،

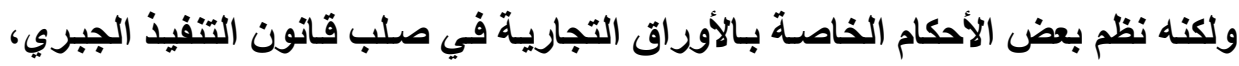
بهدف تسهيل تنفيذ الأوراق التجارية، وهذا ما سنشير إليه في النقاط الآتية: وسنشير إلى الأوراق التجاريـة كسند للحجز التحفظي، ثم الأوراق التجاريـة كسند للحجز التنفيذي، وذلك في النقاط الآتية:

(1) مقابل الوفاء هو الدين النقدي الذي يكون للساحب في مواجهة المسحوب عليه نتيجة علاقات

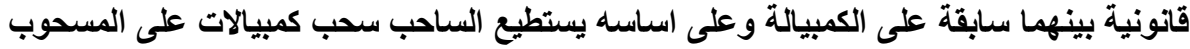

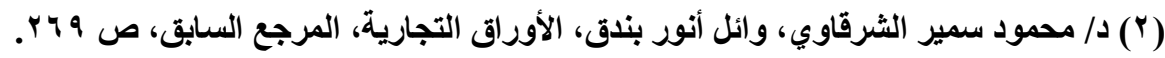

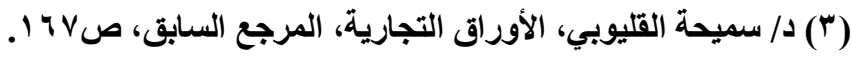

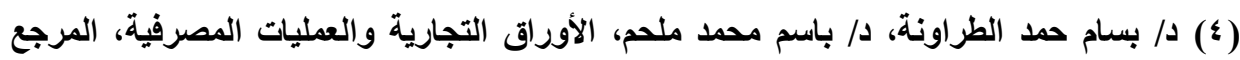

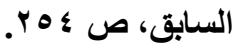


أولاً: الأوراق التجارية كسند للحجز التحفظي

لقد نصت المادة 9 ا من قانون التجاري الأردني، على أنه يجوز إيقاع الحجز

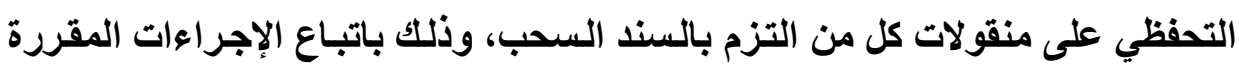

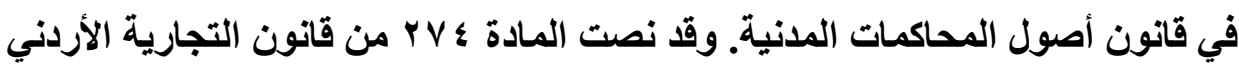
على أنه يسرى على الشيك حكم المـادة 9 ه 1، فيجوز لحامل الشيك أن يطالب بإيقاع الحجز التحفظي على منقولات ضامني الثيك('). وبالنسبة لنظام التنفيذ السعودي فطبقا

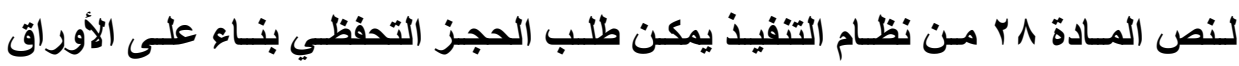
التجارية، لأنها تتضمن حقا محقق الوجود ومعين المقدار.

ونجد أن شـروط الحجز التحفظي وإجراءاتـه في القـانون الأردنسي منـصوص عليها بين قانون أصول المحاكمات وقانون التجاري الأردني ()، ويشترط لتوقيع التهرئ الحجز

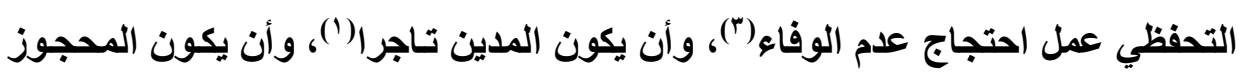

(1) د/ بسام حمد الطراونة، د/ باسم محمد ملحم، الأوراق التجارية والعمليات المصرفية، المرجع

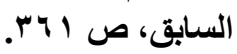

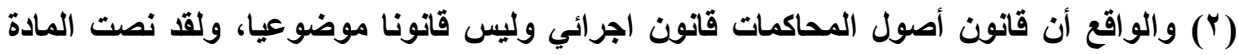

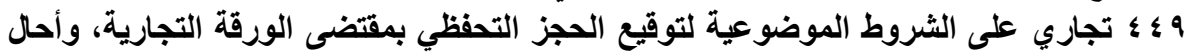

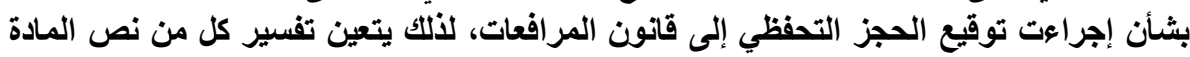

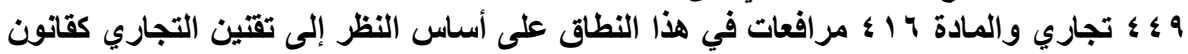

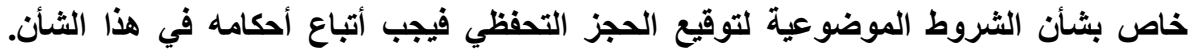

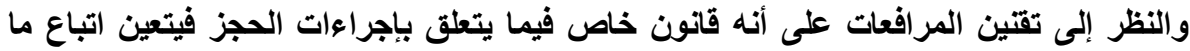
يقضي به في هذا المجال.

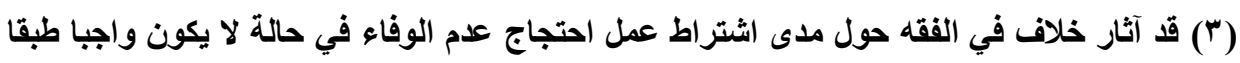

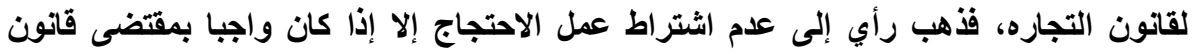

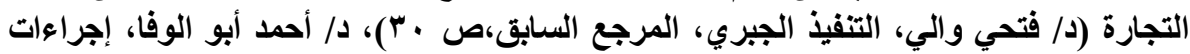

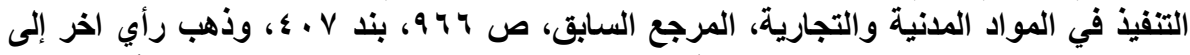

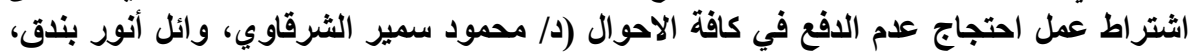

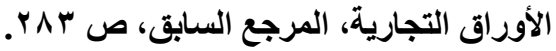


عليه مدينا في الورقة التجارية(")، ويجب اتباع الإجراءات التي نص عليها قانون

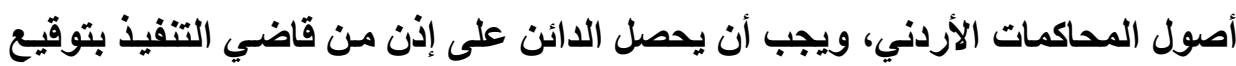

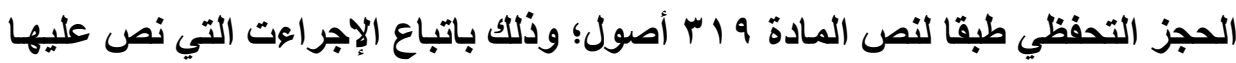
قانون أصول المحاكمات في إصدار الأوامر من قاضي التنفيذ. وبـالرجوع إلى قانون أصول المحاكمـات المدنية الأردنـي نجد أن المواد مـن

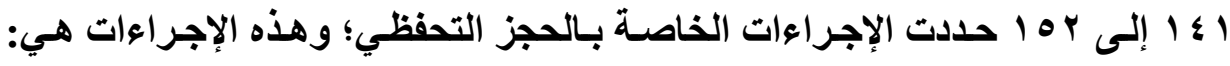
تقديم طلب لتوقيع الحجز التحفظي إمـا قبل إقامـة دعوى أو عند تقديمها أو أثناء نظر الأحرات

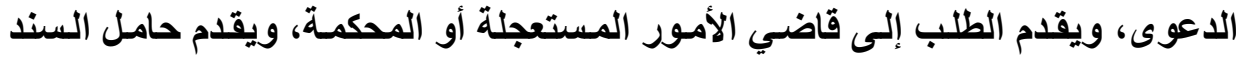
المستندات التي يملكها. وإذا قررت المحكمة إجابة الطلب تكلف طالب الحجز بتقديم تأمين نقدي أو كفالة مصرفية أو عدلية تحددها المحكمة أو قاضي الأمور المستعجلة

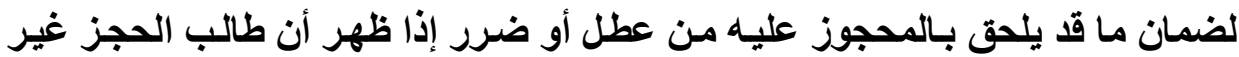

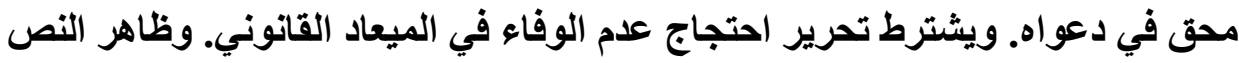

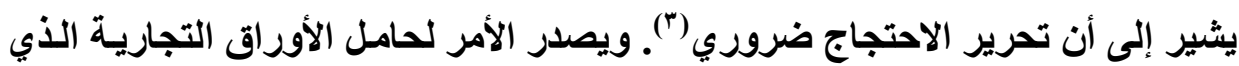
لم يتم الوفاء به بإجراء الحجز التحفظي على منقولا المدين.

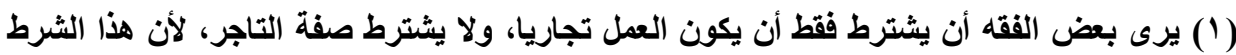

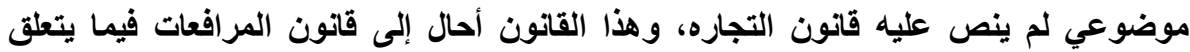

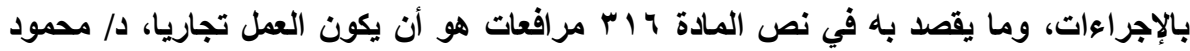

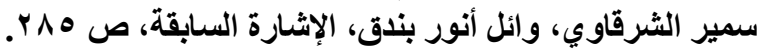

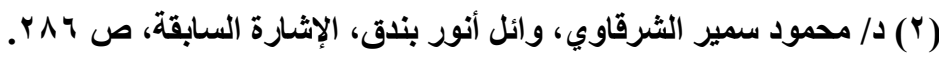

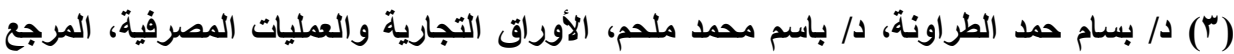

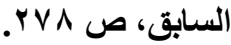


وفي النظام اللبناني يمكن الاستناد إلى الأوراق التجارية ـ ومنها الثيكـ للقيام بـالحجز التحفظي؛ فقد نـصت المـادة ه ؛ ؛ تجـاري على أنسه يحق لحامـل الشك الذي أقيم عليـه الاحتجـاج بعـد اسـتئذان رئسيس دائسرة التنفيذ أن يحجز منقولات الساحب والمظهرين حجزا احتياطيا بدون أن يكون ملزما بتأدية كفالة، ولا ينفذ الشيك مباشرة إلا بعد إثبـات الامتتـاع عن الوفـاء، وهذا الامتــاع يثبت إمـا بالاحتجـاج أو بتصريح

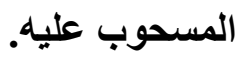
وبالنسبة للقانون المصري فنجد أنه قرر لحامل الأوراق التجارية توقيع الحجز التحفظي على منقولات المدين خشية ما قـ يقوم به من تبديد منقولاتـه تهربـا منه للدفع

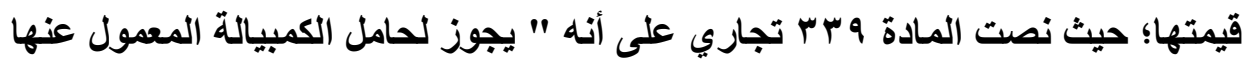
احتجاج عدم الوفاء أن يوقع حجزا تحفظيا بغيز كفالة على أموال كل من الساحب أو القابل أو المظهر أو الضامن الاحتياطي أو غيرهم من الملتزمين بالكمبيالة، مـع مراعاة

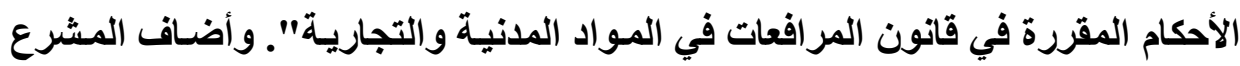

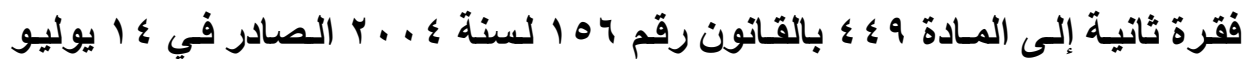
ع . . ب بالنص الآتي: " ويصدر القاضسي أمره بالحجز التحفظي بغير كفالة متى قدم حامل الكمبيالة الطلب مصحوبا بأصل الكمبيالة وباحتجاج عدم الوفاء"('). ويهدف المشرع من هذا النص إلى تثجيع التعامل بالكمبيالة حيث يترتب عليه إلزام القاضي بتوقيع الحجز، ومن ثم تمكين حامل الكمبيالة من الإسراع في الحصول

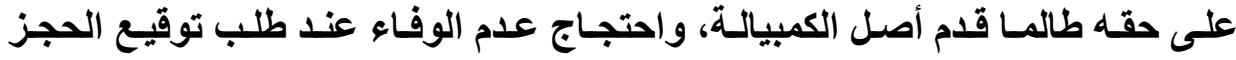


وقد نصت المـادة 7 اب مرافعات على أن " للائن أن يوقع الحجز التحفظي على منقولات مدينة في الأحوال الآتية: إذا كان حاملا لكمبيالة أو سند تحت الإذن وكـان

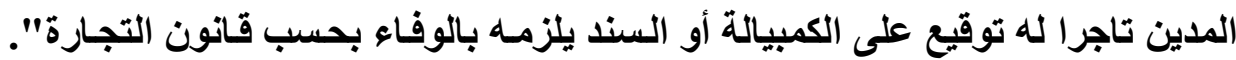
ويتضح من النص المذكور - بالإضافة إلى نص المادة 9 ؟ ؛ تجاري سابق الإشارة ـ أن المشرع نص على شروط معينة لتوقيع الحجز التحفظي تهدف إلى تحقيق التوازن بين أطراف الورقة التجاريـة(')، ويصدر الأمر بـالحجز التحفظي على منقولات المدين من

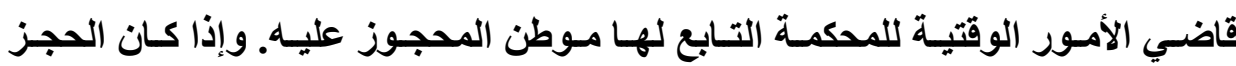

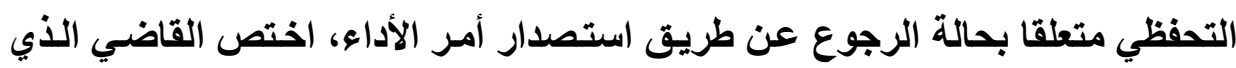

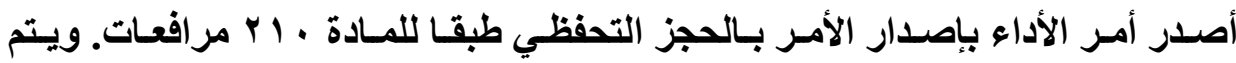

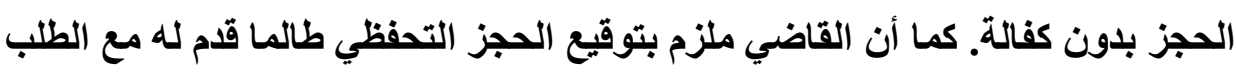

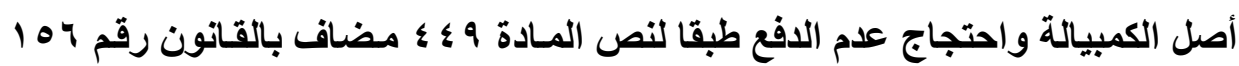

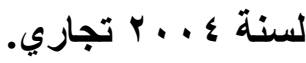

(1) تتمثل هذه الثروط في الآتي: أولا: عمل احتجاج عام الدفع، حيث ألزم القانون حامل الكمبيالة في

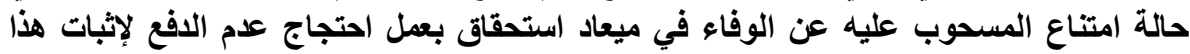

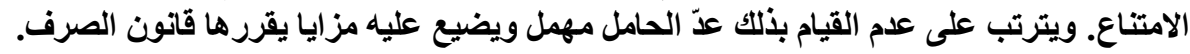

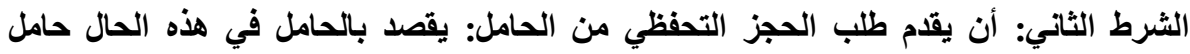

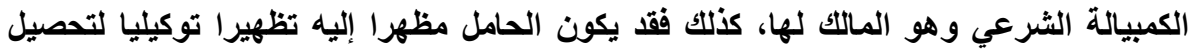
قيمهتها، أو تظهير تأمينيا فيكون حاملا لها بوصفه دائنا مرتهنا، وقد يكون حامل الكمبيالة موفيها

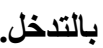
الثرط الثالث: أن يكون المحجوز عليه أحد الموقعين على الكمبيالة أو الورقة التجارية: يجب أن

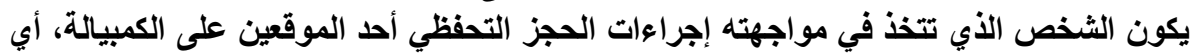

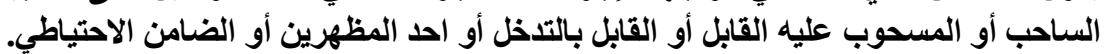

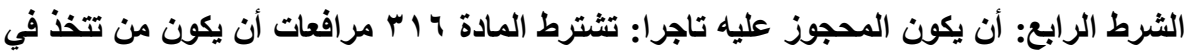
مواجهته إجراءات الحجز التحفظي تاجرا. 
ثانياً: الأوراق التجارية كسند للحجز التنفيذي

في واقع الأمر لم ينص المشرع المصري على عدّ الأوراق التجارية سندات

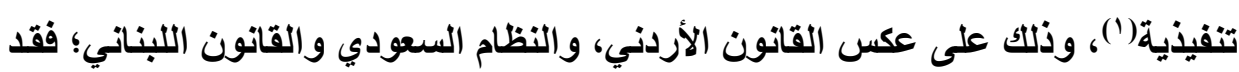

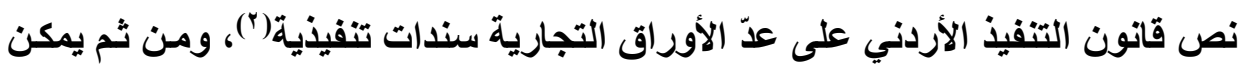

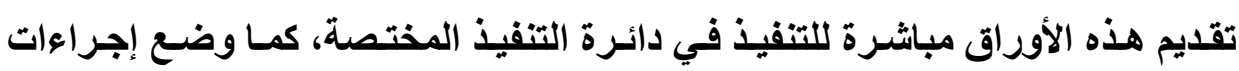

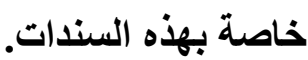

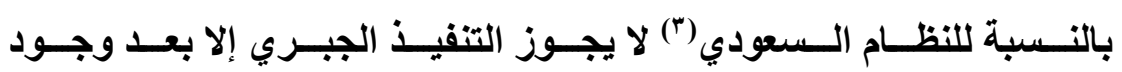

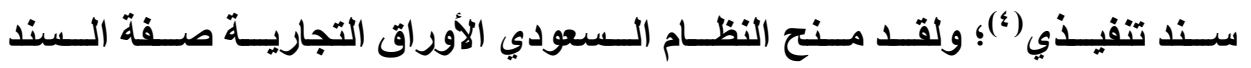

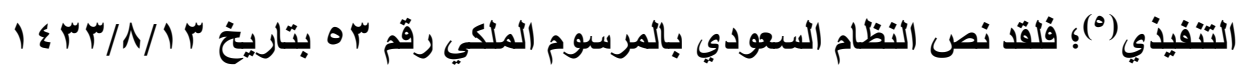

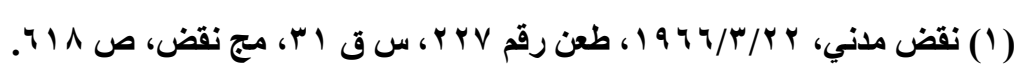

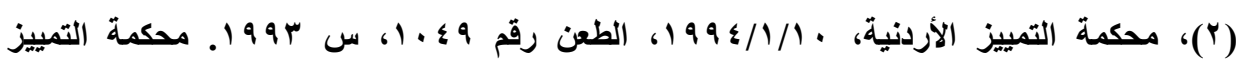

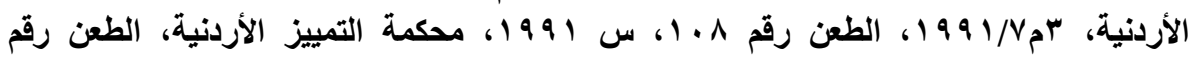

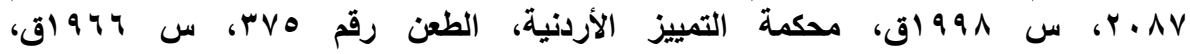
.https://www.eastlaws.com

(T) د/ مفلح بن ربيعان القحطاني، د/ محمد السيد محمد رفاعي، الوسيط في النظام التتفيذ السعودي،

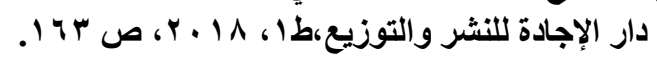

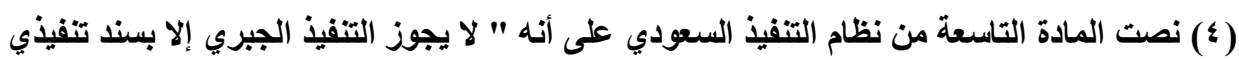

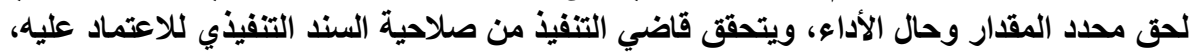

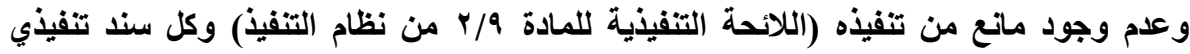

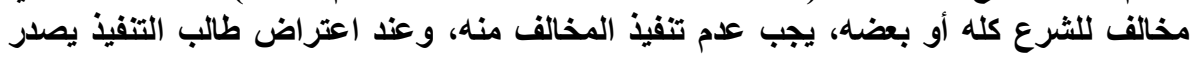

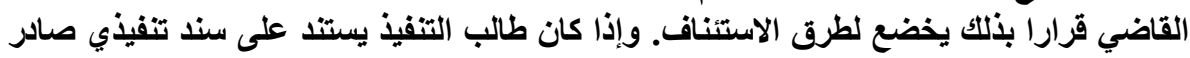

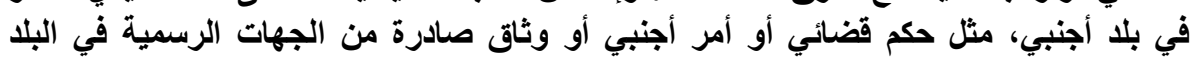

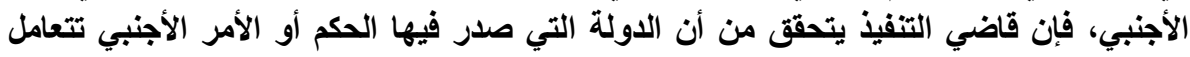

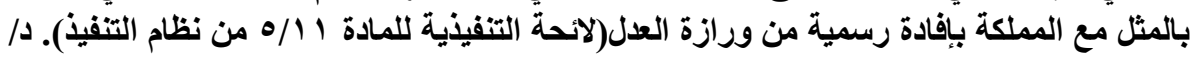

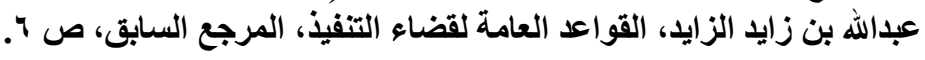

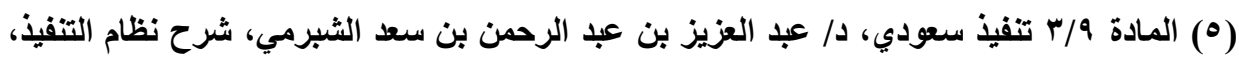

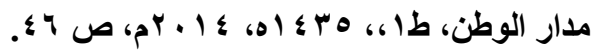


ه، في المادة التاسـعة على أنـه "لا يجوز التنفيذ الجبري إلا بسندٍ تنفيذيّ لحقّ محدد

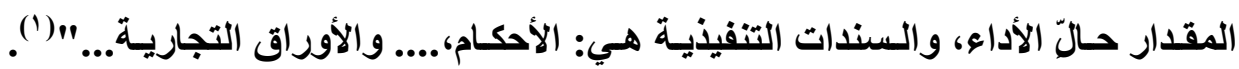

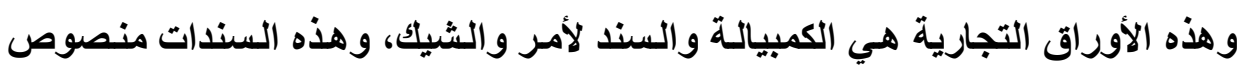

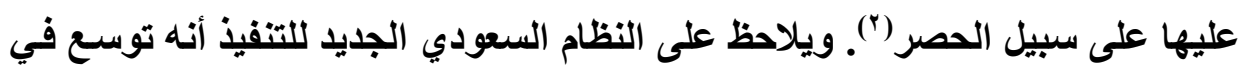

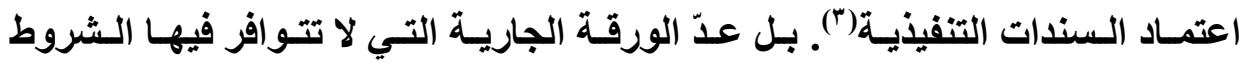
القانونيـة للورقة التجاريـة، بأنـهـ يمكن اللجـوء إلـى تنفيذها كورقة عاديـة أمسام إدارة

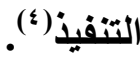

(1) السندات التنفيذية في النظام السعودي هي الأحكام، والقرارات، والأوامر الصادرة من المحاكم.

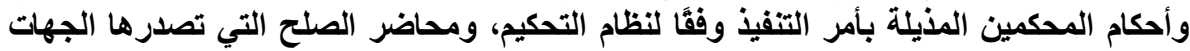

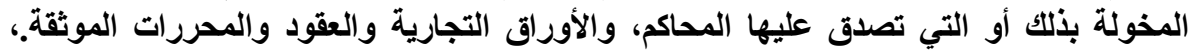

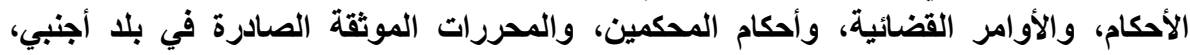

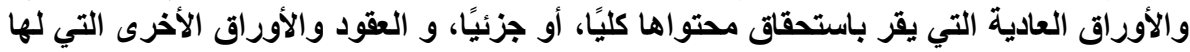

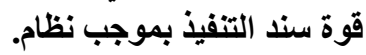

(ץ) د/ مفلح بن ربيعان القعطاني، د/ محمد السيد محمد رفاعي، الوسيط في النظام السعودي، المرجع

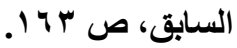

(ए) يلاحظ على النظام السعودي أنه توسع في اعتماد السندات التنفيذية، والتي يمكن تفسيمها إلى الى التي

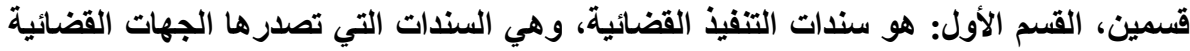

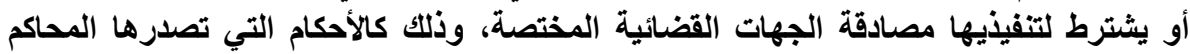

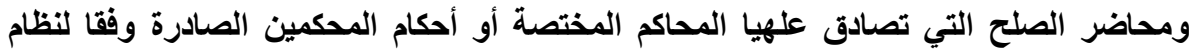

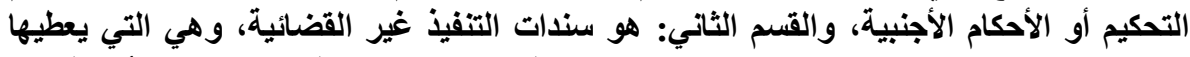

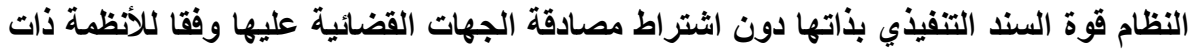

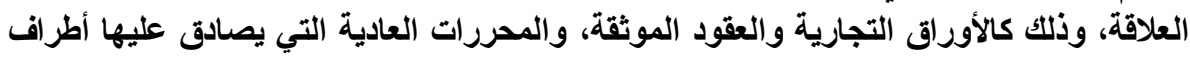

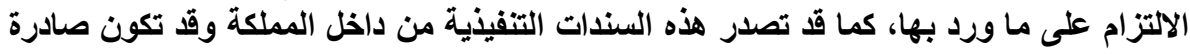

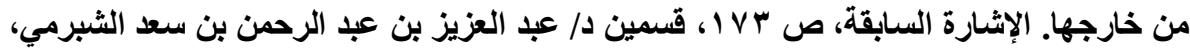

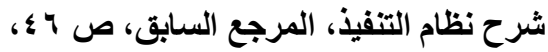

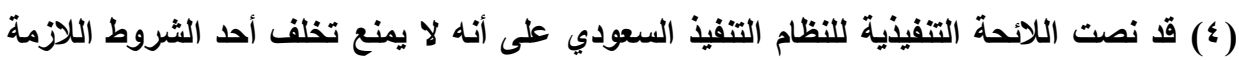

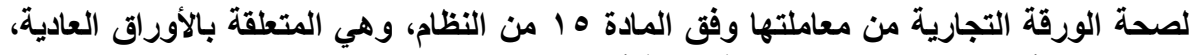

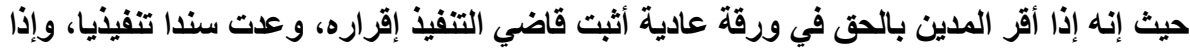

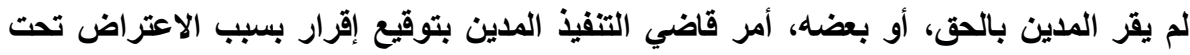
$=$ 
وسنشير إلى الجهـة المختصة بتنفيذ الأوراق التجاريـة في النظـام الأردنـي

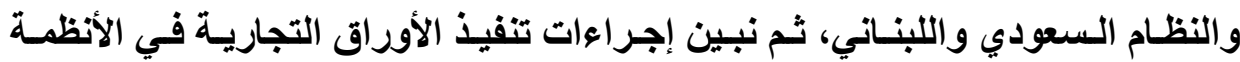
الأتية: الأردنية والسعودية، واللبنانية وذلك في النقاط الآتية: 1ـ الجهة المختصة بتنفيذ الأوراق التجارية في النظام الأردني والسعودي واللبناني لقد نصت المادة الثانية من قانون التنفيذ الأردني على اختصاص دائرة الإجراء

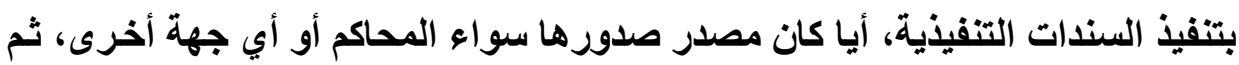
نصت المادة الثانية على أنه إذا كان للائن دين من النقود منى كان ثابتا بورقة تجاريـة قابلـة للتظهير أو بسند عـادي أو بسند مصدق عليهه كاتب العدل، أن يراجع دائـرة

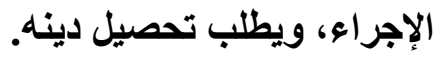

ويثار تساؤل عن مدى وجوب لجوء الدائن أولاً إلى دائرة الإجراء، ومدى

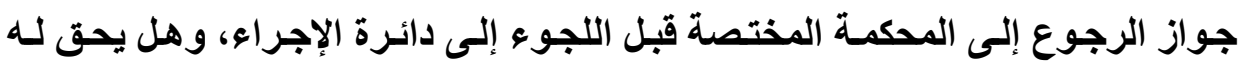
العودة لمراجعة دائرة الإجراء قبل صدور الحكم لتحصيل دينه؟

إن نص المادة الثانية من قانون الإجراءات هو " للائن بدين من النقود إذا كـان دينه ثابتـا بسند عـادي أو بسند مسصدق للدى كاتب العدل أو ورقة مـن الأوراق التجارية القابلة للتظهير أن يرجع دائرة الإجراء ويحصل دينه" يبين من هذا النص أن أن الن النائ حق الدائن بمراجعة دائرة الإجراء قبل اللجوء إلى القضاء للحصول على حكم بدينه أمر جوازي، وليس وجوبيا، فيعود للائن إذن تقدير ما إذا كان من مصحلته تنفيذ السند عن طريق دائرة الإجراء مباشرة أو مراجعة المحكمة المختصة للحصول على حكم بالاين طائلة العقوبة المنصوص عليها في هذا النظام، وتط سندا تتفيذيا فيما لم يعترض عليه، وللائن رفع دعواه أمام المحكمة المختصة. 
ليصار إلى تنفيذه، وبالطبع فالدائن يلجأ إلى دائرة الإجراء أولاً وقبل الحصول على حكم باينه من المحكمة المختصة إذا قدر أن دينه مستوف لثرائطه القانونية ولا يتوقع إثارة

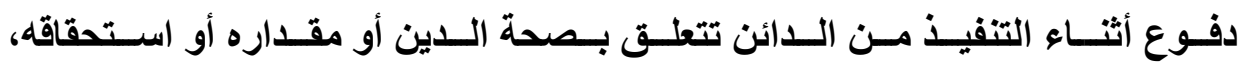
وذلك اختصـارا للوقت والنفقـات، أمـا إذا توقع مثل هذه الـدفوع فيلجـأ إلى المحكمـة

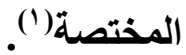

وبالنسبة للمسألة الثاتية، وهي مدى جواز اللجوء إلى دائرة الإجراء متى راجع الدائن المحكمة المختصة؛ في الواقع لم ينص القانون التنفيذ الأردني على هذه المسألة، وبالرجوع إلى القواعد العامة المنصوص عليها في قانون أصول المحاكمـات، إذا أقيمـت الدعوى للدى المحكمة، لا يجوز للمدعى إسقاط دعواه مؤقتـا إلا في غيبـة المدعى عليه أو موافقته إن كـان حاضرا (م بr I أصول) فبإذا أسقط المدعى دعواه يجوز له أن يرجع بعدها دائرة الإجراء ويطلب تنفيذ سند الدين الذي بيده. أما إذا اختار الدائن الاستمرار بمتابعة دعواه أمام المحكمة المختصة فلا يجوز لـه بطبيعة الحسال أن يطلب تنفيذ السند عن طريق دائرة الإجراء طالمـا أن القضية لاتزال منظورة أمسام المحكمة المختصة، إذ لابد من صدور حكم فيها، حيث يصبح الحكم هو السند التنفيذي،

وينفذ كتنفيذ الأحكام.

وبالنسبة للنظام السعودي نجد أنه نص في قانون التنفيذ على أن قاضي التنفيذ هو المختص بوضع الصيغة التنفيذية على الأوراق التجارية(؟). ويجب عند إصدار الأمر

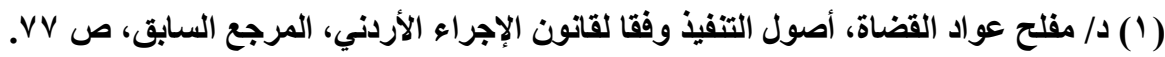

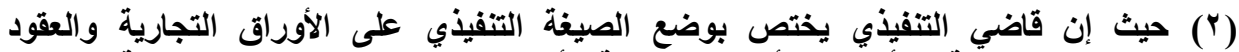

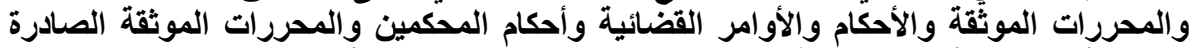

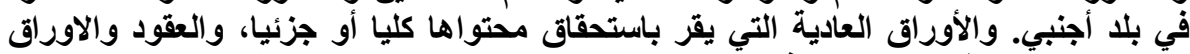

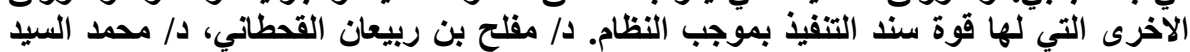

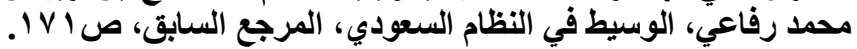


بالتنفيذ أن يتحقق قاضـي التنفيذ من صـلاحية الأوراق التجاريـة كسند تنفيذي، وعدم

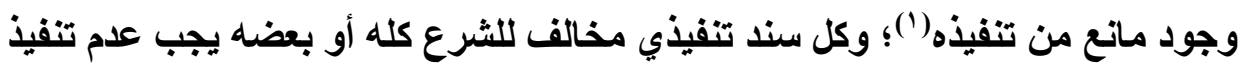

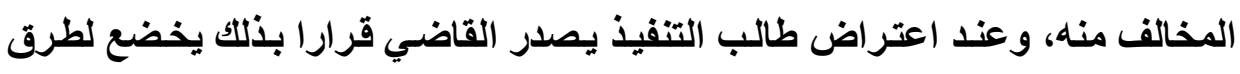

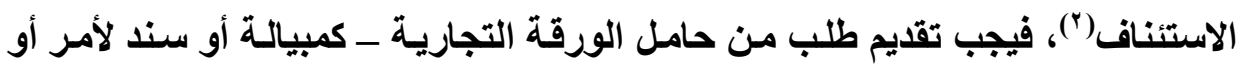
شيك - إلى محكمة التتفيذ المختصة بطلب التنفيذ والحجز، وبعد أن يتحقق قاضـي

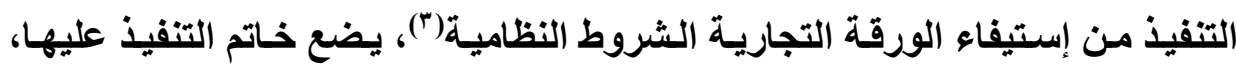

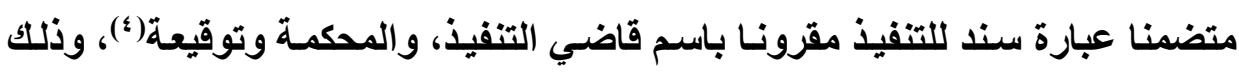

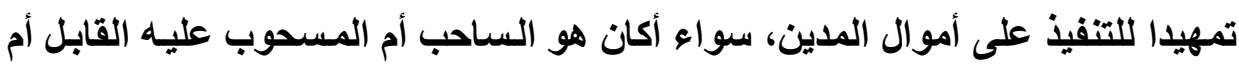

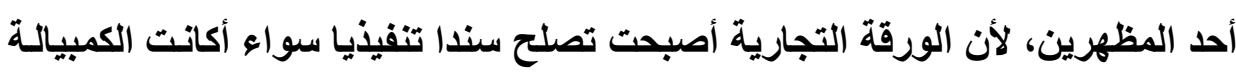

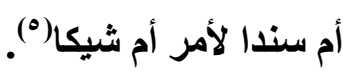

وفي النظام اللبناني يكون الاختصاص عند تنفيذ الشيك للاائرة التنفيذ التابع لها

مكان المنفذ عليه الاصلي أو المختار أو محل سكنه("). r- إجراءات الحجز التفيذي للأوراق التجارية في النظامين الأردني والسعودي واللبناني

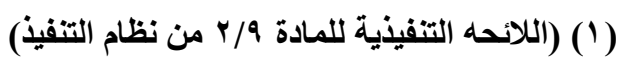

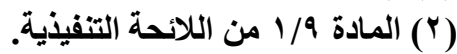

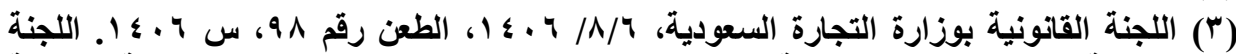

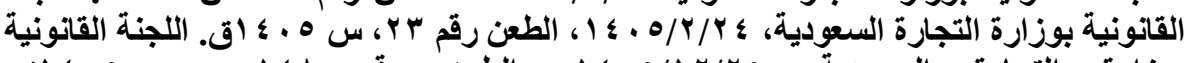

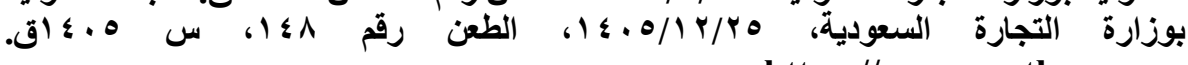
https://www.eastlaws.com

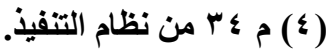

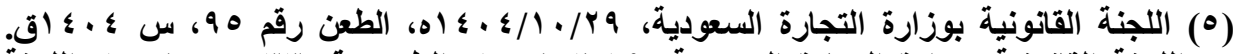

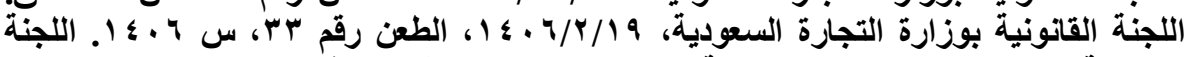

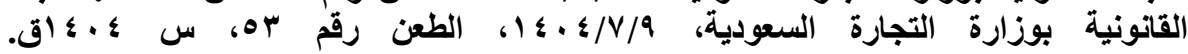
.https://www.eastlaws.com

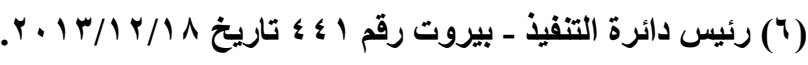


سنشير إلى إجراءات تنفيذ الأوراق التجارية في النظام الأردني، ثم نعالج ذلك في النظام السعودي، ثم موقف المشرع اللبناني، وذلك في النقاط الآتية: - إجراءات تنفيذ الأوراق التجارية في النظام الأردني أـ تقديم طلب التنفيذ

نصت المادة //أ من قانون التنفيذ على أنه " يجوز للائن أن يطلب من الدائرة تحصيل دينه من المظهرين والكفلاء خلال خمسة عشر يوما تلي تاريخ الاحتجاج بالوفاء إذا كان هذا الاحتجاج يتطلبه القانون". ويستفاد من هذا النص أن القانون يجيز لحامل الورقة التجارية أن يطلب من إدارة التنفيذ تحصيل دينه من المظهرين والكفلاء في الأوراق التجارية، ولكن لم يشأ المشرع أن يطلق العنان للاائن في تحصيل دينه الثابت في الورقة التجارية من المظهرين والكفلاء؛ بل اشترط لذلك أن يتقدم طالب التنفيذ باستدعاء موقع منه أو من وكيله إلى دائرة الإجراء المختصة، وفي حال تعدد المدينين يقدم الطلب إلى الدائرة التي في مقرها إقامة أحدهم وفقا للقواعد العامة المقررة في الاختصاص المحلي (م ب أصول المحاكمات). ويشترط لتقديم طلب التنفيذ توافر الثروط الآتية: الشرط الأول: عمل احتجاج عدم الدفع: يقصد باحتجاج عدم الوفاء : ورقة رسمية تحرر بواسطة موظف رسمي هو الكاتب العدل؛ وتبلغ بواسطة أحد المحضرين، وتثبت امتناع المسحوب عليه أو المدين بالورقة التجارية عن الوفاء بقيمة هذه الورقة؛ هذا وقد ألزم المشرع الحامل بتحرير احتجاج عدم الوفاء لإثبات امتناع المسحوب عليه عن الوفاء بقيمة الورقة في ميعاد الاستحقاق، وقد ورد هذا الإلزام في المادة r N 1 من قانون التجاري التي جاء فيها " يجب أن يثبت الامتناع عن القبول أو عن الوفاء بوثيقة رسمية تسمى الاحتجاج لعدم 
القبول أو الاحتجاج لعدم الوفاء"، وهذه المادة جاءت بخصوص سند السحب وتطبق على باقي الأوراق التجارية'(') الثرط الثاني: أن يكون احتجاج عدم الوفاء يتطلبه القانون

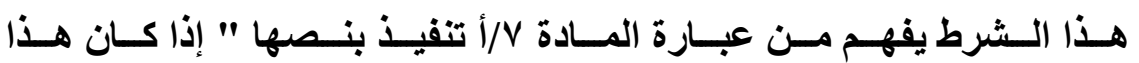
الاحتجـاج يتطلبه القـانون"، ففي حالـة امتنـاع المسحوب عليه عن وفـاء الشيك على

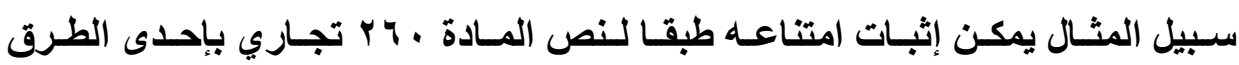

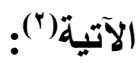

$$
\text { - بورقة احتجاج رسمية. }
$$

- بييان صادر من المسحوب عليه مؤرخ مكتوب على الثيك ذاته مع ذكر يوم

$$
\text { تقديمه. }
$$

- ببيان مؤرخ صادر من غرفة المقاصة يذكر فيه أن الثيك قدم في الوقت المحدد

$$
\text { ولم تدفع قيمته. }
$$

ويلاحظ أن تنظيم احتجاج عدم الوفاء بواسطة كاتب العدل ليس إلزاميا بالنسبة إلى حامل الثيك أو المستفيا منه، فهو بالخيار بين إحدي الطرق السالف ذكرها آنفا، فإن هو اتبع أيا منها حق له الرجوع على المظهرين والساحب وغيرهم من الملتزمين به إذا قدمه في الوقت المحدد ولم تدفع قيمته.

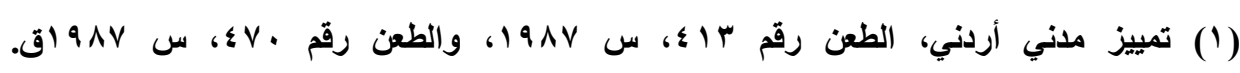
.https://www.eastlaws.com (ץ) صلاح الدين شوشاري، التنفيذ الجبري في المواد المدنية والتجارية والثرعية،، المرجع السابق، 
الثرط الثالث: أن يقام طلب تحصيل الدين من المظهرين والكفلاء إلى دائرة التنفيذ خلال خمسة عشر يوما تلي تاريخ الاحتجاج بالوفاء.

وهذا الشرط مستفاد صراحة مـن نص المسادة V تنفيـذ؛ إذ أوجب المسرع

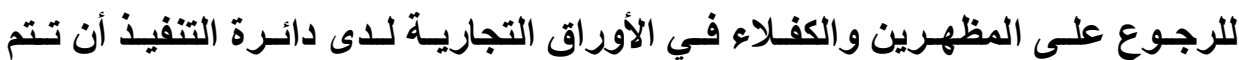

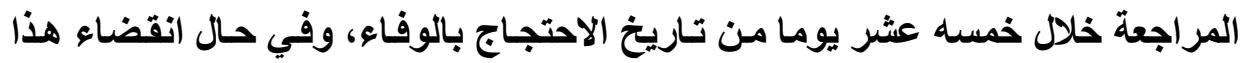
الميعاد ـ التي تعد من مهل السقوط بشأن المراجعة أمسام دائرة التنفيذ - لابد من الاهن مراجعة المحكمة المختصة والحصول على حكم بالدين وفقا للقو اعد العامة' (') وقد فرقت المادة V تنفيذ بين كل من الساحب والمسحوب عليه من جهة، وبين كل من المظهرين والكفلاء من جهة أخرى، ولا شكك في أن التفرقة بين مختلف المدينين بالورقة التجارية لا يتفق مع القواعد العامـة. وكان يجدار بالمشرع عند وضعانه قانون التتفيذ عدم إيراد الفقرة رقم أ من المادة V، فيوفق بذلك في هذا المضمار بين قانون

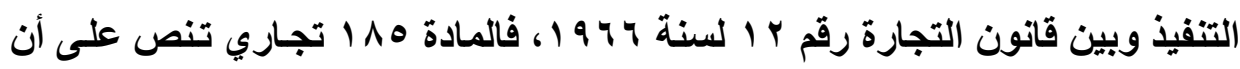
" ساحب السند وقابلة ومظهره وضامنه الاحتياطي مسئولون جميعا تجاه حامله على لجى

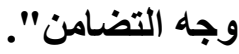

وهذا النص ينطبق على سند السحب، كمـا ينطبق على الأوراق التجاريـة

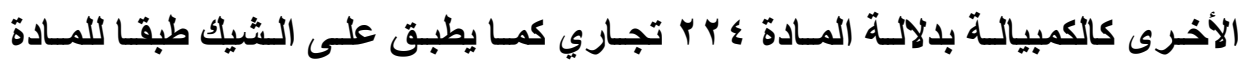

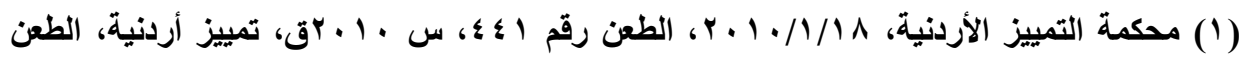

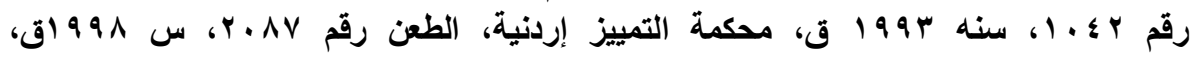

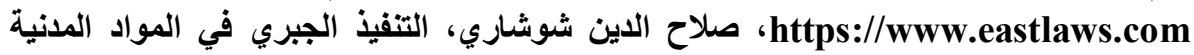

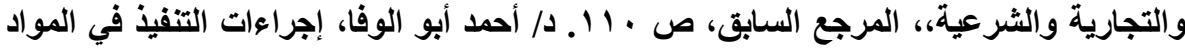

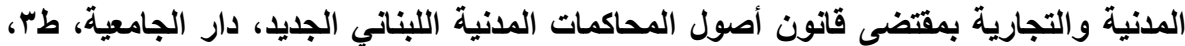


Y Y Y Y Tـاري. أي إن الموقعين على ورقـة تجاريـة يعدون متضامنين في وفـاء قيمـة الورقة للحامل، فله مطالبتهم مجتميعن بكامل قيمة الورقة، أو منفردين دون مراعاة أي أي ترتيب فيما بينهم (').

ويرجع خطأ المشرع في هذا إلى اقتباس الفقرة أ في المادة V تنفيذ عن المسادة

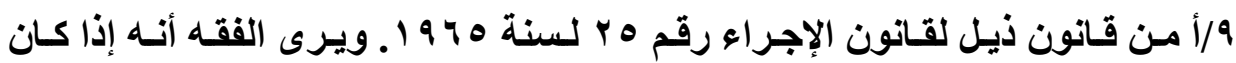

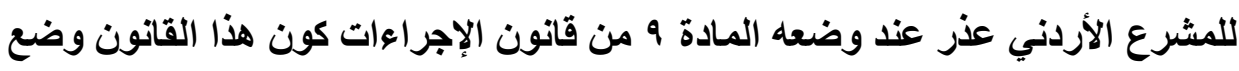

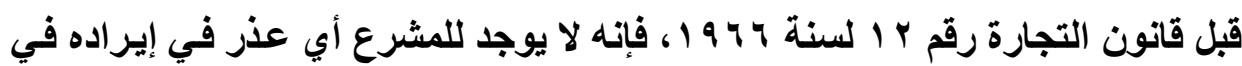
نص الفقره أ في المسادة V تنفيذ؛ إذ إن هذا القانون الأخير وضع بعد قانون التجارة

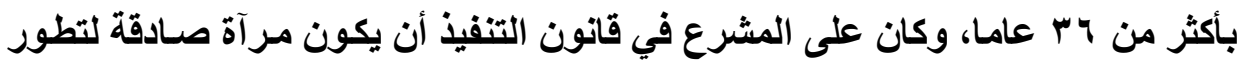

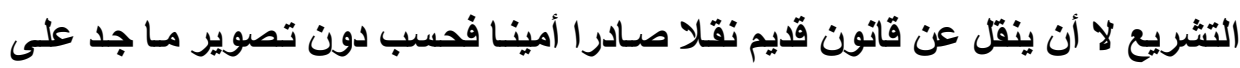

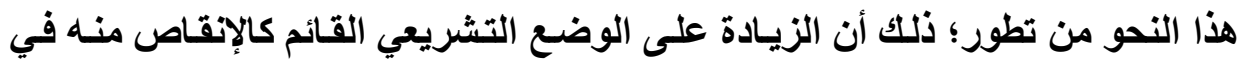

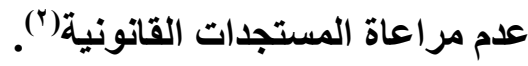

ويجب على دائرة الإجراء أن تتقيد بمضمون السند التنفيذي، فلا يحق لها تحصيل الفوائد لأنها لا تسري إلا اعتبارا من تاريخ المطالبة القضائية، ولابد من صدور

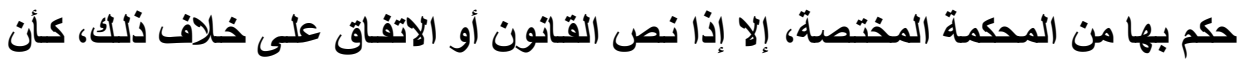

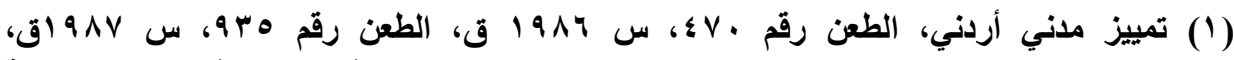

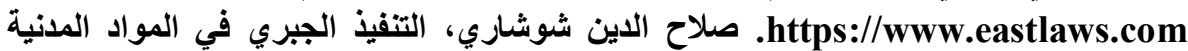

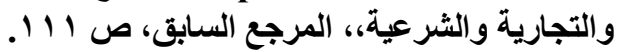
(ץ) صلاح الدين شوشاري، التنفيذ الجبري في المواد المدنية والتجارية والثرعية،، المرجع السابق، 
يشتثل السند على سـريان الفائدة مـن تـاريخ الاستحقاق مـثلا، عندها يجوز لـائرة

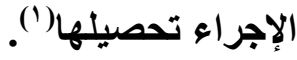

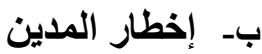

بعد تقديم الطلب تقوم دائرة الإجراء بتبليغ المدين بإخطار يرفق بـه صورة

السند المطلوب تنفيذه، وإذا تعدد المدينون تعددت الصورة بعددهم، ويجب أن يشتمل

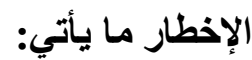

- طلب الوفاء بالدين والمصاريف.

- إنذار المدين بالاطلاع على الملف، وإبداء ما يكون لايه من أوجه الاعتراض على

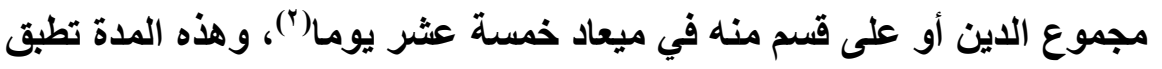

على المدين المعلوم مكان الإقامة والمدين المجهول مكان إقامته، وقد كانت المدة

$$
\text { ه أيام في القانون الملفي. }
$$

- الإخطار بأن الدائرة الإجرائية ستقوم بالتنفيذ الجبري إذا لم يتم الوفاء أو تقديم

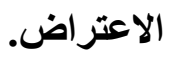

$$
\text { - - عنوان طالب التنفيذ. }
$$

ولا يجوز قبل انقضاء مهلة خمسة عشر يومـا اتخـاذ أي إجراء من إجراءات

التنفيذ كحجز أو حبس أو غيره، وإذا تم اتخاذ مثل هذا القرار عدّ بـاطلا لأن السند قبل

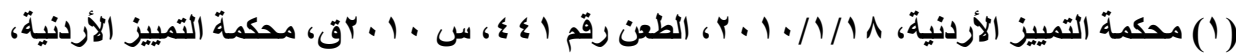

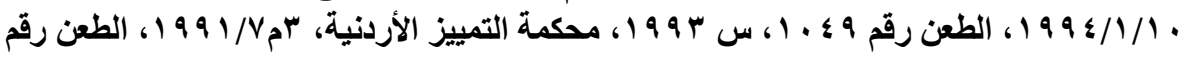


مضي هذه المهلة لا يكتسب القوة التتفيذية التامة، ولكن يجوز للائن طلب إجراء حجز تحفظي، وفي هذه الحالة لا يلزم الائن بإقامة الدعوى بأسـاس الحق خلال مهلة الأيسام الثمانية المحددة في المادة ج 9 أصول، والتي تبدأ من تاريخ قرار الحجز التحفظي لأن السند لاى دائرة التنفيذ يقوم مقـام إقامـة الدعوى بأسـاس الحق، وتسري هذه المهلة بحقه في حسال اعتراض المـين على السند وتكليف رئسيس الإجراء للـائن بمراجعة المحكمة على أن تبـأ مـن اليـوم الذي يلـي تبليفـه قرار التكليف بمراجعة المحكمـة المختصة.

وإذا كانت هناك أسباب استثنائية لدى المدين لـم تمكنه من الاعتراض خلال

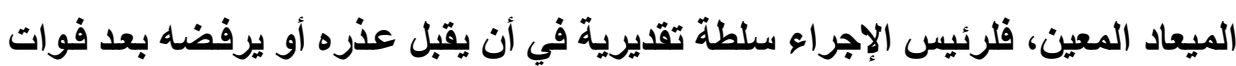

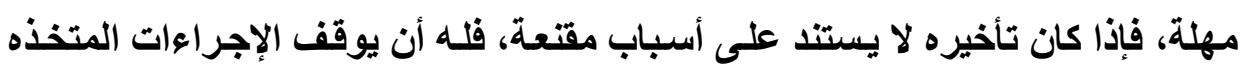

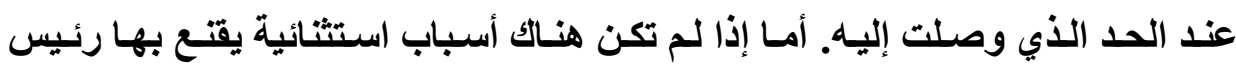
الإجراء، وانتهت المهلة المحدد، دون أن يبدي المدين اعتراضـه على التنفيذ، فيسقط

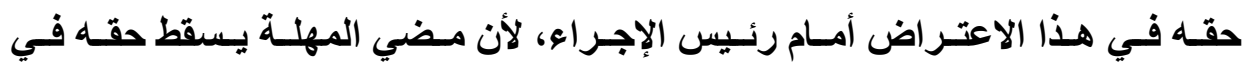
الاعتراض، إلا أنـه يبقـي للمدين الحق بإقامـة دعوى المعارضـة في قيمـة الدين أمسام المحكمة الموضوع التي لها إذا وجلت أن الدعوت جدية أن تقرر وقف التنفيذ. ج - موقف المدين بعد الإعلان بعد إعلان المدين بطلب التنفيذ ينتظر لمعرفة موقفه، ويمكن توقيع صدور أحد المواقف الآتية من المدين: القرض الأول: الوفاء بلين الورقة التجارية: قد يقوم المدين بعد تبليغه بالإخطار بالوفاء بالدين خلال مهلة الإخطار البالغة خمسة عشر يوما تبدأ من اليوم التالي لتـاريخ إعلانـه عملا بالمـادة هـ 1 تتفيذ، ويلاحظ الإعط 
أن قانون التنفيذ الحالي لا يعفي المدين من رسوم التفيذ إذا أوفى المدين خلال مهلة الإخطار بعكس الحال التي كانت في ظل القانون القديم الملفي، والذي كـان ينص على لـى إعفاء المدين من رسوم التنفيذ إذا أوفى المدين بالدين خلال مهلة الإخطار ('). الفرض الثاني: عرض تسوية تتناسب ومقدرته المالية: قد يقوم المدين بعرض تسوية تتناسب ومقدرته المالية خلال مهلة الإخطار، على ألا تقل الافعة الأولى بموجب التسوية عن هب في المائـة من المبلغ المحكوم بـهـ

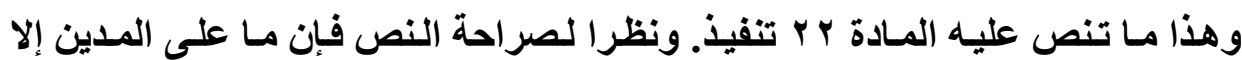
عرض تسوية تكون الدفعة الأولى منها هب في المائسة من المبلِغ المحكوم بـه دون أن يقترن ذلك بالدفع الفعلي، فإذا قام المدين بعرض التسوية يكون قد أوفى بمتطلبـات

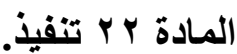
الفرض الثالث: الاعتراض على مجموع الدين أو على قسم منه: قد يقوم المدين بعد تبليغه بـالاعتراض على مجموع الدين أو على قسم منـه

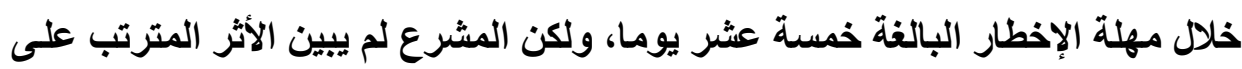
تقديم المدين لاعتر اضه خلال مهلة الإخطار ، كما لـم يبين مـا المقصود بـالاعتر اض هل هو ادعاء الوفاء الجزئسي أو الكلي أو الإنكار؟ كمـا لم يبين المكلف بمراجعة المحكمـة المختصة لإثبات ما اعترض عليه المدين، هل هو الادئن أم المدين؟ 
الفرض الرابع: إنكار المدين للاين كله أو بعضه: قد يقوم المدين بإنكار الدين كله أو بعضه خلال مهلة الإخطار، فعلى اللائن

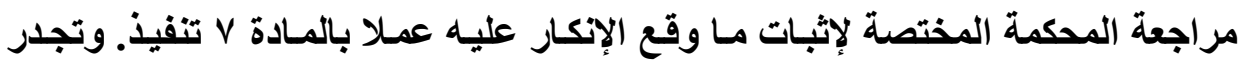
الإشارة إلى أنه لا يشترط أن يثبت المدين إنكاره الدين أو بيـان الأسباب التي يرتكز عليها في هذا الإنكار أمسام رئيس الإجراء؛ ذلكت لأن رئيس الإجراء لا يملك البحث في جدية طلب المدين وفحص أسبابه و أسانيده، لأن المشرع الأردني لم يطلب مثل ذلك من الأن رئيس الإجراء، ويرى الفقة وجوب إعطاء رئيس الإجراء هذه السلطة بيحث مدى جدية

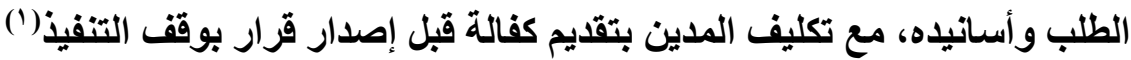
فإذا استطاع الدائن إثبات صحة الدين المطلوب تنفيذه، حكمت المحكمة على المدين بغرامة تعادل خمس قيمة الدين المتنازع بـه تدفع كلها للخزينة، بالإضـافة لمسا تحكم به للائن من رسوم وفائدة قانونية وأتعاب محاماه، والحكم بالغرامسة على المدين الذي أنكر توقيعه لا يمنع الحكم للائن بالأضرار التي لحقته من جراء إنكار المدين الدين إذا طالب المدين بالتعويض عن هذه الأضرار، وعلة الحكم بالغرامة على المدين

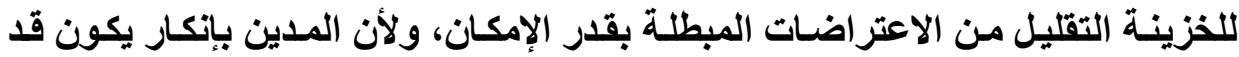
أشغل دائرة التنفيذ المحاكم بلا مسوغ.

ومن الجدير بالذكر أن إنكار الداين المقصود بـه في المـادة V تنفيذ لا يرد إلا

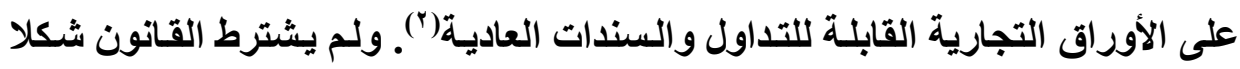

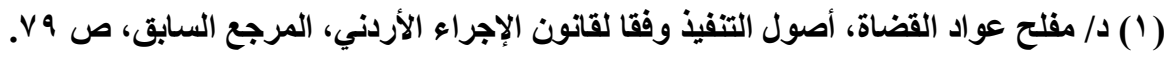

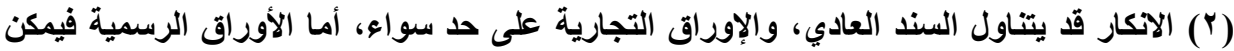

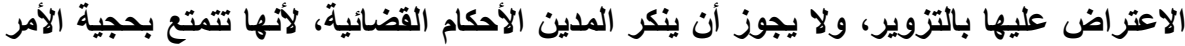
المقضي، ولكن يجوز للمدين أن يدعي الوفاء، أو القيام بتنفيذ الحكم القضائي المطروح للتنفيذ، لأنيا $=$ 


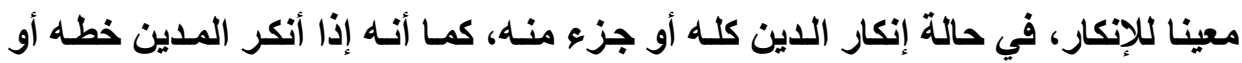

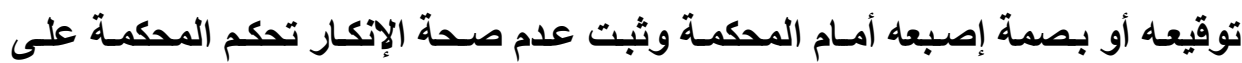

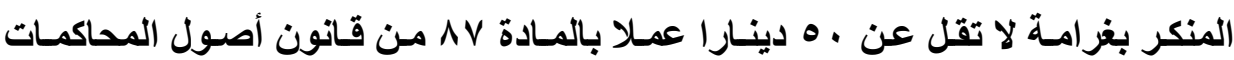

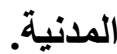

ويرى الفقه الأردني أن منح المدين المنقَّ ضده حق إنكار الدين الوارد في سند

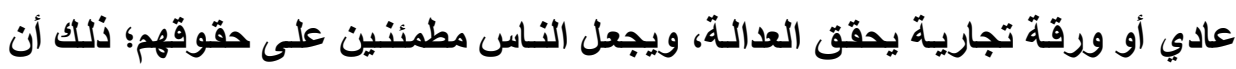
بعض هذه السندات والأوراق تحرر لسبب أو لآخر دون أن يكون محررهـا مدينا بها

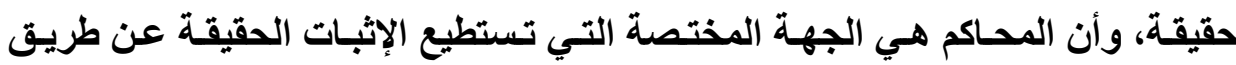
التحقيقات التي تجريها من خلال المرافعات والمواجهات وتبادل الطلبـات والدفوع بين التهين

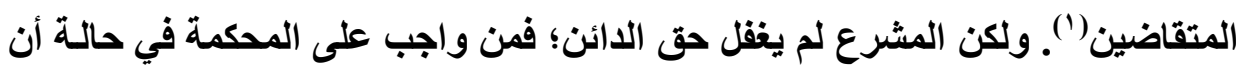
ثبت صحة الاين المطلوب تنفيذه، أن تحكم على المدين بغرامة تعادل خمس قيمسة الدين

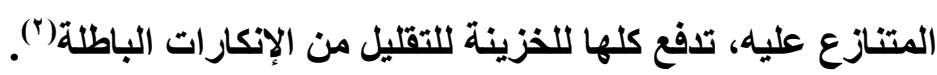
الفرض الخامس: عدم مراجعة المدين دائرة التنفيذ خلال مهلة الإخطار إذا لم يقم المدين بمراجعة دائرة التنفيذ، ولم يعترض على السند خلال مهلة

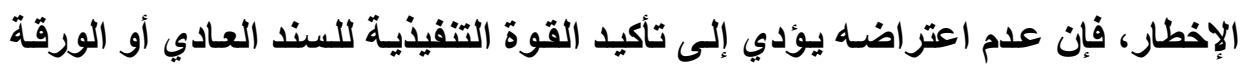

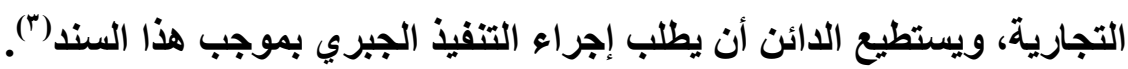

ففي مثل هذه الحالة يعرض الأمر على رئيس الإجراء ليتحقق من صحة هذا الدفع الذائ أثاره

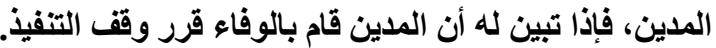

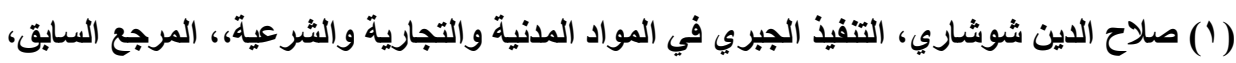

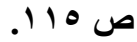

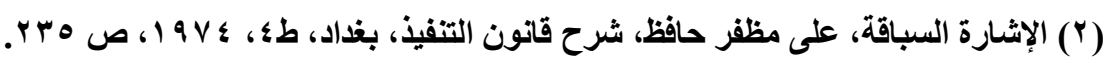

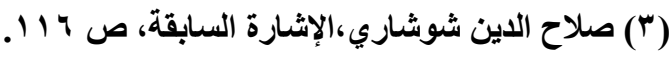


وإذا لم يقلم الاعتراض في الميعاد المعين، وكـان الـائن استوفى الـائن دينهـ كله أو بعضه، فقد أعطى المشرع للمدين الحقى في إقامـة دعوى للمطالبة باسترداد مـا استوفي منه، بغير حق وبتعويض ما لحق به من ضرر. وتقام الدعوى في هذه الحالة

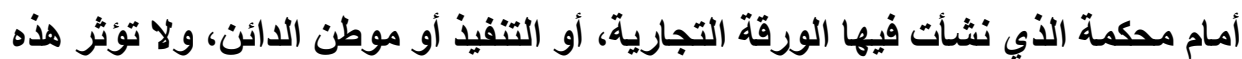

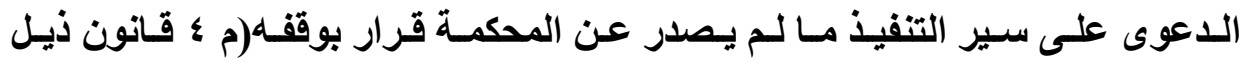

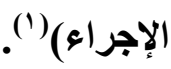

الفرض الساد: إقرار المدين بالدين أو بقسم منه: قــ يقوم المـدين بـالإقرار بالـدين كلـه أو بقسم منـه، ويجب أن يقـع الإقرار بحضور رئيس الإجراء ويدون ذلك في محضر الإجراء. وتقوم دائرة التففيذ بتنفيذ مـا

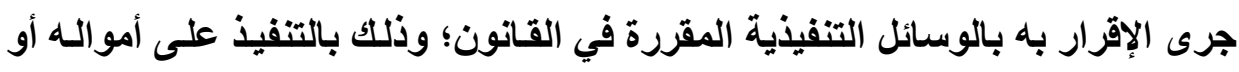
حسبه أو منعه من السفر وفقا لأحكام قانون التنفيذ. وفي حالة الإقرار بقسم من الدين يكون حتما المدين قد أنكر ضمنـا أو صراحة القسم الباقي، وفي هذه الحالة يكلف الدائن بمراجعة المحكمة المختصة لإثبات ما وقع عليه الإنكار (†). الفرض السابع: ادعاء المدين وفاء جزء من الدين: قد يدعي المدين الوفاء بجزء من الدين، ففي هذه الحالـة تستمر الدائرة في

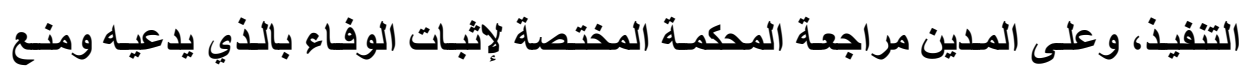

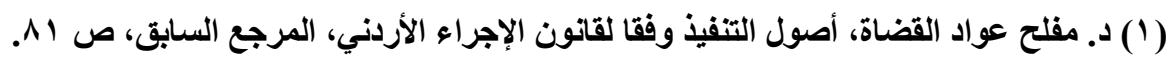

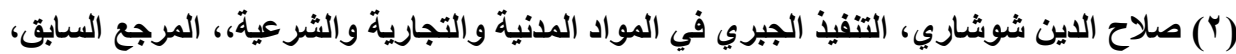


المطالبة بالدين والحصول على قرار بوقف التنفيذ من المحكـة المقـام للايها دعوى(').

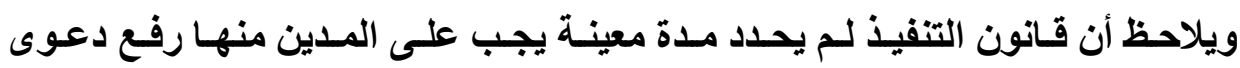
الاسـترداد خلالها، على خـلاف القـانون الملفي الذي كـان يحدد مـدة سـنة مـن تـاريخ التنفيذ. وفي الواقع يجب إقامة دعوى الاسترداد خلال ثثلاث سنوات من اليوم الذي علم فيه صاحب الحق في الرجوع بحقه، على ألا تنقضي خمس عشرة سنة من اليوم الذي نشأ فيه حق الرجوع عملا بالمادة الب اس مدني أردني (؟) - - إجراعات تثفيذ الأوراق التجارية في النظام السعودي لقد أظهرت الإحصائيات في النظام السعودي أن أكثر ما تستقبل محاكم التنفيذ من أنواع السندات التنفيذية هي الأوراق التجارية(")، وهي محصورة في ثُلاث أنواع؛

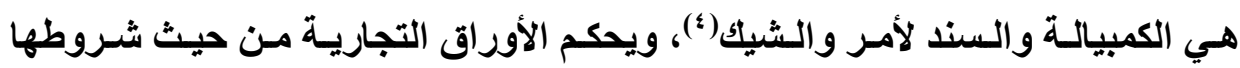
الموضوعية والثكلية والمدد النظامية وطرق تداولها والعقوبـات المترتبة على بعض هض

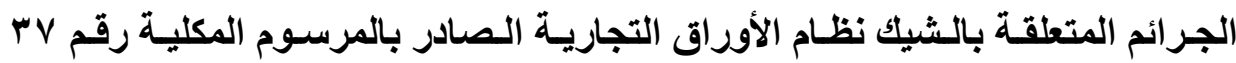

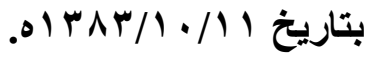

(1) لا يوقف التنفيذ إلا بقرار من المحكمة التي تنظر النزاع، ويتقديم هذا القرار إلى رئيس الإجراء؛

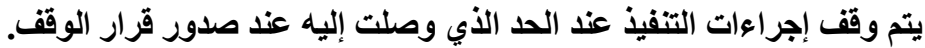

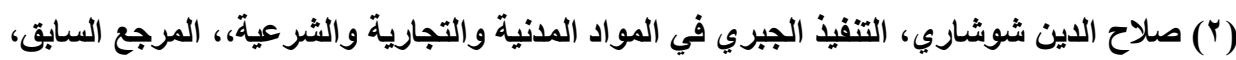
ص ص ال

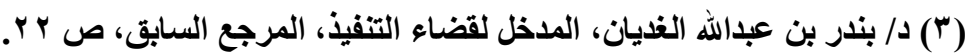

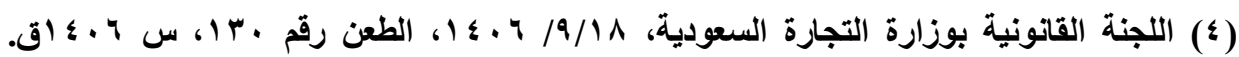

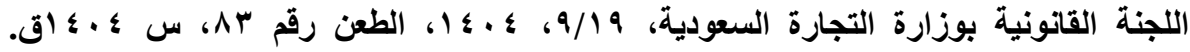
https://www.eastlaws.com 
يتقلم حامل الورقة التجارية بطلب إلى قاضـي التنفيذ لوضع الصيغة التتفيذية لتصبح الورقة سندا تنفيذيا، ويمكن بعد ذلك اتخاذ كافة الإجراعات التتفيذية التي نص عليها قانون التنفيذ السعودي؛ من حجز على المنقول أو على العقار أو حجز ما للمدين

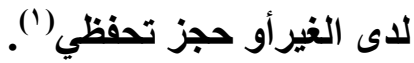
ويجب أن يتضمن الطلب البيانات العامـة وهي الاسـم بالكامل للائن والمدين، واسم المحكمة المقدم لها الطلب، وتاريخ الطلب، ورقم السند التنفيذي، ومقدار الحق،

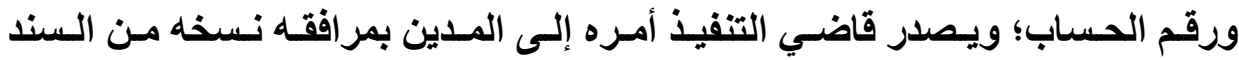
التتفيذي مختوما بختم المحكمة بمطابقتها للأصل، ويبلـغ المدين وفقـا لأحكام الاعلان طبقا للقواعد العامة، فإذا تعذر إبلاغ المدين خلال عشرين يوما من تـاريخ أمر التنفيذ، أمر قاضي التفيذ بنشر الإبلاغ فورا في صحيفة يومية واسعه الانتشار في منطقة مقر المحكمة، وتستوفي من المدين نفقه الإعلان مع استيفاء الاين.

$$
\text { ب- إثبات الامتناع عن الوفاء }
$$

طبقا لنص المـادة ؛ ه من نظام الأوراق: يجب على حامل الكمبيالة أن يثبت الامتناع عن قبولها أو عن الوفاء بها في ورقة رسمية يطلق عليها احتجاج عدم القبول

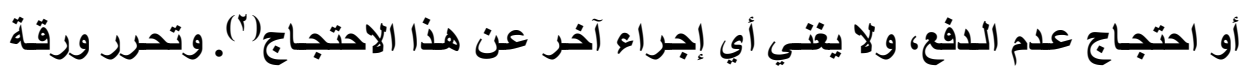

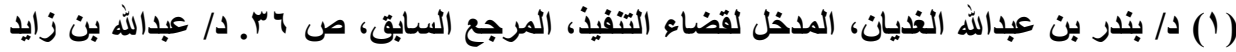

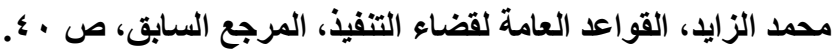

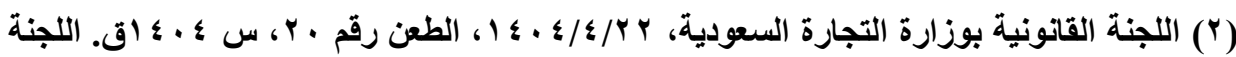

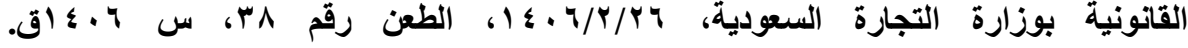
https://www.eastlaws.com 
الاحتجاج بواسطة الجهة التي يعينها وزير التجارة والصناعه، وتشمل ورقة الاحتجاج على صورة حرفيـة للكمبيالة، ومـا أثبت فيها من عبـارات القبول والتظهيز والضمان وغير ذلكك من البيانـات(')، وتتضمن الإنـار بوفـاء قيمـة الكمبيالـة ويـكر فيها أيضا حضور الملتزم بالقبول أو الوفاء أو غيابه(؟). وقد نصت المـادة Vه من نظام الأوراق على أنـه " يجـوز للساحب ولأي مظهر احتيـاطي أن يعفي حامـل الكمبيالـة مـن عمل احتجاج عدم القبول أو عدم الوفاء عند مباشرة حقـه في الرجوع، إذا ضمن الكمبيالة وذيل توقيعه شرط الرجوع بلا مصروفات أو بدون احتجاج أو أية عبارة أخرى تفيد هذا ج- مراعاة المدد النظامية التي نص عليها النظام السعودي ولقد وضع النظام السعودي مددا نظاميـة للأوراق التجاريـة حتى تقبل التنفيذ عليها كسندات تتفيذية في النظام السعودي، فطبقا لنظام الأوراق التجاريـة السعودي،

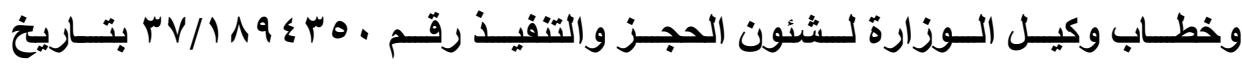

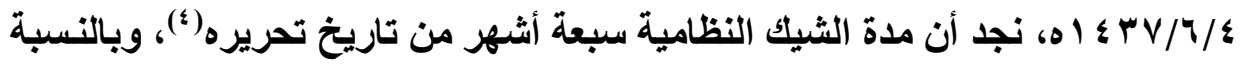

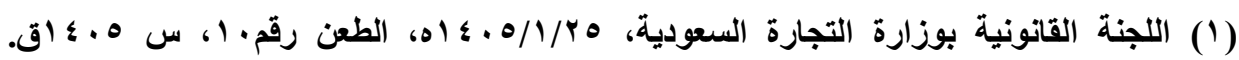
https://www.eastlaws.com

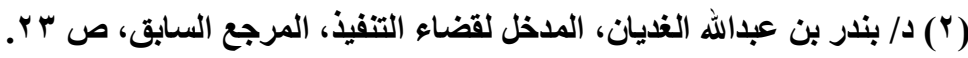

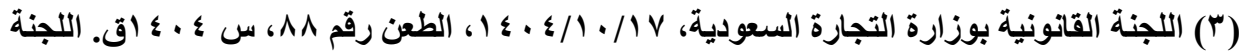

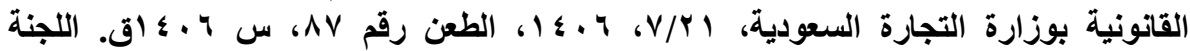

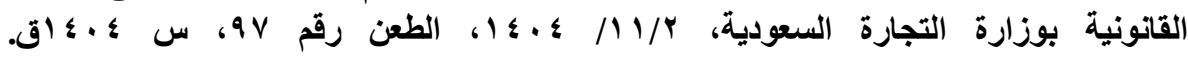


للسند لأمر والكمبيالـة، فالمدة هي أن وجد تـاريخ استحقاق، ثُلاث سنوات من تـاريخ

الاستحقاق، وإن كان لاى الاطلاع فيكون أربع سنوات من تاريخ الإنشاء (').

دـ اختصاص قاضي التنفيذ بالمنازعات المتعلقة بالورقة التجارية

يختص قاضي التنفيذ وفقا للمادة الثالثة بأي منازعة تتعلق بالتحقق من صحة

الأوراق التجارية كسند تنفيذي مثل الادعاء بتزوير السند أو بطلانه لعيب في الرضـا أو لو

المنقَّذ ضده ليس بطرف فيه أو إنكار التوقيع عليه ونحو ذلك، سواء أكاتت الورقة التجاريـة كمبيالـة أم سندا لأمسر أم شيكا متى اكتسبت صفة السند التنفيذي، ويختص

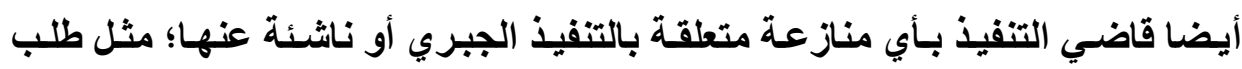

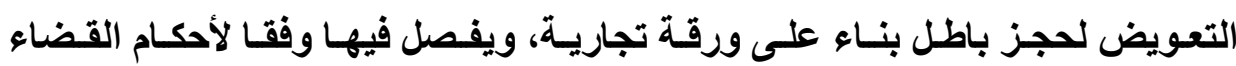

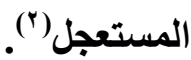

فطبقـا لنص المـادة الخامسسة مـن لائحسة التفيـذ يختص قاضـي الموضـوع أو

الجهة المختصة إذا كان النزاع في موضوع الورقة التجاريـة سواء كانت كمبيالة أم

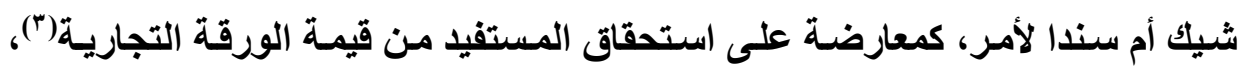
فعليه التقدم بـدعوى موضـوعية لدى المحكمة المختصة؛ كالمحساكم العامـة لـو كانـت المعارضة بسبب عدم استحقاق المستقيد قيمة العقار الذي حررت الورقة التجاريـة ثمنـا

( ) (1) م ع ع نظام الأوراق التجارية وخطاب وكيل الوزارة.

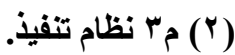

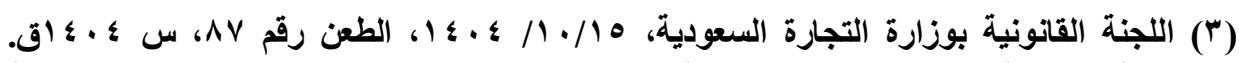

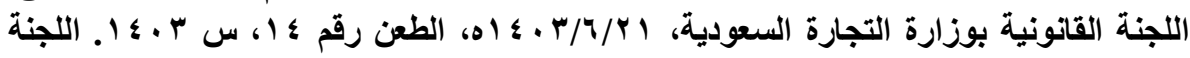

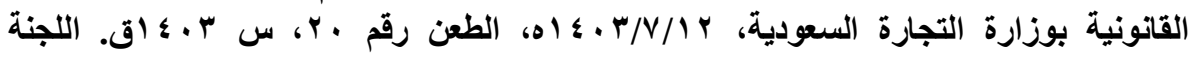

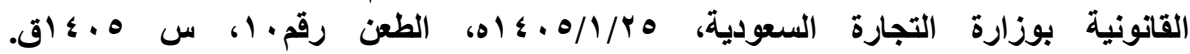
https://www.eastlaws.com 
لله، على أن ذلكت لا يعد موجبـا لوقف التنفيذ(')، بل يستمر قاضسي التنفيذ في إجراء التنفيذ مـا لم يرد من المحكمة المختصة وقف التتفيذ(). وكل منازعة أخرى متعلقة بموضوع الحق فهي من اختصاص قاضسي الموضوع(")؛ كالمنـازعـة المتعلقـة بـإخلال طرفي التعاقد أو أحدهما بالتزاماته الواردة في العقد كعقود المقاولات والتوريد ونحو ذلـك والتـي تعلقت بقيمـة الورقة التجاريـة، هـذه المنازعـات مـن اختصاص قاضـي الموضوع وليس قاضي التنفيذ(؛)؛ بل أكثر من ذلك يمنع قاضي التنفيذ من ممارسـة أي

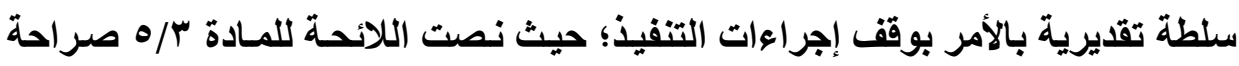
على ذلك بقولها: "لا يحول وجود نزاع في موضوع الورقة التجاريـة من السير في

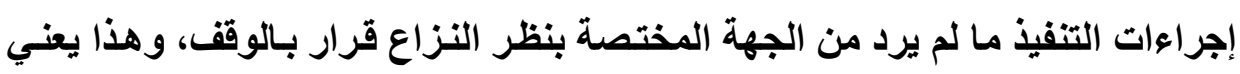
أنه من حق طالب التنفيذ الاستمرار في إجراءات التنفيذ والحجز أو البيع في الوقت

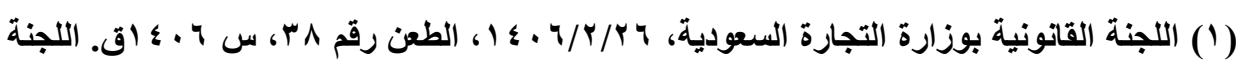

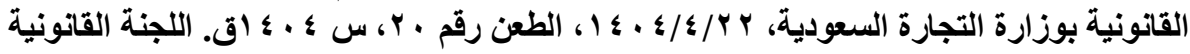

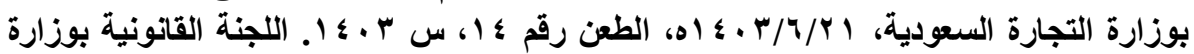
التجارة السعودية، https://www.eastlaws.com

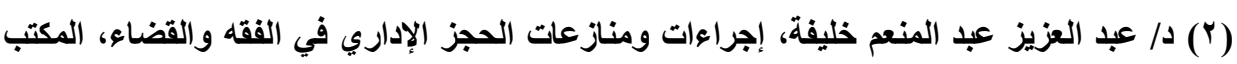

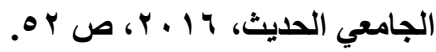

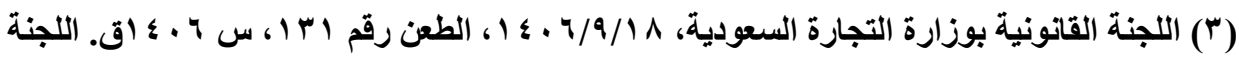

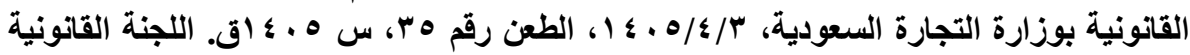

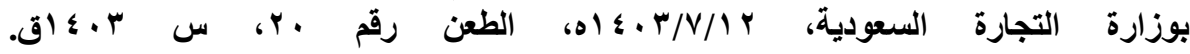
https://www.eastlaws.com

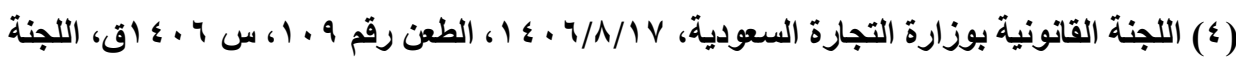

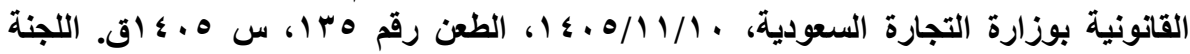

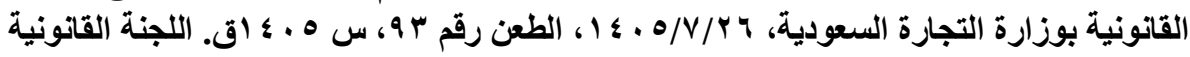

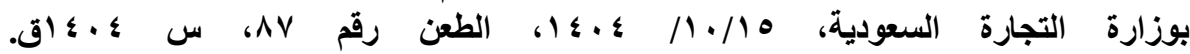
https://www.eastlaws.com 
نفسه الذي ينظر فيـه قاضـي الموضوع نزاعـا في موضوع الورقة التجاريـة، ممـا قــ يلحق الضرر بالمنفذ ضده في هذه الحالـة وهو نص محل نظر استنادا إلى أسباب مختلفة(')، ويرجع ذلك إلى الآتي: أولا: مسألة وقف إجراءات التنفيذ أو الاستمرار فيها تتعلق بالإجراءات أكثر ما تتعلق بالموضوع، ومن ثم يكون لقاضي التنفيذ نظر مسألة

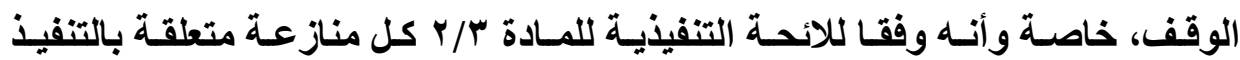
الجبري أو ناشئة عنه فهي من اختصاص قاضي التنفيذ.

ثانيـا: أن بـء إجراعات التنفيذ - وهو تنفيذ عـادى وليس معجلا - يفترض توافر جميع شروطه الموضوعية والشكلية(؟)، أي سند تنفيذي يصلح للتنفيذ الجبري ووضـع عليـه صـيغة التنفيذيـة، وبعد أن تحقق قاضـي التنفيذ المختص مـن الشروط المنصوص عليها في القانون(")، لذا فقاضي التنفيذ يحيط علمـا بـالظروف والملابسات المتعلقة بإجر عات التنفيذ أكثر من قاضسي الموضوع، ويستطيع أن يقيم التوازن بين

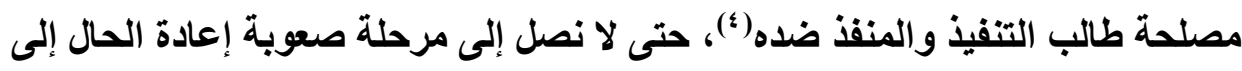

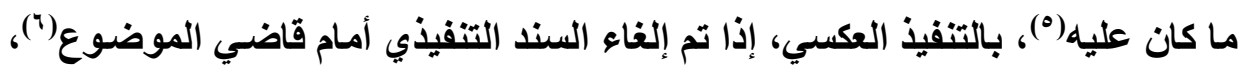

(1) د/ مفلح بن ربيعان القعطاني، د/ محمد السيد محمد رفاعي، الوسيط في النظام السعودي، المرجع

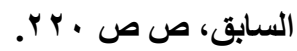

(2) Didier CHOLET Exécution des jugements et des actes, op. cit., n0 30

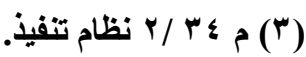
(§)، د/ السيد خميس حسن السري، ضمانات المحكوم عليه في النفاذ المعجل، رسالة حقوق طنطا،

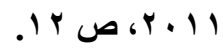

Xavier DAVERAT, Saisie : protection du débiteur, D., septembre 2013, p. 19.

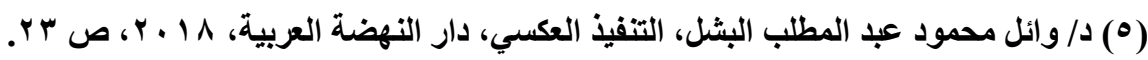

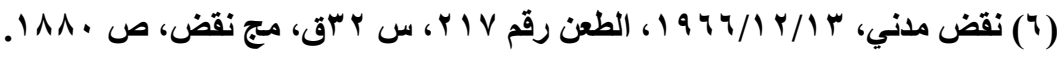


ومن ثم لا ينبغي أن نسند سلطة الأمر بوقف إجراءات التنفيذ إلى قاضسي الموضوع وحده، وإنما العدالة وحسن سير الإجراءات تقتضي أن تعطي السلطة التقديريـة لقاضي

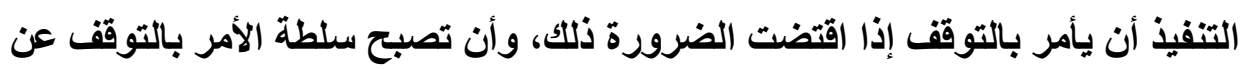
إجراعات التنفيذ مشتركة بين قاضي الموضوع وقاضي التنفيذ.

ثالثا: بالإضافة إلى الأسباب التي نستند إليها حتى تكون لقاضي التنفيذ سلطة في قرار الوقف ما يتعلق بطبيعة المسألة ذاتها؛ فوقف إجراءات التنفيذ يعد صورة من صور الحمايـة الوقتية والتي تتوقف على تحقق شرط الاستعجال، والضرر المحتمل حدوثه، فهي ليست حكما فاصلا في موضوع النزاع، فلن يضر طالب التنفيذ أن توقف إجراعته من قاضي التنفيذ إلى أن يتم الفصل في النزاع في موضوع الورقة التجارية، بل العكس هو الصحيح، لأن إجراءات التنفيذ تتم على مسئوليته فإذا ألغي التنفيذ أصبح من حق المنقَّ ضده أن يطلب بتعويضا عن الضرر الذي لحق بـه من إجراء التنفيذ، و هذه المنازعة يختص بها قاضي التنفيذ(')، فكيف يكون الاختصاص لقاضي الموضوع أن يأمر بالتوقف عن إجراعات التنفيذ، فإذا لم يصدر قرارا بـالتوقف يكون الاختصاص بعد ذلك لقاضي التنفيذ بنظر طلب التعويض لحجز باطل. r- إجراءات التنفيذ في النظام اللبناني في النظام اللبناني يشكل الشيك سندا قابلا للتنفيذ الجبري دون اللجوء إلى

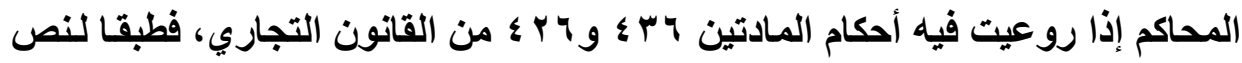
المادة ף بـ تجاري يحق لحامل الثك الادعاء على المظهرين والساحب إذا لم يستوف قيمـة الشك الذي عرض في الوقت المناسب، على أن يكون إثبـات الامتتـاع بوثيقهـ 
رسمية (الاحتجاج) أو بتصريح من المسحوب عليه مكتوب ومؤرخ على الشك ومبين فيه يوم العرض. وقد نصت المادة צ بـ على أن الشيك الذي يصدر في لبنـان ويكون قابل الإيفاء فيها يجب أن يعرض للايفاء في مهلة ثمانية أيام. أمسا الشيك الذي يصدر لهرد خارج لبنان ويكون قابلا للإيفاء فيها فيجب عرضه في مهلة عشرين يوما إذا كان محل إصـاره في بـلاد متاخمـة للبنـان أو سوريا أو في أوربـا أو في بلـ واقعه على شـاطئ البحر المتوسط. وتكون المهلة سبعين يوما إذا كان الثيك صادرا عن أي بلد آخر. ومن ثم لا يجوز تنفيذ الشيك إلا إذا عرض ضمن المهلة المـكوره في المـادة

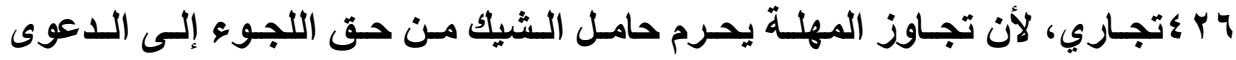
الصرفية مبقيا له الحق في إقامة الدعوى المبنية على أصل العلاقة الناشئة بين الحامل والساحب أو المظهر، حيث إن سقوط الدعوى الصرفية يستتبع سقوط القوة التنفيذيـة للشك(')، ويظل بإمكان صاحب الشيك إقامة دعوى عادية لإثبات حقه. وإذا تحققت الشرط والإجراءات في الشيك يصبح سندا تنفيذيا يحق لحامله طلب الحجز التحفظي بالاستناد إلى الشيك ذاته، وذلك بعد الاحتجاج بعدم الدفع، وكذلك يجوز اتخاذ كافة الإجراءات التنفيذية.

\section{الفرع الثاني}

\section{الأوراق التجارية كسندات تنفيذية في النظام الفرنسي}

سنشير إلى اتخـاذ الإجراءات التحفظيـة بنـاء على الأوراق التجاريـة، ثم عدّ

الشيك سندا تنفيذيا، وذلك في النقاط الآتية:

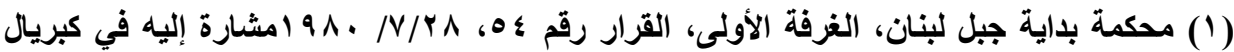

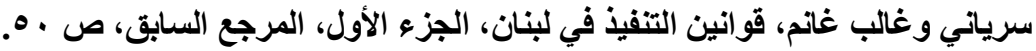


أولا: اتخاذ الإجراءات التحفظية بناء على الأوراق التجارية دون إذن سابق من القضاء

لم ينص المشرع الفرنسي على عدّ جميع الأوراق التجاريـة سندات تنفيذية،

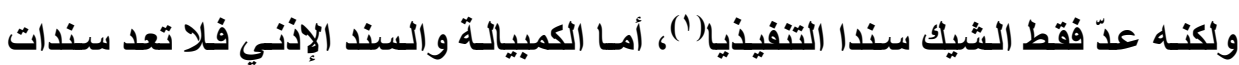

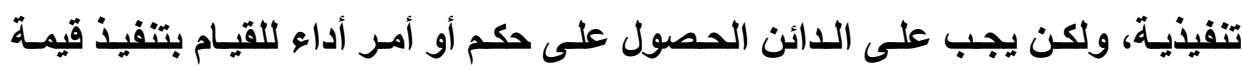
الكمبيالة أو السند الإذني.

وقد نص المشرع الفرنسي في المرسوم رقم • 1991/70 19 على أنسه يمكن

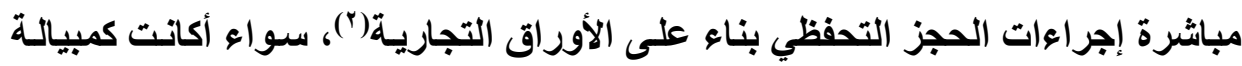

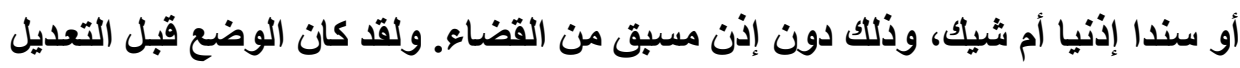

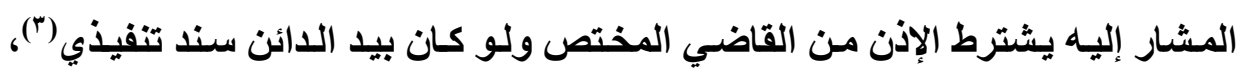

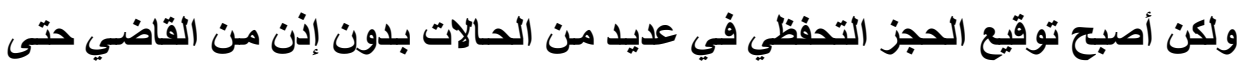

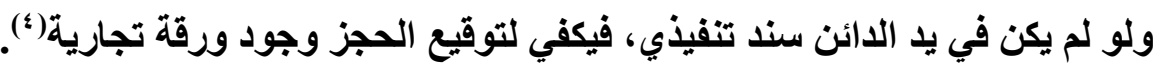

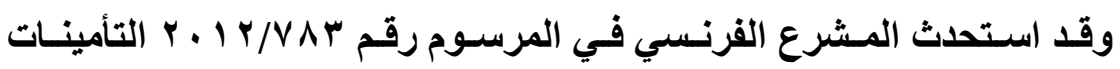

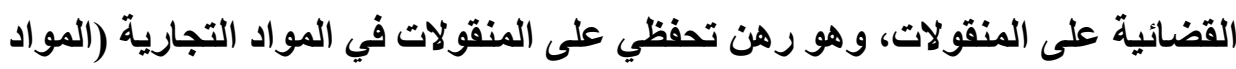

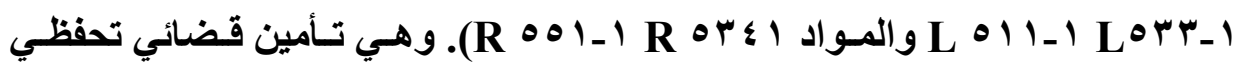

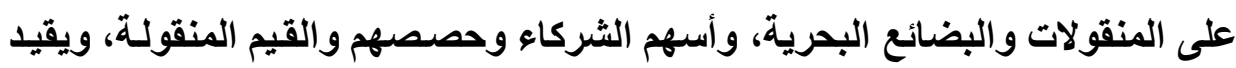

(1) Ph. HOONAKKER, Procédures civiles d'exécution, 4e éd., 2015, Larcier, p 40.

(2) Didier CHOLET, Exécution des jugements et des actes, op. cit., n.37.

(3) Stéphane PIÉDELIÈVRE, Frédéric GUERCHOUN, Saisies et mesures conservatoires, op. cit., n0 65.

(4) Gerard Couchez et Daniel lebeau, voies dexecution, op. cit., P50 
أمر القاضي بالرهن الحيازي في الشهر العقاري. ويترتب على قيد الرهن عدم جواز تصرفات المدين في المال محل الرهن، ويتمتع الدائن بميزتي التقدم والتتبع إذا حصل على سند تنفيذي بحقـه إذا كـان قد أوقـع التـأمين دون سند، ولا يترتب أثر عدم نفـاذ التصرفات إلا بعد الحصول على السند التنفيذي('). ثانياً: الشيك كسند تنفيذي في النظام الفرنسي سنشير إلى تطور التنظيم القـانوني للشيك، ثم النص على عدّ الشيك سـندا تنفيذيا، وذلك في النقاط الآتية: 1 - تطور التظيم القانوني للشيك في النظام الفرنسي لقد نظم المشرع الفرنسي الشيك بقانون رقم \& 1 يونيو عام ه 1 ا بقصد تسهيل سحب النقود المودعة بالبنوك، وذلك دون تقرير عقوبـة جنائية عليه لإصداره بلون رصيد حتى يقبل الأفراد على التعامل به كأدآه وفاء تحل محل النقود في التعامل، وعدّت الثيك ورقة بنكية، ونظرا لزيادة عدد الثيكات التي صدرت بلون رصيد اضطر المشرع الفرنسي في القانون الصادر VI VI إلى تقرير عقوبـة الحبس من شـهر إلى سنتين مع الغرامة التي لا تقل عن ربع قيمة الشيك ولا تتجاوز ضعف قيمته، ثم اضطر المشرع في القانون الصادر في أغسطس 19 ب 9 إلى تقرير جريمة النصب عليه من أجل ردع هذه الجريمـة، ونص على عقوبـة الحبس من سـنه إلى خمس سـنوات مـع

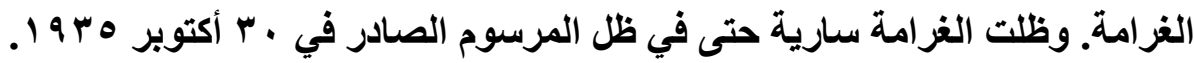

(1) BAKER CHISS, Contribution à l'étude de l'exécution des jugements civils dans les rapports internes et internationaux de droit privé,op. cit, p. 410. 
وقد ذهبت فرنسا إلى إلفاء جريمة إصدار شيك بدون رصيد، وذلك اعتبارا من

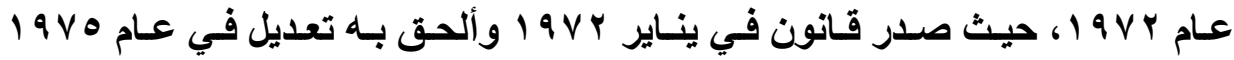
بالقـانون رقم ع ، حيث أبقي هذا القـانون على جنحة إصدار شيك بدون رصيد، مـع اشـتراط القصد الجنـائي الخـاص وهـو قصد الإضـرار بحقوق الغير دون مجرد العلـم بإصدر شيك بدون رصيد. ومنع المشرع البنك من منح الساحب إصدار دفتر شيكات، ثم

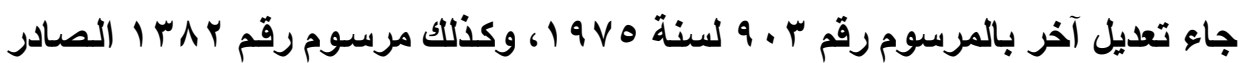

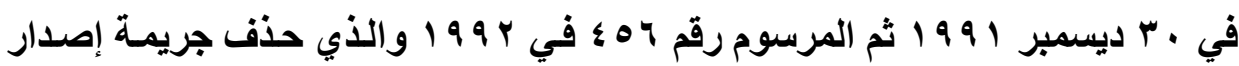
شيك بدون رصيد، وهذا مـا أخذت بـه بعض الدول مثل سويسرا التي لم تجرم واقعة إصدار شيك بلون رصيد '(')

وقد طبقت فرنسـا أحكام جنيف الموحدة بالتشريع الصـادر في • ب أكتوبر

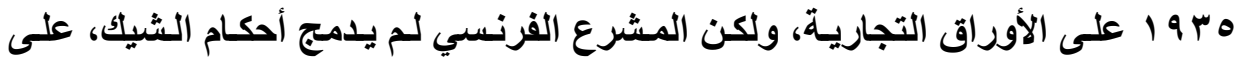
خلاف الكمبيالة والسند لأمر، داخل المجموعة التجارية. وأعدت فرنسا مشروع قانون

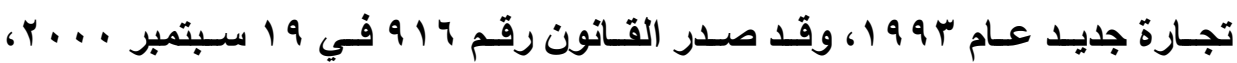
وخصص الكتاب الخامس لكل من الكمبيالة والسند لأمر، أما الشيك فقد عالجه المشرع

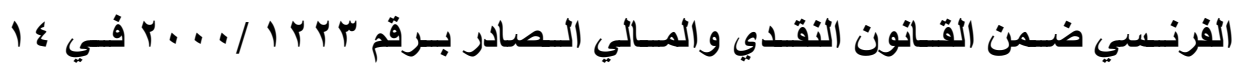

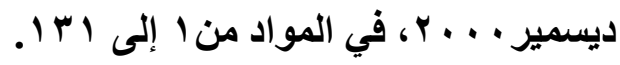

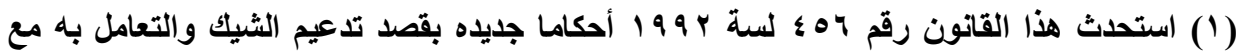

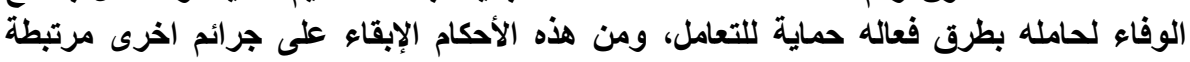

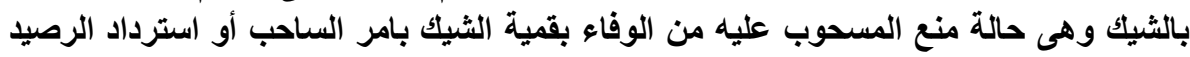

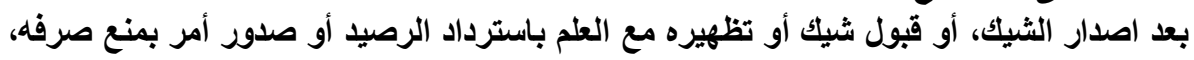

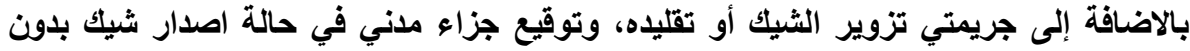

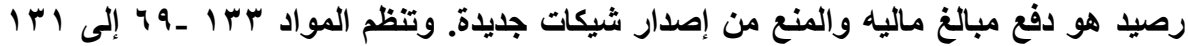

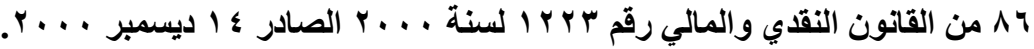


وقد نظم المشرع الفرنسي طريق الرجوع ضـد السـاحب الذي لـم يقم بعمل اعتماد بالمبلغ في البنك، فلا يكون أمام القضاء الجنائي إلا في حالات استثنائية، وذلك في حالة وقفه للحساب، ويمكن ممارسة الحجز التحفظي، وذلك من أجل الحصول على الحي

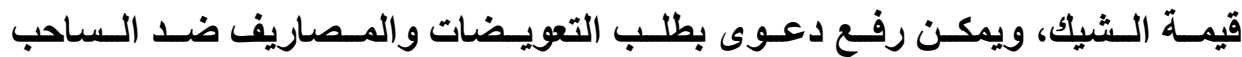
والضامنين (') r- النص على عدّ الثيك سندا تنفيذيا تعدّ ظهر اتجاه حديث في القانون المقارن يتجه نحو التوسـع في تحديد ماهية الأوراق غير القضائية التي تعدّ سندات تنفيذيـة (†)، وقد تبنى قانون التنفيذ الفرنسي

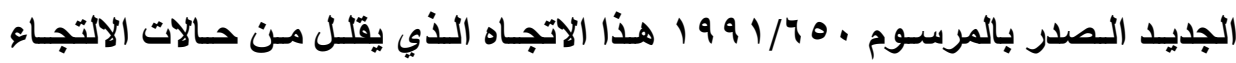
للقضاء للحصول على السندات التنفيذية تجنبا لزيادة النفقات، وقد تم استحداث المشرع الفرنسي سـندات جديدة أضيفت إلى السندات التقليديـة، وذلك في القـانون المرسوم

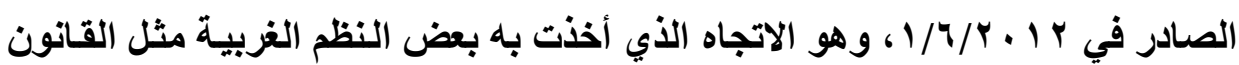

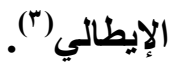

حيث عدّ المشرع الفرنسي بالقـانون الصادر في 1919 الشيك سندا تنفيذيا،

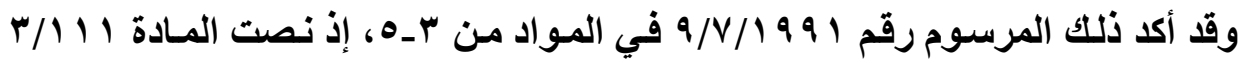

(1) Régine BONHOMME, Chèque, Répertoire de droit commercial, Février 2017, n 0472.

(2) Id.,n 0445.

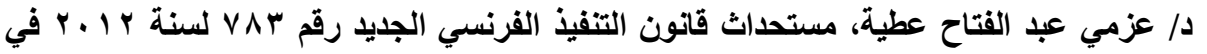

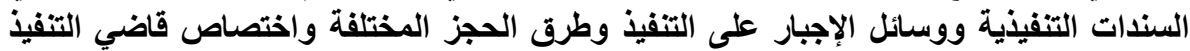

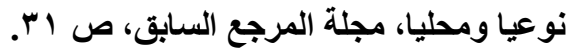

(3) GORCHS-GELZER, Regard critique sur l'ordonnance no 2011-1540 transposant la directive médiation, Dr. et proc. 2011.2 
تنفيذ، كما يمكن لحامل الشيك أن يقوم باتخاذ إجراعات الحجز التحفظي لحماية حقه في مواجهـة الملتزم فـي الشيك، بـدون إذن مسن القضشاء('). وفي حالـة اتخـاذ إجـراءت التحفظية بلون سند تنفيذي، يجب على الدائن البدء خلال شهر في الحصول على سند

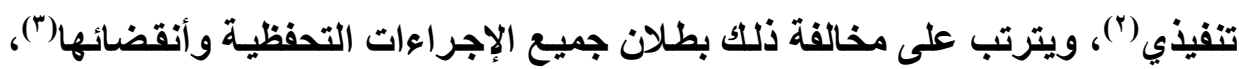
وهذا الجزاء يحمي المدين من الإجراءات التحفظية في حالة عدم وجود سند تنفيذي (؛). ويحق للائن الأي معه شيك ممارسة الحجز التحفظي، وجميع أنواع الحجز سواء أكاء حجزا على العقار أم على منقول أم حجز ما للمدين لاى الغير (॰). وهذا التطور المهم يعطي فاعلية حقيقية للشيك كـأداة وفاء، ويغني المستقيا من الثيك عن الحصول على حكم قضائي بحقه أو أمر أداء وهو ما يوفر الوقت والجها والمصاريف(")، فضلا عن أن هذا التطور يستجيب لاتساع نطاق استخدام الشيك سواء على المستوى الداخلي أو على مستوى العلاقات التجارية الدولية التي زادت بثكل كبير في السنوات الماضية.

(1) Régine BONHOMME, Chèque, op. cit., n. 477. Cass. Com. 23 oct. 2001, Bull. civ. IV, no 173.

(2) art. R. 511-7 C. pr. exéc.

(3) Pierre CALLÉ, Caducité, Répertoire de procédure civile, Septembre 2015, n0 60; Cass. Civ. 2e, 13 juill. 2006, Bull. civ. II, no 210; Cass. Civ. 2e, 6 déc. 2001, Bull. civ. II, no 184 ; RTD civ. 2002. 362, obs. Perrot.

(4) TGI Nice, 20 avr. 1994, D. 1994. Somm. 347, obs. Julien; RTD civ. 1995. 197, obs. Perrot

(5) Civ. 2e, 21 déc. 2000, Bull. civ. II, no 178 ; Gaz. Pal. 2001. Somm. 1376, obs. Véron ; RD banc. fin. 2001. Comm. 76, obs. Dellici.

(6)CASAL, Recouvrement des chèques impayés : une histoire tourmentée, Dr. et proc. 2002. 212 
وسنشير إلى إجراعات تنفيذ الشيك، ثم نقيم موقف المشرع الفرنسي، وذلك في

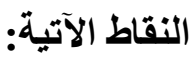

أ- - إجراعات تنفيذ الشيك

لاعتبار الشيك سندا تنفيذيا اشترط المشرع الفرنسي عمل احتجاج عدم اللافع،

ثم إعلان الساحب في الثيك عن طريق المحضر، وسنشير إلى ذلك على النحو الآتي:

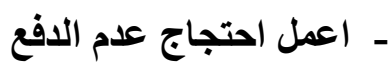

إذا صدر شيك من ساحب لصالح المستفيد وتوجه الأخير إلى البنك المسحوب

عليه الشيك، ثُ تبين عدم وجود رصيد أو كـان الرصيد غير كاف، فإن البنـك يسلم المستفيد شهادة بعدم الدفع(') ('certificate de non- paiement.

ومن أجل إصدار هذه الثهادة يجب اتباع الإجراعات الآتية: تقديم الثيك للبنك

وانتظار ثلاثين يوما، ثم إعادة تقديم الطلب مرة ثانية، وتصدر شهادة عدم الدفع من قبل البنك، بعد مرور ثلاثين يوما تحسب من عرض الشيك للمرة الاولى، وذلك إذا عرض للمره الثاتية، ولم يوجد رصيد أو وجد ولكنه غير كاف للوفاء("). ويتم إخطار المدين بعدم وجود رصيد(")، ويكون ذلكك بدون مصروفات، ويجب أن يتم ذلكك وفقا للقواعد التـي نـص عليهـا القـانون، وإلا ترتب على ذلـك مسئولية الطالب، ويمكن المطالبـة بالتعويضات والمصروفات أمام قاضي الأمور المستعجلة، ولا يمنع من مجانية الافـادة،

(1) Id.

(2) art. L. 131-73 C. mon. Fin, Régine BONHOMME, Chèque, op. cit., n. 445.

(3) art.R. 131-48, al. 2 C. mon. fin. 
أن يكون هناك مصروفات في حالة الرفض('). ويجب أن تثير إفادة عدم الافع الصادرة

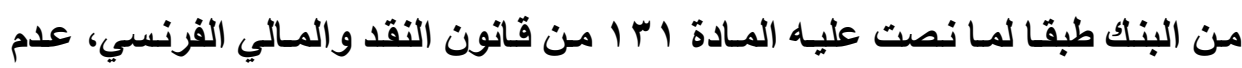
وجود رصيد كاف للوفاء بقمية الشيك.

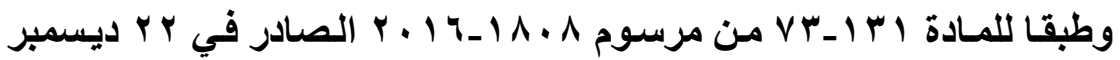

17 ـ ـ ب يجب على البنك أن يستعلم عن رصيد العميل بكافة طرق الاستعلام، في حالة

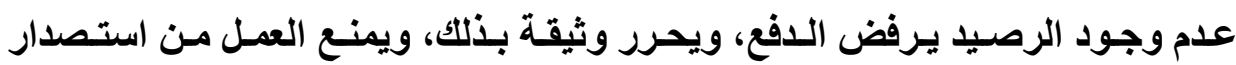
شيكات، ويبلغ المتعاملين مع صاحب الحساب بعدم وجود رصيد.

وجزاء عدم وجود بروتستو عدم الافع في الميعاد المناسب، يعد حامل الشيك مهملا()، ومن ثم يحرم من الرجوع على الموقعين السابقين على الشيك("). ولكن يمكن للحامل المهمل أن يرجع على سـاحب الشيك("). كمـا يمكن للصاحب الحق أن يحتفظ بحقه في مواجهة الساحب الذي قـام بعمل معارضـة ضمنية(ْ) . كمـا يمكنه رفع دعوى

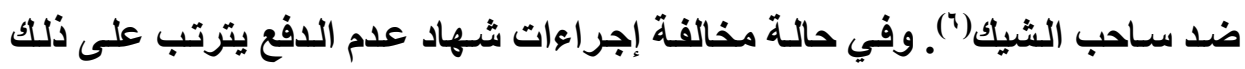
بطلان آثارهـا أو بطلان إعلانها(V)، ولا يكون لها أي أثر في التنفيذ('). ولا يمكن لأي إئي ورقة أخرى أن تحل محل بروتستو عدم الدفع.

(1) Régine BONHOMME, Chèque, op. cit., n. 448.

(2) Cass. Com. 30 janv. 1996, Bull. civ. IV, no 27 ; Cass. Com. 14 févr. 2006, Bull. civ. IV, no 36; Cass, Com. 23 janv. 2007, Bull. civ. IV, no 6.

(3) Cass. Com. 8 mars 1954, Gaz. Pal. 1954. 1.289; Cass. Com. 12 oct. 1982, Bull. civ. IV, no 307.

(4) art. L. 131-4, al. 3 C. mon. fin.

(5) Cass. Com. 4 juin 1991, Bull. civ. IV, no 201.

(6) Régine BONHOMME, Chèque, op. cit., n. 459.

(7) art. L. 131-73 C. mon. fin 
ويمكن الإعفـاء مـن برتستو عدم اللدفع في حالـة وجود شـرط الرجوع دون

مصاريف، أو بدون بروتستو، وهذا الثرط نـادر الوجود في الواقع العملي، ويجب أن يكون هذا الشرط موقعـا عليه،، ويكون موجودا بواسـة الساحب، ويشمل المقر أو الضمان في الثيك، وهذا الثرط يفيد فقط من وقع عليه ومن هم لاحقون لـه(؟). وفي موني حالة وجود هذا الشرط، فِإن حامل الشيك لا يكون ملزمـا بعدل بروتستو عدم الدفع، ولكن من أجل عدم اعتباره مهملا يجب تقديم الثيك في المدة القانونية، وتقديم الدليل على قيامـه بهذا الالتزام("). ويتحمل حامل الشيك المصاريف إذا قام باتخـاذ إجراعات البروتستو بـالرغم مسن وجـود الشرط، ولكن في الحالـة العكسية يمكن لـه تحصيل المصاريف من كل الموقعين(") وفي حالة عدم الافع، فطبقا لنص المادة اب ا ـ9 ؛ من قانون المالي والنقدي، يجب على حامل الشيك إعلان المكلف أو الساحب خلال أربعه أيسام من تـاريخ بروتستو عدم الدفع، وهذا الأمر في حالة غياب شرط الرجوع بدون مصاريف. ويجب الإخطار لكل الضامنين في الشيك في الميعـاد نفسه. ولا يوجد شكلية محدده في إعلان عدم الدفع، ولكن يجب أن يكون خلال المدة التي نص عليها القانون. ولا يؤدي عدم الاعلان أي جزاء إلا إذا كان هناك إهمال يؤدي إلى ضرر، فليتزم بالتعويض ولا يجاوز ذلك قيمة

(1) CA Paris, 21 nov. 1995: D. Affaires 1996. 151.

(2) Cass. Com. 28 oct. 2008, no 07-19.132.

(3) art. L. 131-50, al. 2 C. mon. fin.

(4) Id., al. 3

(5) Id., al. 8 
والواقع أن الإعلان المدين يكون محددا بأمرين: يجب أن يكون الشيك صسادرا

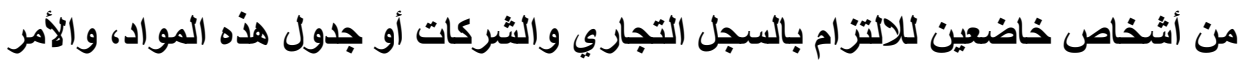

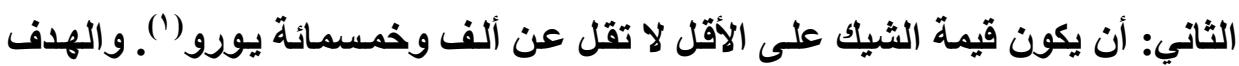

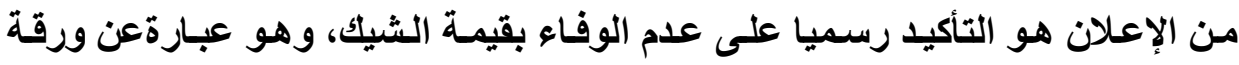
رسمية مرسلة للمدين بواسطة المحضر ، فهي ليست ورقة عرفية، ومرسلة إلى منزل

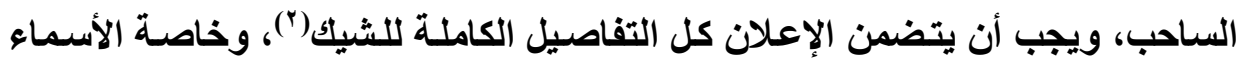

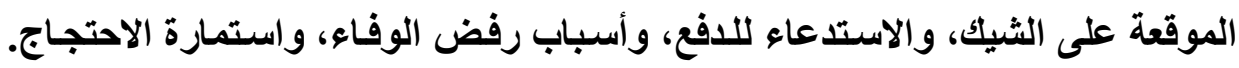

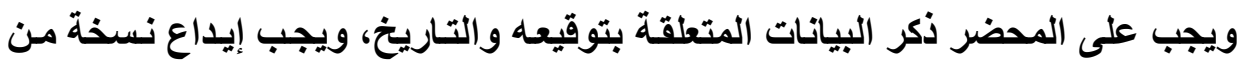
ذلكك في المحكمة، ومخالفة ذلك يترتب عليها إلزامـه بـالتعويض. ويجب القيام بتحرير بروتستو عدم الدفع خلال المهلة التي نص عليها القانون، ويجب على المحضر أن

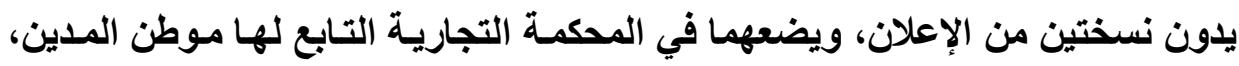
وتحال الأخرى إلى مكتب المدعى العام، ويترتب على مخالفة هذه الأحكام المسئولية

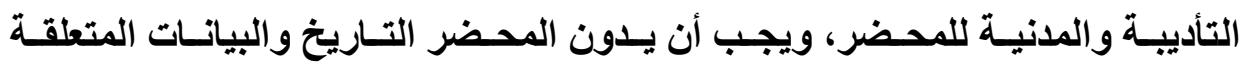
بالإعلان، وإذا تم الدفع يدون على ورقة الإعلان ("). - إعلان المحضر للمدين في الثيك

يقلم المستفيا من الشيك شهادة عدم الدفع إلى المحضر (4)، وعلى هذا الأخير إعلان هذه الافـادة إلى الملتزم في الشيك طبقـا للإجراءات العاديـة للإعلان، ثم ينتظر

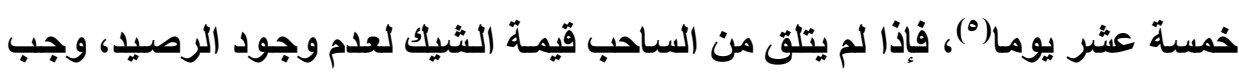

(1) Régine BONHOMME, Chèque, op. cit., n. 458.

(2)Cass. Civ. 1 re, 18 oct. 2005, D. 2005. AJ 3011, obs. Delpech.

(3) Régine BONHOMME, Chèque, op. cit., n. 457.

(4) Id.

(5) CA Paris, 17 mai 1990: D. 1991. Somm. 217, obs. Cabrillac.

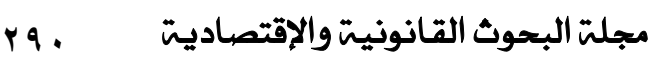


على المحضر تسليم السند التنفيذي('). ويشترط أن تنقضي المدة المنصوص عليها قبل تسليم حامل الثيك السند التنفيذي (ץ)، ويسلم المحضر السند للمستفيد في الثيك(")، ويتم إصداره بدون أي مصاريف بالنسبة للدائن، ولكن يتحمل المدين جميع الرسوم المتعلقة بعدم دفع الشيك(")، ولكن لا يجوز أن تتجاوز قيمة الشيك(ْ) ميستطيع الدائن بمقتضي

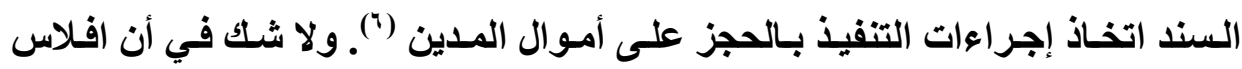
المدين يؤثر على إجراعات التتفيذ الجبري(v).

ويعد الثيك طبقا لهذه الأحكام سندا تنفيذيا بدون تلخل من القضاء(^)، وإذا تم الافع بجزء من المبلغ فِان السند يكون واجب التفيذ فيما يتعلق بالجزء المتبقي والمصروفات، ولا يكون الساحب في حاجة إلى إعلان جديد بشأن المصروفات(9). ولقد كان هذا السند لا يجيز إلا الحجز على المنقولات، ولكن المشرع عدل هذا الاتجاه وأجاز بمقتضاه القيام بجميع أنواع الحجز(·). وفي حالة وجود إجراءات التنفيذ الجامعي فإن

(1) CASAL, Recouvrement des chèques impayés : une histoire tourmentée, op. cit., n0 212, Lasserre Capdeville, le chèque sans provision en France, 1992-2013, JCP 2013, no 1358.

(2) CA Paris, 17 mai 1990, D. 1991, somm. 217, obs. M.C.

(3) Régine BONHOMME, Chèque, op. cit., n. 446.

(4) art. 70-I, L. no 2007-290 du 5 mars 2007.

(5) art. R. 131-11 s C. mon. fin.

(6) Civ. 2e, 28 juin 2006, Dr. et proc. 2006-6, p. 360, obs. A. Leborgne; Cass. Civ. 1re, 10 sept. 2015, Procédures 2015. 323, obs. Laporte.

(7) art. L. 626-13 C. com.

(8) Régine BONHOMME, Chèque, op. cit., n. 480.

(9) Paris, 5 juill. 2001, D. 2001. AJ 2821 et 2001, somm. 3308, obs. P. Julien.

(10) Régine BONHOMME, Chèque, op. cit., n. 450. 
الشيك لا يصرف ضد الشخص الأي أعلن إفلاسه، ولكن يمكن الرجوع على الموقعين اللاحقين على توقيعه('). ووفاة مصدر الشيك أو فقدانه الأهلية لا يؤثر على وثيقة عدم الافع طالما حدث ذلك قبل وفاته أو فقده الأهلية، ولا يؤثر ذلك على صدور السند التتفيذي عن طريق المحضر(). ولقد نص المشرع الفرنسي على الزام المدين بدفع قيمة ثلاثة فاصل أربعه في المائة كضريبة على عدم دفع قيمة الثيك(").

والسند التنفيذي الذي أنشئ بواسطة المحضر نتيجة لعدم الدفع الشيك، لا يعد حكما قضائيا، يستوجب بدء الفوائد القانونية(؛)، كما أن هذا السند التفنيذي لا يؤدي إلى بلى الرهن القضائي، لأنه ليس حكما قضائيا(ْ) ويمكن بنـاء على هذا الشيك كسند تنفيذي

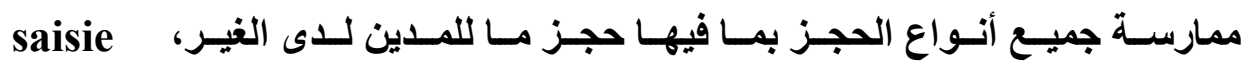
d’atrribution يعد هذا الحجز تحفظيا في مرحلته الأولى، ثم في مرحلة ثانيـة يكون تنفيذيا، كماكسان عليه الوضع في النظام القديم، وكما هو عليه الوضع في القـانون المصري الحسلي، بـل

(1) Cass. Com. 17 mars 1998, Bull. civ. IV, no 103 ; D. Affaires 1998. 671, obs. X. Delpech ; Cass. Com. 11 juin 2014, Bull. civ. IV, no 99.

(2) L. 131-73. C. mon. fin, Cass. Com. 3 juill. 2012, D. 2012. Actu. 1877, obs. Avena-Robardet.

(3) Lasserre Capdeville, interrogations autour de la future évolution du taux de l'intérêt légal, Gaz. Pal. 10-11 sept. 2014, p5.

(4) art. L. 131-73 et L. 313-3 C. mon. fin. • Civ. 2e, 7 janv. 2016, Dr. et pr. 2016. 21, note Lauvergnat.

(5) Civ. 3e, 21 janv. 2016, D. 2016. Actu. 252.

(6) Cass. Civ. 2e, 6 janv. 2012, Bull. civ. II, no 7 ; D. 2012. 1512, obs. Leborgne. 
أصبح الحجز تنفيذيا فقط') ولم يعد يشترط القانون أن يكون بيد الدائن حكم قضائي فاصل في أصل الحق، بل يمكن توقيعه بشأن أي سند تنفيذي حتى لو كـان سندا تنفيذيا

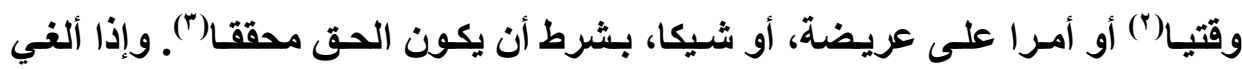
السند الذي بناء عليه تم الحجز فيترتب على ذلك إلغاء الحجز التحفظي (؛). ويمكن التففيذ على المدين المباشر والمدينين المتضامنين المنصوص عليهما

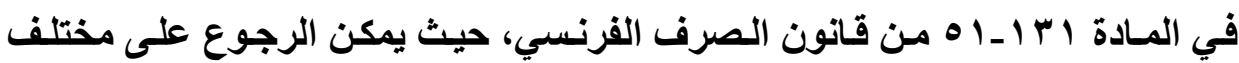
الموقعين، وذلك بالرجوع عليهح جميعا أو فرادا، بلون ترتيب معين، وهذا يختلف بعض الثئ عن القواعد العامة في الرجوع على الضامنين. كما أن هنائ استقلالا في التوقيع،

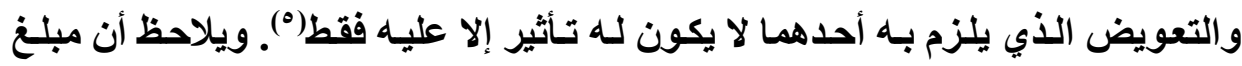
المنفذ بـه هو قيمـة الشيك وقيمـة التعويضات والمصساريف إذا كـان الشيك صسادرا في فزنساب(")

وقد نـص المشرع الفرنسـي على مـدة تقـادم للسند التنفيـذي، وجعلهاعشر سنوات(V)، وذلك في حالة الأحكام ومحاضر الصلح والمحررات الموثقة، وبصفه عامـة

(1) Cass. Civ. 2e, 3 nov. 2005, D. 2005. IR 2826.

(2) Cass., ass. plén., 24 févr. 2006, D. 2006. IR 747; Stéphane PIÉDELIÈVRE, Frédéric GUERCHOUN, Saisies et mesures conservatoires, op. cit., n0 65.

(3) R. PERROT et Ph. THÉRY, Procédures civiles d'exécution, op. cit., no 129, p. 139. Civ. 2e, 6 janv. 2012, D. 2012. 1512, obs. Leborgne.

(4) Cass. Civ. 2e, 17 oct. 2002, Bull. civ. II, no 226.

(5) Régine BONHOMME, Chèque, op. cit., n. 470.

(6) art. L. 131-52 C. mon. fin.

(7) Salati. Droit et pratique des voies d'exécution, op. Cit., n. 111.00 s. 
السندات ذات الطبيعة القضائية('). وبالنسبة للشيكات فقد استثناها المشرع الفرنسي، وأكد ذلك المرسوم الصادر في 1 ا فبراير 17 ـ ب، وجعل لها مدة تقادم خمس سنوات

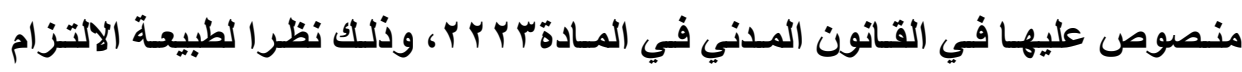

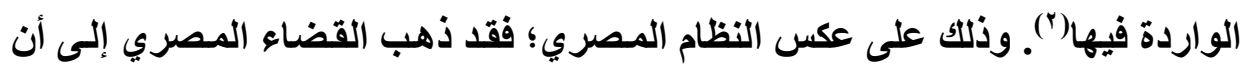
انقضاء السند التنفيذي لا يكون إلا بانقضاء الحق محل السند، وذلك بمدة خمس عشرة

ومنذ قانون ^ . . ب الأي نص صراحة على مدة الواجب المطالبة خلالها بتنفيذ

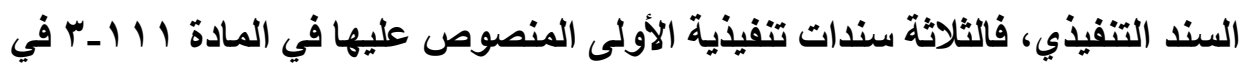

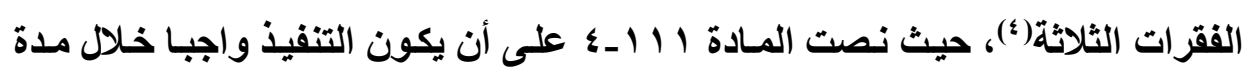

(1) art. 37 L. no 2015-990 du 6 août 2015, art. 208-I-2o.

(2) Ph. Hoonakker, La prescription de l'exécution forcée depuis la loi no 2008-561 du 17 juin 2008, Dr. et pr. 2009. 15.

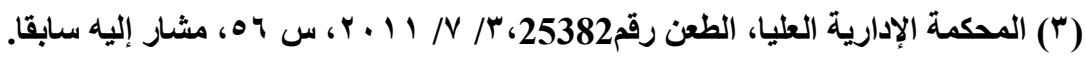

(4) Les titres exécutoires concernés par le délai spécial de dix ans sont ceux qui sont visés aux 10 à 30 de l'article $L$. 111-3 du code des procédures civiles d'exécution. Il s'agit des titres suivants: «1o Les décisions des juridictions de l'ordre judiciaire ou de l'ordre administratif ainsi que les transactions soumises au président du tribunal de grande instance lorsqu'elles ont force exécutoire ; 20 Les actes et les jugements étrangers ainsi que les sentences arbitrales déclarés texécutoires\$ par une décision non susceptible d'un recours suspensif d'exécution ; 3o Les extraits de procès-verbaux de conciliation signés par le juge et les parties». LIBCHABER, Le point sur l'interversion des prescriptions en cas de condamnation en justice, D. 2006. Chron. 254 , n0 144. 
عشرة سنوات(') ما لم يكن يحتاج تحصيل الدين مدة أطول(). وبالنسبة للأنواع الأخرى

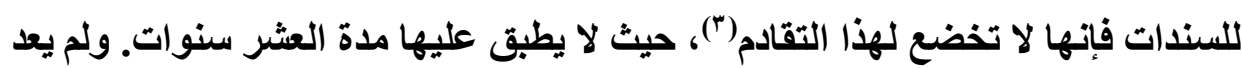

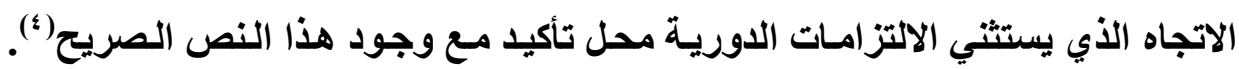
وقد ذهبت بعض الأحكام القضائية إلى أن نص المادة ؛ Y r مدني، يطبق على أسـاس

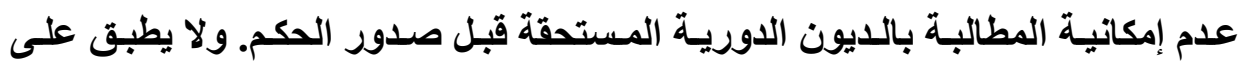

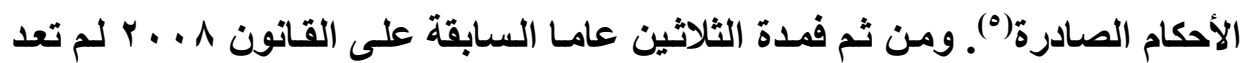
محل تطبيق(")

(1) LIBCHABER, id. n0 143; R. Perrot et Ph. Théry, Procédures civiles d'exécution, op. cit., $n^{\circ} 134$, V. Ph. HOONAKKER, La prescription de l'exécution forcée depuis la loi no 2008-561 du 17 juin 2008, op. cit. n0 15 ,

(2) Cass. Com. 4 juill. 2018, Dalloz actualité, 3 sept. 2018, obs. G. Payan; Jean-Denis PellierRésumé, De la distinction entre prescription de l'obligation et prescription du titre exécutoire judiciaire, Dalloz actualité 23 octobre 2018, n. 20.

(3)id.

(4) CA Paris, 29 mars 2007, Juris-Data no 332188. TGI Paris, 6 mars 1996, Gaz. Pal. 1999. 1. 124, note Moussa.

(5) Civ. 2e, 26 janv. 2017, no 15-28.173.

(6) Jean-Denis PellierRésumé, De la distinction entre prescription de l'obligation et prescription du titre exécutoire judiciaire, op, cit., n. 20. 


\section{بـ تقييم موقف المشرع الفرنسي}

يلاحظ أن المشرع الفرنسي نظم إجراعات مبسطة(') لتحصيل قيمـة الشيك(؟)،

حيث إن السند الذي صدر عن المحضر في حالة عدم دفع الشيك يعد سندا تنفيذيا صادرا

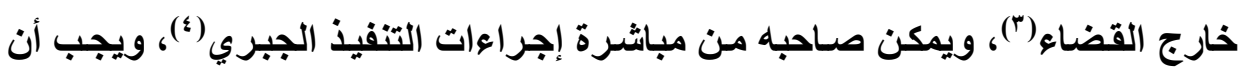

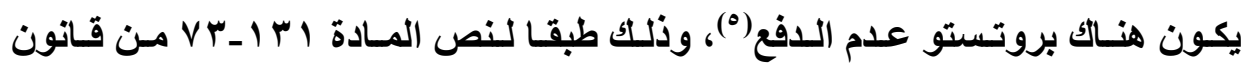
الصرف، ويجب إعلان هذه الافادة للساحب، وفي حالة علم القيام بالدفع أو الرد خلال خمسة عشر يوما من إعلان المدين، فإن المحضر يصدر إفادة بعدم الدفع، ويعد الشيك في هذه الحالة سندا تنفيذيا(")

وهذا السند له طبيعة خاصة؛ حيث إنه يسمح باتخاذ إجراعات التنفيذ الجبري،

ولكنه لا يثبه الحكم القضائي، حيث ذهبت محكمة النقض الفرنسية في عام 1 ـ ـ إلى

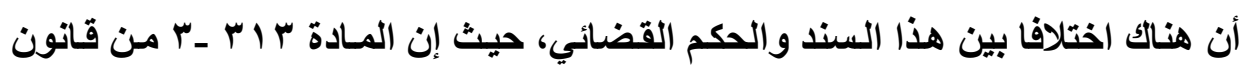
الصرف الفرنسي، تلتزم المدين بالفوائد في حالة صدور حكم بعدم دفع الشيك، إذ إن

(1) Marie-Pierre MOURRE-SCHREIBER, Huissier de justice, op. cit, No 4.

(2) Id., Alain FOURNIER Hypothèque provisoire, Répertoire de droit civil , Septembre 2007, n. 2.

(3) art. L. 131-73 C. mon. fin., reproduit ss. art. L. 111-3; Gauthier, (les titres exécutoires délivrés par l'État), Procédures 1998. Chron. 4 et 5.

(4) Salati, Droit et pratique des voies d'exécution,op. cit., n. 111.

(5) V. H. Solus et R. Perrot, Droit judiciaire privé, tome 3, Procédure de première instance, Sirey 1991, no 1405, p. 1198, spéc. note 1

(6) art. L. 131-73, al. 5 C. mon. Fin. 
هذه الماده لا تنطبق على السند التنفيذي المكون بواسطة المحضر (') كما ذهبت أحكام أخرى إلى أن هذا السند لا يترتب عليه الرهن القضائي، وذللك لأنـه ليس حكمـا قضائيا،

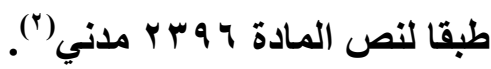

ويرى جانب من الفقـه الفرنسي (") ضرورة تمكين قاضـي التنفيذ مسن رقابـة الثيك كسند تنفيذي، وتمكين المسحوب عليه بالمعارضة في الثيك أمام قاضي التنفيذ،

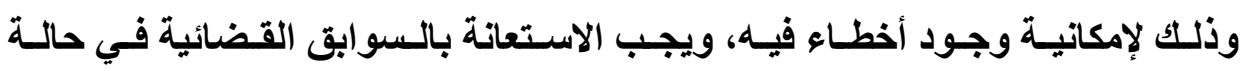
المحررات الموثقة والذي تسمح لقاضي التفيذ بالقيام بالرقابة. ونرى أن اتجاه المشرع الفرنسي بعدّ الثيك سندا تنفيذيا، لا يحقق كل الفائدة بالنسبة للأوراق التجاريـة، حيث إن عدّ الشيك فقط من السندات التنفيذية دون بـاقي لهي الأوراق التجارية رغم التثابه في جميع الأحكام، خاصة وأن استخدام الكمبيالة والسند الإذنـي أصبح أكثر انتشارا في الحياة التجاريـة، وأصبحت هنـاك حاجة ملحة لتسهيل إجراءات تتفيذها، كمـا أن الوسـائل القانونية الحديثة المستخدمة في الدفع مثل الفيزا والكروت الإكترونية حدت من استخدام الشيك، ونتمني أن يطبق المشرع الفرنسي

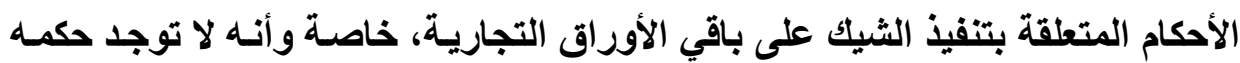
من التفرقة في التنفيذ بين الثيك والكمبيالة والسند الإذني.

(1) Civ. 2e, 7 janv. 2016, Dr. et pr. 2016. 21, note Lauvergnat.

(2) Civ. 3e, 21 janv. 2016, D. 2016. Actu. 252, art. L. 131-73 C. mon. Fin, reproduit ss. art. L. 111-3

(3) Didier CHOLET, Exécution des jugements et des actes, op. cit., n. 80. 
دا طلعت يوسف خاطر

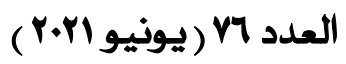

ويرى بعض الفقه أنه يمكن أن ياخذ حكم الشيكات خطابـات الضمان المقبولة

من المدين('). وفي الواقع لا نتفق مع هذا الرأي؛ وذلك لأن نص المسادة 1 ال/ / تنفيذ

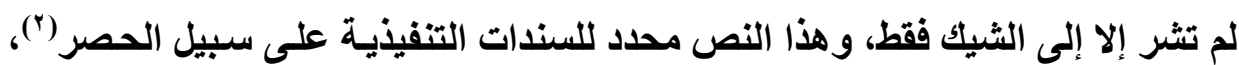
فلا يمكن التوسع في تفسيره بدون سند قانوني.

\section{الفرع الثالث}

\section{هوقف المشرع المصري هن الأوراق التجارية كسندات تنفيذية}

إن مقتضيات العدالة تستوجب ألا يسمح بالتنفيذ إلا بمقتضى حق ثابت على

وجه التأكيد(")، وهذا الحق يكون ثابتا في سند تنفيذي(")، فهذا الأخير الوسيلة الوحيدة

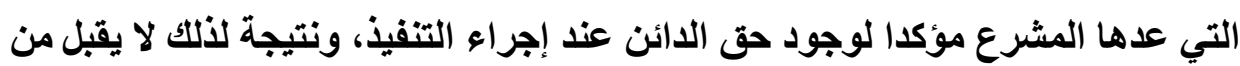
الائن تقديم أي دليل غيره لسلطة التفيذ لكي يقنع هذه السلطة بالقيام بالتنفيذ، وحتى لو كان للائن حق موضوعي مؤكد، ولكنه غير ثابت في سند تنفيذي مستوف للشكل المنصوص عليه قانونا.

وسنشير إلى عدم النص على عدّ الأوراق التجارية سندات تنفيذية، ثم اقتراح

تنظيم تنفيذ الأوراق التجارية، وذلك في النقاط الآتية:

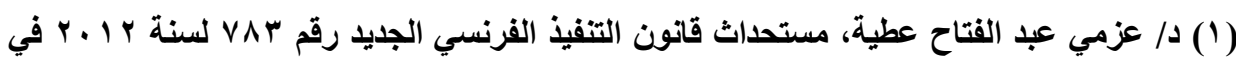

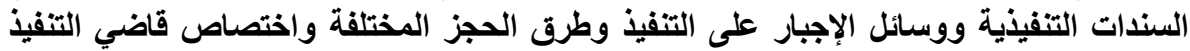

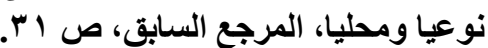

(2) Cass. Com. 2 mai 2001, Bull. civ. IV, no 82 ; RTD com. 2001. 773, obs. Vallens.

(3) R. PERROT et Ph. THÉRY, Procédures civiles d'exécution, op. cit., no 118; LEBORGNE, Droit de l'exécution, op. cit., Dalloz, nos $432 \mathrm{~s}$.

(§) د/ عزمي عبد الفتاح، قواعد التففيذ الجبري في قانون المرافعات المصري، المرجع السابق، ص 


\section{أولا: عدم النص على عدّ الأوراق التجارية سندات تنفيذية}

لم ينص المشرع المصري على عدّ الأوراق التجارية من السندات التنفيذية(')، ورغم ذلك فقد تثدد المشرع المصري في معاملة الملتزمين بالورقة التجاريـة لحمايـة حقوق الحامل حسن النية، فقد قرر حق للـائن في الأوراق التجاريـة في طلب اتخـاذ

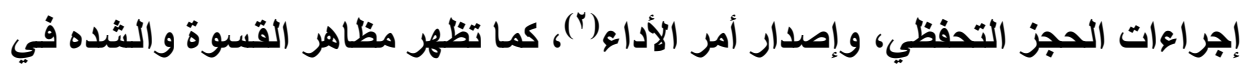
عدة نواح أخرى؛ منها كون المدين ملزمـا بـدفع قيمة الورقة في ميعـاد استحقاقها أيـا

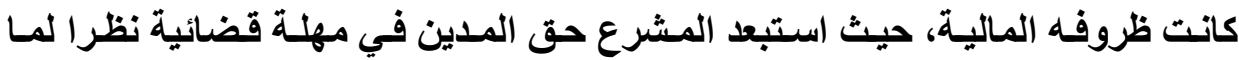

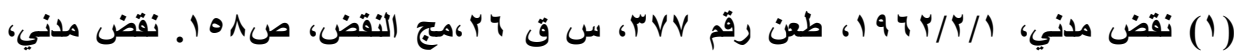

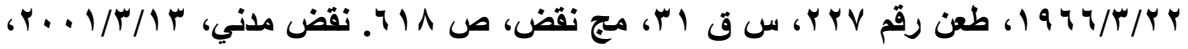

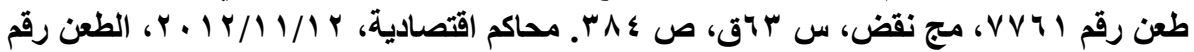

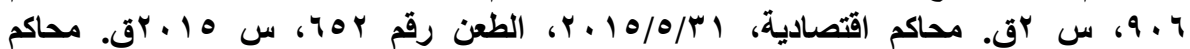

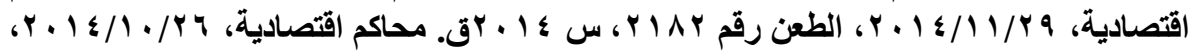

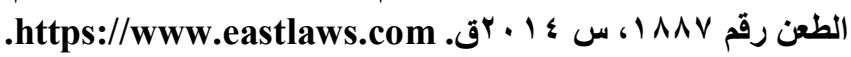

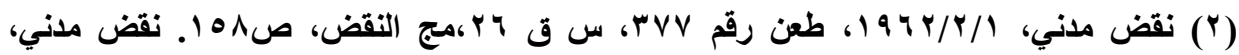

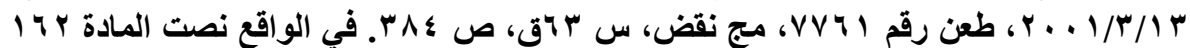

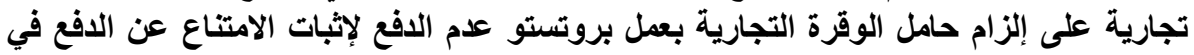

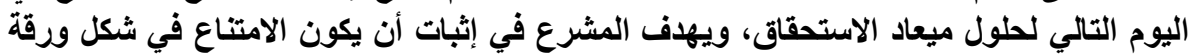

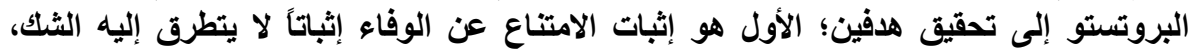

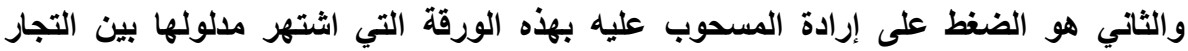

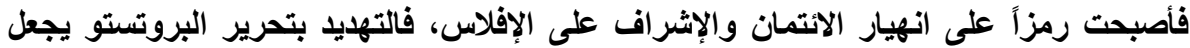

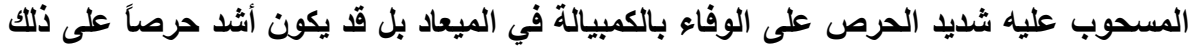

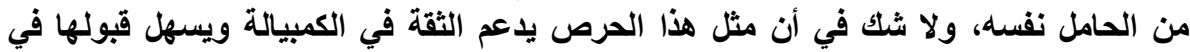

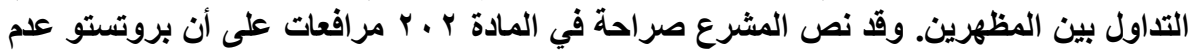

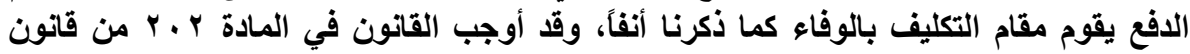

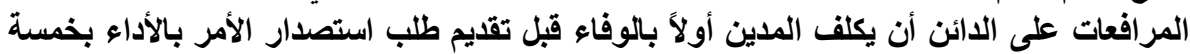

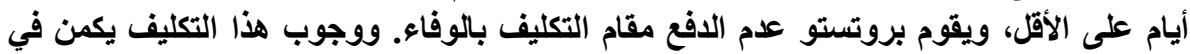

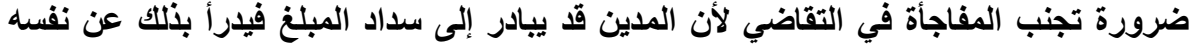

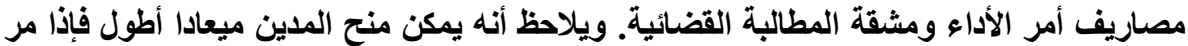
وقت طويل على التكليف فإنه يجب تجليده قبل طلب أمر الأداء. 
تستلزمه هذه الأوراق من السرعة في تنفيذ الالتزامات الناشئة عنها، فقد نصت المـادة

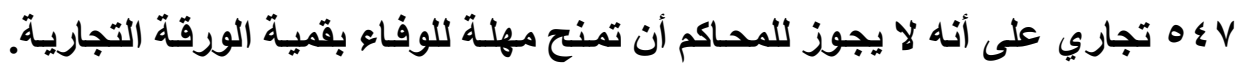

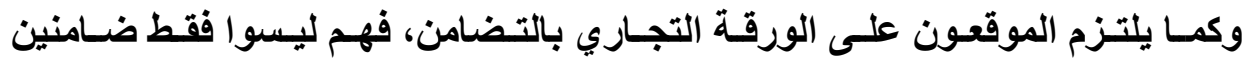
للوفاء بقيمتها بل متضامنين أيضا في هذا الوفاء، فحامل الورقة يستطيع الرجوع على

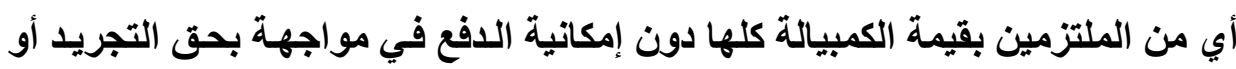

ثانيا: اقتراح تنظيم تنفيذ الأوراق التجارية

للأوراق أهمية كبيرة في الحياة العملية سواء التجارية أو المدنية، لكونها أداة

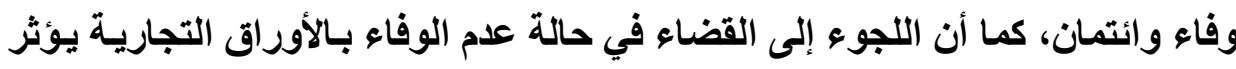

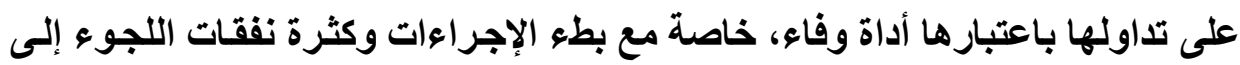

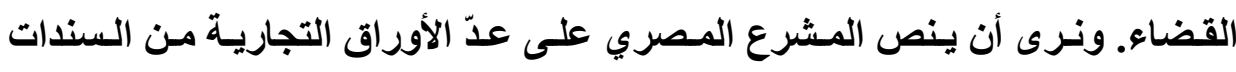

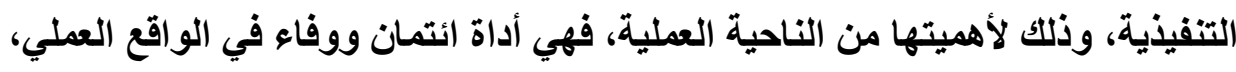
كما أن كثيرا من المشرعين نصوا على عدّ الأوراق التجاريـة من السندات التنفيذيـة، والمشرع المصري اتجه إلى جواز الحجز التحفظي للأوراق التجارية، وذلتك إيمانـا منـهـ بأهمية ضمان الحقوق في الأوراق التجارية. ونقترح أن يضيف المشرع المصري المواد الآتية إلى قانون المرافعات:

1- إضافة الأوراق التجارية إلى السندات التنفيذية نرى إضافة عبارة الآتية إلى نص المادة ـ ^ ب مرافعات على النحو الآتية: " لا يجوز التفيذ الجبري إلا بسند تنفيذي اقتضاء لحق محقق الوجود ومعين المقدار

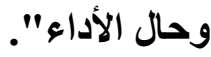


والسندات التنفيذية هي الأحكام والأوامر والمحررات الموثقة ومحاضر الصلح

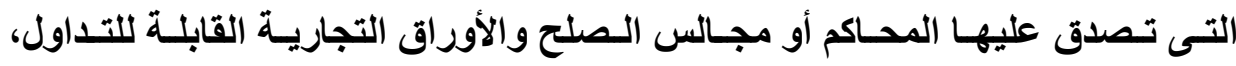
والأوراق الأخرى التى يططيها القانون هذه الصفة. r- الجهة المختصة بوضع الصيغة التنفيذية نرى اضافة العبارة الآتية إلى نص المادة ـ ^ : " يختص مدير إدارة التنفيذ بوضع الصيغة التففيذية على الأوراق التجارية"؛ حيث نقترح أن يختص رئيس إدارة

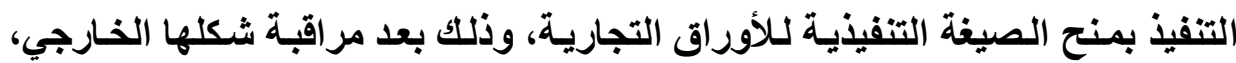
ويمكن لـه استدعاء المدين في الأوراق التجاريـة، ليرى مدلى صحتها مـن الناحيـة الشكلية، كما يمكن للمدين رفع دعوى ببطلان الأوراق التجارية، ويمكن للمحكمة التي لئي تنظر الدعوى أن توقف تنفيذ الأوراق التجارية، ويحكم على المدين بغرامـة تعادل ربع قيمة الورقة في حالة عدم صحة إدعائه. r- إجراءات تتفيذ الأوراق التجارية يضاف إلى المادة IN Y من قانون المرافعات الفقرة الآتية: يطلن المدين في الأوراق التجارية للحضور أمام إدارة التنفيذ، ليقر بالحق أو ينكره أو ينازع فيه، وإذا لم الم يحضر تبدأ إدارة التنفيذ في اتخاذ إجراءات التنفيذ. ـ ـ الاختصاص بالمناز عات المتعقة بالأوراق التجارية يضاف إلى نص المادة PV مرافعات الفقرة الآتية: "يختص قاضي التفيذ بكل منازعة متعلقة بالتحقق من الثروط الثكلية للأوراق التجارية، كالادعاء بالتزوير أو إنكار التوقيع عليها"، وإذا تعلق النزاع بالحق الموضوعي فعلى المدعى عليه رفع التع الأمر إلى المحكمة المختصة طبقا للقو اعد العامة، ولا يقف التنفيذ إلا إذا حكمت محكمة التها الموضوع بوقف التنفيذ". ولانرى أن يأخذ المشرع المصري بموقف القانون الأردني، 
وذلك فيما يتعلق بالزام الدائن باللجوء إلى المحكمة المختصة لإثبات حقه إذا اعترض

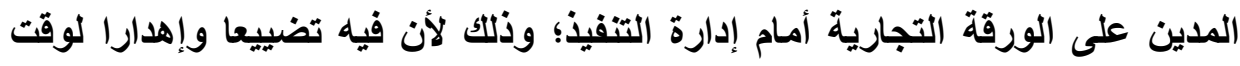

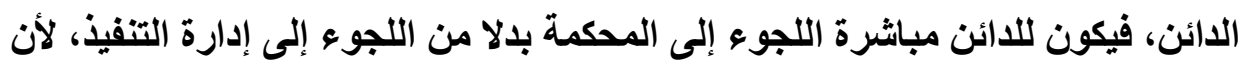

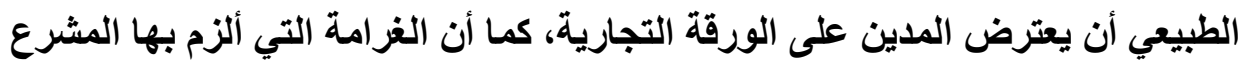

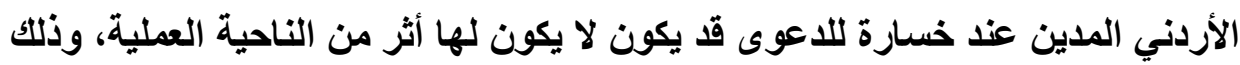
في حالة وجود تعنت من جانب المدين. 


\section{المبمث الثاني \\ المررات العادية والراسمية كسندات تنفيذية}

لم ينص المشرع المصري على عدّ الأوراق العادية أو السندات الرسمية ـ عدا

المحررات الموثقةـ سندات تنفيذيـة(')، على عكس بعض الأنظمة العربية والأوروبية التي نصت على عدّ الأوراق العادية والمحررات الرسمية سندات تثفيذيـة. وقد اتجـه القانون الفرنسي إلى التوسيع في أنواع السندات التنفيذية، حيث منح الإرادة سلطة في

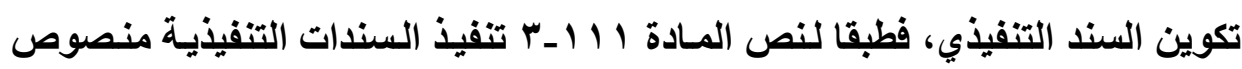
عليها على سبيل الحصر()، ويمكن تقبيم الحسات التي نص عليها القانون القرنسي إلى ثُلاث طوائف؛ الاولى، الأحكام القضائية والأوامر، والتي نصت عليها الفقرات من

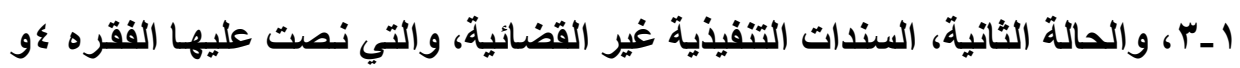
ه، والحالـة الثالثـة، وهـي القـرارات الاداريـة التـي منحهـا المسشرع صـفة السندات

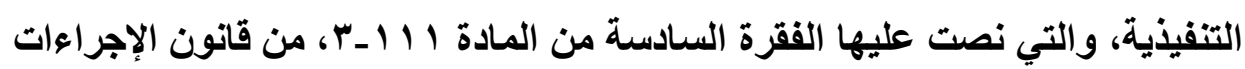

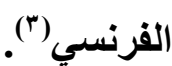

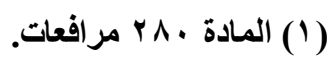

(2) Cass. Com. 2 mai 2001, Bull. civ. IV, no 82 ; RTD com. 2001. 773, obs. Vallens.

(3) Salati, Droit et pratique des voies d'exécution, op. cit., n. 111; Berlioz, limites et difficultés d'exécution de l'acte authentique, op. cit., 1249, Coiffard, authenticité et force exécutoire - l'arbre et le fruit, JCP, 2018. 1096. 
وسنثير إلى ماهية الأوراق العادية والمحررات الرسمية، وذلك في المطلب

الأول، ثم نعالج إجراءات تنفيذ الأوراق العادية والمحررات الرسمية، وذلك في المطلب

\section{المطلب الأول}

\section{هاهية المررات العادية و الرسمية}

اتجهت بعض التشريعات المقارنة إلى منح الإرادة الخاصة سلطة في إنشاء

سـندات تنفيذيـة، وذلك مـن أجل مسايرة التطورات الحديثة، ولكن بالنسبة للنظـام المصري ـعلى عكس هذا الاتجاهـ لم يمنح الإرادة الخاصة للأفراد وحدها سلطة إنشاء السند التنفيذي، فلا بد من تدخل سلطة عامة من أجل وجود السند، سواء أكانت السلطة

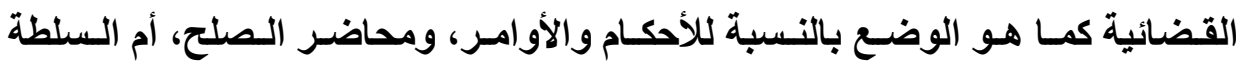
التنفيذية كما هو الوضع في المحررات الموثقة" ('). وسنشير إلى ماهية الأوراق العاديـة، وذلكت في الفرع الأول، ثم نبين ماهيـة الأوراق الرسمية، وذلك في الفرع الثاني، وذلك على النحو الآتي: الفرع الأول

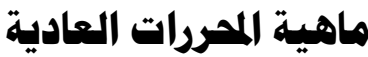

سنشير إلى تعريف الأوراق العادية، وشروطها، وذلك في النقاط الآتية: أولاً: تعريف السندات العادية

السندات العادية هي أوراق تثتتمل على توقيع من صدر عنه أو على خاتمسه أو

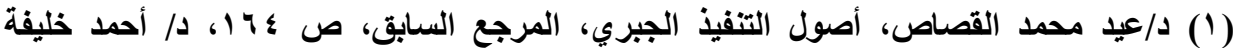

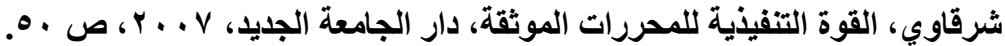

مجلة البحوث القانونيت والإقتصاديت 
بصمة إصبعه، وليست لها صفة السند الرسمي، فهي التي تصدر من الأفراد، ويستقلون بكتابتها، ولا يتدخل موظف عام بحكم وظيفته في تحريرهـا، ولا يتطلب القـانون في السندات العادية إلا أن تكون مكتوبة، وأن تكون موقعة من الثخص المنسوب إليه، لأن هذا التوقيع يتضمن قبول موقع السند لمسا هو مدون فيه(')، ويكون التوقيع بإمضاء الثخص أو بخاتمه أو ببصمة إصبعه كما هو صريح في نص المادة العاشرة من قانون البينات الأردني ()، والمادة ؛ 1 إثبات مصري(ّ) فالسند العادي هو الذي يحمل توقيع حيا للمدين. وقد عرف البعض السندات العادية بأنها أوراق غير رسمية تصدر من ذوى الثأن دون أن يتدخل موظف عام في تحريرها، وهى أوراق معدة للإثبات، ومنها مـا

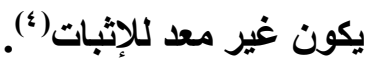
ويعد في حكم السندات العرفية السند الرسمي الذي فقد الشروط الواردة في

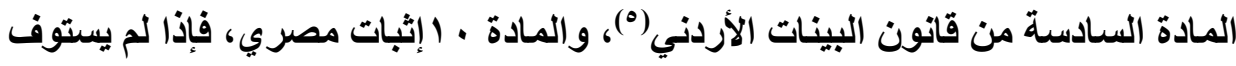
هذا السند الشروط الواردة في هذه المواد فـلا يكون لها إلا قيمـة السندات العاديـة، شـريطة أن يكـون ذوو الشأن قــ وقعـوا عليهـا بتوقيعـاتهم أو بأختـامهم أو ببـصمات

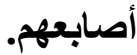

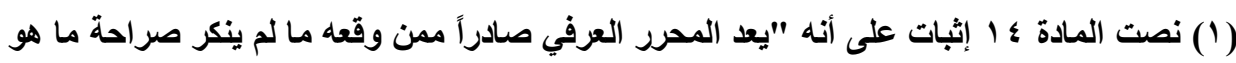

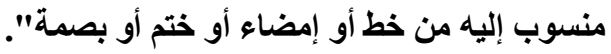

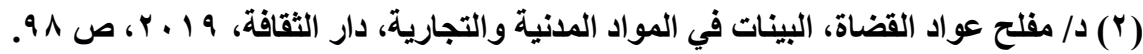

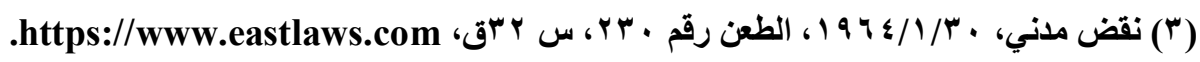

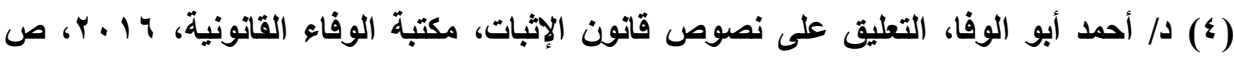


لقد عرف المشرع الأردني السندات العادية في المـادة ـ ا من قانون البينـات، بأنه "السند الذي يشتمل على توقيع مـن صدر عنـه أو على خاتمـه أو بصمة أصـابعه وليس له صفة السند الرسمي". ويتضح من هذا التعريف أن السند العادي هو كل ورقة تصدر عن الأفراد لا يتدخل في كتابتها موظف عـام، وتحمل هذه الورقة توقيع مـن صدرت عنه أو خاتمه أو بصمة أصابعه ولا تتصف هذه الورقة بالرسمية('). وقد عرفت اللائحة القديمة في النظام السعودي في المادة 9/9 الورقة العادية بأنها هي التي تكون موقعة بإمضاء من صدرت منه أو ختمهـ أو بصمته، على عكس الورقة الرسمية التي صدرت من صاحب الشأن بصفته الوظيفية في حدود اختصاصه الوظيفي. وتتميز السندات العرفية بالسرعة في الكتابـة والإعداد وقلـة التكاليف، لذلك يلجأ إليها الناس كوسيلة للإثبات حفاظا على حقوقهم، وجرت العـادة بين التجار على كتابة أكثرية التزاماتهم على سندات عادية. وهذه الأوراق جعلها بعض المشرعين إلى جانب كونها دليل الإثبات، فإنها سند تنفيذي. ثانياً: شروط السندات العادية، يشترط في الورقة العرفية الشروط الآتية: الشرط الأول: الكتابة

يشترط لإنشاء السند العرفي وجود الكتابة()، فبدون كتابة لا يوجد سند. ومهم أن تكون الكتابة مثبتة لتصرف قانوني، ويتضمن حقا معينا(")، وليس هناك شكل خـاص لاص أو صيغة خاصة في الكتابة، وقد تكون الكتابة باللغة العربية أو بغيرها، ويكفي أن يكون

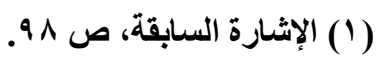

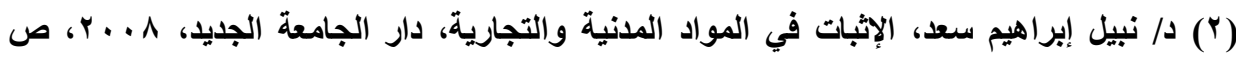
$.1 \% \Lambda$ ("r) د/ مفلح عواد القضاة، البينات في المواد المدنية والتجارية، المرجع السابق، ص ^9. 
الاتفاق الحاصل بين موقعيه، مدرجأ بعبارات واضحة تلال على المعنى المقصود منهر. وقد تكون الكتابة مكتوبة بخط اليد أو بالآلة الكاتبة أو على شكل استمارة نموذجية معدة مسبقا، ويتم تدوين الأمساكن الفارغة فيها بالمعلومـات المطلوبـة كمـا في عقد الإيجـار مثثلا. ولا يشترط أن تكون الكتابـة بخط يـ من وقع السند، فيجـوز أن تكون بخط يـا شخص آخر غير المدين أو الدائن.

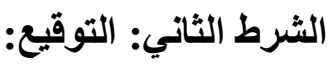
ينطسوي التوقيـع على معنى الجـزم بـأن السنـ العرفي صــادر مـن الموقع على السند، ولـو لـم يكن مضمون السند مكتوبـا بخطهـه وإن إرادتـه قـ اتجهت إلى اعتماد الكتابة والالتزام بها، فالسند العادي يستمد قوتـه التنفيذيـة وحجيته في الإثبات من التوقيع وحده، فإذا خلا السند من توقيع أحد أطرافه فلا تكون له أية حجية قبله، ولا يعد سندا تنفيذيا طبقا للأنظمة التي تأخذ بها، فطبقا للنظام الأردني يكون السند العادي دليلا كـاملا متـى كـان موقعـا مـن الشخص المنـصوص إليـه(')، والتوقيع يعـد شـرطا جوهريا في السند العـادي، لأنـه ينطوي على قبول صساحب التوقيع بمـا هو مدون في السند. وهذا التوقيع قد يكون بالإمضاء أو بـالختم أو ببصمة الإبهام. ولا يمكن عدّ الورقة المكتوبة سندا عاديا إذا خلت من توقيع الثخص المنسوب إليهه حتى ولو كانت مكتوبة بخط يده، لأن مجرد الكتابـة بخط اليـ لا يعنـي أنـه قبل مـا هو مدون فيها، كمـا يشترط أن تشتثل التوقيع على اسـم الموقع ولقبه كـاملين، فـلا يكفي التوقيع بعلامـة مختصرة أو بالأحرف الأولى من الاسم الشخصي مع اسم العائلة)(؟).

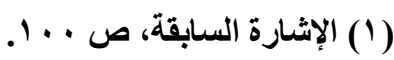
(Y) د/ مفلح عواد القضاة، البينات في المواد المدنية والتجارية، المرجع السابق، ص 9 ( 9. 


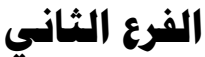

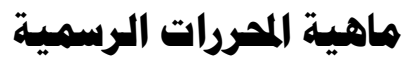

سنثير إلى تعريف المحررات الرسمية، وشروطها، وذلك في النقاط الآتية:

$$
\text { أولاً: تعريف المحررات الرسمية }
$$

يقصد بالورقة الرسمية الورقة التى يثبت فيها موظف عام أو شخص مكلف

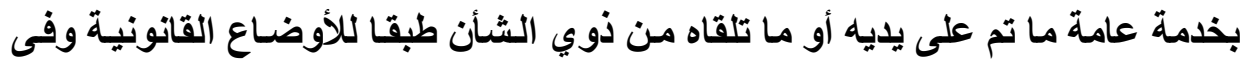

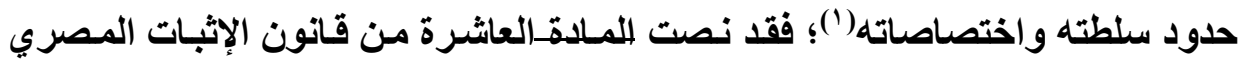

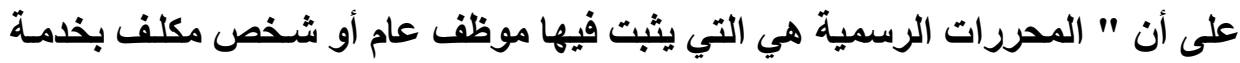

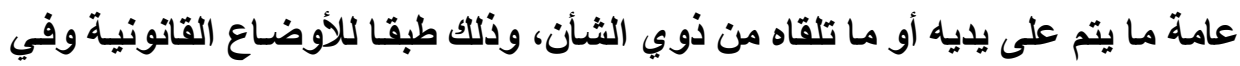

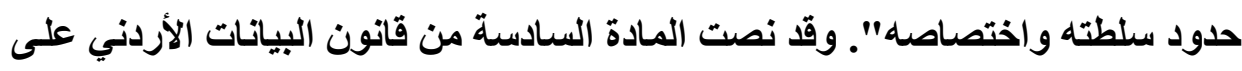

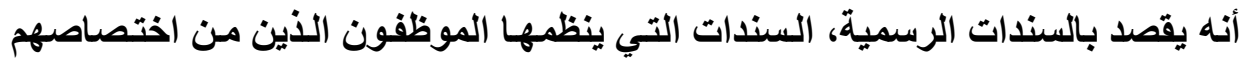

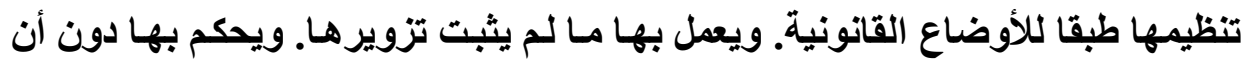

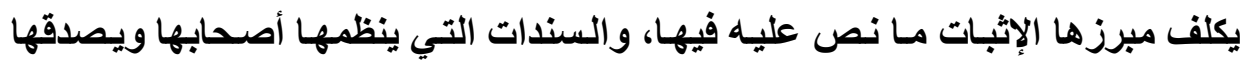

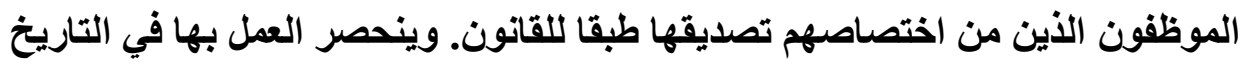
و والتوقيع فقط.

فالسندات الرسمية هي كل ورقة صـادرة من موظف عام أو شخص مكلف

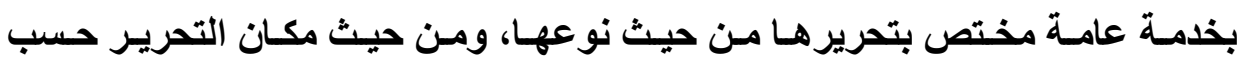

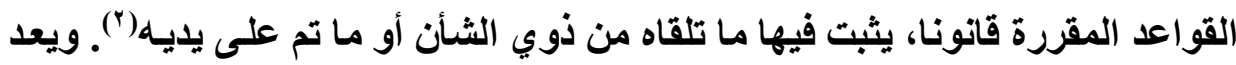

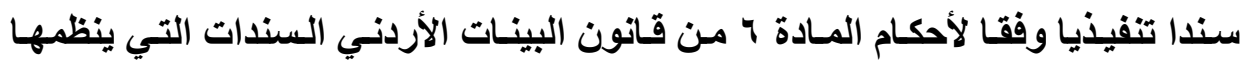
أصحابها ويصدقها الموظفون الذي من اختصاصهم تصديقها طبقا للقانون.

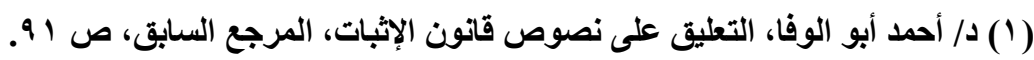

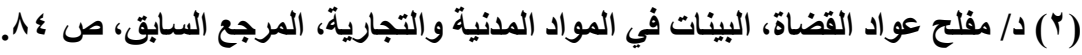

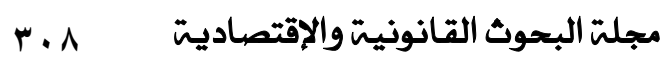


ثانياً : شروط صحة الورقة الرسمية(')، يشترط لصحة الورقة الرسمية الثروط

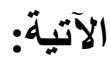
1- صدور المحرر من موظف عام أو مكلف بخدمة عامة: يجب لصحة المحرر الرسمي أن يكون منظمـا من قبل أصحابه ومصدقا من الموظفين الذين من اختصاصهم تصديقه طبقا للقانون، فيجب أن يوقع على الورقة الرسمية موظف عام أو مكلف بخدمه عامة. ويقصد بالموظف العام كل شخص عهدت

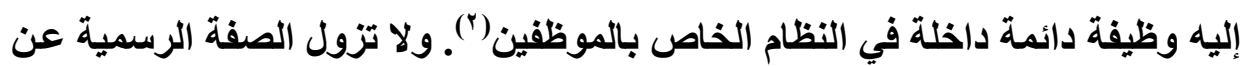
الموظف إذا كان قد عين بشكل يخالف أحكام القانون، كأن يكون فاقدا لثرط من شروط التعيين، فمثل هذا النقص لا يؤثر على رسمية السند، فيقى السند محتفظا بصفته

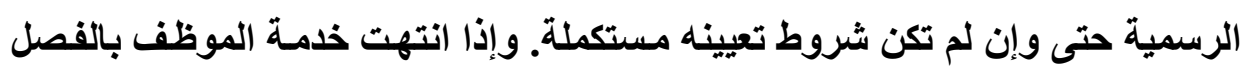

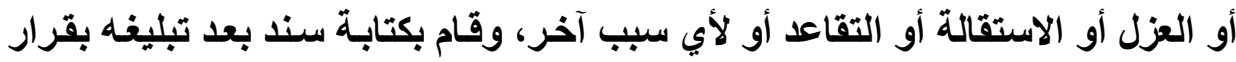

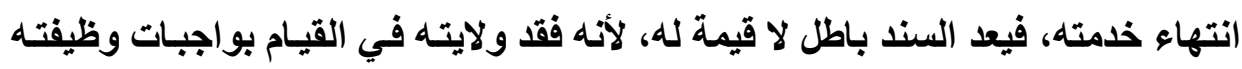
الرسمية. ولكن حمايـة للأوضـاع الظاهرة، يكون توثيق الموظف المعين تعيينا بـاطلا توثيقا صحيحا تطبيقا لنظرية الموظف الفعلي. ويشبت الموظف العام نوعين من البيانات؛ أـ ما تم على يديه وهى الوقائع التى وقعت تحت نظره كتسليم المشترى الثمن للبائع، ب ـ ما تلقاه من ذوي الثأن من أقوال وبيانات، أي ما وقع تحت سمعه.

(1) د/ رمضان أبو السعود، مبادئ الإثبات في المواد المدنية والتجارية، دار الجامعة الجديد، ب I ب؟،

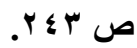
(r) د/ أحمد أبو الوفا، التعليق على نصوص قانون الإثبات، المرجع السابق، ص ه 9. 
r- أن يكون الموظف مختصا بتحرير الورقة:

يجب أن يكون الموظف مختصا موضوعيا و نوعيا بتحرير الورقة (1)، فليس

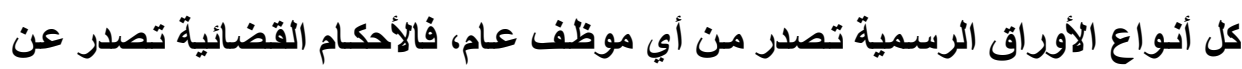

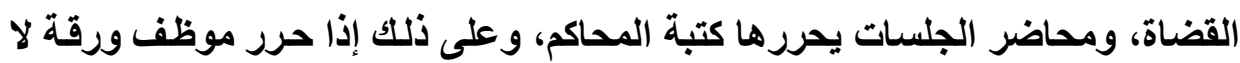

$$
\text { يختص بتحريز ها لا تعد ورقة رسمية(؟). }
$$

ويجب أن يصدر الورقة في حدود اختصاصه المكاني، ولا يستطيع أن يباشر عمله خارج دائرة اختصاصه. وأن يكون صالحا لإصدارها بألا يكون مجنونـا أو معتوهـا أو أن تكون لـه مصلحة شخصية في إصـدارها، ويجب ألا يكـون بينـه وبـين شـاهدي الورقة صلة قرابة. r- مراعاة الأوضاع القانونية لتحرير الورقة لكل نـوع مـن المحررات الرسـية أوضـاعا أو إجـراعات معينـة يجب على الموظف المختص مراعاتها عند تحريره لها(")، فإذا كاتت من الأوراق التي يختص بها الموثقون يجب أن يراعى الإجراءات المنصوص عليها في قانون التوثيق، وإن كاتت الأوراق أحكاما يجب مراعاة القواعد المنصوص عليها لإصدار الأحكام. وإذا تخلف شرط أو أكثر فِان الورقة لا تكتسب صفة الرسمية، وتعد باطلة لكونهـا محررا رسميا، وتفقد حجيتها في الإثبات كليليل رسـي، إلا أنـه لها حجيتها كورقة عرفية متى كانت موقعة من ذوي الثأن الذين يلتزمون بما فيها.

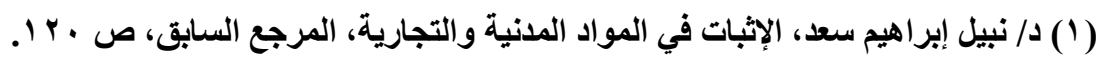

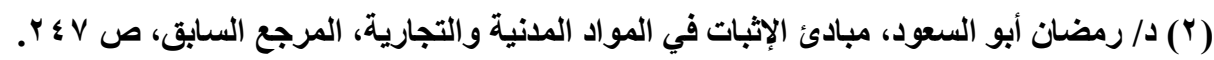

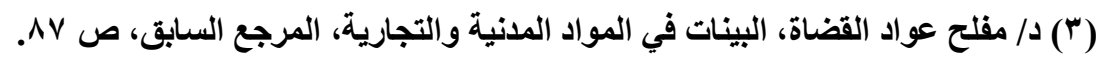

r مجلة البحوث القانونيت والإقتصاديت 


\section{الاطلب الثاني \\ إجراءات تنفيذ المهررات العرفية و الرسمية}

لقد توسع النظام الأردني والسعودي واللبنـاني في اعتمـاد السندات التنفيذيـة، الأمر الأي سيجعل من أطراف الالتزام معها في غنى عن اللجوع للمحكمة المختصة. فلا يحتاج للجوء إلى المحكمة إلا في حدود ضيقة؛ ففي النظام السعودي تقوم دائرة التنفيذ بفص السندات التنفيذية بثقيها القضائي وغير القضائي، وبحث مدى استكمال

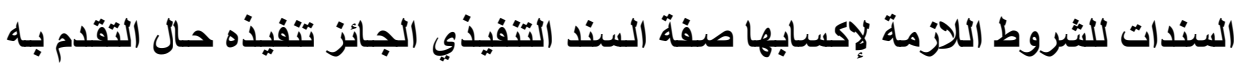

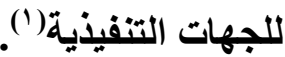

وسنشير إلى المحررات العرفية والمحررات الرسمية سندات تنفيذية في بعض

الأنظمة العربية، وذلك في الفرع الأول، ثم نعالج موقف المشرع الفرنسي من تنفيذ الأوراق العرفية والمحررات الرسمية، وذلـك في الفـرع الثـاني، ثـم موقف المشرع المصري من عدّ الأوراق العرفية والمحررات الرسمية سندات تنفيذية، وذلك في الفرع

\section{الفرع الأول}

المحررات العرفية والرسمية سندات تنفيذية في بعض الأنظمة العربية

في الواقع نصت بعض الأنظمة العربية على عدّ المحررات العرفية والرسيمة سندات تنفيذية، مثل القانون الأردني والنظام السعودي والقانون اللبناني، ومن ثم يمكن تنفيذ هذه المحررات دون حاجـة إلى مراجعة القضاء والحصول على حكم بـالحق موضوع المحرر العادي والمحرر الرسمي، ولكن لا يمنع ذلك منازعة المدين في السند 
العادي أو المحرر الرسمي، سواء تعلق ذلك بانقضاء الحق موضوع السند أو بطلان المحرر أو تزويره.

ولا أهميـة للتفرقة بـين السندات الرسـية والسندات العاديـة، بـدد التنفيذ الجبري عن طريق دائرة الإجراء أو قاضـي التنفيذ في بعض الأنظمة، في حين تبدو الأهمية بين النوعين من حيث الإثبات(')

وسنشير إلى القوة التنفيذيـة للمحررات العاديـة والرسـمية، ثم نبين شـروط

الحق محل المحرر العرفي والمحرر الرسمي، ثم نعالج إجراءات تنفيذ السندات العرفية والرسمية، وذلك في النقاط الآتية: أولا: القوة التنفيذية للمحررات العادية والمحررات الرسمية 1- القوة التنفيذية للمحررات العادية

نصت بعض القوانين العربية على عدّ المحررات العادية سندات تثفيذية، وهذ

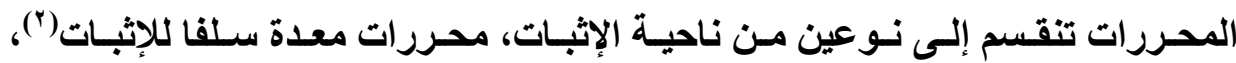
ومحررات غير معدة سلفا للإثبات("). وهنا يثار التساؤل: هل جميع المحررات العاديـة

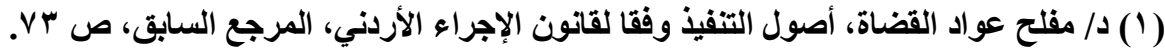

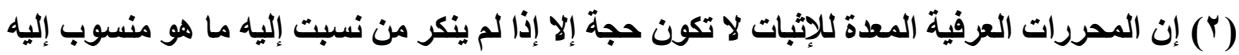

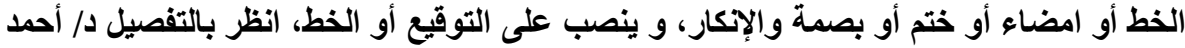

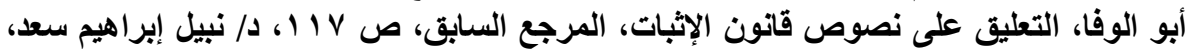

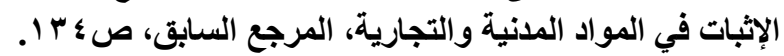

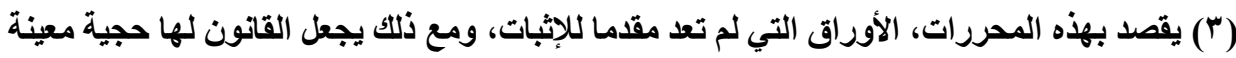

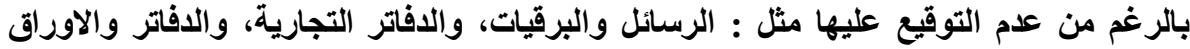

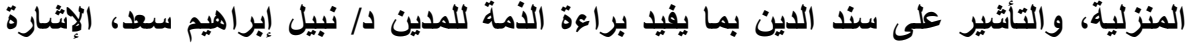


لهـا قـوة تنفيذيـة باعتبار هـا سـندات عاديـة، أم إن القوة التنفيذيـة قاصـرة فقط على المحررات العادية المعدة سابقا للإثبات؟

في الأنظمـة التي أخــت بـالمحررات العاديـة كسنـدات رسـمية مثل القـانون

الأردنـي والسعودي واللبنـاني لـم يـشترط أن يكون المحررات العرفيـة معدة مسسبقا للإثبات، ولكن يشترط لصحتها وجود توقيع من الملتزم بها، لذا فبإن المحررات العاديـة التي لا تحمل توقيعا لا تعد سندا تنفيذيا، ومن ثم إذا لم تكن المحررات غير معدة سـابقا للإثبات لا تحمل توقيع جميع الأطر اف، فإنها لا تصلح أن تكون سندا تنفيذيا، حيث نجد أن الأوراق والدفاتر غير معدة للإثبات غير موقع عليها، حيث يكون إعدادها إمسا بـإلزام قانوني أو بدافع تنظيم الشخص لمعاملاته وشئون حياته، وقد تكون عبارة عن سجلات يلـزم القـانون بعض الأشـخاص بمسكها لبيـان وضـعهم القـانوني كالــاتفر التجاريـة والأوراق والدفاتر الخاصة، ورغم أن لها حجية قانونية، فإنها ليس لها قوة تنفيذية، لأنها لا تحمل توقيعا من ذوي الشأن. ويلاحظ أن الدفاتر التجارية لها حجية بين التجار، ولا يكون حجية على غير التجار('). وهنا يثار التساؤل: هل تعد هذه الدفاتر سندا تنفيذيا بين التجار؟ نري أنـه يجب التفرقة بين أمرين؛ إذا كانت تحمل التزامسا على التاجر صـاحب الدفتر فإنها تعد سندا تنفيذيا، أمسا إذا كانت تتضمن حقا لـه فـلا تعد سندا تنفيذيا لأن المدين لم يوقع عليها، وهذا الدفاتر لا تكون لها قوة تنفيذيـة بالنسبة لغير التجار، وبالنسبة للدفاتر والأوراق المنزلية نجد أنها لا تكون لها قوة تنفيذية إلا في مواجهة من صدرت منـه بشرط أن تحمل توقيعه. 
وبالنسبة للرسائل الموقع عليها تكون لها القوة التنفيذية باعتبار هـا محررات عرفية، وكذلك البرقيات ومكاتبات التلكس والفاكسميلي لها قوة تنفيذية أيضا. وإذا كـان

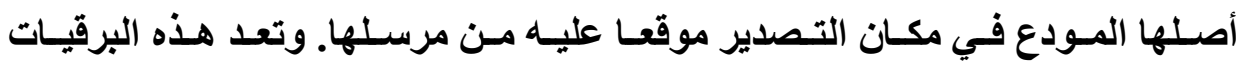
و المكاتبات مطابقة لأصلها حتى يقوم الاليل على عكس ذللك. وإذا أعدم الأصل فلا يعتد بها في مجال السندات التنفيذية؛ فقد ذهب القانون اللبناني إلى أن الرسائل الموقع عليها

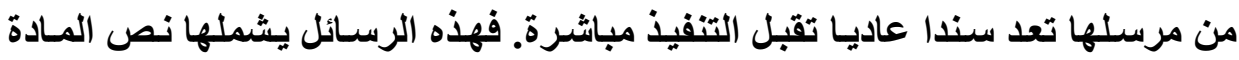

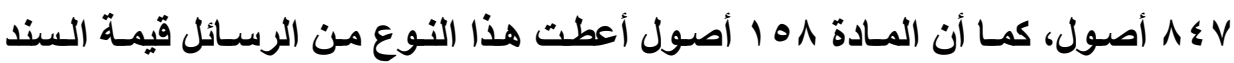
العادي من حيث الإثبات لمصلحة المرسل إليه. ومسألة سرية الرسائل شـأن خـارج عن تقدير رئيس دائرة التففيذ، والتمسك بذلك يتم عبر الاعتراض على التنفيذ ('). وبالنسبة للبرقيات تعد سندا عاديـا يقبل التنفيذ مباشرة إذا كـان موقعا على أصله المودع في مكتب البريد من المرسل، مع العلم بأن التنفيذ لا يتم إلا بالاستناد إلى

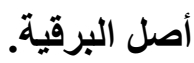
وبالنسبة لصورة الورقة العرفية، هل تصلح أن تكون سندا تنفيذيا؟ في واقع الأمر، ليس لصور المحرر العرفي قوة تنفيذية لأنها لا تحمل توقيعات حيه لذوي الشأن.

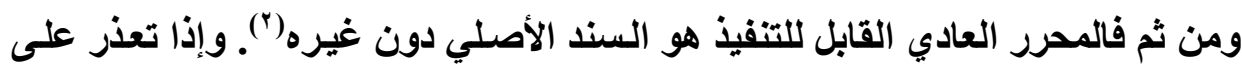
الدائن الحصول على السند العادي الأصلي إما لضياعه وإما لوجوده بحوزة الخصم أو الغير، فهو لا يستطيع الافادة منه، ولا يمكن إجبار الخصم الآخر أو الغير بتسليم ورقة 
عادية لتنفيذها، لأنه طبقا لنص القانون الأردني واللبناني يكون الإلزام بتسليم من أجل تسهيل الإثبات، وليس من أجل القيام بتنفيذ(') وبعض الأنظمـة كالقـانون اللبنـاني عدّ عقود الإيجـار سـندات تنفيذيـة، وذلك للمطالبة بالقيمة الإيجاريـة المشار إليها في العقد، فيمكن تحصيلها عن طريـق دائرة

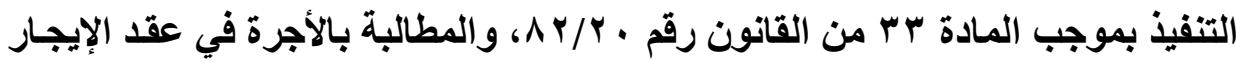
يكون لمدة سنة محددة لا ينفة إلا مرة واحدة لتحصيل إيجار هذه السنة، فإذا استمرت العلاقة التعاقدية دون أن تنظم عقود إيجار لسبب من الأسباب، كامتنـاع المستأجر عن التوقيع مثثلا، لا يصح التنفيذ استنادا إلى العقد السابق المثبت بسند. لأنها لا يعد سندا

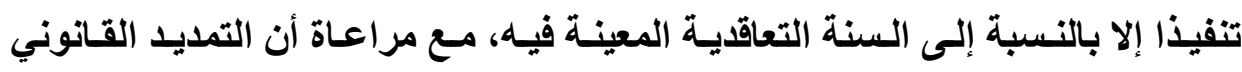
للإيجار يمدد العقود ولا يجدد سندات الإيجار، فهناك عقد محدد مثبت بسند، ولا ينفذ إلا

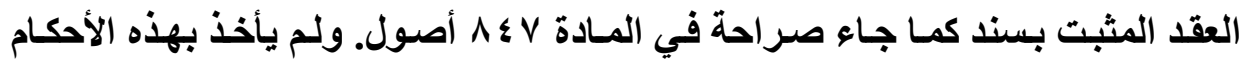
القانون المصري. وبالنسبة للقانون الفرنسي، فيمكن القيام بـالحجز التحفظي في حالة وجود دين يتعلق بالأجرة وكان بناء على عقد الإيجار (r)، ولكن لا يعد عقد الإيجار سندا لـانيا تنفيذيا.

وقد نـصت المـادة V؛ مسن القـانون اللبنـاني المتعلق بالملكيـة المشتركة في

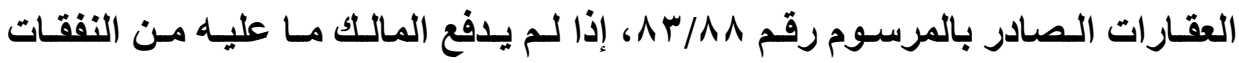
المشتركة ولا سسيما المنصوص عليها في المسادة ؛ ؛ من هذا المرسوم، وهي مبلغ شهري أو فصلي للصندوق، ومصاريف مدفوعة أو متعهر بها، خلال مهلة عشرة أيسام

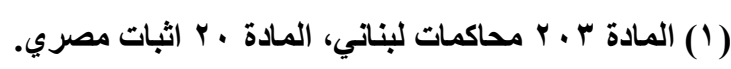
(2) Alain FOURNIER Hypothèque provisoire, op. cit., n0 2. 
من تبليغه الإنذار بدفعها يعد الإنذار بمثابة سند خطي وفقا لأحكام قانون تحصيل الديون الثابتة بسند خطي، ومن ثم يعد سندا تنفيذيا(') ولقد ذهب المشرع اللبنـاني إلى أنـه لا تعد الفـاتورة سنـا عاديـا قابلا للتنفيذ

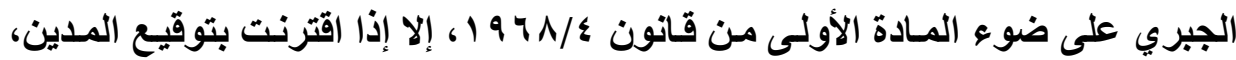
والفاتورة الصادرة عن مستثفي وغير الموقعة من المدين غير مشمولة بمفهوم السند التنفيذ أو التعهد القابلين للتنفيذ مباشرة(؟) وبالنسبة للعقد المتبادل لا ينفذ هذا العقد العادي إلا إذا روعيت فيه قاعدة تعدد النسخ الأصلية عملا بالمادة ب ه 1 أصول، وإذا لم تراع القاعدة لا يعد السند إلا بمثابة بينة خطية على قيام العقد. ويمكن الاعتر اض على التنفيذ في حالة عدم تعدد النسخ("). ومن البديهي أنـه إذا كـان هنـاك التزامـات على الدائن، فعليه حتى يتمكن من مطالبـة مدينه بالتنفيذ، إثبات قيامه بتنفيذ واجباته أو عرضه القيام بالتنفيذ تحت إثراف دائرة التنفيذ. ويشترط أن يكون السند العادي متضمنا حقا يقبل التففيذ الجبري، فـإذا توافر في السند العـادي الشروط الخاصة والشروط العامـة لتنفيذ السندات فإنـه يصبح قابلا للتنفيذ في دوائر التنفيذ، وفقا للإجراءات التي سنبينها فيما بعد. 
إذا كانت للمحررات الرسمية حجة في الإثبات على النساس كافة؛ بما دون فيها

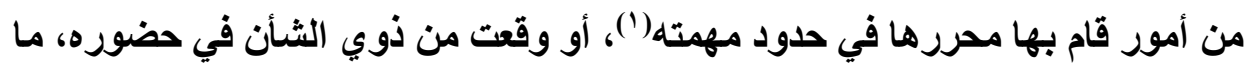

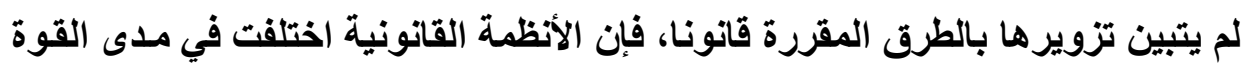

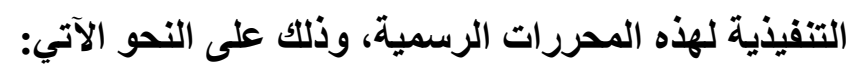
الاتجاه الأول: كل المحررات الرسمية سندات تنفيذية ذهبت بعض الأنظمـة القانونيـة إلـى مــح جميع المحررات الرسـمية القوة

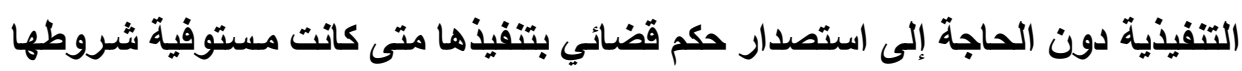

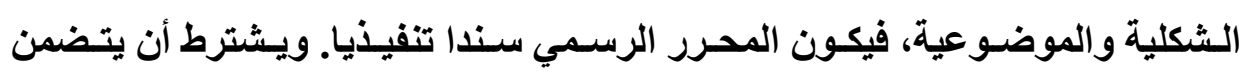

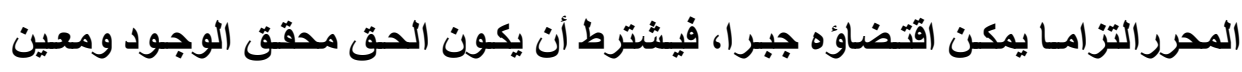

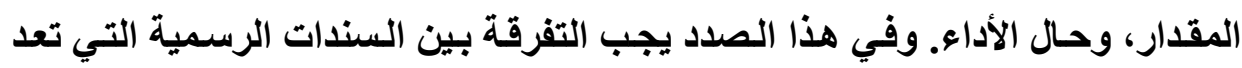

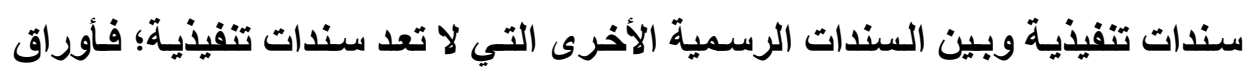

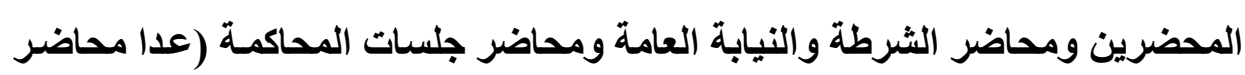

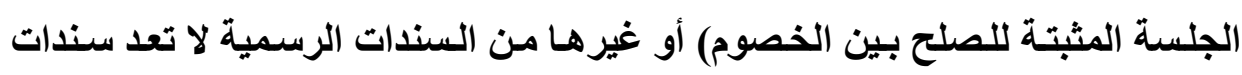

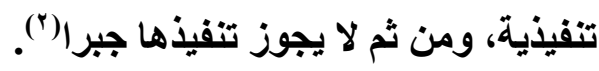

ويعود أساس القوة التنفيذية للسند الرسمي إلى أنها منظمـة من قبل موظف

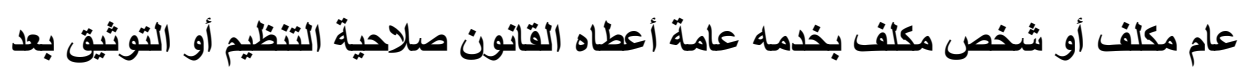

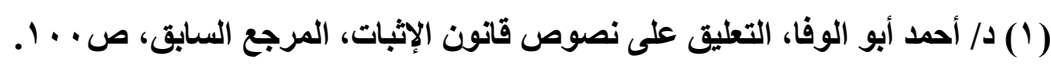

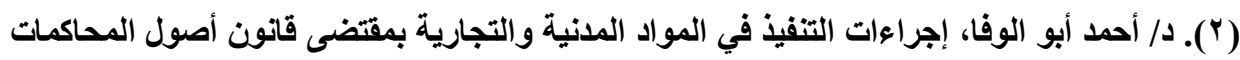

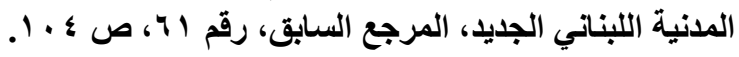


تطبيق سلسلة من الإجراعات التي تكفل صحة البيانات الواردة فيها، والتي تبلغ مبلغا من الثبوت، ما يجعل الحق الأي تضمنها صالحا للتفيذ، دون حاجة لاستصدار حكم من القضاء، فضلا عن أنه يمكن القول بوجود افتراض ضمني من قبل المدين يمنح صساحب الحق سندا تنفيذيا يعفيه من إقامة الاعوى بمضمونه أمام القضاء. ومن الأنظمـة التـي أخذت بهذا الاتجـاه النظـام الأردنسي والسعودي واللبنـاني، فيمكن للـائن أن يطلب التنفيذ الجبري للسند الرسمي للدى دوائر التنفيذ في النظسام

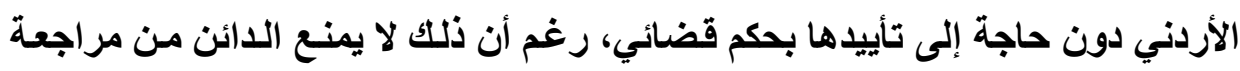
المحكمـة المختصة أولاً للحصول على حكم بموضـوع السند، ثم طرح الحكم لتنفيذ الجبري إذا كان يخشى إثارة نزاعات بشأن موضوع السند أو صحته أمام دائرة التنفيذ، مما يافعه إلى تفضيل مراجعة المحكمة أولاً. ويجب أن يكون المظهر الخارجي للسند لا يبعث على الشك فيه كوجود كثط أو محو أو إضافة، فعند ذاك تثوفر في السند قرينة قانونية على عد سندا رسميا صحيحاً وأعفي من يتمسك بـه من الإثبات صحة صدوره ممن يحمل تواقيعهم وهم: الموظف العام وأصحاب العلاقة أولاً، ومن الإثبات خلوه من التغييرات اللاحقة على إنشائه ثاتياً. ويعد هذا المحرر سندا تنفيذيا دون حاجة لصدور حكم أو أمر من القضاء باعتباره كذلك، فإذا كان الأصل أن تحفظ أصول المحررات الرسمية، ولا يحصل أصحاب الشأن إلا على صور منها موقعة من الموظف المختص، فبإذا كان أصل الورقة موجود فِإن صورتها الرسمية تكون حجة وسندا تتفيذيا بالقدر الذى تكون فيهه مطابقة للأصل('). وعند عدم وجود أصل الورقة الرسمية، فإن الصور الرسمية المنقولة عن الأصل تكون 


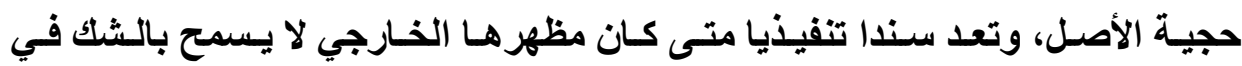

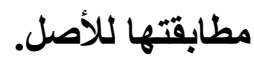

فطبقا للنظام الأردني حتى تكون الورقة الرسمية سندا تنفيذيا يجب أن يقوم بكتابتها موظف أو مكلف بخدمة عامسة(')؛ ومـن أمثلـة السندات الرسمية التي يجوز تنفيذها لدى دوائر التنفيذ الآتي:

- سندات تأمين ورهن الأموال غير المنقولة المنظمة لاى مديريات الأراضي المختصة، وهذا ما نصت عليه المادة ؛ ـ ا من قانون التنفيذ الأردني.

ـ سندات رهن المركبات المنظمة من قبل الموظفين العاملين في دائرة ترخيص السواقين والمركبات، وذلك طبقا لنص المادة V من قانو السير الجديد الأردني. ـ ســدات رهن الآلات والماكينـات للدى كاتب العدل(؟). والسندات الأخرى المنظمـة لـدى كاتـب العـل، أو لـدى القناصـل، وجميـع السندات المحسررة لـدى موظف

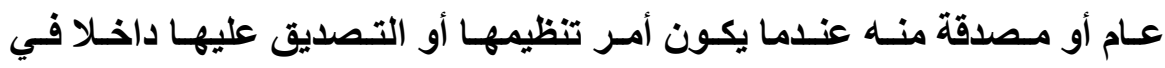
(ختصاصd(") - (خاوم

وطبقـا لهــا الاتجـاه الـذي أخـذ بـه القـاتون الأردنـي والسعودي واللبنـاني، فإذا فقد السند الرسـي صفته كسند رسـي، يصبح سـندا عاديا، يمكن عن طريـق دائرة الإجراء أو قاضي التنفيذ في بعض الأنظمة تنفيذه، وفقا لمـا هو متبع في السند 
الاتجاه الثاني: قصر السندات التنفيذية على المحررات الموثقة فقط بالنسبة لبعض الأنظمة لم تمنح القوة التنفيذية إلا للمحررات الموثقة؛ فطبقا

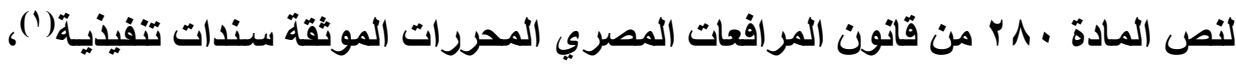
نقلا عن القانون الفرنسي القديم كانت تعد وظيفة الموثق وأعماله ذات طابع قضائي("). ويقصد بـالمحررات الموثقة I'acte notaries: المحررات المشتملة على تصرفات قانونيـة والتـي يحررهـا الموظفـون المختصون بتحرير هـا وتوثيقهـا بمكاتب التوثيق

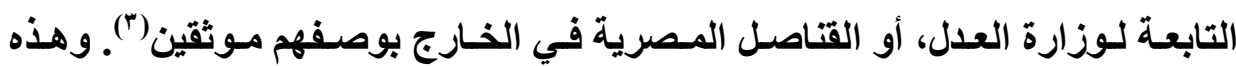
المحررات تتضمن التزاما بشئ يمكن اقتضاؤه جبرا، سواء أكسان العمل ملزمـا للجانبين أو ملزما لجانب واحد، وسواء أكان بين الأحياء أم مضافا إلى مـا بعد الموت، وسواء

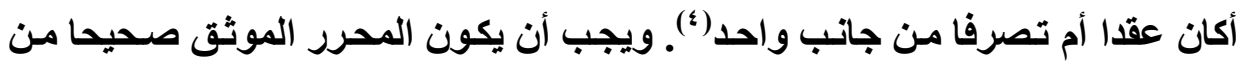
الناحية الثكلية(ْ)، وقد ذهب القضاء المصري إلى أن المحررات الموثقة من السندات التنفيذية التى تقبل التنفيذ بذاتها، وللمدين أن يلجأ إلى القضاء للطعن عليها على خلاف

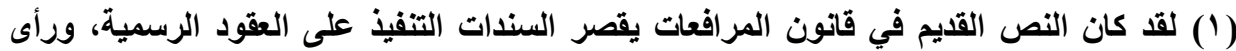

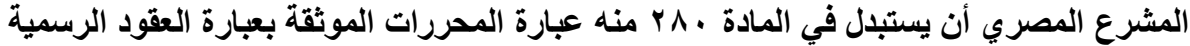

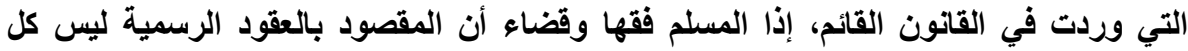

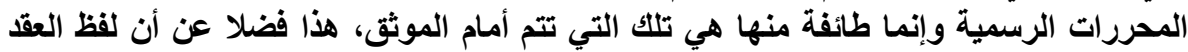

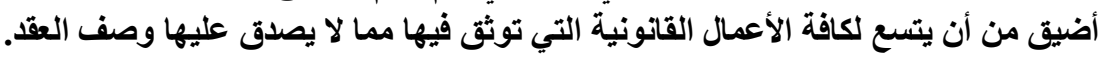

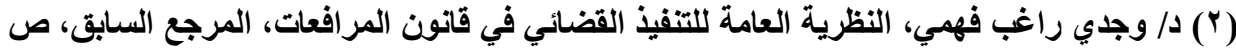

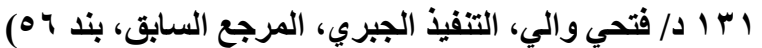

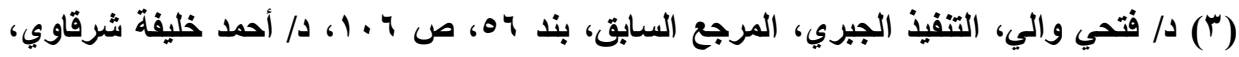

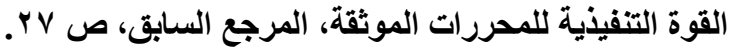

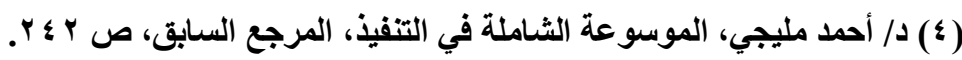
(5) Cass. Civ. 2e, 1er févr. 2018, D. 2018. Actu. 299. 
الأحكام(') وبالنسبة للنظام الفرنسي فإن المحررات الموثقة سندات تنفيذية، وهي من السندات التي لم تصدر عن القضاء(؟)، فهي لا تعد من طبيعة الحكم القضائي("). ولقد

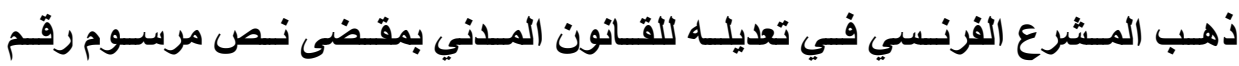

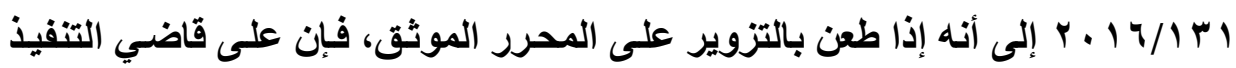
وقف إجراءات تنفيذ المحرر الموثث. ولقد ذهبت القضاء الفرنسي إلى عدم اختصاص قاضـي التنفيذ بالمنازعـات الموضـوعية المتعلقة بمضمون السنـا التنفيذي، وخاصـة

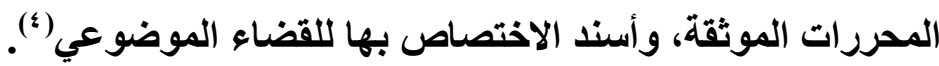
فطبقا لهذا الاتجـاه المحررات الموثقة تعد محررات رسمية، ولكن ليس كل

محرر رسمي يعد محررا موثقا، ومن ثم فالمحررات الرسمية لا تعد سندات تنفيذيةة(ْ).

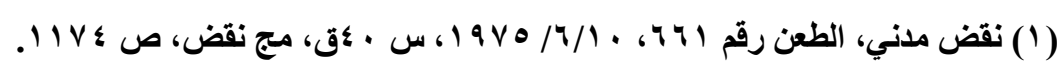

(2) Salati, Droit et pratique des voies d'exécution, op. cit., n. 111; Julienne, le caractère exécutoire de l'acte authentique, JCP 2014. 1250.

(3) Cass. Civ. 2e, 18 févr. 2016, Bull. civ., II, n0 180.

(4) Civ. 2e, 18 juin 2009, Bull. civ. II, no 165; ROUZET, Force exécutoire de l'acte notarié : un singulier pluriel, Defrénois 2010. 282,

(•) إذا كان المحررات الموثقة من مستحدثات قانون المرافعات الحالي، وأكثر توفيقا من اصطلاح

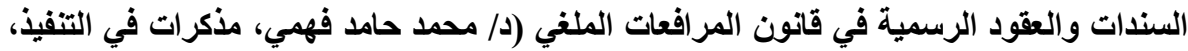

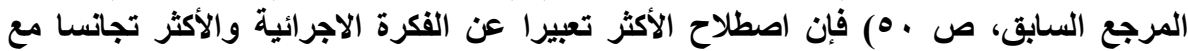

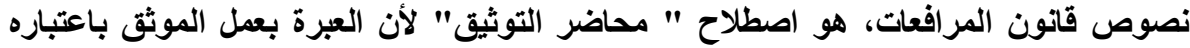

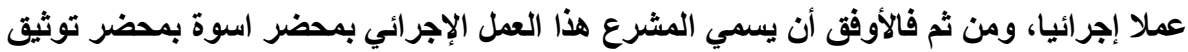

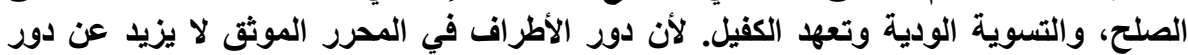

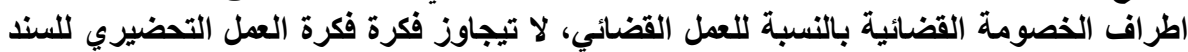

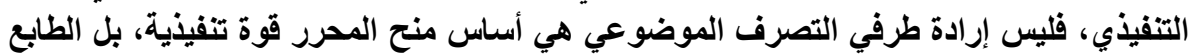

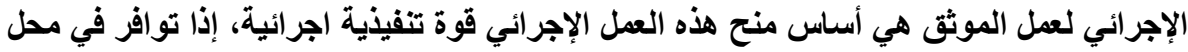

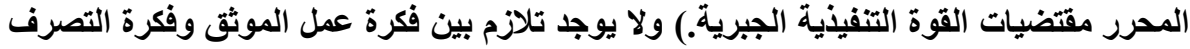

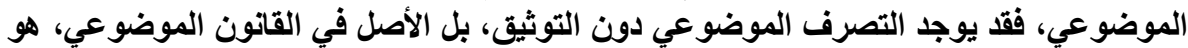

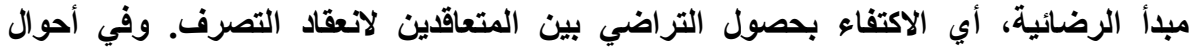
$=$ 
فالمحرر الأي يتم أمام الموثق في القانون المصري هو وحده المعتبر محررا موثقا في مفهوم المادة • ـ r والتي عددت السندات التنفيذية على سبيل الحصر. وهذا المعنى لا يتطابق مع المحرر الرسمي في مفهوم المادة ـ ا الإثبات(') فالثرط الأساسي لاعتبار المحرر سندا تنفيذيا أن يصدر عن طريق موثق وليس أي موظف عام، وكذلك الأمر بالنسبة للمحرر المسجل لا يعد سندا تنفيذيا()، لأنه غير مبرم بواسطة الموثق. وكذلك

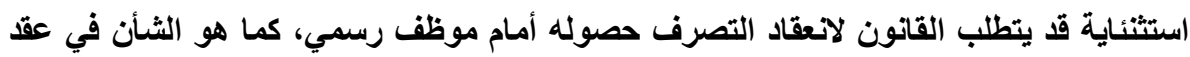

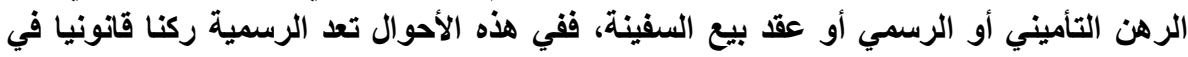

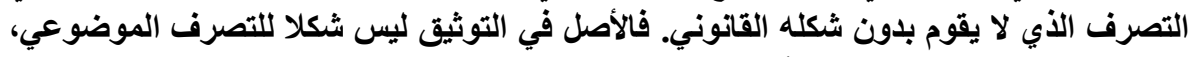

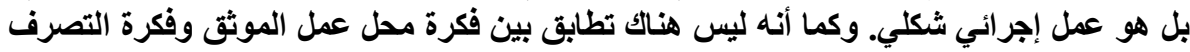

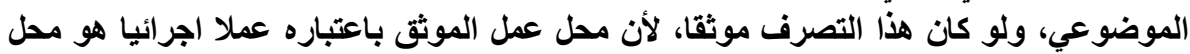

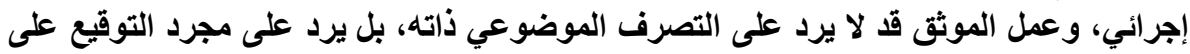

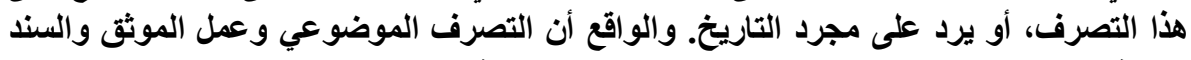

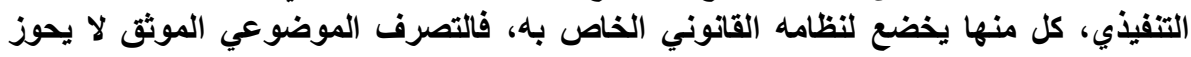

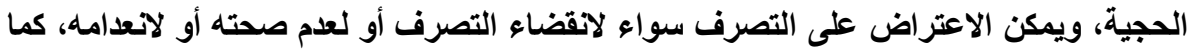

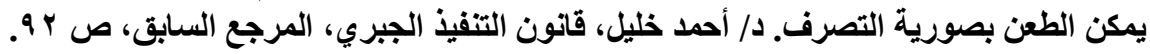

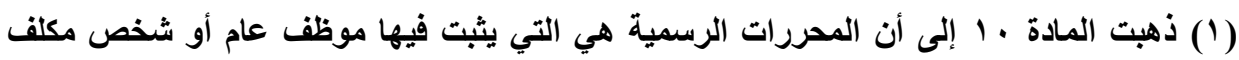

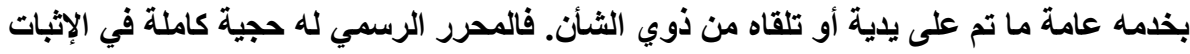

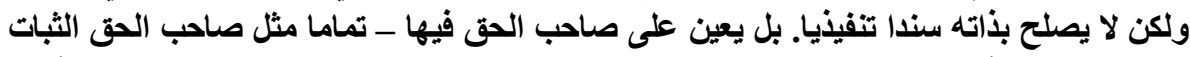

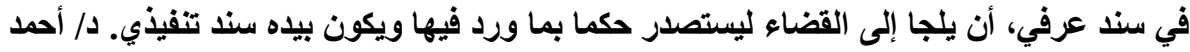

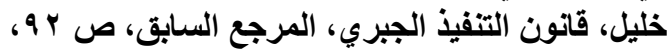

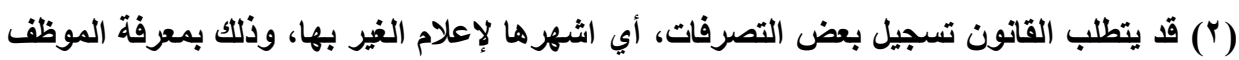

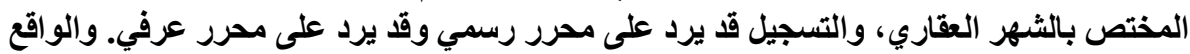

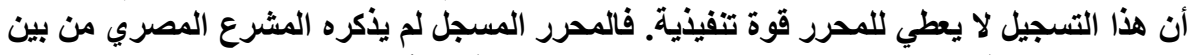

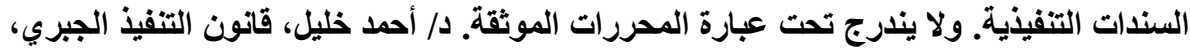


المحرر المصدق على تاريخه أو التوقيع الذي يتضمنه، لا يعد سندا تنفيذيا طبقا لأحكام القانون المصري(') - (') ويثـار التـساؤل عـن الأســاس القـانوني لإضـفاء القـوة التنفيذيـة على هــه

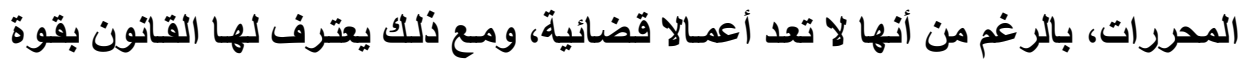
تنفيذية، ويعدها المشرع المصري من السندات التنفيذية(؟)، وقد اختلفت آراء الفقة في تفسير أساس القوة التنفيذية لهذه المحررات؛ فذهب رأي إلى أن الثقة في الموثق هي

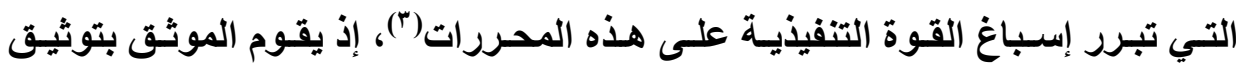
التصرفات القانونية طبقا لإجر اعات قانونية معينة، فهو يتحقى من شخصية ذوي الثأن في التصرف وصفاتهم وأهليتهم، وغير ذلك من الإجراءات التي تؤكد وجود الحق بصورة تغتي عن الالتجاء إلى القضاء. ولكن هذا الرأي منتقد لأن عمل الموثثق يقتصر على مجرد إثبات إبرام تصرف أمامه دون إجراء تحقيق لتأكيد وجود الحق الوارد في

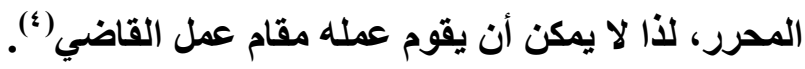

(1) يقصد بالتصرف الموثق هو تصرف يثبت فيه الموظف ما حصل أمامه وفق إجراءات قانونية

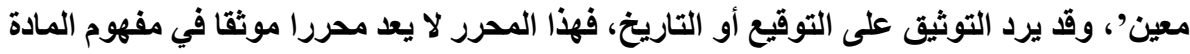

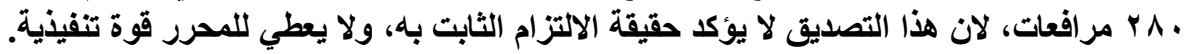
د/ أحمد خليل، الإشارة السابقة.

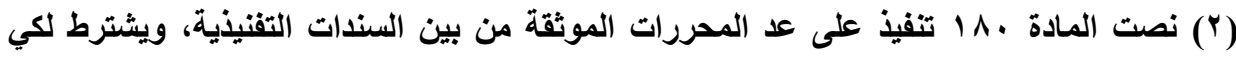

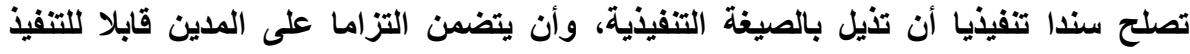

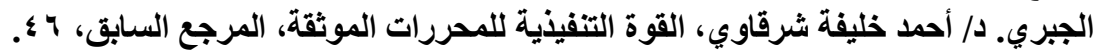

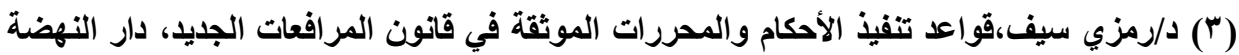

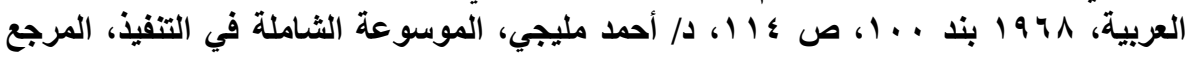


ويذهب رأي آخر إلى أن أسساس القوة التنفيذية للمحرر الموثق هو الخضوع

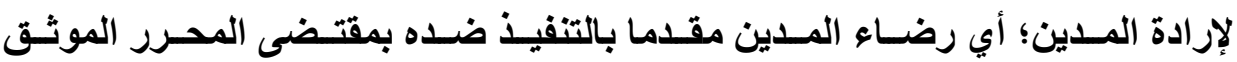
وخضوعه للتنفيذ الجبري في حالـة عدم وفائسه اختبـارا بـالالتزام الثابت في المحرر الموثق(")، وهذا الخضوع مفترض بمجرد اتبـاع أشكال معينة، فهو يرتضي مقدما بالتنفيذ ضده، ولكن هذا الرأي لا يتفق إلا مع تثريعات البلاد التي تتطلب من المدين أن يذكر بعبارة صريحة أمام الموثث ارتضاءه مقدما بالتتفيذ الجبري ضده، كمـا هو الحال في التشريع الألماني والنمساوي، وهو لا يصلح في ظل التشريع المصري أو الفرنسي؛ إذ لا يتطلب هذه التشريعات ذكر هذا الرضا، ولذلك يخالف هذا الرأي قاعدة أن الإرادة لا تفترض؛ إذ ينسب للمدين إرادة لا توجد على الإطلاق(؟). ويؤسس البعض القوة التنفيذية للمحرر الموثث على قاعدة أن العقد شريعة المتعاقدين، ووفقا لهذا الرأي يتمثل الأسـاس القـانوني للقوة التنفيذية للمحرر الموثثق في إرادة أطراف التصرف الموثق، ولكن هذا الرأي غير صحيح لأن هذه القاعدة ليست قاصرة على العقود الموثقة بـل تمتـــ إلى العقود غير الموثقةـة ولـو كـان هذا الرأي صحيحا لأمكن تنفيذ العقود العرفية غير الموثقة تنفيذا جبريـا؛ إذ يخضع العقد العرفي لهذه القاعدة ويعد أيضا شريعة لعاقديه(").

(1) Cass. Civ. 2e, 19 Nov. 2009, Bull. civ. II, no 277; D. 2010. Chron. 538, obs. Sommer et Leroy-Gissenger.

(ץ) د/ فتحي والي، التنفيذ الجبري، المرجع السابق، بند هی، د/ أحمد مليجي، الموسوعة الثاملة في

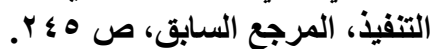
(r) د/ عبد الباسط جميعي، نظام التنفيذ في قانون المرافعات، المرجع السابق ص هراب، هامش رقم 
بينمـا ذهب رأي إلى أن أسساس القوة التنفيذيـة للمحررات الموثقة يكُنْ في عدها نوعـا مـن القضاء الخـاص أو الاستثنائي(')؛ إذ يوجد إلـى جانب قضاء الدولـة العادي قضاء ذاتي أو قضاء خاص، ومن أمثلته التحكيم العادي والأعمال التي تمارسها بعض الهيئات ذات الاختصاص القضائي، كمـا أنها توجد حالات يحق فيها للشخص أن أن يأخذ حقه بنفسه دون حاجه إلى الالتجاء إلى القضاء كحالة الضرورة، والقوة التنفيذية للمحررات الموثقة وهي حالة من الحالات التي يجوز فيها للشخص أن يطلب الأعمـال الفعلية لحقه دون الالتجاء إلى القضاء. وهذا الرأي لا يمكن الأخذ به، لأن عمل الموثث لهن لا يعد قضاء خاصا، لأنه موظف تابع للاولة، فلا ينطبق عليه أحكام القضاء الخاص. ونرى مع البعض أن أساس القوة التنفيذية للمحررات الموثقة يرجع إلى نص المشرع الأي عدّ تسجيلا لما جرى عليه العمل سابقا، وما انتهى إليه التطور التاريخي

$$
\text { للمحررات الموثقة (`) }
$$

ثانيا: شروط الحق محل السند العادي أو الرسمي يشترط لتنفيذ الحق محل السند العادي أو الرسمي توافر الشروط الآتية:

$$
\text { الثرط الأول: أن يكون الحق قابلا للتنفيذ الجبري }
$$

يجب للتنفيذ الجبري أن يكون الحق الثابت في السند مما يقبل التنفيذ الجبري؛ ويكون ذلك إذا لـم يكن مستحيلا تنفيذه لالتصاقة بشخص الإنسان. ويجب أن يطالب الدائن التنفيذ في مواجهة المدين، أمسا إذا طلب التنفيذ في مواجهة الغير، فعلى جهة التنفيذ أن ترفض الطلب. ويشترط أن يكون لهذا المدين موطن أصلي أو مختار أو سكن موني

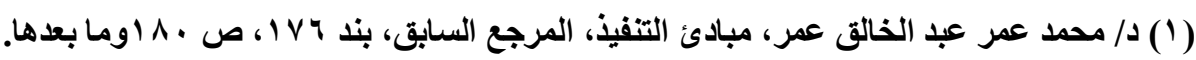

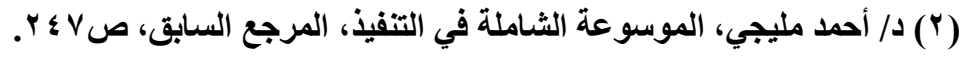


البلاة ذاتها التي فيها مقر الدائرة الإجراء وإذا كان الموطن مختارا فيجب أن يكون قد اختير من أجل التنفيذ، أما إذا كان قد جرى اختياره من أجل عمل قانوني آخر فلا يمكن

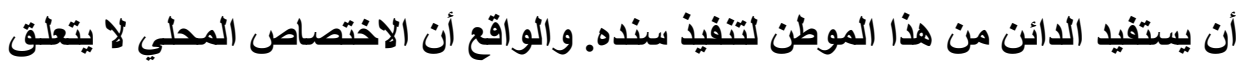

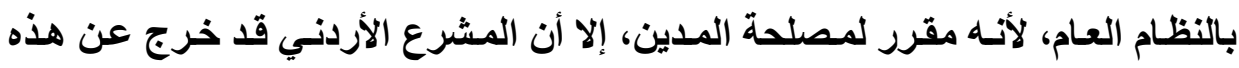

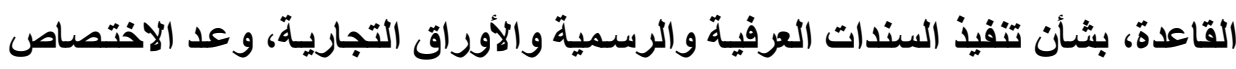

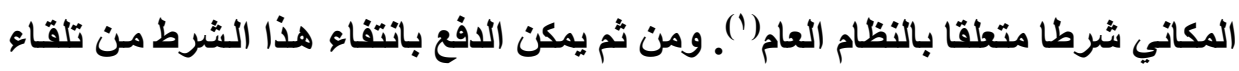

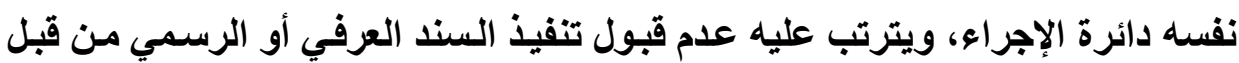

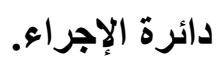

الثرط الثاني: أن يكون الحق مبلفا من النقود: يثترط القانون الأردني أن يكون محل السند العرفي مبلغا من النقود، ويترتب على تخلف ذللك علم جواز تنفيذ السند العرفي، كما لو كان الالتزام بالقيام بعمل، لأن تنفيذ هذا الالتزام من شأنه أن يخلق منازعة تخرج عن اختصاص دائرة الإجراء، حيث الثئ

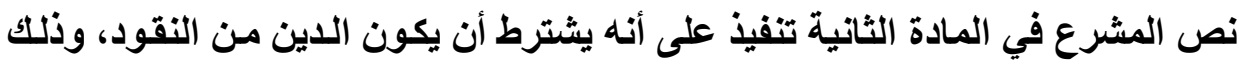

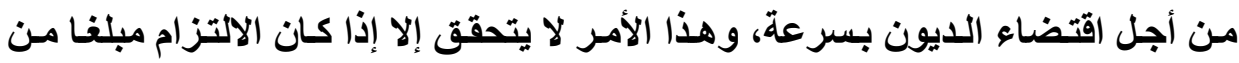

ولم ينص المشرع السعودي على هذا الشرط، ومن ثم يمكن أن يكون محل الالتزام مبلغا من النقود أو أي شئ آخر يمكن تنفيذه جبرا. وبالنسبة للقانون اللبناني

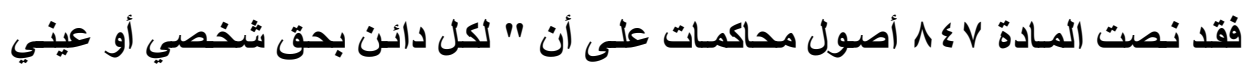


دا طلعت يوسف خاطر

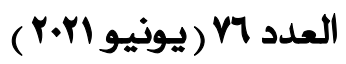

ناشسئ عن عقد أو تعهد مثبـت بسند رسمي أو عـادي أن يطلب تنفيذ...." ومن ثم لا يثترط أن يكون محل السند مبلغا من النقود.

الثرط الثالث: أن يكون حق الدائن حال الأداء معين المقدار

هذا الشرط نصت عليه الفقرة ب من المـادة الثانيـة من قـانون التنفيــ الأردنـي

بقولها: " وكان الدين حال الأداء معين المقدار، ذلك لأنه الدين إذا كان معلقا على شرط

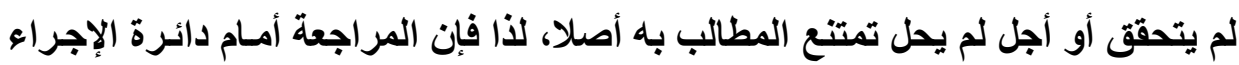
غير مقبول تبعا لذلك، وهذا الشرط منصوص عليه في القانون اللبنـاني والسعودي، والمصري، لأنه من الشروط العامة في السندات التنفيذية.

ويعد الدين حال الأداء، أي الدين المؤجل الأي سقط أجله وفقا لأحكام القانون

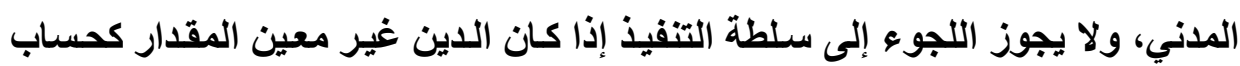
جـار أقفل ولـم تجر تصفيته، لأن ذلك يخرج عن اختصاص سـلطة التتفيذ، فهو مـن

اختصاص محكمة الموضوع(')

ويلاحظ أن من بيده سند تنفيذي لا يكلف بإثبات أن حقه الثابت في ذلك السند

محقق الوجود()، وإنما الذي يكلف بالإثبات هو من يدعي العكس، فوجود السند قرينة

على تحقيق وجود الحق الذي يتضمنه(").

(1) د/ مفلح عواد القضاة، أصول التنفيذ وفقا لقانون الإجراء الأردني، المرجع السابق9 ا ب؟، ص

(2) R. PERROT et Ph. THÉRY, Procédures civiles d'exécution, op. cit., no 118; LEBORGNE, Droit de l'exécution, op. cit., nos 432 s. Cass. Civ. 2e, 19 nov. 2009, Bull. civ. II, no 277 ; D. 2010 . Chron. 538, obs. Sommer et Leroy-Gissenger.

(r) د/ أحمد مليجي، الموسوعة الثاملة في التنفيذ، المرجع السابق، ص 1 اب. 


\section{ثالثًا: إجراعات تتفيذّ السندات العادية والرسمية}

في النظـام الأردنـي واللبنـاني إدارة التفيـذ تختص بتنفيـذ السندات العاديـة والرسمية، أما في النظام السعودي فإن قاضي التنفيذ يختص بتنفيذ المحررات العرفية والرسمية، ويجب تقديم طلب إلى إدارة التفيذ أو قاضي التنفيذ طبقا للنظام السعودي، ثم يتم إبلاغ المدين بالسند التنفيذي وإخطاره بالوفاء. وسنشير إلى إجراءات التنفيذ في النظام الأردني، والسعودي، واللبناني، وذلك

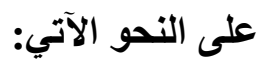

$$
\text { 1- إعراء التنفيذ في النظام الأردني }
$$

لقد اسـتحدث القـانون الأردنـي نظــام السندات الرسـمية و العاديـة كسندات تنفيذية، بموجب قانون الإجراعات رقم هب لسنة ه 9 1، ونص في المـادة الثانية على أن " للائن بدين من النقود إذا كان دينه ثابتا بسند عـادي أو بسند مصدق لدى كاتب العل أو ورقة من الأوراق التجاريـة القابلة للتظهير أن يراجع دائرة الإجراء ويطلب تحصيل دينه، ولا يجوز سلوك هذا الطريق إلا إذا كان للمدين موطن أصلي أو مختار أو سكن بالبلدة ذاتهـا التي فيها مقر الـائرة الإجرائيـة، وكـان الدين حـال الأداء ومعين المقدار"، فطبقا للقانون الأردني يجب أن يكون حق الدائن ثابتا بسند عادي أو رسمي، وأن يطلب تحصيل حقه، ويشترط أن يكون الحق ثابتا بالكتابة، لأنه في حالة عدم وجود الكتابة فإنه يجب التثبت من وجود الالتزام ومقداره، وهذا يخرج عن اختصاص دائرة الإجراء. ويلاحظ أن القانون الأردني قـ أعطى لهذا النوع من السندات قوة تنفيذية، دون حاجة للجوء إلى القضاء والحصول على حكم بـالحق موضوع السند سواء عن

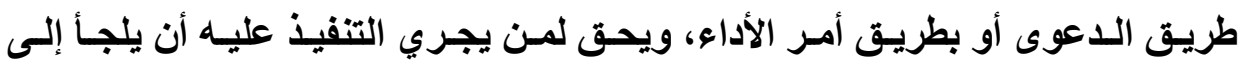
القضاء منازعا في هذا التتفيذ، إمـا لسبب يتعلق بانقضاء الحق موضوع السند بأحد 
أسباب انقضاء الالتزام أو لسبب يتعلق ببطلان السند نفسه بأحد أسباب البطلان أو

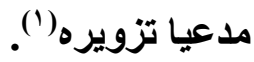

وقد ذهب المشرع الأردني إلى أن اتباع هذا الطريق اختياري للائن؛ فله أن يلجأ إلى المحكمة مباشرة، لأن صاحب الحق هو أدرى بـه من غيره وهو الذي يتحمل وحده الطريق الذي يسلكه في اقتضاء حقه، وهذا أمر منطقي، فهو الذي يختار أن يرفع بحقه دعوى طبقا للقواعد العامة إذا قدر أن منازعة مدينه مؤكدة، وعلى تقدير جديتها

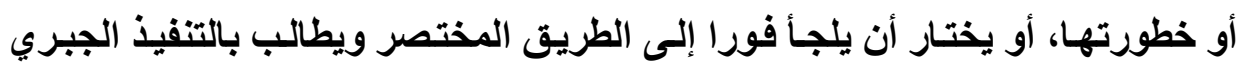

ويجب إعلان المدين، وأن يمنح فترة زمنية للحضور أمسام إدارة التفيذ للوفاء بما عليه، وللمدين أن يحدد اختياره بين الوفاء أو الاعتر اض أو عدم الحضور، وهذه الفروض تم بحثها في إجراعات تنفيذ الأوراق التجاريـة، وهي تطبق على المحررات العرفية، فنحيل إليها منعا من التكرار. وبالنسبة للمحررات الرسمية، فقد قرر المشرع الأردني في المادة وج من قانون كاتب العدل، عدّ السندات الرسمية المنظمة لاى الكاتب أو من يقوم مقامه من السندات

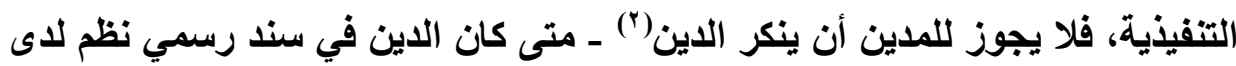

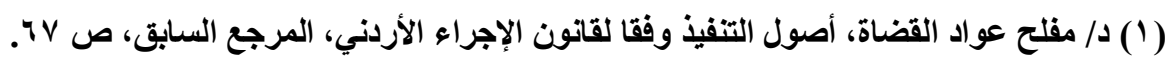

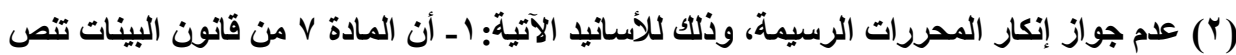

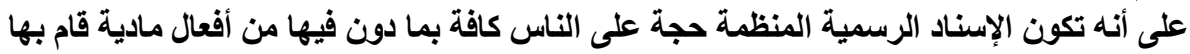

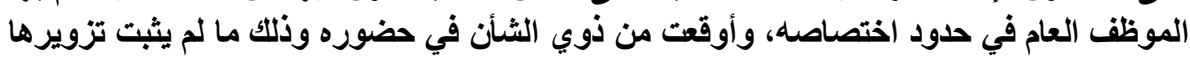

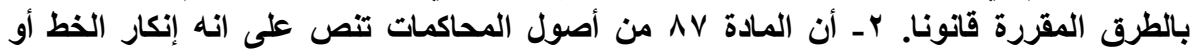

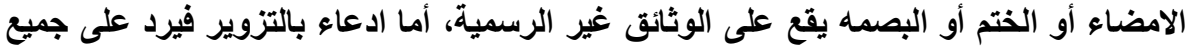

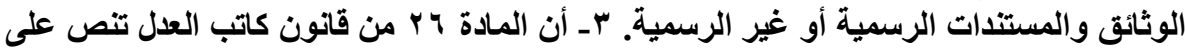

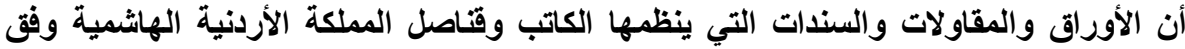


الكاتب العدل أو من يقوم مقامه ـ أمام دائرة الإجراء، وإنكاره للاين لا يترتب على تأخير معاملات التففيذ، لكنه يجوز للمدين أن يدعي الإبطال، أو المقاصة بموجب وثيقة خطية ممضاة من الدائن، ولا يشترط في هذه الوثيقة أن تكون رسمية، فإذا أنكر الدائن هذا لإنائ الادعاء، وتعذر على رئيس الإجراء حل الإثكال دون محكمة، فيقرر رئيس الإجراء وقف التنفيذ حنى يحل الخلاف في المحكمة التي يعود إليها ذلك(') وترجع الحكمة من عدم إمكانية إنكار السند الرسمي، أنه مصدق من قبل موظف عام أعطاه القانون

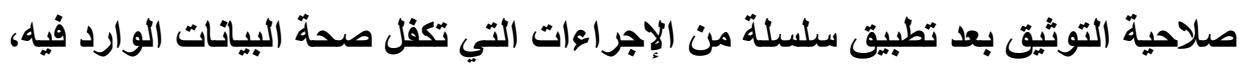
والتي تبلغ مبلغا من الثبوت مما يجعل السند الذي تضمنها صالحا للتفيذ دون حاجة إلى استصدار حكم من القضاء لتأكيد الحق(؟). وفي النظام الأردني، فالبرغم من أن السند الرسمي يتمتع بقوة تنفيذية ويمكن تبعا لذلك تنفيذه مباشرة من قبل دائرة الإجراء دون حاجه لصدور حكم بموضوعه، فِان ذلك لا يمنع صاحب المصلحة، فيما إذا رغب في ذلك، أن يراجع المحكمة للحصول على حكم بموضـوع السند ومـن ثم وضـع الحكم في دائرة الإجراء، إذا كـان يخشى إثـارة

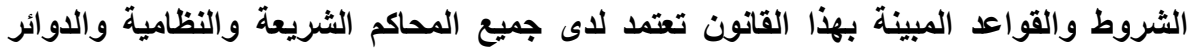

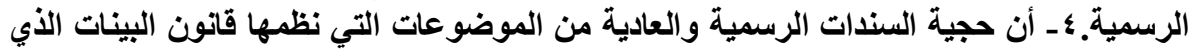

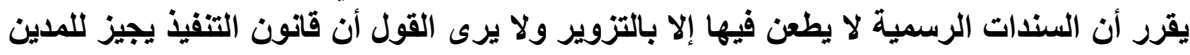

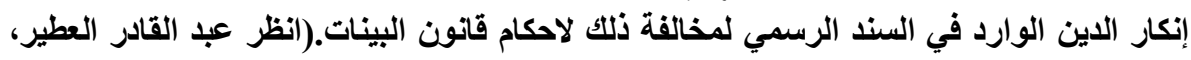

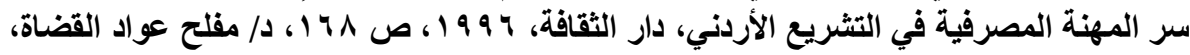

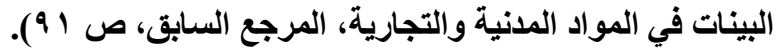

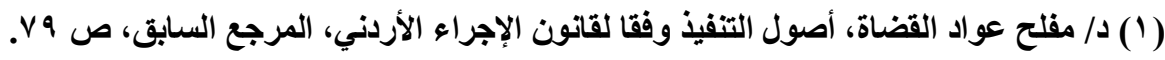

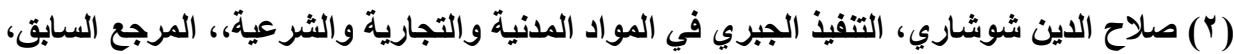


منازعات بثأن موضوع العقد أو صحته أمسام دائرة الإجراء ممـا قد يدفعه إلى تفضيل مراجعة المحكمة أولاً، ومن ثم اللجوء إلى دائرة الإجراء.

وقد اشترط المشرع الأردني في المسادة و r من قانون الكاتب العدل رقم 11

لسنة ب0 19 أن سندات الدين التي ينظمها الكاتب العدل أو قناصل المملكة إذا حل أجل أدائها في حال حياة الدائن، يخطر الكاتب العدل المدين بنـاء على طلب الدائن بورقة إخطار أن يؤدي الدين خلال ثمانية أيام، وعند انتهاء هذه المدة إذا لم يقم المدين بـأداء ما عليه توقع دائرة الإجراء الحجز على أموال المدين بناء على طلب الدائن، وإذا ظهر أن مضمون السند يحتاج إلى تفسير أو ادعى المدين الإبطال أو المقاصة بموجب وثيقة ممضاة من الائن، وأنكر الدائن هذا الادعاء، ورأى رئيس الدائرة أنه لا يمكن حل ذلتك دون محاكمة، فيوقف التنفيذ إلى حين حل الخلاف بواسطة المحكمة. r - إجراءات التنفيذ في النظام السعودي نص النظام السعودي في المادة التاسعة تنفيذ على أن السندات التنفيذية هي العقود والمحررات الرسمية والمحررات العادية التي يقر المدين باستحقاق محتواهـا كليا أو جزئيا، وتلكك العقود المبرمة بين المتعاقدين والتي تم توثيقها وفقا لنظام التوثيق الذي أعدته وزارة العدل، ويشترط للعقد الموثث لاكتسابه صفة السند التنفيذي أن يكون

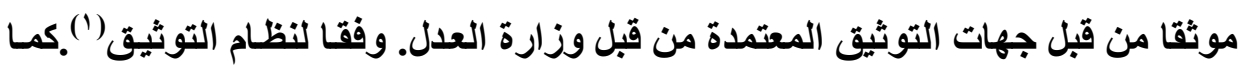
أن هناتك سندات أخرى ذكرت في أنظمة غير نظام التنفيذ، مثل قرار لجنة المساهمات العقاريـة، وعقود الإيجـار التي تصدر تحت إثـراف وزارة الإسكان(†)، فهذه السندات

(1) دا عبد العزيز عبد المنعم خليفة، إجراءات ومنازعات الحجز الإداري في الفقه والقضاء،، المرجع

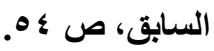
(ץ) د/ عبدالله بن زايد الزايد، القواعد العامة لقضاء التنفيذ، المرجع السابق، ص هـr. 
تنفذ دون حاجة إلى اللجوء إلى المحكمة لإثبات الحق الموضوعي، وقد اشترط النظام السعودي(') بالنسبة للأوراق العادية أن يقز المدين باستحقاق محتواهـا كليا أو جزئيا، وقد عرفت اللائحة في المادة 9/9 هذه السندات بأنها تلك " التي تكون موقعة بإمضاء

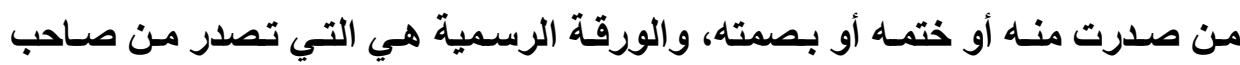
الثأن بصفته الوظيفية في حدود اختصاصه الوظيفي (). وقد بينت المادة ها من النظام السعودي للتنفيذ القواعد والضوابط المتعلقة بتنفيذ الورقة العادية وهي: - إذا حضر المدين وأقر بـالحق في ورقة عاديـة أثبت قاضسي التنفيذ إقراره وعدت سندا تنفيذيا. - إذا أقر المدين بأصل الحق في الورقة العادية ودفع بالأجل، أو الإبراء، أو نحوهمـا، أثبت قاضسي التنفيذ ذلك في محضر، ولا تعد الورقة سندا تنفيذيا، ويزود طالب التنفيذ بنسخة من المحضر، ويحفظ طلب التنفيذ.(م ه 1 لائحة) (ّ). - إذا أعلن المدين في الورقة العاديـة بالحضور بواسطة طالب التنفيذ، ولم يحضر يحفظ طلب التنفيذ. ولا تعد الورقـة سـندا تنفيذيا، هذا الوضـع لا يحقق العدالـة بالنسبة لطالب التفيذ، ونقترح أن ينص النظام السعودي على عدها سندا تنفيذيا، طالما تم الإعلان لشخص المدين أو تم الإعلان للمرة الثانية.

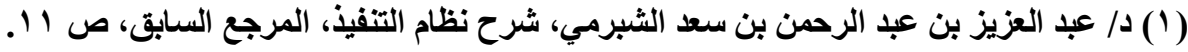

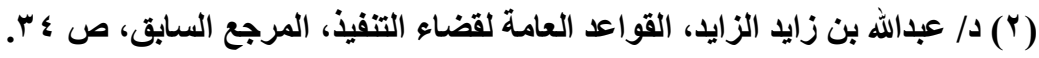
(r) د/ مفلح بن ربيعان القعطاني، د/ محمد السيد محمد رفاعي، الوسيط في النظام السعودي، المرجع

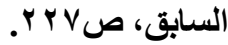


- إذا حضر المدين ولم يقر المدين بالحق، أو بعضه، أمر قاضي التتفيذ المدين بتوقيع

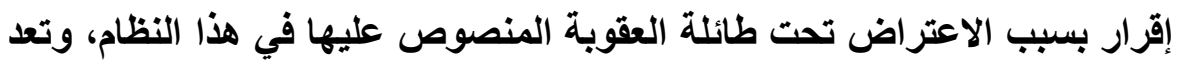
الورقة سندا تنفيذيا فيما لم يعترض عليه، وللائن رفع دعواه أمام المحكمة

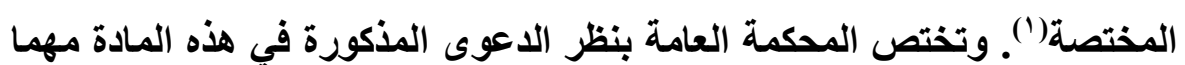

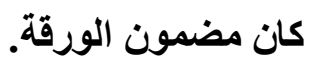

ويمكن للائن اللجوء إلى المحكمة مباشرة؛ فقد نصت المـادة ^ ؛ ا من نظام المرافعات السعودي على أنه يجوز لمن بيده ورقة عادية أن يخاصم من تتضمن هذه

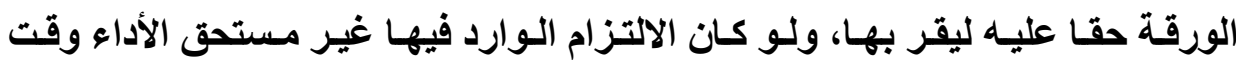

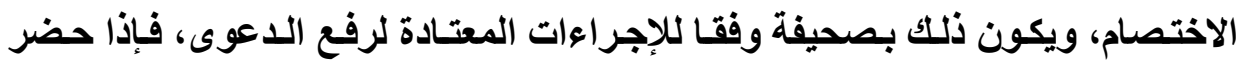

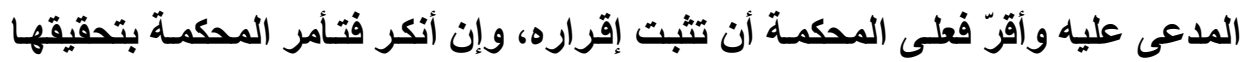

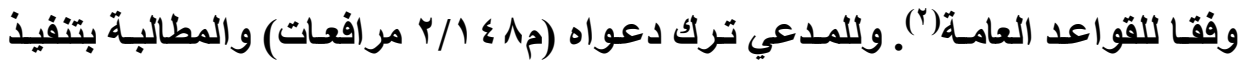

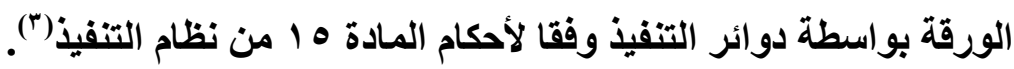
إذا كان النظام السعودي اعترف للمحررات العادية والرسمية بالقوة التنفيذية،

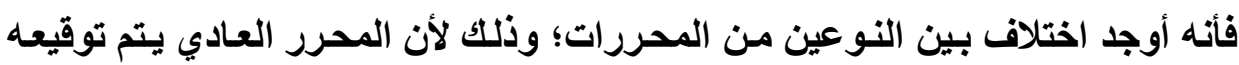
و إمضاؤه أو بصمته من أصحاب الثنأن بصفتهم العادية، أما الورقة الرسمية فهي التي التي تصدر من صاحب الثأن بصفته الوظيفية وفقا لأظظة ذات العلاقة في حدود اختصاصه

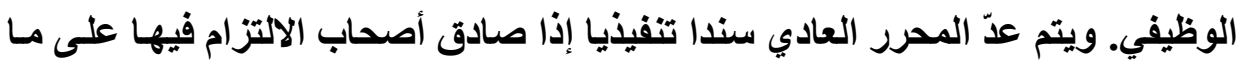

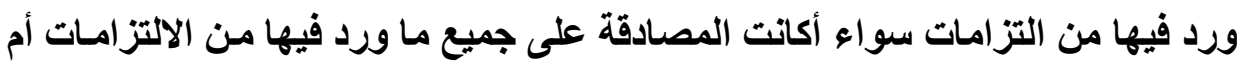

(1) د/ عبدالله بن زايد الزايد، القواعد العامة لقضاء التتفيذ، المرجع السابق، ص ع بـ.

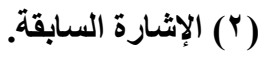

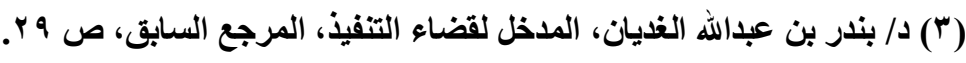


على جزء منها، فالالتزام المصادق عليه يعد المحرر بشأنه سندا قابلا للتنفيذ('). أمسا المحرر الرسمي فلم يشترط النظام السعودي مصادقة ذوي الشأن عليه، كمـا أن النظام السعودي لم يقر نظام الاعتراض على المحرر الرسمي. ويلاحظ أنه يشترط في العقود والمحررات الموثقة أن تكون صسادرة ممن لـه صلاحية التوثيق في حدود اختصاصه ليعترف لها بقوة السند التنفيذي (†)، فإذا كان هناك محررات صدرت من موظف عام ولكنـه غير مختص بإصدارها فلا يعترف لها بصفة السند التنفيذي.

وفي حالـة خلـو السند التنفيذي مـن بيـان ميعـاد الاستحقاق عد حسال الأداء، للمعترض رفع دعوى بعدم حلـول الأجل لـى قاضسي الموضـوع، (م 9/ ج) ولا يوقف التنفيذ ما لم يصدر قرار من قاضي الموضوع بذلك (م ه/9 تنفيذ)، وإذا اتفق الأطراف (اف على خلاف ما تضمنه السند التنفيذي أثبت قاضسي التنفيذ الاتفاق، وعد سندا تنفيذيا، وهم على السند الأول بذلك("). r- إجراءات التنفيذ في النظام اللبناني نصت المـادة \ \ أصول محاكمـات في النظام اللبنـاني على أن " لكل دائن بحق شخصي أو عيني ناشئ عن عقد أو تعهد مثبت بسند رسمي أو عادي أن يطلب تنفيذ هذا السند بحق مدينه مباثرة بواسطة دائرة التنفيذ المختصة. والسند الرسمي (1) دا عبد العزيز عبد المنعم خليفة، إجراءات ومنازعات الحجز الإداري في الفقه والقضاء،، المرجع السابق، ص هـ

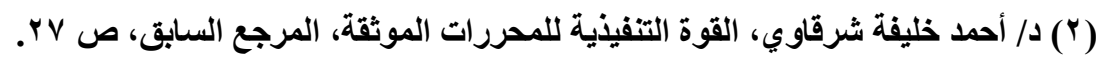
(r) م q نظام تنفيذ. 
القابل للتنفيذ هو السند الأصلي أو الصورة الأولى المطابقة للأصل('). ويلاحظ أن المادة

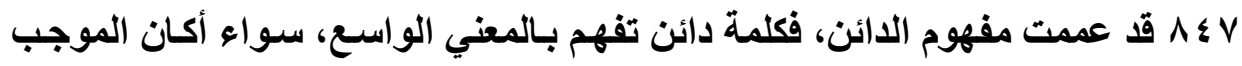
المستحق له شخصيا أم عينيا. ويهدف النص إلى استقطاب أكبر قدر ممكن من الإسناد والتعهـدات التـي يمكـن تنفيـذها مباثـرة أمسام دوائـر التتفيـذ، دون المـرور بمرحلـة المحاكمة، وذلك تجنبا للمماطلة والتعقيد، وترسيخا لقاعدة الثقة في التعامل، وتخفيف ما أمكن تخفيفه عن عاتق القضاء. ويشترط في هذه الحالة أن يكون الحق المطلوب تنفيذه ناشئا عن عقد أو تعهد مثبت بسند رسمي أو عـادي. والواقع أن العقد يعبر عن من اتفـاق بين طرفين أو أكثر، والتعهد يكون صسادرا عن شـخص واحد، وكلاهمـا ملـزم لموقعه. ومن ثم تخرج العقود والتعهدات الشفوية عن حيز تطبيق نص المـادة ل ع أصول(). والسند الرسمي يكون محل التنفيذ، وهو كل سند منظم للدى موظف عـام أو مصدق منه في حدود سلطته واختصاصه، ويشمل السندات المنظمة لدى كاتب العدل أو القتصل اللبنـاني في الخـارج وأمسين السجل العقـاري أو التجـاري أو لـى أقـلام كتـاب المحاكم ودوائر التنفيذ(")

والواقع أنه لا يكون الدائن ملزمـا بـاللجوء المباثـر إلى دائرة التففيذ إذا كـان

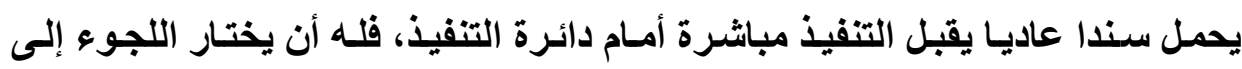

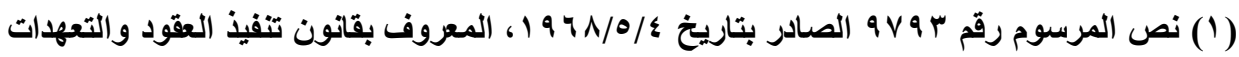

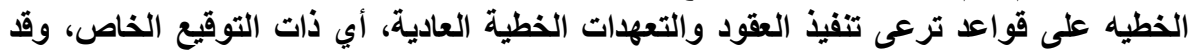

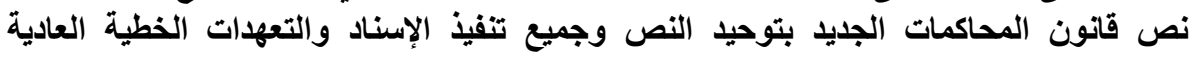

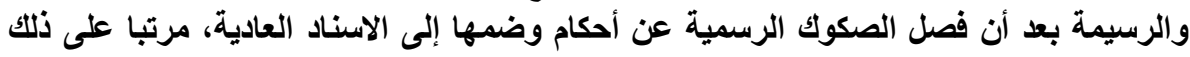

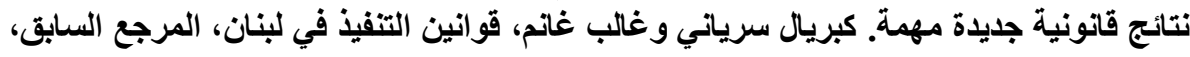


المحكمة إثباتا وتفاديا لكل طارئ قد يحصل أثناء التنفيذ المباشر (') و إذا لجأ الدائن إلى : المحكمة مباشرة، فلا يجوز له الرجوع إلى دائرة التنفيذ(؟). ويبدأ التنفيذ بتقديم طلب وإعلان المدين به، ويكون أمسام المدين إمـا أن يوفي الاين أو يقدم اعتراضه على التنفيذ أمسام المحكمة المختصة، وذلك خلال مهلة معينة نص عليها المشرع اللبناني؛ وهى مهلة عشرة أيام، في حالة تنفيذ السندات العاديـة أو الرسمية. وقد نصت المادة اهـ أصول على تحديد المحكمة المختصة بـالاعتراض هي الواقعة في المنطقة التي يقع فيها دائرة التنفيذ. وتختص وحدها بنظر إثكاليات تنفيذ السندات والتعهدات الخطية الغير المتعلقة بـالإجراءات. على عكس مـا يكون بالنسبة

للأحكام حيث يختص رئيس إدارة التنفيذ بجميع المنازعات المتعلقة بتفيذه. ويمكن لرئيس دائرة التنفيذ أن يقرر منح المدين مهله للوفاء("). ولا يجوز لرئيس دائرة التتفيذ إطالة هذه المهلة أو تقصيرها، بينمـا يجوز تقصير مهلة الإنذار الإجرائي بجعلها متراوحة بين يوم وخمسة أيام في ضوء المادة ^r م أصول. ويلاحظ أن المشرع اللبناني نص على مهلة العشرة أيسام بأنها مهلة إسقاط، لأنه بانقضائها دون تقديم اعتراض يصبح السند غير قابل الطعن عليه، إلا في حالة استثنائية وهي الادعاء بالتزوير. وإذا انقضت مهلة الاعتر اض على التنفيذ دون تقديم الاعتراض ثم أهمل الدائن سير الإجراءات لمدة سنة كاملة مما أدى إلى سقوطها، فيرى

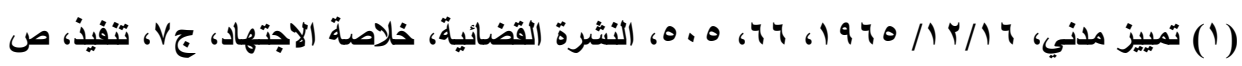

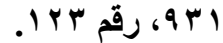

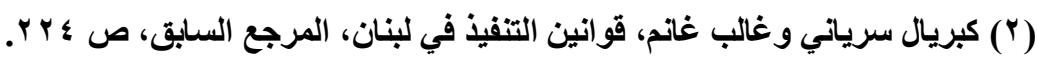

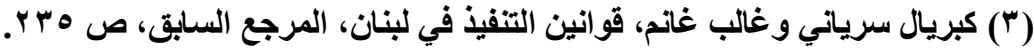




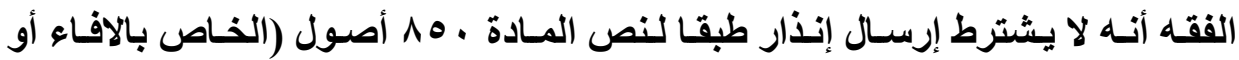
(') (الاعتر اض) (1)

وإذا طعن المدين بانتفـاء الحق كليـا أو جزئيا، وكان الطعن خـارج المهلة، لا يوقف التفيذ إلا إذا ادعى المدين بتزوير السند. وهنـاك أسباب كثيرة للادعاء بانتفاء الحق مثل الصورية وعيوب الرضا وغيرها. ويقصد بالاعتراض خارج المدة، أي خارج

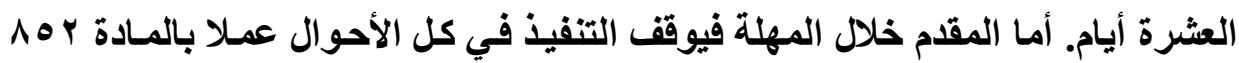
أصول. والطعن بالتزوير إذا رفع أمام القضاء المدني، فهنـا يجب على المنقَّ ضده أن يطلب من المحكمة الحكم بوقف التنفيذ، وإذا حكمت بـه فإنها تبلغ دائرة التنفيذ بوقف التف التنفيذ. ولا يخل وقف التنفيذ بحق الدائن في اتخـاذ الإجراعات الاحتياطية التي يراهـا صيانة لحقه، ويوم تقديم الاعتراض يبلغ قلم كتاب المحكمة إدارة التففيذ فيقف التنفيذ بقوة القانون، كما أن مدة الاعتراض توقف التفيذ. وإذا اتفق الأطراف على عدم الاعتراض مقدما، في صلب السند أو في ملحق لـه، لا يعتد بـه لأنـه مـن قبيل الضغوط على إرادة المـدين، وهو يخـالف النظـام العامـة والمبادئ الأساسية لحق الدفاع(؟) ونرى أن هذا الاتفـاق جائز بعد تقديم طلب التفيذ لأن المدين يعد حرا في اتخاذ الموقف المناسب له. وفي حالة كون الحق المطلوب تنفيذ غير قابل للتجزئسة فإن الاعتراض المقدم مـن أحـد المـدينين يوقف التنفيـذ لمـصلحة الجميـع، أمسا إذا كـان قـابلا للتجزئسة فـان

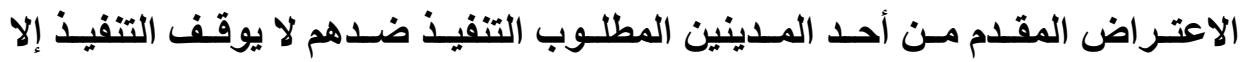


لمصلحته، ويتابع إجراءات التتفيذ بوجه الآخرين على قدر حصصهم") ـوالحكم الصادر

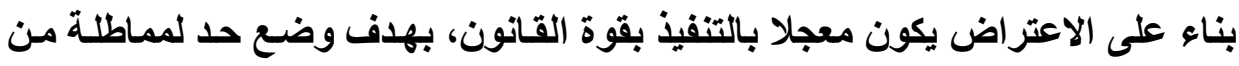

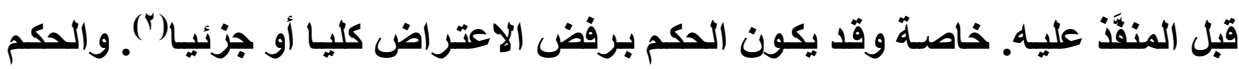

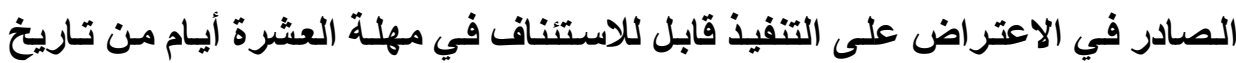
صدرها.

وإذا انطوى السند - موضوع التتفيذ- على شرط تحكيم معد للإتمام في لبنان أو

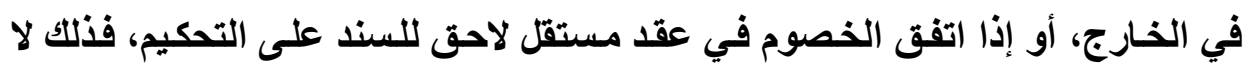
يحول دون التنفيذ المباشرة أمام دائرة التتفيذ بمقتضى السنذ؛ إذ ليس من شـأن الشرط

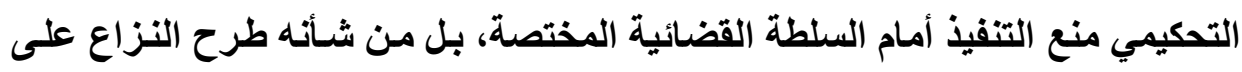

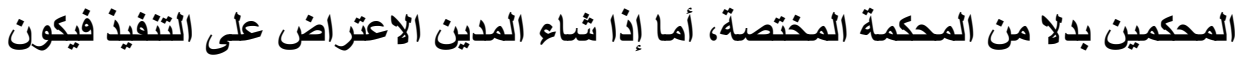
ذللك أمام المحكمين(")

\section{الفرع الثاني}

\section{تنفيذ المررات العرفية والرسمية في النظام الفرنسي}

لم يأخذ المشرع الفرنسي كما أخذت بعض الدول الأوربيـة والعربيةــ باعتبار

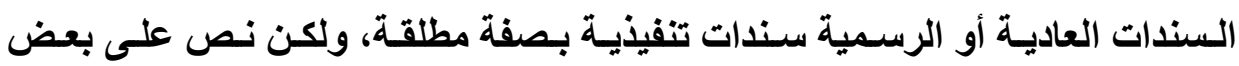
التطبيقات التي تهدف إلى تيسير إجراءات تنفيذ بعض المحررات، فقد أجاز الحجز

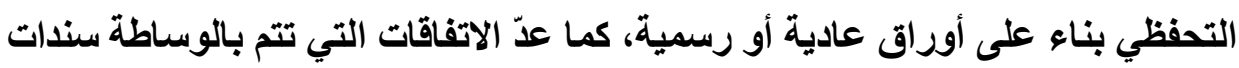

(1) كبريال سرياني وغالب غانم، قوانين التتفيذ في لبنان، المرجع السابق، ص ع ؛ ؟.

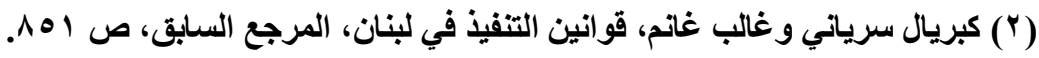

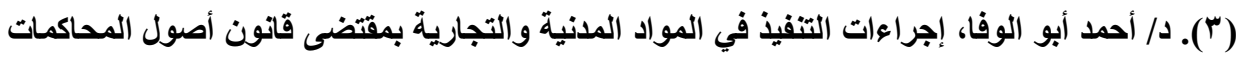

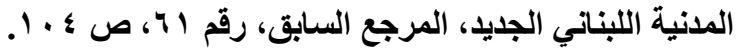


دا طلعت يوسف خاطر

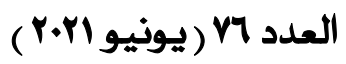

تنفيذية، وكذلك عدّ المحررات التي تتطلق بالديون البسيطة سندات تنفيذية. وكذلك

$$
\begin{aligned}
& \text { الاتفاقات التي تتم بين الزوجين، وسنشير إلى ذلك على النحو الآتي: } \\
& \text { أولا: الحجز التحفظي لايون المثبتة في محررات عرفية أو رسمية }
\end{aligned}
$$

لقد استحدث المشرع الفرنسي في مجال الحجوز التحفظية عديدا من القواعد،

والتي تعد ثورة على الأفكار التقليدية في الحجز التحفظي؛ فقد أجاز الحجز التحفظي

لـلأوراق العرفيـة أو الرسمية دون اشتراط الحصول على إذن سـابق مـن القضاء، بـل

أجاز للحجز دون اشتراط أن يكون حق الدائن محقق الوجود، ولم يشترط أن يكون حق

الأئن حال الأداء أو معين المقدار، وسنثير إلى ذلك في النقاط الآتية:

ا - طبقا للتوجه الجديد في قانون التنفيذ الفرنسي لم يعد إذن القاضي لازما لتوقيع

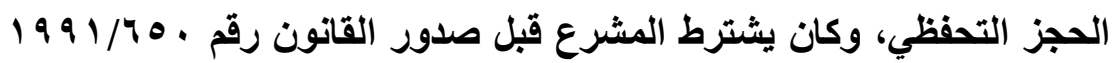

ضرورة الإذن ولو كان الدائن بيده سند تنفيذي. وأصبح الآن فيمكن توقيع

الحجز في حالات عديدة دون إذن من القاضي حتى ولو لم يكن مع الدائن سند

تنفيذي فاصل في أصل الحق ('). فيكفي لتوقيع الحجز التحفظي وجود دين

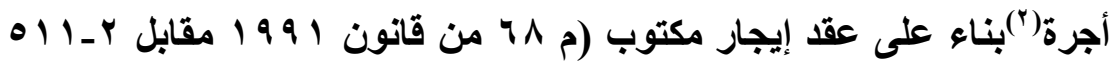

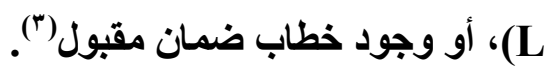

(1) BAKER CHISS, Contribution à l'étude de l'exécution des jugements civils dans les rapports internes et internationaux de droit privé, op. cit., p. $409 \mathrm{~s}$

(2)Gerard COUCHEZ et Daniel lebeau, Voies d'exécution, 11e éd., 2013, Sirey, p. 80.

(3) Alain FOURNIER Hypothèque provisoire , op. cit., n. 3, Valerio FORTI, Exécution forcée en nature, Répertoire de droit civil, Octobre 2016, n. 20. 
r- لم يشترط قانون التنفيذ الصادر بمرسوم رقم . 1991/7 أو المرسوم

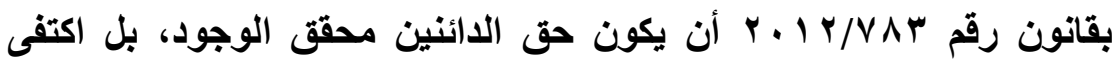
المشرع الفرنسي بعبارة أن لكل شخص يبدو أن حقه مؤسس من حيث المبأ. وقد اختفى اشتراط الخطر أوالاستعجال، واشترط المشرع فقط وجود تهديدات من شأنها أن تمنع الدائن من الحصول على حقه (م ا ـ ا هـ L L). ومن ثم يمكن لأي حق تحتويه ورقة عرفية يصلح لكل الإجراءات التحفظية. وأصبح يكفي لتوقيع الحجز التحفظي أن يبلو من الظاهر أن الطلب جدي ولا ينطوي على تعفف(') ولكن إذا ثارت منازعة جدية حول صحة العقد أو الورقة العرفية

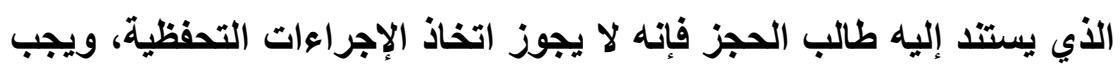
في جميع الأحوال أن يكون حق الدائن مبلغا من النقود. r-ـ لم يعد يشترط المشرع الفرنسي لتوقيع الحجز التحفظي أن يكون حق الدائن حال الأداء أو معين المقدار، وهو في ذلك يختلف الوضع تماما عن القانون المصري، ولذلك فالورقة العرفية تكفي في ذاتها لتوقيع الحجز التحفظي. ثانيا: الاتفاقات التي تتم بالوساطة تعد سندات تتفيذية بناء على توجه للبرلمان الأوروبي رقم 2008/62 والمجلس الأوروبي الصادر في 2008/5/21 حول بعض الاتفاقات التي تتم عن طريق الوسـاطة mediation في المسائل المدنية والتجارية ومنحها القضاء قوة تنفيذية، فقد عدها المشرع الفرنسي في

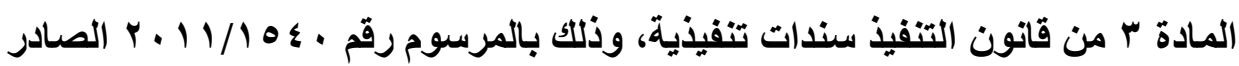

(1) Emmanuel Blanc, les novelles pocédure dexécution, 1993. P 109. 
في 11 نوفمبر | 1 ـ Y(')، والأي نقل توجيه البرلمـان الأوروبي، وتعلق ببعض أحكام

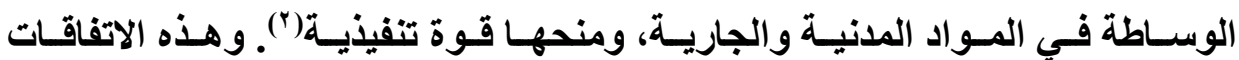
المنـصوص عليهـا في البـاب الخـامس مـن قـانون الإجراعات الفرنسـي الجديــ وذلكـ

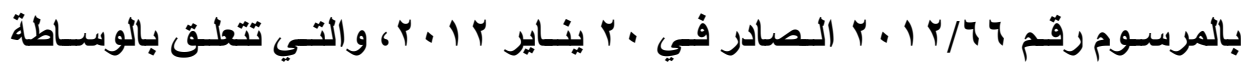

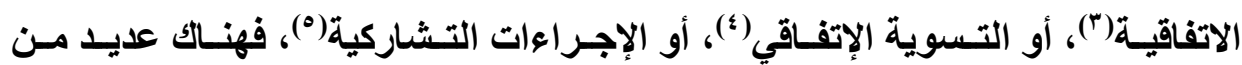

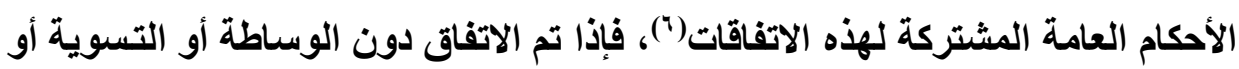

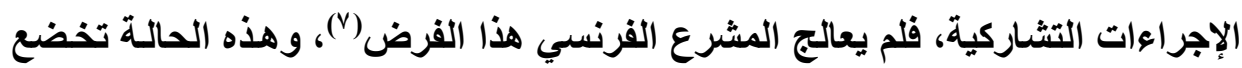
لأحكام المادة Vو 107 من قانون الإجراعات المدنية الجديد(^).

وطبقا لنص المادة ه 10 إجراءات، إذا تم الاتفاق نتيجة الوساطة أو التصالح أو الإجراءات التشاركية، فإنه يكون سندا تنفيذيا بعد مصادقة القاضي المختص من أجل

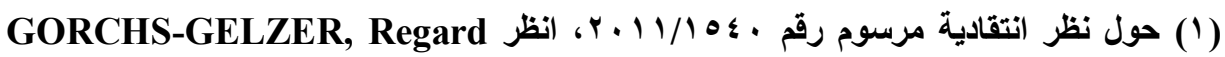
critique sur l'ordonnance no 2011-1540 transposant la directive Jmédiation, op. cit., p. 2.

(2)Didier CHOLET Exécution des jugements et des actes, op. cit., n052,

(3) art. 1532 à 1535 C. pr. civ.

(4) art. 1536 à 1541 C. pr. civ.

(5)FRICERO, POIVEY-LECLERC et SAUPHANOR, Procédure participative assistée par avocat, 2012, Lamy, p. 90.

(6) C. pr. civ., livre III du titre V.

(7)FRICERO, POIVEY-LECLERC et SAUPHANOR, Procédure participative assistée par avocat, op. cit. p. 50.

(8)MARCHADIER, L'attribution de la force exécutoire à la transaction extrajudiciaire après le décret du 20 janvier 2012, Gaz. Pal. 8 déc. 2012. 15. 
التأكـد من أن النزاع يجـوز فيـه التصالح(')، والقاضـي المختص هو رئسيس المحكمـة الابتدائية، ويتبع أمام القاضي نظام الأوامر على عرائض()، ويمكن اللجوء إلى القضاء

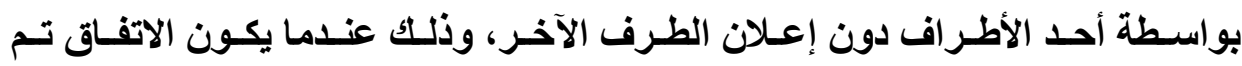
جماعيا(")، كذلك في حالة عدم اعتراض الطرف الآخر على الاتفـاق(")، أو كـان الطرف الآخر أعطى موافقته صـراحة على الوسـاطة(ْ)، وسـلطة القاضسي غير محددة تمامـا بمقتضى النص(")، ولكن ما جري عليه العمل لا يمكن للقاضي تعديل الاتفاق، فيمكن لهـ رفض الاتفاق أو قبوله. ويجب مراقبة الاتفاق مع النظام العام والآداب العامـة، وهذا مـا أخذ به القضاء الفرنسي(V)، فالرقابة تكون شكلية وتتعلق بمدى صحة الاتفاق(^)، وطبقا لنص 1566 إجراعات يصدر القاضي قراره بدون مناقشة للأطراف، والقرار الصادر

(1)STRICKLER et FOULON, Accords et force exécutoire en France, Gaz. Pal. 3 sept. 2013. n. 8

(2) AMRANI-MEKKI, Les nouveaux titres exécutoires : les accords amiables homologués, Dr. et patr. déc. 2013. 55. GUILLEMAIN, Réflexions sur la qualification de l'homologation judiciaire, Gaz. Pal. 22 mai 2012. 12

(3) art. 1557 C. pr. civ.

(4) art. 1541 et 1567 C. pr. civ. AMRANI-MEKKI, Les nouveaux titres exécutoires : les accords amiables homologués, op. cit., 55, GUILLEMAIN, Réflexions sur la qualification de l'homologation judiciaire, op. cit., 12.

(5) art. 1534 C. pr. civ.

(6)MARCHADIER, L'attribution de la force exécutoire à la transaction extrajudiciaire après le décret du 20 janvier 2012,op cit.. 15.

(7) Cass. Civ. 2 e 26 mai 2011, RTD civ. 2011. 559, obs. Gautier.

(8) MAYER, Précisions sur le contrôle "léger " exercé par le juge homologateur d'une transaction, Gaz. Pal. 14-16 juin 2015. 12 
برفض الاتفاق، يكون خاضعا للطعن عليه بالاستئناف، وذلك طبقـا لأحكام الأوراق على عرائض(').

والاتفاقات التي يمنحها القضاء القوة التفيذية لم تشمل فقط المنصوص عليها

في البـاب الخـامس مـن قـانون الإجراعات الفرنسي، والتي تتعلق بـالحلول التوفيقيـة

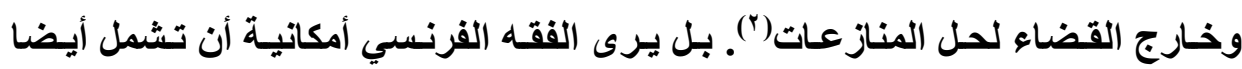
الاتفـاق النـاتج عن توسط شَخص معين من قبل القاضسي (")، هذا الاتفـاق الموقع من الأطراف والوسيط القضائي(؛). ويمكن في هذه الحالة اللجوء إلى القاضي عن طريث الأوامر على العرائض للمصادقة عليها(ْ)، وتطبق هذه القواعد على الاتفاقات التي تتم

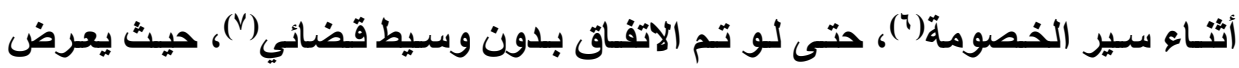
الأطراف الاتفـاق أمسام القاضـي للتصديق عليه(^)، ويجب أن يكون هذا الاتفـاق منهيـا

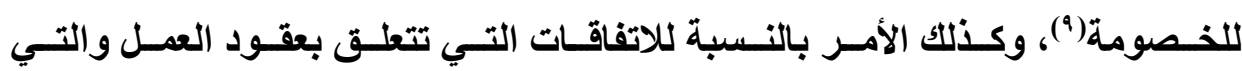

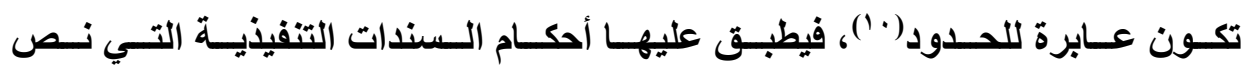

(1) Didier CHOLET Exécution des jugements et des actes, op. cit., n0 or

(2) STRICKLER et FOULON, Accords et force exécutoire en France, op. cit., n. 8.

(3) art. 129-1 à 129-5 C. pr. civ.

(4) art. 130 C. pr. civ.

(5) art. 131, al. 2 C. pr. civ.

(6) art. 131-1 à 131-15 C. pr. civ.

(7) art. 131-12, al. 3 C. pr. civ.

(8) art. 768 C. pr. civ.

(9) art. 384 C. pr. civ.

(10) art. R. 1471-1 C. trav. issu du décr. no 2012-66 du 20 janv. 2012

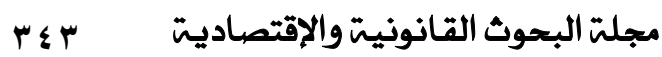




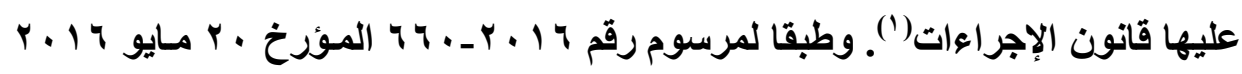
تطبق أحكـام البـاب الخـامس مـن قانون الإجراعات على المنازعـات التي تتعلق بعقد العمل(`)، فمكتب التوفيق يختص بالتصديق على الاتفـاق النـاتج عن التسوية الوديـة للمناز عات العمالية، وذلك طبقا للشروط المنصوص عليها في هذا المرسوم(") وتعد

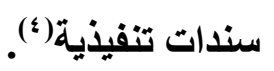

وفي حالـة تصديق القاضـي على الاتفـاق فإنـه يكون أشـبه بمحاضـر الصلح trasnsations ، ويصبح هذا القرار سندا تنفيذيا(ه). وقد يكون القائم بالوسـاطة خبيرا ثم ينتهي إلى حل، فإذا صدق عليه القاضي صار سندا تنفيذيا، وأهمية هذا التجديد تكمن في كونـه أعطى لاتفاقات الأطراف التي تتم خـارج القضاء قوة تنفيذيـة إذا صدق عليها رئيس المحكمة الكلية، فهذه السندات إجراء مركب من إرادة الخصوم وإرادة القاضسي، ولا يحتـاج إلى وقت لإصداره، وإجراء التصديق بواسطة القاضسي أفضل من إجرائسه بمعرفة الموثق. ولا يعد السند التففيذي في هذه الحالـة حكمـا قضائيا بـالمعنى الفني

(1) art. R. 1471-2 C. trav.

(2) Didier CHOLET Exécution des jugements et des actes, op. cit., n0 . ๑

(3) art. R. 1471-1, C. trav., mod. par Décr. no 2016-660 du 20 mai 2016, art. 31

(4)GORCHS-GELZER, Le contrôle judiciaire des accords de règlement amiable, Rev. arb. 2008. 33, CADIET, NORMAND et AMRANI MEKKI, Théorie générale du procès, 2e éd., 2013, PUF, nos $147 \mathrm{~s}$. FRICERO, Accord des parties, homologation, octroi de la force exécutoire : quel rôle pour le juge ?, RJPF 2010-1/8

(5)Cass. Soc. 6 juin 2007, JCP S 2007. 1619, note Brissy. 
الاقيق، ولكنه أقرب إلى محاضر الصلح التي تصدق عليها المحاكم(')، والفرق بينهما أن هذه الاتفاقات تتم بعيدا تمامـا عن تلدخل القاضي، وليس لله رقابـة على مضمونها، ولكنه يراقب ظاهريا اتفاق الوساطة الأي يصدق عليه. وهذه الاتفاقات في الواقعــلا

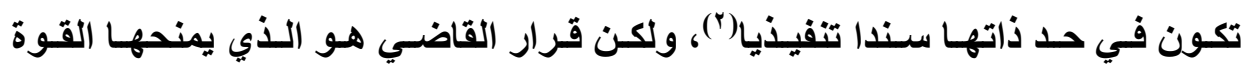
التنفيذية(")، وهذه الاتفاقات يمكن توثيقها وعدها سندا تنفيذيا(")

وهذه الأحكام المتعلقة بالتصديق تثير إثكالية، وخاصة عندما لا ينطبق عليها

الباب الخـامس من قانون الإجراعات الفرنسي، فالتصديق يعد عمـلا قضائي، والذي يسمح للأطر اف بـالاعتراض عليه، ويجب إعلانهـ من أجل التنفيذ، فالطبيعة التعاقديـة لهذه الأعمال غير واضحه للغاية(ث)، ويجب تحديد طبيعة سلطة القاضسي وحدودها في

(1) طبقا لنص المادة ب ـ 1 مرافعات مصري يمكن للخصوم أن يطلبوا من المحكمة اثبات ما اتفقوا

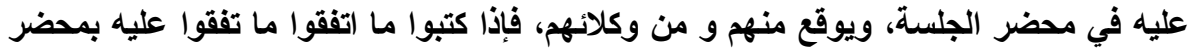

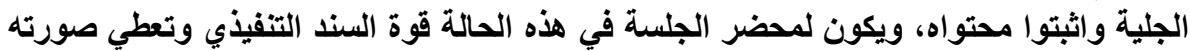

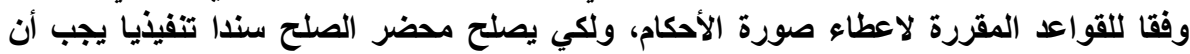

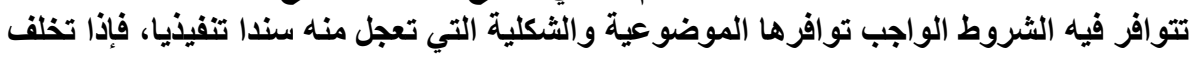

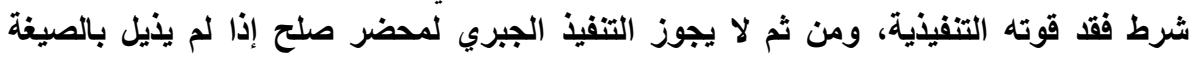

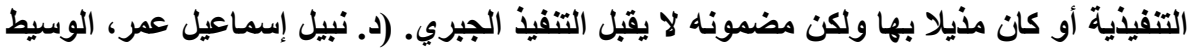

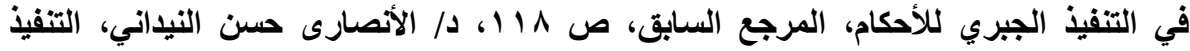

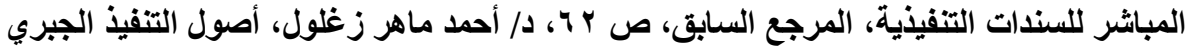
القضائي، المرجع السابق، بند VI V I ).

(2) art. 3 de la L. no 91-650 du 9 juill. 1991 [art. L. 111-3 devenu C. pr. exéc.,], Cass. , avis, 20 oct. 2000, D. 2000. IR 296; JCP 2001. II. 10479, note Desdevises.

(3) Cass. Civ. 2e, 27 mai 2004, D. 2004. IR 1773.

(4) CASS. Civ. 2e, 21 oct. 2010, D. 2010. 2590.

(5)GORCHS-GELZER, Le contrôle judiciaire des accords de règlement amiable, op. cit.. 33; CADIET, NORMAND et AMRANI MEKKI, Théorie générale du procès, op. cit., nos $147 \mathrm{~s}$. 
دا طلعت يوسف خاطر

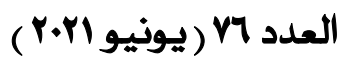

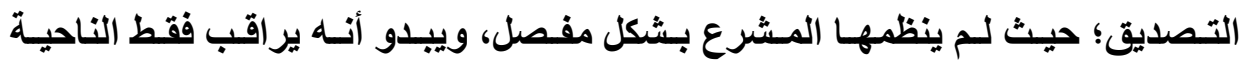
الإجرائية ومدى مخالفة الاتفاق للنظام العام، وفضلان عن مراقبة عمل القاضي، لأن العمل في الأســس يكون اتفـاق الأطر اف وليس عمـل القاضـي(')، ويعد السند عمـلا تصالحيا، شبيها بالصلح أو التوفيق، صسادرا من القاضسي(؟)، حيث إن التنفيذ يكون للقرار القضائي("). ويرى جانب من الفقه أن الاتفاق النـاتج عن ذلك يدون في محضر

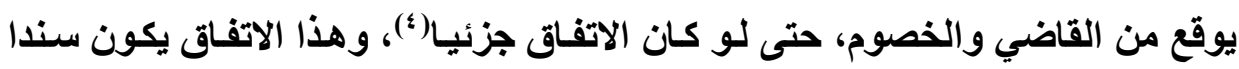
تنفيذيا، حيث لا يكون خاضعا لأي طعن، ولا يحتاج إلى إعلان، حيث إن السند ليس

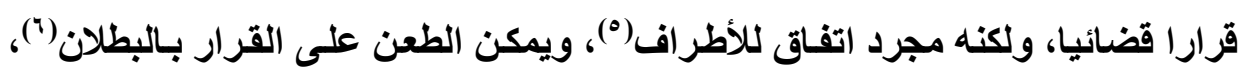

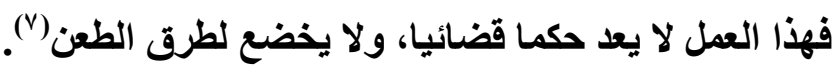
ثالثا: الاتفاقات التي تتعلق بالديون البسيطة

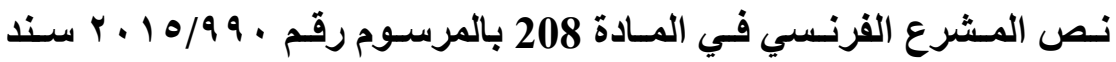
تنفيذي جديد، ويعرف هذا القانون بقانون ماكرون، ويهدف إلى تسهيل تحصيل الديون من أجل النشاط الاقتصادي، حيث يمكن للمضر التدخل لتحصيل الديون البسيطة دون حاجة إلى اللجوء إلى القضاء، فطبقا للمـادة ؟ ؟ ا ام ع مدني، يمكن للمحضر مطالبة

(1) Cass. Civ. 2e, 7 mars 2002, Bull. civ. II, no 29.

(2) FRICERO, Accord des parties, homologation, octroi de la force exécutoire : quel rôle pour le juge?, op. cit., p8.

(3) Cass., avis, 20 oct. 2000, JCP 2001. II. 10479, note Desdevises.

(4) art. 130 C. pr. civ.

(5) CA Paris, 23 janv. 1991, D. 1991. IR 67.

(6) Didier CHOLET Exécution des jugements et des actes, op. cit., n0 4

(7) Cass. Soc. 6 juin 2007, JCP S 2007. 1619, note BrissySoc. 
المدين بدفع الديون صغير القيمة متى كانت ناشئة عن سبب تعاقدي أو نتيجة لالتزام قانوني لا يتجاوز القيمة التي نص عليها القانون ه 1 ـ ب، وإجراءات التنفيذ تكون خلال

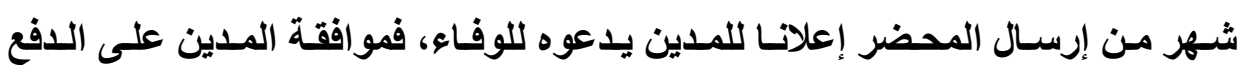
وطريقته باون أي إجراعات شكلية(')، تتم بانشاء سند تنفيذي، ويتحمل الدائن جميع المصاريف في هذه الحالة، ويتم إنشاء السند التنفيذي عن طريق المحضر، وقد أشـارت

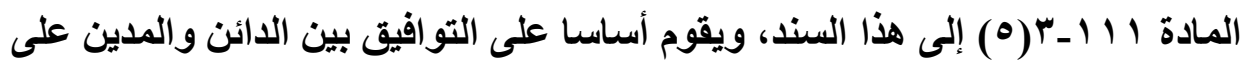
الوفـاء بقيمـة الديون البسيطة. وقد استتبع المشرع الفرنسي تنظيم هذه النوع مـن السندات بالمرسوم رقم 2016/285، الصادر في 9 مارس وذلك عملا بالمادة 208 من قانون 6 أغسطس 2015.

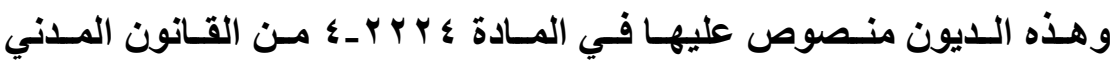
الفرنسي، حيث حددت هذه المـادة إجراءات ميسره لتحصيل هذه الديون، وســح للمحضر استدعاء المدين للاتفاق مع الدائن على قيمة الوفاء وطريقة الدفع، بدون أي

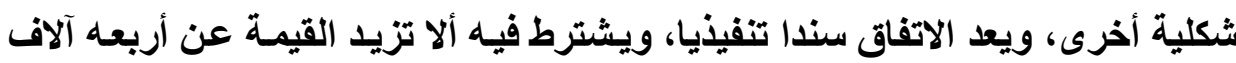
يورو، وذلك إبتداع من أول أكتوبر 17 ـ ب، وقد نصت المادة 111 تنفيذ على هذا النوع من السندات تحت عنوان الإجراءات البسطية لتحصيل الديون الصغيرة('). وهذا السند التنفيذي يقوم المحضر بتنفيذه في نطاق التسوية بين الدائن والمدين على القيمـة وطريقة الدفع، وهذه الديون قليلة القيمة، فلا تحتاج إلى اللجوء إلى القضاء للحصول على سند تنفيذي.

(1) Didier CHOLET, Exécution des jugements et des actes, op. cit., n. 81. (2) Id. 
ويشترط لإعلان المدين أن يطلب اللدائن ذلك، كمـا يشترط ألا تزيــ القيمـة مـع

الفوائد عن أربعة آلاف يورو، ويجب أن تكون هذه الديون ناتجه عن تصرف عقدي أو التزام قـانوني، فضلا عن الإعلان، وتتخـذ الإجراءات خـلال شـهر مـن الإعلان وذلتك بارسال خطاب مسجل بعلم الوصل إلى المدين لإبداء رأيه في المشاركة في الإجراءات، ولا يمكن اتخاذ أي إجراء خلال هذه المدة"'). وهذا الخطاب يجب أن يتضمن البيانـات الآتية: اسم المحضر، واسم الدائن وعنوانه أو مكتبه المسجل، ومقدار المبلغ المستحق في أصل الدين والفائدة، مع التمييز بين العناصر المختلفة للايون(؟). ويجب أن يتضمن

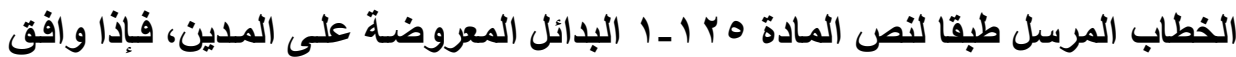
المدين على المشاركة في إجراءات التحصيل فيجب أن يكون ذلك خلال ثُلاثين يومـا من تاريخ استلام الخطاب، سواء تم الاتفاق بطريق وسيط أو عن طريق رسـالة إلكترونية أو إفادة بالقبول، وفي هذه الحالة يقترح المحضر الاتفاق عن القيمـة وطريقة الدفع(")، وفي حالة تم الاتفـاق بين الدائن والمدين يصدر المحضر بدون أي إثكاليات للسند

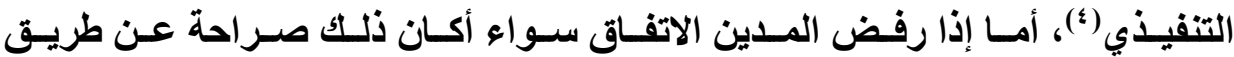
إرســال إفـادة بـالرفض أم بـاي وسـيلة اخـرى، أم عـدم الـرد خـلال المــدة المحـدةة،

(1) Berlioz, limites et difficultés d'exécution de l'acte authentique, op. cit., 1249, Coiffard, authenticité et force exécutoire, l'arbre et le fruit. Op. cit., 1096, Julienne, le caractère exécutoire de l'acte authentique, op. cit., 1250; Templier, la pratique de l'exécution, JCP 2014. 1251.

(2) art. R. 125-1, 10 à 30 C. pr. exéc.

(3) art. R. 125-4) C. pr. exéc.

(4) art. L. 125-1, al. 3 C. pr. exéc. 
دا طلعت يوسف خاطر

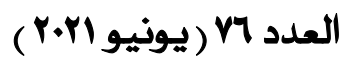

أي بطريق ضمني، ففي هذه الحالة يمكن للدائن اللجوء إلى القاضي للحصول على سند

تنفيذي (1)

ويجب على المحضر عن الكتابة التأكد من الآتي:

- رفض المدين المشاركة في إجراعات تحصيل الديون الصغير عن طريق إرسال

خطاب(r). (ن)

ـ انقضاء مدة شهر من إعلان المدين بدون رد على مشاركته(")

ـ الرفض الصريح للتسوية على قيمة الدين أو طريقة دفعه(؛).

وطبقا لنص المادة ^ r r مدني، تقف مدة التقادم من وقت الاتفاق بين الدائن

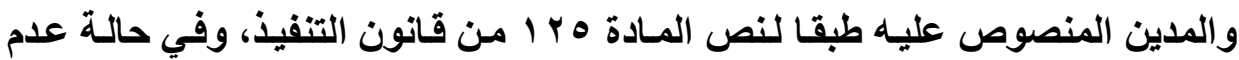

سبر الإجراعات، تبدأ مدة التقادم من تاريخ رفض المدين، الثابت في المحضر ، أو من

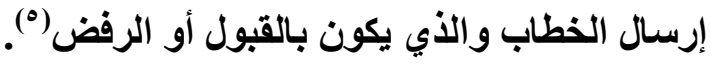

ويلاحظ على موقف المشرع الفرنسي أنسه في المـادة 111 تنفيذ، حساول أن

يوسع في نطاق السندات التفيذية(')، حيث إن أغلب السندات المنصوص عليها في هذه

(1) Berlioz, limites et difficultés d'exécution de l'acte authentique, op. cit., 1249; Templier, la pratique de l'exécution, n.1251.

(2) art. R. 125-5, 10 C. pr. exéc.

(3) Salati, Droit et pratique des voies d'exécution, op. cit., n. 111.

(4) Julienne, le caractère exécutoire de l'acte authentique, JCP 2014. 1250.

(5) art. R. 125-1, II) C. pr. exéc.; Salati, Droit et pratique des voies d'exécution, op. cit., n. 111.

(6) DAGOT, La force exécutoire de l'acte notarié, LPA 6 janv. 1993, p. 23; GORE, L'acte notarié, instrument de l'exécution forcée, LPA 11 août 1997, p. 5. 
المادة تصدر عن السلطة العامة، فقد حاول المشرع أن يوسع في انثاء السندات خارج

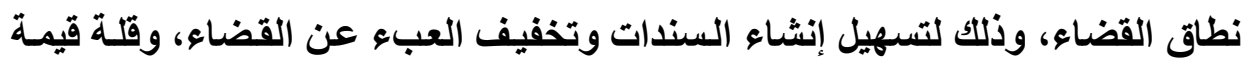

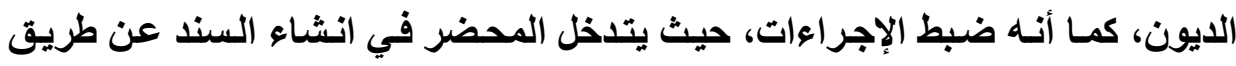

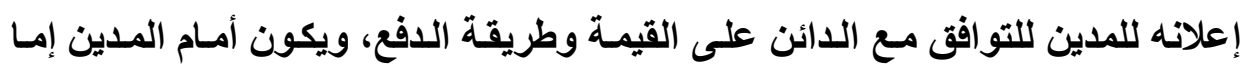

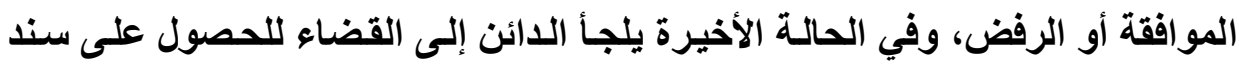

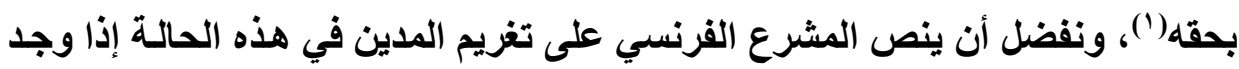

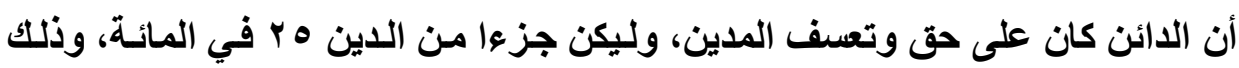
لحث المدين على المشاركة في الإجراءات، مع علدم الإخلال بالتعويضات.

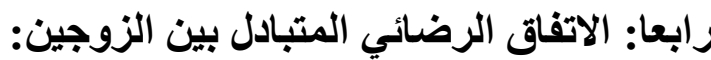
نص المشرع الفرنسي على عدّ الاتفاق الرضائي على الطلاق بين الزوجين

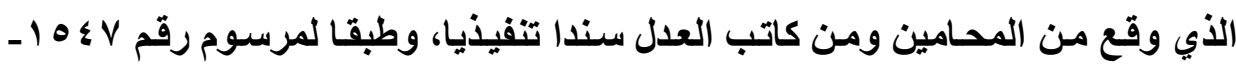

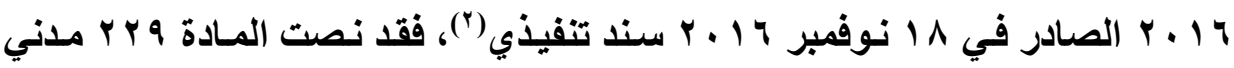
على أنه يمكن للزوجين الاتفاق على النفقة والطلاق عن طريق المحامين، ويتم اداعه التهائ

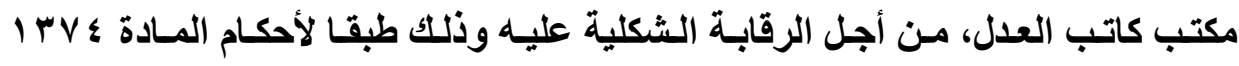

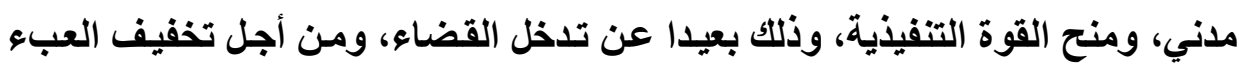

(1) Valerio FORTI, Exécution forcée en nature, op. cit., n.98.

(2)Nonnenmacher, de quelques aspects de la force exécutoire du divorce non judiciaire, JCP, 2017, 1338; FRICERO, POIVEY-LECLERC et SAUPHANOR, Procédure participative assistée par avocat, op. cit., p, 51. 
عن المحاكم والسرعة في الإجراءات، ومن ثم يصبح سندا تنفيذيا يمكن بناء عليه البدء

في التنفيذ وذلك طبقا لنص المادة 11 ــ ــ من قانون التنفيذ(').

الفرع الثالث

\section{هوقف المشترع المصري هن عد المحررات العرفية والرسمية سندات تنفيذية}

سنشير إلى عدم عدّ المحررات العرفية والمحررات الرسمية ــ ماعدا المحرر

الموثث سندات تنفيذية، ثم اقتراح بتعديل موقف المشرع المصري، وذلتك في النقاط

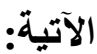

أولاً: عدم عدّ المحررات العرفية والرسمية ـماعدا المحرر الموثقـ- سندات

\section{تنفيذية}

لـم يعترف المششرع المـصري بـصفة السندات التنفيذيـة للمحررات العاديـة، وبالنسبة للمحررات الرسمية، فلم يعترف بصفة السند التنفيذي إلا للمحررات الموثقة، وهذا الاتجاه التقليدي حافظ عليه المشرع المصري منذ صدور قانون المرافعات الحالي. ولم يمنح المشرع المصري أي دور لـلإرادة في تكوين السند التنفيذي معدا المحرر الموثث باعتباره عملا إجرائيا ذات طابع عام. ومن ثم يخرج عن فكرة السند التنفيذي الأوراق المثبتـة لتصرفات موضـوعية ولـو كسان القـانون يخص هذه الأوراق بمسمى خــاص بهـــا، كــالأوراق العرفيـــة والأوراق التجاريـــة والأوراق الماليـــة والأوراق الرسـية، فالتصرف الموضـوعي لا يرتب أي أثُر تنفيـذي بـالمعني القنـي في قـانون

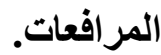

(1) Gijsbert, divorce sans juge: le notaire peut-il apposer la formule exécutoire?, Defrénois 14 sept. 2017, p. 27 ; Nonnenmacher, de quelques aspects de la force exécutoire du divorce non judiciaire, op.cit.. 1338. 
ويرى جانب من الفقه أن المحررات الموثقة تختلف عن الأوراق العرفية؛ فلا تعد الأوراق العرفية سندات تنفيذية حتى ولو صدق على التوقيع الوارد بها رسميا أو حتى لو حكم بصحة هذا التوقيع، ولا عبرة باتفـاق الخصوم على أن ورقة عرفيـة مـا تكون لها القوة التفيذية(')، وإذ مثل هذا الاتفاق لا يتفق مـع أسس التقاضسي ولا يؤمن معه الاعتساف عن أنـه يخـالف النظام العـام، ومن ثم لا يملك قلم المحضرين إجراء التنفيذ بمقتضى مثل هذه الورقة العرفية(؟). وقد يبدو لنا غريبا أن تكون للمحررات الموثقة فقط القوة التنفيذية التي يقوم بتـريرهـا أشـخاص ليسوا قضاة القوة التنفيذيـة نفسها التي للقرارات الصادرة مـن القضاة، فالالتزام الذي يتعهد به الشخص أمسام الموثق يمكن تنفيذه جبر|("). ولا يمنح هذه القوة التففيذيـة للسندات الرسـية الأخرى، خاصـة وأن الأسـاس القـانوني للقوة التنفيذيـة للمحررات الموثقة يرجـع إلى الخضوع الإرادي للمدين للمحرر الموثثى(؛)؛

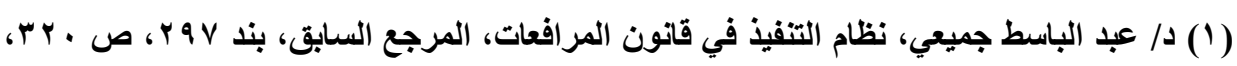

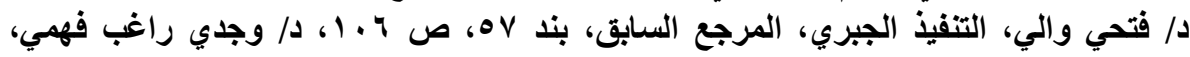

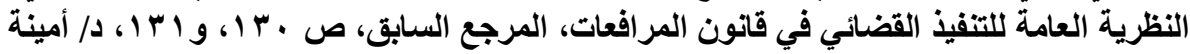

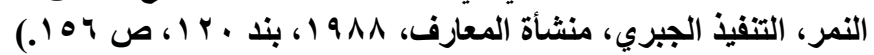

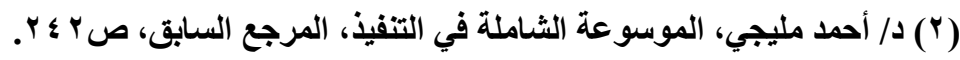

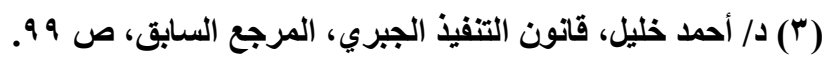

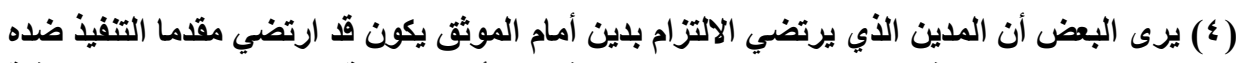

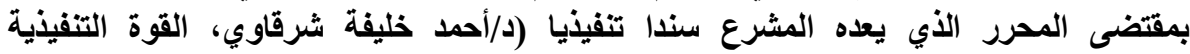

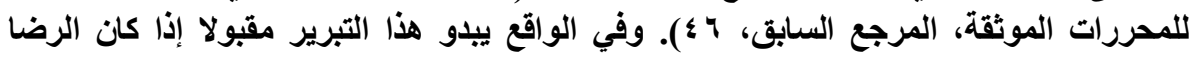

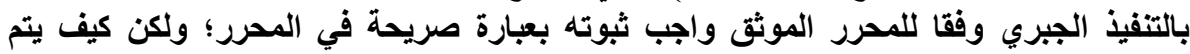

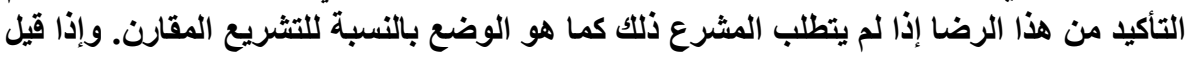

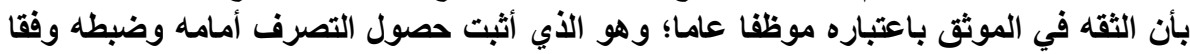

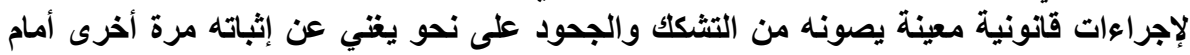

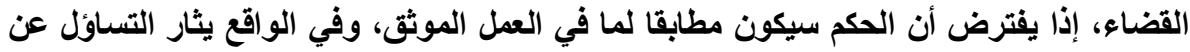
سبب الثقة في الموثق وعدم الثقه في غيره من الموظفين العموميين؟ 
وهذه الحكمـة متـوافرة فـي جميـع المحررات العرفيـة والرسـية، والتـي تشثير إلـى الخضوع الإرادي للأطر اف للالتزام المشار إليه في المحرر.

ويرى بعض الفقهـ أن تصرف الموثق ليس سندا تنفيذيا')، بل هو العمل التحضيري للسند التنفيذي، لأن السند التنفيذي عمل إجرائسي ذو طابع عـام، فليس

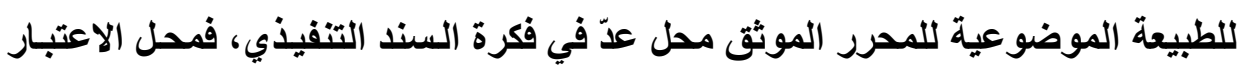

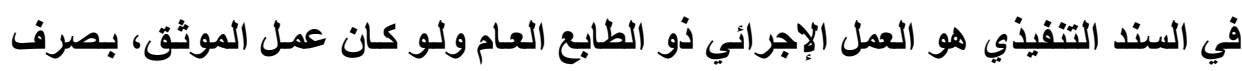

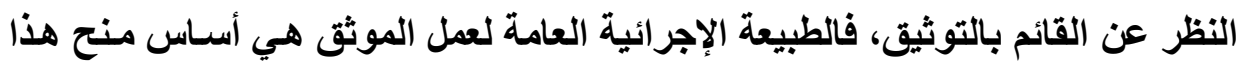
العمل الإجرائي قوة تنفيذية.

والقانون المصري لا يمنح عمل المأذون الشرعي قوة تنفيذية؛ وعلة ذلك أن

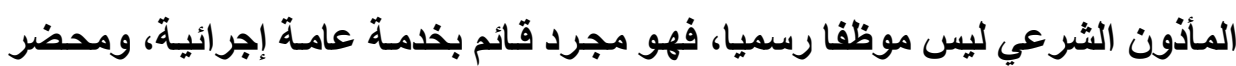
التوثيق هو محضر رسمي بمفهوم الرسيمة في قانون الإثبات، كما أن القانون لا يطمئن

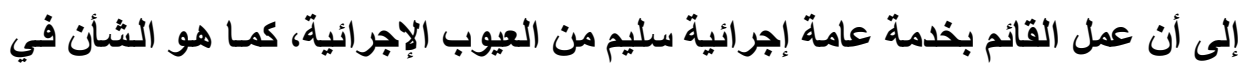

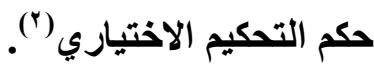
وإذا كانت المادة 280 مر افعات لا تعتد بالسندات العرفية كسند تنفيذي، ولكن المشرع المصري نظم طريقا لتسهيل حصول صاحب الحق على سند تنفيذي وذلك عن

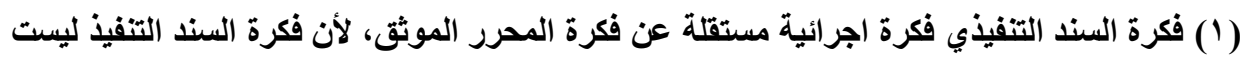

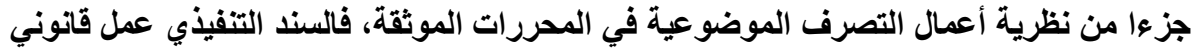

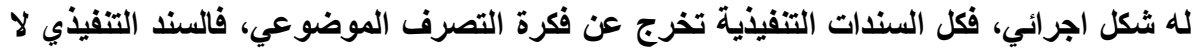

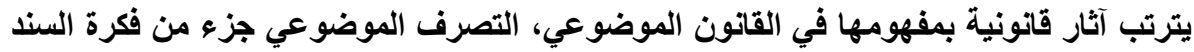

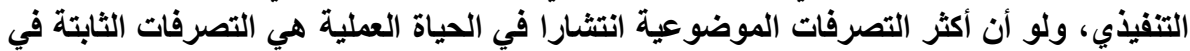

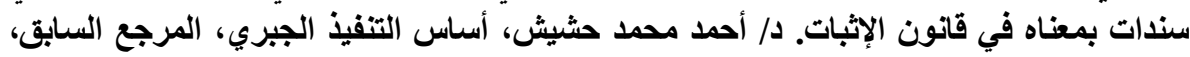


طريق استصدار أوامر الأداء من المحكمة المختصة إذا توافرت فيها شروط استصدار أمر الأداء(')، ويعد أمر الأداء في هذه الحالة سندا تنفيذيا يعطي للائن الحق في التنفيذ

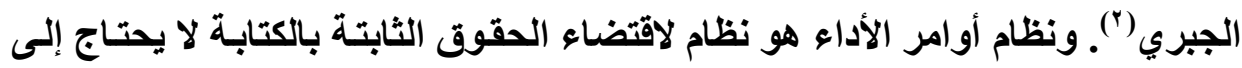

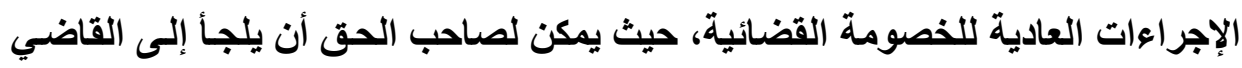
لاستصدار أمر بأداء الحق(") إذا توافر الشروط الآتية: أن يكون مبلـفا من النقود أو

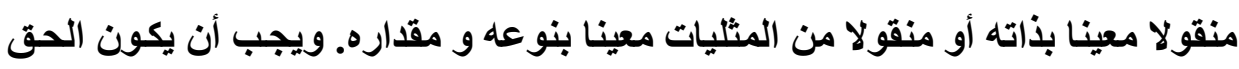

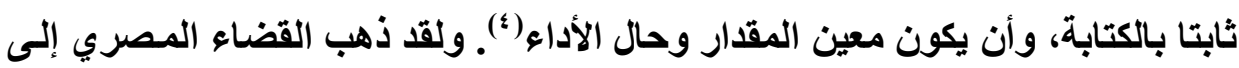
أن أوامر الأداء و إن كانت تصدر بطريقة تختلف عن الإجراءات المعتادة لرفع الدعوى،

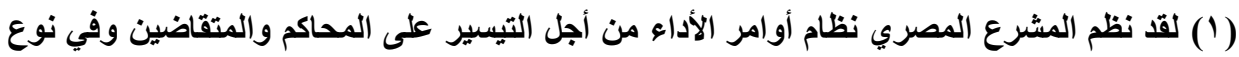

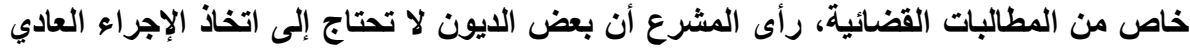

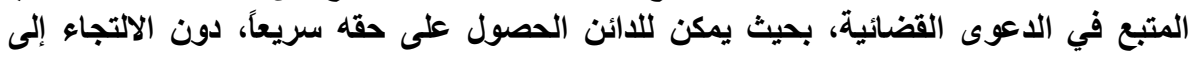

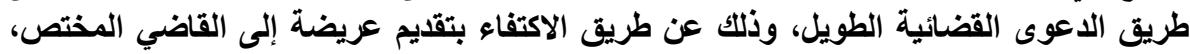

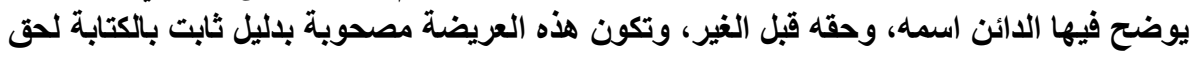

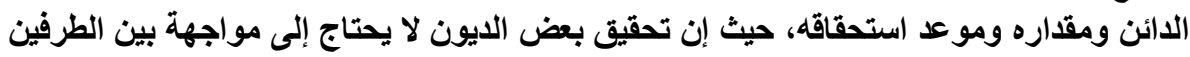

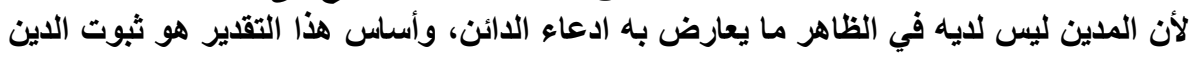

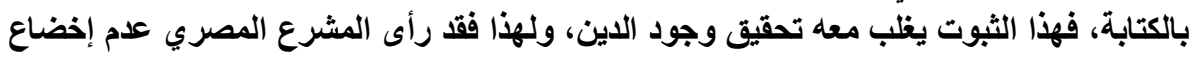

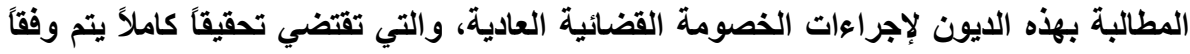

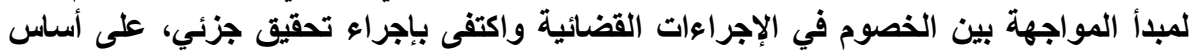

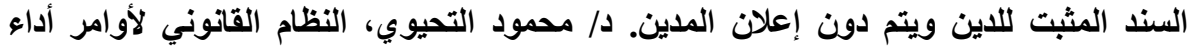

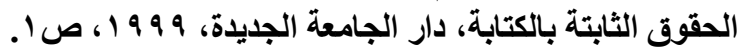

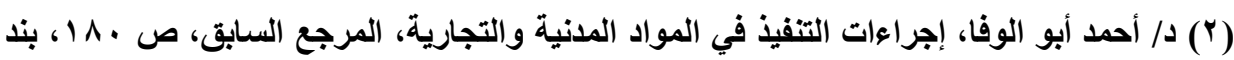
.$\wedge 7$

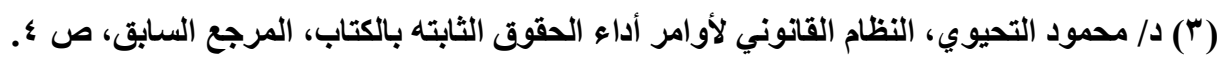

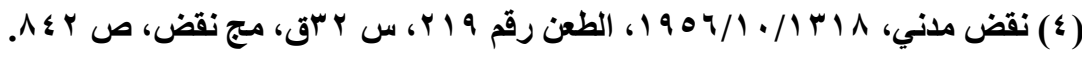


و تثبه طريقة استصدار الأوامر على العرائض ـ فإنها تصدر بموجب السلطة القضائية للقاضى لا الو لائية، و لها ما للأحكام من قوة. (') ثانياً: اقتراح بعَّ المحررات العرفية والرسمية سندات تتفيذية المشرع المصري لا يعترف بسلطة الإرادة الخاصة لأطراف العمل في تكوين

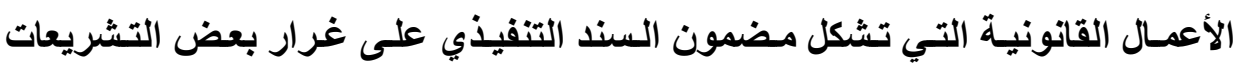

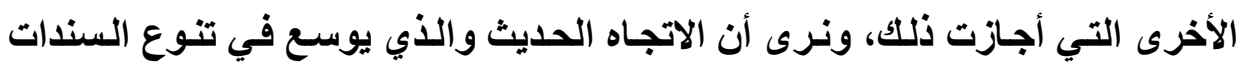

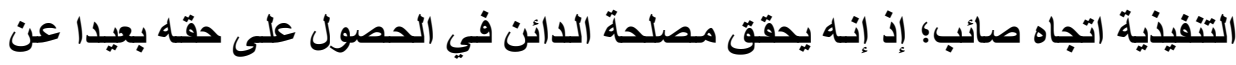
الإجراءات المطولة أمام القضاء، والإعفاء من كثرة التكاليف، خاصة وأن اللجوء إلى الهى

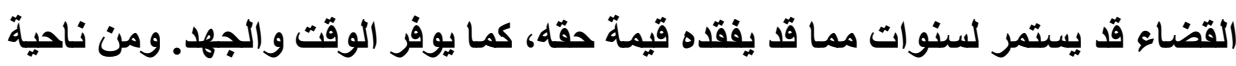

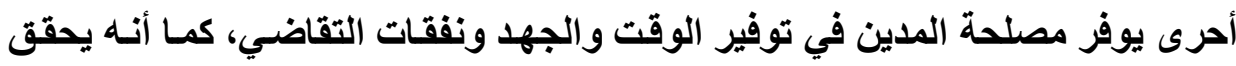
المصلحة العامـة في تقليل عدد القضايا المكلسـة بالمحساكم، ويقوي الانتمـان ويجلب

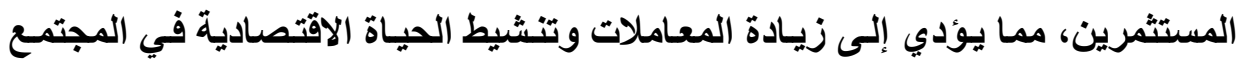
لاسيما في ظل التطور الاقتصادي الهائل الذي يشهده العـالم ويسير بخطى سريعة،

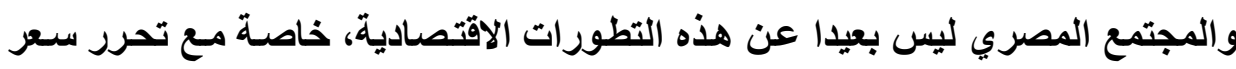

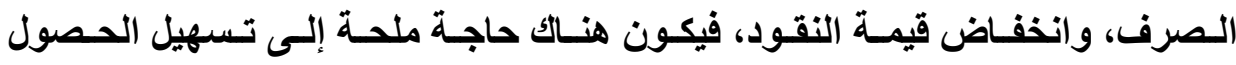

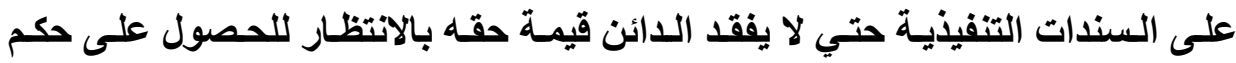
قضائي.

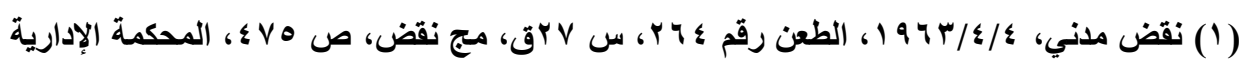

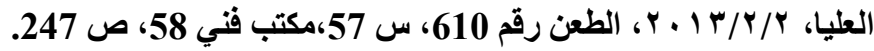


ونقترح أن يـص المسشرع على عدّ المحررات الرسـمية والعرفيـة سـندات

$$
\text { تنفيذية، ويكون التنظيم على النحو الآتي: }
$$

أولاً: إضافة فقرة إلى نص المـادة • ـ ب مرافعات تنص على أن: " السندات التنفيذيـة

هـي... المحـررات العرفيـة..."، وأن تـستبدل كلمـة المحسررات الموثقـة بكلمـة

$$
\text { المحررات الرسمية. }
$$

ثانياً: إضافة مادة تتضمن استدعاء المدين عن طريق مدير إدارة التفيذ في المحررات

$$
\text { العرفية لإيضاح موقفه على النحو الآتي: }
$$

ا ـ إذا حضر وأقر بـالحق في المحرر العـادي، أثبت ذلك في محضر وعد سندا

$$
\text { تنقيذيا. }
$$

r- إذا حضر المدين واعترض على الحق في المحرر العرفي حرر رئيس إدارة التنفيذ محضر ا بذلك، وأحسال الأطراف إلى محكمة الموضوع المختصة، وإذا ثبت عدم أحقية المدين في الاعتراض حكم عليه بغرامة لا تقل عن ربيع قيمـة المبلغ المدون في الورقة العرفية، مع أحقية الائن بالتعويض.

r- إذا حضر المدين وأقر بـالحق ولكنـه نـازع في الأجل، فبإن مدير إدارة التفيذ يحيل النزاع إلى قاضي التنفيذ ليحم في هذه المسألة.

ع- إذا لم يحضر المدين بعد اعلانـه لشخصه أو إعلانـه مرتين، فبإن مدير إدارة التنفيذ يعد الورقة العرفية صحيحة، ويعد سندا تنفيذيا، ويمكن للمدين أن يلجأ إلى المحكمة العادية للاعتراض، وله أن يطلب منها وقف التنفيذ. 


\section{خلاصة الفصل الأول}

نخلص من هذا الفصل إلى أن بعض الأنظمة شرعت بتظيم سندات تنفيذية حديثة تتوافق مع التحولات والتطورات الاقتصادية الحالية، ولاسيما في مجال اقتضاء الحقوق واستيفائها والتعجيل بالوفاء بالديون، فطبقا لبعض الأنظمة القانونية مثل

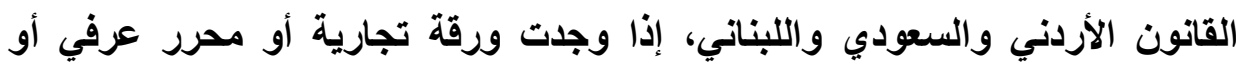
محرر رسمي، تضمن حقا معين المقدار وحال الأداء فيكون سندا تنفيذيا. فيجوز لحامل الورقة التجارية أو المستفيد منها مراجعة دائرة التنقيذ في بعض الأنظمة القانونية

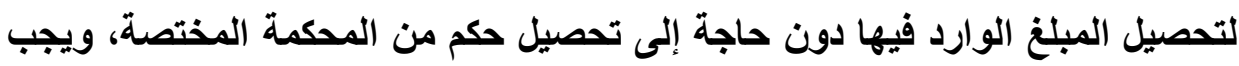

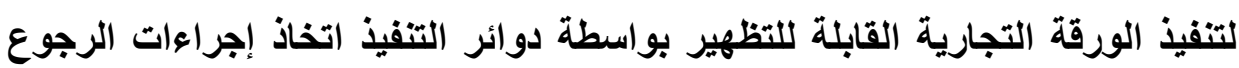
المقررة في القانون التجاري، كتقيم احتجاج عدم وفاء المسحوب عليه في سند السحب، وإشعار المظهرين والكفلاء خلال المدة المقررة في القانون.

وبالنسبة للقانون الفرنسي فقد اعترف بالثيك كسند تنفيذي، كما عدّ اتفاقات

الخصوم التي تتم بطريق الوساطة سندات تنفيذية.

وبالنسبة للنظام المصري، لم ينص على عدّ الأوراق التجارية أو المحررات

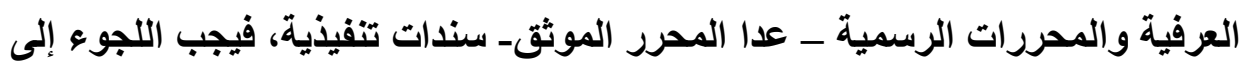
القضاء للحصول على حكم أو أمر. ولا شكك في أن ذلك فيه إرهاق للائن وزيادة تكاليف خاصة، مع تعقيد الإجراءات أمام المحاكم. 


\section{الفصل الثاني \\ التطورات الحديثة في تفعيل إجراءات \\ تنفيذ السندات التنفيذية فيتية}

إذا كانت جميع الأنظمة القانونية الحديثة قد منعت الدائن من مباشرة إجراعات

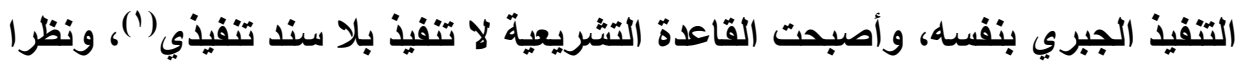

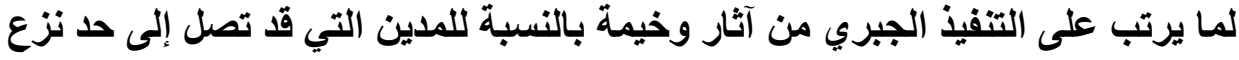

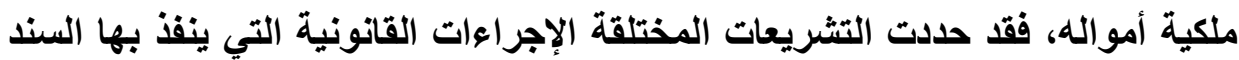
التنفيذي، فلا يستطيع الدائن مباشرة التنفيذ الجبري بدون اتباع الإجراءات القانونية الأجئية التي نص عليها المشرع)" . وقد اختلفت الاتجاهات التشريعية في تنظيم قواعد التنفيذ الجبري إلى اتجاهين؛ الأول: أن تكون هذه القواعد ضمن نظام المرافعات كما هو الثأن

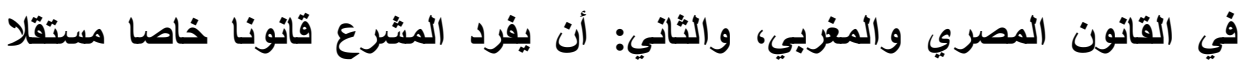
لإجراءات التنفيذ، وذلك كما في الأردن والعراق والنظام السعودي الحالي والنظام

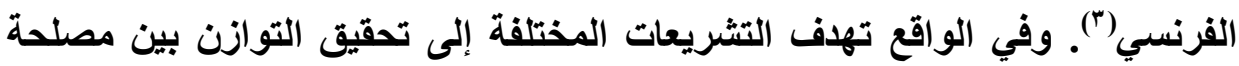

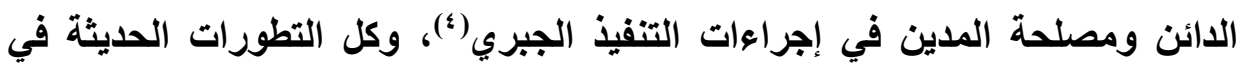

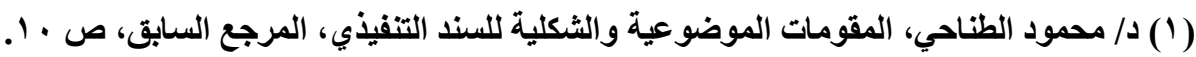

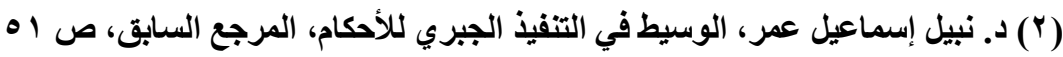

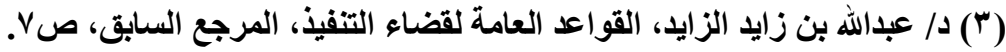

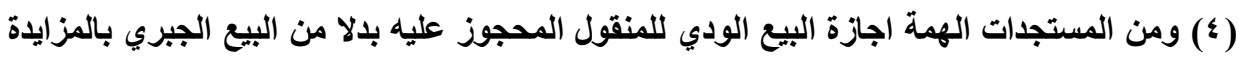

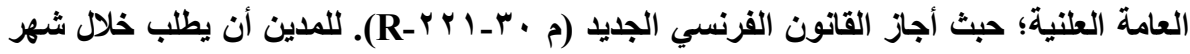

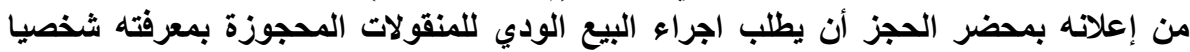

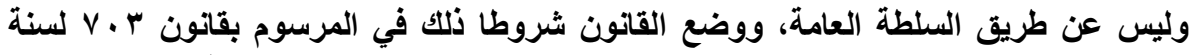

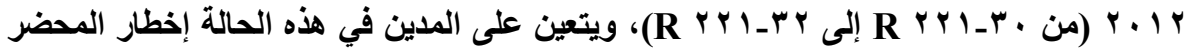

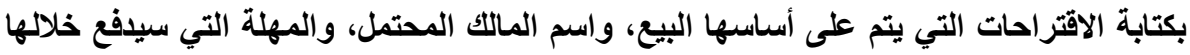
$=$ 
الأنظمة القانونية المختلفة تهاف إلى غاية واحدة؛ وهي تحقيق التوازن بين المصالح

ولن نتتاول بالتفصيل إجراءات تنفيذ السندات التنفيذية، فكان دراستها

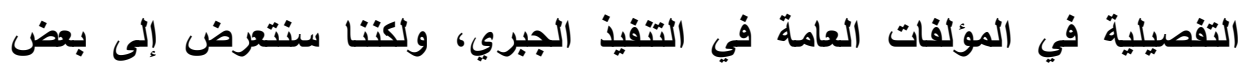

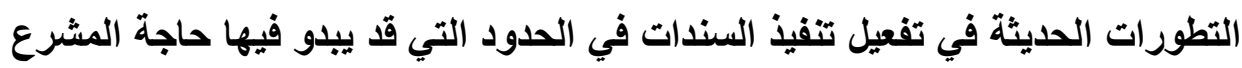
المصري إلى النظر في هذه التطورات في القانون المقارن.

وسنشير إلى التطورات الحديثة في تفعيل إجراءات تنفيذ الأحكام والأوامر

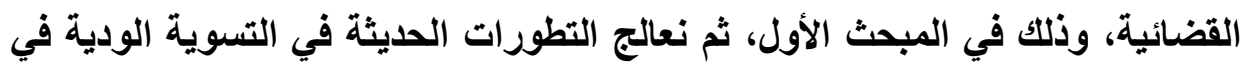

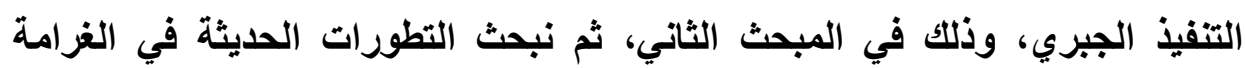

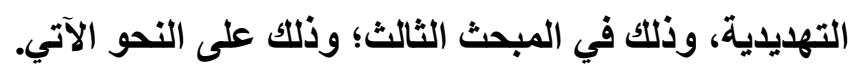

المشتري الثمن المقترح. وعلى المحضر اخطار الدائن الحاجز وغيره من المتدخلين أن وجدوا

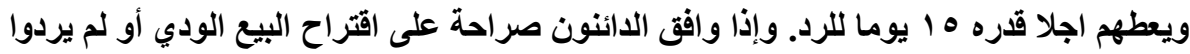

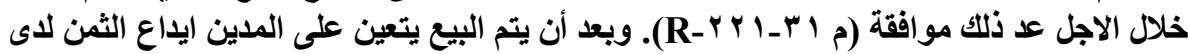

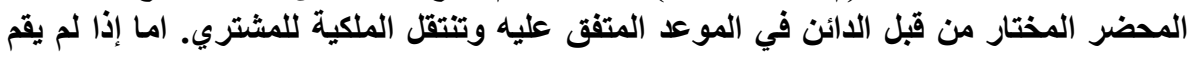

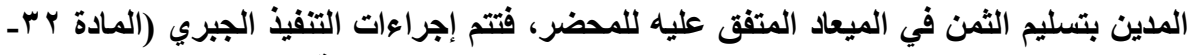

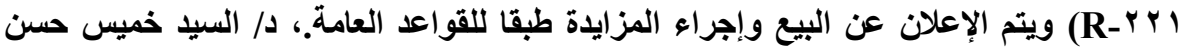

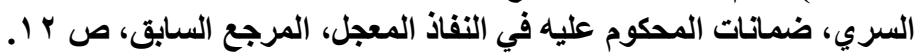

Xavier DAVERAT, Saisie : protection du débiteur, op. cit. p, 20.

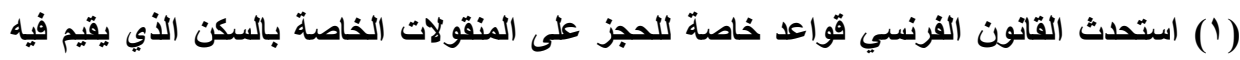

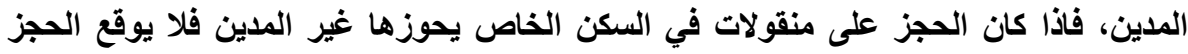

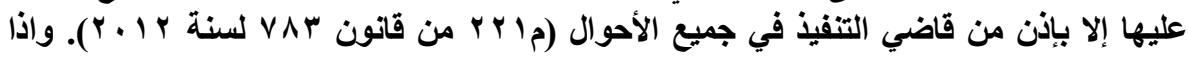

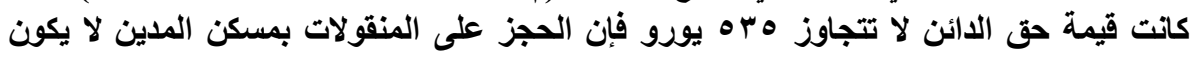

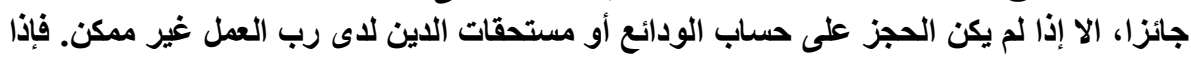

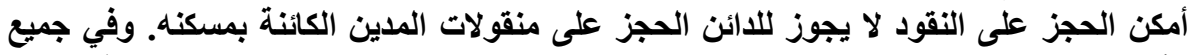

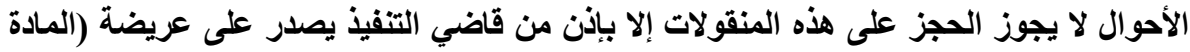

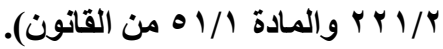




\section{المبحث الأول \\ التطورات الحديثة في تفعيل \\ إجراءات تنفيذ الأحكام والأواهر القضائيسة}

لا يعد الحكم سنـا تنفيذيا إلا إذا تـوافرت فيـه شروط معينة؛ أولها؛ أن يكون

الحكم صادرا بالإلزام(')، فلا يجوز تنفيذ الحكم المقرر أو الحكم المنشأ، ولم يتضمن هذا

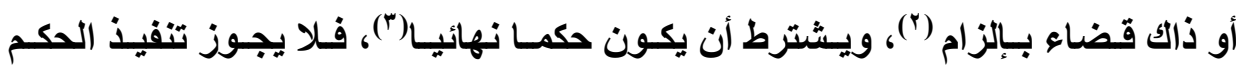
الابتدائي إلا إذا كان ناقذا نفاذا معجلا.

ويمنـح القضاء إلى جانب الحمايـة القضائية نوعـا أخر مـن الحمايـة تسمى

الحماية الولائية، حيث يصدر عن القضاء نـوعين من الأوامر؛ أولهمـا: الأوامر على هولى عرائض، والأخر: أوامر الأداء. وهذه الأوامر لها أهمية كبيرة في الواقع العلي نظرا لما تتميز به من بساطة الإجراءات وسرعتها.

وسنشير إلى التطورات الحديثة في التنفيذ المعجل للأحكام، وذلك في المطلب

الأول، ثم نعالج التطورات الحديثة في تفعيل تنفيذ الأوامر القضائية، وذلك في المطلب

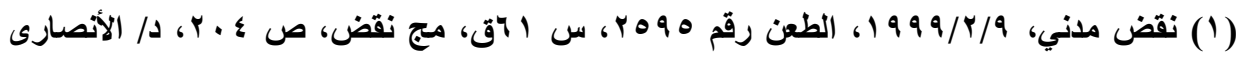

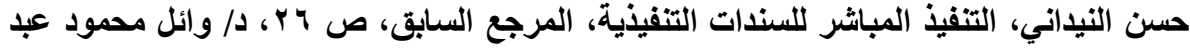

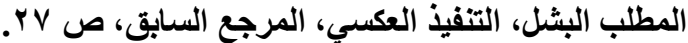

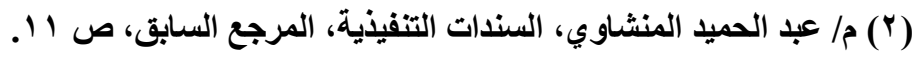
(3) Civ. 2e, 6 janv. 2012, D. 2012. Pan. 1509, obs. Leborgne. 


\section{المطلب الأول \\ التطورات الحديثة في التنفيذ المعبل للأحكام الاول}

تأخذ أغلب التشريعات المقارنة بمبدأ التقاضى على درجتين(')، فلا تعترف بالقوة التفيذية إلا بالنسبة للأحكام النهائية أو الناقذه نفاذا معجلا(؟)، فيجب أن تكون الأحكام حائزه على قرر كاف من الاستقرار والثبات كي تستكمل بناءها القانوني لتشكل

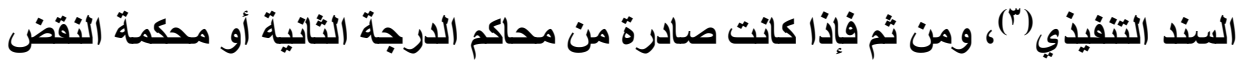
فإنها تنفذ نفاذا عاديا (4)، أما إذا كان الحكم صادرا من محكمة أول درجة فإنها لادهن ينفة

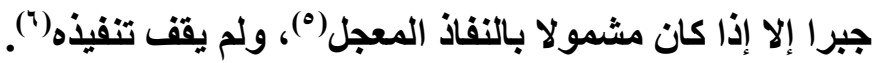

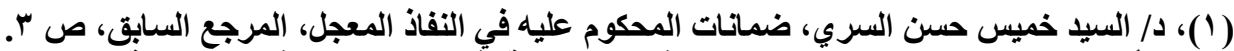

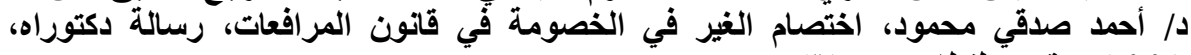
ا

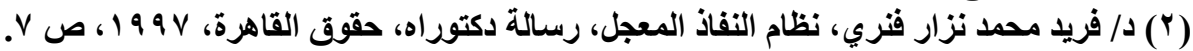

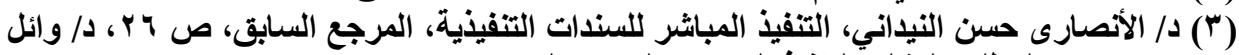

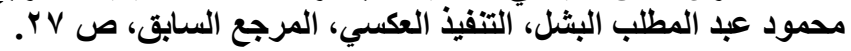

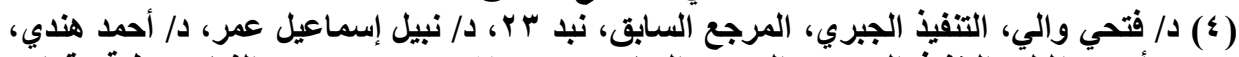

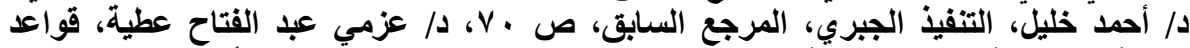

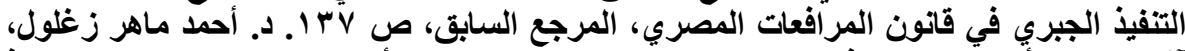

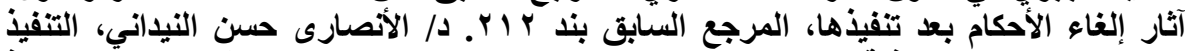

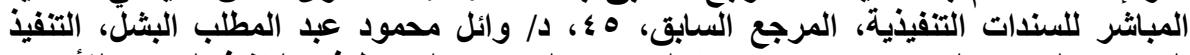

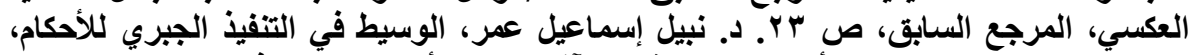

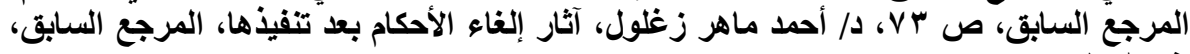

Civ. 2e, 15 sept. 2016, JCP 2016. 1034, note Dorol, Civ. 2e, 18 déc. 2003,

Bull. civ. II, no 401.

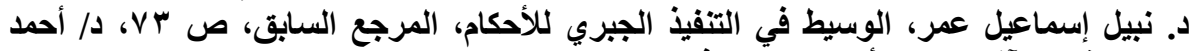

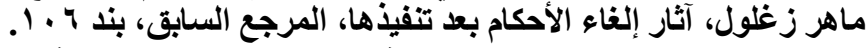

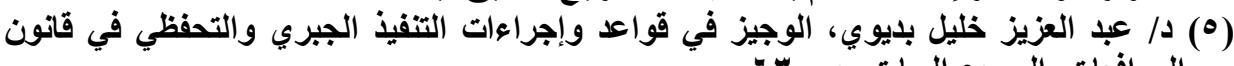

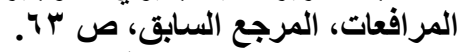

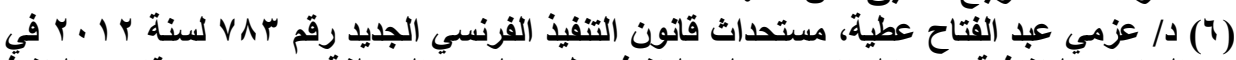

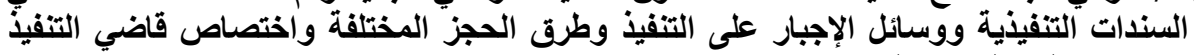

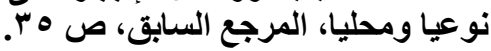


وسنشير إلى ماهية التفيذ المعجل، وذلك في الفرع الأول، ثم نبحث التطورات الحديثة في تفعيل التنفيذ المعجل في النظام الفرنسي، وذلك في الفرع الثاني، ثم موقف المشرع المصري من تفعيل التفيذ المعجل، وذلك في الفرع الثالث.

\section{الفرع الأول \\ ماهية التتنفيذ المعبل}

ذهبت أغلب القوانين المقارنة إلى ربط القوة التفيذية للحكم بحيازته قوة الأمر

المقضي(')؛ أي بزوال الطعن فيه بطرق الطعن العادية(؟)، وقد نصت على ذلك المادة مرافعات والمادة ا .0 إجراعات فرنسي على أنه لا يجوز تنفيذ الأحكام جبرا مادام الطعن فيها بالاستئناف جائز)("آ). وترجع الحكمة من ذلك إلى أن الأحكام الانتهائية تتمتع بالاستقرار الأي يسمح بتنفيذهاء). والهدف من تقرير هذه القاعدة حماية مصلحة المدين، ولكن في بعض الظروف قد تتعرض مصلحة الدائن للخطر حال تأخير

(1) Cass. Civ. 2e, 21 sept. 2000, D. 2000. IR 276.

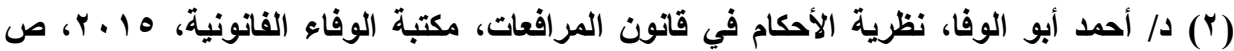

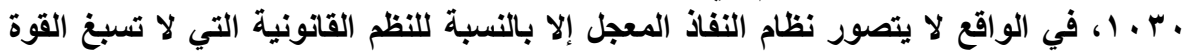

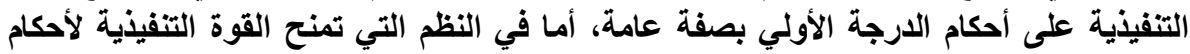

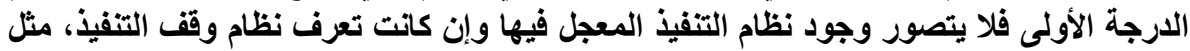

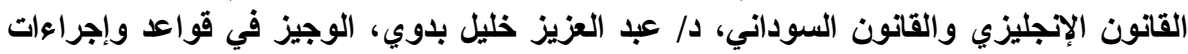

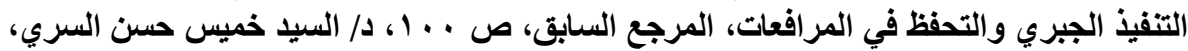

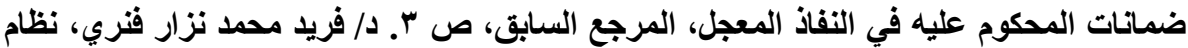

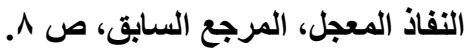

TGI Paris, 15 mai 1990, D. 1990, p.553.

(3)Cass. Civ. 2e, 2 mai 1984, Bull. civ. II, no 74; Cass. Civ. 2e, 9 oct. 1991,

Bull. civ. II, no 243.

(؛) د/ عزمي عبد الفتاح عطية، قواعد التنفيذ الجبري في قانون المرافعات المصري، المرجع السابق، 
تنفيذ الحكم(')، ولاعتبارات معينه تتمثل في أن تأخير التنفيذ حتي يحوز الحكم قوة الأمر

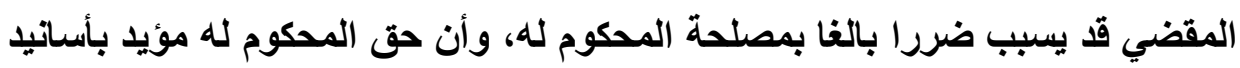

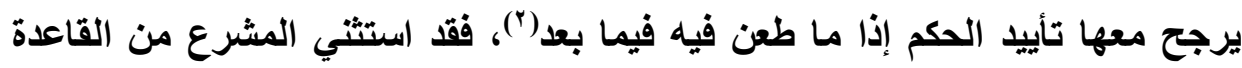
العامة في التتفيذ حالات معينة قرر فيها صلاحية الأحكام غير الحائزة لقوة الأمر المقضي لإجراء التتفيذ الجبري، وهذا ما يطلق عليه التنفيذ المعل للأحكام ("). ويقوم

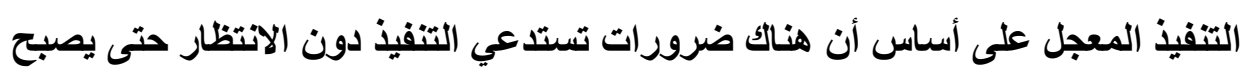

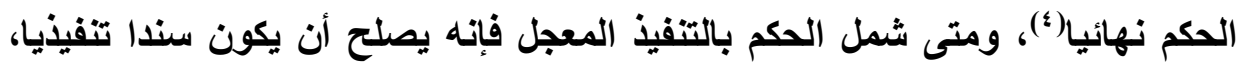
ويمكن مباثرة التنفيذ الجبري واتخاذ كافة الإجراءات، ما لم يكن التنفيذ عن طريق

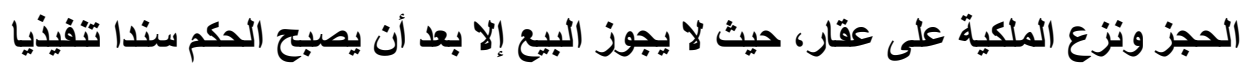

(1)، د/ السيد خميس حسن السري، ضمانات المحكوم عليه في النفاذ المعل، المرجع السابق، ص 9.

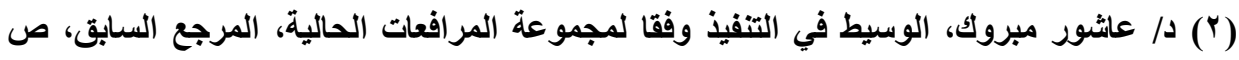

("آ) استخدم المشرع المصري مصطلح " النفاذ المعجل" إلا أن بعض الفقه ذهب إلى أن هذا المصطلح

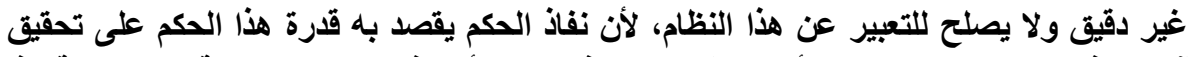

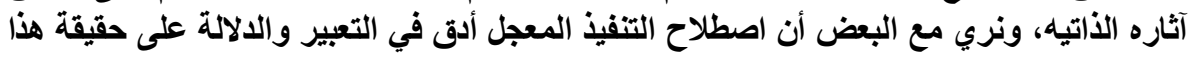

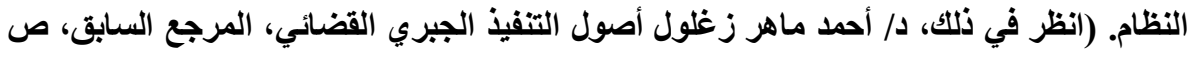
(ع) د/ عبد العزيز خليل بديوي، الوجيز في قواعد وإجراءات التتفيذ الجبري والتحفظي في قانون

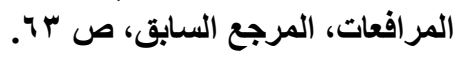

(5) Art. 111-10 code de l'exé. 
وسنشير إلى تعريف التنفيذ المعجل، وأنواعه، وذلك في النقاط الآتية:

$$
\text { أولا: تعريف التنفيذ المعجل }
$$

لـم يعرف المشرعان المـري والفرنسي نظـام التنفيذ المعجل، وتركـا هذه المهمة للفقه، فقد عرفه الفقه الفرنسي بأنـه المكنة المتاحة للطرف الرابح في تنفيذ الحكم مباشـرة رغم الإستئناف أو المعارضـة(1)، ولكن بصفة مؤقتة، أي مـع انتظـار نتيجة الطعن في الحكم، فإذا تأيد الحكم فبإن المحكوم لـه يحتفظ بمـا أخذ، وإلا فعليه أن يرده(؟). وعرف الفقه المصري التنفيذ المعجل بأنه" نفاذ الحكم رغم قابليته للطعن فيه بطرق الطعن العادية أو الطعن فيه فعلا بإحد هذه الطرق"("). وقد عُرف بأنـه "وسيلة فنية بمقتضاها يضع المشرع نظامـا قانونيا يخول المحكمة أو الشخص منح أو طلب تنفيذ الحكم الابتدائي قبل أن يصير انتهائيا نظرا لوجود دواع مهمـة تستدعي مثل هذا التنفيذ المبكر للحكم القضائي"(؛)، وعرفة البعض الآخر بأنـه النظام الذي يتيح تنفيذ الحكم رغم الأثر الموقف لطرق الطعن العادية(ْ)، وهو يعد بمثابة عدالة سريعة ووسيلة للحـد مـن الممارسـات التسويفية مـن قبـل المحكوم عليـه("). وقـ عُرف بأنسه إمكاتيـة

(1)Cass. Civ. 2e, 10 mars 2005, Bull. civ. II, no 60.

(2) R. Perrot, institutions judiciare, 4e ed. 1992, domat, p. 556.

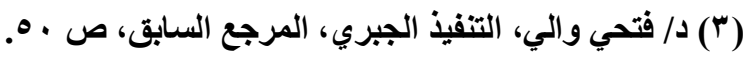

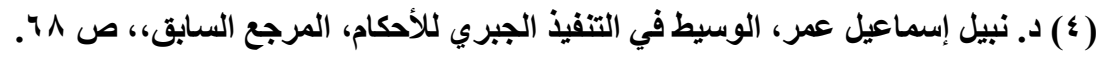

(5) Cass. Civ. 2e, 2 mai 1984, Bull. civ. II, no 74; Cass. Civ. 2e, 9 oct. 1991, Bull. civ. II, no 243. 
الشروع في تنفيذ الحكم قبل أن تكتمل شرط النهائية في الحكم لأن وقت تكاملها لم يحل

ويعد التنفيذ المعجل من أفكار الحمايـة القانونيـة الوقتيـة التي تواجـه الخطر

اللاهم الذي يتعرض لـه أصل الحق، وتهدف إلى حمايـة هذا الحق مـن خلال التتفيذ

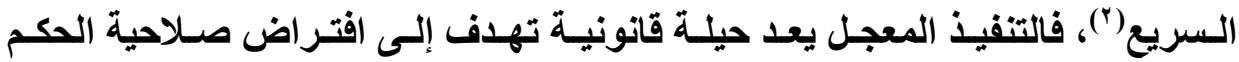
للشروع في التنفيذ الجبري قبل أن يصير هذا الحكم حائزا للصفة النهائية("). وهو نظام يخـالف القاعدة العامـة في تنفيـذ الأحكـام (4)؛ فرغم قابليـة الأحكـام للطعن العـادي أو

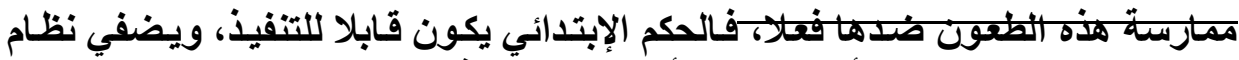

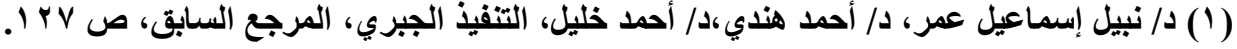

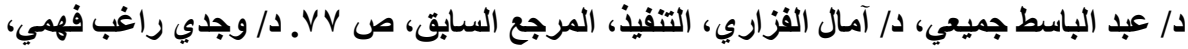

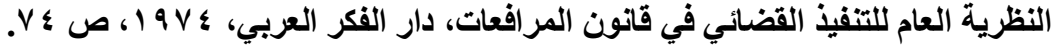

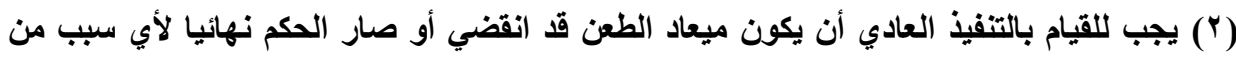

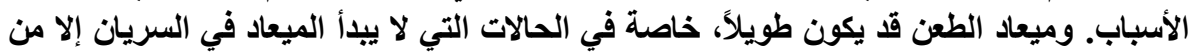

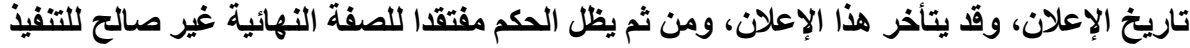

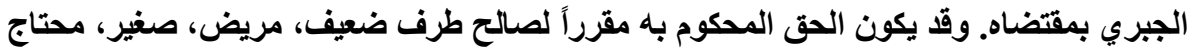

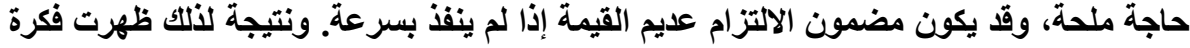

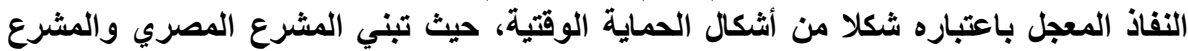

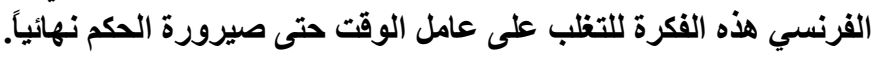

Didier CHOLET Exécution des jugements et des actes, op. cit., n0 30

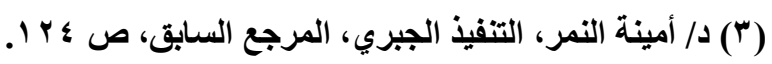

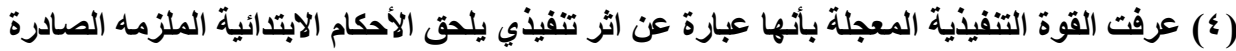

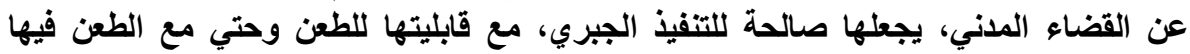

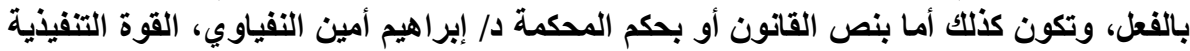

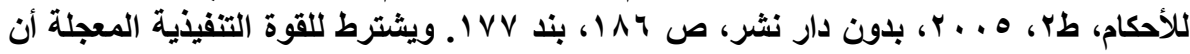

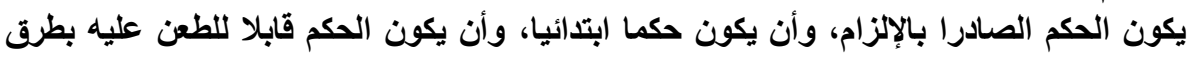

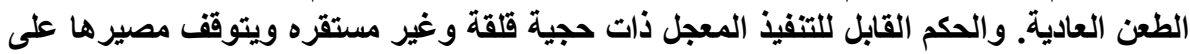

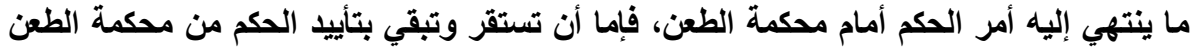

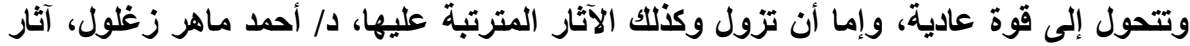

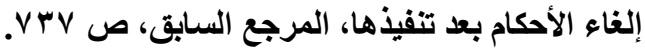


الطعون ضدها فعلا، فالحكم الإبتدائي يكون قابلا للتنفيذ، ويضفي نظام التفيذ المعجل قوة تنفيذيـة وقتيـة تتعلق بـالحكم ويرتبط مصير ها بمصيره، فهي تستثر إذا تم تأييد الحكم في مرحلة الطعن، وتزول بما رتبته من آثار إذا ألغته محكمة الطعن ('). ويعد التنفيذ المعجل استثناءً على الآثـار الموقفة لطرق الطعن العاديـة والتي تعد ركيزة في النظام القضائي؛ حيث إن طرق الطعن العاديـة ضمانه للافاع وتحقيق العدالة، والتي تمنع التتفيذ للأحكام أثناء مدة الطعن وأثثاء ممارسه الطعن()، ولكن من جانب آخر فإن وقف التنفيذ كأثر للطعن العادي قـ يسبب أضراراً خاصة في حالة الطعن بهدف المماطلة مما يسبب إضرار بـالمحكوم لـه(")، فيعد التنفيذ المعجل مسكنا للآثار

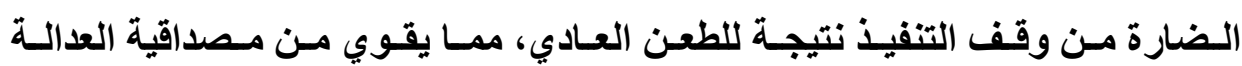
ويعززهـا(؛)، فالتنفيذ العادي يكون للأحكام القضائية التي حسزت قوة الشئ المقضي

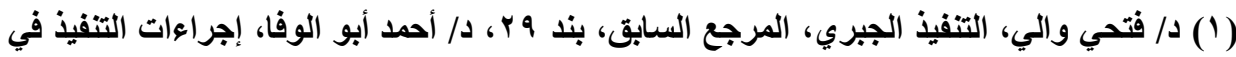

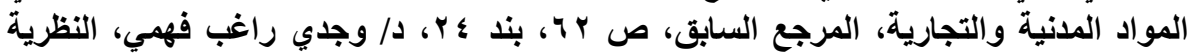

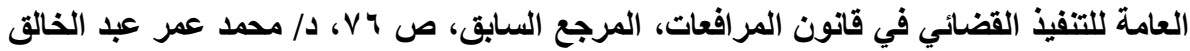

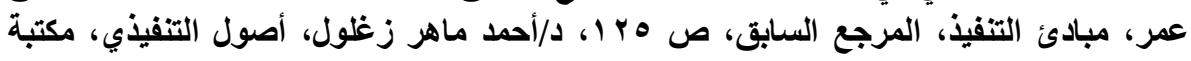

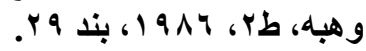

(2) Cass. Civ. 2e, 2 mai 1984, Bull. civ. II, no 74; Cass. Civ. 2 e, 9 oct. 1991, Bull. civ. II, no 243.

(3) BLAISSE, Arrêt et aménagement de l'exécution provisoire par le premier président, JCP 1985. I. 3183, LE BARS et VILLACÈQUE, La charrue avant les bœufs : le projet de suppression de l'effet suspensif de l'appel en matière civile, D. 2002. Chron. 1987 et D. 2002. Chron. 1989.

(4) BERTIN, La nouvelle procédure civile, Le décret du 28 août 1972, Gaz. Pal. 1972. 2. Doctr. 669, spéc. no 29, CADIET et JEULAND, Droit judiciaire privé, 8e éd., 2013, Litec, p, 90. 
به(')، أما التنفيذ المعجل فيقوم على أساس تنفيذ الحكم رغم قابليتة للطعن العـادي ()؛ حيث إنه لا يلغي الآثار الموقفة للطعن، ولكنهـه يحيدها(")، كمـا أن التنفيذ المعجل يكون طالب التنفيذ فيه بتحمل المخاطر (\&).

التفيذ المعجل صورة من صورة الحمايـة القضائية الوقتية أو المستعجلة(ه) تمارس في مرحلة التفيذ الجبري(")، حيث وجد لمواجهة خطر التأخير الذي يترتب عليهه أضرار، ويهدف إلى حمايـة من يبدو للوهلة الأولى أنـه صـاحب الحق الظـاهر، فجوهر الحماية الوقتية تقديم حمايـة عاجلة تحـافظ على الحقوق تجنبـا للاضضرار التي تلحق بها، وتقوم هذه المفترضـات بالنسبة للتنفيذ المعجل، وتأخذ صورة منح الحكم

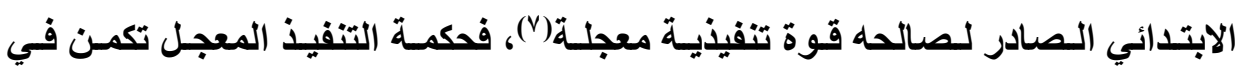

(1) art. 500 C. pr. civ.; J. MIGUET, Jugements. Exécution provisoire, J.-Cl. Pr. civ., fasc. 516, nos 5 s. ; GLASSON, TISSIER et MOREL, Traité théorique et pratique d'organisation judiciaire, de compétence et de procédure civile, t. 3, 3e éd., 1929, Sirey, no 887

(2) Cass. Civ. 2e, 7 mars 1974, Bull. civ. II, no 89.

(3)Cass. Civ. 1re, 21 nov. 1995, Bull. civ. I, no 416 ; D. 1996. IR 19.

(4) Ph. HOONAKKER, Exécution provisoire, D. septembre 2016, n0 40.

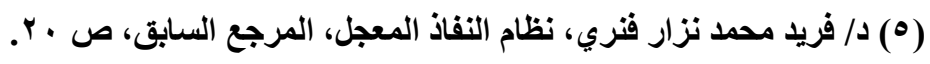

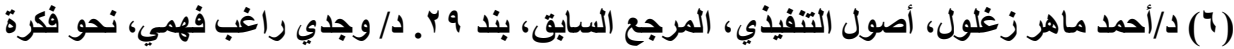

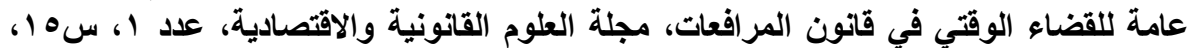

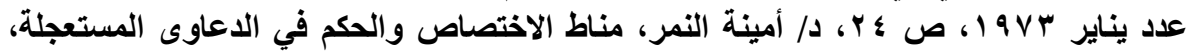

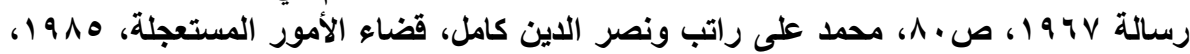

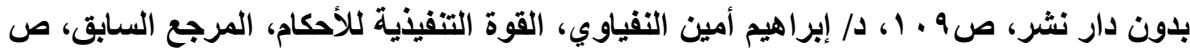

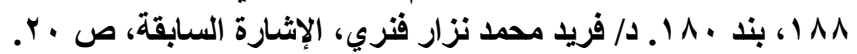

M. frances, essai sur la notion d'urgence et provisoire dans la procedure de refere, these Toulouse, 1935, p. 90.

$$
\text { (V) د/أحمد ماهر زغلول، أصول التنفيذي الجبري القضائي، المرجع السابق، بند } 9 \text { ب. }
$$


الإسر اع في تنفيذ حقوق اللائن، ونتيجة لذلك كان طبيعيا أن يسمح المشرع بإجراء

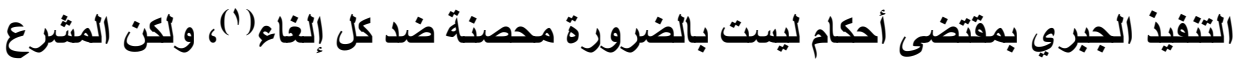
المصري والفرنسي قد نصا على درجة معينة من استقرار الأحكام، حيث يجب أن يكون

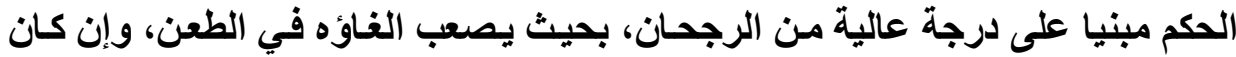
الحكم صادرا تنفيذا لحكم سابق حائز لقوة الأمر المقضي، أو كان الحكم مبينا على سند الته

$$
\text { ثانيا: أنواع التم يطعن فيه بالتزويز. }
$$

اختلفت التشريعات المقارنة في تنظيم أنواع التنفيذ المجل وحالاته، ويرجع

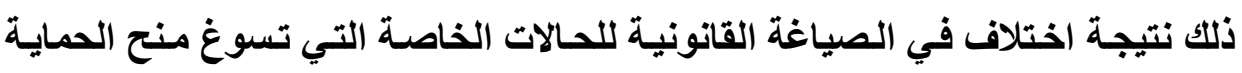
الوقتية المتعلقة بالقوة التنفيذية للأحكام(") وتنقسم حالات التنفيذ المعجل حسب مصدر تقريره إلى نوعين؛ التنفيذ المعجل القانوني، والتنفيذ المعجل القضائي. وهذا الاخير ينقسم: إلى نفاذ معجل قضائي وجوبي أي يتوجب على المحكمة أن تأمر به متى توفي لوفرت

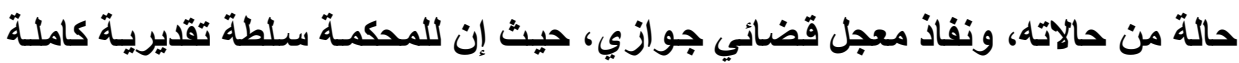

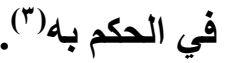

(1) د/ أحمد خليل، طلبات وقف التنفيذ، دار الجامعة الجديدة، 999 19 ، ص ه.

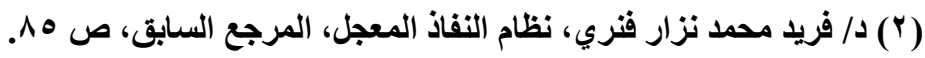

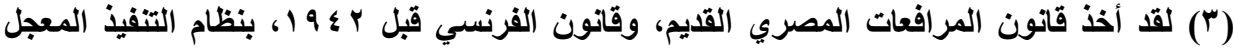

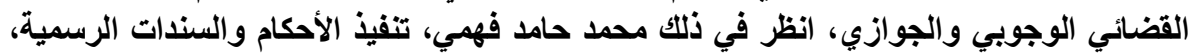

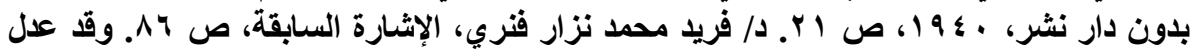
المشرع الفرنسي والمصري هذا الاتجاه، واصبح التنفيذ المعجل إما قانونا أو قضائيا جوازيا. . P. Baudas, l'exécution provisoire, thèse, 1958, p.15. 
ويقصد بالتتفيذ المعجل القانوني؛ أي كون التنفيذ بقوة القانون(')، ولا يكون للقاضي أي سلطة تقديرية بشأنه()، فقد رأى المشرعان المصري والفرنسي أن هنـاك بعض الحالات الملحة التي تستوجب التنفيذ المعجل، فشموله بالنفـاذ المعجل القانوني. وهذا التفيذ لا يتطلب أن يقدم المحكوم لصالحه طلبا. وحالات التنفيذ المعجل القانوني نص عليها المشرع على سبيل الحصر (")؛ وهذه الحسات هي : الأحكام الصادرة في

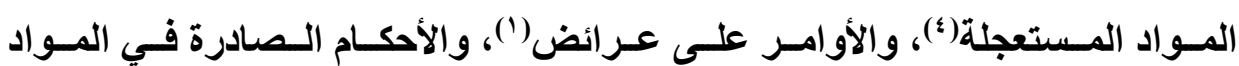

(1) يرجع ذلك إلى أن المشرع قد قدر في هذه الحالات توافر حالة الاستعجال التي تبرر حاجة المحكوم

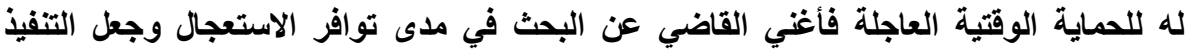

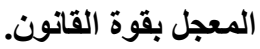

(2) LOYER-LARHER, note sous Rennes, 7 juill. 1977, Gaz. Pal. 1978. 1. 149, Cass. Civ. 1re, 4 juill. 2007, Bull. civ. I, no 252, FAUVEL, La réforme de l'exécution provisoire des jugements nonobstant opposition et appel, thèse, Paris, 1932.p. 84

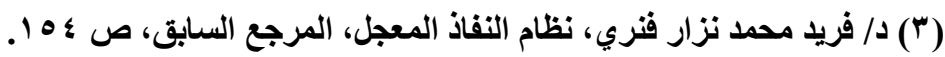

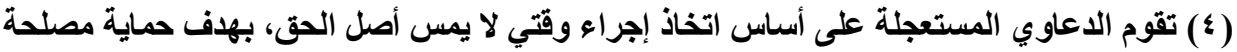

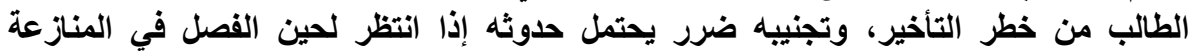

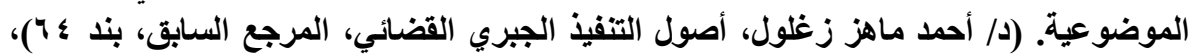

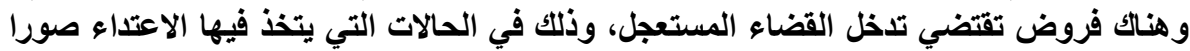

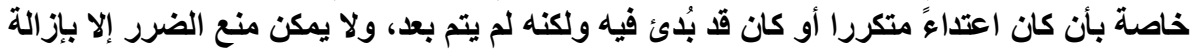

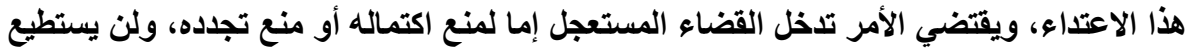

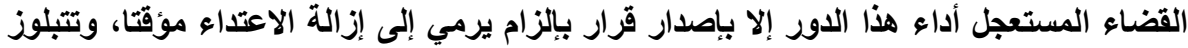

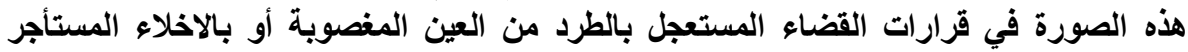

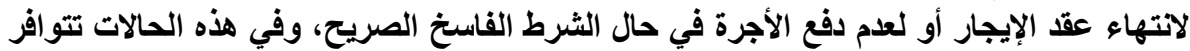

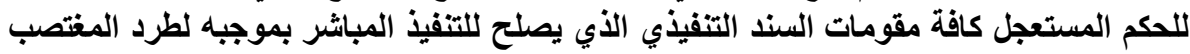

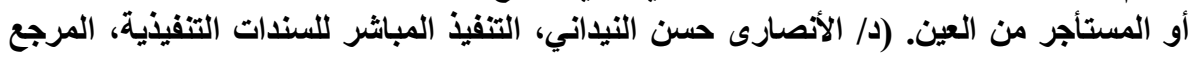

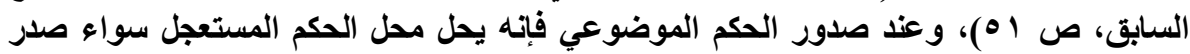

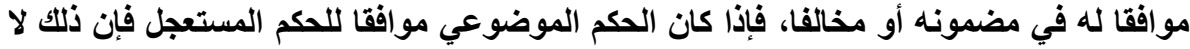

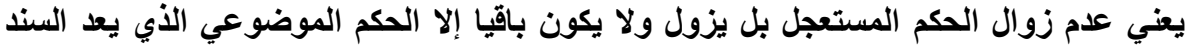
الوحيد لاتمام إجراءات التنفيذ إذا لم تكن قد تمت، أما إذا كان الدكم الموضوعي مخالفا للحكم $=$ 
التجارية(؟)، والأمر الصادر في المسائل الأسرية بإجراعات حماية المضرورة من اعمال العنف(ז)، والأوامر الصادرة بالإجراعات التحفظية أثناء سير الدعوى(")

والنوع الثاني هو التنفيذ المعجل القضائي، وهو الذي يقرره القاضسي(ْ) إذا

توافرت فيه شروط معينة"(")، فيجب أن يطلبه صـاحب المصلحة أثناء سير الخصومة وقبل صدور الحكم، فصاحب المصلحة يثبت للمحكمة أن ظروفه تقتضي سرعة تنفيذ الحكم المحتمل صدوره لصالحه، فإذا انتهت الخصومة دون طلب التتفيذ المعجل تكون المحكمة قد استنفذت ولايتها، ولا يجوز العودة إلى القضية مرة أخرى، كما لا يجوز في

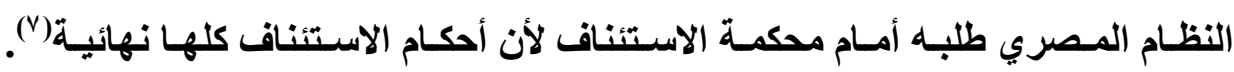

المستعجل فإن ذلك يغي إلغاء الحكم المستعجل ويتعين إعادة الخصوم إلى الحالة التي كانوا عليها قبل تنفيذ الحكم المستعجل (د/ أحمد ماهر زغولة الثول، آثار إلغاء الأحكام بعد تنفيذها، المرجع السابق،

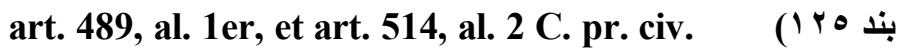

(1) article 495, alinéa 2, C.P.C.

(2) PH. HOONAKKER, l'effet suspensive des vois de recours dans le nouveau code de procedure civile, thèse Strasbourg, 1988, nos 154 s.; Cass. Com. 1er oct. 2013, Gaz. Pal. 2014. 362, obs. N. Fricero

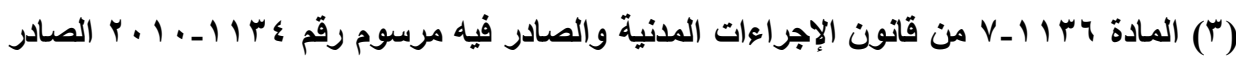

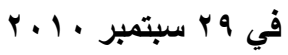

(4) art. 514, al. 2 C. pr. civ

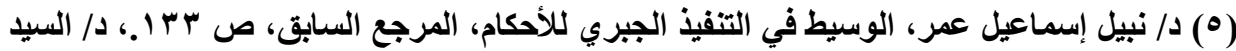

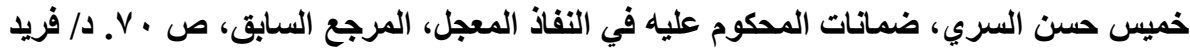

$$
\text { محمد نزار فنري، المرجع السابق، صن ـ } 9 .
$$

BLÉRY, L'efficacité substantielle des jugements civils, op. cit., n. 145 et 162 ,BAKER CHISS, Contribution à l'étude de l'exécution des jugements civils dans les rapports internes et internationaux de droit privé, op. cit., p. $409 \mathrm{~s}$.

(6) Ph. HOONAKKER, Exécution provisoire,op. cit., n012

(7) Civ. 2e, 6 janv. 2012, D. 2012. Pan. 1509, obs. Leborgne. 
ويشترط للحكم بالنفاذ المعجل توافر شرط الاستعجال، وللقاضي سلطة تقديرية في مدى توافر شروط التنفيذ المعجل القضائي. وقد عدد المشرع الحسالات التي يمكن للمحكمة إصدار الحكم مشمولا بالنفاذ المعجل، ويمكن تقسيمها إلى حالات قائمسة على قوة سند الحق(')، وحالات قائمة على الحاجة للحماية القضائية السريعة(؟).

وللقاضـي حريـة في إصـار الأمـر بالتنفيذ المعجل سـواء كل الحكم أو أجزاء منه("). ويصدر سواء بناء على طلب أحد الخصوم أو من تلقاء القاضي نفسه في النظام الفرنسي(")، ويمكن للقاضي أن يصدر الأمر بالتتفيذ المعجل بنـاء على طلب الخصوم

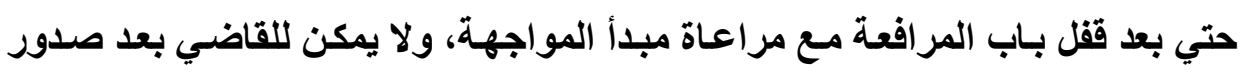
حكم أن يعيد ويصدر أمر بالتنفيذ المعجل(0)، فلا يمكن للقاضسي أن يكمل حكمـا بإصدار الأمر بالتنفيذ المعجل(")، لأن ذلك أصبح من اختصاص محكمة الطعن("). ولكن في حالة طلبه واغقل القاضي الحكم به فإنه يمكن له أن يحكم بالتتفيذ المعجل(؟).

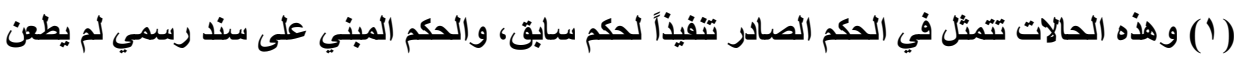
عليه بالتزوير، والحكم المبني على سند عرفي لم يجداه المحكوم عليه، والحئ والحكم المبني على إقرار

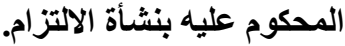

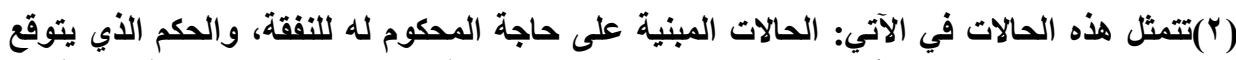

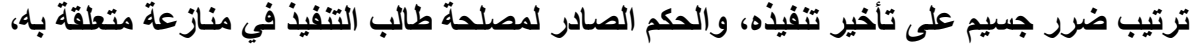

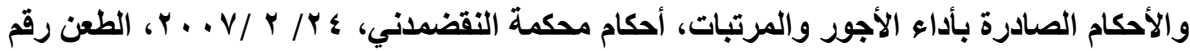

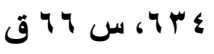

http://site.eastlaws.com/GeneralSearch/Home/Index?SearchTxt

(3) art. 515, al. 2 C. pr. civ., STRICKLER et FOULON, Accords et force exécutoire en France, Gaz. Pal. 3 sept. 2013. 8.

(4) art. 515 C. pr. Civ.

(5) Ph. HOONAKKER, Exécution provisoire, op.c it., n0 38.

(6) art. 461 et 462 C. pr. civ. 
وإذا كان الحكم المشمول بالنفاذ المعجل يصبح صالحا كسند تنفيذي، وقد يطعن

المنقَّ ضده في الحكم بالاستئناف، فإذا ما تم إلغاء الحكم في مرحلة الاستئناف، يجب إعادة الحال إلى ما كاتت عليه عن طريق التنفيذ العكسي("). ويلاحظ أن قو اعد التنفيذ المعجل تتعلق بالنظـام العـام؛ فـلا يجـوز للخصوم الاتفاق على إضافة التنفيذ المعجل إلى الأحكام القضائية(؛)، لأن مصدر التنفيذ المعجل

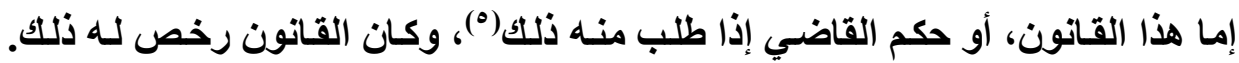
ولكن يجوز للخصوم الاتفاق على كون الحكم الصادر نهائيا، فللخصوم الحق في التنازل عن الاستئناف عن طريق الاتفاق.

(1)I'article 516 NCPC; J. MIGUET, Jugements. Exécution provisoire, op. cit., fasc. 516 fasc. 519, no 133.

(2) article 463 du code de procédure civile

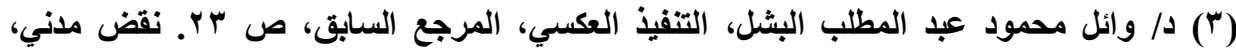

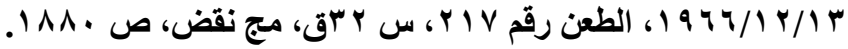

Cass. Civ. 2e, 7 janv. 2010, D. 2010. Pan. 1307, obs. Leborgne; Cass. Civ. 12 juill. 2011, D. 2011. 2031; Cass. Civ. 2e, 15 sept. 2016, JCP 2016. 1034, note Dorol.

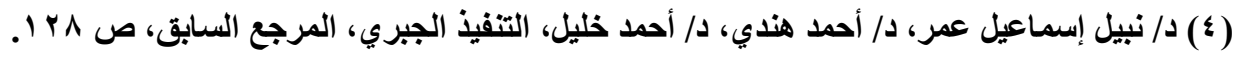

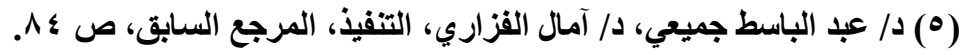




\section{الفرع الثاني \\ التطورات الصديثة في التنفيذ المعجل في النظام الفرنسي}

كان القانون الفرنسي القديم الصادر في 7 ـ 9 (يتبنى تتظيمـا قانونيا للتنفيذ

المعجل لا يسمح به إلا في حالات محددة(')، وكان يميز في التنفيذ المعجل بين التنفيذ

المعجل الإجباري والاختياري، وكان يشترط تقديم طلب للتنفيذ المعجل. وقد عدل قانون

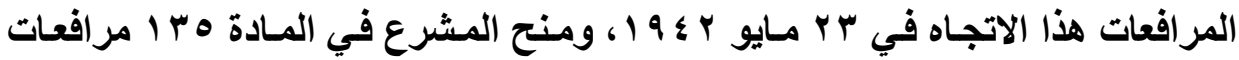
للقاضـي سلطة تقديريـة كبيرة في منـح التنفيذ المعجل للحكم، ولكنهـا قيـت سـلطاته بضرورة تـوافر شـروط الحمايـة الوقتبـة، مسن اسـتعجال وخشية مسن خطر التـأخير، واشترط المشرع الفرنسي التسبيب في حالة الحكم بالتنفيذ المعجل القضائي، أمـا في حالة التنفيذ المعجل القانوني فيصدر بشكل تلقائي ودون اعتداد بإرادة القاضس، وهذا

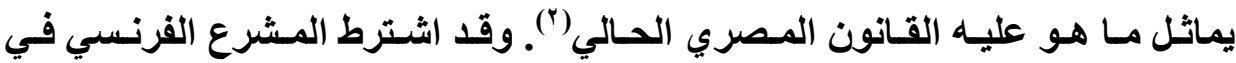

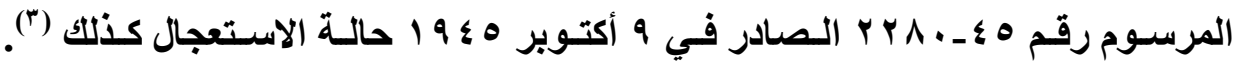
وراعى هذا التطور منذ تعديل بr مايو ب \& 9 ا نتيجة لموقف الفقه والقضاء(")؛ حيث شهر القانون الفرنسي تظورا ملحوظا في شأن سلطة القاضي في الأمر بالتفيذ المعجل، وقد نص على قواعد موحدة لنظـام التنفيذ المعجل، وقد ألغى القـانون نظـام التنفيذ المعجل القضائي الوجوبي، قاصرا هذا النظام على النفاذ الجوازي فقط ومانحا المحكمة سلطات وصلاحيات أوسع، فقد كاتت هذه السلطة محددة للغاية في ظل قانون المرافعات

(1) د/ فتحي والي، التنفيذ الجبري، المرجع السابق، ص هو 1 الد/ فريد محمد نزار فنري، نظام النفاذ

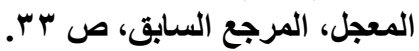

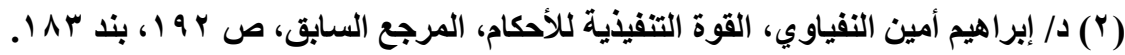

(3)Ph. HOONAKKER, Exécution provisoire, D. septembre 2016, n0 40.

(4) THOMAS, La réforme de l'exécution provisoire, JCP 1943. I. 358. 
القديم(')، فالتففيذ المعجل لا يتم إلا بناء على طلب، ولم يكن للقاضي الأمر به من تلقاء نفسه، وكان يدور بين تنفيذ معجل قانوني، وتنفيذ معجل قضائي، ولكن التعديلات التي

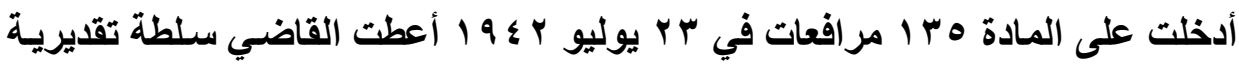
كبيرة في التنفيذ المعجل، فقد ألغت التفرقة السابقة في التنفيذ المعجل القضائي بين الوجـوبي والجـوازي، واستبـلهها المشرع بتنفيذ معجل جـوازي يعتـــ على السلطة التقديرية للقاضي مع الإبقاء على مبدأ الطلب، فلا يستطيع أن يأمر به من تلقاء نفسهة، وبضرورة توافر شرط الاستعجال أوالخشية من التأخير، وكان القاضسي ملزمسا بتسبيب حكمه.

وقد كاتت التطورات الحديثة في القانون الفرنسي بصدوره المرسوم رقم VT-

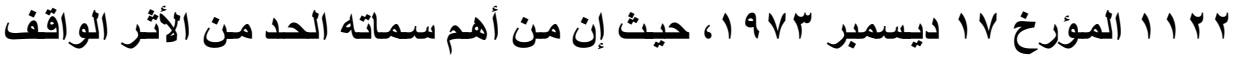
للطعن بالاستئناف، إذ منح القاضي إصدار الأمر بالتنفيذ المعجل من تلقاء نفسه إذا وجد ذلك ضـروريا، ومتى كـان غير ممنوع ومتفقـا مـع طبيعـة المنازعـة. وقد تـدعم ذلكـ

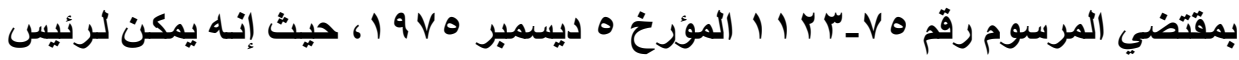
المحكمة الاسئتناف أن يأمر بالتتفيذ المعجل من تلقاء نفسه إذا كان ذلك ضروريا، ولا

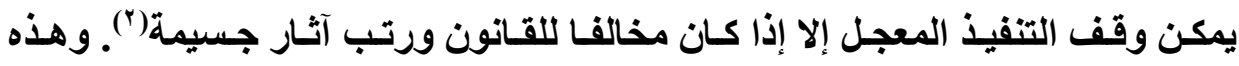
الأحكام نصت عليها المواد من \& اه إلى צ به من قانون المرافعات الفرنسي الجديد، وقد توالت التعديلات بعد ذلك. وتهدف هذه التطورات إلى تحقيق مصالح الدائن بصفة

(1) R. Maurice, exécution provisoire, repertoire de procédure, encyclopedie D., 2ed., 1979 no 47.

(2) PERROT, Procédure de l'instruction. Jugements et voies de recours. Voies d'exécution et mesures conservatoires, RTD civ., 1983, 407, spéc. p. 418 
دا طلعت يوسف خاطر

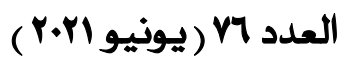

عامة وضمان العدالة(')، ويكمن للقاضسي أن يـأمر بمـا يرى مـا يكفل مصلحة المحكوم عليه من ضمانات، ويمكن للخصم الآخر أن يطعن في قرار القاضسي إذا خـالف شروط

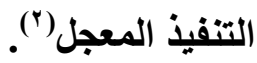

والواقع أن المشرع الفرنسي اتجه نحو تحرير نظام التنفيذ المعجل من قيوده،

محاولا حمايـة الدائن خـلال درء خطر محاولـة المـينين التسويفية، ومـا أداه ذلك مـن

فقدان العدالة لمصداقيتها، ويتجلي ذلك كله في التوسع التدريجي والمتواصل لسلطات القاضي في منح التنفيذ المعجل. وقد وضع المشرع الفرنسي عديدا من الإصلاحات في

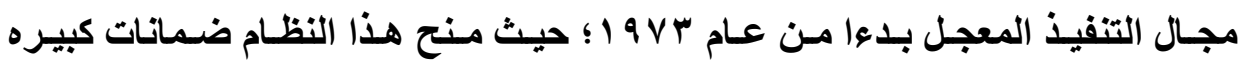
للمحكـوم لـه تجعلـة يتفــادي الضرر الذي مـن الممكن أن يحلق بـه نتيجـة البطع في إجراءات التقاضي التقليدية.

مظاهر التطورات الحديثة في التنفيذ المعجل في التشريع الفرنسي الآتي: أولاً: عدم اشتراط الاستعجال للحكم بالنفاذ المعجل القضائي:

أدخلت تعديلات جوهرية على هذا التنفيذ المعجل في فرنسا، على أثرها أصبح للقاضي سلطة تقديرية كاملة في شمول الحكم بالنفـاذ المعجل القضائي حتى من تلقاء

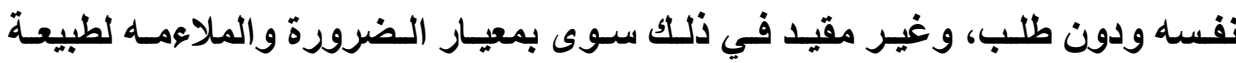

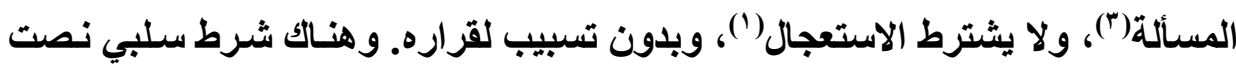

(1) FAUVEL, La réforme de l'exécution provisoire des jugements nonobstant opposition et appel, op. cit., p. 80 s.; RIBEREAU, De l'exécution provisoire des jugements en matière civile, thèse, Bordeaux, 1901, p. $5 \mathrm{~s}$.

(2) Ph. HOONAKKER, Exécution provisoire, op.cit., N0 5

(3) Bertin, le petit noel du procedure, Gaz pal, 1974, I, doct. 149. 
عليه المادة ه اه ؛ ألا وهو كون التنفيذ المعجل القضائي ممنوعا قانونيا(؟)، والواقع أن حالات المنع محددة على سبيل الحصر(")

$$
\text { ويلاحظ على هذه التعديلات الآتي: }
$$

1 ـ الحكم بالتنفيذ المعجل متى وجد ضرورة، والتناسب مع طبيعة النزاع

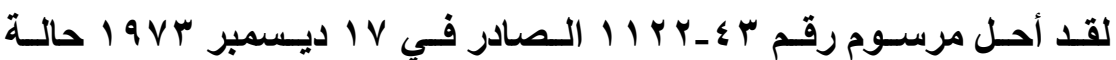

الضرورة محل اشتر اط الاستعجال للحكم بالتنفيذ المعجل للأحكام الابتدائية، ولقد كـان

شـرط الاسـتعجال والخطر المحدق متطلبـا في القـانون ب ؛ 9 أمنتقدا مـن قبـل الفقـه الفرنسي(؛)، وقد استبال المشرع هذين الشرطين بشرط اكثر مرونهه وهو الضرورة والتناسب مع طبيعة النزاع. وذلك بنصه في المادة ه 10 ه إجراعات على أنه " في غير

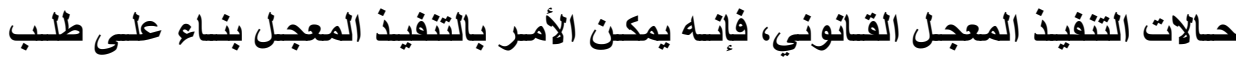
الأطر اف أو من تلقـاء نفس القاضس، وفي كل مرة يقدر فيها القاضسي ضرورة ذلكك وتناسبه مـع طبيعة النزاع المطروحة مـا لـم يكن ذلك التنفيذ ممنوعا من القـانون".

(1) Ph. HOONAKKER, Exécution provisoire,op. cit., n054.

(2) Paris, 28 sept. 1993, Dr. sociétés 1994, no 8.

(3) Ph. HOONAKKER, Dernières réformes de l'exécution provisoire. Raison et déraison, D. 2006. Chron. 754

(4). P. Baudas, l'exécution provisoire, op. cit, p.15.

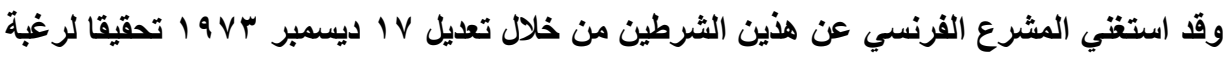

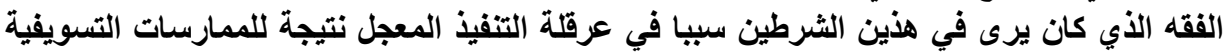

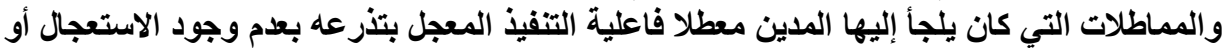
خطر محقى. 
دا طلعت يوسف خاطر

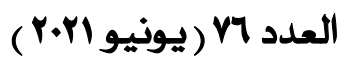

ويلاحظ أن المشرع الفرنسي منح القاضي سلطة الأمر بالتنفيذ المعجل من تلقاء نفسه دون أن يتيح أي رقابة للاستئناف على منحه هذا القرار.

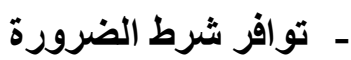

طبقـا لنص المـادة ه 1 ه إجراعات يمكن أن الحكم بالتنفيذ المعجل إذا وجدت حالة الضرورة، وهذه الحالة قائمة على القناعة الشخصية للقاضي، ولا يكون في حاجة إلى تسبيب قراره، ويكفيه أن يعلن ضرورة التنفيذ المعجل للحكم('). ويشترط ألا يحظر

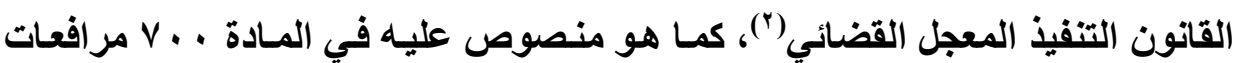
والمتعلقة بالمـصـاريف. ومـن ثم يتمتع القاضـي في التنفيـ المعجل القضائي بسلطة تقديرية واسعة، تسمح له بتزويد الحكم بالقوة التنفيذية المعجلة أو عدم تزويده (").

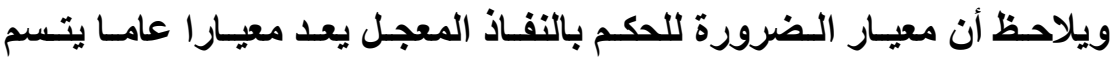
بالمرونة، ويهدف المشرع من ذلك إلى تقوية سلطة القاضي، وفتح باب الاختيـار أمامـه في الحكم بالتنفيذ المعجل، وتقدر الضرورة بـالنظر إلى مصالح المحكوم لـه، وهذا يخضع إلى تقدير القاضسي بشكل كلي، ويهدف المشرع بموجب شرط الضرورة إلى مواجهة تسويف المدين عن طريق اللجوء إلى طرق الطعن الممكنه(")، فهذا الشرط يخول القاضي منح التنفيذ المعجل كلما ارتأى ذلك ضروريا لحمايـة حق الدائن. ويرى

(1) LOBIN, L'exécution provisoire, Gaz. Pal. 14-15 sept. 1984, p. 9 s., spéc. p. 11.

(2) Id.

(3) L. LARHER, la reforme de I execution proviso ire, Gaz Pal. 1976, 2, Doct. 586.

(4) Ch. LOYER-LARHER, La réforme de l'exécution provisoire, Gaz. Pal. 1976. 2. Doctr. 587. 
البعض أن حالة الضرورة تقتضي وجود شرط الاستعجال كمبرر لمنح التنفيذ يخشى معه ترتيب ضرر للائن من عدم التنفيذ(').

وقد انتقد بعض الفقهـ الفرنسي هذا الاتجـاه، وذهب إلى أن الشروط القديمـة كاتت كافية، وليس هناك حاجة إلى استبدالها بشرط الضرورة، ولكن الشروط الجديدة ستكون لا مفر منها، ويمكن أن توجد الضرورة دون استعجال أو خطر التأخير، ولكن توافر الاستعجال أو خطر التأخير يؤدي إلى توافر شرط الضرورة(؟). - - اشتر اط التناسب مع طبيعة النزاع

اشترط المشرع الفرنسي للحكم بالتنفيذ المعجل القضائي أن يتناسب التنفيذ

المعجل مع طبيعة النزاع، ويرى جاتب من الفقه أن هذا الشرط غير دقيق(")، ويبرر جاتب آخر من الفقه أن الههف من هذا الشرط ألا يترتب على التنفيذ المعجل ضرر لا يمكن استـدراكه(؛). ويلاحظ أن هذا الشرط أكد على اتجـاه المشرع في منح القاضسي سلطة واسعه في الأمر بالتنفيذ المعجل، ويلاحظ من خلال تطبيق القضاء الفرنسي أن هذا الشرط أخذ بطريقة سلبية من خـلال عدم التناسب، بحيث يعد غير متناسب مـع طبيعة النزاع كل نفاذ معجل يرتب ضررا لا يمكن تداركه(ْ). ويرى بعض الفقه أن شرط التناسب مع طبيعة النزاع يتعلق بشكل جوهري بالأحكام الصادرة في مسائل الأحوال

(1) Cass. 2e civ. 9 mai 1983, Gaz. Pal. 1983, pan. 258.

(2) J. MIGUET, Jugements. Exécution provisoire, op. cit., n0 70.

(3) Ch. Loyer-larher, l'exécution provisoire, analyse de la jurisprudence des Cours d'appel d'angers et de Rennes, Gaz Pal, 1982, doct. 152.

(4) L. LARHER, la reforme de l execution provisoire, op. cit., Doct. 586.

(5) Ch. Loyer-larher, l'exécution provisoire, analyse de la jurisprudence des Cours d'appel d'angers et de Rennes, Gaz Pal, 1982, doct. 152. 
الثخصية، ويقرر أنـهـ لا يمكن الحكم بالتتفيـذ المعجـل للأحكـام المتعلقة بـالطلاق أو

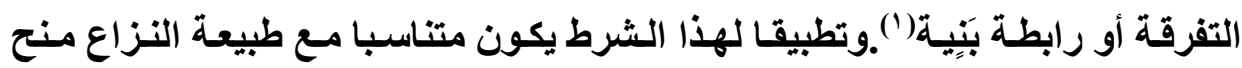
التنفيذ المعجل لحكم صدر ضد شركة عقارية بالتعويض لشخص مسن ومريض ألحقت

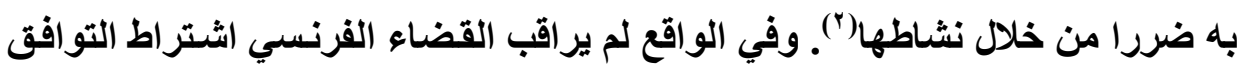

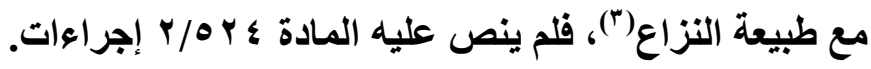
- اشتراط ألا يكون التنفيذ المعجل ممنوعا قانونا

اشترط المشرع شرطا سلبيا: يتمثل في عدم جواز التففيذ المعجل في الحالات الممنوعـه قانونــا(؛)، ويلاحظظ أن حـالات حظـر التنفيذ المعجلـ منـصوص عليهـا فـي التثريعات المختلفة، ومن الصعب استيعاب هذه الحالات أو تجميعها، ويكفي الفقه عادة ذكر أهم الأمثلة على حالات المنع، ومنها المسائل المتعلقة بالشهر العقاري حيث إنها

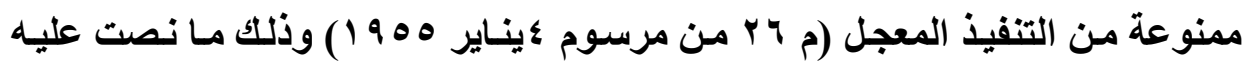
المادة • اس إجر اعات بخصوص مسائل الطعن بـالتزوير؛ كذلك مـا نصت عليه المـادة V. . .

(1) PH. HOONAKKER, l'effet suspensive des vois de recours dans le nouveau code de procedure civile, op. cit., n0 50.

(2) CA Leyon, 18 dec. 1979, JCP, 1980, II, n0 19417, note Burki.

(3) Civ. 2e, 10 mars 1982, Bull. civ. II, no 41

(4) LOBIN, L'exécution provisoire, op. cit., p. 9 s., spéc. p. 11.

(5) Cass. Civ., 23 jav. 1983, Gaz Pal. 1985, I, p. 124, obs. S. Guinchard. 
نص القانون الفرنسي السابق الصادر في ب مـايو Y \& 19 على وجوب طلب

التنفيذ المعجل من المحكمة، وإذا لم يطلب منها فلا تستطيع تقريره. ولكن عدل المشرع الفرنسي في المرسوم الصادر في V د I V V I هذا الاتجاه، ويعد اتجاهـه الجديد ثورة في ميدان التشريع، حيث أتاح الإمكانية للقاضي بالامر بالتنفيذ المعجل من تلقاء نفسه، وقد كرست المادة 10 ه إجراءات فرنسي هذا الحل؛ وذلك بـالنص صراحة على بلى بله منح التنفيذ المعجل بنـاء على طلب أو من تلقاء نفس القاضسي('). وقد اتجـه المشرع الفرنسي إلى هذا الاتجاه نزولا على موقف الفقه الذي منح القاضي سلطة تقديرية كاملة في منح التنفيذ المعجل وتقدير ملاعمته(؟)؛ ومن ثم فقد سمح المشرع للمحكمة بحريـة واسعة في الأمر بالتففيذ المعجل متى قدرت ضرورته وملاءمته، وهذا يعتمد على قناعة القاضي الشخصية. وهـذا الاتجـاه الجديــ خـالف بـهـ المسشرع الفرنسسي مبــأ الطلب فـي قـانون المرافعات، حيث إن القاعدة أن المحكمة لا يجوز لها أن تقضي بشئ لم يطلبه الخصوم، وبناء عليه يجب على الخصم ذي المصلحة أن يطلب شمول الحكم بالنفـاذ المعجل، فإذا فعل ذلك فإن على المحكمة أن تتأكد من توافر حالة من حسالات التنفيذ المعجل، وعندما تتشكل لايها القناعة بأن هذه الحالة متوافرة بشروطها، فلها أن تأمر بالتتفيذ المعجل للحكم، والقاعدة أنـه إذا قضت المحكمة دون طلب من الخصم صساحب المصحلة فإنها

(1) Ch. Loyer- Larher, La réforme de l'exécution provisoire, Gaz Pal. 1976, doc. P. 587.

(2) R. Morel, traité élémentaire de procedure civile, 2 éd. 1949, n0 626. 
تكون قد قضت بأكثر مما طلبه الخصوم ولو توافرت حالة من حالات التنفيذ المعجل('). ويمكن القول بأن المشرع الفرنسي سمح للمحمة بالحكم بالتنفيذ المعجل دون طلب على تقدير أن الخصم الذي يطلب بحقه يطالب في الوقت ذاته بتميكنه من اقتضائه في أقرب وقت ممكن وبغير عائق يمنع التنفيذ، ومن ثم -بناء على هذه الإرادة الضمنية - يكون للقاضي أن يحكم بالتنفيذ المعجل.

وبالنسبة لموقف المشرع المصري في قانون المرافعات الحالي فقد أغقلت المادة ـ ج م ما كان منصوصا عليه في القانون السابق من وجوب الطلب لصحة الحكم بالتنفيذ المعجل (م اجq مر افعات سـابقا، ويرى البعض وجوب تقديم الطلب في حالة التنفيذ المعجل القضائي(؟) بـ - عدم اشتر اط التسبيب نصت المـادة V IV مرافعات على وجوب اشتمال الأحكام على الأسباب التي بنيـت عليهـا وإلا كانـت باطلـه، ويجمـع الفقـه المـصري على وجـوب تسبيب الأحكـام الصادرة بالتنفيذ المعجل وإلا كان حكمها باطلا("). ويجب أن تكون الأسباب جدية وغير غامضة، فـلا يكفي أن يشير القاضسي إلى تـوافر حالـة مـن الحسالات التي نص عليها

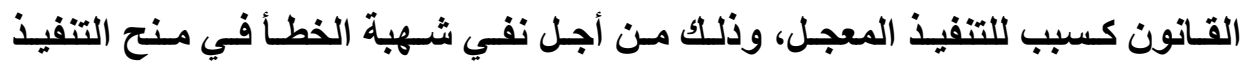

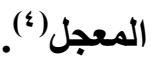

(1) د/ فريد محمد نزار فنري، نظام النفاذ المعجل، المرجع السابق، ص 104.

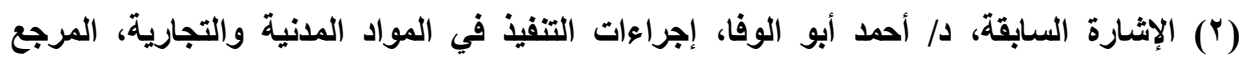

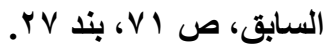

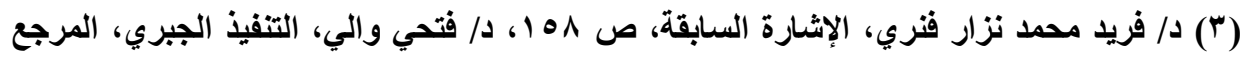

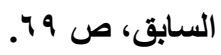

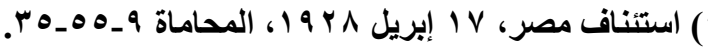


وبالنسبة للقـانون الفرنسي فقد جـاء بـأمر مغـاير للقاعدة العامـة في وجوب

تسبيب الأحكام؛ حيث يستفاد من عبارة نص المسادة ه 10 ه إجراعات التي تتيح للقاضي الأمر بالتنفيذ المعجل في كل مره يقدر فيها القاضي ضرورة ذلك، حيث إن هذا المعيار يفتح المجال لتقدير شخصي كبير للقاضسي دون أيسه إثـارة لمعيـار موضسوعي يضبط أسس منح هذا التنفيذ، بحيث يمكن القول بأن التفنيذ المعجل قد يثذ عن قاعدة وجوب التسببب باعتباره أسلوبا أو طريقة من طرق القرار القضائي الهادف إلى إجبار المدين على تنفيذ التزامسه، مثلـه في ذلك مثنل الغزامـة التهايديـة غير مستلزم تسبيب الأمر

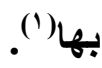

ويـرى الفقـه أن تسبيب التنفيـ المعجـل يكون واجبـا بالنسبة لحـالات التنفيذ المعجل القضائي فحسب، وذلك لأنه يخضع لتقدير القاضي()، فالتنفيذ المعجل القانوني

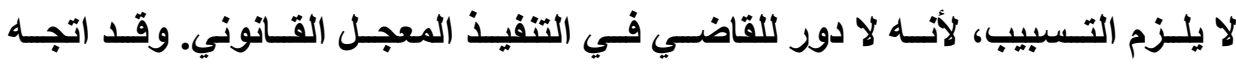
الفقيهPerrot إلى ضرورة تسبيب الأمر بالتنفيذ المعجل لما يحققه من فائدة تكمن في احتمال الطعن في الحكم وإصلاحه، كما يؤدي إلى تفـادي التعسف غير المبرر في منح التنفيذ المعجل (ّ). وذهب البعض إلى أنسه القاضـي ليس في حاجـة إلى تسبيب قراره ويكفيه أن يعلن أن التتفيذ المعجل للحكم مسألة ضرورية لا مفر منها، وهو مـا يترتب عليه تسهيل مهمته(")، بينما يرى البعض من الفقه الفرنسي ضرورة التسبيب حتى لو

(1) Cass. Civ., 13 avril 1976, D. 1976, IR 93, obs. Perrot.

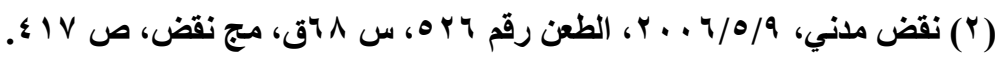

P. Baudas, l'exécution provisoire, op. cit., p.15.

(3) Perrot, obs. CA Douai 5 avril, 10 mai 1984, RTDC 1984, 774.

(4) Ch. LOYER-LARHER, La réforme de l'exécution provisoire, op. cit., 587. 
ولا يلزم التسبيب في حالة رفض التنفيذ المعجل لأنه يعد تطبيقا للقاعدة العامـة في التنفيذ ولا يحتاج معه إلى تسبيب، كما أن إغفـال المحكمة طلب التنفيذ المعجل يعد رفضا ضمنيا لهذا الطلب() ولا يجوز اللجوء إلى الطعن لإغةـال أحد الطلبات، وإنمـا يتعين العودة إلى المحكمة التي أصدرت الحكم للفصل فيما أغقلت فيه. ثاتيا: جواز تقديم طلب التنفيذ المعجل في مرحلة الاستئناف نصت المادة 235 من قانون المرافعات المصري على عدم جواز تقديم طلبـات جليـدة في الاسـتئناف، وتحكم المحكمة مـن تلقـاء نفسها بعدم قبولهـا، فالقاعدة في القـانون المـصري عـدم جـواز طلب الأمسر بالتتفيـذ المعجـل لأول مـرة أمسام محكمـة الاستئناف، وذلك باعتباره طلبا جديدا. وأكد الفقه المصري أن طلب التنفيذ المعجل من بن الطلبـات الجديـدة التـي لا يجـوز إبـداؤها أول مـرة أمسام محكمـة الاستيتئنس، وذلـك لأن موضوع الطلب وسببه مختلف رغم وحدة الأطراف في الخصومة، فالحمايـة الوقتية

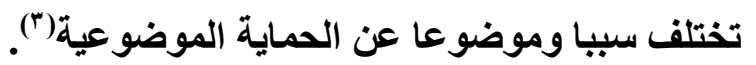
وبالنسبة للقانون الفرنسي، نجد أن قانون الإجراءات الفرنسي السابق، نص

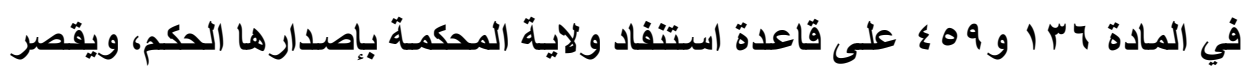
مكنة طلب التنفيذ المعجل على مرحلة أول درجة، وكرس مبدأ عدم جواز تقديم طلبات

(1) Rennes 24 fev. 1984, rev. jud. 1984, p. 86, note Ch. Lacher.

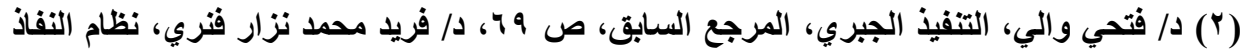

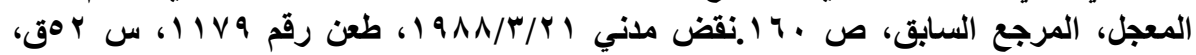
.https://www.eastlaws.com

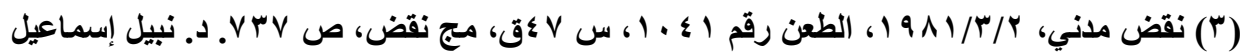

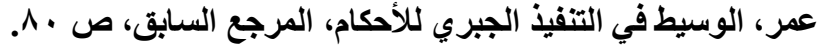


جديدة أمسام محكمة الاستتناف('). ولكن أسفرت التطورات التي وصل إليها المشرع الفرنسي بصدد أصول التظيم القضائي عن التخلي بشكل كامل عن القاعدة التقليدية الخاصـة بثبـات المنازعة بالنسبة لنظام التنفيذ المعجل، وقد أقرت المراسيم العديدة الصادرة ابتداء من و IVY ومـا بعدها منهجـا جديدا يعتمد على فكرة تطور النزاع " Evolution du litige مما يتيح إبداء طلبات جديدة في الاستنئاف(؟). وقد نص المشرع الفرنسي على جواز تقديم طلب التنفيذ المعجل أمام محكمة الاستئناف، سواء قدم الطلب في شكل طلب تابع للطلب الأصلي أو طلب عارض؛ حيث أجسازت المـادة 7 Yه مرافعات تقديم طلب شمول الحكم بالقوة التفيذية المعجلة لأول مرة أمام الرئيس الأول لمحكمة الاستتنـاف بوصفة قاضيا للأمور المستعجلة(") في الحالات الآتية: إذا لم يقدم في خصومة أول درجة، أو إذا قدم وأغفل القاضي الفصل فيه، أو قدم ولكن رفض(؛). ويكون ذلك بطريق الأمر على عريضة، ويصدر قرار لا يكون قابلا للطعن عليه بالنقض(').

(1) art. 915 C. pr. civ.; Cass. Civ. 2e, 5 janv. 1978, Bull. civ. II, no 9 ; Gaz. Pal. 1978. 1. 249, obs. Viatte ; RTD civ. 1978. 427, obs. Perrot.

(2) Ph. HOONAKKER, Dernières réformes de l'exécution provisoire. Raison et déraison, op. cit. 754 ,

(3) Art. 771 et 779 C. pr. Civ; RIVES, La juridiction du conseiller de la mise en état, RTD civ. 1984. 648, CA Paris, 10 oct. 1980, Gaz. Pal. 1980. 2. 656; CA Versailles, 22 oct. 1999, Gaz. Pal. 13-14 avr. 2001, p. 22

(4) GERBAY, Réflexions sur la juridiction du premier président de la cour d'appel,op. cit.,. 65; CANS et SCHRICKE, Le référé du premier président, in La pratique du référé dans les juridictions civiles de la région parisienne, 1979, PUF, n. 60.

(5) Art. 525-2 C. pr. civ, créé par le Décr. no 2014-1338 du 6 nov. 2014. 
د/ طلعت يوسف خاطر

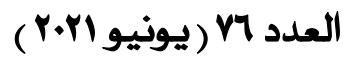

ويلاحظ أن سلطة الأمر بتنفيذ المعجل لم تمنح لمحكمة الاستئناف بكامل هيئتها

ولكن للرئيس الأول من تـاريخ انعقاد اختصاصه(')؛ وإذا منح قاضـي التحضير التنفيذ

المعجل فـلا يجـوز للـرئيس الأول أن يوقف التنفيــ. ويلاحظ أن الـرئيس الأول يكـون

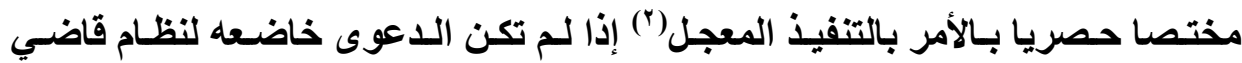
التحضير("). ويرى البعض أن المشرع الفرنسي منح الرئيس الأول السلطة تعلو عن

سلطة الممنوحة لمحكمة الاستئناف في الحكم بالتنفيذ المعجل (4).

ولقد اختلف الفقه الفرنسي حول عدّ طلب التنفيذ المعجل من الطلبـات الجديدة

أم من الطلبـات الفرعية التي يجوز إبداؤها أمسام محكمة الاستئناف؛ فذهب جانب من فن فئ

الفقه إلى أنه إذا لم يكن طلب التنفيذ المعجل أمام محكمة أول درجة فلا يمكن طلبه أمسام

محكمة الاسـتئناف(*)، بينمـا ذهب الجانب الآخر إلى عدّ الطلب التنفيذ المعجل مـن

الطلبـات الفرعيـة التـي يجوز تقديمها أمسام محكمـة الاستئناف("). وقد حسم القـانون

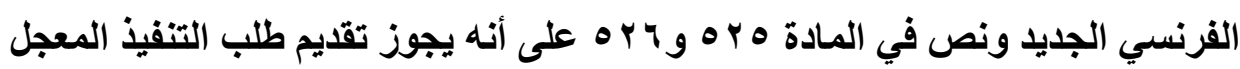

(1)CA Lyon, 25 sept. 1979, Gaz. Pal. 1979. 2. 635; CA Colmar, 18 déc. 1980, Rev. jur. Est 1980, 39.

(2)Ph. HOONAKKER, Exécution provisoire,op. cit., n0111.

(3) S. GUINCHARD et MOUSSA, Droit et pratique des voies d'exécution, Dalloz, 8e éd., 2015, p.242.

(4) J.A. Fusil, la jurisdiction du premier president de la Cour d 'appel, Gaz Pal. 1975, doc. P, 347.

(5) P. CUCHE, précis d procedure civilee et commerciale, 10 éd. 1954, p. 348.

(6) GLASSON, TISSIER et MOREL, Traité théorique et pratique d'organisation judiciaire, de compétence et de procédure civile, op. cit., p. 357. CA Grenoble, 2 oct. 1963, RTDC, 1967, n0 384. 
في مرحلة الاستئناف. ويعد هذا النص تجديدا لم ينص عليه المشرع الفرنسي من قبل، حيث وضعت هذه المادة حدا للجدل الذي ثار في الفقه الذي كـان قائمـا في ظل القانون السابق حول جواز طلب التنفيذ المعجل من محكمة الاستئناف. ويلاحظ أن السلطة التقديرية للأمر بالتنفيذ المعجل مقصورة على قاضي أول درجة؛ ففي مرحلة الاستئناف نصت المادة ه ب ه إجراءات على أنسه يجب للحكم بالنفاذ المعجل أن يكون هناك طلب(')، ولا يتوقف تقديم الطلب على رفع الاستئناف من الطرف المحكوم عليه، فيمكن تقديم الطلب حتي لو لم يرفع الاستئناف()، ويجب أن يكون هنـاك الك

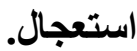

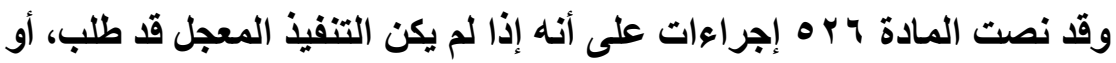

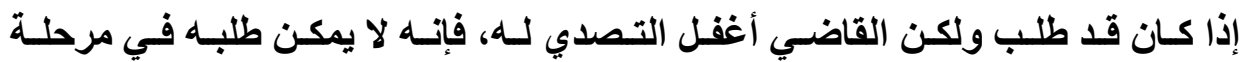
الاسـتئناف إلا مـن الـرئيس الأول بوصـفه قاضـيا للأمسور المستعجلة أو مـن قاضـي التحضير منذ انعقاد اختصاصه، فهذا النص قـ أكمل مـا أثسار إليها المشرع في المـادة ه به إجراءات، مجيزا طلب التنفيذ المعجل لأول مرة من الرئيس الأول أو من قاضسي التحضير في حالة إغفـال محكمة أول درجـة الحكم بـه رغم طلبه. ولـم تستلزم المـادة צ Y ه إجراءات توافر شرط الاستعجال، وإذا قضي قاضسي أول درجـة بالتنفيذ المعجل الجزئي، فإنه يمكن إعادة طلب التنفيذ المعجل من الرئيس الأول أو من قاضي التحضير تطبيقا لنص المادة 7 ro إجراعات.

(1) Ph. HOONAKKER, Exécution provisoire,op. cit., n043.

(2) S. Guinchard, Code de procedure civile, 1993, p. 13. Berlioz, limites et difficultés d'exécution de l'acte authentique, op. cit., 1249. 


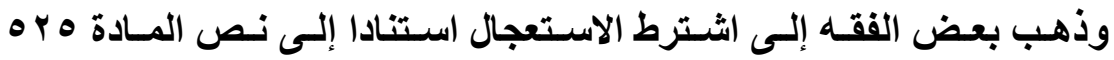

إجراءات(')، إذ قد يعسر المدين ولم يستطع الوفاء(؟)، وللقاضي سلطة تقديرية في بيان

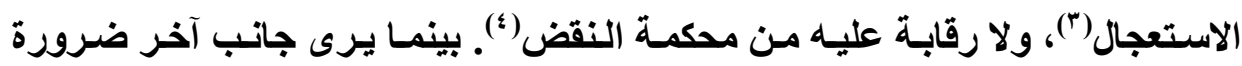

توافر حالة الضرورة(') الملاعمة لطبيعة المسألة حتى بحكم القاضي بالنفاذ المعجل("). ثالثا: منع محكمة الاستئناف من وقف التنفيذ المعجل

إذا كـان المشرع الفرنسي والمصري منح المحكوم لـه الحق في طلب تنفيذ

الحكم الصادرله تنفيذا معجلا، فقد منح أيضا ضمانات معينة للمحكوم عليه؛ منهـا أن يطلب وقف تنفيذ الحكم مـن محكمـة الاسـتئناف، وذلـك خشية مـن إلفــاء الحكم فـي الاستئناف(N)، وصعوبة إعادة الحال إلى مـا كاتت عليه عن طريق التنفيذ العكسي(م). ويرى الققه أن طلب وقف التنفيذ المعجل لا يعد طعنـاً في قضاء أول درجـة يوجه إلى إسى

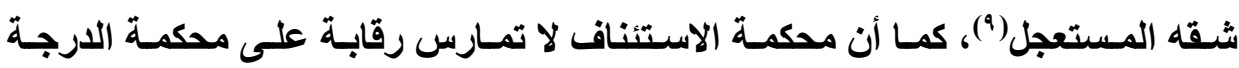

(1) Ph. HOONAKKER, Dernières réformes de l'exécution provisoire. Raison et déraison, op. cit. n0 754.

(2) Cass. Civ. 2e, 6 janv. 1960, D. 1960. Somm. 92.

(3) Civ. 2e, 6 mars 1974, Bull. civ. II, no 85.

(4) Cass. Civ. 2e, 9 mai 1983, Gaz. Pal. 1983. 2. Pan. 258.

(5) art. 525 C. pr. civ., Ph. HOONAKKER, Exécution provisoire,op. cit., n0 56.

(6)Ch. Loyer-larher, l'exécution provisoire, analyse de la jurisprudence des Cours d'appel d'angers et de Rennes, op. cit., doct. 152.

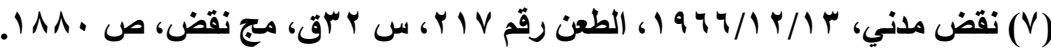

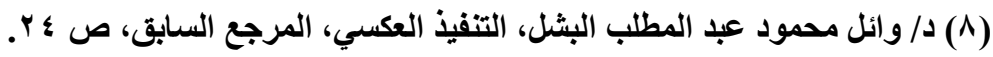

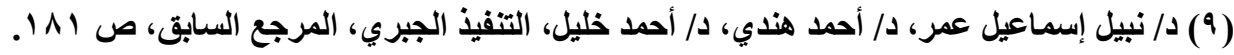


دا طلعت يوسف خاطر

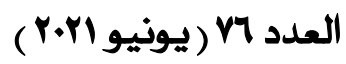

الأولى عند نظر طلب وقف التتفيذ؛ لأن التنفيذ المجل قد لا يكون مقرراً بناء على حكمها و إنما قد يستتد إلى نص القانون.

وقد تطور المشرع الفرنسي في مسألة وقف التنفيذ أمام محكمة الاستنناف؛ إذ

أجاز في القانون القديم وقف التتفيذ المعجل سواء القانوني أو القضائي(')، ولكن عدل التئل هذا الاتجاه، ونص في قانون المرافعات الجديد على قصر وقف النفـاذ المعجل على العى

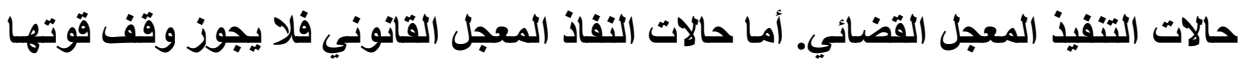

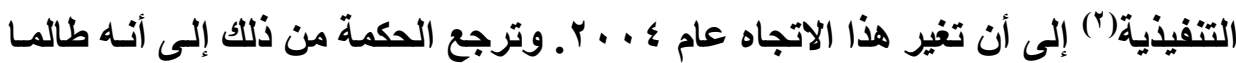
أن المشرع هو الذي قرر النفاذ المعجل فلا يمكن أن يوقفه القاضي، أما في حالات النفاذ

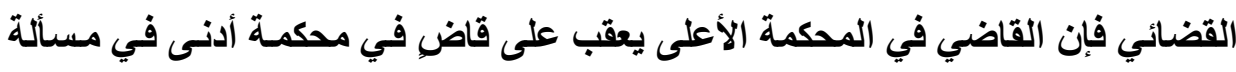
النفاذ المعل، وهو أمر منطقي تماما (").

لقد كان النص قبل تعديل قانون الإجراءات الفرنسي في YVY I يخص محكمة

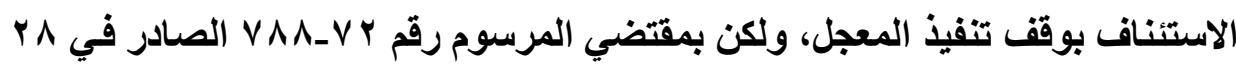
أغسطس IqVץ قصر الاختصاص بوقف التتفيذ على الرئيس الأول لمحكمة الاستئناف بوصفة قاضيا للأمور المستعجلة طبقا لنص المادة ؟ به إجراءات. ويمكن وقف التنفيذ التهني

(1) Léon Fauvem, La réforme de l'exécution provisoire des jugements nonobstant opposition et appel, these paris, 1932, p. 32.

(2) CA Paris, 15dec. 1976, J.C.P, $19 \vee \checkmark$ n.18354.

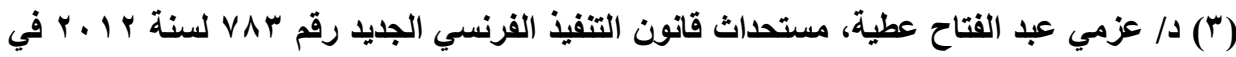

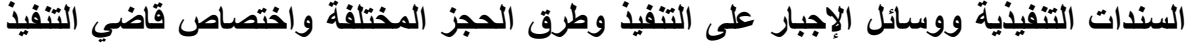

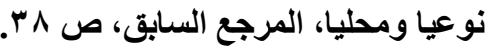


د/ طلعت يوسف خاطر

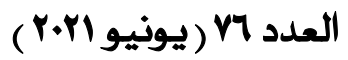

المجلل بنوعيه القضائي والقانوني على حد سواء(') وقاضي التنفيذ غير مختص

بطلب وقف تنفيذ التنفيذ المعجل(").

وطبقا لنص المادة § به إجراعات فالرئيس الأول لمحكمة الاستئناف لا يمكنه

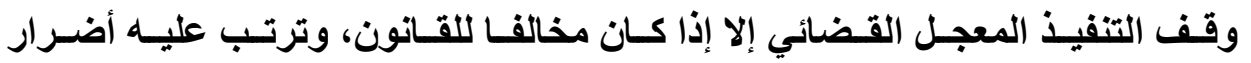

جسيمة(")، ويمكن في هذه الحالة الأخيره أن يتخذ الإجراءات المنصوص عليها في

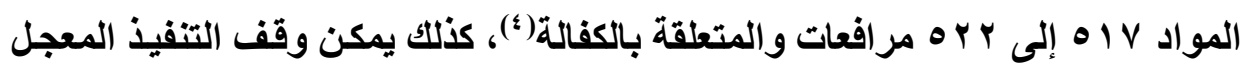

القانوني إذا توافرت شروط معينه، وسنشير إلى ذلك في النقاط الآتية:

1 - إقف التنفيذ المعجل القضائي

طبقـا نص المشرع الفرنسي في قـانون الإجراءات السابق على جواز وقف

التنفيذ المعجل القضائي إذا كان يؤدي التتفيذ المعجل إلى خطر لا يمكن تداركه(•). ولكن

عدل المشرع الفرنسي هذا الاتجـاه في قانون الإجراءات الحـالي، ونص على حالات

محدد لوقف التنفيذ المعجل في المادة ؟ ب إجراعات؛ فقد ألغى المشرع سلطة الرئيس

الأول لمحمة الاستئناف في رقابة محكمة أول درجة، فلم يعد يجوز وقف تنفيذ التنفيذ

(1) Ph. HOONAKKER, L'effet suspensif des voies de recours dans le nouveau code de procédure civile : une chimère ? Contribution à l'étude de l'exécution provisoire, op. cit. n0 60.

(2) Ph. HOONAKKER, Exécution provisoire,op. cit., no 130.

(3) Décr. no 76-1236 du 28 déc. 1976; Cass. Civ. 2e, 13 juin 2002, Bull. civ. II, no 132.

(4) art. 22, Décr. no 81-500 du 12 mai 1981.

(5)FAUVEL, La réforme de l'exécution provisoire des jugements nonobstant opposition et appel, op. cit., p. 125; TOUZET, De l'exécution provisoire des jugements, thèse, Paris, 1901, p. 125 s.

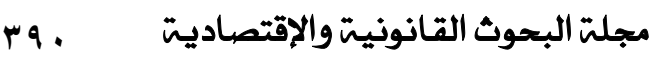


المعجل إلا طبقا للشروط المنصوص عليها في المـادة ؟ ؟ إجراعات، وهذه الشروط تقيا سلطة الرئيس الأول في وقف التنفيذ، حيث قضي بأنه لا يمكن وقف التنفيذ المعجل القضائي إلا إذا توافر شرطان؛ أن يكون التنفيذ المعجل القضائي ممنوعا قانونا ويترتب عليه ضرر جسيم يصيب المحكوم عليه('). وهذا يقتضي التفرقة بين المخاطر العادية والمخاطر الجسيمة من التنفيذ(؟)، وقد ذهبت محكمة النقض الفرنسية إلى أنه لا يمكن وقف تنفيذ النفاذ المعجل الصادر بشأن بعض التدابير المتعلقة بـالحكم بـالطلاق إلا إذا

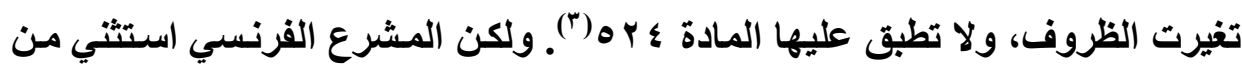
ذلك بعض المسائل التجارية التي تهدف إلى حماية الثركة، وذلك بمقتضي القانون رقم

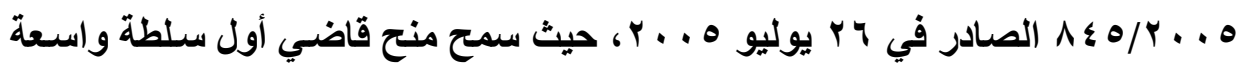
في وقف التنفيذ المعجل(๕)

ويلاحظ على نص المادة ؛ به إجراءات أنها تحد تماما من حالات وقف التنفيذ

المعجل القضائي، ويستبعد المشرع أي رقابـة على قاضسي أول درجة، حيث أن نصت

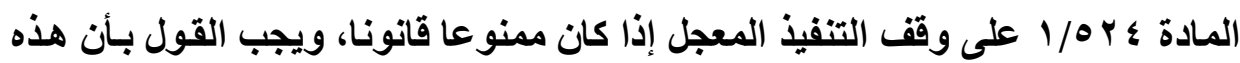
الحالات محدد ومحصورة جدا، فنادرا ما يمنع القانون التنفيذ المعجل القضائي(ه). وهذه الحالة تنطبق على وقف التنفيذ سواء أكان قضائيا أم تنفيذا معجلا قانونيا"ج). ويرى

(1) Cass. Civ. 2e, 13 juin 2002, Bull. civ. II, no 131, Dr. et proc. 2002. 361, obs. Hoonakker.

(2) l'article 1152, alinéa 2, du code civil.

(3) Civ. 2e, 28 janv. 1998, Bull. civ. II, no 34.

(4) art. R. 661-1, al. 3. C. com.

(5) Ph. HOONAKKER, Exécution provisoire,op. cit., n0 139.

(6)- J. MIGUET, Jugements. Exécution provisoire, op. cit., fasc. 519, no 46. 
بعض الفقه الفرنسي التوسع في فهم النص؛ فهذه الحالة لا تنطبق فقط على كون التتفيذ المعجل ممنوعا قانونا، ولكن أيضا في حالة عدم توافر شروط التفيذ المعجل فيكون ممنوعا قانونا، سواء أكان التنفيذ المعجل غير متناسب مع موضوع النزاع أم لم تتو افر

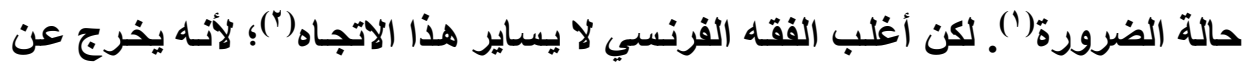

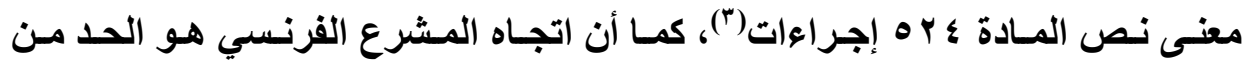

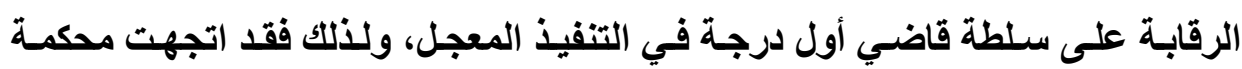

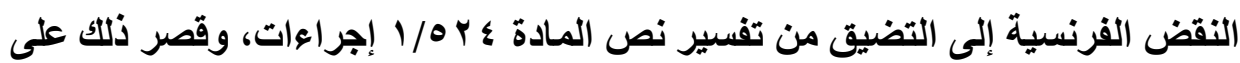
حالات منع التفيذ المعجل قانونا(؛)، وأن يترتب أثر جسيم، ولا يمكن اصلاحه، فيجب أن تكون الآثار من الخطورة ما يستوجب وقف تنفيذ الحكم المستعجل(ه). وبهذا المفهوم فإنـهـ إذا كـان التنفيذ المعجل لا يتفق مـع طبيعة النزاع فإنـهـ يمكن أن يـؤدي إلى آثـار

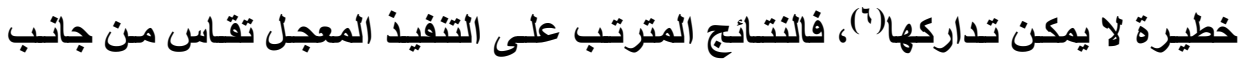

(1) BURKI, note sous Lyon, 18 déc. 1979, JCP 1980. II. 19417; CANS et SCHRICKE, Le référé du premier président, in La pratique du référé dans les juridictions civiles de la région parisienne, op. cit., p. 53 s., spéc. p. 70

(2) Civ. 2e, 5 janv. 1978, Bull. civ. II, n. 11

(3) Ph. HOONAKKER, Exécution provisoire,op. cit., n0141. Cass., Civ. 2e, 12 mars 1997, Bull. civ. II, no 75 ; D. 1997. IR 113 ; Gaz. Pal. 13-14 oct. 1999, p. 11, obs. du Rusquec.

(4) Cass., 12 mars 1997, id.

(5) Ph. HOONAKKER, Exécution provisoire,op. cit., n0 145

(6) Cass. Civ. 2e, 29 mai 1991, Bull. civ. II, no 169. Cass. Civ. 2 e, 5 juin 1996, Bull. civ. II, no 139 ; Cass. Civ. 2e, 5 févr. 1997, Bull. civ. II, no 36. Cass. Soc. 11 déc. 1990, Bull. civ. V, no 641;CA Nancy, 6 oct. 1983, D. 1984. 232. 
المدين ومن جاتب الدائن، فقد يترتب على التتفيذ المعجل إفلاس المدين أو مخـاطر لا

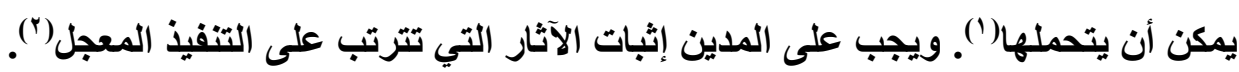
ومن ناحية الدائن يجب أن يثبت أنه يترتب على وقف التنفيذ آثار خطيره بالنسبة لهـ("). وفي حالة التنفيذ غير المالي يجب تقييم الحالة على أساس معيار شخصي للمدين، فقد قضي بأنه طرد المستأجر المريض يؤدي ذلك إلى مخاطر صحية قد يترتب عليها وفاتها

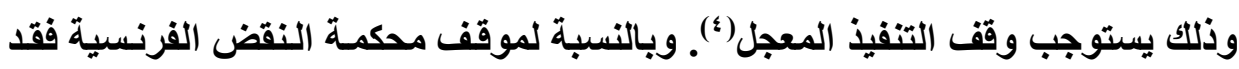
اتجت أولا إلى تأييد الاتجـاه الموضوعي لتقيبم الآثار التي تترتب على التتفيذ(॰)، ثم

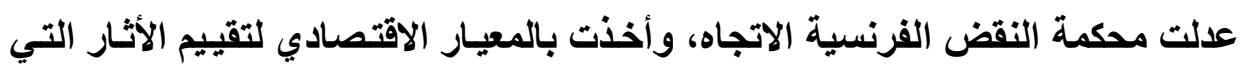
تترتب على التنفيذ المعجل(").

(1) LOYER-LARHER, La réforme de l'exécution provisoire, op. cit., Doctr. 587 n. 592, BERTIN, Le grand Noël du procédurier, Gaz. Pal. 1976. 1. Doctr. 313, spéc. no 118; CA Paris, 19 mai 1982, RTD civ. 1982. 660, obs. Perrot. Cass. Civ. 2e, 3 mars 1983, Bull. civ. II, no 66.

(2)Cass. Civ. 2e, 18 avr. 1980, Gaz. Pal. 1980. 2. 490, note Viatte.

(3) BLAISSE, Arrêt et aménagement de l'exécution provisoire par le premier président, op. cit., 3183, BERTIN, Le grand Noël du procédurier, op. cit., no 118. LARHER, La réforme de l'exécution provisoire, op. cit., Doctr. 587 ; Loyer-larher, L'exécution provisoire. Analyse de la jurisprudence des cours d'appel d'Angers et de Rennes, op. cit., 153, CA Rennes, 7 juill. 1977, Gaz. Pal. 1978. 1. 149, note LoyerLarher, Colmar, 19 janv. 2007, Rev. jur. Est 2007. 84 LOYER.

(4)CA Versailles, 4 déc. 1992, Gaz. Pal. 1993. 1. Somm. 192; CA Paris, 3 mars 1994, Gaz. Pal. 12-14 juin 1994, p. 22

(5) Cass. Civ. 2e, 16 janv. 1980, Gaz. Pal. 1980. 1. Somm. 240; Cass. Civ. 3e, 25 oct. 1983, Bull. civ. III, no 199.

(6) Cass., ass. plén., 2 nov. 1990, JCP 1991. II. 21631. 
وذهب الفقه الفرنسي إلى عدم رقابة الرئيس الأول على تناسب التنفيذ المعجل مع طبيعة النزاع(')، ولكن اتجهـ الفقه التقليدي إلى ضرورة الرقابـة على مدى توافق

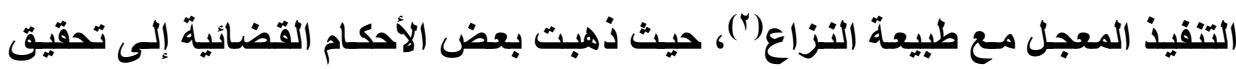
رقابة غير مباشرة على هذا الشرط، من خلال مدى حاجة الدائن للتففيذ المعجل، ومدى

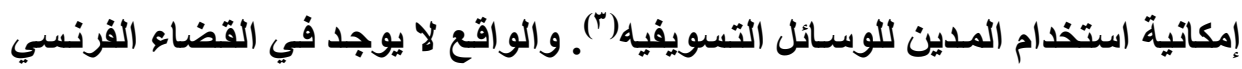
تطبيقات كثيرة في هذه المسألة، حيث إن القضاء امتنع عن رقابة أسباب التناسب مـع طبيعة النزاع(")، وعلي الرغم من أن نص المـادةه ه ؛ إجراعات تلزم بالتسبيب إلا أن دور الرئيس الأول محدد بحالة استثنائية في الرقابة على التفيذ المعجل القضائي، ولا

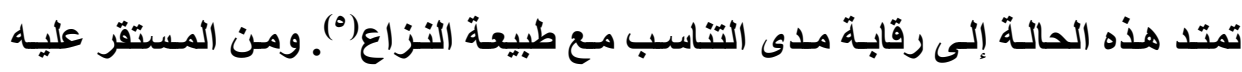

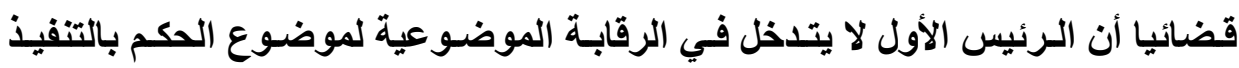
المعجل، ولا يملك بحث مدى سوء التقدير من جانب الدرجة الأولى في إصدار الأمر

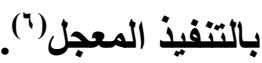

(1)GERBAY, Réflexions sur la juridiction du premier président de la cour d'appel, D. 1980. Chron. 65; LOYER-LARHER, La réforme de l'exécution provisoire, op. cit., p. 591

(2) CA Versailles, 12 et 19 déc. 1979, Gaz. Pal. 1980. 2. Somm. 603; CA Versailles, 28 févr. 1989, Gaz. Pal. 1990. 2. Somm. 586.

(3) Bordeaux, 28 avr. 1982, Gaz. Pal. 1982. 2. 366, note du Rusquec.

(4)CA Colmar, 24 févr., 30 mars et 8 mai 1978, Rev. jur. Est 1978. 89; CA Rennes, 24 févr. 1984, RTD civ. 1984. 566, obs. Perrot. CA Rennes, 22 avr. 1986, JCP 1987. II. 20820, note Cadiet; CA Paris, 5 août 1988, Bull. avoués 1988. 158.

(5) Ph. HOONAKKER, Exécution provisoire,op. cit., n0 160.

(6) CANS et SCHRICKE, Le référé du premier président, in La pratique du référé dans les juridictions civiles de la région parisienne, op cit., $p$. $=$ 
وقد حاول بعض الفقه توسيع رقابـة الرئيس الأول(') والحكم بوقف التنفيذ،

فعندما توجد مخالفة قانونية مثل عدم مراعاة حقوق الدفاع أو عند وجود تسبيب كاف يمكن وقف التنفيذ(؟) وقد ذهبت بعض الأحكام إلى الحكم بـالوقف بنـاء على مدى قوة

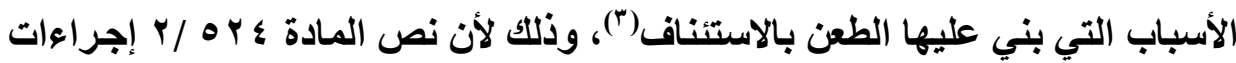

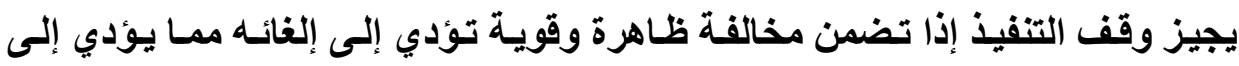

$$
\text { حدوث أخطار من تنفيذه لا يمكن تداركها"( }
$$

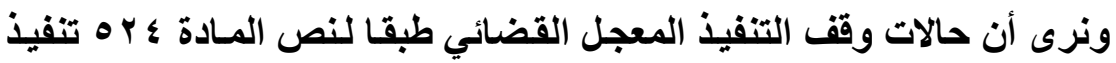
محددة جدا، حيث إنـه لا يمكن أن يراقب الرئيس الأول شرطي الضرورة والتناسب،

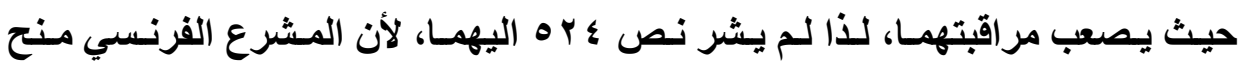
القاضي أول درجة سلطة تقديريـة واسعه بشأنهما، وهذه السلطة تجعل قرار القاضي بالتنفيذ المعجل بعيدا عن أي رقابـه، وبـلكك يكون المشرع الفرنسي قد ألغى عمليـا إمكانية إيقاف التنفيذ المعجل القضائي، لأن الايقاف مشترط بأن يكون التنفيذ المعجل قد منح بثكل مخالف للقانون، وهذه الحالات محده على سبيل الحصر(').

76; PH. HOONAKKER, l'effet suspensive des vois de recours dans le nouveau code de procedure civile, op. cit., nos 694 s; LOYER-LARHER, La réforme de l'exécution provisoire, op. cit., p. 153 s.

(1) GERBAY, Réflexions sur la juridiction du premier président de la cour d'appel, op. cit., p. 65.

(2) CAParis, 4 oct. 1976, D. 1977. 28, note Bettinger ; CA Lyon, 25 nov. 1980, JCP 1981. II. 19704, note J. A.

(3) CA Toulouse, 3 juill. 1981, Gaz. Pal. 1982. 1. 90.

(4) LOBIN, L'exécution provisoire, op. cit., p. 9 s., spéc. p. 11.

(5) J. Viatte, suppression du controle de l'exécution provisoire, Gaz. Pal., 1974, I doc. 463. 
د/ طلعت يـوسف خاطر

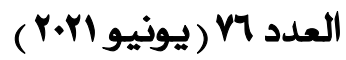

r - - وقف التنفيذ المعجل القانوني

بالنسبة للتنفيذ المعجل القانوني فقد اكدت محكمة النقض الفرنسية عدم جواز

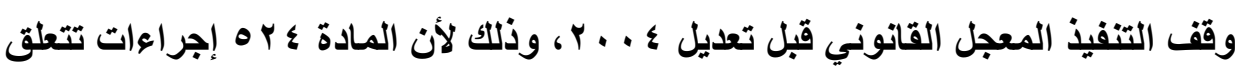

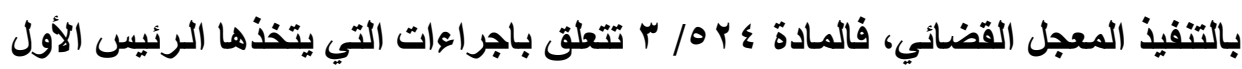

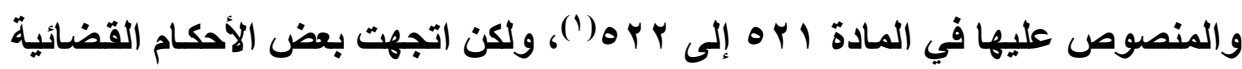

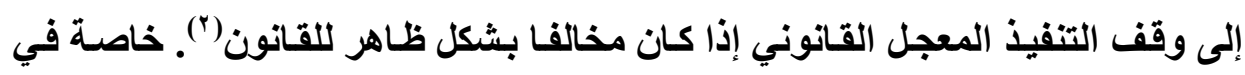
حالة مخالفـة حقوق الــاع(")، وأمـام هذا الاتجـاه الذي يـرى ضرورة مراقبـة التنفيذ

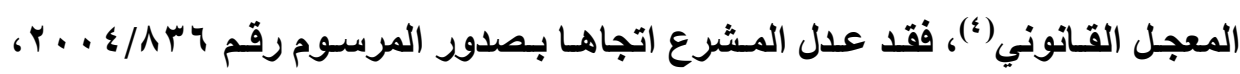

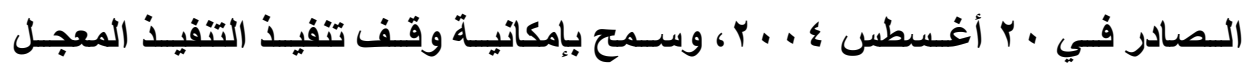
القانوني(•)، وقد نصت المادة ؛ به إجراعات على أنه لا يمكن وقف تنفيذه إلا إذا كاتت

(1) Civ. 2e, 13 janv. 2000, Bull. civ. II, no 5 ; RTD civ. 2000. 400, obs. Perrot ; Cass. Soc. 28 juin 2001, Bull. civ. no 237; Cass. Soc. 18 mai 2004, RTD civ. 2004. 556, obs. Perrot

(2) CA Nancy, ord. 1er prés., Gaz. Pal. 1998. 1. Somm. 233, obs. Humbert.

(3)CA Lyon, ord. 1er prés., 24 juill. 2002, Dr. et proc. 2003. J18. 95, obs. Fricéro.

(4) Ph. HOONAKKER, L'arrêt de l'exécution provisoire de droit enfin consacré par le législateur !, D. 2004. Chron. 2314.

(5) Décr. no 2004-836 du 20 août 2004, art. 8, en vigueur le 1er janv. 2005

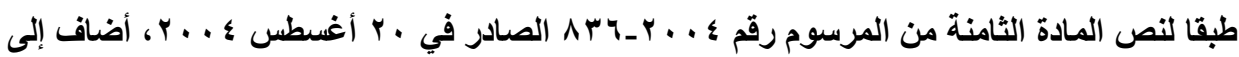

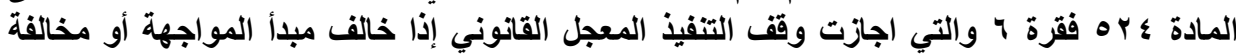

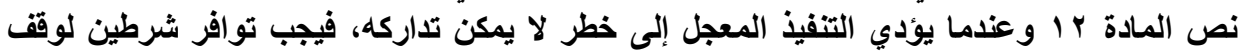

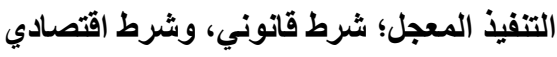


هناك مخالفة لمبدأ المواجهة('). و ترتب عليه آثار خطيرة("). ويشترط أن يكون هنـاك طعن بالاستئناف("). ولكن لا يشترط أن يكون الاستئناف مقبولا، لأنه لا يجوز للرئيس الأول بحث مدى قبول الطعن بالاستنئاف(؛). ولا يجوز طلب وقف التنفيذ في حالة تمسام التنفيذ(ه)، والقرار الصادر مـن الرئيس الأول يكون قابلا للطعن عليه طبقا للقواعد

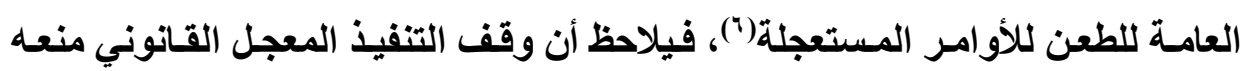
المشرع من حيث الأصل إلا في حالات استثنائية)(V).

وقد اتجه بعض أحكام القضاء الفرنسي إلى وقف التنفيذ المعجل القانوني في حالة مخالفة المبادئ الأساسية للتقاضسي وخاصـة حقوق الدفاع ومبدأ المواجهة، وقد

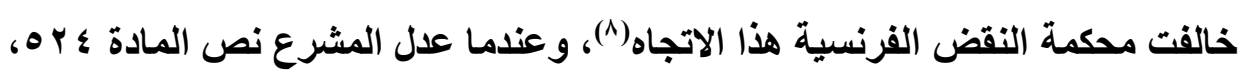

(1) S. GUINCHARD, CHAINAIS et FERRAND, Procédure civile, Dalloz, 32e éd., 2014, no 1346.

(2) Cass. Civ. 2e, 8 déc. 2005, Bull. civ. II, no 310.

(3)Cass. Civ. 2e, 18 févr. 2016, Gaz. Pal. 17 mai 2016, p. 71, obs. L. Raschel.

(4) PERROT, Procédure de l'instance, Jugements et voies de recours. Voies d'exécution et mesures conservatoires, op. cit., spéc. p. 793.

(5) CA Paris, 26 mai 1967, RTD civ. 1968. 198, obs. Raynaud; CA Paris, 20 oct. 1988, Bull. avoués 1988. 161. CA Montpellier, 17 déc. 1981, Gaz. Pal. 1982. 2. Somm. 384. CAToulouse, ord. réf., 1er mars 1995, D. 1996. 131, note Prévault; Cass. Civ. 2e, 24 janv. 2008, Bull. civ. II, no 22 supérieure à celle due en vertu de l'exécution provisoire

(6)GUINCHARD et MOUSSA (dir.), Droit et pratique des voies d'exécution, op. cit., nos 553.71 et 553.431, PERROT La compétence du juge des référés, Gaz. Pal. 1974. 2. Doctr. 895, spéc. no 9.

(7) Ph. HOONAKKER, Exécution provisoire,op. cit., n0 136.

(8) WIEDERKEHR, Droits de la défense et procédure civile, D. 1978. Chron. 36. 
لم يسمح بالوقف إلا في حالة مخالفة مبدأ المواجهة، أما باقي حقوق الدفاع الأخرى فلم ينص عليها صراحة('). وقد اتجـه البعض إلى التوسـع في تفسير نص المـادة ؛ ؟ ه والتي أحالت إلى المسادة ب ا من قـانون الإجراعات ليشمل الرقابـة المبـادئ الأساسية للتقاضـي() و الواقع أن محكمة النقض الفرنسية قد تشددت في تفسير نص المسادة ه ro فيما يتعلق بوقف تنفيذ المعجل، ولكي يحكم القاضي بوقف التنفيذ يجب توافر شرط آخر، وهو شرط اقتصادييتمثل في وجوب أن يترتب على التنفيذ المعجل القانوني آثار خطيرة لا يمكن اصلاحها (").

ونـرى أن المشرع الفرنسي أخذ بموقف معتدل ومنطقي عندما قصر سلطة

المحكمة في وقف النفاذ على حالات النفـاذ المعجل القضائي دون حالات النفـاذ المعجل

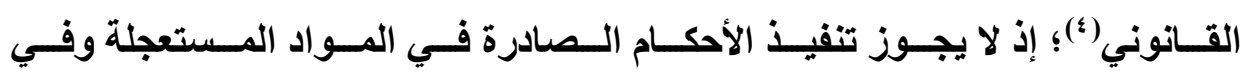
مواد النفقات(')إلا في حالات استثنائية(")، وفكرة القانون الفرنسي هي إعطاء فاعلية

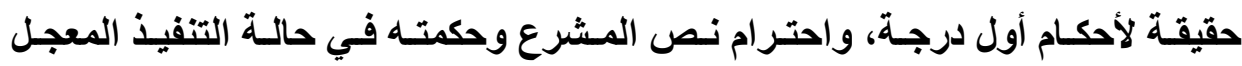

(1)Cass. Civ. 2e, 15 oct. 2009, Bull. civ. II, no 246.

(2) Cass., ass. plén., 21 déc. 2007, Bull. ass. plén., no 10.

(3) Cass., ass. plén., 2 nov. 1990, JCP 1991. II. 21631.

(4) VALLENS, L'exécution provisoire du jugement de redressement ou de liquidation judiciaire, D. 1997. Chron. 11.

(5) id., Trib. Paris, 15 dec. 1976, jep, p. 40.

(6) depuis le décret no 2004-836 du 20 août 2004, l'exécution provisoire de droit peut être arrêtée, mais les conditions posées sont bien plus restrictives que celles du sursis à l'exécution ouvert contre les décisions du juge de l'exécution frappées d'appel. 
رابعا: منع المشرع الفرنسي الطعن في حكم القاضي بالكفالة في التفيذ المعجل لقد كان نص المشرع الفرنسي في قانون المرافعات القديم على أنـه من أجل حماية مصالح المحكوم عليه في حالة الحكم بالتنفيذ المعجل، إلزام المحكوم لـه بتقديم كفالة كضمانة لإعادة الحال إلى ماكـان عليه إذا ألغي الحكم المشمول بالنفـاذ المعجل، وكان يجوز للمنقَّ ضده أن يعترض على الكفالة.

ومن التطورات المهمة التي أخذ بها المشرع الفرنسي منع الطعن في الكفالك،،

لأن المنازعة في الكفالة كاتت تحدث في الغالب ويترتب عليها وقف التنفيذ لحين الفصل

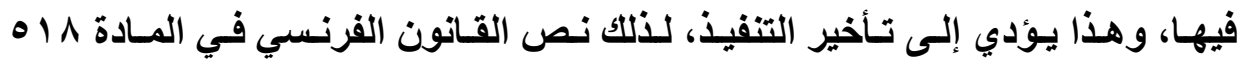
مرافعـات على أن المحكمـة تحدد نـوع الكفالـة بحكم غير قابـل للطعن. وبــلك ألغيـ النصوص التي تنظم المنازعة في الكفالة، ولم تعد المحاكم تنشخل بها، ولم يعد التنفيذ يتعطل بسبب بطء المحكوم لصالحه في اختيار الصورة المناسبة وتفضيله الاتتطار حتى يصبح الحكم نهائيا، مما يهدر فائدة النفاذ المعجل. خامسا: تقييم موقف المشرع الفرنسي: رحب القضاء الفرنسي بموقف المشرع؛ فالقاضسي يمكنه أن يتصرف دون رقابة عليه من المحكمة الأعلى درجة، فقد نص المشرع الفرنسي في قانون الإجراعات الحسالي على قواعد جديدة رأست نظامـا متطورا وغير مسبوق في هذا المجـال، وقد

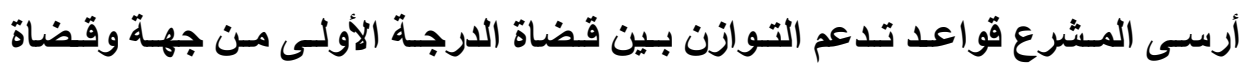

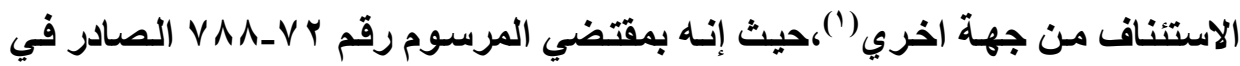

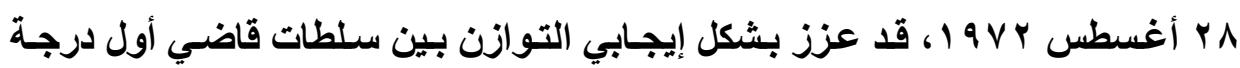
(1) J. Viatte, les référé du premier president, Gaz. Pal. 1973, 2 dpc. 576. 
وسلطات قاضي الاستئناف فيما يتعلق بمصالح كل من أطراف التنفيذ المعجل، كمـا أن هذا المرسوم منح رئيس المحكمة سلطه قاضسي المستعجل، ومنحه حق أوامر التنفيذ المعجل، وهذا الاختصاص آثار عديدا من الصعوبات في الواقع العملي وقت صدوره('). وفي الواقع يتم تقدير حالة الضرورة بالنسبة للمحكوم له المستفيد من التتفيذ المعجل، وهو معيار واسع يمنح لقاضسي أول درجة سلطة تقديريـة كبيرة، ويهدف إلى مواجهة الأعمال التسويفية التي كان يقوم بها المدين في القانون السابق عندما اشترط المشرع وجود الاستعجال(؟). وقد منح المشرع الفرنسي سلطة تقديريـة كاملـة لقاضي أول درجـة فـي الحكم بالتنفيذ المعجل، بـل وقد ألغى المـشرع هذه السلطة لمحكمـة الاستنئاف(") ولكن يلاحظ أن سلطة قضاة الدرجة الأولى غير معصومة من الخطأ. وهذه السلطة المطلقة لا يوجد رقابة عليها()، وهي تهدد حقوق المدين، حيث إن طرق الطعن لا يتحقق لها أية حماية، لأنه التنفيذ المعجل لا يخضع لرقابة محكمة الاستتئاف،

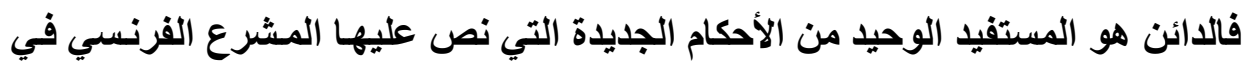
هذه المسألة(ْ). ويجب الاحتراز عند تطبيق هذه السلطة؛ وذلك لأن أغلب قضاة الدرجة الأولى يطبقون هذه النصوص دون تبصر بالمواقف الصعبة التي يمكن أن تترتب على مده

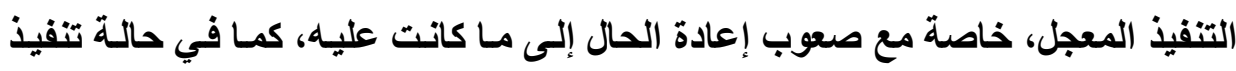

(1) Ph. HOONAKKER, Exécution provisoire, op. cit., No 6.

(2) J. MIGUET, Jugements. Exécution provisoire, op. cit., fasc. 517, nos 86 et 87

(3) Civ. 3e, 8 avr. 1999, Bull. civ. III, no 90; JCP 1999. IV. 2036; Gaz. Pal. 1999. 1. Pan. 169.

(4) PERROT, Procédure de l'instance. Jugements et voies de recours. Voies d'exécution et mesures conservatoires, op. cit., spéc. p. 568

(5) Ph. HOONAKKER, Exécution provisoire, op. cit., n0 57. 
حكم بهـدم مبنس، أو بيع مززاد علنـي، أو طرد ســاكن. لذا يطالب بعض الفقـه بتدخل المشرع بإضـفاء بعض الرقابـة على قضاة الدرجـة الأولى، بحيث يحـ مسن السلطة المطلقة الممنوحه لهؤلاء القضاة بصدد أمرهم بالتنفيذ المعجل ('). ويلاحظ على موقف المشرع الفرنسي أنـه نظم قاعدة متطورة وغير مسبوقة في مجال منح التففيذ المعجل الممنوح من الرئيس الأول لمحكمة الاستئناف؛ حيث أتاح صدور حكم موضوعي في أول درجة ثم يعقبه في وقت لاحق صدور الأمر بالتتفيذ المعجل في مرحلة الاستئناف.

ويرى الفقه أن هدف السمه الأساسية للتنفيذ المعجل في النظام الفرنسي هي الحد من الأثر الموقف للتنفيذ للطعن العادي ضد الأحكام()، ويذهب الاتجـاه في فرنسا إلى محاولة أن يكون التفيذ العادي للأحكام هي القاعدة حتي لو كـان هنالك طعن غير عادي، وذلك بعيدا عن التنفيذ المعجل، وقد قدم مشروع بذلتك، حتى تكون حمايـة المنفذ ضده عن طريق قاضـي التنفيذ(")، وهو مشروع قدم في خمسة إبريل r . . ب ، ولكن نظرا للمعارضة الشديدة لذلك في هذه الفترة، تم سحب الاقتراح()؛، وهذا الاقتراح ايده

(1) J. Viatte, suppression du controle de l'exécution provisoire, op. cit., 463.

(2) Ph. HOONAKKER, L'effet suspensif des voies de recours dans le nouveau code de procédure civile: une chimère ? Contribution à l'étude de l'exécution provisoire, op. cit., no 92.

(3) Ph. HOONAKKer, Le juge de l'exécution, Gaz. Pal. 1993. 1. Doctr. 321, spéc. no 31.

(4)MAGENDIE, L'exécution immédiate des décisions de justice : l'injuste critique d'une réforme nécessaire, D. 2002. Chron. 2411; S. GUINCHARD, Le projet de suppression de l'effet suspensif de l'appel, LPA no 112, 5 juin 2002, p. $4 \mathrm{~s}$. 
د/ طلعت يـوسف خاطر

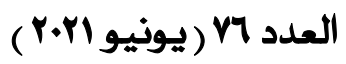

بعض الفقه الفرنسي، وذلك لأنه يحقق فائدة للنظام التنفيذ ويحمي المدين(')، حيث إن

الدائن في نظام التتفيذ المعجل يكون مفضلا عن المنفذه ضده(؟).

الفرع الثالثث

\section{هوقف المشرع المصري من التطورات الصديثة في التنفيذ المعبل}

لقد نهج المشرع الفرنسي نهجا مختلفا عن المشرع المصري في حالات التفيذ

المعجل القضائي، حيث جـاء المشرع الفرنسي بأحكـام عامـة، ولـم ينص على حـالات محددة كما فعل المشرع المصري. وقد أكمل المشرع الفرنسي اتجاهـا في تعديل نظام التتفيذ المعجل؛ حيث أقر تعديلا مهمـا وجذريا، منـه منح القاضـي سلطة الأمر بالتنفيذ

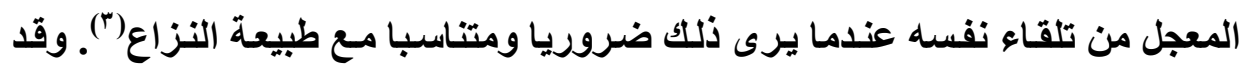
ألغي المشرع شرط الاستعجال، تاركا للقاضي حرية كبيره وسلطة واسعه في التقدير( (؛). ومـنح اللرئيس الأول لمحكمة الاسـتئناف الأمسر بالتنفيـذ المعجل، ومنـع وقف التنفيذ المعجل إلا إذا توافرت شروط محددة، وهدف المشرع من ذلك الحد من وقف التنفيذ المعجل سواء التنفيذ المعجل القضائي أو القانوني. وبالنسبة للقانون المصري فقد نصت المادة rAv من قانون المرافعات على أنه " لا يجوز تنفيذ الأحكام جبراً مادام الطعن فيها بالاستئناف جائزاً إلا إذا كان النفاذ

(1) V.en ce sens Ph. HOONAKKER, L'exécution immédiate, Mélanges Julien, 2003, Édilaix, p. 209.

(2) Ph. HOONAKKER, Exécution provisoire,op. cit., n0 10

(3)Ph. HOONAKKER, Procédures civiles d'exécution, op. cit., p 52

(4) LOBIN, L'exécution provisoire, op. cit., p. 9 s., spéc. p. 11. 
المعجل منصوصا عليه في القانون أو مأمورا به في الحكم"(')، فالمشرع المصري أجاز شمول الحكم بالنفاذ المعجل من أجل معالجة الحالات التي تتطلب السرعة في

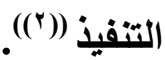

وإذا نظرنا إلى القانون المقارن نجد أن بعض النظم القانونية تعترف لأحكام

محاكم أول درجة بالقوة التنفيذية العادية، ومن ثم لا تكون بحاجـة إلى القوة التتفيذيـة الوقتية أو المعجلة؛ ذلك لأن الحكم يحوز القوة التنفيذية العادية فور صدوره بالرغم من

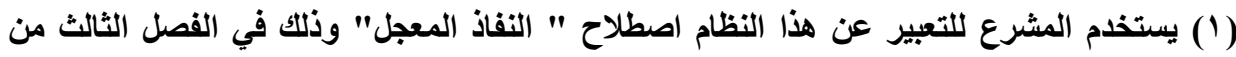

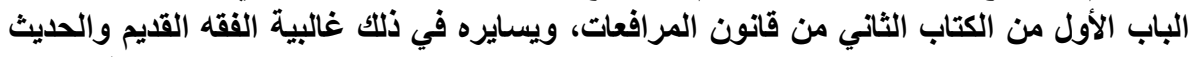

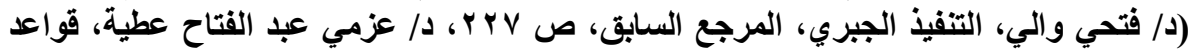

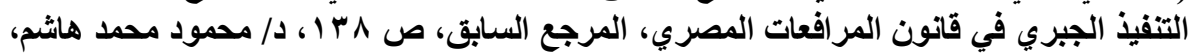

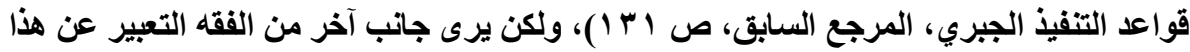

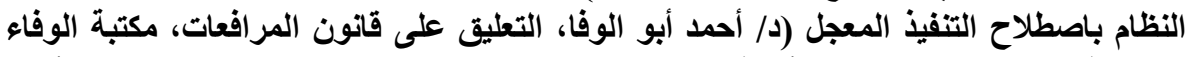

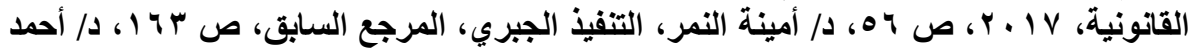

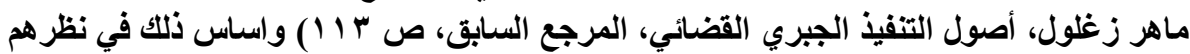

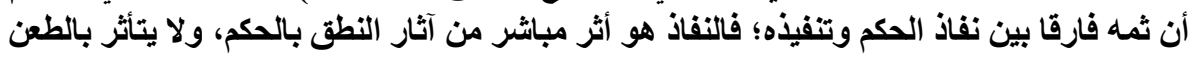

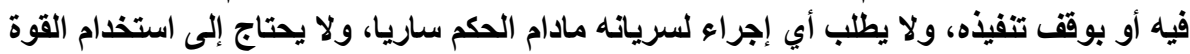

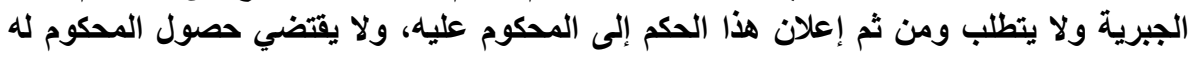

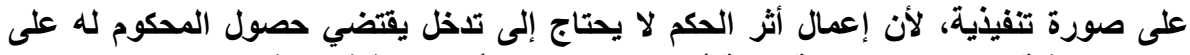

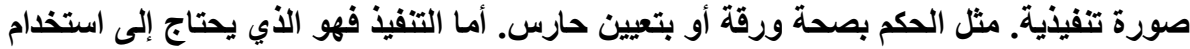

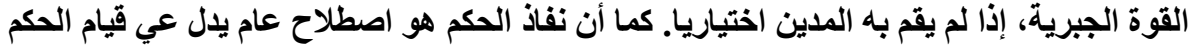

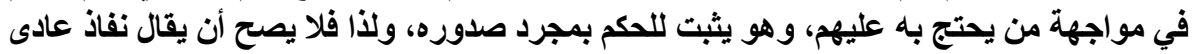

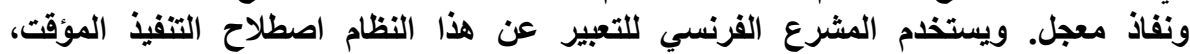
بائه تلفئ ويرفض بعض الفقه المصري التعبير عن التنفيذ المعجل بأنه تنفيذ مؤقت، لأن إجراءات التنفيذ لا تختلف باختلاف طبيعة السند فالأصح أنه قوة تنفيذية

VALLENS, L'exécution provisoire du jugement de redressement ou de liquidation judiciaire, op. cit., 111. HÉBRAUD, L'exécution des jugements civils, Op. Cit., 170 s. 
الطعن عليه بطرق الطعن العادية، وقد تعتمد بعض الأنظمة درجة واحدة للتقاضسي مثل الأحكام في الشريعة الإسلامية، والبعض الآخر يعتمد على تعدد درجـات التقاضي، ومـع ذلك يعترف لأحكام الارجـة الأولى بـالقوة التففيذيـة العاديـة، إلا أنـه يقيـ هذه القاعدة بوجوب الحصول على أمر بتثفيذ الحكم من القاضـي الذي أصدره وإعطساء المحكمـة

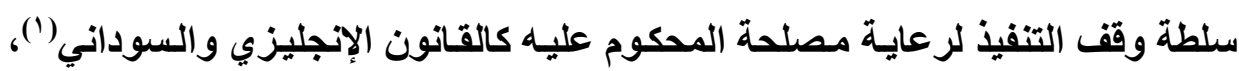
ونجد أن بعض القوانين العربية مثل القانون الأردني، قـ نص في المادة 9 المن قانون الإجراعات على أن تكون الأحكام الإبتدائية واجبة التنفيذ بمجرد صدورها، إلا أنسه يمكن

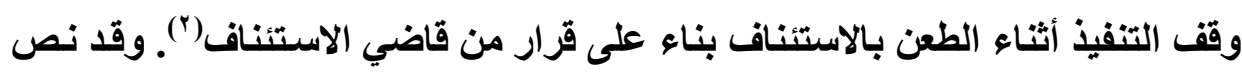

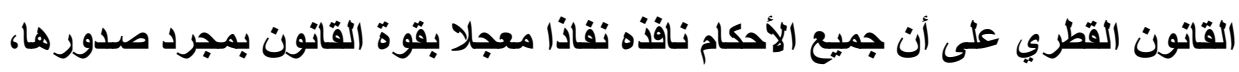
ولكن عدل المشرع هذا الاتجـاه بالقانون رقم ب لسنة 9 أ ـ ب، واخذ بمسا جرى عليه العمل في القانون المصري الحالي.

والواقـع أن موقف المشرع المصري في التفيذ المعجل شـبيها لمـا اعتمـده القانون الفرنسي القديم، على عكس النظام الفرنسي الحديث؛ حيث توسع المشرع الفرنسي في حالات النفاذ المعجل، كما أنه أجاز طلب شمول الحكم بالنفـاذ المعجل من قاضي الاستنئاف، ولو بعد صدور الحكم، وذلك كله على خلاف الأمر بالنسبة للقانون

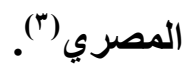

وسنشير إلى أهم ســات التففيذ المعجل في النظـام المصري، ثم مقترحسات بتعديل نظام التتفيذ المعجل وذلك في النقاط الأتية:

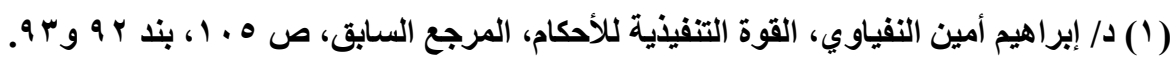

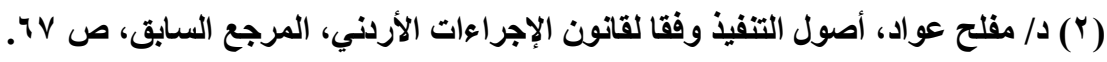

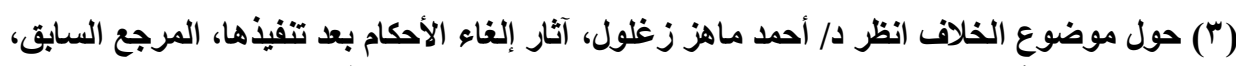

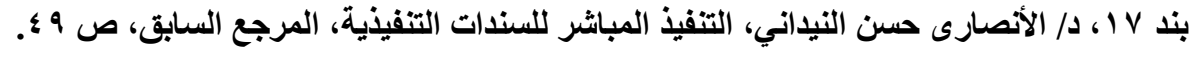


أولاً: أهم سمات التنفيذ المعجل في النظام المصري 1- اشتراط توافر الاستعجال في حالات التتفيذ المعجل القضائي طبقا r r مرافعات لا يكون التفيذ المعجل إلا بنص القانون أو بأمر القاضي، وهذا ما نص عليه القانون الفرنسي في المادة ؛ اه مرافعات فرنسي، فالتنفيذ المعجل لا يلحق الحكم إلا بأمر من المحكمة ما لم يكن الحكم مشمولا به بقوة القانون، فلا يجوز اكتساب القوة التتفيذية المعجلة باتفاق الأطراف(') وقد عددت المـادة ـ ج ج مرافعـات الحسالات التي يمكن أن يصدر فيها الأمسر بالتفيذ المعجل من المحكمة، ثم نصت الفقرة الأخيرة من هذه المـادة على قاعدة عامـة وهي جواز الأمر بالتنفيذ المعجل إذا كان يترتب على تأخير التنفيذ ضرر جسيم بمصلحة

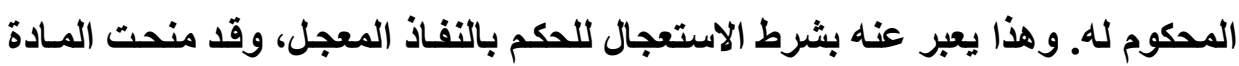

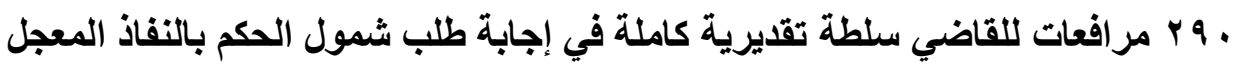

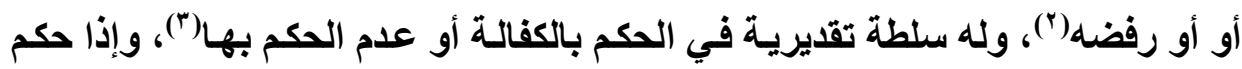

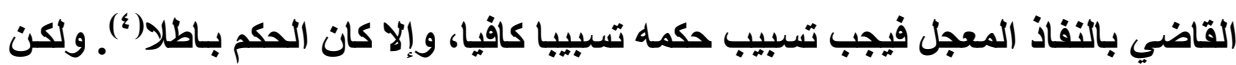
هذا التسبيب لا يكون لازمسا متـى رفض القاضـي الأمسر بالتتفيذ المعجل، لأن الأمسر بالرفض يعد رجوعا إلى القاعدة فلا يحتاج إلى تسبيب.

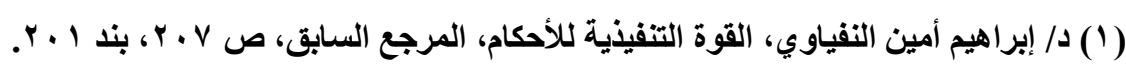

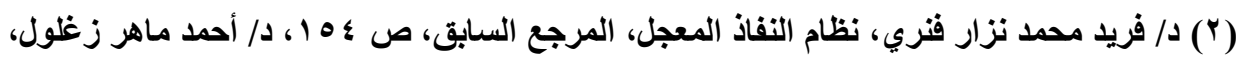

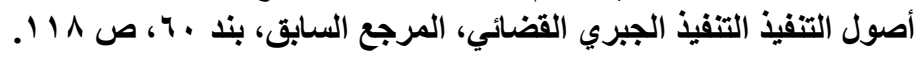

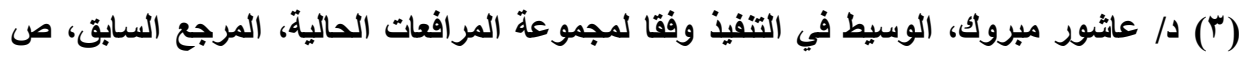
ivo

(؟) د/ إبراهيم أمين النفياوي، القوة التنفيذية للأحكام، المرجع السابق، ص 9 ( 1 ، بند ب9 1. 
ويجد المشرع المصري أساسه القـانوني في منح القاضسي سلطة تقديريـة في

تقدير الاستعجال فى أن نظام التنفيذ المعجل أحد مظاهر الحمايـة المستعجلة في مرحلة التنفيذ(') فالقاضي يملك من حيث المبدأ السلطة الكاملة في تقدير توافر شروط الحماية المستعجلة، أي تقدير عنصر الاستعجال، وهو يملك التدابير الملائمسة في حالة الحكم بالتنفيذ المعجل، فيمكن أن يحكم مطلقا أو مقيدا بنظام الكفالة.

ويلاحظ أن التعداد المنصوص عليه في المادة ـ ج ب مرافعات جـاء على سبيل

المثال، فهو بعد أن عدد الحالات التي يجيز للقاضي فيها أن يقرر حكمهـ بالنفـاذ المعجل حرص على أن توضح أن التعداد الذي أورده ليس على سبيل الحصر وإنمسا ورد ذلك على سبيل التمثيل() ويرى بعض الفقه أنه يجوز للمحكمة أن تأمر بالتنفيذ المعجل كلما توافرت مقتضيات الاسـتعجال ولو في غير الحسالات المنصوص عليها. كمـا يرى أن التعداد المنصوص عليه في المادة ـ ج ج لا يسلب القاضسي سلطته التقديريـة في توافر

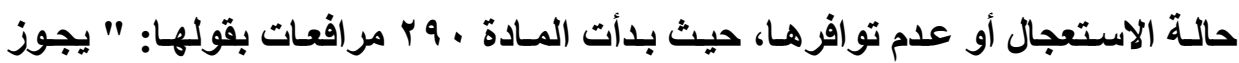

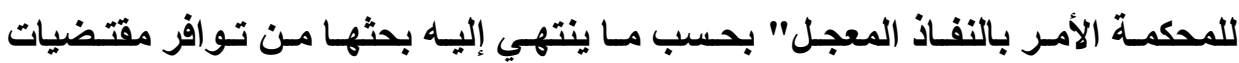
الاستعجال من عدمه، وهو يعني أن الأمر في النهائية جوازي للمحكمة بحسب ما انتهي

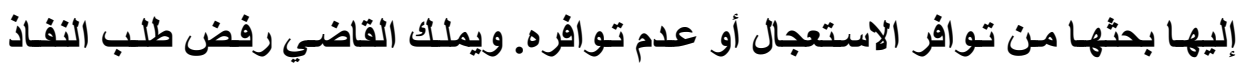

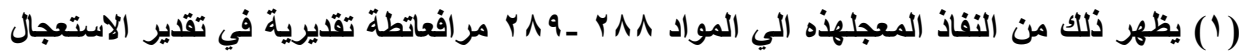

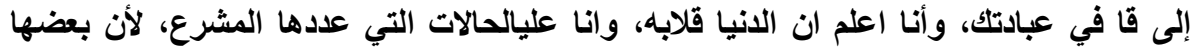

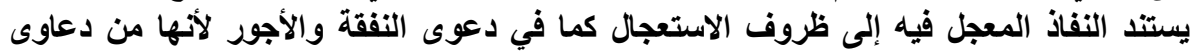

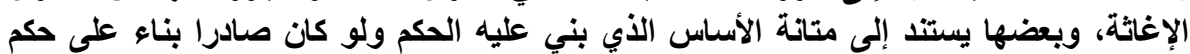

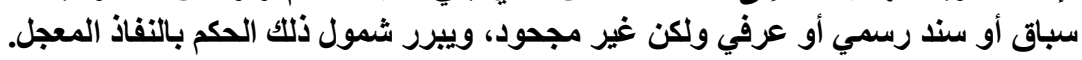

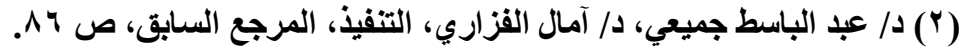


المعجل حتى لو تحققت حالة من الحـالات المذكورة في المـادة ـ ج ب لأن النفـاذ المعجل جوازي أي خاضع لتقدير القاضي(') ونرى عكس هذا الاتجاه؛ حيث إن تقدير حالات الاستعجالة في بعض الحالات الخاصة قد فرضها المشرع، فليس للقاضـي أي سلطة تقديريـة بشأنها، حيث لا يكلف بيحث الاستعجال، وعليه أن يسلم بوجوده. فقد سلب المشرع أي سلطة تقديرية للقاضي

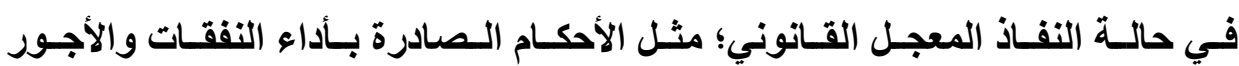

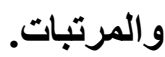

والواقع أن السلطة التقديرية للمحمة في الحكم بالنفاذ المعجل هي القاعدة، ولكن هذا لا يمنع المشرع من التذخل ليحد من إطلاقات هذه السلطة، فالمشرع قد يقدر توافر الاستعجال في حالـة معينة فيعفي القاضـي من بحثُه ويفرض عليه منح التدبير المستعجل الملائم، كما في الحالات التي يكون التفيذ المعجل بقوة القانون، فقد افترض شروط التنفيذ المعجل، ومن ثم فسلطة القاضـي التقديريـة محددة بالمعجل القضائي، ويجب أن يسبب حكمه على نحو كـاف ومنتج(؟). وهو يستخلص شروط النفـاذ المعجل

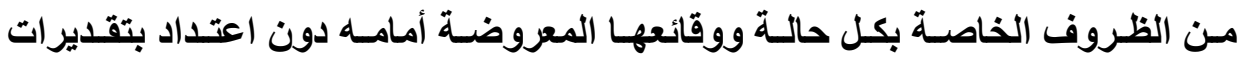
الخـصوم أو تكيـيفهم بالمخالفـة لهـذه الوقـائع، فتقدير الاسـتعجال يخـرج عـن سـلطة الخصوم وتقديراتهم، ويستمد من الظروف المحيطة بالدعوى وتقدرها المحكمة، كل

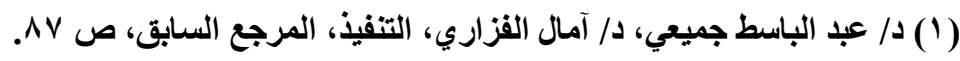

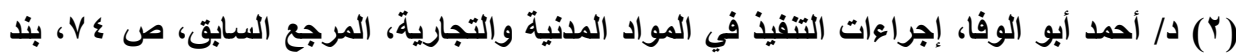

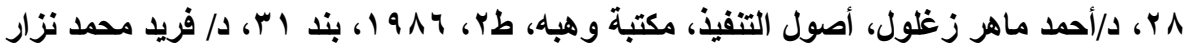

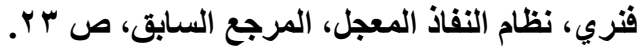


حالة على حده('). ويقع على عاتق طالب التنفيذ المعجل إثبات الاستعجال طبقا للقواعد العامة للإثبات، ولكن في الحالات التي حددها المشرع كأمثله للاستعجال القضائي، فهذه النصوص تضع قرينة بسيطه على توافر الاستعجال ممـا يعفي طالب التفيذ من عبء إثباتهـ؛ وينقله إلى خصمه لكي يثبت عدم تـوافر الاستعجال في هذه الحالـة، ويكفي القاضي في هذا الفرض الإشارة إلى توافر حالة المنصوص عليها في القانون كتسبيب

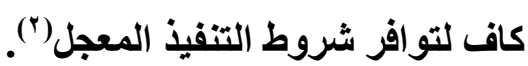
r ـ أجاز المشرع وقف تنفيذ النفاذ المعجل القانوني والقضائي من محكمة الطعن

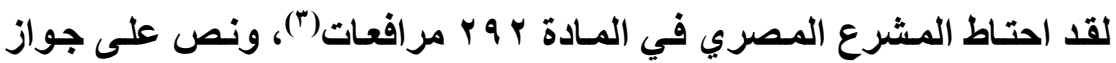
وقف التفيذ المعجل(4)، إذا توافرت شروط معنية(ْ)؛ ويرجع ذلك إلى تحقيق التوازن بين مصلحة المحكوم لـه والمحكوم ضده في التنفيذ المعجل(")، وطالمـا سـمح القانون للمحكوم له أن يطلب تنفيذ حكم أول درجة نفاذا معجلا، فإنه سمح في الوقت ذاته رعاية لمصالح المحكوم عليه أن يطلب من محكمة الاستئناف وقف هذا التنفيذ الذي منحته

(1) د/ فتحي والي، التنفيذ الجبري، المرجع السابق، بند بr، أحمد ماهر زغلول، أصول التنفيذ

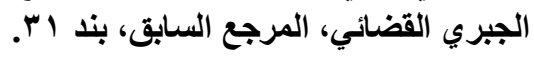

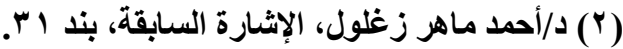

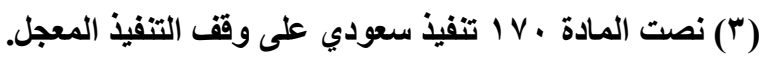

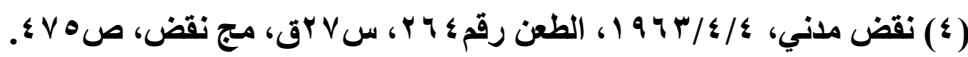

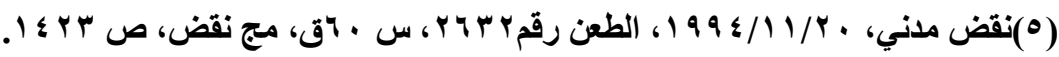

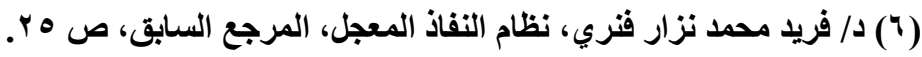
Xavier DAVERAT, Saisie : protection du débiteur, op. cit., p. 21. 
محكمة أول درجة، ويشترط لذلك خشية وقوع ضرر جسيم من التنفيذ(')، فقد يصعب إعادة الحال إلى ما كاتت عليه قبل التنفيذ()، ويشترط أن تكون أسباب الطعن في الحكم يرجح معها إلغاؤه(r)، ولم يفرق المشرع بين التنفيذ المعجل القانوني والتتفيذ المعجل القضائي")، والحكم الصادر بوقف النفاذ المعجل حكم وقتي بمعني الكلمة(ْ). ويلاحظ أن موقف المشرع المصري على عكس مـا أخذ بـه المشرع الفرنسي الذي حرم محكمـة الطعن مـن وقف التنفيذ المعجـل بقـوة القـانون أو القاضـي إلا إذا توافرت شروط حدت من الأمسر بوقف التنفيذ كمـا سبق الإشـارة إلى ذلك، ونرى أن موقف المشرع الفرنسي هو الأولى بالاعتبار، كما مود أن ينص المشرع المصري على عدم جواز وقف التنفيذ المعجل القانوني: وذلك للأسباب الآتية:

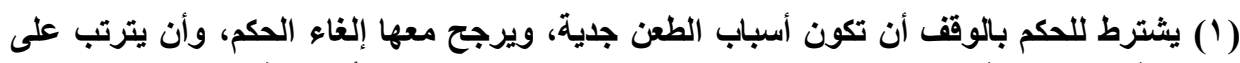

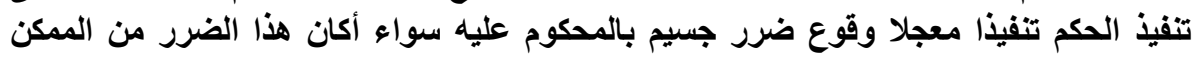

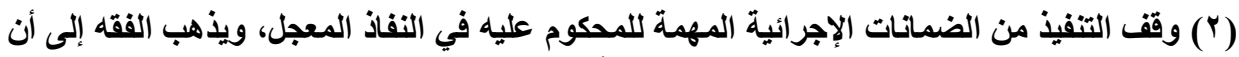

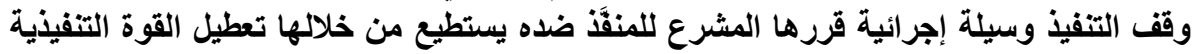

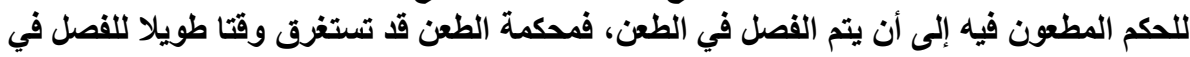

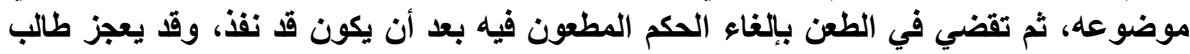

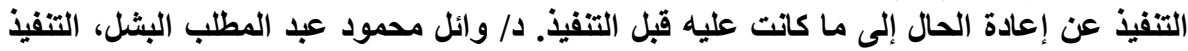

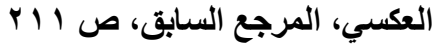

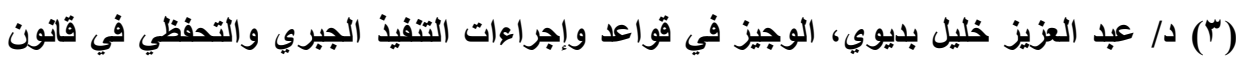

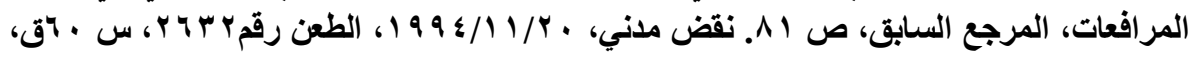

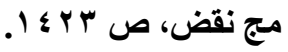

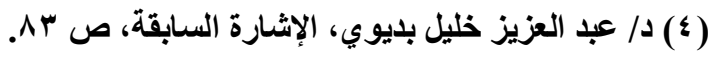

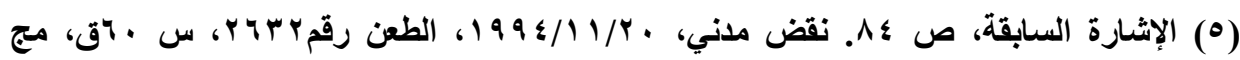

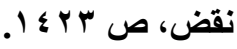


أ- وقف التنفيذ المعجل القاتوني يحرم المحكوم له من ميزة نص عليها القانون، فلا يجوز للقاضي أن يمنع حق لثخص منحه إياه القانون. وخاصة وإن شرط الاستعجال مفترض بقوة القانون. ب- لا يملك قاضي أول درجة سلطة تقديرية بشأن التفيذ المعجل القانوني، ومن ثم لا يملك قاضي ثاني درجة سلطة تقديرية بموقفه. ج- رقابة قاضي ثاني درجة تكون على أسباب حكم أول درجة في التنفيذ المعجل، وهذا لا يتحقق إلا في حالة التنفيذ المعجل القضائي، أما التنفيذ المعجل القانوني فلا يوجد بشأنه تسبيب.

وذهب جانب من الفقه إلى تأييد موقف المشرع المصري على أسـاس أنسه إذا استطاع المدين أن يثبت أن الحمايـة الممنوحة للـائن ليس لها مبرر وأن يشكك في شرعية التنفيذ، وذلك بناء على أسباب تتسم بالجد. فلا شك في أن السماح للتنفيذ رغم العيوب التي تعتريه على هذا النحو من شأنه أن يعرض مصلحة المدين لآثار وخيمة لا لا لهابل

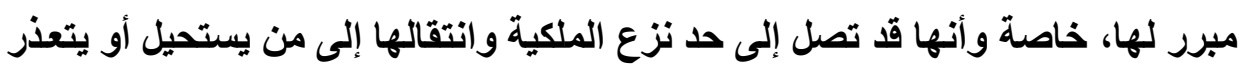
استعادتها منه بعد الحكم ببطلان التنفيذ(')، لذا أجاز المشرع تقديم طلب وقف التنفيذ، كما أن تنظيم المشرع وقف التنفيذ المعجل حل وسطي يسعى للموازنة بين مصلحتين لا يمكن تغلب إحدا هما على الأخرى بصفة مطلقة، وهمـا مصلحة المحكوم لله ومصلحة

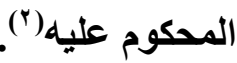


ويمكن لنا الرد على هذه الحجة بالقول بأن تشكيك المدين في شرعية التنفيذ المعل ينصب فقط على التنفيذ المعجل القضائي، حيث قد يخطئ القاضي في تقديره، أو أن تكون الظروف التي صدر فيها الأمـر بالتنفيذ المعجل قد تغيرت ولم يعد هنـاك

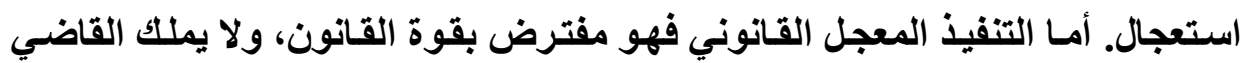
سلطة بثأن تقريره، فلا تملك المحكمة العليا سلطة بثأن وقفه. ويرى جانب آخر في معرض تأييده لموقف المشرع المصري أن وقف التنفيذ يرجع حتميته إلى حتمية ظاهرة قانونية أخرى وهي قابلية التنفيذ الجبري بتنظيمهـ الراهن للإلغاء، فق كاتت هذه الظاهرة هي السبب الذي نشأت منه الحاجه إلى وقف

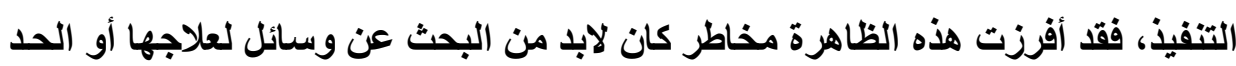
منها، لكنها لا تقوى على ذلك كما يقوى نظام وقف التنفيذ (1)، فظاهرة إلغاء السند التنفيذي تستوجب طلب وقف التنفيذ من محكمة الطعن (") والواقع أن درجة الاستقرار

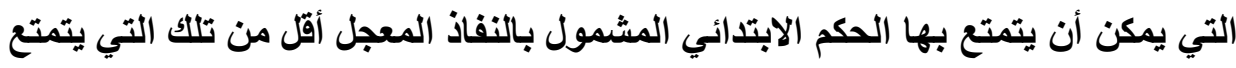

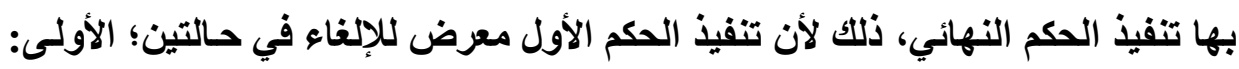

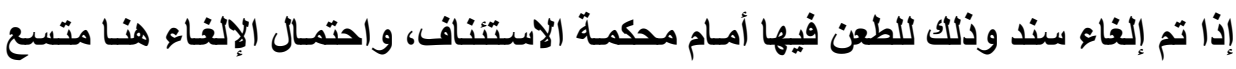
نسبيا، والثانية: إذا تأيد سنده في الاستثناف يمكن مرة فقط يتم إلغاؤه من محكمة

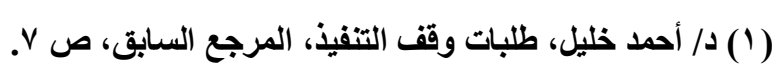

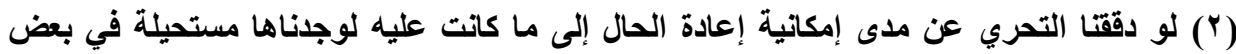

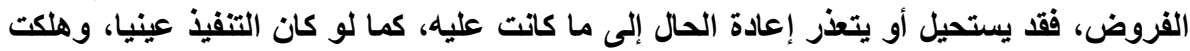

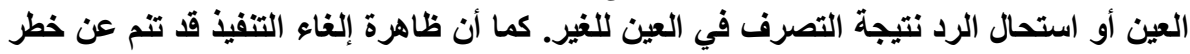

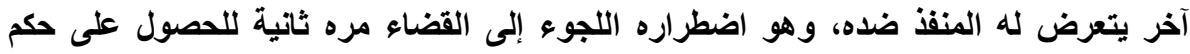

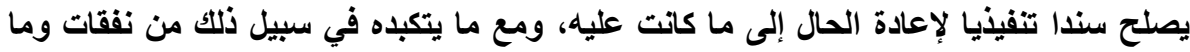

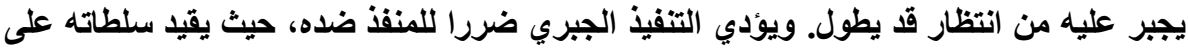

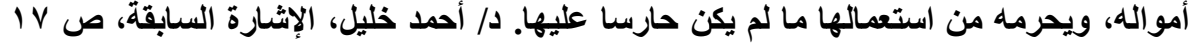


النقض سواء مباشرة أو بطريق الإحالة. وإذا كانت ظاهرة قابلية التنفيذ للإلغاء ظاهرة

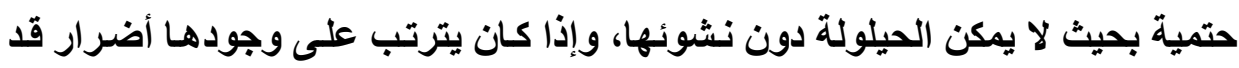

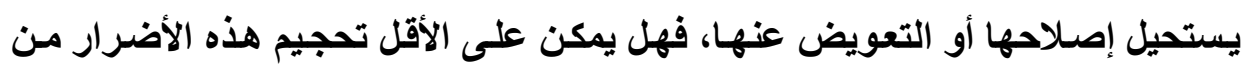

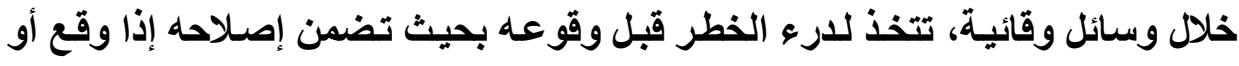

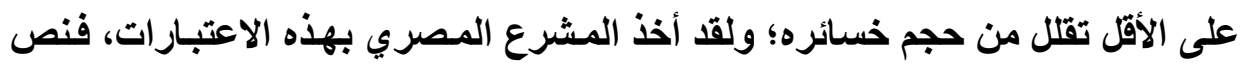
على بعض الوسائل منها وقف التنفيذ. ويالرغم من وجهة هذه الحجة فأنه يمكن الرد عليها؛ وذلك بأن نظام الكفالة

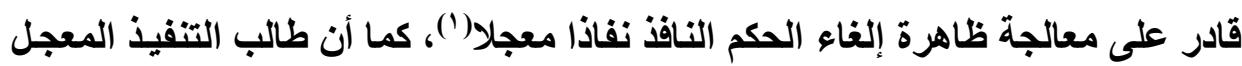

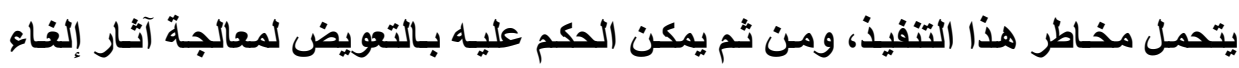
التتفيذ المعجل، ومن ثم فلا حاجة لوقف التتفيذ المعجل عندما يكون قانونيا، وقصر

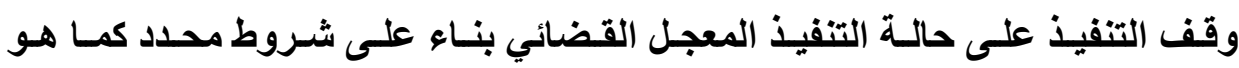
منصوص عليه في القانون الفرنسي. ويرى بعض الفقه أن وقف التتفيذ لا يضر بمصلحة الائن، لأن وقف التنفيذ

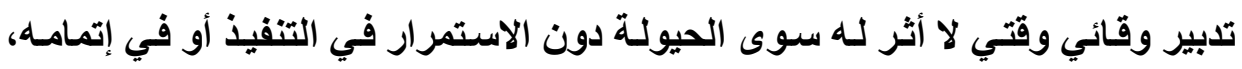

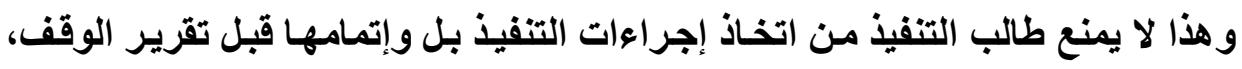

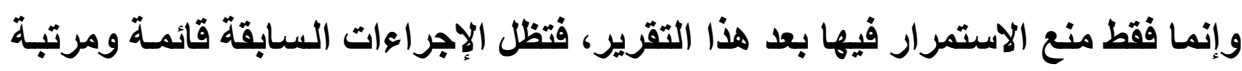

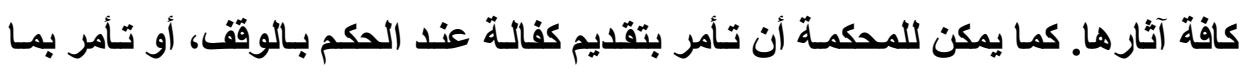
تراه كفيلا لحماية حق الدائن(")

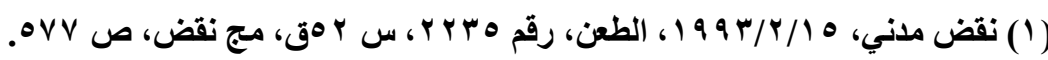

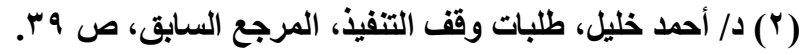


ويمكن الرد على هذه الحجة بـالقول بأنـه قد يترتب على وقف التنفيذ أضرار

جسيمة بالدائن، وذلك في حالة إفلاس المدين أو إعساره، كمـا أن وقف التنفيذ يؤثر على الائتمـان في بعض المعـاملات وخاصـة التجاريـة، بالإضـافة إلى أن وقف التتفيذ

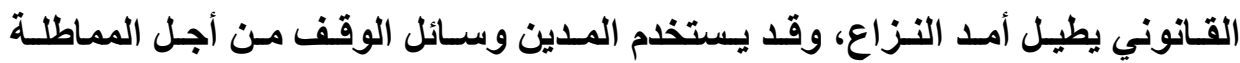
والمشاكسة للائن، لذا نرى أن الحل المنطقي أن يقتصر الوقف على التنفيذ المعجل القضائي دون التنفيذ المعجل القانوني، ويكون وقف التنفيذ المعجل القانوني بشروط أكثر تشددا مما هو عليه نص المادة . 9 r مرافعات.

ويرى جاتب من الفقه(') أن وقف التتفيذ المعجل يهدف في ذاته إلى الوقاية من أضرار الخضوع لتنفيذ هو مؤقت بطبعه، فهذه الفكرة الحل المثالي المنشود حيث تجمع بين الشموليه والوقائيـة، إذ إن دوره الوقائي ضـ خطر الاستمرار في تنفيذ معرض للإلغاء، ومن ثم ضد مخاطر استحالة إعادة الحال إلى مـا كانت عليه(؟)، فوقف التنفيذ حماية عاجلة متوازنة، ويحقق مصلحة المدين، ويمثل الوجه المقابل لحق الدائن في التنفيذ غير محصن، هذا الوقف لا يتحقق إلا بعد ترجيح حق المـدين في مواجهـة

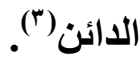
وبالرغم من منطقية هذه الحجة فأنه يمكن الرد عليها، بأنها تصدق على وقف التنفيذ المعجل القضائي، أما بالنسبة لوقف التففيذ المعجل القانوني فقد افترض المشرع حكتـه، ولا يجوز للقاضسي أن يخـالف هذه الحكمه بوقف التنفيذ، فالمشرع هو الذي رجح حق الدائن في مواجهة المدين، وهذه القرينـة لا يمكن للقاضـي مخالقتها، أمـا في 
التنفيذ المعجل القضائي، فيمكن أن يخطئ القاضسي ويرجح حق الدائن، والواقع يكون على غير ذلك، فلو أثبت المدين ترجيح حقه كان على القاضي أن يأمر بوقف التنفيذ. ونرى في تنظيم الحالي للقانون المصري بشأن وقف التففيذ المعجل إمعانـا في تحقيق مصلحة المدين على مصلحة الدائن بصفة مطلةة، كمـا أن ظاهرة قابلية التنفيذ للإلغاء لا تثير أدنى مشكلة، ولا تمثل أي خطورة؛ لأن إلغاء التنفيذ هو إعادة الحسال إلى هـ

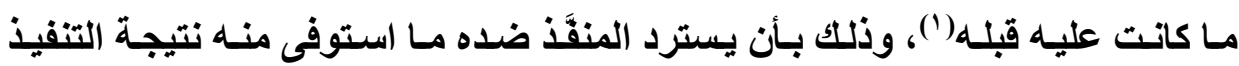

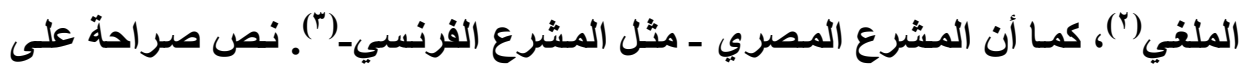
عدم بيع العقار إلا إذا كان في يد الدائن سند تنفيذ نهائي، فهذه ضمانة للمدين. r- أجاز المشرع الاعتراض على الكفالة

طبقا لنص المادة • و ץ مرافعات الكفالة جوازية للمحكمة(")، ولكن هناك بعض الحالات الخاصة نص فيها المشرع على إعفاء بعض الأشخاص من تقديم كفالة وذلك

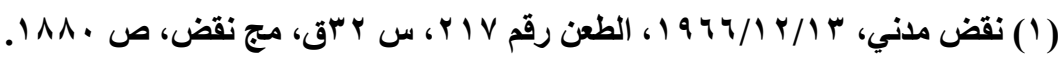

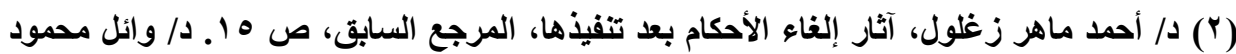

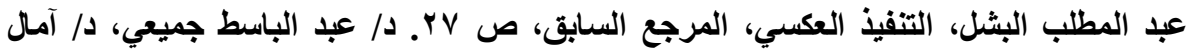

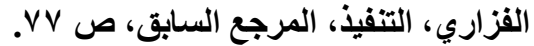

(3) art. L. 311-4 C. pr. exéc.; BLÉRY, L'efficacité substantielle des jugements civils, op. cit., n. 145 et 162. BAKER CHISS, Contribution à l'étude de l'exécution des jugements civils dans les rapports internes et internationaux de droit privé, op. cit., p. 409 s.

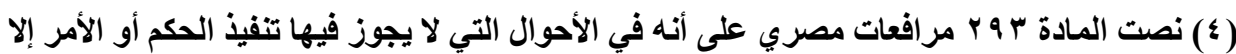

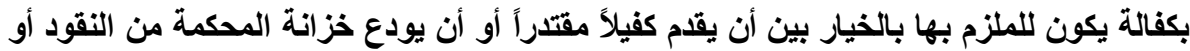

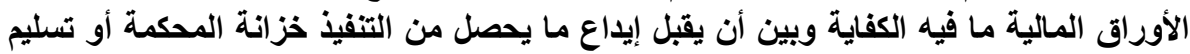

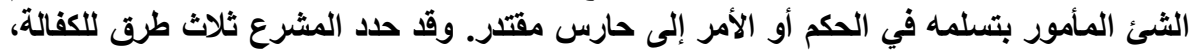

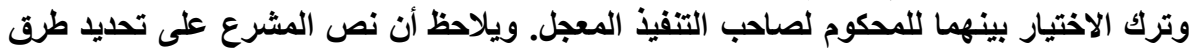
تقديم الكفالة ورد على سبيل الحصر وليس على سبيل المثال. ونص المشرع الصنّ على أن يقدم كفيلاً $=$ 
رعاية لمصالحهم، فلا يصح الحكم بها؛ مثال ذلك الحكم الأحكام المستعجلة. وطبقا لنص المادة و Y مر افعات أن النفاذ المعجل واجب بقوة القانون للأحكام الصادرة في المواد التجارية وذلك بشرط تقديم كفالة'(')، ويبرر وجوب الكفالة أن القانون سمح بالتنفيذ المعجل دون اشتر اطوجود الاستعجال()، وفي مقابل ذلك نص على وجوب الكفالة. وقد ذهب جاتب من الفقه إلى أن المحكمة لا تحكم من تلقاء نفسها بالكفالة، بل

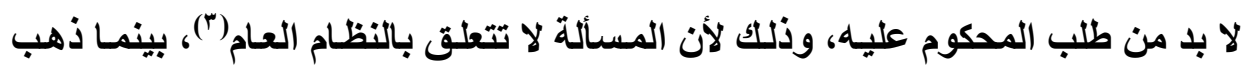
الرأي الغالب إلى القول بأنه لا يشترط للحكم بالكفالة أن بطلبها المحكوم عليه، فالحكم

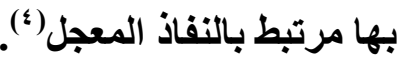
ووفقا لنص المـادة ؟ ج ب مر افعـات على المحكوم لله أن يعلن اختيـاره للكفالة

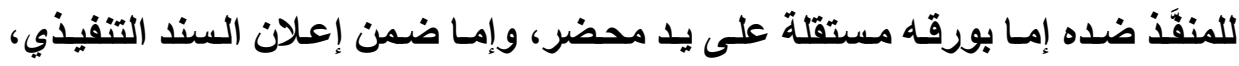
ويجب عدم بدء إجراءات التنفيذ إلا بعد مرور ثُلاثة أيسام من إعلان الخيار بالكفالـة.

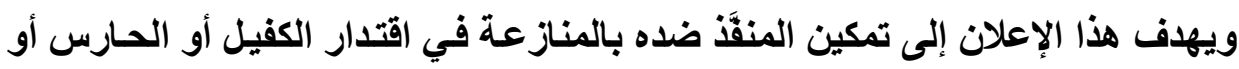

مقتدراً، ويقصد بالاقتدار اليسر الذي يمكن المحكوم عليه من الرجوع على الكفيل في حالة إلغاء

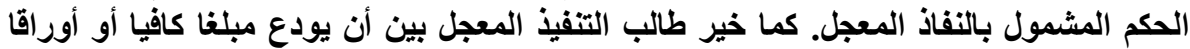

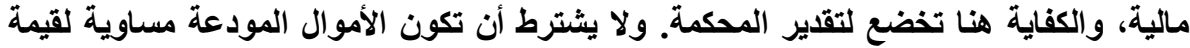

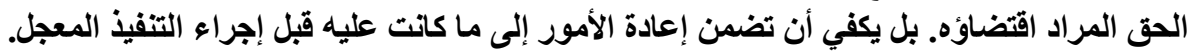

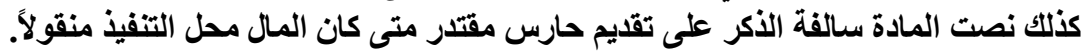

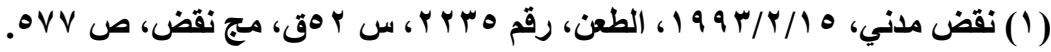

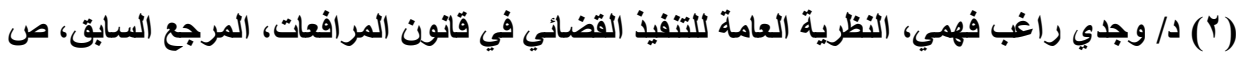


في كفاية الكفالة المودعة خزانة المحكمة، وإذا بوشرت إجراءات التففيذ دون الاختيار لطريق الكفالة أو دون إعلان الخيار فهذه الإجراعات تكون باطلة'('). وقد منحت المادة هو ب مرافعات المنقَّ ضده الحق في المنازعة في طريقة

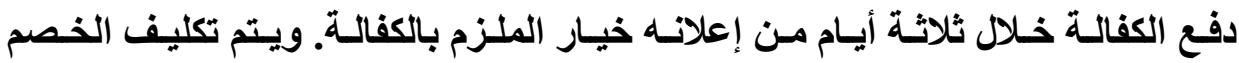
بالحضور أمام قاضي التنفيذ ويكون حكمه في المنازعة نهائياً. وتعد دعوى المنازعة في كفاية الكفالـة منازعة موضوعية، لذا ذهب البعض إلى أنها ليس لها أثر واقف للتففيذ إلا إذا أمرت به المحكمة(؟) بينمـا يذهب رأي آخر إلى أن المنازعة في الكفالة

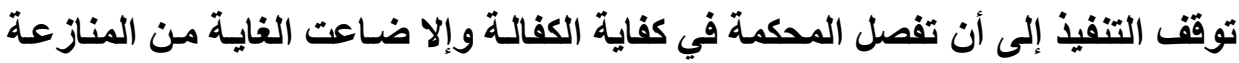

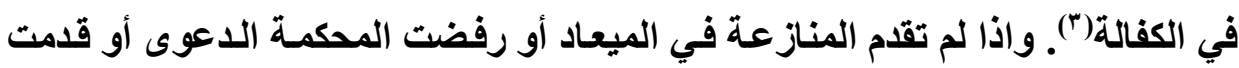
وتم الفصل فيها، فإن الكفالة تقدم على النحو الذي فصلت فيه المحكمة، أو تبعا للطريق الأي اختاره طالب التنفيذ تبعا للأحوال المختلفة.

ويلاحظ أن موقف المشرع المـصري يخـالف اتجـاه المشرع الفرنسي الـذي حصن نظام الكفالة في التففيذ المعجل من الاعتر اض عليه،، سواء تعلق بـالأمر بـالحكم بها أو تعلق باختيـار نظام الكفالة، ونرى أن موقف المشرع الفرنسي أولى بالاتبـاع؛

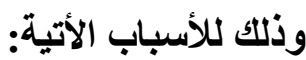
1 - تجنب المنازعات الفرعية التي تضيع الوقت وتثتت الجها وتزيد في النفقات، وخاصة وأنه يترتب على الكفالة وقف التنفيذ إلى حين الحكم فيها. 
دا طلعت يوسف خاطر

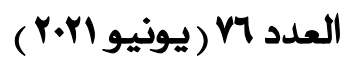

r- الكفالة وجدت كضمانة للمحكوم عليه، وتقديرها يخضع للقاضي، وللقاضي سلطة تقديرية في الحكم بها في أغلب الحالات، وهذه السلطة التقديرية لا يجوز

المنازعة فيها.

r- خضوع اختيار المحكوم له لطريقة الكفالة، يخضع للسلطة التقديرية للقاضي، فيمكن للقاضي أن يعترض على كفاية الضامن، لإعادة الحالة إلى ما كان عليه

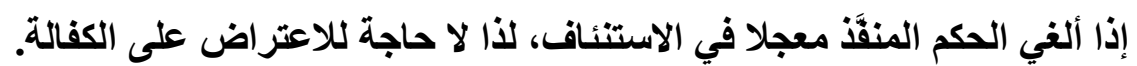
ثانيا: اقتراح تعديل موقف المشرع المصري

1 ـ ـ اقتراح منح القاضي سلطة تقديرية واسعة في الحكم بالنفاذ المعجل القضائي

نتجيـة للتطورات الحديثة في التنفيذ المعجل أصبح للقاضـي سلطة تقديريـة

كاملة في شمول الحكم بالنفاذ المعجل حتى من تلقاء نفسه، وغير مقيد في ذلك سوى بمعيار الضرورة والملاعمة لطبيعة المسألة، ونرى أن هذا التطور يتفق مـع التطورات الاقتصادية الحديثة، ويتفق مع الاتجـاه الذي يمنح القاضي سلطة تقديريـة يزن فيها

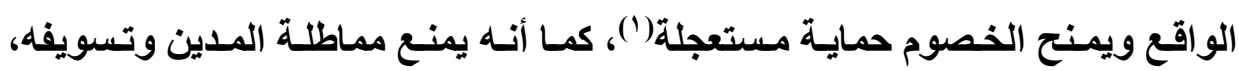
بالإضافة إلى تحقيق الائتمان الاقتصادي.

لذا نرى تعديل نص المادة ـ ج ب من قانون المرافعات ويكون نصها على النحو الآتي: " يجوز الأمر بالنفاذ المعجل بكفالة أو بغير كفالة في كل مره يقدر فيها القاضي ضرورة ذلك وتناسبه مع طبيعة النزاع المطروح، وذلك بناء على طلب الأطراف أو من تلقاء نفس القاضي".

(1) Stéphane PIÉDELIÈVRE, Frédéric GUERCHOUN, Saisies et mesures conservatoires, op. cit., n0 65. 


\section{r ــ اقتراح بعدم جواز وقف التنقيذ المعل القانوني}

في حقيقة الأمر ما أخذ به المشرع الفرنسي من تعديلات فيمـا يتعلق بالتتفيذ

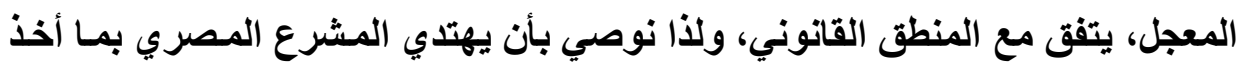

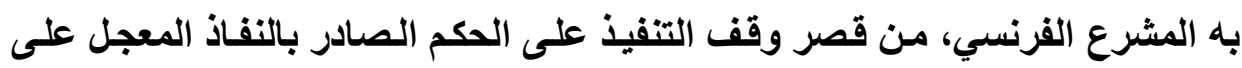
شروط محددة ولا يكتفي بالآثار التي تترتب على التنفيذ المعجل. وذلك لإعطاء فاعلية

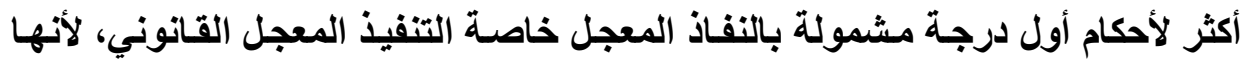

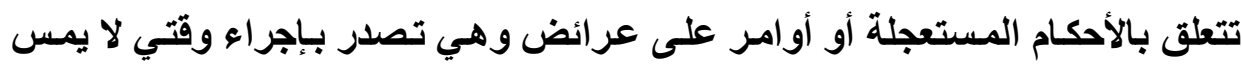

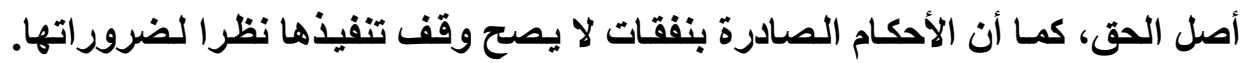

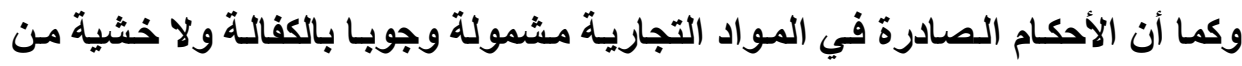

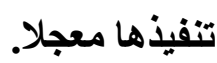

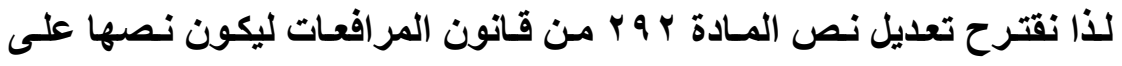

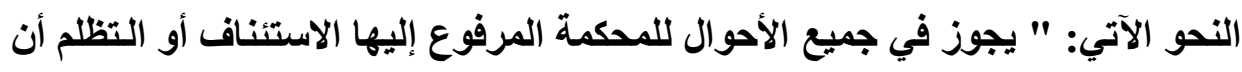

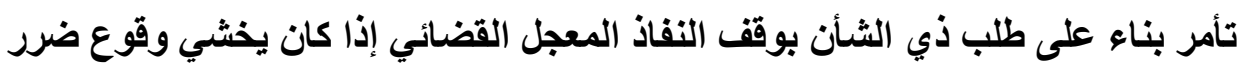
جسيم..."، وبالنسبة للتنفيذ المعجل القاني لا يقف التنفيذ. rـ اقتراح بعدم الطعن في الكفالة

الكفالة ضمانة يتقلم بها طالب التنفيذ المعجل، من أجل ضمان تعويض الضرر

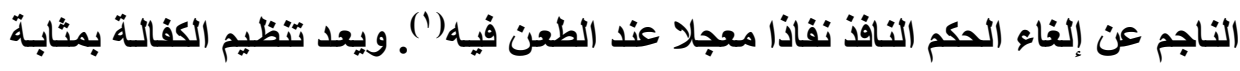
ضمان لإعادة الحال إلى ما كاتت عليه في حالة تعذره، وتعويض الضرر إن وجد في حالة إلغاء الحكم المطعون فيه. 
والواقع أن منح المحكوم عليه الحق في الاعتراض على الكفالة فيه إطالة لأمد النزاع، وتـأخر في التنفيذ المعجل، لأن الاعتراض يؤدي إلى وقف التنفيذ إلى حين الفصل في المنازعـة في الكفالـة، لـا نقترح أن ينص المشرع المـصري في المـادة هو بمن قانون المرافعات على أن " المنازعة في الكفالة لا تؤدي إلى وقف التنفيذ، ويكون الحكم في الكفالة على وجه السرعة، بحكما انهائيا". ع - منح محكمة الاستئناف الحق في الحكم بالتثفيذ المعجل نقترح أن ينص المشرع المصري في قانون المرافعات على إمكانية تقديم طلب لمحمة الاستئناف التي تنظر الاستئناف بطلب بالتنفيذ المعجل، وذلك في حالة رفضه في أول درجة أو تقديمه، ولكن أغقلت محكمة أول درجة الحكم بـه، أو لم يطلب، ولكن استجدت ظروف للمطالبه به".

\section{الامطاب الثاني \\ التطورات المديثة في تفعيل تنفيذ الأواهر القضائية}

تعد الأوامر القضائية من السندات التفنيذيـة شـائعه الاستعمال(')، وقد حدثث تطورات مهمة في النظام الفرنسي بشأن الأوامر القضائية، حيث عدت الأوامر على عرائض مـن الأعمـال القضائية، واجب المشرع تسبيب الأمـر على عريضة، واجـاز الطعن فيها بالاستئناف. وسنشير إلى ماهية الأوامر القضائية، وذلك في الفرع الأول، ثم التطورات الحديثة في تفعيل تنفيذ الأوامر القضائية في النظام الفرنسي، وذلك في الفرع الثاني،

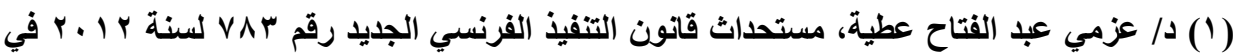

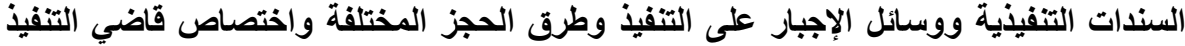

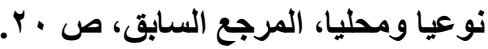


دا طلعت يوسف خاطر

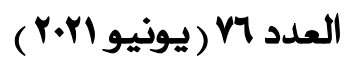

وموقف القـانون المصري من تظوير نظام الأوامر القضائية في الفرع الثالث، وذلك

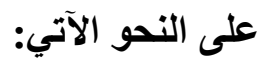

\section{الفرع الأول \\ هاهية الأواهر القضائية}

يصدر القضاء نـوعين من الأوامر؛ أولهمـا: الأوامر على عرائض، والآخر:

أوامر الأداء، ويمكن تعريف الأوامر على عرائض بأنها قرارات تصدر مـن القضاء بنـاء على طلبـات ذوي الشأن على عرائض(')، وتصدر بنــاء على سـلطة القاضـي الولائية. وعرفت بأنها الأوامر التى يصدرها قضاة الأمور الوقتية بمـا لهم من سلطة ولائية، وذلك بناء على الطلبات المقدمة إليهم من ذوى الشأن على العرائض و تصدر فى غيبة الخصوم و دون تسبيب بإجر اءو وقتى أو تحفظى فى الحساتات التى تقتضى دون السرعة أو المباغتة، و هى واجبـة النفـاذ بقوة القـانون بمجرد صدورها عملاً بنص

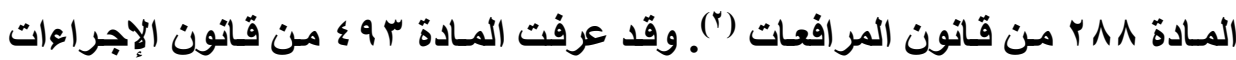
الفرنسي الجديد الأمر على عريضة بقولها: القرار الوقتي الذي يصدر دون مواجهة

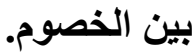

وتتفيـذ الأوامـر على عـرائض تتفيـذا معجـلا بقـوة القـانون فـي النظــامين

المصري(") والفرنسي، حيث تنص المادة ه ه ؛ من قانون الإجراءات الفرنسي الجديد على عدّ الأوامر الصادرة على عرائض نفاذه نفاذه نفـاذا معجلا قانونيا، ويـذهب بعض

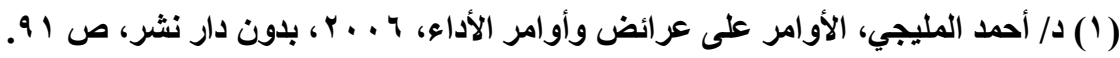

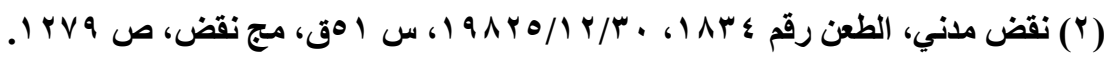

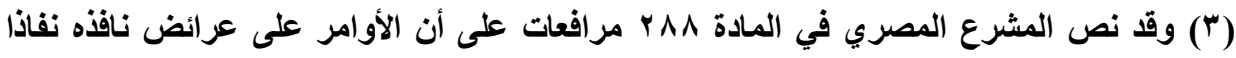
معجلا بقوة القانون ويدون كفالة، وذلك ما لم ينص الأمر على تقديم كفالة.

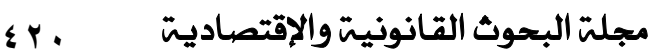


الفقه الفرنسي(') إلى أن تنفيذ الأمر على عريضة يعد بمثابة تنفيذ نهائي، لأنه لا يمكن وقف التنفيذ المعجل القانوني.

وطبقـا لنص المسادة . . r مرافعـات يجب تقديم الأمسر الصادر على عريضة للتنفيذ خلال ثلاثين يوما من تاريخ صدوره وإلا سقط الحق فيهه، ولا يمنع هذا السقوط من استصدار أمر جديد، وفي النظـام المصري يتم التظلم مـن الأمر على عريـة، وللمحكمة المرفوع أمامهـا التظلم من الأمر أن تأمر بوقف النفـاذ المعجل إذا توافرت شروطه نفسها (º) وهذه الشروط هي أن يطلب المتظلم من المحكمة وقف التنفيذ قبل أن يتم التنفيذ، وأن يكون هنـالك خشية مـن وقوع ضـرر جسيم مـن التنفيـ، وتـرجح

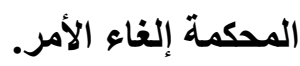

وبالنسبة لأوامـر الأداء فيقصد بهـا أعمـال الحمايـة القضائية التأكيديـة التي

تتضمن قضاءً بإلزام، وتتضمن أوامر الأداء قضاءً قطعيا بـالتزام بـأداء معين، واستناداً إلى هذا المضمون فهي تحوز القوة التنفيذية، وتقبل التنفيذ الجبري بعد زوال إمكانية الطعن فيها. ولكن يمكن أن يكون الأمر مشمولا بالنفـاذ المعجل وخاصـة في المسائل التجاريـة. ولا يترتب على التظلم أو الاستئناف من الأمر أثر موقف للتنفيذ المشمول بالنفـاذ المعجل. ولكن يجوز طلب وقف التنفيذ أمسام محكمة الطعن أو التظلم، وقرار المحكمة يقبل الطعن فيه على استقلال. وفي حالة تنفيذ أمر الأداء نفاذاً معجلاً في مـادة

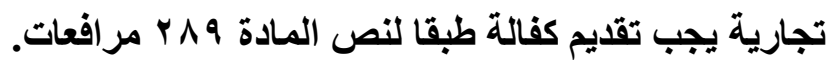

(1) PH. HOONAKKER, l'effet suspensive des vois de recours dans le nouveau code de procedure civileop. Cit., p.18,

(r) د/ أحمد المليجي، الأوامر على العرائض وأوامر الأداء،المرجع السابق، ص 91 أ. 
وقد ذهب القضاء المصري إلى أن " المشرع أنزل أمر الأداء منزلة الأحكام

وعاملـه معاملتهـا ـ اشتباه أوامـر الأداء مـع الأوامـر على العرائض مـن حيث طريقة استصدارها، إلا أنها مع ذلك تصدر بموجب السلطة القضائية لا الولائية"(1"). وهنـاك عديــ مـن أوامـر الأداء التـي يـصدرها القضاء، ومـن أهمهـا الآتـي:

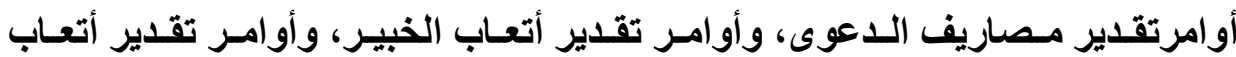
المحامي، وأوامر تقدير الرسـوم القضائية. وهذه الأوامر تتخذـ شكل الأمسر، ولكنهـا تتضمن قضاءً موضوعيا تأكيدياً بإلزام مثل الأحكام القضائية"(؟).

\section{الفرع الثاني \\ التطورات الحديثة في تفميل تنفيذ الأواهر القضائية في النظام الفرنسي}

استحدث القـانون الفرنسـي تطورات مهمـة في نظــام الأوامـر، وتهـدف هذه التطورات إلى تفعيل تنفيذ الأوامر القضائية(")؛ وذلك على النحو الآتي: أولاً: عدم حصرية الأوامر على عرائض في النظام الفرنسي نص المشرع المصري في المادة 194 مرافعات على أن استصدار الأمر على عريضة لا يكون إلا في الأحوال التي نص عليها القانون، فحالات الأمر على عريضة منصوص عليها على سبيل الحصر، وعلي عكس ذلك القانون الفرنسي، فلم ينص على حالات حصرية لنظام الأوامر على عرائض.

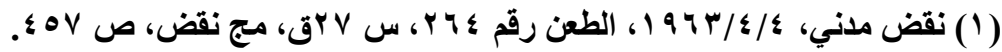

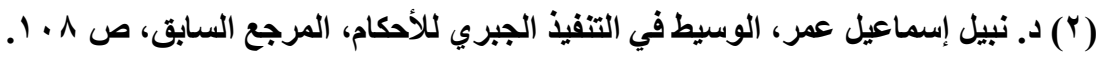
(3) Sylvie PIERRE-MAURICE, Ordonnance sur requête, D., mars 2011, n.1 et s. 
دا طلعت يوسف خاطر

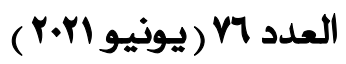

وطبقـا للنظــام الفرنسسي يوجــ نوعـان مسن الأوامسر؛ النـوع الأول: حـالات

منصوص عليها صراحة في القانون(')، حيث يجوز للقاضي إصدار أمر على عريضة

دون حاجة لبحث حالة الضرورة أو الاستعجال، لأنها مفترض بقوة القانون()، ويلاحظ أن المشرع الفرنسي قد يعبر عن هذا النـوع بـنص صريح في اللجوء إلى اتخـاذ إجراءات الأمر على عريضة، وقد يستخدم المشرع تعبيرا واضتح الدلالة على اتخـاذ إجراءات الأمر على عريضة، وقد يكون النص غير واضـح الدلالـه ولكن يعبر عن المعني، بإصدار القاضـي أمره دون مواجهة الخصم الآخر ("). ومن هذه الحسالات مـا

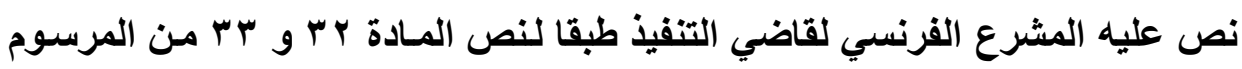
الصادر في اب يوليو ب999 19، وما نص عليهه من منح هذه السلطة لرئيس المحكمة المختصة، كما هو منصوص عليه في المادة I Y M من قانون التجارة.

النوع الآخر: نصت عليه المادة Y / Y / إجراءات، حيث يمكن إصدار أمر على

عريضة إذا كاتت توجد حالة استعجال أو كاتت الضرورة تقتضي إصدار الأمر في غيبة الخصم الآخر. وهذا النوع الاخير كان نتيجة لاجتهاد القضاء الفرنسي منذ صدور المادة

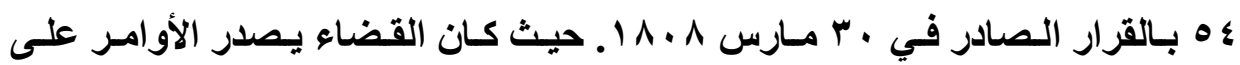
عرائض في حالة تقديره وجود الاستعجال(").

(1) ESTOUP, La pratique des procédures rapides, référés, ordonnances sur requête et procédures d'injonction, avec le concours de G. MARTIN, 2e éd., 1998, Litec, n. 308.

(2) Ph. HOONAKKER, GUINCHARD, Droit et pratique de la procédure civile, 2009/2010, 6e éd., 2009, Dalloz Action, n. 3302.

(3) Sylvie PIERRE-MAURICE, Ordonnance sur requête, op. cit., n. 10.

(4) Sylvie PIERRE-MAURICE, Ordonnance sur requête, op. cit., n. 8. 


$$
\begin{aligned}
& \text { ويثمن الفقه الفرنسي موقف المشرع لأنـه يصعب من الناحية العملية تحديـ } \\
& \text { الحالات التي يصدر فيها الأمر على عريضة، فطبيعة الأوامر على عرائض يصعب معها } \\
& \text { التحديل بناء على نص(')، ولهذا ذهب المشرع الفرنسي منذ عـام ^ ـ ^ 1 إلى السماح } \\
& \text { للقضاء باتباع إجراءات الأمر على عريضة حتي بـون نص محدد(؟)، ولكن بشرط }
\end{aligned}
$$

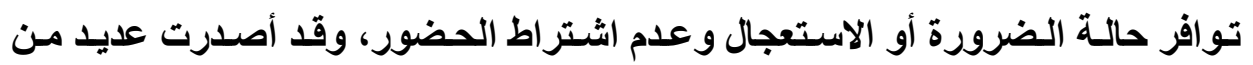

$$
\begin{aligned}
& \text { المحاكم الفرنسية أمرا على عريضة مع عدم وجود النص("). } \\
& \text { والواقع أن الأوامر على عرائض واسعة النطاق في القانون الفرنسي، حيث } \\
& \text { يمكن اللجـوء إليهـا في الاحـوال الآتيـة: الأوامـر على عرائض في قـانون الأحـوال } \\
& \text { الثخصية والأسرية(؛)، والأوامر على عرائض في قانون الوصاية(ْ)، وكذلك في قانون }
\end{aligned}
$$

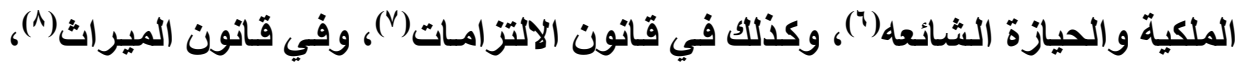

(1) Id., n. 14; CÉZAR-BRU, HÉBRAUD et SEIGNOLLE, Juridiction du président du tribunal, t. II : Les ordonnances sur requête, 4e éd., 1970, Litec, no 7.

(2) art. 54, Décr. du 30 mars 1808, art. 812 al. 2 C. pr. civ.

(3) CA Nîmes , 28 févr. 2008, JCP E 2008. 1623, note Ferrière.

(4) art. 99 C. civ., art. 1046 C. pr. civ.,, TGI Bayonne, 17 nov. 1995, BICC 15 mars 1996, no 342.

(5) art. 457 et 495 code civil, Cass. Civ., 22 oct. 2008, BulI. civ. I, no 239 , CA Paris, 10 oct. et 5 déc. 2007, , D. 2008. 1188.

(6) Cass. Civ. 3e, 1er déc. 2009, inédit.

(7) Sylvie PIERRE-MAURICE, Ordonnance sur requête, op. cit., n.20.

(8)CÉZAR-BRU, HÉBRAUD et SEIGNOLLE, Juridiction du président du tribunal, t. II : Les ordonnances sur requête, op. cit., no 7. 


$$
\begin{aligned}
& \text { وفي القانون التجاري(') وفي قانون الثركات() وفي قانون الملكية الفكرية() وبصفة } \\
& \text { عامة يلاحظ أن عديدا من النصوص تخير الطالب بين اتخاذ الإجراعات المستعجلة أو }
\end{aligned}
$$

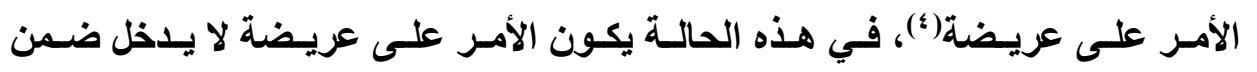

$$
\begin{aligned}
& \text { النصوص المحدة لإصداره، ولكن طبقا للقواعد العامة، ويجب توافر شروطه من عدم } \\
& \text { لـزوم مبـدأ المواجهـة(ه)، وتـوافر حالـة الاسـتعجال، وفـي هـذ الحالـة يتسـاوى اتخـاذ }
\end{aligned}
$$

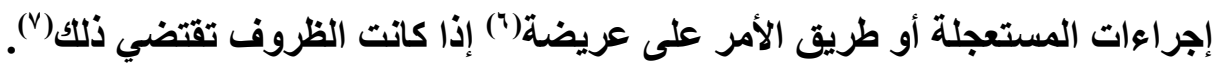

$$
\begin{aligned}
& \text { ونرى أن موقف المشرع الفرنسي منطقيا، لأنسه يصب حصر حالات الأوامر } \\
& \text { على عرائض في الواقع العملي، وذلك لأن هذا الإجراء يهـف إلى حمايـة الحقوق } \\
& \text { الموضوعيه والتي يصعب تحديدها في الواقع العملي(^)، لذلك يصعب حصر الحساتات }
\end{aligned}
$$

(1) art. L. 144-3 C. com.; Sylvie PIERRE-MAURICE, Ordonnance sur requête, op. cit., n. 28.

(2) Com. 19 déc. 2006, no 05-17.671, JCP E 2007. 1503, note Lécuyer

(3) STRICKLER, Procédure civile, 3e éd., 2010, Paradigme, spéc. E. 47, p. 211.

(4) art. 145 C. pr. civ., art. 815-6 C. civ.,; l'article 1290 du code de procédure civile énonce que « Les mesures urgentes prévues à l'article 220-1 du code civil sont prescrites par le juge aux affaires familiales statuant en référé ou, en cas de besoin, par ordonnance sur requête ».

(5) TGI Versailles, ord., 9 mars 2007, www.legalis.net

(6)Cass. Civ. 2e, 5 juin 1985, Bull. civ. II, no 111 ; Cass. Civ. 23 nov. 1994, Gaz. Pal. 1995. 1. Pan. 121. ; Cass. Civ. 24 mars 2005, no 02-20.795, inédit.

(7) Décr. du 31 juill. 1992, art. 32 et 33.

(8) HÉBRAUD, Le domaine des ordonnances sur requête, in Les ordonnances sur requête dans la pratique judiciaire française, colloque de Lille, mai 1964, Paris, Litec, 1967, p. 9 s., spéc. p. 11. 
التي يصدر فيها الأوامر على عرائض(')، ولهذا يكون منطقيـا منح معيـار عام على أسـاسـه يمكن إصـار الأمـر على عريضة، وهو مـا ذهب إليـه النظام الفرنسي، وهذا المعيار هو حالة الضرورة والاستعجال، وعدم وجود حاجة لمبدأ المواجهة. وقد نصت إند المـادة ب ا Y مـن قـانون التظيم القضائي القرنسي على أن في كل الاحوال لـرئيس

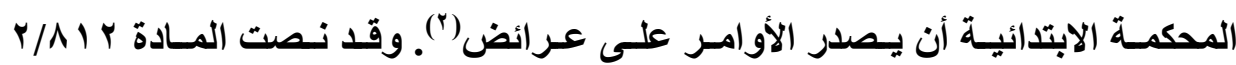
إجراءات على أن يشترط لإصدار الأمر على عريضة وجود حالة الضرورة وتقتضي الإوني الظروف ذلك وبدون مواجهة. وقد نصت المادة ب q ؛ إجراعات على أن إجراعات الأمر

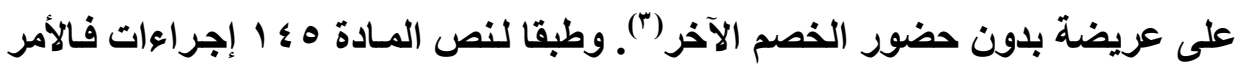
على عريضة يعد استثناءً من مبدأ المواجهة والتي تقتضيه الظروف، ويجب توافر شروط استصدار الأمر على عريضة(؛)، فاللجوء إلى الأمر على عريضة معلقا على توافر شروطه وذلك في الحالات التي لا يوجد فيها نص. وهذه الشروط محصورة في شرط الاستعجال أو الضرورة وعدم وجود حاجة للمواجهة. والواقع أن التفرقة بين الحالات المنصوص عليها صراحة والحالات التي لـ يوجد فيها نص، تثمثل في أن الحالات المنصوص عليها يكفي أن يكون الطلب داخلا

(1) CÉZAR-BRU, HÉBRAUD et SEIGNOLLE, Juridiction du président du tribunal, t. II : Les ordonnances sur requête, op. cit., no 7.

(2) article L. 213-2 du code de l'organisation judiciaire dispose ainsi qu'« en toutes matières, le président du tribunal de grande instance statue en référé ou sur requête ".

(3) Cass. Civ. 2e, 10 févr. 2011, D. 2011, IR 600; Cass. Civ. 2e, 27 juin 2019, D. actu. 31 juill. 2019, obs. M. Kebir

(4) Cass. Civ. 2e, 2 juill. 2009, inédit, Cass. Soc. 23 mai 2007, Bull. civ. V, no 84. 
ضـمن حسالات الــص دون اشـتراط الـضرورة أو الاسـتعجال، حيـث افترض المسشرع توافرهما بالنص عليه(')، وذلك لأن الاستعجال أو الضرورة مفترض في الحسالات التي نص عليها المشرع صراحة بـاللجوء إلى الأمر على عريضة، فلا يمكن للقاضسي أن يشكك في إرادة المشرع ويتجها إلى افتراض توافر الاستعجال أو الضرورة، والوضع على غير ذلك بالنسبة للقاعدة العامة في الحالات غير المحددة بنص، والتي يتطلب فيها المشرع تـوافر الاستعجال أو الضرورة، حيث يجب النظر إلى كل حالـة على حدة، ويقتضي الاسـتعجال أو الضرورة أن هنـاك حالـة تقتضي التصرف بسرعة ومفاجـأة الخصم الآخر بالعمل القـانوني، ولا نكون في حاجـة إلى المواجهةة(؟). ويقول الفقـهـ الفرنسي التعبير عن الاستعجال بأنه عبارة عن حالـة ظاهرة تشكل مخالفة قانونية)("). ويتم بحث مدى الاستعجال أو الضرورة في تاريخ صدور القرار وليس في تـاريخ تقديم الطلب(") وقد ذهبت عديل من الأحكام القضائية الفرنسية إلى أن شرط الاستعجال لا يكون متطلبا لإصدار الأمر على عريضة طبقا لنص المادة ه ؛ أفي جميع الحالات(ه). ويلاحظ أن المشرع الفرنسي لم يشر إلى شرط الاستعجال أو الضرورة إلا في

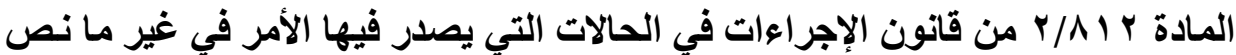

(1)Cass. Civ. 2e, 28 oct. 1999, Lamy cassation. Cass. Com. 19 déc. 2006, no 05-17.671, inédit.

(2) Sylvie PIERRE-MAURICE, Ordonnance sur requête, op. cit., n.78.

(3) l'arrêt Ferodo du 17 mai 1977, Dr. ouvrier 1977. Chron. 467. La jurisprudence Ferodo a posé comme condition de recours à l'ordonnance sur requête " l'urgence à faire cesser un trouble manifestement illicite $»$.

(4) Sylvie PIERRE-MAURICE, Ordonnance sur requête, op.cit., n.79.

(5) SOMMER et NICOLÉTIS, Chronique de jurisprudence de la Cour de cassation. Deuxième chambre civile, D. 2008. 2373. 
عليه المشرع، والمتعلقة بـالامر على عريضة الصادر من رئيس المحكمة الابتدائية،

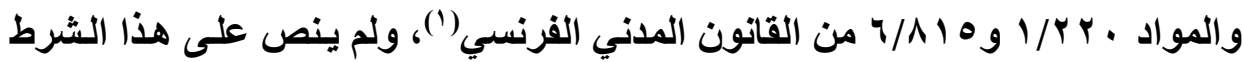
في المواد الأخرى مثل المادة ه ؛ 1 إجراعات(؟)، والتي حددت الحالات التي يمكن فيها اللجوء إلى الأمر على عريضة، مما يدل على أن هذا الثرط مطلوب فقط في حالة الأمر على عريضة في حالات التي لا يوجد فيها نص صريح("). وبصفة عامـة تتميز الأوامر

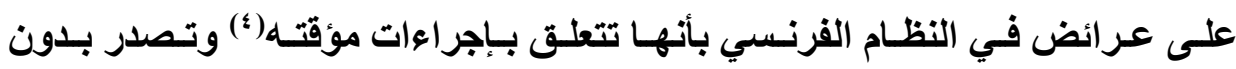
مواجهة.

ثانياً: اشتراط تسبيب الأوامر على عرائض في النظام الفرنسي

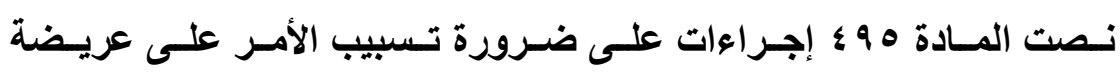

سواء أكان بالقبول أم الرفض(*)، والواقع أن تسبيب الأمر على عريضة يكون واجبـا في حالة صدور الأمر طبقا للقاعدة العامـة، فبإذا كـان يتأسس على حالـة من الحالات المنصوص عليها صراحة، فإن الأمر يكفي فيه ذكر توافر النص المشار إليه وشروط تطبيقه، أمسا في حالـة عدم وجود نـص وخاضـع للقاعدة العامـة، فإنـه يجب تسبيب

ويرى الفقه الفرنسي أنه في حالة عدم وجود نص خاص للجوء إلى الأمر على

عريضة، فالقاعدة أنسه لا يمكن اللجوء إلى هذا الطريق إلا إذا وجدت حالـة ضرورة

(1) article 220-1 C. civ.; l'article 257 C. Civ.; l'article 815-6 C. civ..

(2) Cass. Civ. 2e, 9 avr. 2009, inédit..

(3) Sylvie PIERRE-MAURICE, Ordonnance sur requête, op. cit., n. 76.

(4) CA Toulouse, 14 févr. 2002, D. 2003. 160, note Strickler.

(5) Cass. Civ. 2e, 23 juin 2016, Dalloz actualité, 8 juill. 2016, obs. Kebir.

(6) Sylvie PIERRE-MAURICE, Ordonnance sur requête, op. cit., n.116. 
واسـتعجال، حيـث إن المسشرع خيـر صـاحب المـصلحة بين اللجـوء إلسى الإجـراءات المستعجلة أو الأمر على عريضة، ولكن في هذه الحالة الأخيرة يجب توافر الضرورة

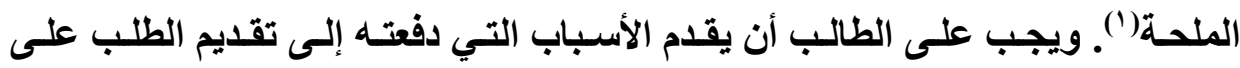
عريضة في غيبة الخصم الآخر()، وتذهب بعض الأحكام إلى أنه لا يشترط ذكره توافر حالـة الـضرورة في الطلب(")، لأن القاضسي هـو الذي يتولي بيـان مـدى تـوافر حالـة

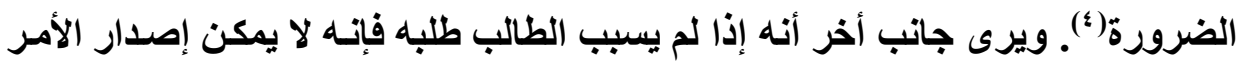

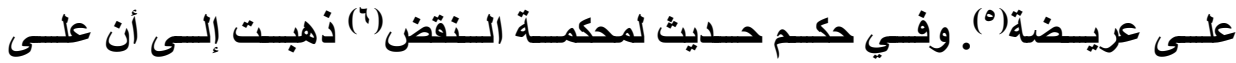
محكمة الاستنئاف ان تراقب من تلقاء نفسها مدى تسبيب قاضي أول درجة عند إصدار الأمر على عريضة في مدى توافر شروط إصداره الأمر على عريضة ومن أهمها مدى

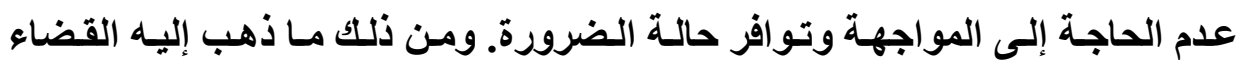
الفرنسي مـن طلب تعيـين خبير لتحديــ المسئول عـن الـضرر، حيث لـم يحـد بعد

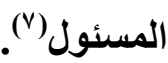

(1) Cass. Com. 26 janv. 1999, Bull. civ. IV, no 28.

(2) Cass. Com. 4 mai 2010, inédit

(3) Cass. Civ. 2e, 10 janv. 2008, , inédit.

(4) Cass. Civ. 2e, 17 févr. 2011, no 10-16.737.

(5) Sylvie PIERRE-MAURICE, Ordonnance sur requête, op. cit., n. 64.

(6) Cass. Civ. 2e, 8 sept. 2011, Dalloz actualité, 29 sept. 2011, obs. Fleuriot ; Cass. Civ. 2e, 26 juin 2014, Dalloz actualité, 8 juill. 2014, obs. Mélin

(7) Cass. Civ. 2e, 25 nov. 1987, Bull. civ. II, no 245. 
د/ طلعت يوسف خاطر

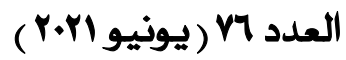

واشـتراط التسبيب أدي إلـى أختلـف كلمـة الفقهـه حـول طبيعـة الأمسر على

عريضة(')؛ فقد ذهب البعض إلى تكييف الأمسر على عريضة على أسـاس أنسه عمل أل

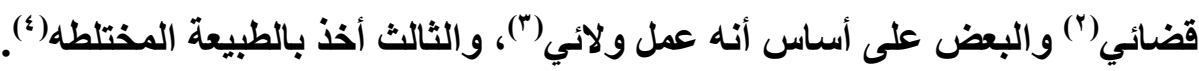

وذهب أغلبية الفقه(•) والقضاء(") الفرنسي إلى تكيف الأوامر على عرائض

على أساس أنها من الأعمال القضائية، وذلك على أساس أنها قابلة للطعن عليها، وأنها

تؤثر على حقوق أطراف النزاع. وقد اتجه المشرع الفرنسي إلى تأكيا هذه الطبيعة

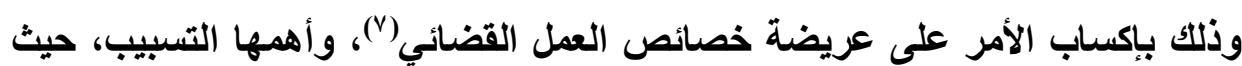

استلزم القانون تسبيبها كما تسبب الأحكام(^)، والطعن فيها بالاستئناف.

(1) Sylvie PIERRE-MAURICE, Ordonnance sur requête, op. cit., n.88.

(2)R. MARTIN, Matière gracieuse et ordonnance sur requête unilatérale, JCP 1976. I. 2787.

(3) R. MOREL, Traité élémentaire de procédure civile, op. cit., no 234; BERGEL, La juridiction gracieuse en droit français, D. 1983. Chron. 153, spéc. p. 154.

(4) CADIET et JEULAND, Droit judiciaire privé, op. cit., no 653

(5)CROZE et MOREL, Procédure civile, 1988, coll. Droit fondamental, PUF, no 7.

(6) Cass. Soc. 24 mai 1995, Bull. civ. V, no 168 ; RTD; Cass. Civ. 2 e, 20 nov. 2003, Bull. civ. II, no 343.

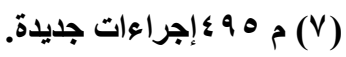

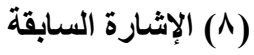

$\varepsilon \psi$

مجلت البحوث القانونيت والإقتصاديت 
ويرى الفقه الفرنسي علم حيازة الأمر على عريضة حجية كاملة، وإمكانية الرجوع في الأمر على عريضة، على أسلس الحجية المؤقتة (1)، فيمكن للقاضي الذي الذي

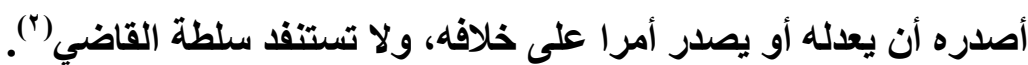
ولايزال النظام المصري مختلفا في هذه المنهجية عن النظام الفرنسي، حيث تعد الأوامر على عرائ من الأعمال الولائية التي لها نظامها القانوني الخاص، فهذه الأعمال مزيج من الطبيعة القضائية والطبيعة الإدارية، ولذلك فإن النظام القانوني لهذه الأنها

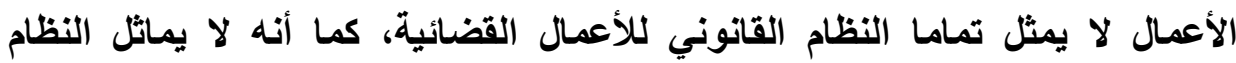

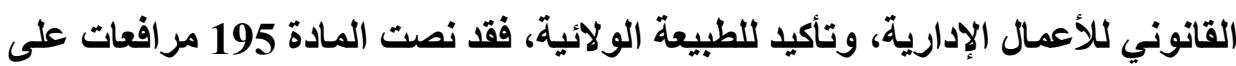

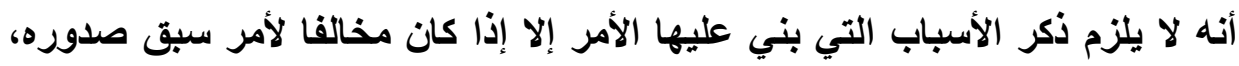

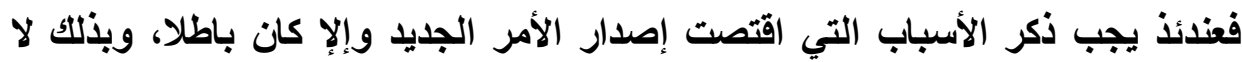
يخضع القاضي لأي رقابة. ويلاحظ على بعض القوانين العربية مثل القانون الكويتي والاردني أنه لم يتطلب التسبيب في كافة الأحوال.

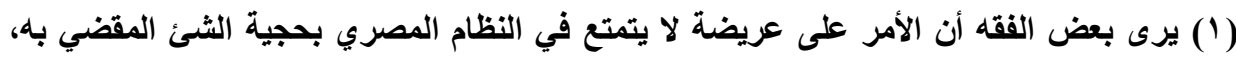

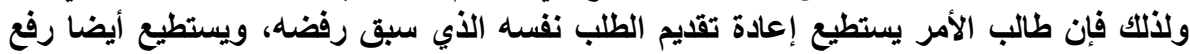

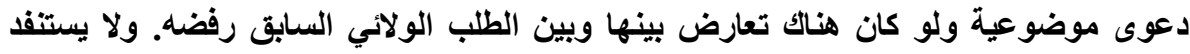

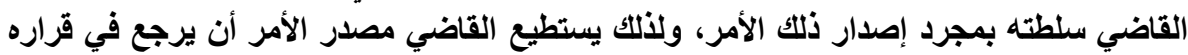

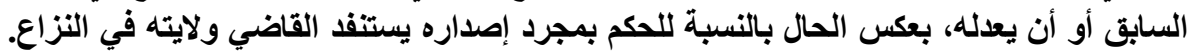

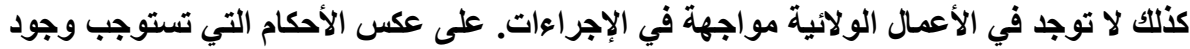

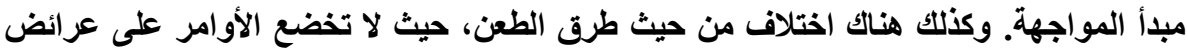
طرق الطعن نفسها التي تخضع لها الأحكام القضائية، فالأوامر على عرائض حلض تخضع الأنع لطريق التظلم

(2)Sylvie PIERRE-MAURICE, Ordonnance sur requête, op. cit., n.129, n. 52. 
ثالثاً: الاكتفاء بالطعن بالاستنناف في الأوامر على عرائض و إلغاء نظام التظلم نص المشرع المصري في المـادة لو 19 مرافعات على أنها يجوز النظلم من الأمر على عريضة إلى المحكمة المختصة إلا إذا نص القانون على خلاف ذلك، ويكون

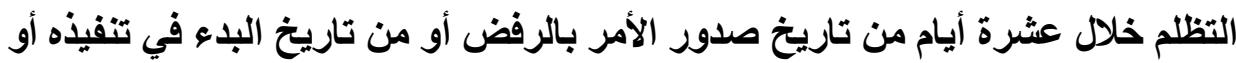
إعلانه، ثم نص المشرع على الطعن بالاستئناف في القرار الصادر في التظله. وبالنسبة لموقف المشرع الفرنسي فقد نص قانون الإجراءات الفرنسي على

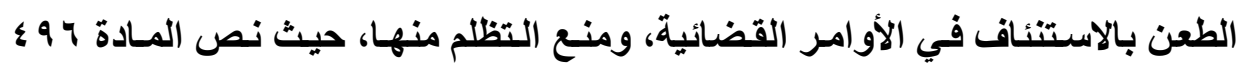
مرافعات على أنه يجوز الطعن بالاستئناف في حالة رفض الأمر على عريضة، وبدافون إعلان، وذلك حتي لا يفسد النظلم فاعلية الأمر على عريضة وضياع عنصر المفالجأة التها.

وهذا التحول في النظام الفرنسي نتيجة للأخذ بالطبيعة القضائية للأمر على عريضة. ولعنص المفاجأة في نظام الأمر على عريضة أهية عملية؛ فأحيانا قد يتطلب

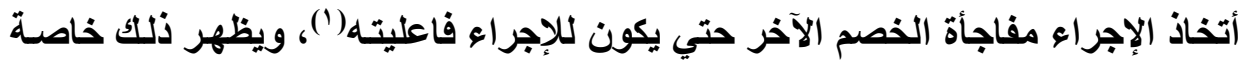

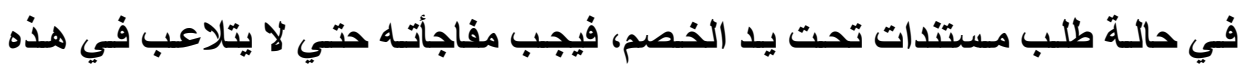
المستندات، وقد يكون الدليل في شكل برنامج معين على جهاز كمبيوتر يسهل التلاعب

فيه أو معاينة مكان معين مثل الثقة المؤجرة لمعرفة مدى مخالفة شروط التعاقد ("). نصت المادة 9 ؟ ؛ إجراءات على أنه إذا رفض إصدار الأمر فإن طالب الأمر له الحق في الطعن بالاستتناف خلال خمسة عشر يومـا من رفض الأمر، وإذا تم قبولهه، فإنه يكون للغير الاعتراض على الأمر، وذلك من أجل تعديل الأمر أو سحبه، ويكون

(1) TGI Paris, réf., 1er juin 1976, JCP 1976. II. 18395.

(2) CA Paris, 14 avr. 1994, Juris-Data, no 024740. 
ذلك في شكل إجراعات خصومة حضورية. فطبقا لهذه المادة يجب التفرقة بين الفروض الاتيـة: الفرض الأول: في حالة رفض الأمر علـي عريضة، فِإن القرار يكون خاضـعا للطعن بالاستئناف، ويكون هو الطريق الوحيد للطعن، ويلغي أي طريق آخر ('). ولا يمكن اللجوء إلى الطعن بالاستئناف عندما يصدر الأمر من رئسيس محكمة الاستئناف على أساس القاعدة التي تقضي بأنه لا يجوز الاستئناف على الاسئتناف(؟).

الفرض الثاني: إذا صدر القرار بأمر الأداء، فإنه يمكن للخصم الآخر أو الغير أن يرجع إلى القاضي الذي أصدر الأمر وذلك من أجل إعادة النظر في الأمر("). وهذا الطريق الخاص يهـف إلى محاولة تفهم القاضي موقف الخصم الآخر الأي صدر القرار في غيابه بهدف الرجوع عن قراره أو تعديله أو سحبه. ويكيف الفقه الفرنسي هذه هوهي

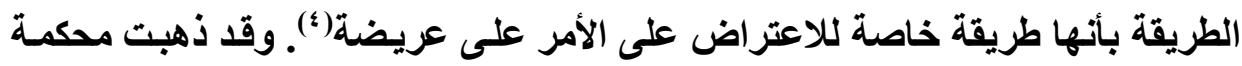

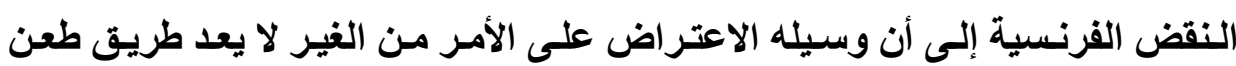

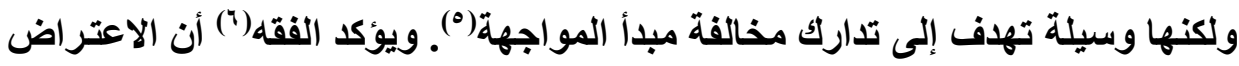

(1) Cass. Civ. 3e, 13 déc. 1977, Bull. civ. III, no 441. Cass. Soc. 17 déc. 2002, Bull. civ. V, no 395.

(2) Sylvie PIERRE-MAURICE, Ordonnance sur requête, op.c it., n.129, n. 138.

(3) NORMAND, obs. ss. Civ. 2e, 5 juin 1985, RTD civ. 1986. 404, spéc. p. 405

(4) V. BAUDIN, Des voies de recours contre les ordonnances sur requête, thèse, Dijon, 1902, p. 50; MINGAUD, Des voies de recours contre les ordonnances du président du tribunal civil, 1931, these, p. 90; PERRIN, Des ordonnances sur requête: étude de jurisprudence, thèse, Paris, 1902.

(5) Cass, Civ. 1re, 13 juill. 2005, Bull. civ. I, no 334; RJPF 2005, no 12, p. 22, obs. Eudier.

(6) CADIET et JEULAND, Droit judiciaire privé, op. cit., no 650, p. 459 
بطريـق السحب هو طريـق خـاص، يتبع فيـه الإجراعات المستعجلة، ولكن لايشترط

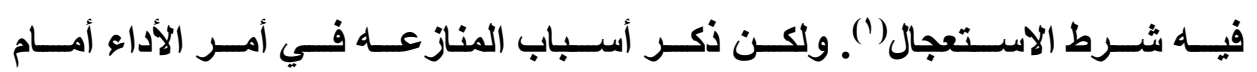

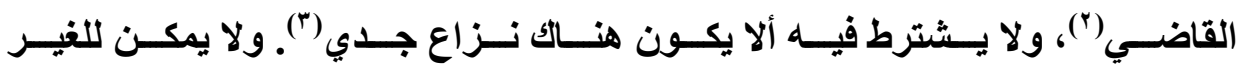

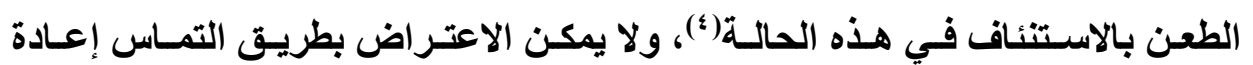
(النظر (ن)

\section{الفرع الثالث}

\section{هوقف المشرع المصري هن التطورات الحديثة في الأوا هر القضائية}

في الواقـع لـم يـساير المسشرع المـصري التطـورات التـي أخـــ بهـا المسشرع

الفرنسي، حيث اختلفت منهجية المشرع المصري عن المشرع الفرنسي، وسنشير إلى أهم هذه ســات تنظيم المشرع المصري للأوامر القضائية ومـدى فاعليتها، ثم نقدم اقتراحا بتعديل بعض أحكام المشرع المصري وذلك في النقاط الآتية:

(1) Cass, Civ. 2e, 3 janv. 1979, Bull. civ. II, no 6 ; D. 1979. IR 291, obs. Julien

(2) Cass. Civ. 2e, 20 févr. 1980, Bull. civ. II, no 39; Cass Civ. 2e, 1er juin 1988, Gaz. Pal. 1989. Somm. 167, obs. Guinchard et Moussa. CA Dijon, 17 oct. 1995, G. c/ M., Juris-Data, no 052879.

(3) ESTOUP, La pratique des procédures rapides, référés, ordonnances sur requête et procédures d'injonction, op. cit., n0 272.

(4) Cass. Civ. 2e, 20 févr. 1980, Bull. civ. II, no 39; Cass. Civ. 2 e, 6 avr. 1987, JCP 1987. IV. 213.

(5) Cass. Civ. 2e, 9 Nov. 2006, Bull. civ. II, no 316 
أولا: السمات الأساسية لتظظيم الأوامر القضائية ومدى فاعليتها 1- حصر المشرع المصري حالات استصدار الأوامر على عرائض

أخذ المشرع المصري بمبدأ حصر حالات استصدار الأمر على عريضة؛ فقد

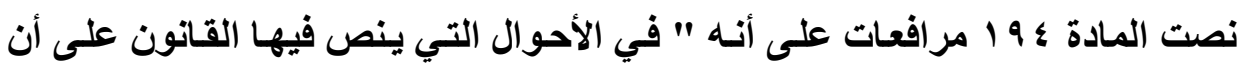
يكون للخصم وجه لاستصدار أمر، ..."؛ فيستفاد من نص هذه المسادة أن الأمر على لهى

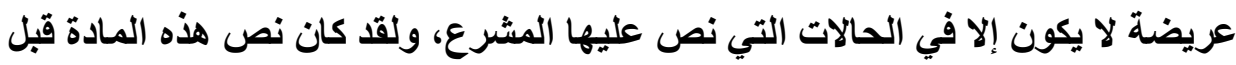

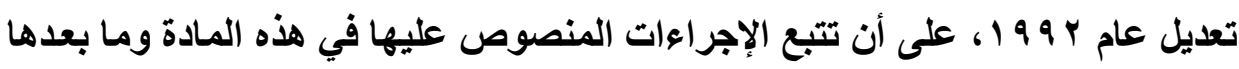
في الأحوال التي يكون للخصم فيها وجه في استصدار الأمر، ولقد وردت هذه الاحوال

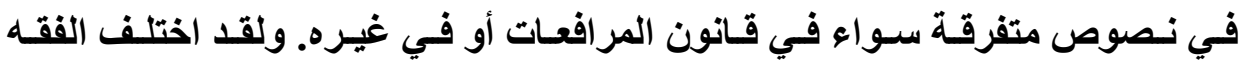

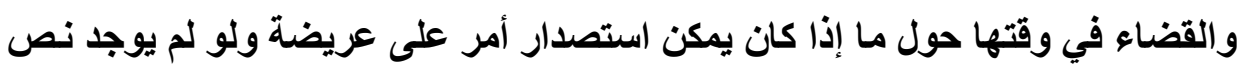

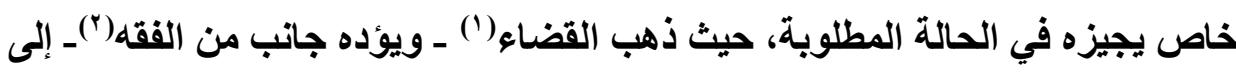

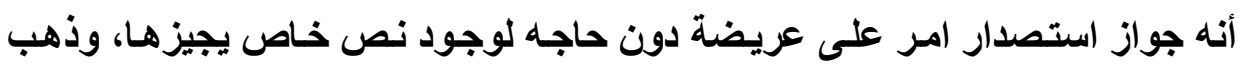

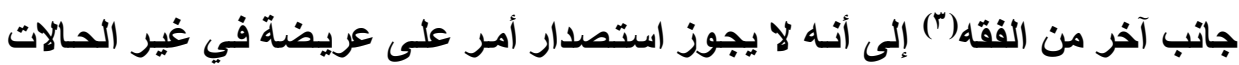

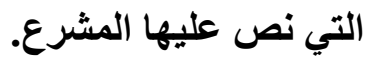

وقد وجد المشرع إسـاءة البعض لنظـام الأوامر على عرائض؛ حيث طلب

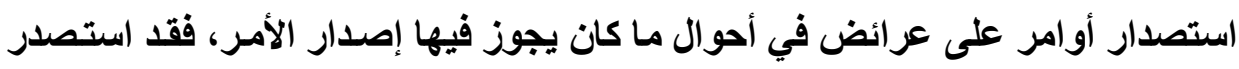

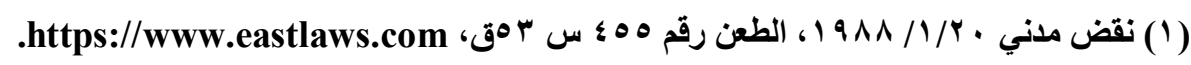

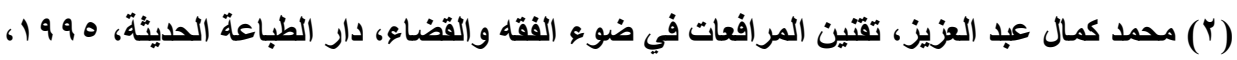

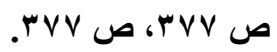
(r) داعبد المنعم الشرقاوي وعبد الباسط جميعي، شرح قانون المرافعات الجديد، بدون دار نشر،

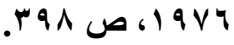


أمرا على عريضة لمنع بعض الأشخاص من السفر، في حين أن ذلك يقيد حريـة التقلّ، فيجب أن يكون بقانون يصدر من السلطة التشريعية('). ونتيجة لسوء الاستخدام العملي

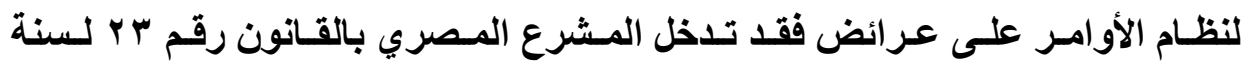

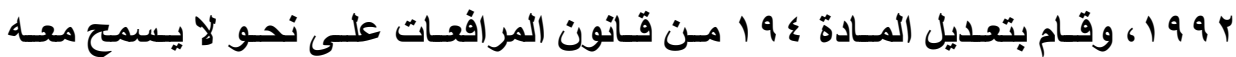
بـالاختلاف حـول تفسير ها، ونـص المـشرع على أن حـالات الأوامـر على عـرائض منصوص عليها على سبيل الحصر، فلا يجوز القياس عليها أو الإضافة إليها. وقد انتقد بعض الفقه موقف المشرع المصري()؛ فيرى البعض أن المشرع قد جانبه الصواب بحصره لحالات استصدار الأوامر على عرائض(")؛ لأن ذلك يتنافي مـع طبيعة هذه الأوامر التي لا تقبل الحصر ويصعب سلفا توقع مـاقد يجد بعد صدورها نتيجة التطورات الاجتماعية والاقتصادية المتلاحقة التي يمر بها المجتمع، كمـا أن هذا الحصر يحرم المتقاضـين مـن أسـلوب قضضائي ميسر يواجـه مسشـلكل الحيـاة العمليـة

ونتفق مع الفقه الأي يرى أن اتجاه المشرع المصري في حصر حالات الأوامر على عرائض اتجاه خاطئ، لأنه يصعب حصر حالات الأوامر على عرائض سلفا، ونرى أن حصر الأوامر على عرائض قد يكون مبررا في بداية صدور التثريع، وذلك لترسيخ هذا النظام وبيان حدوده، ولكن مع مرور الوقت، وترسيخ مبادئ الأوامر على عرائض،

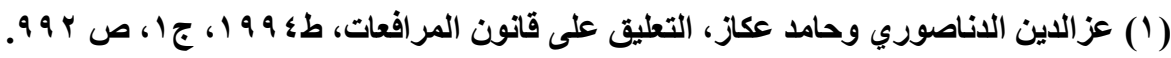

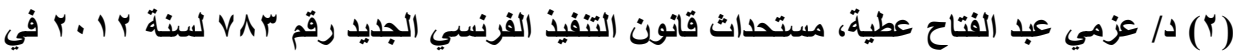

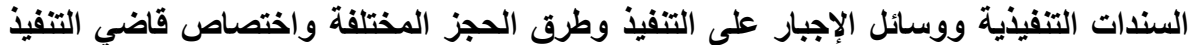

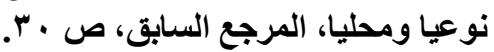

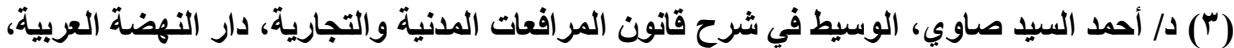

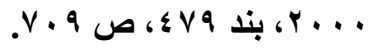




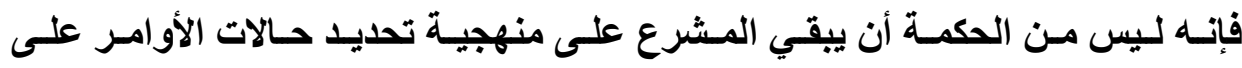

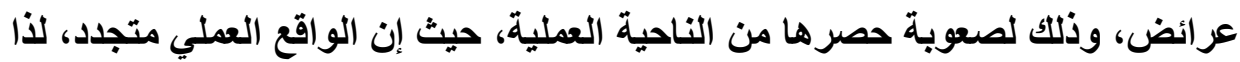

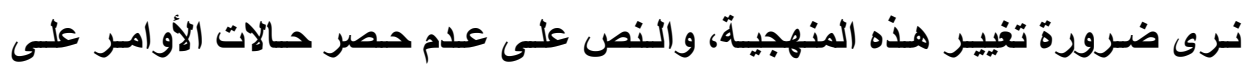

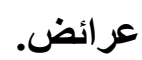
r- النص على التظلم من الأوامر على عرائ أخذ المشرع المصري بإمكانية الاعتراض على الأعمال الولائية، ولكن على لألى

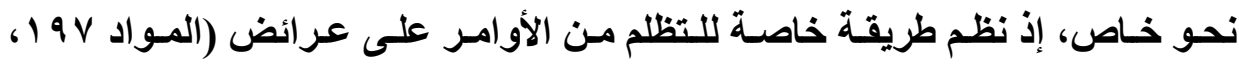

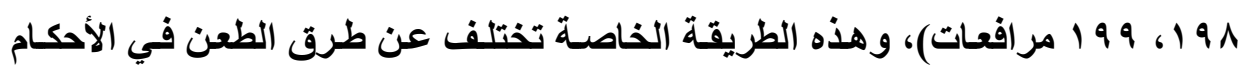
القضائية، وعلة عدم إخضاع الأعمال الولائية طريق الطعن نفسه في الأحكام القضائية،

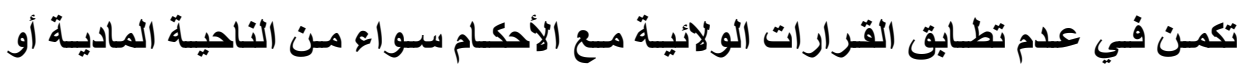

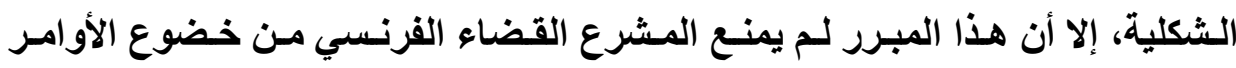

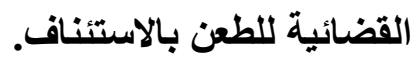

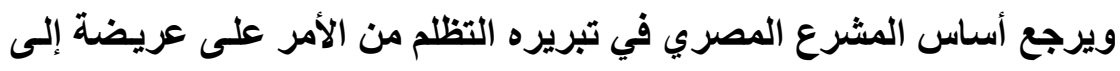

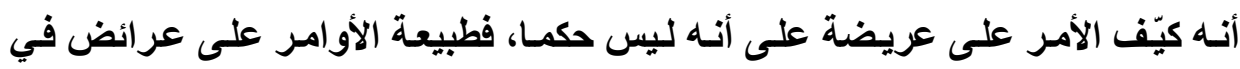

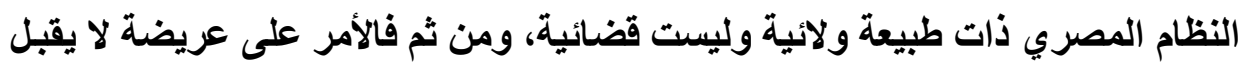

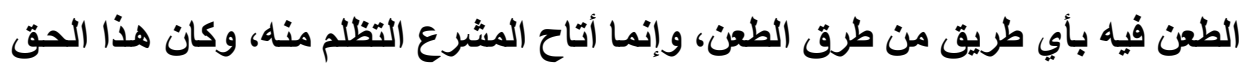
قاصرا على طالب الأمر إذا رفض طلبه، وعلى من صدر عليه الأمر (') وعند صدور القانون رقم 11 السنة 99 9 1 أجاز المشرع للغير التظلم من الأمر إذا أضيرت مصحلته

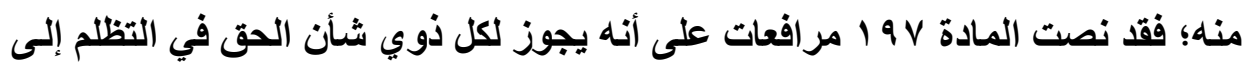

(1) د/ أحمد أبو الوفا، إجراءات التنفيذ في المواد المدنية والتجارية، المرجع السابق، ص هـ ا. 
المحكمة المختصة إلا إذا نص القانون على خلاف ذلك، كما نصت المادة 99 ألى مرافعات على أنه لذوي الثأن بـلا من التظلم للمحكمة المختصة الحق في التظلم منـه لنفس القاضي الأمر. وإذا كاتت الدعوى الأصلية قد رفعت أمسام المحكمة المختصة جاز رفع التظلم على سبيل التبعية أمام هذه المحكمة في أية حالة تكون عليها الدعوى الأصلية. فيكون لمن صدر عليه الأمر الخيار بين التظلم إلى المحكمة المختصة أو إلى القاضي الأمر، وليس لله الحق في الجمع بينهما'(')

ونظرا لأن التظلم من الأمر ينشئ خصومة حقيقية بين ذوي الشأن فقد نص

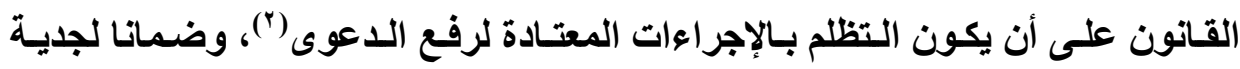
التظلم أوجب المشرع في المادة V 19 مرافعات وجوب تسبيب التظلم و إلا كان باطلاج"). وميعاد التظلم يكون خلال عشرة أيام تبدأ من تاريخ صدور الأمر بالرفض أو من تـاريخ البـدء في تنفيذ الأمـر أو إعلانـهـ بحسب الأحوال. ويضاف إلـى هذا الميعـاد مواعيد المسافة، ونص المشرع على عدّ القرار الصـادر من القاضـي حكمـا يطعن فيـه بـالطرق المقررة للطعن في الأحكام(؛)، مع مراعاة أنه حكم وقتي ().

(1) الإشارة السابقة، ص آس 1. ـ م/ مصطفي مجدي هرجه، الأوامر على العرائض، دار محمود للنشر

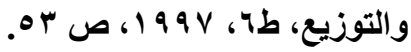

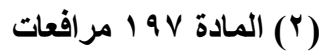
(T) د/ أحمد السيد صاوي، الوسيط في شرح قانون المرافعات المدنية والتجارية، المرجع السابق، ص .$\vee 70$

(؛) يعد التظلم خصومة بالمعني الصحيح، فيمكن تقديم طلبات عارضة فيها وتعديل الطلبات، والتذخل

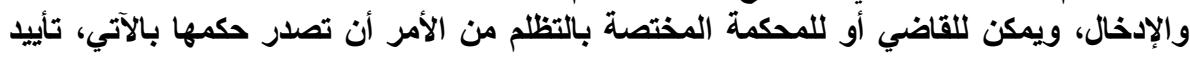
الأمر أو تعديله أو إلغاؤه أو إصدار أمر جليد. 
ويلاحظ أن المشرع المصري اتبع منهجية مختلفة عن النظام الفرنسي في

الأوامر على عرائض؛ حيث أخضع المشرع المصري الأوامر على عرائض باعتبارهـا

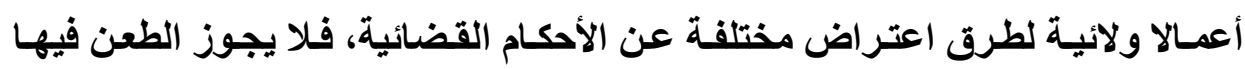
بالطرق العادية (الاستنتناف)، ويجوز فقط التظلم من الأمر على عريضة، ونظرا لأن العمل الولائي لا يحوز الحجية، فإنـه يجوز رفـع دعوى بطلان أصلية لإلغائهـ وإزالـة

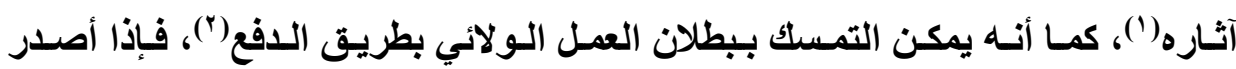
القاضي قرارا برفض الحجر على مجنون فإنه يمكن رفع دعوى ببطلان هذا القرار، وإذا حدث تمسك بهذا القرار في دعوى أمسام القضاء فإنسه يكون لذوي المصلحة الدفع ببطلان ذلك القرار.

ويؤيد بعض الفقه موقف المشرع المصري على أسـاس أن محكمة الاستئناف

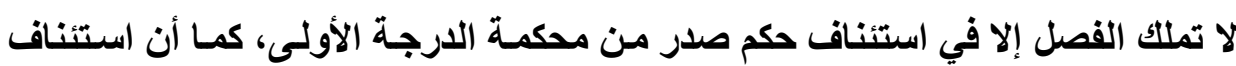
الأمر على عريضة فيه إخلال بلرجات التقاضي(")، كما قيل أن طريق الطعن يرمسي إلى له إصلاح خطأ في الحكم، وليس هذا في العمل الولائي، كما أنه ليس هناك فائدة عملية من استخدام الطعن ضد العمل الولائي؛ إذ يغني عنها إمكاتية تعديل العمل أو إلغائه وإمكانية رفع دعوى أصلية ببطلانه.

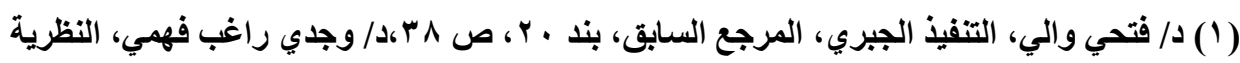

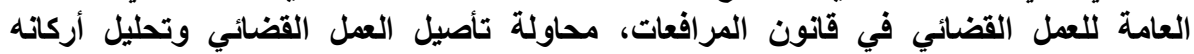

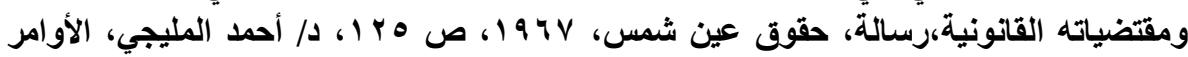

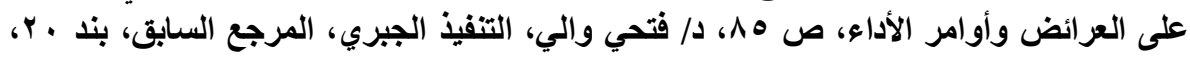

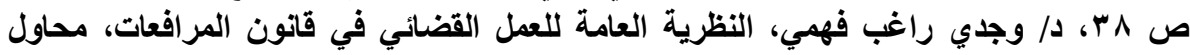

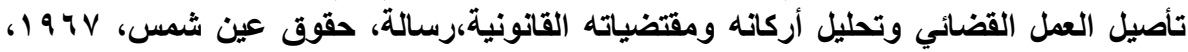


والواقع أن أغلبية الفقه المصري قد انتقد موقف المشرع المصري من عدم

خضوع الأعمـال الولائية لطرق الطعن (')؛ وذلك لأن أسـاس الطعن هو الضرر، وقد يلحق العمل الولائي بالشخص ضررا ومما يوجب فتح باب الطعن من ذلك العمل، كذلك إمكانيـة الرجوع عن العمل الولائي وإمكانيـة رفع دعوى أصلية ببطلانـه ليس فيهمـا الكفاية، وذلك لأن القاضي لا يعدل عن عمل ولائي أو يلغيه مـا لـم تنشأ ظروف جديدة،

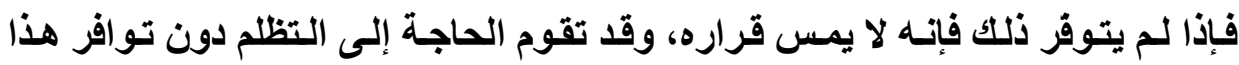
الثرط. وأمـا بالنسبة لدعوى البطلان فإنها تتعلق بشروط صحة العدل الولائي، وقد يكون العمل صحيحا ولكنه غير ملائم، وعندئــ لا يمكن الطلب بطلانـه، عن طريق هذه

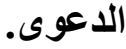

وإذا نظرنـا إلى موقف القانون المقارن نجد أنسه الققهـه والقضاء الفرنسي قد

استشعر الأثر السيئ لعدم خضوع الأوامر على عرائض لطرق الطعن مـن الناحية العملية، قبل تعديل المشرع الفرنسي لموقفه، فقد اتجهه إلى اضفاء الطبيعة القضائية على بعض الأعمال الولائية، حتى يتوصل إلى إجازة الطعن فيها بطرق الطعن الخاصـة بالأحكام.

ومن جنبا نؤيد الرأي الأي يوجب فتح باب الطعن بالاستئناف ضد الأمر على عريضة، وذلك لأن المشرع أجاز الطعن في أمر الأداء بالاستئناف، بالاضافة إلى التظلم منـه، ولـم يُجز ذلك في الأمـر على عريضة رغم أن إجراعات استصدار الأمـر على إسى عريضة هي نفسها إجراءات استصدار أمر الأداء، بالإضـافة إلى أن التظظيم الحسالي للاعتراض على الأمر على عريضة يطيل الإجراءات ويعقدها؛ وذلك لأن القرار الصادر

(1)، فتحي والي، الإشارة السابقة، بند · ץ، د/ وجدي راغب فهمي، النظرية العامة للتنفيذ القضائي

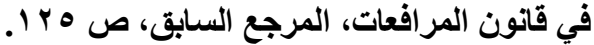


في التظلم يطعن عليه بالاستئناف، فلو نص المشرع مباشرة على الطعن بالاستئناف في حالة رفض الأمر سيكون فيه اقتصاد في الإجراعات، وقلـة في النفقات، بالإضـافة إلى منع الاختلاف حول طبيعة قرار القاضي بتعديل الأمر، فهل يعد ذلك أمرا جديدا أم يعد الاجد حكما، هذا الأمر آثار خلافا حول طبيعة القرار الصادر في التظلم('). والواقع أن التظلم أمسام نفس القاضسي لا يكون لـه فائدة بالنسبة للطالب الذي رفض طلبه، وذلك لأن التظلم أمام نفس القاضسي الأمر يقوم على فكرة أن القاضسي لـ يستمع عندما أصدر الأمر إلى وجهة نظر المتظلم. وهذا لا يقوم بالنسبة لطالب الأمر. فيكون غير منطقي التظلم بصفة عامـة أمسام القاضسي الذي أصدره، لأن هذا التظلم قد يكون مفيدا لمن صدر ضده الأمر.

ونـرى أنـه يجب الأخذ بنظـام الطعن بالاستتئناف في حالـة رفض الأمـر أمسام

رئيس محكمة الاستئناف ودون إعلان حتى لا يفسد التظلم فاعلية الأمر وضياع عنصر المفاجاة، وهو ما أخذ به المشرع الفرنسي في المادة 9 و ؛ إجراعات.

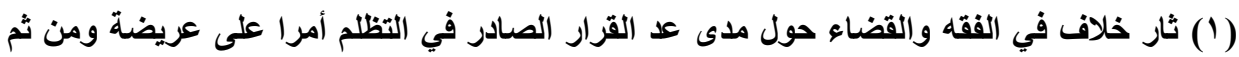

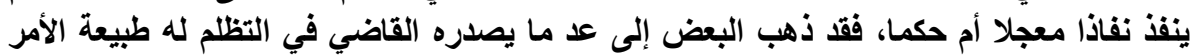

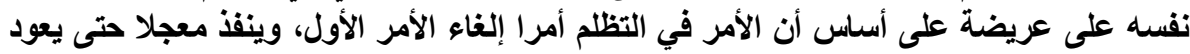

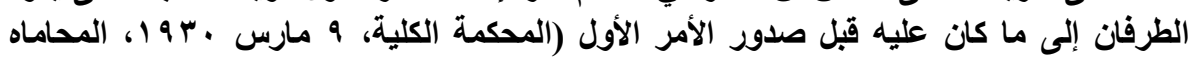

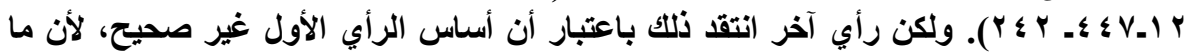

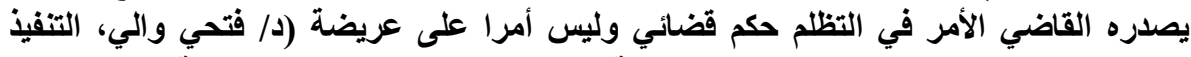

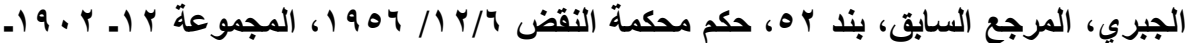

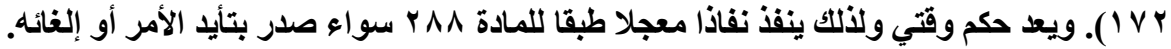


rــ النص على وقف التتفيذ المعل القانوني للأمر على عريضة (أمر الأداء في حالة

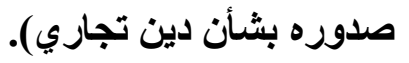

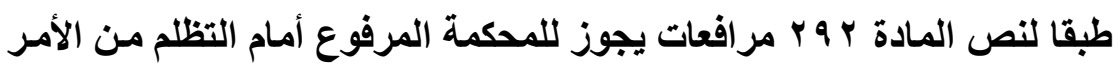

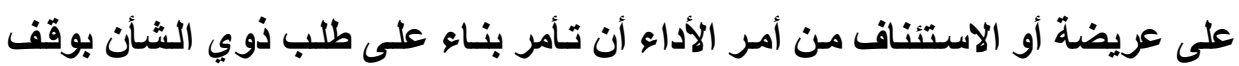

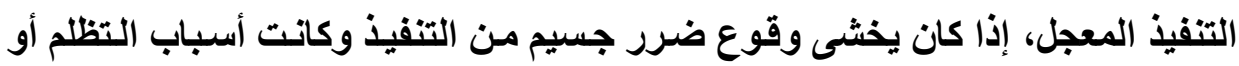

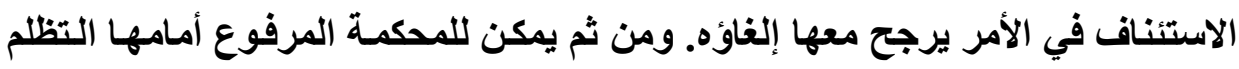
من الأمر على عريضة أو الاستئناف من الأمر أن توقف التنفيذ المعجل سواءو أكاء أكان

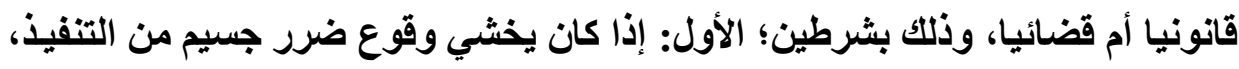

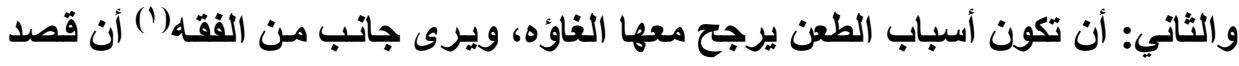
المشرع من هذا الشرط هو التخفيف مـن قسوة حصر حسالات النفـاذ المعجل مقدما

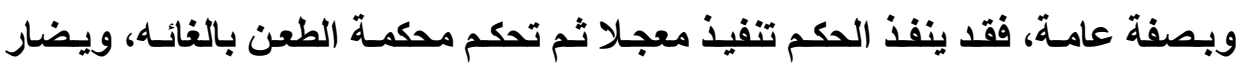
المحكوم عليه من جراء هذا التتفيذ، لذا اشترط المشرع شرطا آخر وهو أن تكون أسباب الطعن في الأمر يرجح معها الغاؤه، حيث إن رجحان إلغاء الأمر على عريضة أو أو الوناء

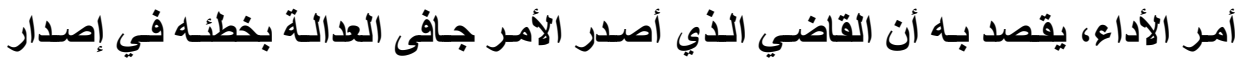

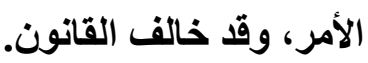

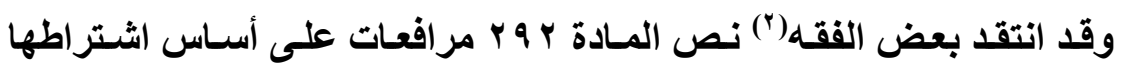

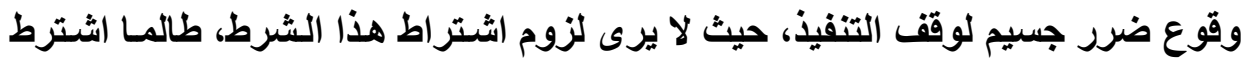

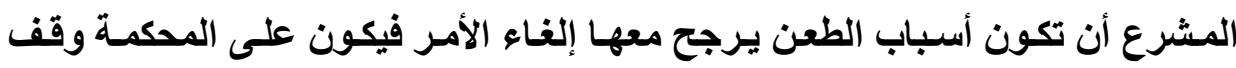
التنفيذ دون النظر إلى هذا الثرط، وذلك لأن المشرع بالنص على حالات التنفيذ المعجل 
قد راعي مصلحة المحكوم لـه، وبـالنص على وقف التنفيذ يكون قـ راعى مصلحة المحكوم عليه، ويعود بالخصوم إلى القاعدة العامـة في التنفيذ، وليس من العدالة أن تقيد محكمة الطعن فلا تحكم بوقف تنفيذ حكم تراه جافى العدالة لمجرد أن هذا التنفيذ لا يخشي منه وقوع ضرر جسيم. كمـا أن القانون يجيز لمحكمة الدرجة الأولى أن تـأمر بالتنفيذ المعجل إذا كان يترتب على تأخير التنفيذ ضرر جسيم بمصلحة المحكوم له، فلا أقل من أن يترك لمحكمة الارجة الثانية إعادة تقدير ما قررته محكمة الارجة الأولى. ونرى أن هذا الرأي السابق يمكن قبوله بالنسبة لوقف التنفيذ المعجل القضائي في حالة صدورة بناء على تقدير محكمة أول درجة، أما في حالة وقف التتفيذ المعجل

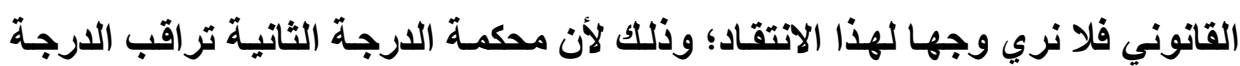
الأولى فيما يتعق بسلطتها في التقدير، فيكون لمحكمة الدرجة الثانية الحق في إعـادة تقدير مـا قررته محكمـة الدرجـة الأولى في مسألكة التتفيذ المعجل القضائي في حالـة واحده فقطوهي الفقرة الأخير من نص المادة ـ ج ب مرافعات، والمتعلقة بالحكم بالتنفيذ المعجل إذا ترتب على تأخير التنفيذ ضرر جسيم بمصلحة المحكوم له. والواقع أن وقف تثفيذ الأمر على عريضة بنـاء على هذه الشروط العامـة في نص المادة ب ج ج مرافعات يؤدي إلى شل فاعلية الأوامر على العرائض وأمر الأداء، ويهدر قوتها القانونية، فالمشرع نص على عدّ الأمر على عريضة نافذا نفـاذا معجلا بقوة القانون، ووقف تنفيذه يؤدي إلى ضياع الحكمة من تنظيم الأوامر القضائية والتي

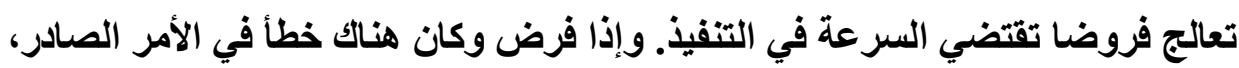
فإنه يمكن التظلم من وصف الأمر وتصحيح الخطأ القانوني. لذا نرى أن ينص المشرع على منع وقف التنفيذ المعجل للأوامر على عرائض لأنها صادرة بقوة القانون، ويجوز وقف تنفيذ المعجل لأمر الأداء في حالة صدوره بناء على قرار المحكمة، أمـا في حالة 
صدوره في مسألة تجاريـة فإنها يكون نافذا نفـاذا معجلا بقوة القـانون فلا يجوز وقف التنفيذ.

؟ - عدم النص على التتفيذ المعجل القانوني لأمر الأداء

في الواقع لم ينص المشرع المصري على التفيذ المعجل القانوني لأمر الأداء

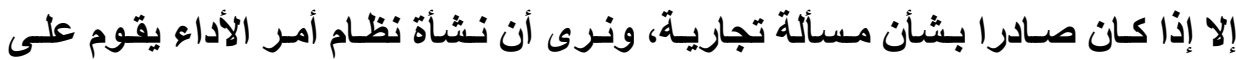
أساس السرعة والبساطة في الإجراءات، وهذا يقتضي إضفاء القوة التنفيذية المعجله بقوة القانون بمجرد صدوره، كمـا أن المشرع نص في المـادة ب^^ مرافعـات على أن الأوامر على عرائض تنفذ تنفيذا معجلا وبقوة القانون فور صدورها بغير كفالة إلا إذا نص الأمر على تقديم كفالةة(')، فالقانون يعد الأمر على عريضة كالحكم الصادر في المواد المستعجلة، لها طبيعة القوة التنفيذيـة نفسها للأحكام في المواد المستعجلة. وترجع الحكمة في النفاذ المعجل للأوامر على العرائض في أنها في الغالب تـأمر باتخاذ إجراء سريع تحفظي أو وقتي، وأنها تصدر في غقلة من الخصم وتهدف إلى مباغتة الخصم وهذا يقتضي التنفيذ المعجل(). ونـرى أن أمر الأداء في حاجـة كذلك للتفيذ

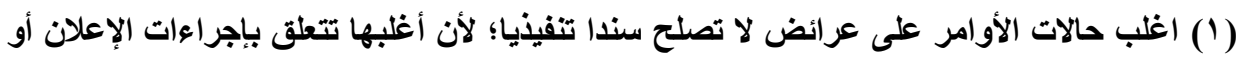

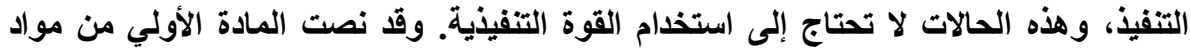

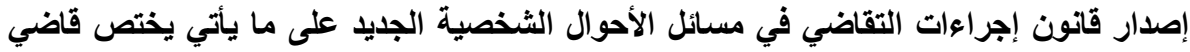

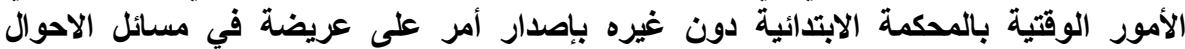

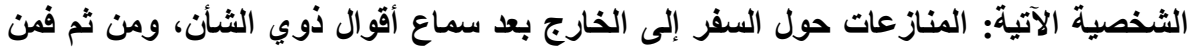

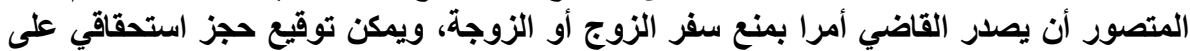

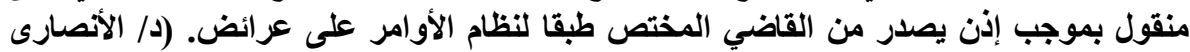

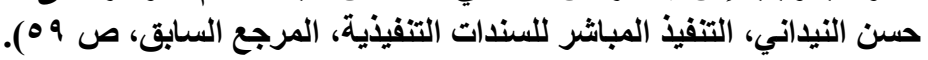

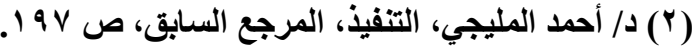


المعجل القانوني، وذلك حتى لا يهار الوقت بـالإجراءات المعقد خاصـة في حالة الطعن في الأمر. ثانيا: اقتراح بتعديل موقف المشرع المصري من خلال ما تقدم ذكره، يمكن لنا أن نقترح الآتي: 1- اقتراح بعدم النص على حصرية الأوامر على عرائض

نقترح أن يضيف المشرع بعد الفقرة الأولى في المـادة ؛ 9 أمرافعـات العبارة الآتية: " في الأحوال التي ينص فيها القانون على أن يكون للخصم وجـه في استصدار أمر أو إذا كاتت توجد حالة استعجال أو كاتت الضرورة تقتضي إصدار الأمر في غيبة فئة الخصم الآخر، يقدم عريضة بطلبه إلى قاضي الأمور الوقتية....".

r - اقتراح بالنص على الطعن بالاستئناف في حالة رفض الأوامر على عرائض اقترح تعديل نص المادة V 19 مرافعات لتكون على النحو الآتي: " في حالة رفض الأمر يكون للطالب الاعتراض بطريق الاستتناف بـون إعلان وحضور، ولذوي الثأن الحق في التظلم إلى المحكمة المختصة إلا إذا نص القانون على غير ذلك..." وذلك لأن التظلم لا يحقق أي فائدة بالنسبة لطالب الأمر على عريضة والأي تم رفض طلبه، ويجب أن تكون الإجراءات بدون إعلان الخصم الأخر ويدون حضور حتي لا يفسد الإعلان فاعليه الأمر عي عريضة، وحتى لا يضيع عنصر المفاجأة. r- اقتراح بمنع وقف التنفيذ المعجل لأمر على عريضة نقترح أن ينص المشرع المصري في المادة ب ج ج مرافعات على استثناء الأمر على عريضة من وقف التنفيذ المعجل، لأنها صادرة بقوة القانون. 
فيكون النص على النحو التالي " يجوز في جميع الأحوال للمحكمة المرفوع

اليها الاستئناف أو التظلم أن تأمر بنـاء على طلب ذي الشأن بوقف التنفيذ المعجل القضائي......" فنرى اضافة مصطلح التنفيذ المعجل القضائي. ع- النص على التنفيذ المعجل لأمر الأداء

نص المشرع المصري على أن أمر الأداء الصادر في مسألة تجاريـة يكون نفـاذا نفـاذا معجـلا بقوة القـانون، ولكن في الأحوال الأخرى يخضع للتنفيذ المعجل القضائي، وذلك إذا كان يترتب على تأخير التنفيذ ضرر جسيم بمصلحة المحكوم لهه،

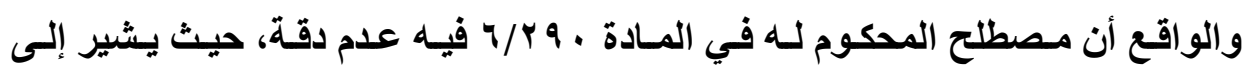
الأحكام القضائية وليس إلى الأوامر.

ونقترح أن ينص المشرع في المادة ب^^ إضـافة عبارة أوامر الأداع، ويكون

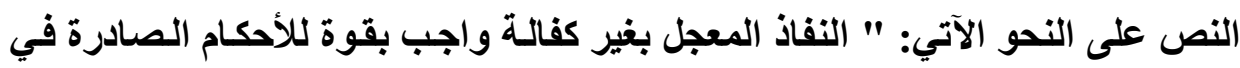

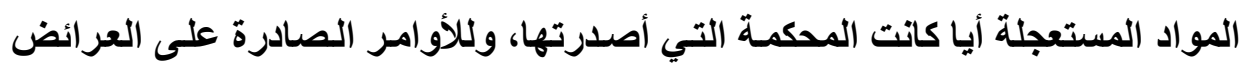
وأوامر الأداء، وذلك ما لم ينص الحكم أو الأمر على تقديم كفالة". 


\section{المبحث الثاني \\ التطورات الصديثة في \\ التسسوية البودية في التنفيذ البمبري}

التسوية الودية في مرحلة التنفيذ الجبري تهدف إلى حل الخلافات الناشئة بين أطراف التنفيذ، والوصول إلى حل رضائي يقبله الدائن والمدين في طريقة تنفيذ السند، وينتج عنها اتفاق يكون له قوة السند التنفيذي، ولقد أخذت أغلبية الدولة العربية بهذه الوسيلة التي كانت لها أثر كبير في إنهاء النزاعات التنفيذية. وهناك اتجاهات مختلفة في تنظيم التسوية الوديـة في مرحلة التنفيذ الجبري، فمن الأنظمة ما يسند هذا الأمر إلى قاضي التنفيذ الذي يستدعي المدين لتقديم تسوية يرضـاها الـائن، مثل القـانون الكويتي والقـانون الأردنـي، وبعض الأنظمـة تُسند هذه الوسيلة إلى لجنه مختصة، مثل القانون الإماراتي.

وسنشير إلى التسوية الودية في بعض القوانين العربية، وذلك في المطلب

الأول، ثم نعـالج التسوية الوديـة في النظـام الفرنسي والمصري، وذلك في المطلب الثاني، وذلك على النحو الآتي:

\section{الإطاب الأول}

\section{التسوية الودية في بعض القوانين العربية}

سنشير إلى التسوية الوديـة في القانون الأردني واللبنـاني، وذلك في الفرع

الأول، ثم نعالج التسوية الوديـة في القـانون العراقي والكويتي والإمـار اتي، وذلك في الفرع الثاني، وذلك على النحو الآتي: 


\section{الفرع الأول \\ التسوية الودية في القانون الأردني والبناني}

سنشير إلى التسوية الودية في القانون الأردني، ثم نعالج التسوية الوديـة في القانون اللبناني، وذلك في النقاط الآتية:

$$
\text { أولاً: التسوية الودية في القانون الأردني }
$$

منح المشرع الأردني حقا للمدين في عرض تسوية وديـة أثنـاء مدة الإخطار؛ فطبقا لنص المـادة r r مسن قـانون التنفيذ الأردني، يجوز للمسدين أن يعرض تسوية تتناسب ومقدراته خلال مدة الإخطار على أن لا تقل الدفعة الأولى بموجب التسوية عن

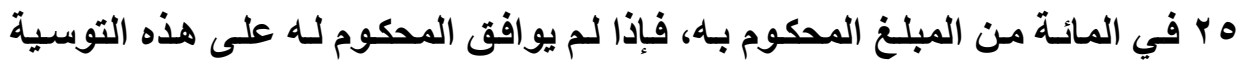
فللرئيس أن يأمر بدعوة الطرفين لسماع أقوالهمـا، ويقوم بـالتحقيق مـع المدين حول اقتداره على دفع المبلِغ، ولـه سـماع أقوال الدائن وبياناتهـه على اقتـار المحكوم عليه وإصدار القرار المناسب، وقرار القاضي يكون سندا تنفيذيا.

ويستفاد من هذه المادة أنه إذا لم يسدد المدين الدين، فيجب عليه أن يعرض تسوية تتناسب وقدرته المالية على ألا تقل الدفعه الأولى من هذه التسوية عن هץ\% من المبلغ المحكوم به موضوع التنفيذ(')، وباقي المبلغ يمكن تقسيطه بنسب تثفق مـع قرراته المالية. ولا شكك في أن هذه الوسيلة تراعي مصلحة المدين، وتلزمـه بالوفاء الاختياري للسند التنفيذي.

وحق للائن الاعتراض على التسوية الودية المقترحة من المدين، بالادعاء بمقدة المدين على دفع مبلغ الدين كاملا أو قرته على دفع أقساط لاحقة أعلى من (1) د/ مفلح عو اد القضاة، أصول التفيذ وفقا لقانون الإجراءات الأردني، المرجع السابق، ص بـ 1. 
الأقساط التي عرضها المدين(')، ففي هذه الحالة يجوز لرئيس التتفيذ أن يدعو الطرفين

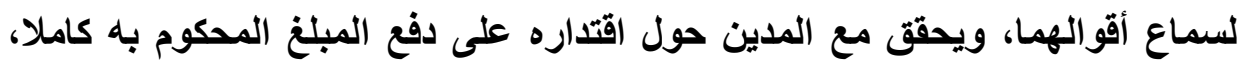
وله سماع أقوال الدائن وبياتاته على اقتار المحكوم عليه، ومن ثم يصدر القرار المناسب.

ولم يشر قانون التنفيذ الحالي إلى الفرض الذي يتخلف فيه المدين عن دفع

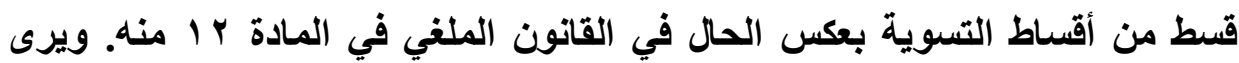
بعض الفقه أنه في هذه الحالة يجوز حبس المدين إذا اشترط الدائن ذلك عند إبداء موافقته على التسوية المعروضة من المدين("). وإذا لم يعرض المدين التسوية خلال مدة الإخطار وهي خمسة عشر يوما، فلرئيس التتفيذ حبس المدين طالما لم يتم الوفاء أو لم يعرض التسوية. ثانياً: التسوية الودية في القانون اللبناني لم يأخذ القانون اللبناني القذيم بنظام التسوية الودية(")، وذلك على أساس عدم

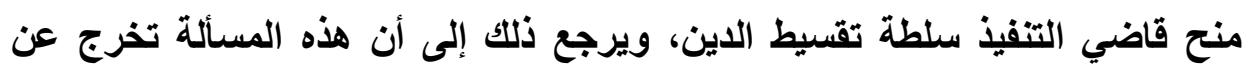

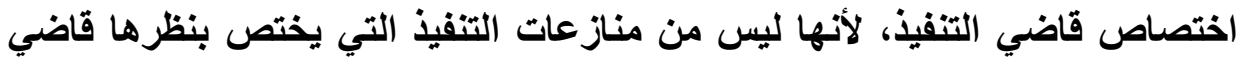
التنفيذ(\$)

(1) صلاح الدين شوشاري، التنفيذ الجبري في المواد المدنية والتجارية والثرعية، المرجع السابق،

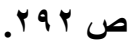
(r) (r) الإثارة السابقة.

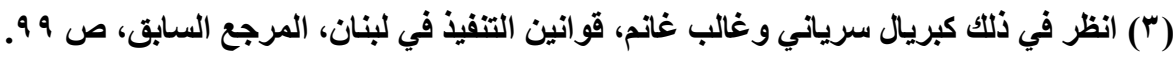

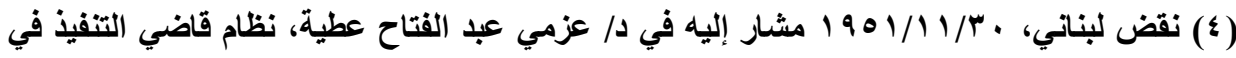

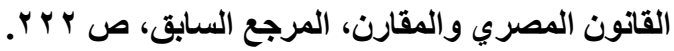


ولكن المشرع اللبناني نص في قانون التنفيذ اللبناني الحالي في المادة على قاعدة مستحدثة غايتها مراعاة وضع المدين وإعطاؤه فرصة للإيفاء غير المرهق وتجنيبه التنفيذ القسري على أمواله. ويشترط أن يكون محل السند التنفيذي دينا نقديا، وأن يطلب المنفذ ضده من رئيس إدارة التنفيذ مهلة للإيفاء بما عليه في السند

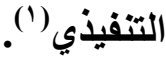

ومن ثم لا يمكن إعمال التسوية الودية طبقا للمادة و ج ^ تنفيذ في الايون غير النقاية، ويجب على المنفذ ضده أن يتقلم بدعواه في مهلة الإنذار، وهذه المهلة تختلف تبعا لأنواع السندات التنفيذية وتبعا لما قد يتخذه رئيس دائرة التففيذ من قرارات تتناول مدة الإتار، فإذا كان التفيذ مبنيَّا على حكم ولم ثُقصر مهلة الإنذار فتكون مدة تقديم طلب التسوية خلال خمسة أيام من تاريخ الإعلان، أما إذا اتخذ رئيس دائرة التنفيذ قرارا بتقصير المهلة فيتوجب إقامة الدعوى خلال المهلة المقصرة. وإذا كان التنفيذ مبنيا على عقد أو تعهل مثبت بسند رسمي أو عادي، فالمهلة التي يجب خلالها تقديم طلب التسوية تكون عشرة أيام، لأن مهلة الإنذار محددة بعشرة أيام في المادة . ـهـ، ولا يجوز قصر مدة الإنذار في هذه الحالة لعدم وجود نص.

ويشترط للإفادة من مهلة الإيفاء توافر الثروط المنصوص عليها في المادتين

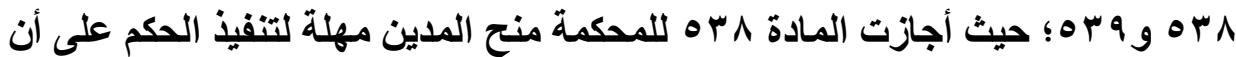
تبين الأسباب الدافعة إلى ذلك، كما أن هذه المادة حددت وقت سريان مهلة التنفيذ، وحفظت حق المحكوم له باتخاذ التدابير الاحتياطية: أما المادة و به فحرمت منح المهلة، بل أجازت الرجوع عنها بعد منحها بناء على طلب الائن في الحالات الآتية: 
د/ طلعت يـوسف خاطر

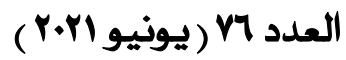

- في حالة إفلاس أو عدم ملائة المحكوم عليه

- في حالة قيام المحكوم عليه بفعل أدى إلى إنقاص التأمينات الخاصة التي

أعطاها للمحكوم له بموجب عقد أو عدم تقديمه لهذا الأخير التأمينات التي

$$
\text { تعهد بها نحوه بموجب عقد. }
$$

- في حالة حجز أموال المحكوم عليه أو بعضها من قبل دائنين آخرين.

ومهما كانت الأسباب الدافعة إلى منح مهلة الوفاء لا يجوز أن تتجاوز هذه

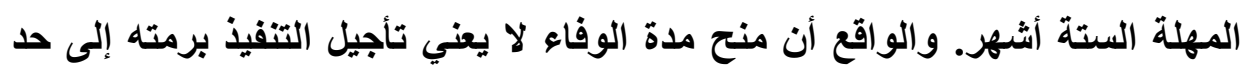
أقصاه سته أشهر، بل يعني تقسيط الدين - موضوع التنفيذ- عبر مهلة الستة أشهر، وبالثكل الذي يراه رئيس دائرة التففيذ متناسبا مع وضع المدين وجدية الأسباب المدلى مئى بها ومعطيات الدعوى على وجه عام. وإن ما يحملنا على اعتماد هذا الرأي الأسباب الآتية('): يتحدث النص عن مهلة للوفاء لا عن مهلة للتنفيذ، كما أن الغاية من القاعدة

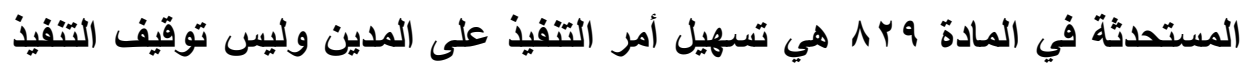
كليا بإرجاء الدفع إلى مدة بعيدة. وإن كنا نرى أن هذه المدة قصيرة، حيث يفضل أن تمتد المدة سنه، أو يترك الأمر لاتفات الأطر اف على ذلك.

وتقديم طلب منح المهلة لا يؤدي بحد ذاته إلى وقف التتفيذ، لأن التفيذ لا يقف

إلا بقرار من رئيس التنفيذ في ضوع سلطته التقديرية المنصوص عليها في المادة

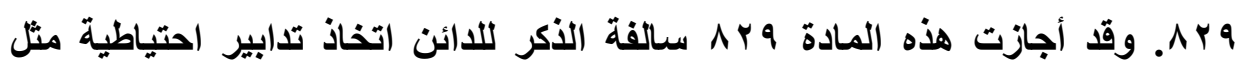
الحجز الاحتياطي، وهذا حق طبيعي للائن، وذلك لضمان حقوقه. وتنظر الدعوى طبقا للقواعد المنصوص عليها في القضاء المستعجل؛ لأن رئيس دائرة التقفيذ لا يفصل في 
أساس الحقوق، بل يقتصر دوره على منح مهلة لتنفيذ الحقوق المثبتة في السند التثفيذي.

\section{الفرع الثاني \\ التسوية الودية في التنفيذ \\ في القوانين العراقية والكويتية والإهاراتية}

سنشير إلى التسوية الودية في القانون العراقي، ثم القانون الكويتي، وبعد ذلك في القانون الإماراتي، وذللك في النقاط الآتية: أولاً: التسوية الودية في التتفيذ الجبري في القانون العراقي

نص قانون التنفيذ العراقي على إخطار المدين بالتنفيذ وتكليفهـ بالوفاء خلال سبعة أيام تحسب من اليوم التالي لتاريخ الإبـلاغ. ومن بـاب تشجيع القانون العراقي للمدين الأي يبادر إلى التنفيذ فقد أعفاه من رسوم التحصيل إذا قام بسداد مـا هو ملزم به خلال يومين من اليوم التـالي لإعلانـهـ. وفي الوقت ذاته فبإن القـانون العراقي يدفع

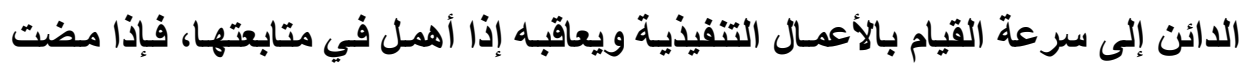
مدة سنة على آخر إجراء تنفيذ دون قيام طالب التنفيذ بمراجعة دائرة التنفيذ، وكان ذلك

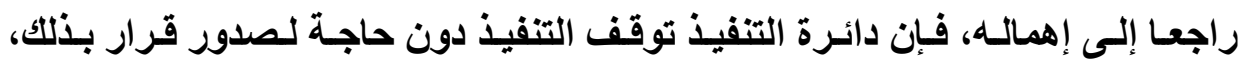
وتستأنف إجراءات التنفيذ من آخر إجراء توقفت عنده إذا تقدم طالب التنفيذ بعريضة يطلب فيها تجديد الإجراعات (م ع ا تنفيذ) ويجب تقديم هذا الطلب خلال خمسة عشر عاما من آخر إجراء وإلا سقط الحق في تقديمه ('). (1) د/ عزمي عبد الفتاح عطية، نظام قاضي التنفيذ في القانون المصري والمقارن، المرجع السابق، 
وإذا أبلغ المنقَّ ضده بالإعلان فإن موقفه لا يخرج من أحد الفروض الآتية: ا ـ الادعاء بالوفاء بالدين خارج دائرة التنفيذ:

قد يدعي المدين أنه قام بسداد الدين أو تصالح مع الدائن خارج دائرة التتفيذ،

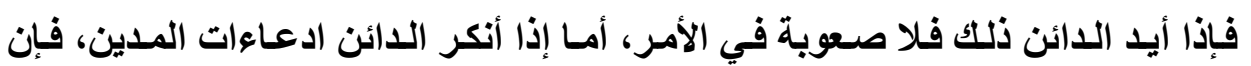
الدائرة تستدعي المدين لمواجهته وسماع دفاعه، فإذا وجدت لايسه أن وسـائل الإثبات مقبولـة فإنهـا توقف التنفيـذ، وتـأمره خـلال خمسـة عشر يومـا أن يلجـأ إلى المحكمـة المختصة لإثبات دعواه. (م 11 تنفيذ). r- الإقرار بالمبلغ كاملا في السند التفيذي وتقديم طلب بالتسوية الودية: إذا أقر المدين بالدين يصدر قاضسي التنفيذ قرارا بالتنفيذ عليه، ويأخذ حكم

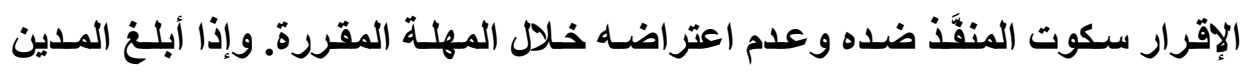
بإخطار التنفيذ فإنها قد يحضر طوعـا أثنـاء مهلة التنفيذ، وقد لا يحضر، وفي الحالة الأخيرة فبإن دائرة التنفيذ تـأمر بضبطه قسرا وذلك بعد صدور أمر بذلك من قاضسي

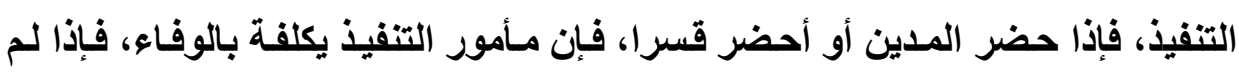

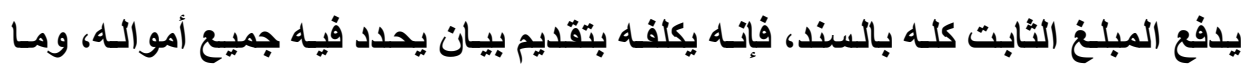
يقترحه من تسويه للاين حسب حالته المالية، ويجير قانون التنفيذ العراقي تقسيط الدين (مه / / ) مو وقد تكون التسوية في صورة طلب إعطائه مهلة سداد. ويعرض الأمر على قاضي التنفيذ، ويقدر القاضسي مدى ملائمـة هذه التسوية؛ وذلك بالنظر إلى مقدار الدين ومدى حالة المدين المالية. ولم يضع القانون معيارا معينا في هذا الثأن، بل ترك الأمر للسلطة التقديرية للقاضي. ويجب عرض التسوية على اللدائن لإبـاء رأيسه فيها، فإذا وافق عليهـا فـلا صعوبة في الأمر، أما إذا رفضها فإنه يتعين عليه إثبات قدرة المدين على عرض تسوية لإبل 
أفضل، فإذا ثبت إدعاؤه قرر القاضي تعديل التسوية على حسب ما أثبته الدائن. ويمكن للمدين الاعتراض على هذه التسوية، فإذا قدم أسبابا أو أدلة تبرر تغييرهـا كـان لقاضي التنفيذ تعديل التسوية التي سبق اعتمادها. فإذا لـم يقدم المدين تسوية للدائن مدعيا عسره، ففي هذه الحالة يكون من سلطة قاضـي التنفيذ تقدير هذا الأمر، فبإذا اقتنع بدعوى المدين كلف الدائن بإثبات مقدرة المدين على الوفاء('). وإذا نجـح الدائن في إثبات قدرة المدين فإن هذا الأخير يلزم بالتسوية التي يقررها قاضي التنفيذ، وإذا تعارضت أدلة الإثبات التي يقدمها الدائن والمدين فـإن قاضسي التنفيذ هو الذي يـرجح تلـك الأدلـة. ويمكن تعديل التسوية إذا تـدهورت حالـة المدين المالية بعد التسوية (مو م تنفيذ). وإذا كـان الفرض العكسي، وتبدلت أحوال المدين إلى التحسن، فإنه يجوز للائن طلب إعادة النظر في التسوية(؟). ثانياً: التسوية الودية في القانون الكويتي نص القانون الكويتي على أنه يتم إعلان المدين عن طريق مأمور التنفيذ للقيام بالوفاء أو عرض التسوية الودية، وذلك خلال مدة محددة، وقد تختلف تلك المدة من حالة إلى أخرى، فبان كـان المطلوب تنفيذه هو قرار أو حكم فبإن المهلة التي تعطى للمدين هي أسبوع واحد، أمسا إن كـان المحكوم بـه من المواد المستعجلة فتكون المدة أربعاوعشرين سـاعة، أمسا إذا كـان أي سند تنفيذي آخر فبإن المدة هـي خمسة أيسام، وتحسب المدة من تاريخ إعلان المنقَّ ضده.

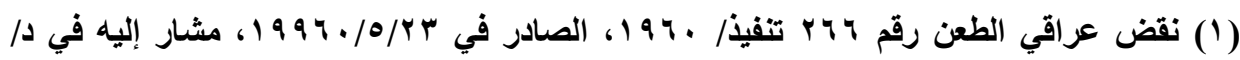

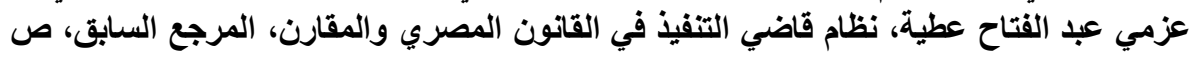


وإذا حضر المنقَّذ ضـده وعرض التسوية خـلال المهلة، والتـي يقدمها وفقـا لظروفه، حسب موارده المالية، وقد تكون في شكل طلب إمهاله مدة معينة لدفع الدين

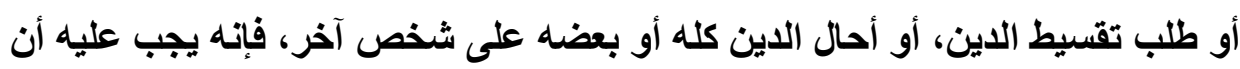
يبين كيفية تسديا الباقي (')

ويجب على رئيس اللائرة عرض التسوية على الدائن ليقدم رأيها فيها، وإذا اعترض عليها يجب أن يبين أسباب هذا الاعتراض ويقدم الأدلة المقتعه التي تقيس اقتدار المدين على عرض تسوية أفضل، وإذا أثبت ذلك بأدلة يقتنع بها رئيس الدائرة فإن لهذا الأخير تعديل التسوية وفقا لطلب الدائن، وإذا لم يثبت الـائن صحة اعتراضهـ

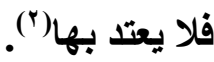

وإذا لم يقبل المدين التسوية التي قررها رئيس دائرة التنفيذ، نتيجة اعتراض اللائن، وقدم أسباب أو أدله مقنعه تبرر تغيير التسوية، فبإن لرئيس الدائرة أن يعدل

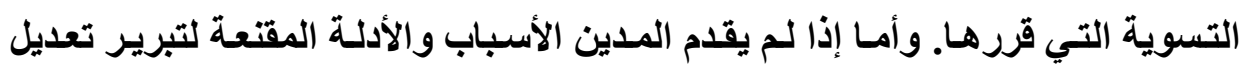

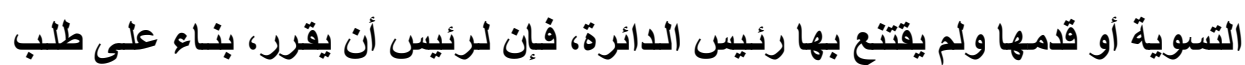
الائن، حبس المدين لأنه في هذه الحالة يعد متمردا أو مماطلا. ويثار التساؤل في حالة تبديل أحوال المدين المادية، وثبت لرئيس الدائرة هذا التبديل، وقد كان هناك تسوية موافق عليها من الدائن، فهل يجوز طلب تعديل التسوية؟

(1) د/ عزمي عبد الفتاح عطية، د/ مساعد العنزي؛ قواعد التنفيذ الجبري في قانون المرافعات

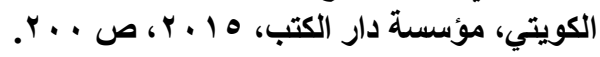
(r) م Y Y Y مرافعات كويتي. 
لم يتطرق قانون المرافعات الكويتي إلى هذه المسألة، وقد ذهب البعض(') إلى الى

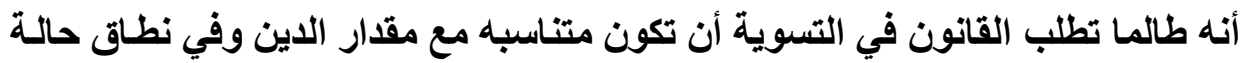

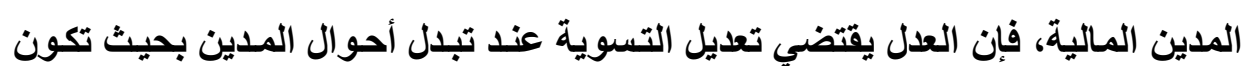

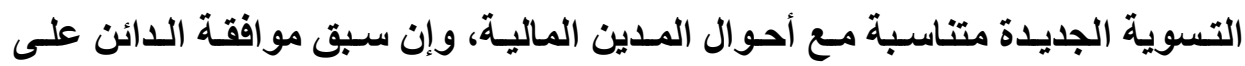

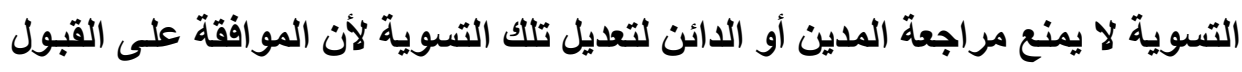
في كثير من الأحيان غير رضائية.

ولقد أجاز قانون المرافعات الكويتي لرئيس التنفيذ حبس المدين مدة لا تجاوز

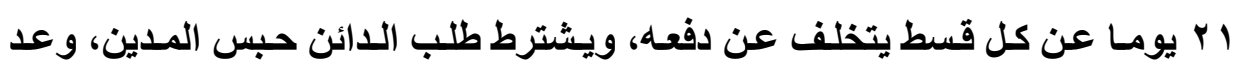
المدين مماطلا وممتنعا عن الافع. ثالثا: التسوية الودية في القانون الإماراتي: نظم المشرع الاماراتي التسوية الودية في مرحلة التنفيذ الجبري؛ حيث يجوز

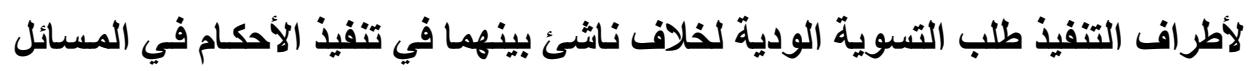

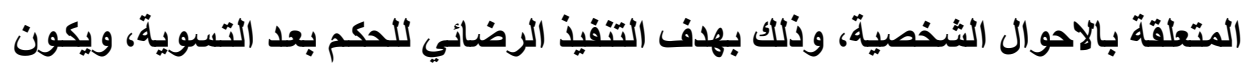

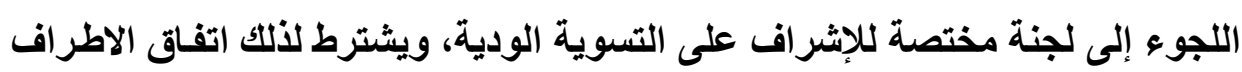

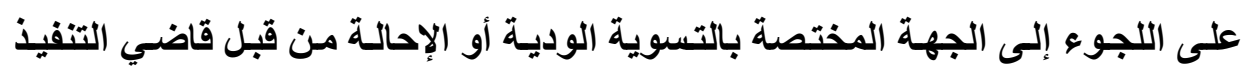

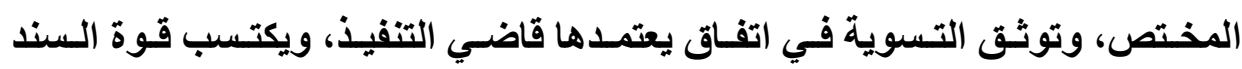

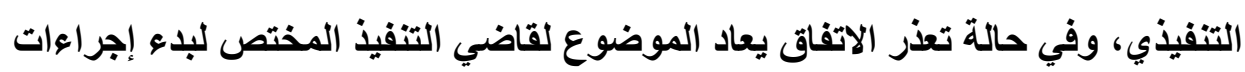
التنفيذ(ب)

(1) مبارك محمد ظافر، حبس المدين طريقا من طرق التنفيذ الجبري، دارسة في القانون الكويتي، دار

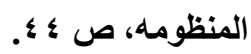

(2) https://www.dc.gov.ae/PublicServices/ServiceDetails.aspx?serviceid=1836\&lang=ar 


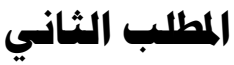 \\ التسوية الودية في التنفيذ الجبري \\ في النظاهين الفرنسي والمصري في الفيني}

سنشير إلى التسوية الودية في القانون الفرنسي، وذلك في الفرع الأول، ثم

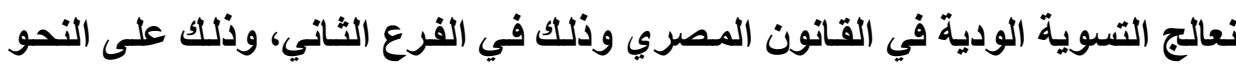
الآتي:

\section{الفرع الأول \\ هوقف القانون الفرنسي هن التسوية الودية}

راعي المشرع الفرنسي حقوق المدين أثناء التنفيذ الجبري، ووضـع ضمانـات

معينة تحمي المدين، وهذا ما يعبر عنه الجانب الإنساني في التنفيذ الجبري. ومن أهم الوسـائل التي تحقق هذا الجانب الإنساني التسوية الوديـة التي تراعي حسال المـدين

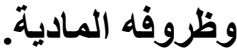

وطبقا للمرسوم رقم 2012/783 الصادر في 2012/6/1، والذي نظم مسألة

التسوية الودية أثناء التتفيذ الجبري، أجازت المـادة ؟ ؟ ب ا فقرة ا ب ب من القانون المدني للقاضي أن ينظم اقتضاء الدين d'amenager le reglement la dette من المدني، وذلك بعد مراعـاة مقدار الدين وظروف المدين المالية، وذلك ماعدا ديون النفقة، وتتم جدولة الدين في حدود سنتين، وله أن ينقص مقدار الفوائد بشرط ألا تقل عن الفائدة القانونية، وأن يقدر القاضي سداد أصل الدين أولاً ثم الفوائد بعد ذلك. وإذا قرر القاضي الجدولة فإن هذا القرار يوقف إجراعات التنفيذ بقوة القانون إذا كانت قد بدأت في مواجهة الدائن. ويقف سريان الفوائد خلال فترة التوقف. وقد حاول المشرع 
الفرنسي حمايـة الديون الخاصـة بالمستهلكين، وقرر مبدأ تسوية المنازعات الخاصة

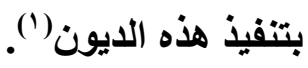

وبالنسبة لرعايـة بعض الفئـات الضصيفة مثل المستأجر فقــ اهتم المشرع

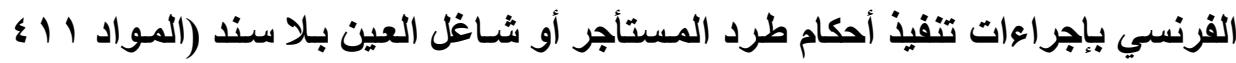
إلى 10 ؛ من لقانون الإيجار) وأجاز للمستأجر اللجوء إلى القاضي لوقف قرار الطرد،

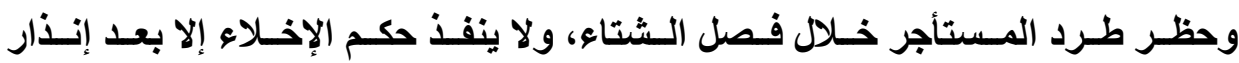

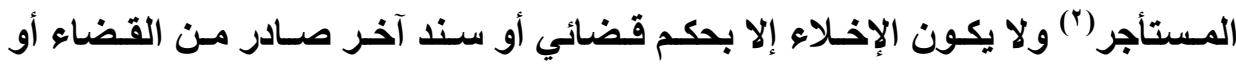
بموجب محضر صلح مصدق عليه، ولا ينفذ قرار الإخلاء إلا بعد مضي شـهرين من

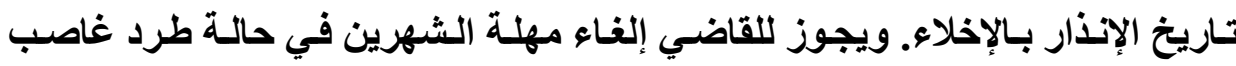
العقار بلا سند، ولكن يجوز للقاضي في غير هذه الحالة مـ مهلة الإخلاء لمدة لا تزيلا عن ثلاثة أشهر، ثم عدلت هذه المدة إلى سنة. والواقع أن المشرع الفرنسي وضع قواعد تهف في مجملها إلى رعاية

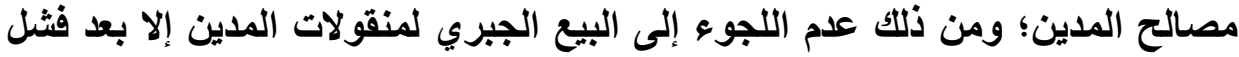

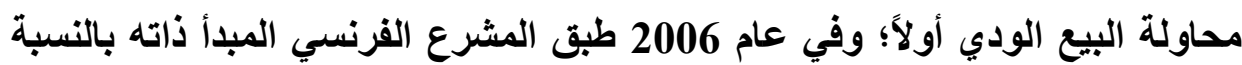
للبيع الجبري للعقار.

(1)Vigneau, La reforme du droit du surendettement par La loi du La Juillet 2010, D. 2010.2593.

(2) J.Beauchard, le logement et le procedute civile d'execution, PTD.civ 1993 P 109. 


\section{الفنرع الثاني \\ هموقف المشرع المهري هن التسوية الودية}

لم ينظم المشرع المصري التسوية الوديـة بين الـائن والمدين في المرحلة السابقة على البيع الجبري، ولكنه نظم أحكام التسوية الودية بعد البيع، ونص على عدّ القرار الصادر بشأنها سندا تنفيذيا. والواقع أن المشرع نظم مسائل التسوية المتعلقة بالديون العقاريـة عن طريق لجنه اصبغ على أحكامها صفة السندات التنفيذيـة؛ فقد

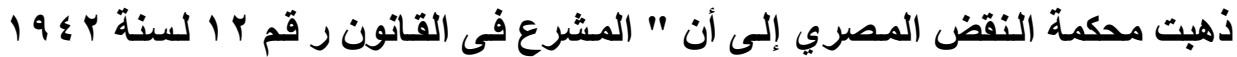

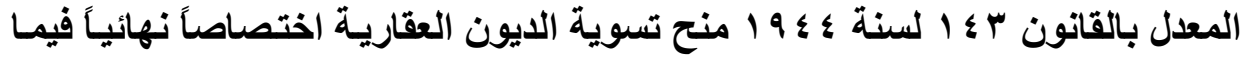
خصها بنظرة من مسائل تتصل بتسوية الايون العقارية، و أسبغ على قراراتها من الأثر

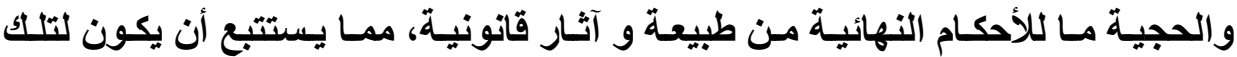
القرارات أثر هذه الأحكام من اكتساب القوة التنفيذية، فتدخل بهذا المعنى فى مدلول

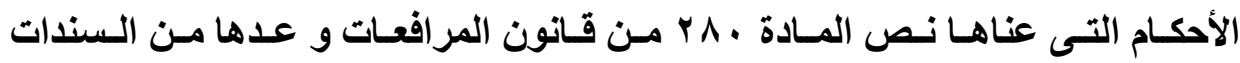

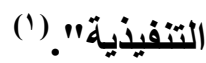
وسنشير إلى التسوية الودية بعد الحجز والبيع، ثم اقتراح بالتسوية الودية قبل

$$
\text { البيع الجبري، وذلك على النحو الآتي: }
$$

أولاً: التسوية الودية المتعلقة بتوزيع حصيلة التنفيذ

في نظم المشرع المصري في قانون المرافعـات التسوية الوديـة في مرحلة توزيع حصيلة التنفيذ، حيث يقوم قلم الكتاب المحكمة التي أودعت بها حصيلة التنفيذ عـرض الأمسر على مـدير إدارة التنفيـذ المخـتص لاتخـاذ إجـراءات التوزيـع، وهـــه 
الإجراءات تـتم على مـرحلتين؛ إحـدها: إعداد القائمسة المؤقتـة. والأخرى: القائمسة النهائية. والقائمة المؤقتة عبارة عن مشروع للتوزيع يقوم مدير إدارة التنفيذ بإعداده

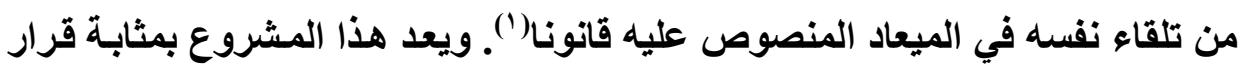

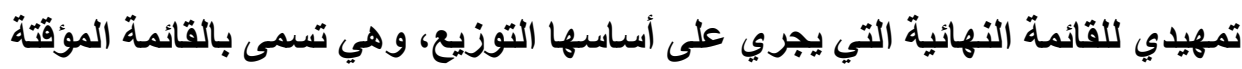

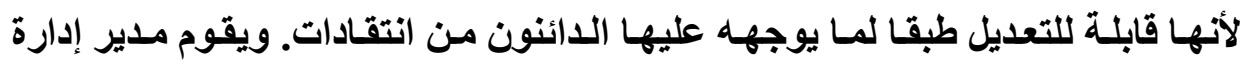

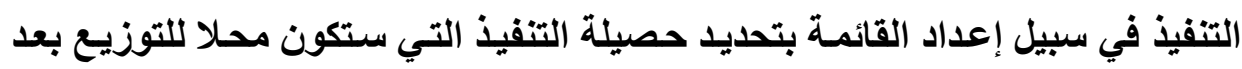
استنزال النفقات التي لها أولوية في الاستيفاء على أي حق ولو كان ممتازاً، ثم يتأكد

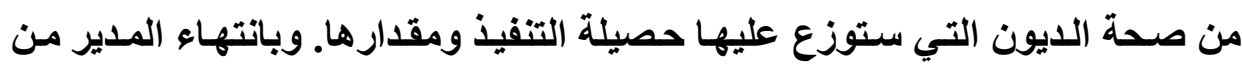

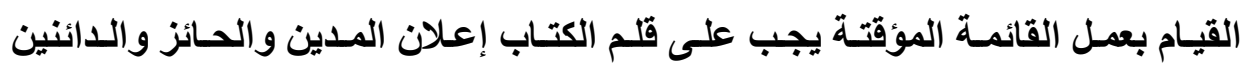

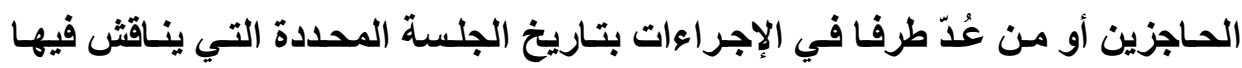

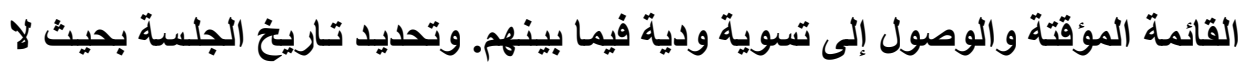

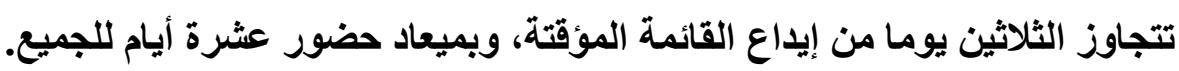
ويتم مناقثة القائمة المؤقتة في جلسة التسوية الودية القضائية. والهدف من

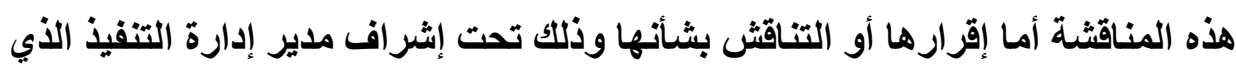

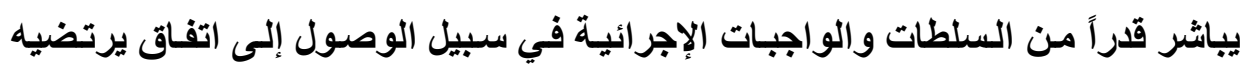

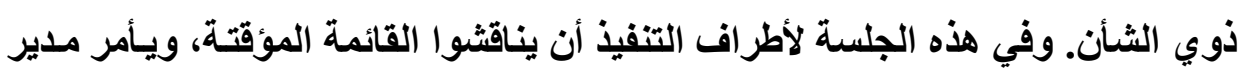

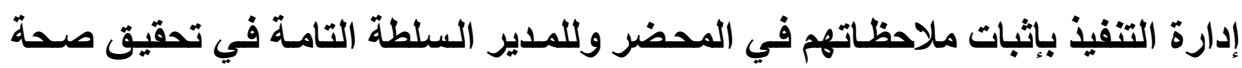
الإعلانات والتوكيلات وقبول التذخل من كل ذوي شأن لم يعلن أو يصح إعلانه.

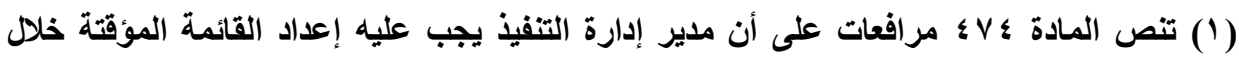

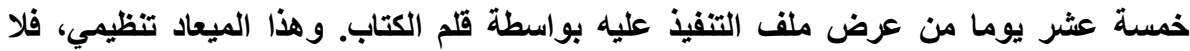

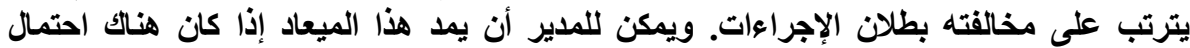

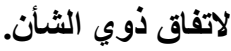


ويتمتـع المـدير بعديـ مـن السلطات أثنـاء قيامسه بمباشـرة إجراعات التسوية

الودية؛ فله أن يقبل تلخل من أغفل إعلانه، فإذا حضر ذوو الشأن وانتهوا إلى الاتفـق

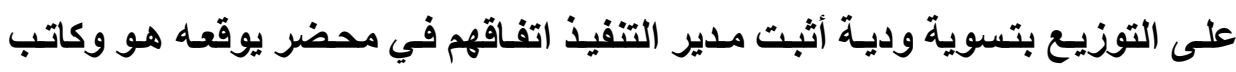
الجلسة والحاضرون، ويكون لهذا المحضر قوة السند التنفيذي. وهذه التسوية تعد تسويه ودية أمام القضاء، وهذه القائمة التي أعدها مدير إدارة التنفيذ لا تقيد أطراف التتفيذ، فقد أعدها المدير على سبيل الاسترشاد لا على سبيل الإلزام، فيمكن للأطراف

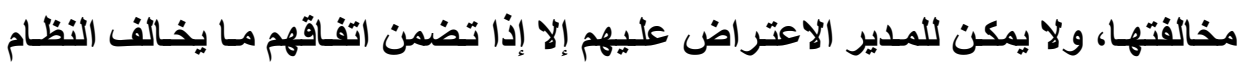
العام. ومن السلطات التي يتمتع بها أيضا تعيين خبيز، ولـه فضلا عن ذلكك اتخـاذ أي تدابير تقتضيه حسن سير الإجراءات. وتخلف المدين أو الحسائز أو الكفيل العيني أو بعض الدائنين عن حضور هذه الجلسة لا يمنـع من إجراء تلكك التسوية طالمـا اعتمد

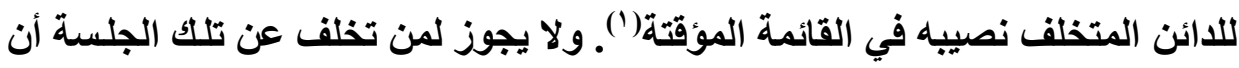
يطعن في التسوية الودية التي أثبتها المدير بناء على اتفاق الخصوم الحاضرين (VV) مرافعات). وقد نصت المادة ^ \؛ مر افعات على أنه في حالة تخلفهم جميعا عن حضور الجلسة المحددة للتسوية الودية عدت القائمة المؤقتة قائمة نهائية في حقهم جميعا.

وإذا لـم تتيسر التسوية الوديـة لاعتراض بعض ذوي الشأن يأمر مدير إدارة

التنفيذ بإثبات مناقضاتهم في المحضر، ويحيل الاعتر اض إلى قاضي التفيذ على الفور؛ ولا يجوز إبداء مناقضات جديدة بعد هذه الجلسة.

ويلاحظ أنـه متى تمـت التسوية الوديـة على النحو سـالف الذكر، فعلى إدارة التنفيذ أن يعد خلال الخمسة أيام التالية قائمة التوزيع النهائية بما يستحقه كل دائن من أصل حقه وفو ائده ومصروفات ويودعها قلم كتاب محكمة التنفيذ. 
وبعد الحكم بالقائمسة النهائيـة تـأمر إدارة التنفيذ بتسليم أوامـر الصرف على خزانة المحكمة وشطب القيود سواء تعلقت بليون أدرجت في قائمسة التوزيع أو بديون لم ياركها التوزيع بعد؛ وذلك لأن حكم إيقاع البيع يطهر العقار منها، ولأن شطبها لا يتم إلا بهذا الأمر الذي يقلم للجهة المختصة بذلك.

وفي حالة وجود معارضات للتسوية الودية التي قامت بها إدارة التفيذ يأمر مدير إدارة التفيذ بالإحالة إلى قاضي التفيذ الذي ينظر فيها على الفور، ولا يجوز تقديم مناقضات جديدة بعد هذه الجلسة. والحكم في المنقاضة لا يقبل الطعن بالاستئناف إلا إذا كان المبلغ المتنازع فيه يزيد على أربعين ألف جنية، ويكون ميعاد الاستئناف عشرة أيام.

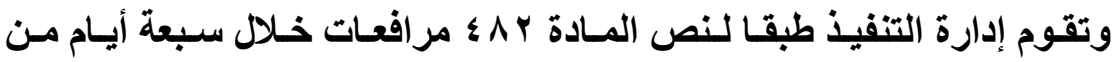
الفصل في المناقضات إذا كـان حكمه نهائيـا أو من انقضاء ميعـاد استئنافها، بإيداع

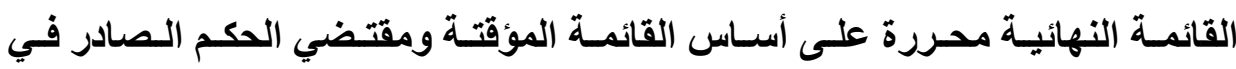

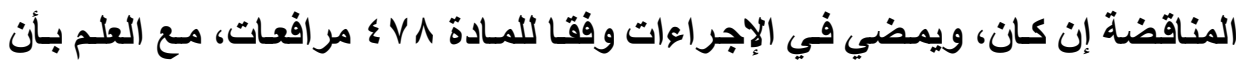

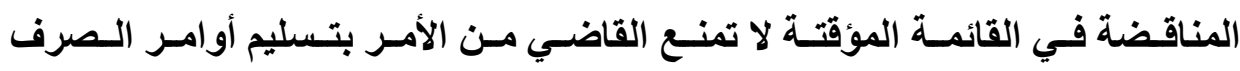
لمستحقيها من الدائنين المتقدمين في الدرجة على الدائنين المتنازع في ديونهم. ثانياً: اقتراح بتنظيم تسوية ودية قبل القيام بالحجز أخذت عديد من التشريعات الحديثة بنظام التسوية الوديـة السابقة على البيع؛ وذلك لما يحققه من مراعاة لمصلحة المدين، والوصول إلى التتفيذ الإرادي للسند، حيث يعرض المدين على القاضي تسوية على حسب قدراته المالية، ومع أخذ رأي الائن في 
ولم ينص المشرع المصري على تنظيم التسوية الودية السابقة على البيع رغم

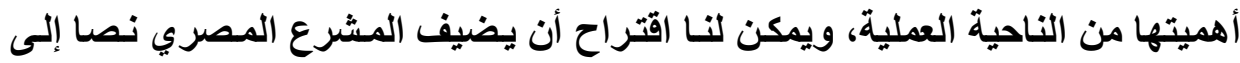
المادة 281 من قانون المرافعات، يتضمن الآتي:

أولاً: لا يجوز إجراء التنفيذ إلا بعد مضي عشرة أيام على الأقل من إعلان السند

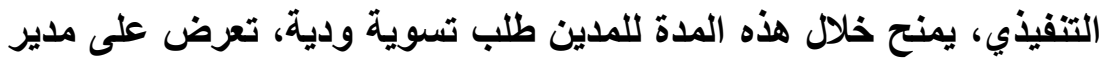

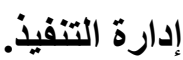

ثانياً: للمدين أن يطلب أثناء الميعاد تأجيل الوفاء فترة معينة، أو يطلب تقسيط الدين، مع إلزامه بدفع قيمة 25\% من قيمة الدين كدفعه أولى، ويمكن تقسيط الباقي على ألا تتجاوز مدة التقسيط عاما واحدا، وذلك بعد أخذ رأي الدائن.

ثُاثثا: للائن الاعتراض على التسوية التي يقدمها المدين؛ بإثبات قدرة المدين على الوفاء بالدين كله دفعه واحده، ويقدر مدير إدارة التنفيذ مدى صحة الأدلة

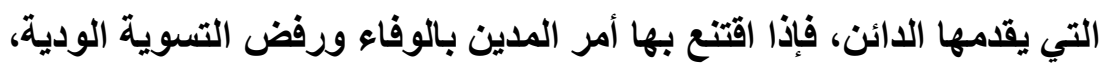
وإذا أقنعه المدين بعدم قدرته، أصدر قرارا بالتسوية الودية. ويعد هذا القرار سندا تنفيذيا. رابعا: إذا لم يوف المدين بما التزم به بمقتضى التسوية الودية، تلفى التسوية ويلزم بدفع غرامه قدرها ه ب\% من قيمة الدين. خامسا: إذا لم يقدم المدين خلال الميعاد طلبا بالتسوية الودية، يجب على مدير إدارة التنفيذ البدء في إجراءات الحجز على المدين. 


\section{المبحث الثالث \\ التطورات الحديثة في الغراهة التهديدية}

هجر المشرع الفرنسي الفلسفة التي كانت تنحساز للمدين باعتباره الطرف

الضعيف، وارتكز قانون التنفيذ الفرنسي على فلسفة قوامها تحقيق فاعلية للإجراءات

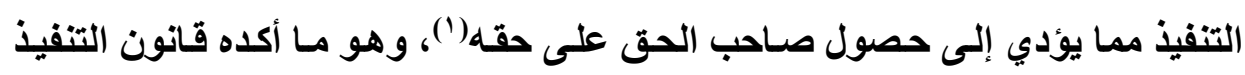

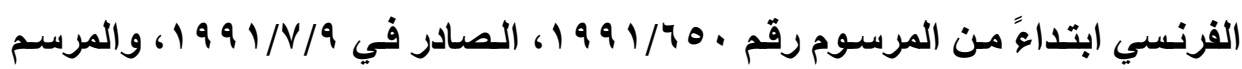

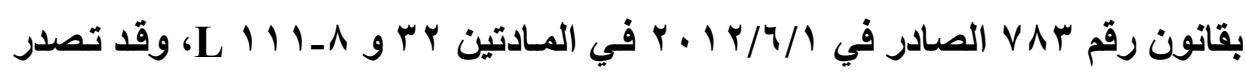

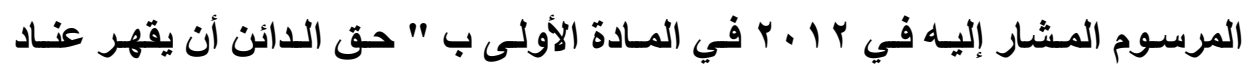

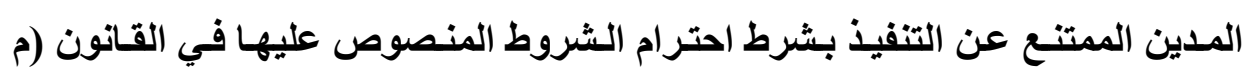

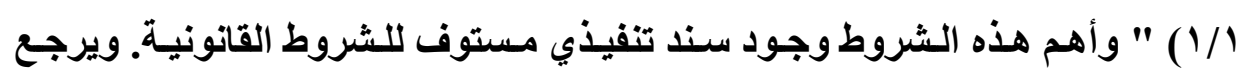

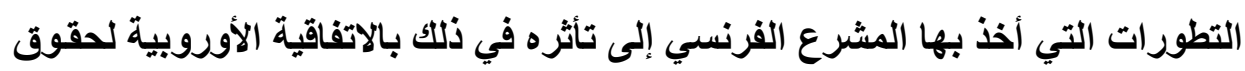

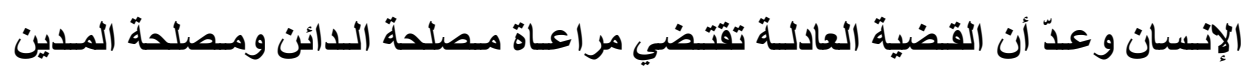

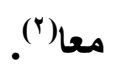

ومسن أهم الوسـائل التي حظيت بتطور المشرع الفرنسي الغرامـة التهايديـة كوسيلة لإجبار المدين على الوفاء بالتزاماته، ومنع المدين من عرقلة إجراءوات التنفيذ.

(1) Xavier DAVERAT, Saisie : protection du débiteur, op. cit., n. 2.

(2) Gerard Couchez et Daniel lebeau, voies dexecution, 19 éd. 2012, no 13.P10. 
ويلاحظ على نظام الغرامـة التهديدية أنها نظريـة خلقها القضاء لا المشرع في بلايـة

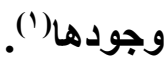

ولا نهدف من هذه الدارسة البحث الشامل للغرامسة التهديدية، لأن محلها هذه

الاراسة المؤلفات العامة والخاصة في القانون المدني وقانون المرافعات، وإنما الغرض هده ينصب على الجديد في نظام الغرامة التهديدية كوسيلة لإجبار المدين على التنفيذ. وسنشير في هذا المبحث إلى مفهوم الغرامـة التهديليـة، وذلك في المطلب

الأول، ثم نعالج، المستحدث في الغرامسة التهديدية في النظامين الفرنسي والمصري، وذلك في المطلب الثاني.

\section{الإطبا الأول \\ هفهوم الغرامة التهديدية}

ظهرت الغزامة التهديدية في بدايتها كنظرية فقهية وليست تشريعيه، وقصد

منهـا اجبـار المـدين على تنفيذ التزامسه عينيـا خـلال مـدة معينـة؛ حيـ عرف الغرامـة التهديديـة بأنها إلزام المحكوم عليه بـفع مبلـغ مـن المسال عن كل فترة زمنية (يوم، أسبوع، شهر) يتأخر فيها عن تنفيذ الأحكام الصادرة ضده، وذلك إلى أن يتم التنفيذ فعلا أو إلى أن يثبت امتناعه النهائي عن التنفيذ(؟).

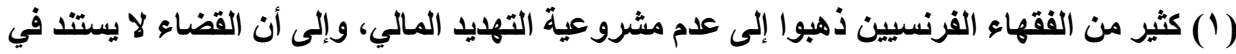

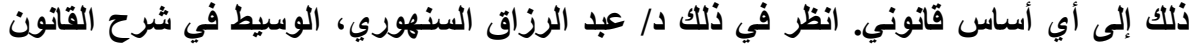

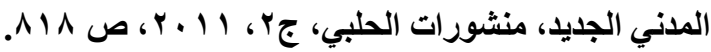

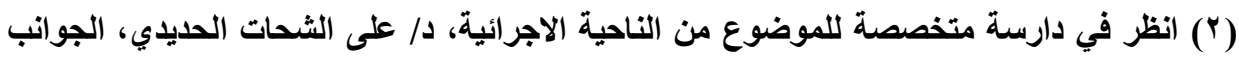

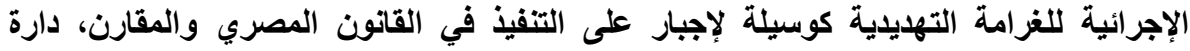

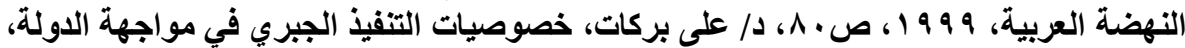

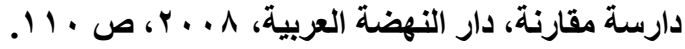


ويلاحظ أن للغرامـة التهايديـة مفهومين؛ الأول: تقليـدي، باعتبارهـا وسـيلة

لإجبار على تنفيذ التزام عيني. والآخر: حليث، أخذت به بعض التشريعات، ويتمثل في

مد نطاق استخدام الغرامة التهايدية ليشمل كافة السندات التنفيذية. وسنشير إلى المفهوم التقليدي للغرامة التهايدية، وذلك في الفرع الأول، ثم

نعالج المفهوم الحديث للغرامة التهايدية، وذلك في الفرع الثاني:

\section{الفرع الأول}

\section{المفهوم التقليدي للغراهة التهديدية}

ظهرت فكرة الغرامة التهايدية كوسيلة لإلزام المدين بتنفيذ التزام عينى خلال

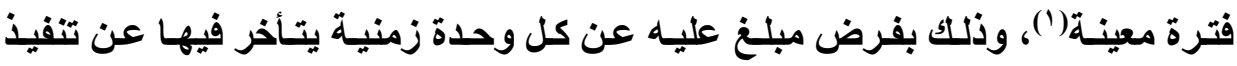
التزامه الممتع أصلا عن تنفيذه، ويزيد هذا المبلغ كلما زاد التأخير. وقد ابتدع القضاء الفرنسي هذه الوسيلة لكنها لم تقنن في فرنسا إلا حديثا جداً.

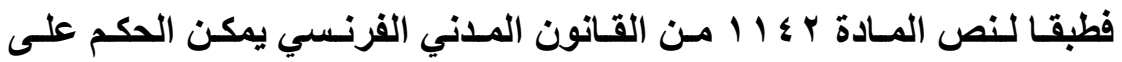
المدين بالغرامـة التهايدية عند امتناعه عن تنفيذ عيني لالتزامه،، وقد ذهب القضاء الفرنسي الحديث إلى أن لأحد أطراف الالتزام التعاقدي إجبار الطرف الآخر على تنفيذ

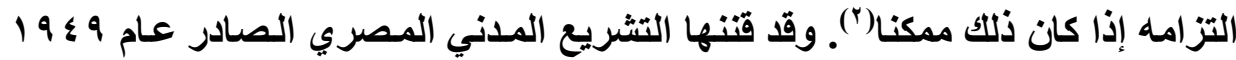

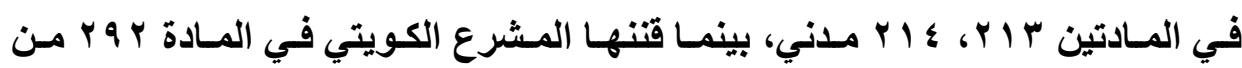
القانون العدني، وقنن ذلك في المادة اهب من قانون الموجبات والعقود اللبناني المسادة

(1) د/ عبد الرزاق السنهوري، الوسيط في شرح القانون المدني الجديد، المرجع السابق، ص ؛ . ^.

(2) Cass. Civ. 1re, 16 janv. 2007, Bull. civ. I, no 19. 
ويشترط للحكم بالغرامـة التهايديـة أن يكون الالتزام المطلوب تنفيذه عينـا

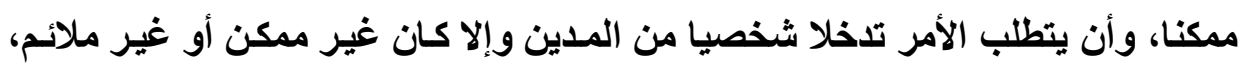

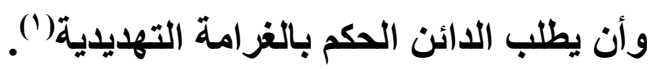
و اتسع نطاق تطبيق الغرامـة التهايديـة فأصبحت تستخدم في حالـة الالتزام

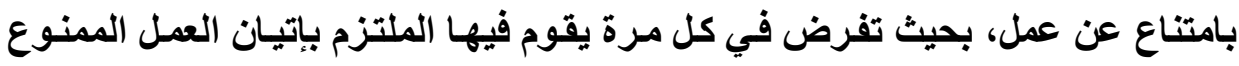

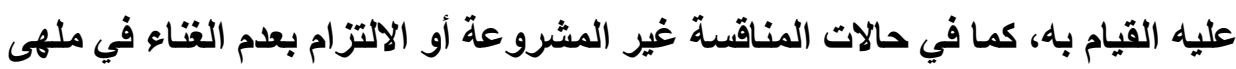
منافس. ويتسم الحكم الصادر بالغرامـة التهايدية بأنه حكم وقتي وبأتها حكم تهايدي وليس حكم تعويض(") ونظرا لعدم معرفة عدد المرات التي يخالف فيها المدين فبان الغرامة تقتضي أن يتعين مقارها liquidation عند التنفيذ أو إذا طالت مدة الإصرار على مخالفة المدين لالتز امه("). و إذا كاتت الغرامة التهايدية قد بدأت في أول ظهورهـا في القضاء كنوع من التعويض يستحقه الدائن لعدم استيفائه لحقه أو للتأخر في ذلك، ثم بدأ ينظر إليها على الثى أنها جزاء على المدين المماطل فيعتد عند تصفية مقارها بالعنت الذي بدا من المدين. وفي مرحلة أخيرة من التطور أصبحت الغرامة مستقلة عن التعويضات وينظر عند تصفيتها إلى الضرر الذي أصاب الايائن، ومقار العنت الذي بدا من المدين. وقد استمرت النظرة إلى الغرامة التهايدية بأنها ليست وسيلة تنفيذ السندات التنفيذية، لأن الالتجاء إليها لا يؤدي إلى انقضاء الالتزام الأصلي، واقتصر دورها لها على الته

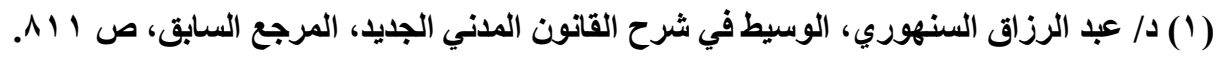

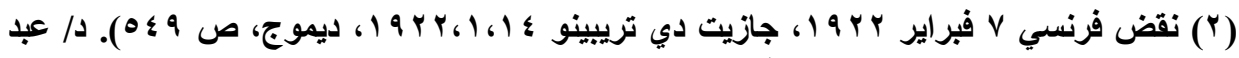

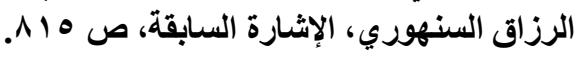

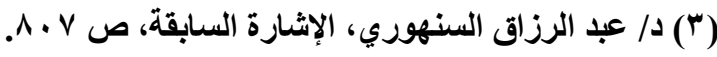


كونها وسيلة ضغط لتنفيذ بعض أنواع الالتزامات. ولذلك لم يكن الحكم الصادر بها غير قابل للتفيذ الجبري لأن الحق غير محقق الوجود لاحتمـال إعفاء القاضـي المدين من مبلغ الغرامة نهائيا، كما أن الحق غير معين المقدار قبل إجراء التصفية، لأن القاضي قد يزيد مقدار الغرامـة أو ينقصه، لذلك أوردت المـكرة الإيضاحية للقانون المـني أن حكم الغرامة التهديدية غير واجب التنفيذ لأنه حكم وقتي.

\section{الفزرع الثاني}

\section{الفهوم العديث للاغراهة التهديدية}

وجدت الغرامة التهديدية طبقا للتصور التقليدي في القانون المدني على أنها ذات طبيعة تهذيدية وليست تعويضا أو عقوبـة خاصـة، ولكن هذا التصور التقليدي تم العدول عنـهـ وتعد هولنـا أول دولـة تصدر قانونـا ينظم فكرة الغرامـة التهديديـة عـام

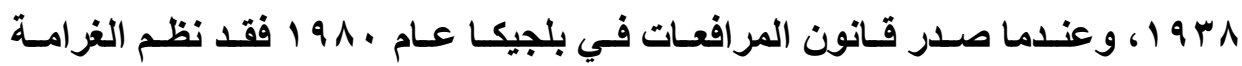
التهايديـة في صلب قـانون المرافعـات ولليس في القـانون المـانـي (')، باعتبار هـا أداة للإجبار على تنفيذ الأحكام القضائية بصرف النظر عن نوع الالتزام. وأساس الفكرة في القانون البلجيكي أن بلاد القارة الأوروبية لا تعرف جريمة احتقار العدالة المعروفة في لاجي إنجلترا، لذلك لابد أن تستخدم الغرامـة التهديدية كوسيلة للإجبار على تنفيذ الأحكام، ومن ثم ترد في صلب القانون الإجرائسي (المرافعات) مـع وجودهـا في القانون المدني. ويستهذف وجود الغرامة التهديدية في صلب القانون الإجرائسي التأكيد على دورهـا في احترام تنفيذ الأحكام والأوامر الصادرة من القضاء مما يتحقى معه مبدأ سيادة القانون، وهو أساس الدولة الحديثة. 
وقد أجاز القانون البلجيكي لكل القضاة سواء في القضاء المدني أو الإداري أو

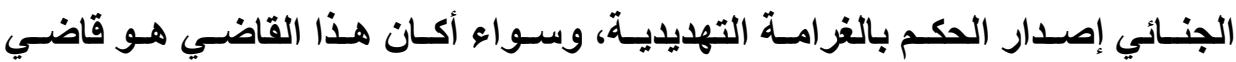
الموضوع أو قاضي الأمور المستعجلة. وأجاز القانون البلجيكي الحكم على جهة الإدارة بغرامة تهايدية إذا امتتعت عن إعادة موظف مفصول لعمله أو برد مبالغ تم خصمها،

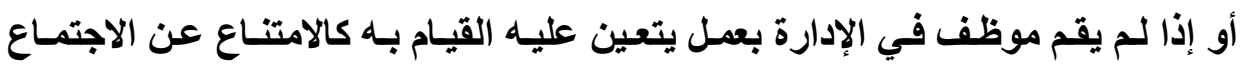

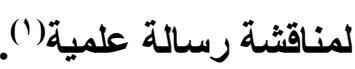

وقد أجاز القانون البلجيكي تصفية مقار الغرامة بمعرفة أي قاض، فلا يشترط أن يكون القاضسي الذي حكم بالغرامـة أو أن يكون القاضسي المختص بالتنفيذ. ويكون

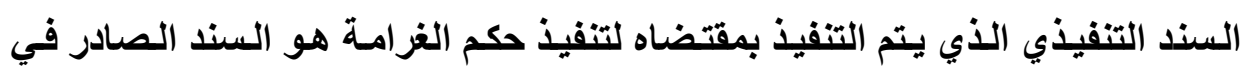
موضوع والذي حسم النزاع الأصلي، لذلك لا ينفذ حمم الغرامـة إلا إذا كان هذا السند واجب التنفيذ، وبعد إعلان المنقَّ ضده حسب القواعد العامة في التنقيذ. ومن ثم فالاتجاه الحديث ينظم الغرامة التهايدية ضمن أحكام قانون المرافعات، وليس القانون المدني، كما أنه جطلها وسيله للإجبار على تتفيذ السندات التنفيذية، ولم يقصرها على تنفيذ الالتزامات المدنية التي تتطلب تلدخلا شخصيا من المدين، فلم تعد الغرامة وسيلة من وسائل الإجبار على التنفيذ العيني الجبري فقط، بل أصبح وسيلة لتنفيذ كافة السندات التنفيذية سواء تعلق بتنفيذ عيني أو بطريق الحجز.

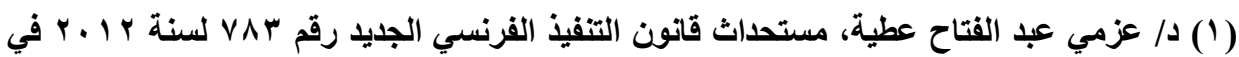

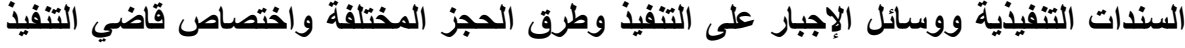

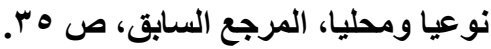




\section{الاملب الثاني \\ المستحدث في الغرامة التهديدية \\ في النظاهين الفرنسي والهري}

مـن أجل إجبـار المـدين على التفيـذ الاختيـاري اتجـه القضاء الفرنسبي منـــ منتصف القرن التاسع عثر - ومن بعده القضاء المصري- إلى استحداث وسيلة يمكن عن طريقها إجبار المدين على التنفيذ الاختياري؛ وذلك عن طريق إلزامه بدفع مبلغ من النقود كغرامة عن كل فترة زمنية يتراخى فيها عن القيام بهذا التنفيذ، إلى أن يتم التتفيذ بالفعل أو إلى أن يثبت امتناعه النهائي عن التفيذ، وبعدها يقوم القاضسي الذي حكم بالغرامـة بتصفية مبلـغ هذه الغرامـة حسبما يسفر عـهـ موقف المـدين للمتـع. وظل القضاء المصري والفرنسي يطبقان هذه الوسيلة دون سند من النصوص كحل عملي لمواجهة تعنت المدين. ونظرا لفاعلية هذه الوسيلة فقد أخذت بها التشريعات المختلفة؛

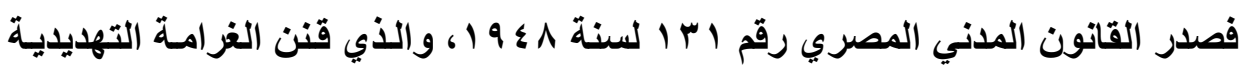

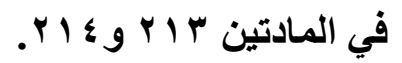

وقد صدر في فرنسا أول تشريع يجيز استخدام الغرامة التهديدية للإجبار على التنفيذ عام 9 \ 19 في مجال طرد المستأجرين وشاغلي العين بـلا سند، ولـم يتم تقنين

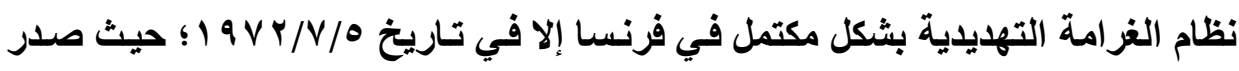

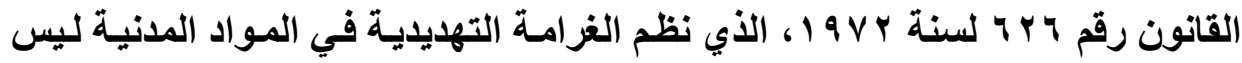
فقط لضمان تنفيذ الالتزامـات، كما هو الشأن بالنسبة للنظام المصري، ولكن أيضا لضمان تنفيذ الأحكام والقرارات الصادرة من القضاء، فنص في المـادة الخامسة منـه على أنه يجوز للمحاكم، ولو من تلقاء نفسها، أن تأمر بالغزامة التهديدية لضمان تنفيذ أحكامها. وقد صدر القانون رقم • ه 7 لسنة ا99 19، وتناول المشرع الفرنسي موضوع 
الغرامة التهديدية بصورة أكثر شمولا في المواد سr إلى V فأجساز لأي قاض ولكو من

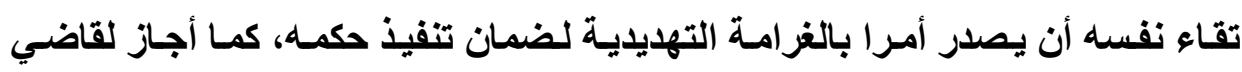

التنفيذ أن يأمر بالغرامة لتنفيذ الأحكام الصادرة منه أو من غيره من القضاءل' ('). وسنشير إلى التطورات الحديثة في الغرامـة التهديديـة في القانون الفرنسي، وذلك في الفرع الأول، ثم موقف المشرع المصري من الغرامـة التهايدية، وذلك في الفرع الثاني.

\section{الفرع الأول \\ التطورات الحديثة في القانون الفرنسي في الغرامة التهديدية}

في الفترة الأخيرة أحدثت بعض التشريعات مثل القانون الفرنسي انقلابـا في

الأوساط القضائية والقانونية الفرنسية؛ حيث كاتت هنـاك ثورة على الأفكار التقليدية

التي ظلت قائمة لفترة زمنية طويلة في القانون العـام. فقد أصبحت الغرامـة التهديديـة وسيلة لتنفيذ السندات التنفيذيـة،كما سـمح للقضاء الإداري الفرنسي بـالحكم بالغرامـة التهديدية على جهة الإدارة والذي كان ممنوعا") وسنشير إلى ذلك في النقاط الآتية: أولا: الغرامة القطعية ضمانة لتنفيذ السندات أثثير خلاف في الفقه حول استقلال الغرامـة التهديدية عن التعويضات أو عدم

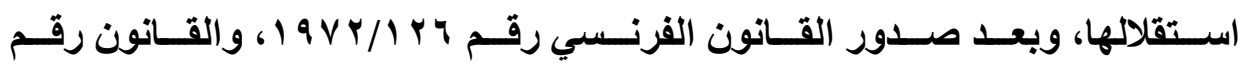

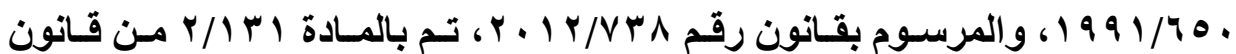

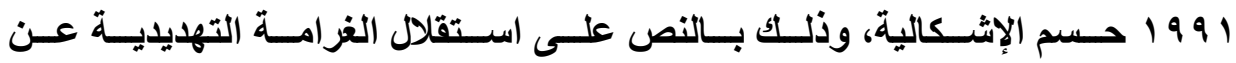

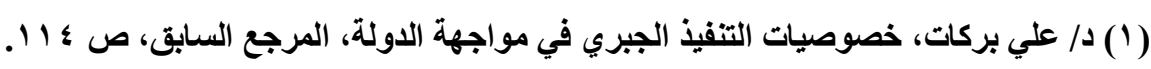

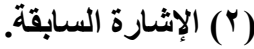


التعويضات(') إعطاء كل القضاة بمـا فيهم قاضسي الأمور المستعجلة الحكم بالغرامـة التهديدية. وله يحكم بها دون طلب، والتمييز بين الغرامـة الوقتيـة والغرامـة التهديدية القطعية التي أنثئت لمعالجة عيوب الغرامة الوقتية، ولم يعد جائزا الرجوع عن الغرامة التهديدية القطعية عند تصفيتها إلا للقوة القاهرة أو الحسادث المفـاجيء. ومن ثم فقد حسم قانون التنفيذ الفرنسي الجديـ بعض الخلافـات حول الغرامـة التهديديـة القطعيـة وكانت بعض أحكام القضاء قد رفضتها لكونها عقوبة مدنية ولكنها أصبحت أمرا قائمسا بصدور قانون التنفيذ الجديل.

وقد نص قانون التنفيذ الفرنسي الجديد في المـادة بr على حق المحسكم في فرض غرامة تهايدية لضمان تنفيذ أحكامها وأوامرها. وبذلك أصبحت الغرامـة الوقتية وسيلة للإجبار على تنفيذ الالتزام الشخصي، وأصبحت الغرامـة القطعية وسيلة لتنفيذ الأحكام الصادرة من كل أنواع الالتزامات ولو بدفع مبلغ من النقود؛ فقد نص المشرع الفرنسي على أن لقاضي التفيذ أن يصدر أحكاما بالغرامة التهديدية لضمان تنفيذ الحكم

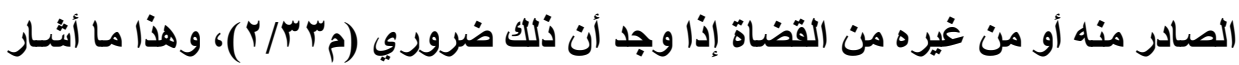

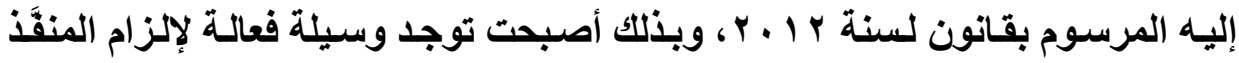

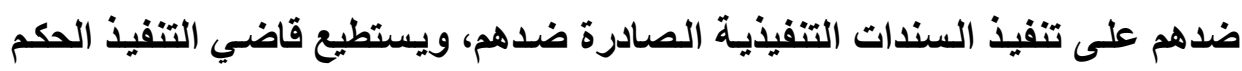
بالغزامة ولم يكن الحكم الأصلي مشمولا بها. وأوجب قانون التنفيذ على القاضسي عندما يحكم بها أن يحدد نوعها، فبإذا لم يحدد تكون وقتية. وألزم القانون على القاضـي عند الحكم بالغرامـة القطعيـة أن يحدد مدتها حتى لا يلتزم المدين بدفع مبلِغ كبير للـائن بخلاف التعويضات، مــا يؤدي إلى الإثراء بلا سبب على حساب المدين، كما أصبح فرض الغرامـة القطعية أمرا احتياطيا.

(1) Cass. Civ. 17 jan. 1976, D. 1976, p. 58. 
ومن أبرز التعديلات التي جاءت بقانون التنفيذ أنه أسند إلى قاضي التنفيذ تصفية مقدار

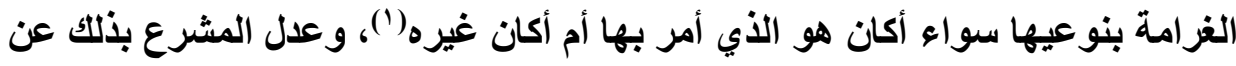

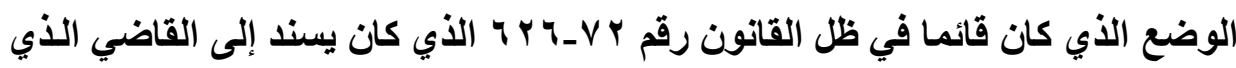
أصدر الغرامة تحديد مقدارها دون غيره، ويختص قاضي التنفيذ بذلك دون غيره إلا إذا

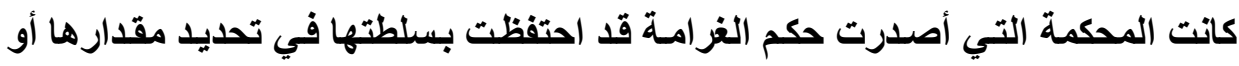

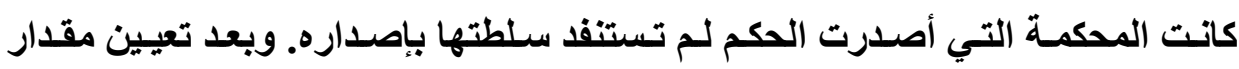

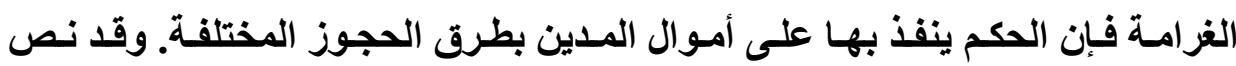

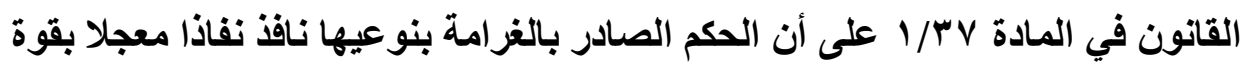

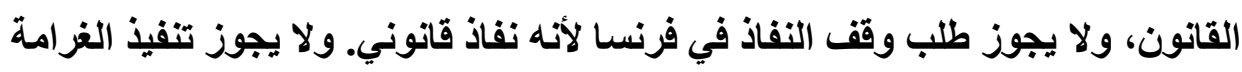
التهايدية دون تصفيتها من قبل قاضي التنفيذ. وبالنسبة لموقف الفقه من هذه التطورات الحديثة(")، فقد انقسم حول جواز

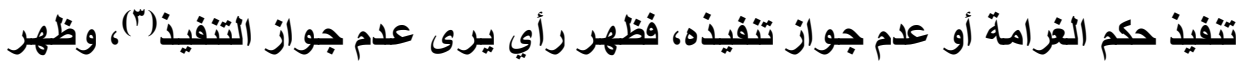

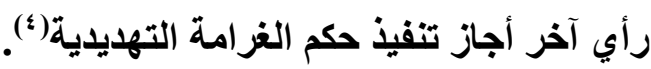

(1) Cass. Civ. 20 nouv. 1991, D. 1991, p. 163.

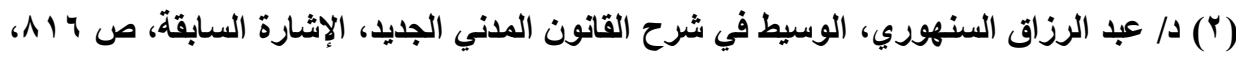

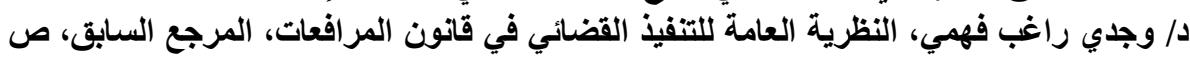

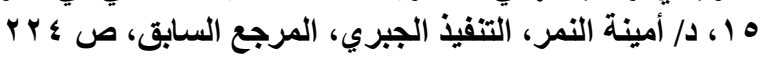

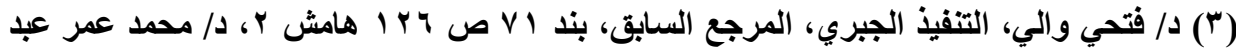

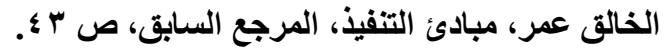

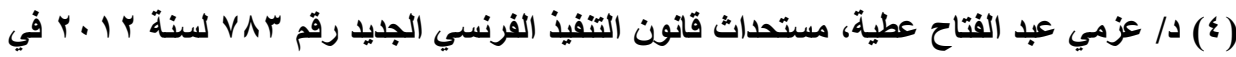

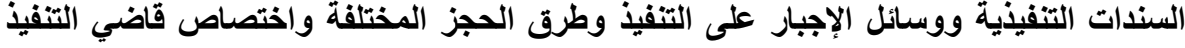

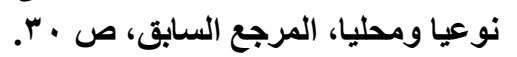


ونرى أن الغزامة القطيعة تعد عقوبة على عدم التنفيذ والمماطلة، ولم تعد ذات

طبيعة تهايديـة، ويرجع ذلك إلى أن العقوبـة يجب تنفيذها كمـا نطق بها، أمسا الغرامـة التهديدية فهي شئ وقتي، ولا تنفذ إلا عندما تتحول إلى تعويض نهائي، وهي في هذا التحول قد تنتقض أو تلغي، فالذي ينفذ في الواقع ليس الغرامـة التهايدية الوقتية بـل التعويض النهائي (') ثانيا: الحكم بالغزامة التهديدية على جهة الإدارة ثار خلاف في فرنسا حول جواز إصدار المحاكم الإدارية لأحكام مقترنة الغرامة التهدياية، إلى أن أجازت محكمة النقض الفرنسية الحكم على الإدارة بغرامـة تهديدية،

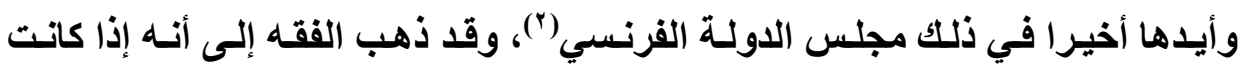
القوانين لم تعـالج مدى أحقيـة المحاكم في الحكم بالغرامـة التهديديـة ضـد الدولـة، فـأن التنظيم التشريعي في مجموعة يؤكد حق القضاء في الحكم بالغزامـة التهديديـة ضد الاولة، كما أن المشرع لم يمنع هذا الحكم(").

فقد كان الوضع في فرنسا قبل التعديلات التشريعية الآخيرة أن لاولة تتمتع بالحصانة، ومن ثم لا يجوز استخدام الوسـائل التهديدية لإجبار الدولة على التنفيذ(؛). وقد استمر مجلس الدولـة الفرنسي على هذا المبدأ، ولكن حدث تطور في الاتجـاه القضائي نحو فكرة حق المحاكم العادية في نظر دعاوى التعويض عن الأعمال المادية

(1) د/ عبد الرزاق السنهوري، الوسيط في شرح القانون المدني الجديد، الإثارة السابقة، ص 14 (14.

(2) R. Perrot et Ph. Théry, Procédures civiles d'exécution, op. cit., $\mathbf{n}^{\circ} 140$.

(3) S. GUINCHARD et MOUSSA, Droit et pratique des voies d'exécution, op. cit., p. 282.

(4) Glasson, Tissier, Morel, traite theorique et pratique d organisation judiciaire de competence et procedure civile, op. cit., p. 15. 
التي تقوم بها جهات الإدارة أو التي تتتج عن تصرفاتها، واستقر قضاء محكمة التنـازع الفرنسية على أن المحاكم العادية تملكك الحكم بالغرامـة التهديدية ضـ جهة الإدارة إذا ارتكبت عملا ماديا أو عملا منبت الصلة بالسلطات الإداريـة، ويمثُل اعتداء على حق يحميه القانون(') وقد اتبعت محكمة النقض الفرنسية هذا الاتجاه حيث استقر قضاؤها على منح المحاكم العادية سلطة الحكم بالغرامـة التهديديـة ضد الجهات الحكوميـة(')، متى تأخرت عن تنفيذ الأحكام الصادرة ضدها، ولكن اقتصر الأمر على حالات الاعتداء

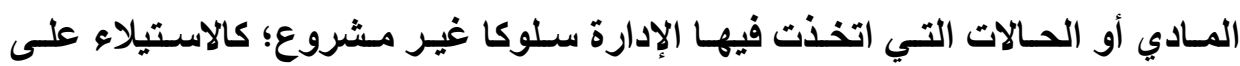
ممتلكات الأفراد. وذهبت محكمة النقض إلى أن الغرامة التهديدية مجرد إجراء تهديدي

مؤقت ولا يعد حكما بالتعويض، ومن ثث يحق لقاضي الأمور المستعجلة الحكم به("). وقد سمح المشرع الفرنسي لمجلس الدولة بمقتضى القانون رقم 9 به لسنة ـ 19 1 الحكم بالغرامة التهديدية على الأثخاص الاعتبارية العامة؛ وذلك بقصد ضمان

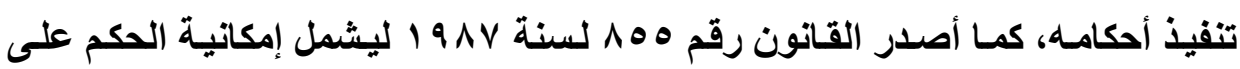
الأثـخاص الاعتباريـة الخاصـة المكلفة بـإدارة المرافق العامـة، ثم أصدر القـانون رقم ه r ا لسنة ه9 9 1، ليحق لكافة المحاكم الإدارية الحكم بالغرامة التهديدية.

(1) Trib. Conf. 29 mai 1967, JCP, 1967, II, 15178, trib conf., 2 dec. 1968, JCP, II, 15908.

(2) Cass. Soc. 5 juill. 1984, Gaz. Pal. 1984, pan. p. 324, Cass. Civ., 9 juin 1970, D. 1970, p. 202.

(3) Cass. Com, 17 avr. 1956. JCP, 1956, II, 9330. 


\section{الفرع الثاني \\ هموقف المشرع المصري هن الغرامة التهديدية}

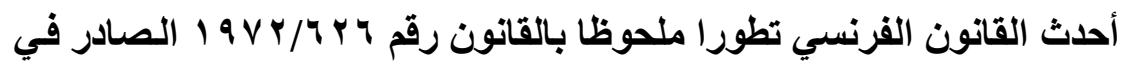

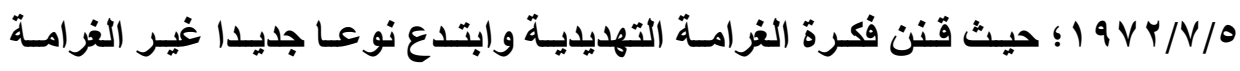

التهديدية؛ وهي الغرامة التهديدية القطعية، ثم صدر قانون التتفيذ الفرنسي رقم .

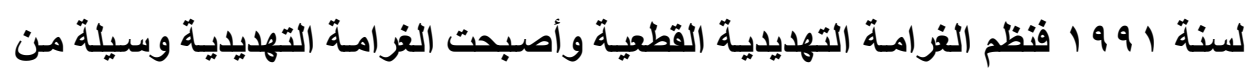
وسائل التنفيذ الجبري، ومنح قاضي التنفيذ سلطة الأمر بها لاحترام القرارات الصادرة منه، بل ولاحترام الأحكام والأوامر الصادرة من غيره من القضاة.

وإذا كـان المتفق عليه بين النظام المصري والفرنسي جواز الحكم بالغرامـة

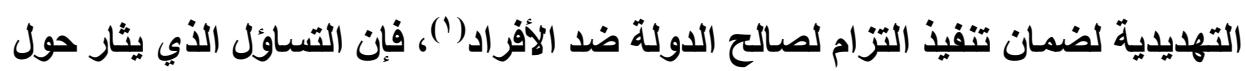

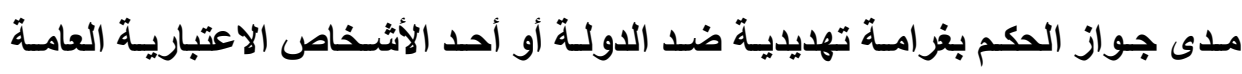
لإجبار ها على تنفيذ الأحكام المدنية الصادرة ضدها، تكمن إجباته في أن القانون المدني المصري لم ينص على ذلك، حيث قصر الحكم بالغرامـة التهايدية على المنازعات بين

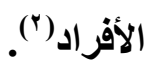

والوضع في مصر يختلف عمـا جرى في فرنسا؛ حيث إن القضاء المصري

قصر سـلطة القاضسي في الحكم بالغزامـة التهديليـة على المنـازعـات التي تثـار بـين الأفراد()، فلا يوجد في التطبيقات القضائية ما تدل على حق القضاء في الحكم بالغرامة

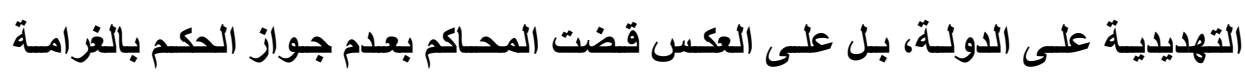

(1) د/ على بركات، خصوصيات التنفيذ الجبري في مواجهة الدولة، المرجع السابق، ص 110

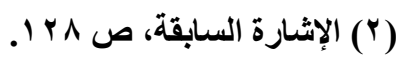

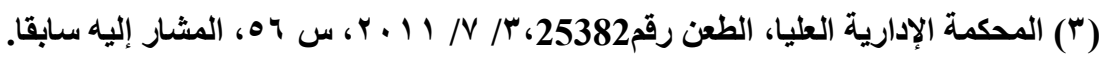


التهديدية على الدولـة(1)، كمـا ذهبت محساكم القضاء الإداري إلى أنها لا تملك إكراه الإدارة عن طريق الغرامة التهديدية(؟)

والمتتبع لموقف المشرعين المصري والفرنسي يلاحظ أن كـلا منهمـا اتخــ وجهة مخالفة تماما للآخر، حيث عدّ المشرع المصري امتــاع الموظف عن تنفيذ حكم قضائي أو تعطيل جريمـة يعاقب عليهـا قانونـا بـصفة شخصية، بينمـا أجـاز القـانون الفرنسي الحكم على الدولـة بكافـة مؤساستها بغرامـة تهديديـة لإجبار هـا على القيـام بالتنفيذ أو الإسراع في التنفيذ.

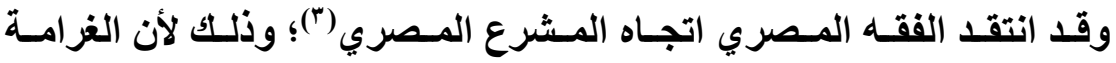
التهديليـة وسـيلة فعالـة لإجبـار الدولـة على تنفيـذ الأحكـام، خاصـة لـصعوبة إثبـات المسئولية الجنائية عن الامتــاع عن تنفيذ الأحكام، كما أن الواقع العلـي يؤكد عدم جدوي قواعد المسئولية الجنائية في إجبار الدولة على القيام بتنفيذ(؛)، ولا يعد ذلك تـخلا مـن جاتب قضاء الدولـة في عمل أجهزة الحكومـة، وإنمـا مجرد تـذكير الإدارة

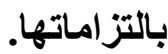

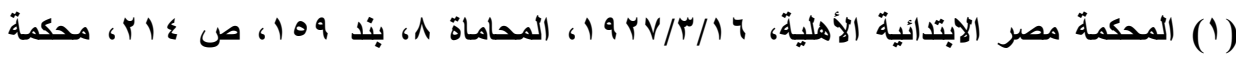

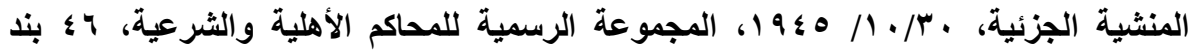

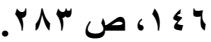

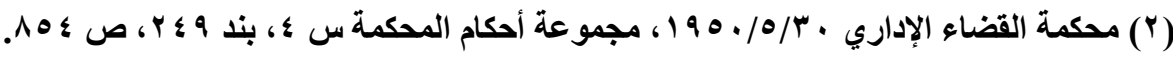

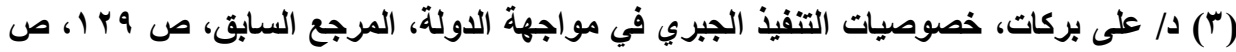

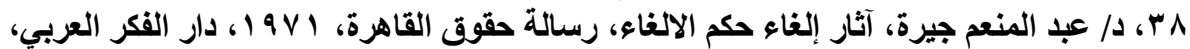

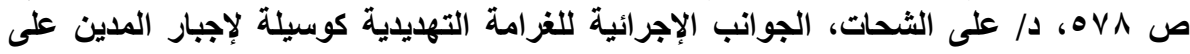

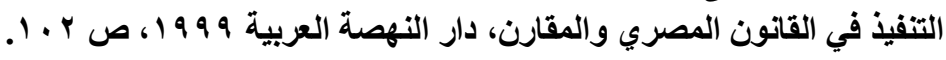

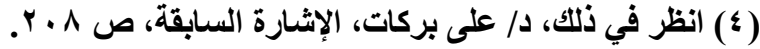


كمـا يلاحظ أن الغرامـة التهايديـة لاتز ال في مسصر محافظـة علـى سـماتها التقليدية، ومتعلقة بكونها وسيلة لاجبار الشخص على التزامسه الذي يتطلب تـخلا شخصيا منه، ولا يمنح قاضي التنفيذ سلطة في إصدارها لاجبار المدين على التنفيذ. ونقترح أن يتلخل المشرع المصري للنص على الآتي:

أولاً: إضافة نص صريح للقضاء بصفة عامة بالحكم على الأشخاص الاعتبارية بالغرامة التهايدية لإجبار الدولة على سرعة تنفيذ الأحكام القضائية

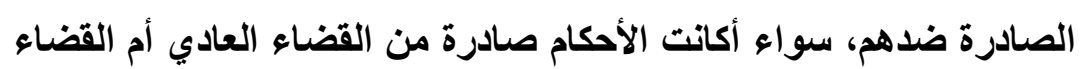
الإداري. ثانياً: أن ينص قانون المرافعات في المواد المتعلقة بالتففيذ على أن لقاضي التنفيذ

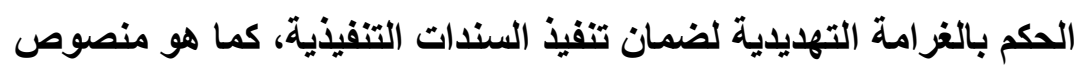
عليه في القانون الفرنسي؛ حيث يحقق ذلك فاعلية تنفيذ السندات التنفيذية. 


\section{خلاصة الفصل الثاني}

خلصنا في هذا الفصل إلى أن التطورات الحديثة في التنفيذ المعجل قد تعلقت بالتخلي عن الاستعجال للحكم بالتنفيذ المعجل القضائي، وأجاز المشرع الفرنسي طلب التنفيذ المعجل القضائي في مرحلة الاستثناف، ومنـع وقف التنفيذ المعجل في مرحلة الاستنئاف إلا لأسباب محدودة جدا، كمـا أن المشرع الفرنسي منـع الطعن في الحكم الصادر بالكفالة في التنفيذ المعجل. لابل مدلابل

ويلاحظظ أن المشرُع الفرنسي لـم يـص على حصر الأوامـر على عرائض،

واشترط التسبيب لإصدار الأمر على عريضة، ومنع التظلم من الأمر، وأجاز الطعن فيه بالاستئناف، ونص على النفاذ المعجل لأوامر الأداء. كما خلصنا في هذا الفصل إلى أن أغلب التشريعات العربية قد نظمت التسوية الودية قبل الحجز والبيع، ويلاحظ أن التشريعات أسندت التسوية الودية لإدارة التنفيذ، والبعض الأخر أسندها إلى جهة مختصة، وبعض التشريعات ألزمت المدين بدفع جزء

$$
\text { من الاين، وتسوية الجزء الباقي. }
$$

وقد لاحظنا اتجاه الفكر الإجرائي الحديث إلى النص في قانون الإجراءات على الغرامة التهديدية للإجبار على تنفيذ السندات، ويصدرها قاضي التنفيذ، فهي وسيلة وقائية لإلزام المدين بالوفاء دون اللجوء إلى الحجز والبيع. 


\section{نتائج البحث}

من خلال هذا البحث، يمكنتا الخروج بعديد من الملاحظات والنتائج على المستجدات الحديثة في السندات التنفيذية، كما يمكنا إبداء بعض التوصيات التي تعالج بعض القصور التثريعي في هذا الموضوع، وذلك على النحو الآتي: أولا: ملاحظات البحث

1- توصلنا إلى فكرة أن السند التفيذي في التثريعات الحديثة وليذة التطورات التاريخية التي نتجت من تفاعل النظم الجرمانية والرومانية، وهو عبارة عن محرر مكتوب، له شكل محدد طبقا للقانون، ومنصوص عليه على سبيل الحصر، والسند التنفيذي مفترض ضروري ولازم وكاف للتنفيذ الجبري، ويتكون من ركنين؛ موضوعي وشكلي.

ץ- لاحظنا أن الأنظمة القانونية اختلفت منهجيتها في تعداد السندات التنفيذية بين ثلاثة اتجاهات، اتجاه يضيق من السندات التفيذية، واتجاه متوسع في تحديد السندات، والاتجاه الثالث متوسط في تحديد السندات. r- خلصنا من هذا البحث إلى أن بعض التشريعات الحديثة عدت الأوراق التجارية؛ وهي الكمبيالة والسند لأمر والثيك، من السندات التنفيذية.

ع - توصلنا إلى أن بعض الأنظمة مثل القانون الفرنسي عدت الثيك فقط من السندات التنفيذية. هـ لاحظنا أن بعض الأنظمة القانونية قد نصت على عدّ الأوراق العادية سندا تنفيذيا متى تضمنت حقا معين المقدار وحال الأداء. 
צ- توصلنا إلى أن بعض الأنظمة سمحت للائن بسند عادي أو ورقة تجارية الخيار بين أن يلجأ مباشرة إلى القضاء أو اللجوء إلى قاضي التنفيذ للمطالبة بتنفيذ حقه، ولا يجوز له الجمع بين الطريقين. V- - لاحظنا أن القانون المصري لم ينص على عدّ الأوراق التجارية والأوراق العادية من السندات التفيذية على عكس الاتجاه الحديث في السندات التنفيذية. 1- وجدنا أن بعض الأنظمة القانونية قد نصت على عدّ جميع المحررات الرسمية سندات تنفيذية متى تضمنت حقا معين المقدار وحال الأداء، وذلك على عكس المشرع المصري، الذي لم ينص على عدّ جميع المحررات الرسمية سندات تنفيذية ما عدا المحررات الموثقة. 9- توصلنا إلى أن القانون الفرنسي أنشأ سندات تنفيذية جليدة بمقتضى قانون ماكرون لتحصيل الديون قليلة القيمة بإجراءات مبسطة. • 1 ـ عدّ القانون الفرنسي التسوية الودية للايون التي لا تزيد عن أربعة آلاف يورو من السندات التنفيذية، وهو ما يعرف بقانون ماكرون. 1 ا ــ عدّ المشرع الفرنسي الاتفاق الرضائي على الظلاق بين الزوجين الذي وقع عليه المحامون من السندات التنفيذية. r ا - لاحظنا أن المشرع الفرنسي أحدث تطورات حديثة بشأن التففيذ المعجل للأحكام؛

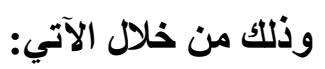

- عدم اشتراط الاستعجال للحكم بالتنفيذ المعجل القضائي، والاكتفاء بوجود حالة الضرورة والتناسب مع طبيعة النزاع. - الحكم بالتنفيذ المعجل من تلقاء نفس القاضي. 


$$
\text { - عدم اشتراط تسبيب الحكم بالتنفيذ المعجل. }
$$

- جواز تقديم طلب التنفيذ المعجل في مرحلة الاستنناف لأول مرة.

- منع محكمة الاستنناف من وقف التنفيذ المعل إلا بناء على شروط ضيقة

با ا- توصلنا إلى أن المشرع الفرنسي استحدث بعض التطورات في نظام الأوامر القضائية تهاف إلى تفعيل تنفيذ الأوامر، وذلك على النحو الآتي:

$$
\text { - الشتر حصرية الأوامر على عرائض في النظام الفرنسي. }
$$

؛ اـ توصلنا إلى أن بعض الأنظة القانونية نصت على التسوية الودية قبل الحجز والبيع، وأخذت هذه الأظظة بطرق مختلفة في تنظيم هذه السندات، فالبعض أسند

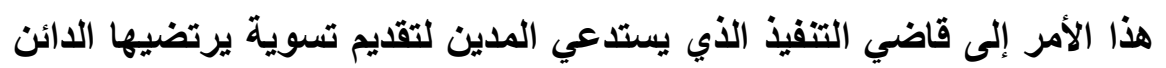

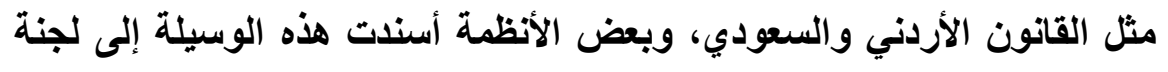

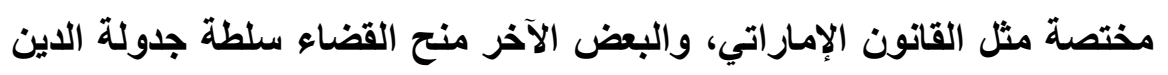

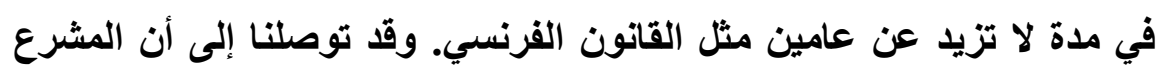

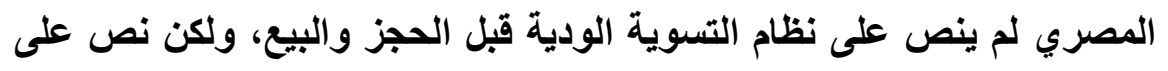

$$
\text { التسوية الودية بعد البيع. }
$$

1 اــ توصلنا إلى أن بعض التشريعات مثل القانون الفرنسي أحثث ثورة على الأفكار

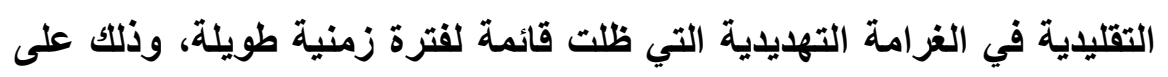

$$
\text { النحو الآتي: - ne }
$$


- - النص على الغزامة التهايدية ضمن أحكام قانون المرافعات وليس القانون المدني باعتباره وسيله لإجبار المدين على تنفيذ السندات، وأطلق عليها غرامة قطعية، ولم تعد الغرامة قاصرة على تتفيذ الالتزامات المدنية التي تتطلب تلخلا شخصيا من المدين. - النص على حق قاضي التنفيذ بالحكم بالغرامة إذا لم تنفذ الأوامر أو الأحكام الصادرة من أي قضاء آخر. - أجاز المشرع الفرنسي للقضاء الإداري الحكم بالغرامة التهديدية على جهة الإدارة إذا امتتعت عن تثفيذ السندات. 7 ا ـ لاحظنا أن المشرع المصري لايزال محافظا على السمات التقليدية لنظام الغرامة

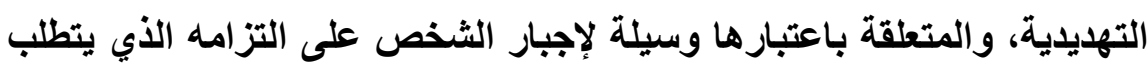
تلخلا شخصيا منه، ولا يمنح قاضي التفيذ سلطة في إصدارها لإجبار المدين

$$
\text { ثانيا: مقترحاث البحث: }
$$

يمكن لنا تقديم بعض الاقتراحات لتطوير نظام السندات التنفيذية وإجراءاتها

$$
\text { في النظام المصري؛ وذلك على النحو الآتي: }
$$

أ. اقتراح النص على عدّ الأوراق التجارية والعرفية والرسمية سندات تنفيذية:

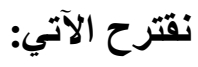

1- النص على عدّ الأوراق التجارية (الكمبيالة والسند لأمر (لإذن) والثيك) من

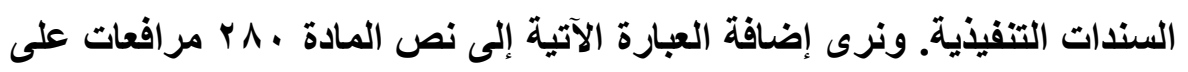
النحو الآتي: " لا يجوز التنفيذ الجبري إلا بسند تنفيذي اقتضاءً لحق محقى 
الوجود ومعين المقار وحال الأداء. والسندات التنفيذية هي الأحكام والأوامر والمحررات الرسمية والعرفية ومحاضر الصلح التي تصدق عليها المحاكم أو مجالس الصلح والأوراق التجارية القابلة للتداول، والأوراق الأخرى التي يعطيها القانون هذه الصفة".

r- النص على الجهة المختصة بوضع الصيغة التفيذية

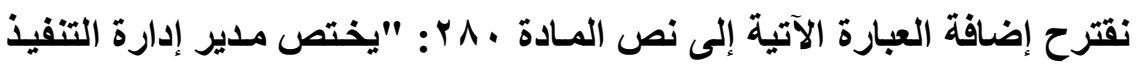
بوضع الصيغة التفيذية على الأوراق التجارية والمحررات العرفية". r- إجراءات تنفيذ الأوراق التجارية والأوراق العادية يضاف إلى المسادة ا Y م من قانون المرافعـات الفقرة الآتيـة: يعلن المدين في الأوراق التجارية والمحررات العرفية للحضور أمام رئيس إدارة التنفيذ، ليقر بـالحق أو لوه ينكره أو ينـازع فيه، وإذا لم يحضر بعد إعلانـه لشخصه أو إعلانـه مرتين تبـأ إدارة

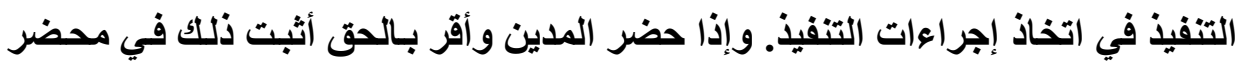
وعدً سندا تنفيذيا. - إذا حضر المدين واعترض على الحق، أو طعن بالتزوير أو أنكر التوقيع حرر رئيس إدارة التنفيذ محضرا بذلك، وأحال الأطراف إلى محكمة الموضوع المختصة، وإذا ثبت عدم أحقية المدين في الاعتراض حكم عليه بغرامة لا تقل عن ربع قيمة المبلغ المدون في الورقة العرفية، مع أحقية الدائن بالتعويض. - إذا حضر المدين وأقر بالحق ولكنه نازع في الأجل، فإن مدير إدارة التنفيذ يحيل النزاع إلى قاضي التنفيذ ليحم في هذه المسألة. 
ـ - النص على حق الددين طلب وقف التنفيذ في حالة الطعن بالتزوير في الورقة الرسمية

نقترح أن ينص المشرع المصري على "حق المدين في المنازعة في السند الرسمي، وذلك بطريق رفع دعوى تزوير أمسام المحكمة المختصة، ولا يقف التنفيذ إلا إذا حكت المحكمة بوقف التنفيذ، ويحكم على المدين بغرامة لا تقل عن ربع قيمة الحقى إذا كان ادعاؤه غير صحيح"، وذلك من أجل منع المدين من التسويف في الوفاء. ب. النص على تعديل نظام التنفيذ المعل: نرى ضرورة الأخذ بالاتجاهات العديثة في التنفيذ المعجل الذي يمنح القاضي

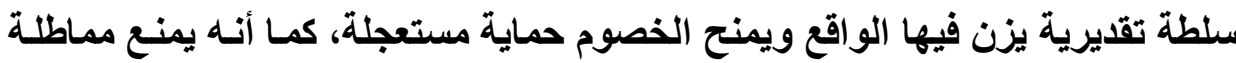
المدين وتسويفه، بالإضافة إلى تحقيق الانتمان الاقتصادي. نقترح أن ينص المشرع المصري على التعديلات الآتية: 1- تعديل نص المادة . _ r من قانون المرافعات ويكون نصها على النحو التالي"

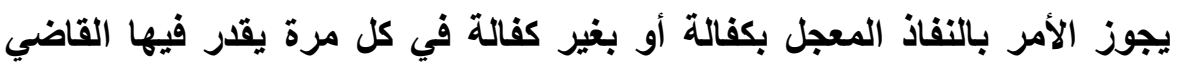

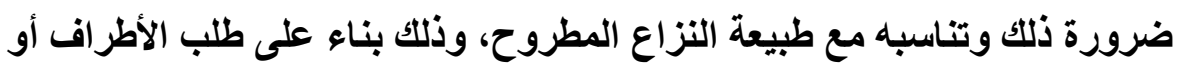
من تلقاء نفس القاضي". r- اقتراح بعدم جواز وقف التنفيذ المعجل القانوني نقترح تعديل نص المسادة بو ج من قانون المرافعات ليكون نصها على النحو الآتي " يجوز في جميع الأحوال للمحكمة المرفوع إليها الاستتناف أو التظلم أن تأمر

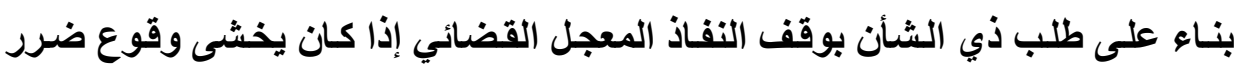
جسيم من التفيذ..."، فنرى إضافة مصطلح التنفيذ المعجل القضائي. 


$$
\text { r- اقتراح بعدم الطعن في الكفالة }
$$

نقترح أن ينص المشرع المصري في المادة هو ب من قانون المرافعات على أن

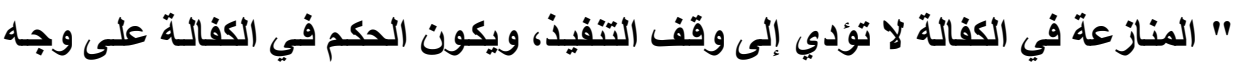

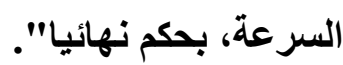

ع - اقتراح بمنح محكمة الاستئناف الحق في الحكم بالتتفيذ المعجل

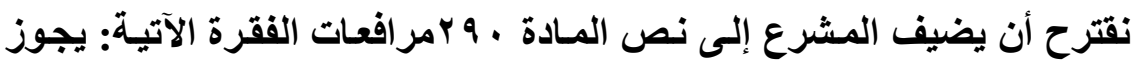
للمحكوم له تقديم طلب لمحكمة الاستئناف بالتنفيذ المعجل، وذلك في حالة رفضه في أول درجـة أو تقديمسه، ولكن أغقلت محكمـة أول درجـة الحكم بـهـ أو لـم يطلب، ولكن

$$
\text { استجدت ظروف للمطالبة به. }
$$

ج. اقتراح بتعديل بعض أحكام نظام الأوامر القضائية 1 - اقتراح بعدم النص على حصرية الأوامر على عرائض

نقترح أن يضيف المشرع بعد الفقرة الأولى في المسادة ؛ 19 مرافعات العبارة الآتية: " في الأحوال التي ينص فيها القانون على أن يكون للخصم وجـه في استصدار أمر أو إذا كاتت توجد حالة استعجال أو كاتت الضرورة تقتضي إصدار الأمر في غيبة الخصم الآخر، يقدم عريضة بطلبه إلى قاضي الأمور الوقتية....". r ـ ـ اقتراح بالنص على الطعن بالاستئناف في حالة رفض الأوامر على عرائض تعديل نص المسادة V 19 مرافعات لتكون على التحو الآتي " في حالة رفض الأمر يكون للطالب الاعتراض بطريق الاستئناف بدون إعلان وحضور، ولذوي الشأن الحق في التظلم إلى المحكمة المختصة إلا إذا نص القانون على غير ذلك..." 
r- النص على التنفيذ المعجل لأمر الأداء

نقترح أن ينص المشرع في المسادة ^^^ إضـافة عبـارة أوامر الأداع، ويكون النص على النحو الآتي: "النفاذ المعجل بغير كفالة واجب بقوة للأحكام الصادرة في المواد المستعجلة أيا كاتت المحكمة التي أصدرتها، وللأوامر الصادرة على العرائض بلـ وأوامر الأداء، وذلك ما لم ينص الحكم أو الأمر على تقديم كفالة". د. اقتراح بالنص على نظام التسوية الودية قبل البيع بالمزاد العلني: لم ينص المشرع المصري على تنظيم التسوية الوديـة السابقة على البيع رغم أهميتها من الناحية العملية، لذا نقترح الآتي: ا - لا يجوز إجراء التنفيذ إلا بعد مضي عشرة أيام على الأقل من إعلان السند التففيذي، يمنح خلال هذه المدة للمدين طلب تسوية ودية، تعرض على مدير إدارة التففيذ. ويتضمن الطلب تأجيل الوفاء فترة معينة، أو يطلب تقسيط الدين، مع إلزامه بدفع قيمة 25\% من قيمة الدين كدفعة أولى، ويمكن تقسيط الباقي على ألا تتجاوز مدة التقسيط عاما واحدا، وذلك بعد أخذ رأي الدائن، وللائن لاعتراض على التسوية التي يقدمها المدين أمام مديرة إدارة التنفيذ". ه. النص على نظام الغرامة التهايدية القطعية

نقترح أن يتدخل المشرع المصري للنص في قانون المرافعات على الآتي: "يجوز لمدير إدارة التنفيذ الحكم بالغرامة التهديدية لإجبار المدين على الوفاء

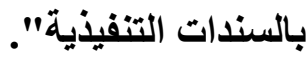




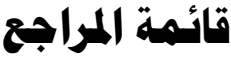

$$
\text { أولًَا: قائمة المراجع العربية: }
$$

1. أنور طلبة، تنفيذ الجبري ومنازعاته الموضوعية والوقتية، ج991، المكتب

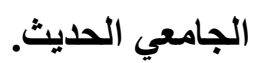

Y. د. إبراهيم أمين النفياوي، القوة التنفيذية للأحكام، طץ، ه . ـ Y، بدون دار نثر.

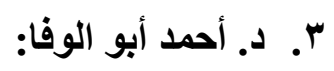

- إجراءات التنفيذ في المواد المدنية والتجارية بمقتضى قانون أصول المحاكمات

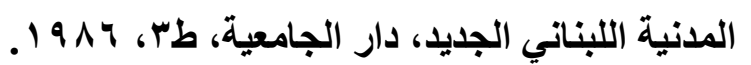

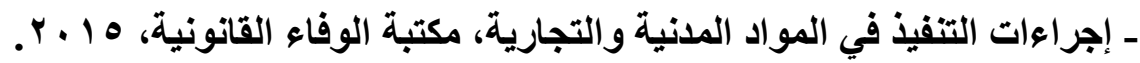

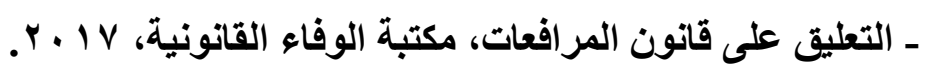

ـ التعليق على نصوص قانون الإثبات، مكتبة الوفاء القانونية، 17 ـ بـ.

ـ ـ نظرية الأحكام في قانون المرافعات، مكتبة الوفاء القانونية، 10 ـ بـ.

؛. د. أحمد العيد صاوي، الوسيط في شرح قانون المرافعات المدنية والتجارية، دار

$$
\begin{aligned}
& \text { النهضة العربية، .... ب. } \\
& \text { ๑. ـ. أحمد المليجي: }
\end{aligned}
$$

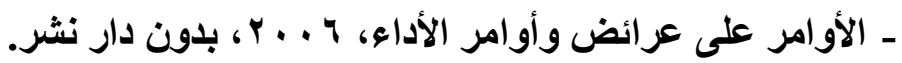

$$
\text { ـ ـ التنفيذ، دار النهضة العربية، ؛ } 199 .
$$


ـ الموسوعة الثاملة في التنفيذ، طه، المركز القومي للإصدارات القانونية،

$$
. r \cdot \Lambda
$$

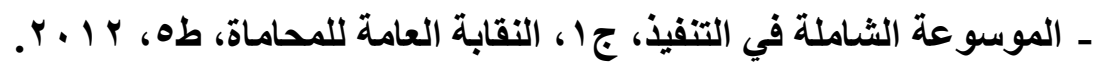
I. د. أحمد خليفة شرقاوي، القوة التنفيذية للححررات الموثقة، دار الجامعة الجديد،

$$
\text { .r. V V }
$$

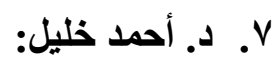

ـ ـ طلبات وقف التنفيذ، دار الجامعة الجديدة، 1999 1.

ـ ق قانون التنفيذ الجبري، دار الجامعة الجديدة، 1999.

^. د. أحمد صدقي محمود، اختصام الغير في الخصومة في قانون المرافعات، رسالة

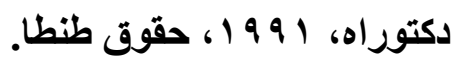

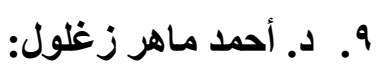

ـ ـ آثار إلغاء الأحكام بعد تنفيذها، الطبعة الثانية، بدون دار نثر، ولا سنة نثر.

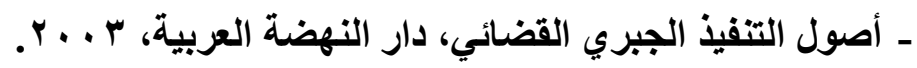

ـ أصول التنفيذ، مكتبة وهبه، طץ، 1919 أم

• 1.د. أحمد محمد حشيش، أساس التنفيذ الجبري، بدون دار نثر، 991 1.

11.د. أسامة أحمد شوقي المليجي، الإجراءات المدنية للتفيذ الجبري في قانون

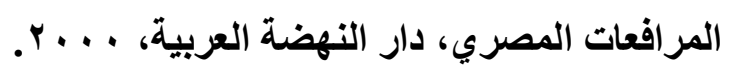

rا.د. الأنصاري حسن النيداني، التفيذ المباشر للسندات التنفيذية، دار الجامعة

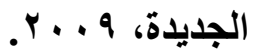

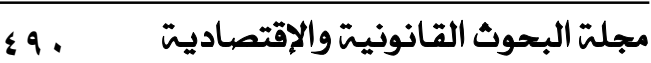


با.د. السيد خميس حسن السري، ضمانات المحكوم عليه في النفاذ المعجل، رسالة

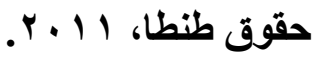
ع ا.د. العربي عبدالقادر، طرق التنفيذ، دار الكتاب الحديث، بدون سنه نشر.

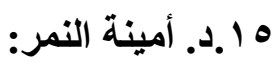

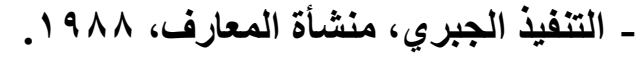

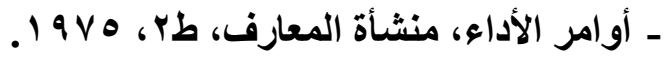
ـ مناط الاختصاص والحكم في الدعاوى المستعجلة، رسالة V7 9 ا I . 17.د. بسام حمد الطراونة، د. باسم محمد ملحم، الأوراق التجارية والعمليات

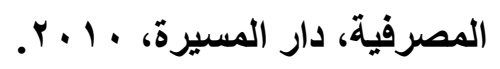

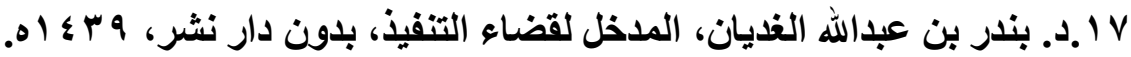
1 ا.د. رمزي سيف، قواعد تنفيذ الأحكام والمحررات الموثقة في قانون المرافعات

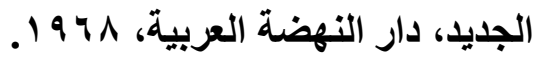
9 1.د. رمضان أبو السعود، مبادئ الإثبات في المواد المدنية والتجارية، دار الجامعة

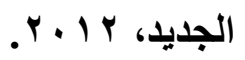

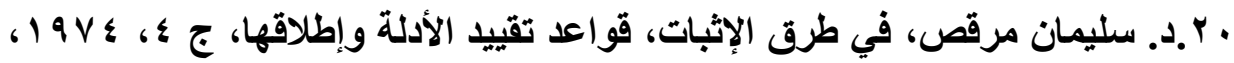
مطبوعات معهد البحوث والدراسات العربية.

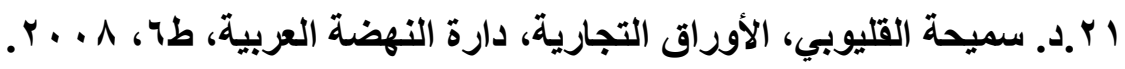

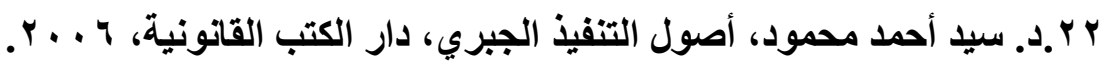

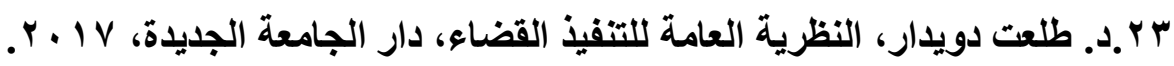


؟ Y.د. عاشور مبروك، الوسيط في التففيذ وفقا لمجموعة المرافعات الحالية، دار

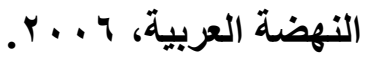

ه Y.د. عبدالباسط جميعي، د. آمال الفزاري، التففيذ، منشأة المعارف، 999 19.

צY.د. عبدالباسط جميعي، مبادئ التفيذ الجبري وفقا لقانون المرافعات المصري،

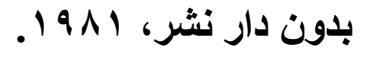

rV .د. عبدالرزاق السنهوري، الوسيط في شرح القانون المدني الجديد، منشورات

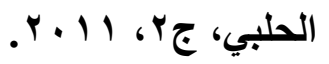

^ץ.د. عبدالعزيز بن عبدالرحمن بن سعد الشبرمي، شرح نظام التنفيذ، مدار الوطن،

$$
\text { ط }
$$

q ب.د. عبدالعزيز خليل بديوي، الوجيز في قواعد وإجراعات التنفيذ الجبري والتحفظي

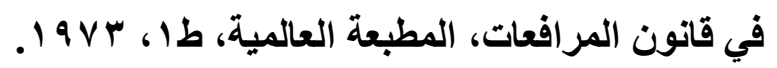

• •.د. عبدالعزيز عبدالمنعم خليفة، إجراعات ومنازعات الحجز الإداري في الفقه

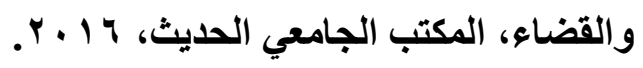

اس.د. عبدالله بن زايد الزايد، القواعد العامة لقضاء التتفيذ، بدون دار نشر، 9 جـ اه.

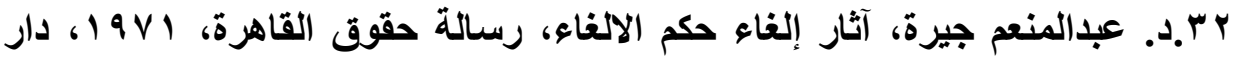
الفكر العربي.

rrr.د. عبدالمنعم عبدالعظيم جيرة، القواعد العامة في التتفيذ الجبري، مكتبة الوطنية، بدون سنة نشر.

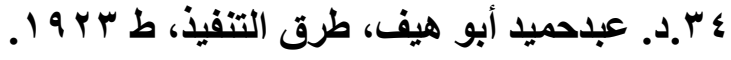




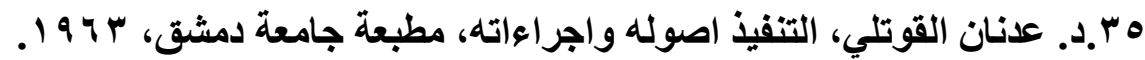
צr.د. عزمي عبدالفتاح عطية:

ـ قواعد التتفيذ الجبري في قانون المرافعات المصري، بدون دار نشر، ب . . . .

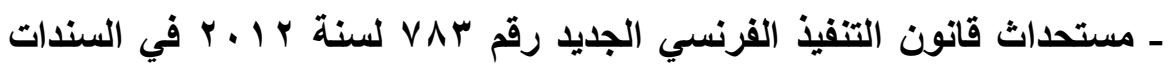
التنفيذية ووسائل الإجبار على التنفيذ وطرق الحجز المختلفة واختصاص قاضي

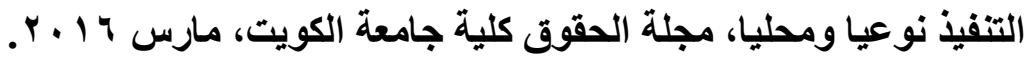
ـ نظام قاضي التفيذ في القانون المصري والمقارن، دار النهضة العربية،

V.J.د. على الثحات الحديدي، الجوانب الإجرائية للغرامة التهايدية كوسيلة لإجبار على التنفيذ في القانون المصري والمقارن، دارة النهضة العربية، 999 و 1 . ^ץ.د. على بركات، خصوصيات التنفيذ الجبري في مواجهة الدولة، دارسة مقارنة، دار

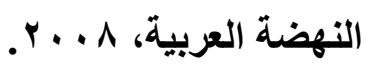

9 ؟.د. عيد محمد القصاص، أصول التنفيذ الجبري، دار النهضة العربية، 999 19.

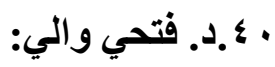

ـ التنفيذ الجبري في المواد المدنية والتجارية، دار النهضة العربية، 991 19. - بحث نحو مشروع جديد للفصل في القضايا المدنية والجديدة، الندوة المشتركة المصرية الفرنسية حول تسوية المنازعات المدنية البسيطة باستخدام الحلول التشريعية والتقيات الحديثة، المركز القومي للاراسات القضائية، القاهرة 
ـ مناهج البحث في قانون المرافعات، من الشرح على المتون إلى المدرسة

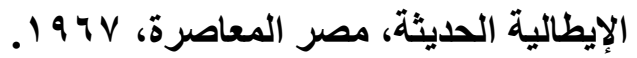

اء.د. فريد محمد نزار فنري، نظام النفاذ المعجل، رسالة دكتوراه، حقوق القاهرة،

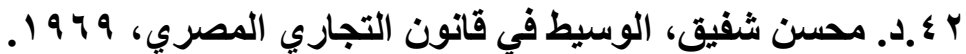

بـ ـد. محمد حامد فهمي، مذكرات في التنفيذ، مكتبة عبدالله وهبه، ؛ ؛ 9 ـ

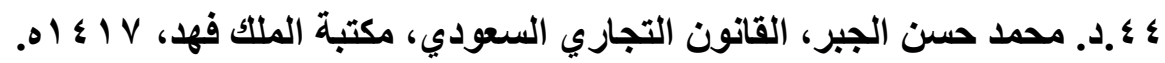

ه ؛ .د. محمد عبدالخالق عمر، مبادئ التنفيذ، مطبعة جامعة القاهرة، 19 VV

צ ؛ .د. محمد مصطفي عبدالصادق، الأوراق التجارية والإفلاس في التشريعات العربية،

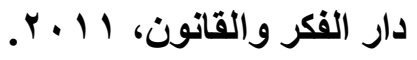

V V .د. محمد نعيم عبدالسلام ياسين، نظرية الدعوى بين الثريعة الاسلامية وقانون المرافعات المدنية والتجارية، القسم الأول.

^§ ـد. محمد السيد محمد رفاعي، الوسيط في النظام التنفيذ السعودي، دار الإجادة

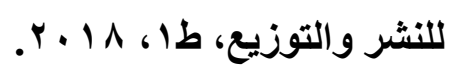

9 ؛.د. محمود التحيوي، النظام القانوني لأوامر أداء الحقوق الثابتة بالكتابة، دار

الجامعة الجديدة،

••.د. محمود السقا، فلسفة وتاريخ النظم الاجتماعية، دار الفكر العربي، و ^ 19.

1ه.د. محمود الطناحي، المقومات الموضوعية والثكلية للسند التفيذي، طا،

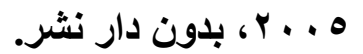


rه.د. محمود سمير الثرقاوي، وائل أنور بندق، الأوراق التجارية، دار النهضة

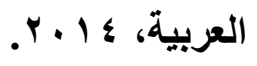
rه.د. محمود محمد هاشم، قواعد التنفيذ الجبري، 999 19، بلون دار نشر. \& \& هـ. محمود مختار بريري، القواعد الخاصة بالثيك وفقا لأحكام قانون التجارة

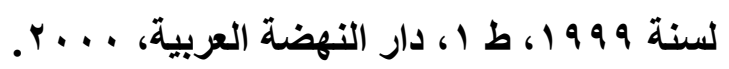

هـ.د. مساعد العنزي؛ قواعد التنفيذ الجبري في قانون المرافعات الكويتي، مؤسسة

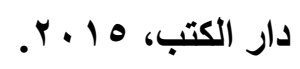

צه.د. مقلح عواد القضاة: ـ أصول التنفيذ وفقا لقانون الإجراء الأردني، دار الثقافة، 9 أب . ـ البينات في المواد المدنية والتجارية، دار الثقافة، 9 ـ ـ ب. Vه.د. نبيل إبراهيم سعد، الإثبات في المواد المدنية والتجارية، دار الجامعة الجديد، r...

^ه.د. نبيل إسماعيل عمر، الوسيط في التفيذ الجبري للأحكام، دار الجامعة الجديدة،

$$
\text { .r...b }
$$

9ه.د. نبيل إسماعيل عمر، د. أحمد هندي، د. أحمد خليل، التنفيذ الجبري، دار الجامعة

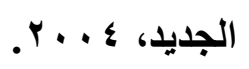

• 7. .د. نجيب أحمد عبدالله الجبلي، التنفيذ الجبري ضد الكفيل، المكتبة الجامعي الحديث،

$$
.1 \text {. }
$$

آ.د. وائل محمود عبدالمطلب البشل، التنفيذ العكسي، دار النهضة العربية، 1 ـ ـ؟. 


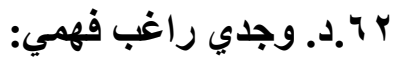

ـ النظرية العام للتنفيذ القضائي في قانون المرافعات، دار الفكر العربي، ع 19 ا. ـ النظرية العامة للتفيذ القضائي في قانون المرافعات المدنية والتجارية، دار

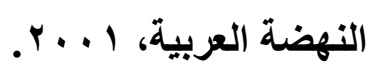

ـ النظرية العامة للعمل القضائي في قانون المرافعات، محاولة تأصيل العمل القضائي وتحليل أركانه ومقتضياته القانونية، رسالة، حقوق عين شمس،

ـ مبادئ التفيذ القضائي في قانون المرافعات الجديد " الكويتي" 191 | . ـ نحو فكرة عامة للقضاء الوقتي في قانون المرافعات، مجلة العلوم القانونية

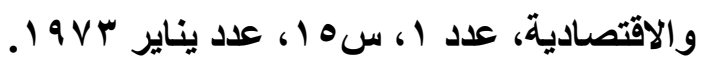
rا.د. عبدالمنعم الشرقاوي وعبدالباسط جميعي، شرح قانون المرافعات الجديد، بدون

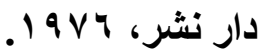
צ 7.صلاح الدين شوشاري، التنفيذ الجبري في المواد المدنية والتجارية والثرعية،

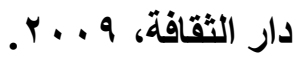

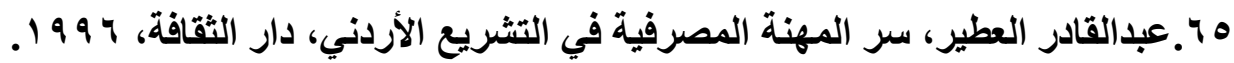
7 7. عز الدين الدناصوري وحامد عكاز، التعليق على قانون المرافعات، ط؛ 99 1، ج ج.

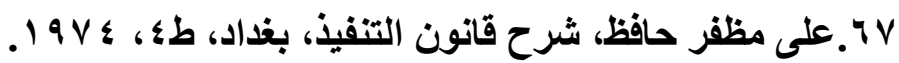
^1.كبريال سرياني وغالب غانم، قوانين التنفيذ في لبنان، الجزء الأول، دار

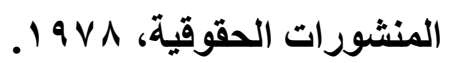


د دلعت يوسف خاطر

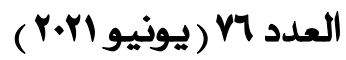

9 7.م/ عبدالحميد المنشاوي، السندات التنفيذية، دار الفكر الجامعي، ب99 19. •.V. . عبدالفتاح مراد، التفيذ العملي، ه99 19، بلون دار نشر.

ا.V/ مصطفي مجدي هرجه، الأوامر على العرائض، دار محمود للنشر والتوزيع، $.199 V .76$

Vr.Vr القانون الكويتي، دار المنظومة.

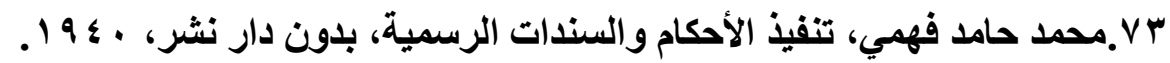
؟ Vحمد على راتب ونصر الاين كامل، قضاء الأمور المستعجلة، هـ9 1، بدون دار نشر.

ه V.محمد كمال عبدالعزيز، تقنين المرافعات في ضوء الفقه والقضاء، دار الطباعة

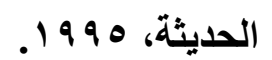

\section{ثانيًا: المراجع الأجنبية}

2. Alain FOURNIER Hypothèque provisoire, Répertoire de droit civil, Septembre 2007.

3. AMRANI-MEKKI, Les nouveaux titres exécutoires: les accords amiables homologués, Dr. et patr. déc. 2013. 55.

4. BAKER CHISS, Contribution à l'étude de l'exécution des jugements civils dans les rapports internes et internationaux de droit privé, thèse, Paris $I, 2008$ 
دا طلعت يوسف خاطر

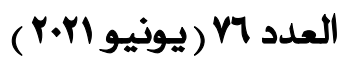

5. BERLIOZ, limites et difficultés d'exécution de l'acte authentique JCP, 2014, 1249 .

6. BERTIN:

- La nouvelle procédure civile, Le décret du 28 août 1972, Gaz. Pal. 1972. 2. Doctr. 669, spéc. no 29،

- Le grand Noël du procédurier, Gaz. Pal. 1976. 1. Doctr. 313, spéc. no 118

- le petit noel du procedure, Gaz pal, 1974, I, doct. 149 .

7. Besniers, Cours d'histoire des institution et des faits sociaux, les cours de droit 1955, p. 829

8. BLAISSE, Arrêt et aménagement de l'exécution provisoire par le premier président, JCP 1985. I. 3183

9. BLÉRY, L'efficacité substantielle des jugements civils, 2000, LGDJ

10. CADIET et JEULAND, Droit judiciaire privé, 8e éd., 2013, Litec.

11.CADIET, NORMAND et AMRANI MEKKI, Théorie générale du procès, 2e éd., 2013, PUF. 
دا طلعت يوسف خاطر

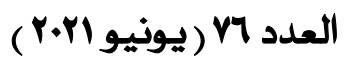

12. CANS et SCHRICKE, Le référé du premier président, in La pratique du référé dans les juridictions civiles de la région parisienne, 1979, PUF.

13. CASAL, Recouvrement des chèques impayés: une histoire tourmentée, Dr. et proc. 2002. 212

14. CÉZAR-BRU, HÉBRAUD et SEIGNOLLE, Juridiction du président du tribunal, t. II: Les ordonnances sur requête, $4 \mathrm{e}$ éd., 1970, Litec

15. Ch. Loyer-larher:

- l'exécution provisoire, analyse de la jurisprudence des Cours d' appel d' angers et de Rennes, Gaz Pal, 1982, doct. 152.

- La réforme de l'exécution provisoire, Gaz. Pal. 1976. 2. Doctr. 587.

16. COIFFARD, authenticité et force exécutoire - l'arbre et le fruit, JCP, 2018. 1096 .

17. CROZE et MOREL, Procédure civile, 1988, coll. Droit fondamental, PUF.

18. Didier CHOLET, Exécution des jugements et des actes, D., septembre 2015. 
د/ طلعت يوسف خاطر

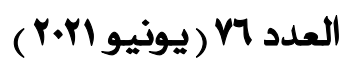

19. Emmanuel Blanc, les novelles pocédure dexécution, 1993

20.ESTOUP, La pratique des procédures rapides, référés, ordonnances sur requête et procédures d'injonction, avec le concours de G. MARTIN, 2e éd., 1998, Litec.

21.FAUVEL, La réforme de l'exécution provisoire des jugements nonobstant opposition et appel, thèse, Paris, 1932 .

\section{FRICERO:}

- -Accord des parties, homologation, octroi de la force exécutoire: quel rôle pour le juge ?, RJPF 2010-1/8

- - Procédures civiles d'exécution, 4e éd., Gualino, 2014.

23. FRICERO, POIVEY-LECLERC et SAUPHANOR, Procédure participative assistée par avocat, 2012 ،

24. Gerard Couchez et Daniel lebeau, voies dexecution, 19 éd. 2012

25. GERBAY, Réflexions sur la juridiction du premier président de la cour d'appel, D. 1980. Chron. 65

26. GIJSBERT, divorce sans juge: le notaire peut-il apposer la formule exécutoire?, Defrénois 14 sept. 2017 
د ا طلعت يـوسف خاطر

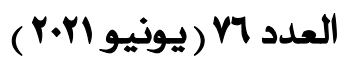

27. GLASSON, TISSIER et MOREL, Traité théorique et pratique d'organisation judiciaire, de compétence et de procédure civile, t. 3, 3e éd., 1929, Sirey

28. GORCHS-GELZER:

- Regard critique sur l'ordonnance no 2011-1540 transposant la directive médiation, Dr. et proc. 2011.

- Le contrôle judiciaire des accords de règlement amiable, Rev. arb. 2008.

29. GORE, L'acte notarié, instrument de l'exécution forcée, LPA 11 août 1997 .

30. GUILLEMAIN, Réflexions sur la qualification de l'homologation judiciaire, Gaz. Pal. 22 mai 2012 .

31. GUINOT, Aperçu historique de la formule exécutoire, Dr. et proc. 2010, supplément au no 11 .

32. H. Solus et R. Perrot, Droit judiciaire privé, tome 3, Procédure de première instance, Sirey 1991, no 1405, p. 1198

33. HÉBRAUD: 
دا طلعت يوسف خاطر

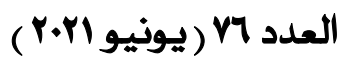

- -Le domaine des ordonnances sur requête, in Les ordonnances sur requête dans la pratique judiciaire française, colloque de Lille, mai 1964, Paris, Litec, 1967

- -L'exécution des jugements civils, RID comp. 1957 .

34. J. Maurice CAZAUX, la formale ecexution, thèse Paris, 1942

35. J. MIGUET, Jugements. Exécution provisoire, J.-Cl. Pr. civ., fasc. 516

36. J. Viatte:

- -les référé du premier president, Gaz. Pal. 1973.

- suppression du controle de l- exécution provisoire, Gaz. Pal., 1974, I doc. 463 .

37. J.A. Fusil, la jurisdiction du premier president de la Cour d 'appel, Gaz Pal. 1975, doc. P, 347 .

38. J.Beauchard, le logement et le procedute civile d'execution, PTD.civ 1993 P 109.

39. Jean-Denis PellierRésumé, De la distinction entre prescription de l'obligation et prescription du titre exécutoire judiciaire, Dalloz actualité 23 octobre 2018.

$0 . r$ مجلت البحوث القانونيت والإقتصاديت 
دا طلعت يوسف خاطر

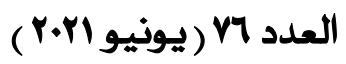

40. JULIENNE, le caractère exécutoire de l'acte authentique, JCP 2014. 1250 .

41. KRINGS, Force exécutoire et titre exécutoire en rapport avec les exécutions forcées de décisions et d'actes, in Mélanges Kerameus, 2009, Bruylant-Sakkoulas, p. 672 .

42. L. LARHER, la reforme de l execution proviso ire, Gaz Pal. 1976, 2, Doct. 586 .

43. Lasserre Capdeville:

- interrogations autour de la future évolution du taux de l'intérêt légal, Gaz. Pal. 10-11 sept. 2014 .

- le chèque sans provision en France, 1992-2013, JCP 2013, no 1358 .

44. LE BARS et VILLACÈQUE, La charrue avant les bœufs: le projet de suppression de l'effet suspensif de l'appel en matière civile, D. 2002. Chron. 1987 et D. 2002. Chron. 1989 .

45. LEBORGNE, Droit de l'exécution, 2e éd., 2014, Dalloz.

46. Léon Fauvem, La réforme de l'exécution provisoire des jugements nonobstant opposition et appel, these paris, 1932. 
د ا طلعت يـوسف خاطر

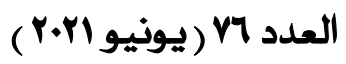

47. LIBCHABER, Le point sur l'interversion des prescriptions en cas de condamnation en justice, D. 2006. Chron. 254 , n0 144 .

48. LOBIN, L'exécution provisoire, Gaz. Pal. 14-15 sept. 1984

49. M. frances, essai sur la notion d'urgence et provisoire dans la procedure de refere, these Toulouse, 1935, p. 90 .

50. MAGENDIE, L'exécution immédiate des décisions de justice: l'injuste critique d'une réforme nécessaire, D. 2002. Chron. 2411

51. MARCHADIER, L'attribution de la force exécutoire à la transaction extrajudiciaire après le décret du 20 janvier 2012, Gaz. Pal. 8 déc. 2012 .

52. Marie-Pierre MOURRE-SCHREIBER, Huissier de justice, Répertoire de procédure civile Janvier 2017

53. MAYER, Précisions sur le contrôle « léger » exercé par le juge homologateur d'une transaction, Gaz. Pal. 14-16 juin 2015. 12

54. MINGAUD, Des voies de recours contre les ordonnances du président du tribunal civil, 1931, thèse . 
دا طلعت يوسف خاطر

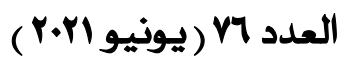

55. BERGEL, La juridiction gracieuse en droit français, D. 1983. Chron. 153, spéc. p. 154 .

56. NONNENMACHER, de quelques aspects de la force exécutoire du divorce non judiciaire, JCP, 2017, n. 1338 .

57. P. Baudas, l'exécution provisoire, thèse, 1958.

58. P. CUCHE, précis d procedure civilee et commerciale, 10 éd. 1954.

59. PERRIN, Des ordonnances sur requête: étude de jurisprudence, thèse, Paris, 1902.

60. PERROT:

- La compétence du juge des référés, Gaz. Pal. 1974. 2. Doctr, 895.

- Procédure de l'instance. Jugements et voies de recours. Voies d'exécution et mesures conservatoires, RTD civ. 1983 .

61. Ph. HOONAKKER, GUINCHARD, Droit et pratique de la procédure civile, 2009/2010, 6e éd., 2009, Dalloz Action, n. 3302 .

62. Ph. HOONAKKER: 
دا طلعت يوسف خاطر

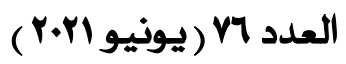

- I- effet suspensive des vois de recours dans le nouveau code de procedure civile, thèse Strasbourg, 1988.

- L'exécution immédiate, Mélanges Julien, 2003, Édilaix.

- L'arrêt de l'exécution provisoire de droit enfin consacré par le législateur !, D. 2004. Chron. 2314.

- Le juge de l'exécution, Gaz. Pal. 1993. 1. Doctr. 321, spéc. no 31 .

- Dernières réformes de l'exécution provisoire. Raison et déraison, D. 2006. Chron. 754

- Procédures civiles d'exécution, 4e éd., 2015, Larcier

- Exécution provisoire, D. septembre 2016

- La prescription de l'exécution forcée depuis la loi no 2008561 du 17 juin 2008, Dr. et pr. 2009 .

63. Pierre CALLÉ, Caducité, Répertoire de procédure civile, Septembre 2015, n0 60 .

64. PRÉVAULT, L'évolution de l'exécution forcée en droit français, Dr. et proc. 2001. 72 .

65. PUTMAN, La contrainte dans le droit de l'exécution, RRJ 1994. 341 . 
د ا طلعت يـوسف خاطر

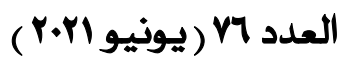

66. Régine BONHOMME, Chèque, Répertoire de droit commercial, Février 2017 DAGOT, La force exécutoire de l'acte notarié, LPA 6 janv. 1993.

67. R. Maurice, exécution provisoire, repertoire de procédure, encyclopedie D., 2ed., 1979 n0 47 .

68. R. Morel, traité élémentaire de procedure civile, 2 éd. 1949, n0 626 .

69. R. Perrot et P. Théry, Procédures civiles d'exécution, 3e éd., Dalloz, 2013.

70. R. Perrot, institutions judiciare, 4e éd. 1992, domat

71. Richardson, A guide to negotiable intstruments, 4th, ed. London, 1970 .

72. R. MARTIN, Matière gracieuse et ordonnance sur requête unilatérale, JCP 1976. I. 2787.

73. RIBEREAU, De l'exécution provisoire des jugements en matière civile, thèse, Bordeaux, 1901.

74. RIVES, La juridiction du conseiller de la mise en état, RTD civ. 1984 .

75. S. GUINCHARD et MOUSSA, Droit et pratique des voies d'exécution, Dalloz, 8e éd., 2015 
د دلعت يوسف خاطر

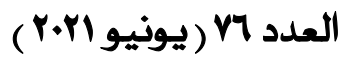

76. S. GUINCHARD, CHAINAIS et FERRAND, Procédure civile, Dalloz, 32e éd., 2014, no 1346.

77. S. Guinchard:

- Code de procedure civile, 1993 .

- Le projet de suppression de l'effet suspensif de l'appel, LPA no 112, 5 juin 2002.

78. Salati, Droit et pratique des voies d'exécution, D. ACTION 2018/2019, n. 111 .

79. SOMMER et NICOLÉTIS, Chronique de jurisprudence de la Cour de cassation. Deuxième chambre civile, $D$. 2008. 2373.

80. Stéphane PIÉDELIÈVRE, Frédéric GUERCHOUN, Saisies et mesures conservatoires, Répertoire de procédure civile Octobre 2018.

81. STRICKLER et FOULON, Accords et force exécutoire en France, Gaz. Pal. 3 sept. 2013 .

82. STRICKLER, Procédure civile, 3e éd., 2010, Paradigme.

83. Sylvie PIERRE-MAURICE, Ordonnance sur requête, D., mars 2011

84. TEMPLIER, la pratique de l'exécution, JCP 2014. 1251.

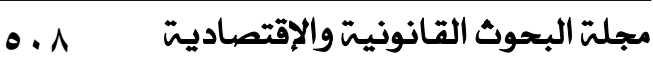


دا طلعت يوسف خاطر

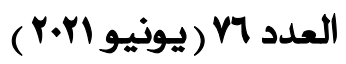

85. THOMAS, La réforme de l'exécution provisoire, JCP 1943. I. 358 .

86. TOUZET, De l'exécution provisoire des jugements, thèse, Paris, 1901

87. V. BAUDIN, Des voies de recours contre les ordonnances sur requête, thèse, Dijon, 1902

88. Valerio FORTI, Exécution forcée en nature, Répertoire de droit civil, Octobre 2016.

89. VALLENS, L'exécution provisoire du jugement de redressement ou de liquidation judiciaire, D. 1997. Chron. 11.

90. Vigneau, La reforme du droit du surendettement par La loi du La Juillet 2010,D. 2010.2593.

91. WIEDERKEHR, Droits de la défense et procédure civile, D. 1978. Chron. 36.

92. Xavier DAVERAT, Saisie: protection du débiteur, D., septembre 2013. 